UNIVERSIDAD NACIONAL DE LA PLATA

FACUltad DE PeRIOdismo y COMUnicación SOCIAL

DOCTORADO EN COMUNICACIÓN SOCIAL

TESIS DE DOCTORADO

Políticas públicas cinematográficas

Neofomentismo en Argentina, Brasil y México (2000-2009)

Roque González

atilioroquegonzalez@yahoo.com.ar

Director:

Dr. Guillermo Mastrini 


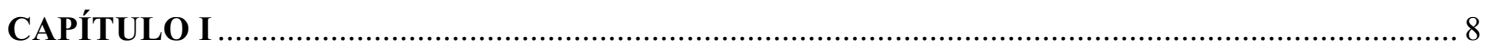

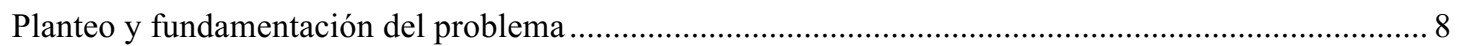

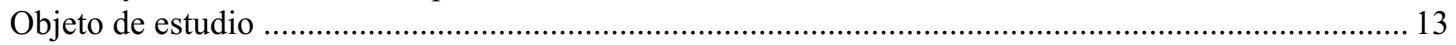

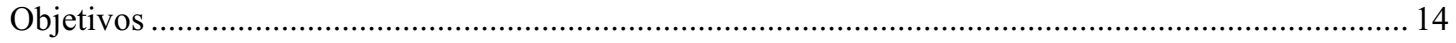

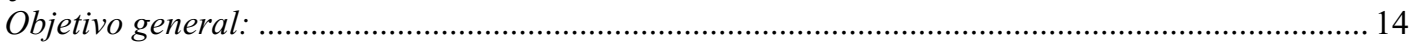

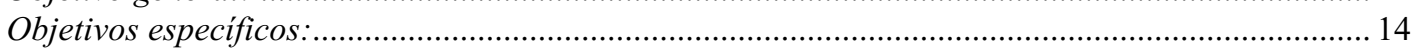

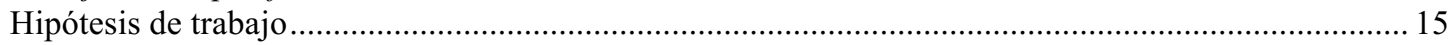

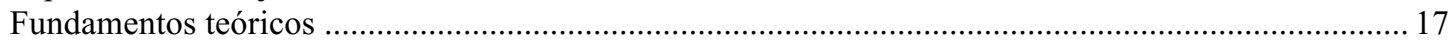

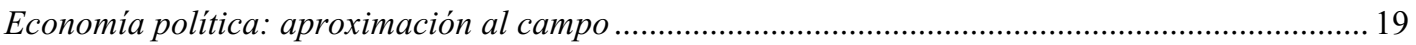

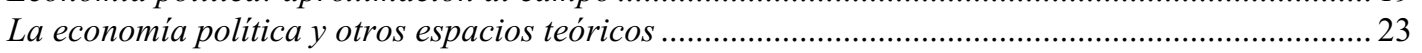

La economía política y el cine ..................................................................................................... 26

Referentes latinoamericanos en los estudios de la economía política del cine ............................29

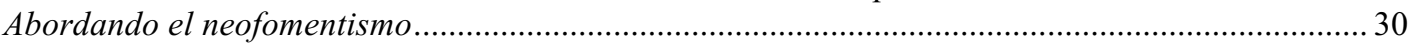

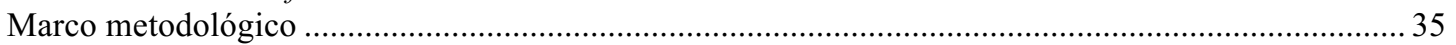

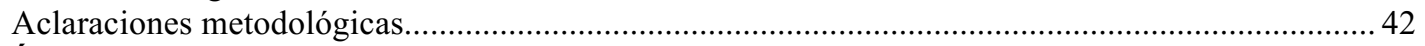

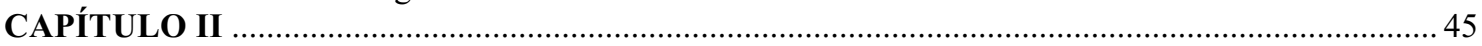

POLÍTICAS PÚBLICAS CINEMATOGRÁFICAS: INSTITUCIONES Y MECANISMOS DE

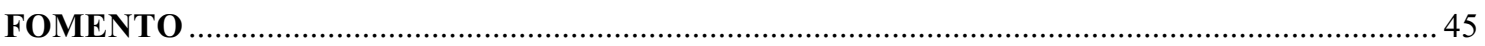

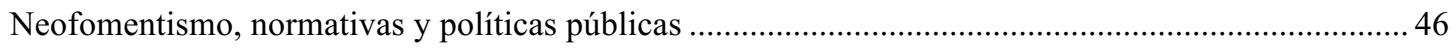

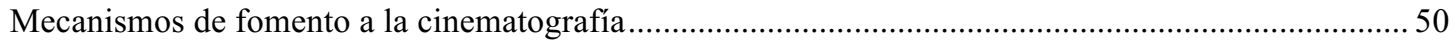

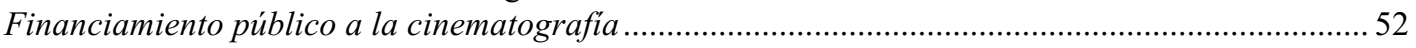

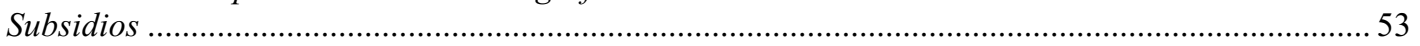

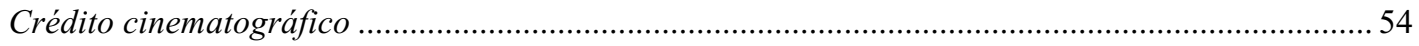

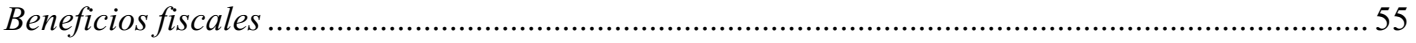

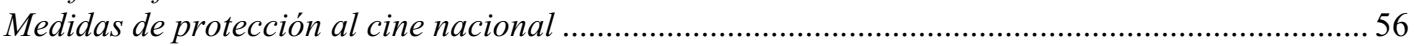

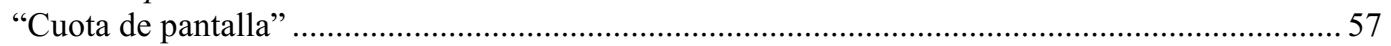

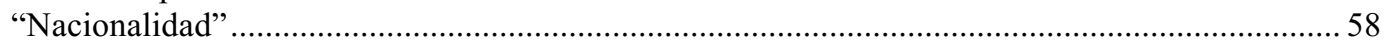

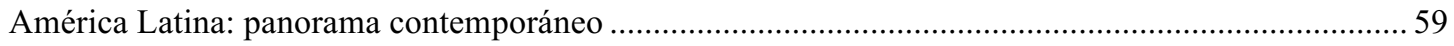

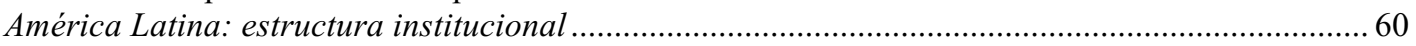

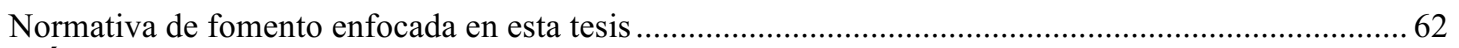

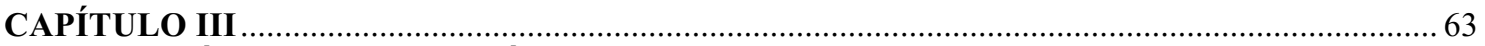

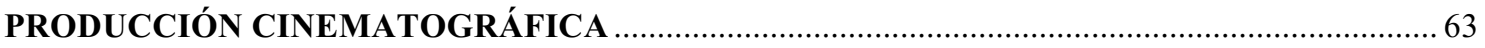

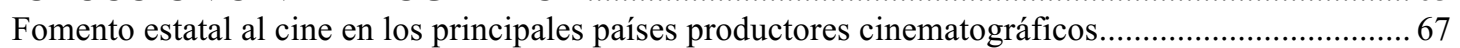

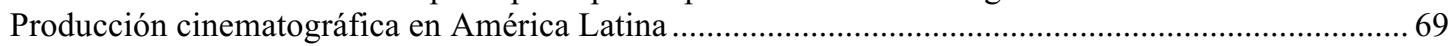

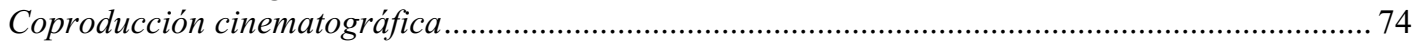

Un caso de estudio: las coproducciones en el Mercosur entre 2000 y $2008 \ldots \ldots \ldots \ldots \ldots \ldots \ldots \ldots \ldots \ldots \ldots . . .76$

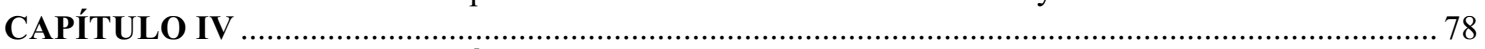

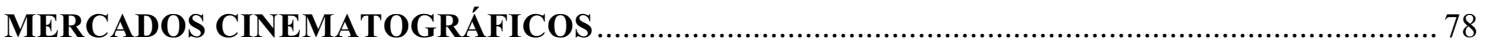

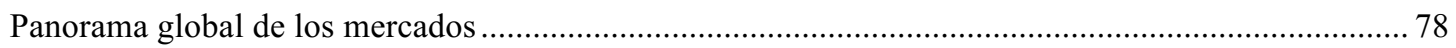

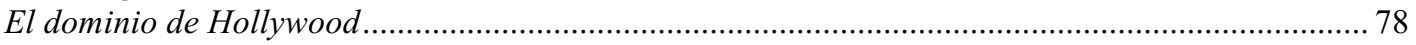

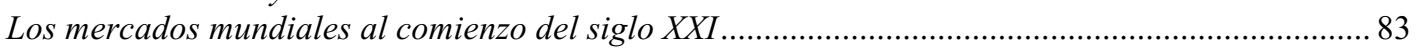

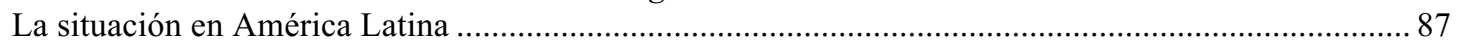

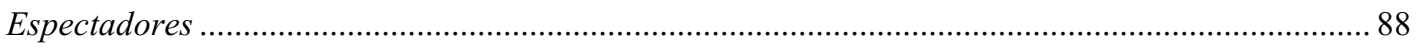

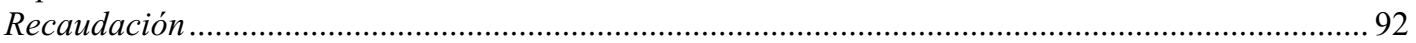

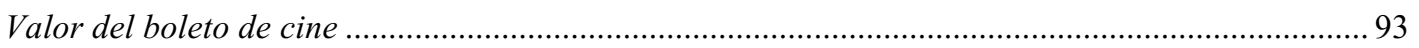

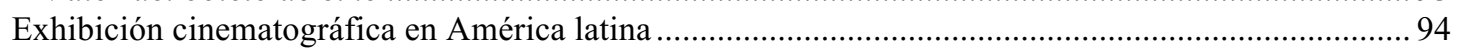

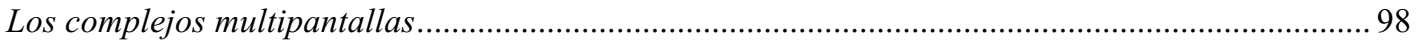

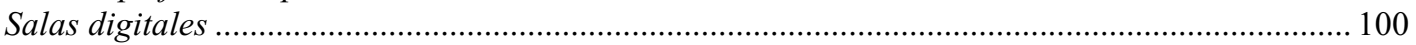

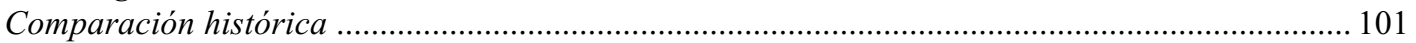

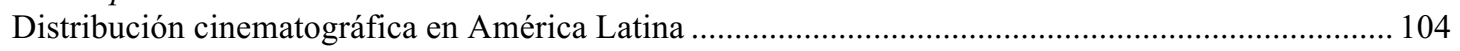

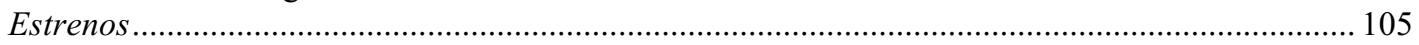

La presencia del cine nacional en América Latina ............................................................................ 106

La circulación de las películas iberoamericanas en América Latina ............................................... 107

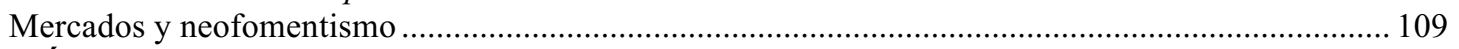

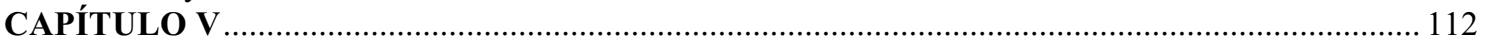

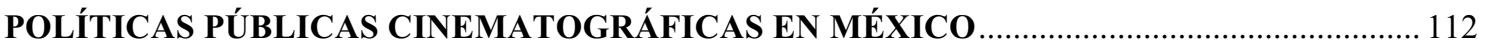

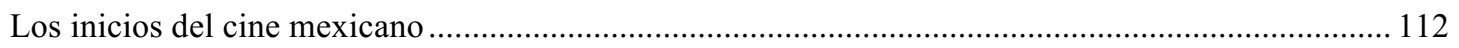

Políticas públicas cinematográficas en México....................................................................... 114

Fomentismo cinematográfico en México .................................................................................. 114 
Instituciones del Estado empresario cinematográfico .......................................................... 116

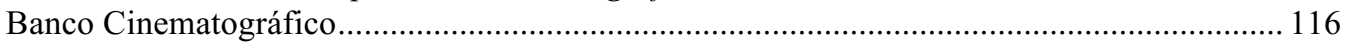

Estudios Churubusco Azteca............................................................................................ 117

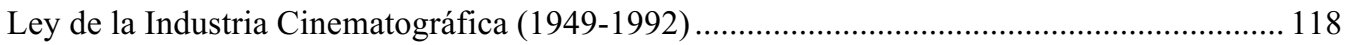

Comercialización cinematográfica estatal......................................................................... 119

Echeverría y el segundo esplendor de la industria cinematográfica (1970-1976)..................... 120

López Portillo y el comienzo del fin del Estado empresario..................................................... 122

La década de 1980: prolegómenos del desmantelamiento ...................................................... 123

Instituto Mexicano de Cinematografía (1983-1989) .......................................................... 123

Políticas cinematográficas neofomentistas............................................................................ 124

Neoliberalismo y Tratado de Libre Comercio de América del Norte ......................................... 125

Estructura actual del gobierno federal en materia cinematográfica......................................... 128

Instituto Mexicano de Cinematografía (1989-presente) ..................................................... 128

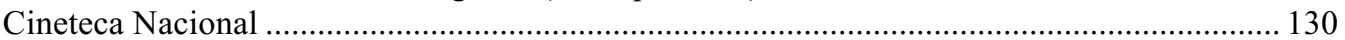

Instituto Nacional del Derecho de Autor ......................................................................... 130

Mecanismos vigentes de fomento al cine mexicano .................................................................. 131

Fondo para la Producción Cinematográfica de Calidad (Foprocine) ...................................... 131

Fondo de Inversión y Estímulos al Cine (Fidecine) ............................................................... 132

Constitución del Fondo de Inversión y Estímulos al Cine (Fidecine) ................................. 133

Estímulo fiscal del Cine (Eficine) .................................................................................... 134

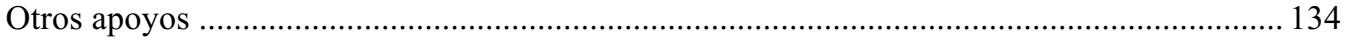

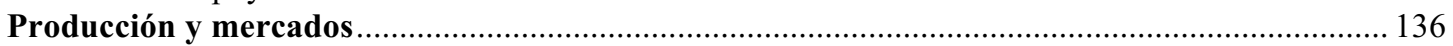

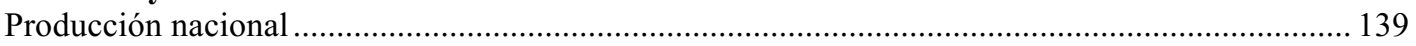

Participación de mercado de los filmes nacionales................................................................. 143

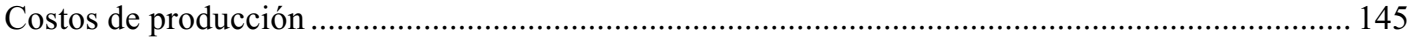

Filmes iberoamericanos no nacionales.................................................................................. 147

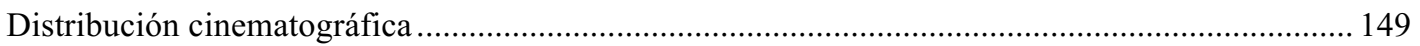

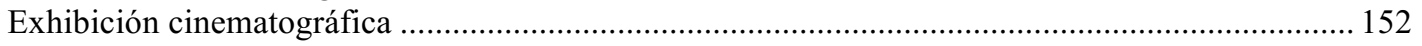

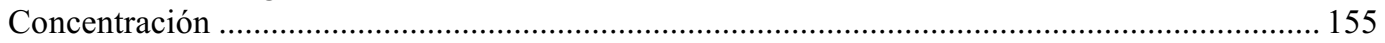

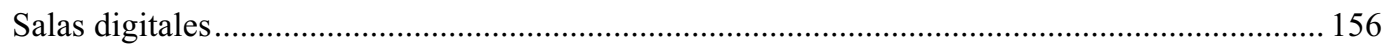

La recuperación operada desde finales de la década de 1990 ..................................................... 157

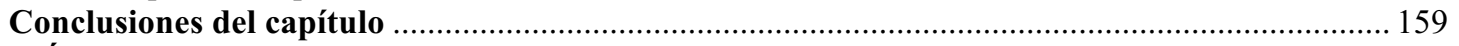

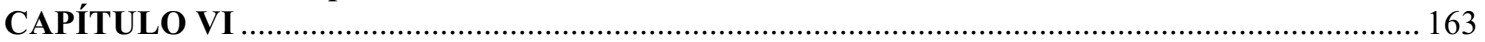

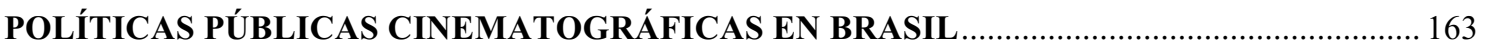

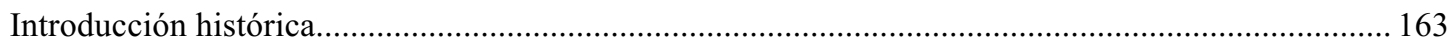

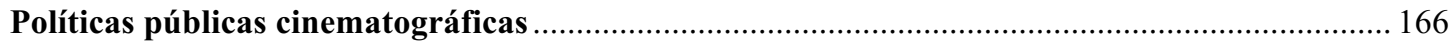

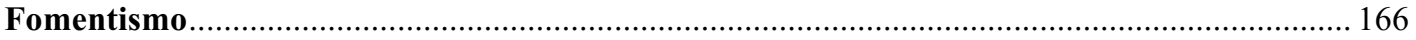

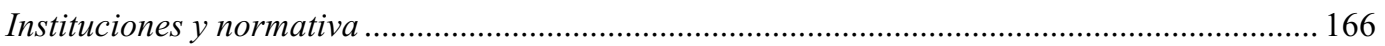

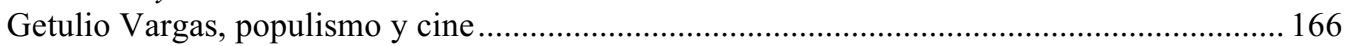

Una etapa intermedia (1946-1965) .............................................................................. 171

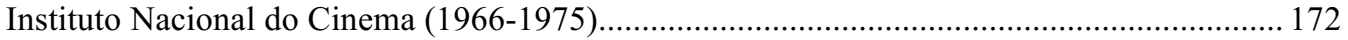

Empresa Brasileira de Filmes (Embrafilme) (1969-1990) ..................................................... 173

Conselho Nacional de Cinema (Concine) (1976-1990) .......................................................... 176

La influencia de Embrafilme en el cine brasileño........................................................... 177

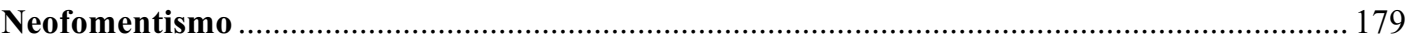

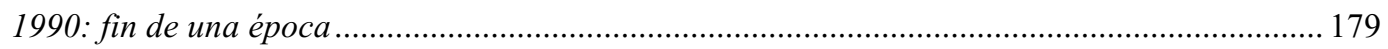

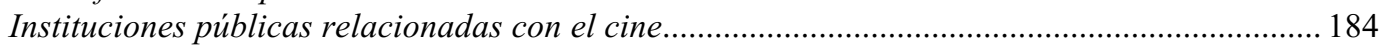

Secretaría para el Desarrollo del Audiovisual (1995-2002)................................................ 184

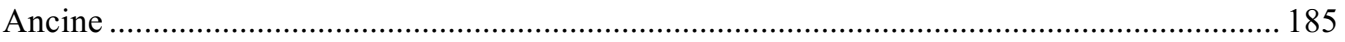

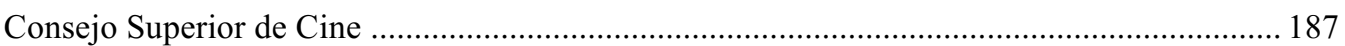

Secretaría del Audiovisual ............................................................................................... 188

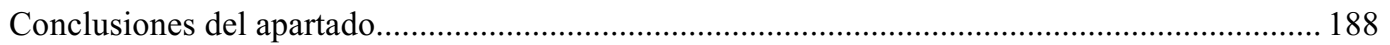

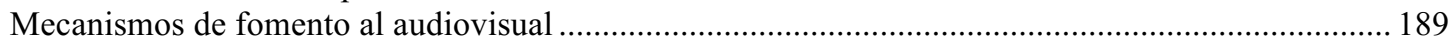

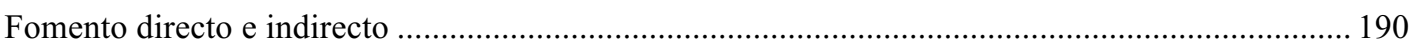

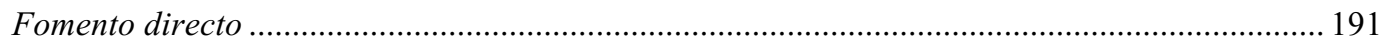

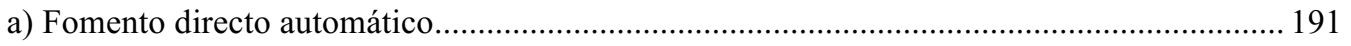

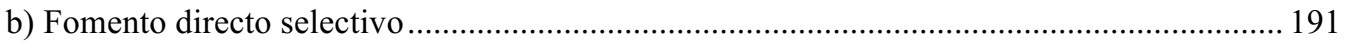

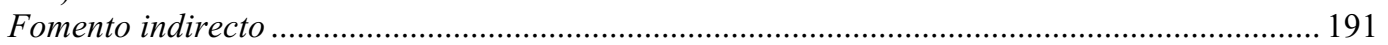

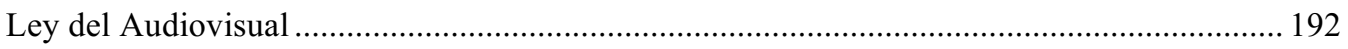

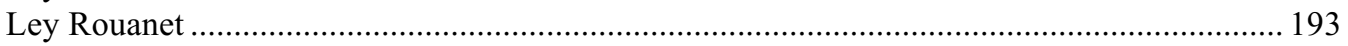


Fondos de Financiación de la Industria Cinematográfica Nacional (Funcines) ..................... 193

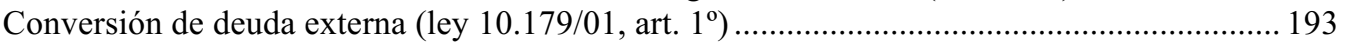

Otros.

Fondo Sectorial del Audiovisual ............................................................................................. 194

Cinema Perto de Você (Cine cerca de usted) ............................................................................ 195

Programas Especiales de Fomento........................................................................................... 195

Convocatorias de la Secretaría del Audiovisual (Ministerio de Cultura) .................................. 196

Leyes estaduales y municipales de incentivo al audiovisual ................................................... 196

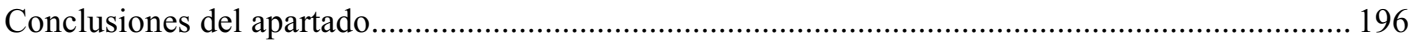

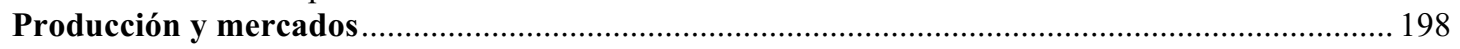

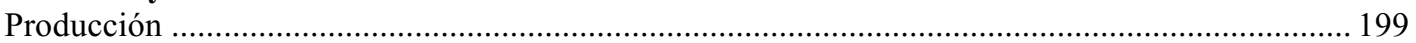

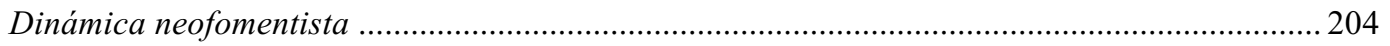

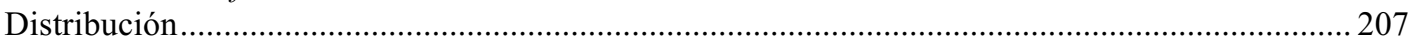

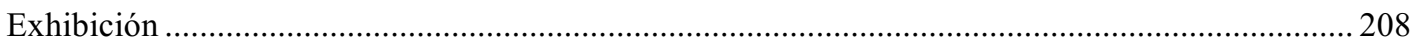

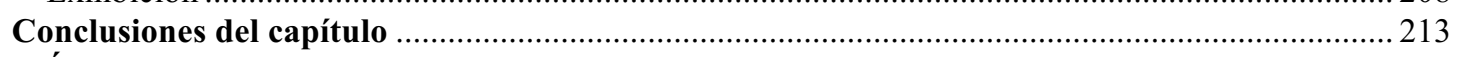

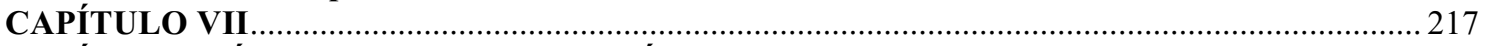

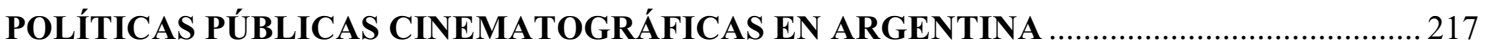

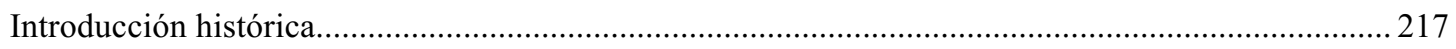

Políticas públicas cinematográficas en la Argentina............................................................ 222

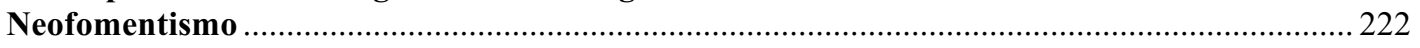

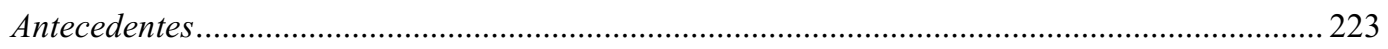

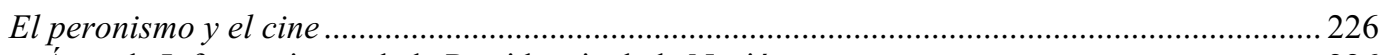

Área de Informaciones de la Presidencia de la Nación.......................................................... 226

"Revolución Libertadora " y Frondizi ................................................................................... 227

Creación del Instituto Nacional de Cinematografía ............................................................. 228

La ley de cine de 1968 y la posterior normativa sobre cine ....................................................... 229

Incaa: estructura administrativa ....................................................................................... 234

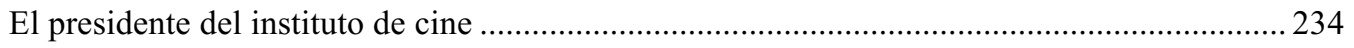

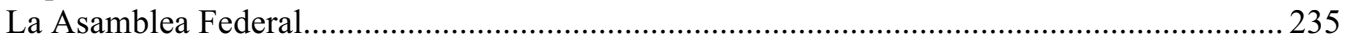

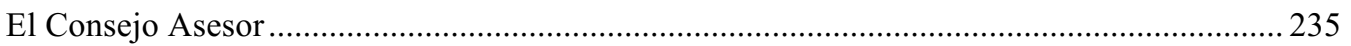

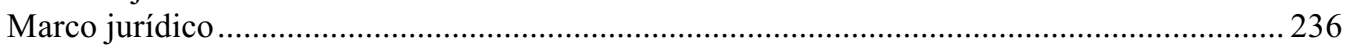

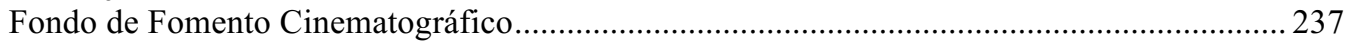

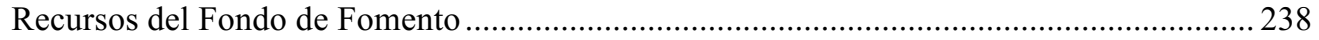

Antecedentes del Fondo de Fomento .......................................................................... 239

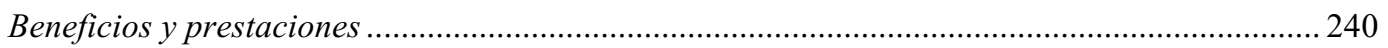

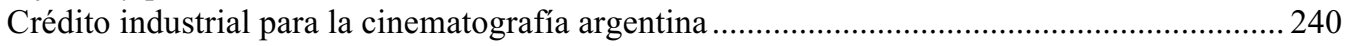

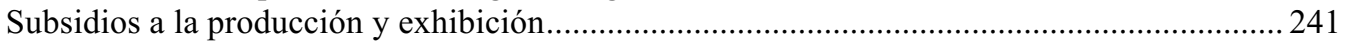

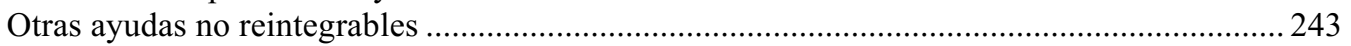

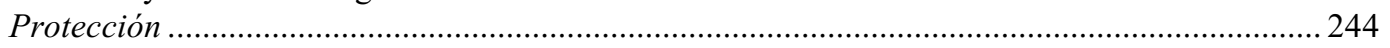

Concepto de "película nacional" en la Argentina ................................................................ 244

El concepto de nacionalidad en el caso de las coproducciones ...................................... 244

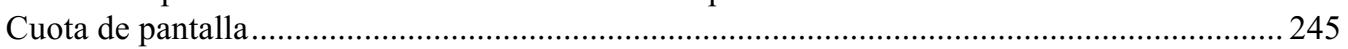

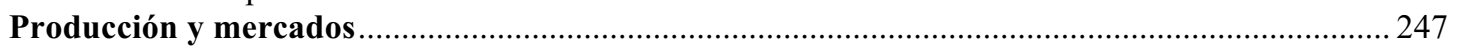

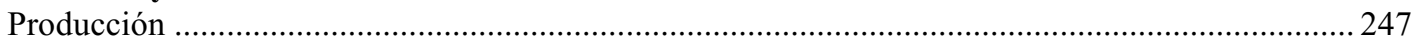

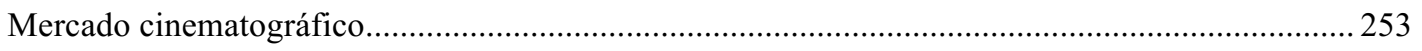

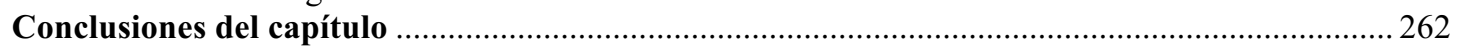

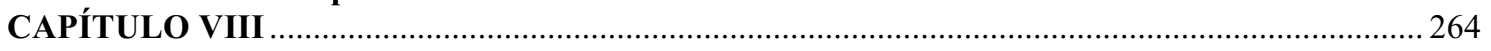

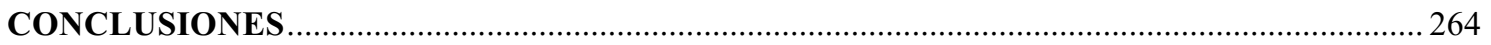

Políticas, producción y mercados cinematográficos contemporáneos en Argentina, Brasil y México 279

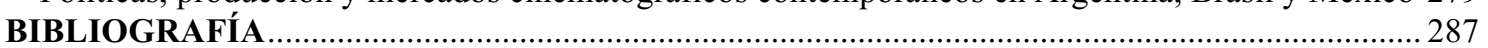

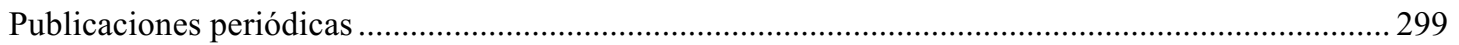

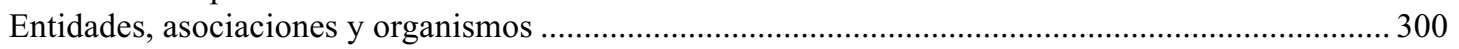

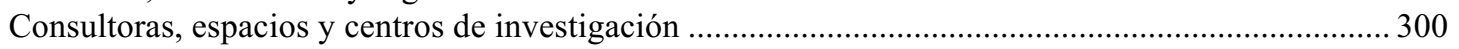

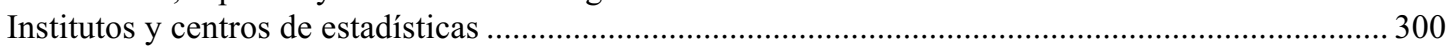

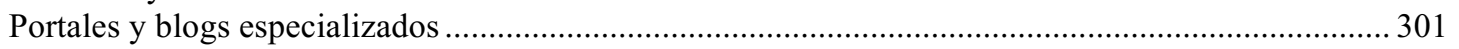

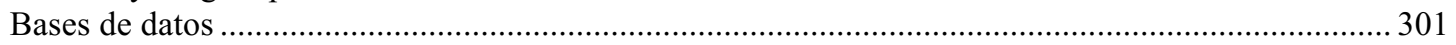

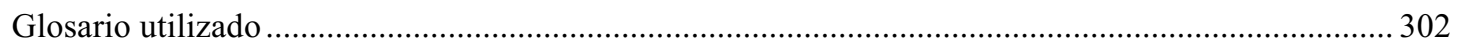

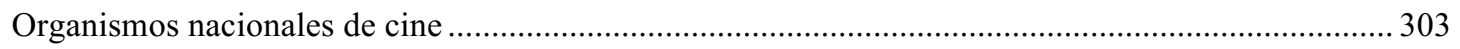

Organismos regionales de integración cinematográfica ................................................................... 304 


\section{Lista de cuadros}

Cuadro 1 - Hipótesis, variables y operacionalización ................................................................... 16

Cuadro 2 - Tipología de políticas cinematográficas ....................................................................... 31

Cuadro 3 - Características de las políticas cinematográficas, de la producción y el mercado durante el

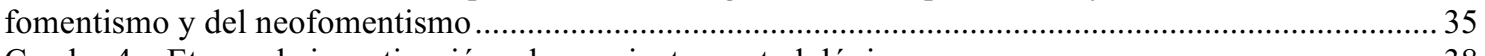

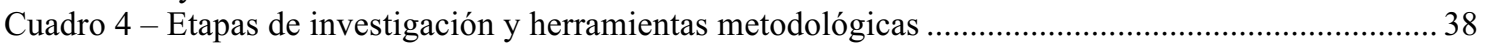

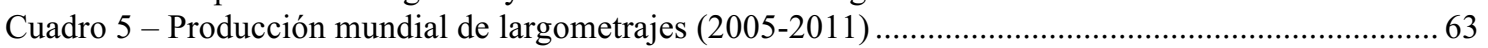

Cuadro 6 - Principales productores de largometrajes a nivel mundial (2005-2011) ...............................64

Cuadro 7 - Nivel de producción cinematográfica, por número de países y películas (2005-2011) ........... 66

Cuadro 8 - Países con mayor número de largometrajes producidos, por participación de mercado

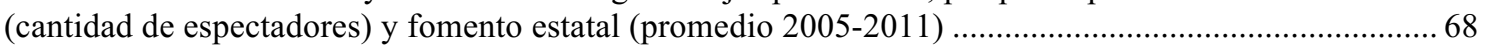

Cuadro 9 - América Latina: cantidad de largometrajes producidos $(2000-2009)$................................. 71

Cuadro 10 - América Latina: costo medio de realización de un largometraje de ficción, en miles de

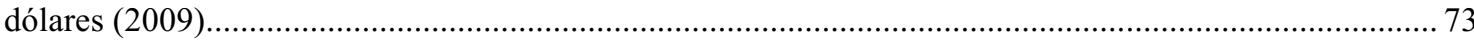

Cuadro 11 - Mercosur y España: participación en las coproducciones realizadas, en porcentajes (2000-

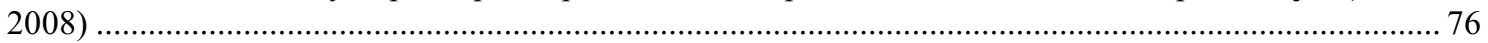

Cuadro 12 - Recaudación total para los 10 mayores mercados, en millones de dólares (2006-2011) .......84

Cuadro 13 - Entrada promedio a nivel mundial, en dólares $(2005-2011)$..........................................85

Cuadro 14 - Top 10 de los países con mayor cantidad de entradas vendidas (2005-2011) ....................86

Cuadro 15 - América Latina: índice de concurrencia anual al cine por persona - media- (2000-2009) 91

Cuadro 16 - América Latina, Estados Unidos, Europa Occidental y Asia: salas, por millón de habitantes

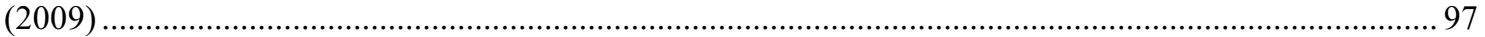

Cuadro 17 - América Latina: filmes nacionales, market share —-media— (2000-2009)........................ 107

Cuadro 18 - América Latina: oferta y demanda de filmes latinoamericanos no nacionales. Cantidad de estrenos y market share — media- (2000-2009) ...................................................................... 107

Cuadro 19 - México: promedio de concurrencia a las películas nacionales, por espectadores (2000-2009)

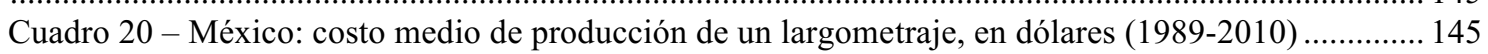

Cuadro 21 - México: estrenos nacionales con más de 2,5 millones de espectadores (2000-2009).......... 146

Cuadro 22 - México: cantidad de largometrajes nacionales estrenados y de títulos nacionales que superaron los 2,5 millones de espectadores (1990-2013) .................................................................. 146

Cuadro 23 - México: porcentaje de mercado de filmes de estreno, por origen (2000-2009)................. 149

Cuadro 24 - México: número de espectadores e índice de concurrencia por habitante (1938-2010) ...... 155

Cuadro 25 - México: concentración en el sector de la exhibición (2000-2013) .................................... 156

Cuadro 26 - Brasil: top 20 filmes brasileños, por cantidad de espectadores (1995-2014) ...................... 200

Cuadro 27 - Brasil: top 10 productoras por monto de apoyo estatal, en dólares (2000-2009)............... 201

Cuadro 28 - Brasil: recursos públicos destinados al cine y al audiovisual, por eslabón de la cadena de

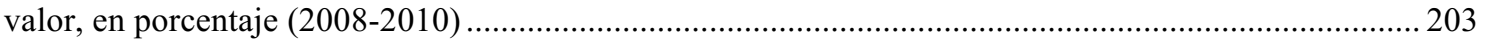

Cuadro 29 - Brasil: cantidad de largometrajes nacionales estrenados y de títulos nacionales que superaron

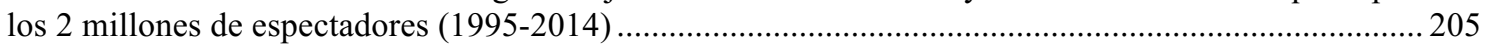

Cuadro 30 - Brasil: cantidad de salas por estados (2013) .............................................................. 211

Cuadro 31 - Brasil: porcentaje de mercado de filmes de estreno, por origen (2000-2009) .....................213

Cuadro 32 - Argentina: productoras con mayores aportes del Incaa (2008-2011)............................... 249

Cuadro 33 - Argentina: top 10 películas argentinas, según espectadores (2001-2009) ........................ 249

Cuadro 34 - Argentina: filmes argentinos que superaron los 1,1 millones de espectadores (1990-2014)253

Cuadro 35 - Argentina: mercado cinematográfico (2009) .................................................................... 254

Cuadro 36 - Mundo, países elegidos: cantidad de cines (1948) .......................................................... 261

Cuadro 37 - Argentina, Brasil, México: índice de concurrencia a los cines (1960-2010) ..................... 266

Cuadro 38 - Argentina, Brasil, México: porcentaje del mercado cinematográfico latinoamericano (2010)

Cuadro 39 - Argentina, Brasil y México: estrenos comerciales latinoamericanos no nacionales, porcentaje

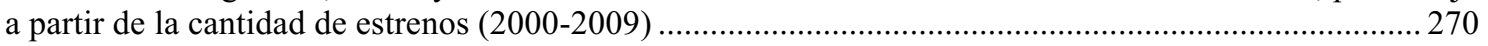
Cuadro 40 - México (1942-1992), Brasil (1969-1990) y Argentina: características del Estado empresario

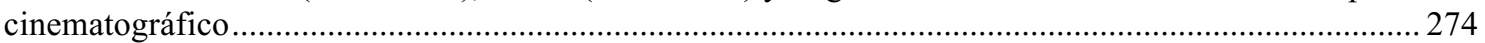
Cuadro 41 - Argentina, Brasil y México: dimensiones históricas y contemporáneas de las políticas públicas y el mercado cinematográficos 280

\section{Lista de gráficos}




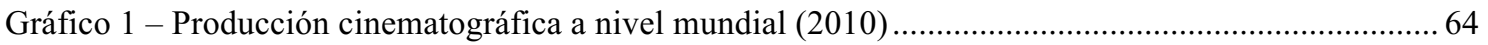

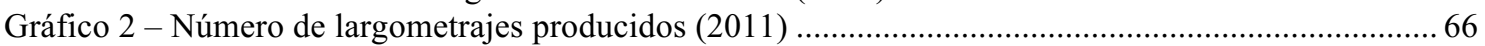

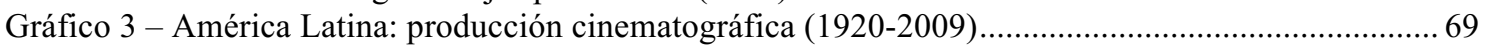

Gráfico 4 - América Latina: cantidad total de largometrajes producidos (2000-2009) ..........................70

Gráfico 5 - América Latina: evolución en la cantidad de largometrajes producidos (2000-2009) ............ 72

Gráfico 6 - Contraste de tendencias entre total de entradas y recaudación a nivel mundial (2005-2011). 85

Gráfico 7 - América Latina: cantidad total de espectadores (2000-2009)............................................ 89

Gráfico 8 - América Latina: evolución en la cantidad de espectadores (2000-2009) .............................90

Gráfico 9 - América Latina: cantidad de espectadores, en millones (1957-2009) ................................92

Gráfico 10 - América Latina: recaudación total, en dólares corrientes (2000-2009) ............................. 92

Gráfico 11 - América Latina: recaudación cinematográfica total, por países, en millones de dólares

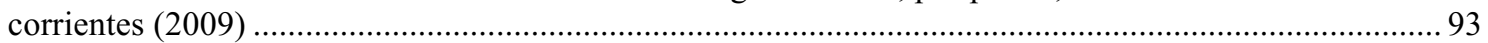

Gráfico 12 - América Latina: precio promedio del boleto de cine, en dólares (2000-2009) ................... 94

Gráfico 13 - América Latina: cantidad de salas de cine $(2000-2009)$..................................................95

Gráfico 14 - América Latina: evolución en el número de salas de cine (2000-2009)............................96

Gráfico 15 - América Latina: cantidad de salas por complejo cinematográfico (2009) ....................... 100

Gráfico 16 - América Latina: salas digitales 2K/3D (2007-2010) ................................................... 101

Gráfico 17 - América Latina: cantidad de butacas de cine (1920-2009)............................................ 102

Gráfico 18 - América Latina: evolución en el número de estrenos comerciales (2000-2009)................ 105

Gráfico 19 - América Latina: evolución en el número de estrenos nacionales (2000-2009).................. 106

Gráfico 20 - América Latina: cantidad de estrenos iberoamericanos no nacionales (2006-2009).......... 108

Gráfico 21 - América Latina: cantidad total de estrenos iberoamericanos no nacionales (2006-2009)... 109

Gráfico 22 - México: filmes producidos (1930-2010) ........................................................................ 139

Gráfico 23 - México: estrenos nacionales y extranjeros (1990-2009) …............................................ 140

Gráfico 24 - México: apoyo del Estado a la producción cinematográfica, en millones de dólares (2001-

2007)

Gráfico 25 - México: presupuesto estatal asignado a la producción fílmica, en millones de dólares (2003-

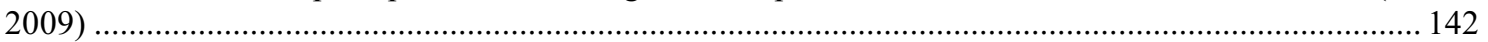

Gráfico 26 - México: estrenos nacionales y porcentaje de mercado por espectadores (1992-2010) ....... 144

Gráfico 27 - México: recaudación de largometrajes estrenados, por origen (2000-2009)...................... 148

Gráfico 28 - México: participación de mercado (espectadores), por distribuidora (2010) ..................... 152

Gráfico 29 - México: cantidad de butacas de cine (1933-2010) .......................................................... 158

Gráfico 30 - México: cantidad total de espectadores cinematográficos (1933-2010).......................... 159

Gráfico 31 - Brasil: porcentaje de mercado de los filmes nacionales, por espectadores (1971-2009).... 182

Gráfico 32 - Brasil: composición del financiamiento público al cine y al audiovisual, en \% del total de recursos (2002-2009)

Gráfico 33 - Brasil: recursos públicos destinados al cine y al audiovisual, en millones de dólares (2000-

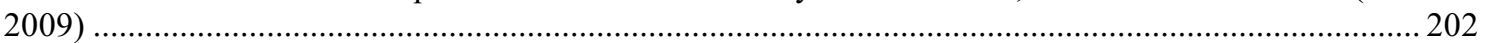

Gráfico 34 - Brasil: porcentaje de espectadores de cine nacional, por productoras (2000-2009) ........... 202

Gráfico 35 - Brasil: cantidad de largometrajes producidos (1936-2009) ........................................... 204

Gráfico 36 - Brasil: market share de distribuidoras, por espectadores (2009)................................... 207

Gráfico 37 - Brasil: distribuidoras nacionales, market share por espectadores (2009)......................... 208

Gráfico 38 - Brasil: cantidad de butacas de cine (1955-2013) ............................................................. 209

Gráfico 39 - Brasil: exhibidoras cinematográficas, porcentaje por público (2009) ............................. 210

Gráfico 40 - Brasil: cantidad total de espectadores cinematográficos (1957-2013) ........................... 212

Gráfico 41 - Brasil: cantidad de espectadores de estrenos extranjeros y nacionales (1971-2009).......... 212

Gráfico 42 - Argentina: número de largometrajes realizados (1971-2010) .......................................... 248

Gráfico 43 - Argentina: presupuesto del Incaa, en millones de pesos (2002-2008)............................ 250

Gráfico 44 - Argentina: montos del fomento estatal, por eslabón de la cadena productiva (2008) ......... 251

Gráfico 45 - Argentina: película argentina media (50.000 espectadores), contribución por medio (2007)

Gráfico 46 - Argentina: cantidad de largometrajes nacionales estrenados y de títulos nacionales que

alcanzaron los 1,1 millones de espectadores (2000-2009) ................................................................. 252

Gráfico 47 - Argentina: cantidad de estrenos comerciales (1971-2009) ............................................... 254

Gráfico 48 - Argentina: número de estrenos nacionales, cantidad de espectadores de filmes extranjeros y

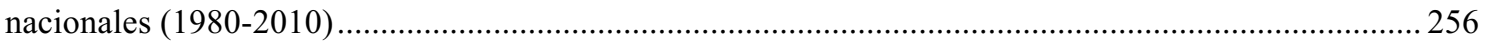

Gráfico 49 - Argentina: porcentaje de mercado de las distribuidoras según origen, por títulos, copias y

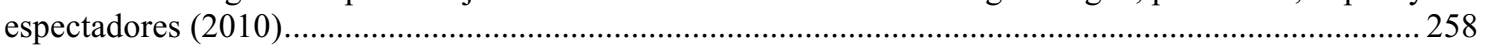

Gráfico 50 - Argentina: porcentaje de mercado de las salas según origen, por espectadores (2000-2010) 
Gráfico 51 - Argentina: porcentaje de mercado de las salas según nacionalidad, por cantidad de pantallas,

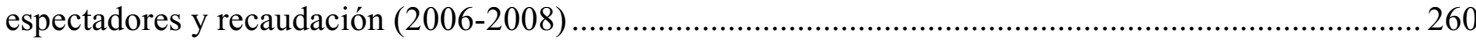

Gráfico 52 - Argentina: cantidad de butacas de cine (1955-2013) ................................................... 261

Gráfico 53 - Argentina, Brasil y México: porción de mercado de los filmes nacionales, en porcentaje

(2001-2009)

265

Gráfico 54 - Argentina, Brasil y México: cantidad total de espectadores (1957-2009)......................... 266

Gráfico 55 - Argentina, Brasil y México: número de butacas (1947-2009)......................................... 267

Gráfico 56 - Argentina, Brasil y México: cantidad de largometrajes producidos (2000-2010).............. 268

Gráfico 57 - Argentina, Brasil y México: estrenos comerciales latinoamericanos no nacionales,

porcentaje a partir de la cantidad de espectadores (2000-2009)

271 


\section{CAPÍTULO I}

\section{Planteo y fundamentación del problema}

El cine, hijo de la revolución industrial, es una industria cultural característica del siglo XX. Adorno señaló cómo el cine era uno de los pocos sectores de la producción cultural donde la inversión capitalista y la división del trabajo había alcanzado una forma avanzada, mientras que otros sectores se caracterizaban todavía por una producción de tipo artesanal (teatro, música, pintura, etc.): en estos últimos casos la individualización de la obra seguía conservando toda su importancia - conceptos vertidos por el pensador alemán en una época donde industrias culturales posteriormente relevantes se encontraban en sus inicios, como la radio, o todavía eran prácticamente desconocidas, como la televisión (Adorno, 1964, citado en Tremblay, 2011).

Del cine, de sus relatos, de su manera de narrar, nacieron las restantes industrias audiovisuales, como la televisión y el video. Sin embargo, a pesar de la masividad de la televisión, del video hogareño, de la creciente penetración de internet y de los dispositivos móviles en el consumo audiovisual, el cine continúa siendo la primera ventana de la cadena de comercialización en la cual una película inicia su recorrido.

La producción audiovisual, y entre sus manifestaciones el cine, asumen significativa importancia en la difusión de la cultura y en la ampliación del comercio internacional. De hecho, el cine es - muchas veces - elevado a la condición de industria de importancia estratégica, teniendo en cuenta la significativa participación que posee en las balanzas comerciales de algunos países, como Estados Unidos, Francia e Inglaterra. Actualmente llega a ser un ítem de importancia en las discusiones bilaterales y multilaterales de los acuerdos comerciales internacionales.

El Estado estuvo presente desde las primeras épocas del cine en su fomento y protección: desde las primeras décadas del siglo XX hasta la actualidad el cine sigue siendo la única industria cultural en el mundo que de manera constante recibe el apoyo y el fomento estatal, siendo Estados Unidos el caso paradigmático: desde hace más de ochenta años este sector es beneficiado en el país del Norte tanto con el apoyo explícito, principalmente, del Departamento de Estado como con múltiples subsidios directos (desgravaciones y exenciones fiscales, pagos diferidos, amortizaciones aceleradas) e indirectos (incontables estrategias y recursos políticas y económicos que presionan a nivel mundial en favor de sus propias empresas), amén de la defensa siempre firme del 
sector que el gobierno estadounidense emprende en toda negociación internacional, tanto a nivel multilateral como bilateral.

La conformación y el desarrollo de la actividad cinematográfica y audiovisual sólo pueden llevarse a cabo con el firme apoyo del Estado, debido a las altas y riesgosas inversiones necesarias que este sector requiere, amén de la concentración oligopólica de la distribución y la exhibición — básicamente, en manos de las majors (Buena Vista, UIP, Warner, Fox, Sony), o de grandes empresas asociadas a éstas-, y de los reducidos mercados que presentan la mayoría de los países. Esto es cierto en todo el mundo, a excepción de Estados Unidos, China y la India, países que cuentan con un enorme mercado interno que hace posible la amortización de sus productos audiovisuales $-\mathrm{y}$, en el caso de Estados Unidos y China, sus industrias de cine también cuentan con apoyo estatal.

En América Latina el apoyo estatal al cine estuvo tempranamente presente en países como Brasil, México, Argentina, Chile y Perú. Los restantes países fueron incorporando algunas medidas de fomento durante el transcurso del siglo $\mathrm{XX}$, como exenciones fiscales o subsidios para alguna etapa de la cadena cinematográfica de valor. Sin embargo, los únicos países que llegaron a constituir una industria cinematográfica fueron Argentina, México y Brasil.

El advenimiento de la televisión y el video hogareño hizo mella en la atracción y la llegada masiva del cine. Pero, fundamentalmente, el gran golpe que recibió el sector cinematográfico en América Latina se produjo durante la neoliberal década de 1990, en un contexto de desregulación y retirada del Estado benefactor: si hasta la década de 1980 países como Argentina, Brasil y México producían decenas de largometrajes anuales, a finales de esa década y comienzos de la siguiente el número de producciones cinematográficas se podía contar con los dedos de la mano.

Sin embargo, durante la primera década del siglo XXI, en el marco de un cambio en el signo político de distintos gobiernos de la región — más alejados del neoliberalismo ortodoxo (como Argentina y Brasil) - la situación general de la mayoría de los mercados cinematográficos y del cine nacional en la región cambió, mejorando en aspectos como el aumento en la cantidad de producciones nacionales —en casi todos los países de la región - y en algunos indicadores de mercado - como el incremento en la cantidad de salas en países como México, Brasil y Colombia, o la suba en el número de espectadores en territorios como México, Brasil, Colombia, Perú y Venezuela-. Este mejoramiento — sobre todo, en el incremento de producciones nacionales - se debió al 
regreso del fomento estatal ("neofomentismo"), mediante distintas variantes (subsidios, incentivos fiscales, créditos blandos, premios, entre otras).

Sin embargo, la situación general en las tres grandes cinematografías latinoamericanas no llega a emular los "años dorados" de mediados del siglo XX ni termina de configurar una "industria", sino un ecosistema fragmentado en el que conviven algunas pocas empresas profesionales con innumerables microemprendimientos sin sustentabilidad, atomizados e inconexos (Getino, 2005), con el peso puesto - tanto desde el sector público como desde el privado - en la producción mas no en la comercialización ni en la exhibición de los filmes nacionales. De esta manera, las políticas "neofomentistas" - un concepto que aporta esta tesis y que se explicará más adelante- no alteran en gran medida en la concentración que se da en todos los eslabones de la cadena de valor. Esta situación se repite en los restantes países de la región.

Esto sucede en el marco de una creciente convergencia digital audiovisual que está cambiando radicalmente a la industria del cine, siendo la década 2000-2009 el período donde este proceso se ha fortalecido: luego de cien años, el celuloide está siendo desplazado en las salas por el formato digital $-\mathrm{y}$, a partir del lobby de Hollywood, por su padrón de facto: el DLP-DCI- ${ }^{1}$ Por otro lado, luego de veinte años de predominio del video como ventana principal de amortización de las majors dentro de Estados Unidos, desde mediados de la década de 2000 este formato bajó sostenidamente su participación a manos de internet y su consumo predominantemente gratuito, ubicuo y en red — sin que ello produzca una monetización significativa para los grandes estudios hollywoodenses-. A su vez, la asistencia a las salas de cine bajó progresivamente en Estados Unidos y se mantuvo, en promedio, estable en América Latina.

En este contexto, las majors han fortalecido distintas estrategias de integración vertical y horizontal de las distintas industrias audiovisuales, y han conformado distintos consorcios — por ejemplo, el Digital Cinema Initiative sobre cine digital, o el Digital Entertainment Content Ecosystem sobre contenidos audiovisuales en la "nube" de internet- para pensar en conjunto distintas estrategias a largo plazo, buscando preservar e incrementar la participación oligopólica y cartelizada que vienen teniendo en la gran mayoría de los mercados cinematográficos mundiales, especialmente desde la década de $1980^{2}$ con el claro apoyo del gobierno estadounidense. ${ }^{3}$

\footnotetext{
${ }^{1}$ Digital Light Processing-Digital Cinema Initiative.

${ }^{2} \mathrm{Sin}$ embargo, la construcción y ejecución de la presencia predominante hollywoodense a nivel mundial puede rastrearse hasta la década de 1910.
} 
Mientras tanto, las agencias nacionales de cine latinoamericanas continúan con normativas y políticas públicas similares a las de hace medio siglo. El neofomentismo es una reparación al neoliberalismo más ortodoxo, pero está lejos del "fomentismo" -participación activa del Estado en la producción, distribución y exhibición cinematográfica entre las décadas de 1940 y 1970 - de las épocas doradas de los cines latinoamericanos -especialmente, mexicano, argentino y brasileño-, como se mostrará en esta tesis, especialmente, en los respectivos capítulos nacionales.

A su vez, estos cambios en la industria cinematográfica se dan en un marco de reacomodamientos en el sistema capitalista mundial que atraviesa a la industria del cine (Wasko, 2011).

La presente tesis busca analizar este neofomentismo (las políticas públicas cinematográficas durante la década de 2000) en México, Argentina y Brasil. Estas políticas públicas comenzaron a mediados de la década de 1990 —en Argentina, con mayor fuerza; tímidamente, en Brasil (basadas en la exención fiscal) y en México (a partir de la aprobación de la nueva ley de cine en 1998, por un impulso decisivo del sector cinematográfico, y de la creación del Fondo de Inversión y Estímulos al Cine)—. Durante la década de 2000 estas políticas estatales de apoyo al cine prosiguieron y se afianzaron, inclusive buscando expandirse a nivel regional — por ejemplo, en los casos de la Conferencia de Autoridades Cinematográficas de Iberoamérica (CACI) y de la Reunión Especializada de Autoridades de Cine y Audiovisual del Mercosur (Recam). Por su parte, el estudio se focaliza en México, Argentina y Brasil porque son los países que poseen mayor historia en la producción, distribución y exhibición cinematográfica en toda América Latina, no sólo al interior de cada país sino a nivel regional. Fueron los países pioneros en la industrialización del cine en el subcontinente, tuvieron star system (alla Hollywood) y sistema de grandes estudios. Y en los casos de México y Brasil, tuvieron las políticas públicas de fomento y regulación cinematográfica más importantes de la región, sin parangón hasta el día de hoy. A su vez, estos tres países representan desde hace la década de 1930 el $80 \%$ promedio de toda la producción cinematográfica latinoamericana. Hablar de ellos es hablar del cine de América Latina.

Para encarar esta investigación la presente tesis se inscribe en la Economía Política de la Comunicación y la Cultura (en adelante, EPCC), campo de estudio que pone en primer lugar de sus investigaciones el proceso social y las relaciones sociales, basado en la idea

\footnotetext{
${ }^{3}$ Obama, en el plan de recuperación económica que lanzó apenas asumió su mandato (la Recovery Act), incluyó el apoyo a la digitalización de las salas de cine.
} 
de que la comunicación es un proceso social de intercambio, en el sentido de que la comunicación y la sociedad están mutuamente constituidas, y de que la tendencia en los análisis políticos-económicos e institucionales es centrarse en cómo la comunicación está socialmente construida, en las fuerzas sociales que son parte en la conformación de los canales de comunicación, y en la multiplicidad de mensajes transmitidos mediante estos canales (Mosco, 2009).

A su vez, el estudio y análisis de las relaciones sociales que realiza la EPCC —en diálogo con el análisis tradicional marxista- presta especial importancia a las relaciones de poder que ocurren, principalmente, en las empresas y gobiernos responsables de la producción, distribución e intercambio de las mercancías de comunicación y de la regulación del mercado de comunicación.

Gran parte de los estudios de la EPCC han abordado la actividad del Estado como productor, distribuidor, consumidor y regulador de la comunicación, surgido principalmente por las presiones para controlar las demandas en conflicto de las empresas nacionales e internacionales en crecimiento. Estas investigaciones se basan tanto en los Estados-nación — que es lo que se abordará en esta tesis-, los bloques regionales y la organización de instancias gubernamentales multilaterales.

A su vez, son relativamente pocos los estudios que analizan en clave comparada las políticas cinematográficas en América Latina: se destaca el esfuerzo pionero de Octavio Getino (1984, 1987, 1998, 2005) y el trabajo de Edwin Harvey (2005), más algunos informes que tocan tangencialmente la temática (Rey, 2005; Sandoval Peña, 2003), sin olvidar algunas tesis de maestría y doctorado que comenzaron a incluir este tópico en Iberoamérica y el Mercosur —aunque buceando en los genéricos términos del "audiovisual" o de la "integración"- a lo largo de la década de 2000 (Motta da Silva, 2003; Gómez García, 2006; De Mora, 2009; Moguillansky, 2011).

En esta área de vacancia, el abordaje de la presente tesis recortará la problemática referida a las políticas públicas cinematográficas en Argentina, Brasil y México, considerando a tales fines las relaciones de poder que se expresan en la cadena de valor (producción, distribución y exhibición). 


\section{Objeto de estudio}

La presente tesis de doctorado se centra en las políticas públicas cinematográficas en México, Argentina y Brasil en el período 2000-2009, en el contexto de la concentración económica en el sector.

Se estudiará exclusivamente al cine y no a la relación de éste con la televisión, el video u otras ventanas de exhibición, ni se estudiará la convergencia audiovisual.

A su vez, esta investigación buscará incorporar las prácticas de los agentes involucrados en el sector (directores, productores, técnicos varios, distribuidores, exhibidores y funcionarios, entre otros), además de los resultados de mercado para, entre todos, analizar en contexto a las normativas.

El cine en América Latina durante este período se caracterizó por la vuelta del apoyo estatal al cine (neofomentismo) - luego del desmantelamiento de las ayudas públicas a este sector hacia finales de la década de 1980 y comienzos de la de 1990—, con el énfasis puesto en la producción.

Por otra parte, el sector cinematográfico en América Latina sólo puede existir por el fomento estatal, teniendo nula recuperación de los costos a través de la taquilla en sus respectivos mercados nacionales $-\mathrm{y}$ menos aún, en los mercados internacionales, donde casi no circula.

A esta situación se suma la posición oligopólica en el mercado de la distribución y la exhibición por parte de las majors de Hollywood - tanto en Estados Unidos como en el resto del mundo (salvo contadas excepciones, como China e India) - y los importantes cambios tecnológicos acaecidos durante la última década - especialmente, la convergencia entre las distintas ventanas de exhibición (salas, televisión, video, internet, dispositivos móviles) y la digitalización de la distribución y la exhibición.

Sin embargo, en América Latina - y, en especial, en los países analizados (México, Argentina y Brasil) — las políticas públicas en este sector se enfocaron exclusivamente en el cine. Recién a finales de la década de 2000 se comenzaron a dar algunos intentos por pensar políticas públicas "audiovisuales" —específicamente, que construyan mayores sinergias entre el cine y la televisión- : tales son los casos en Argentina - a partir de la sanción de la Ley de Servicios de Comunicación Audiovisual, en 2009, junto con los concursos de contenidos para TV Digital lanzados en 2010 y coordinados desde el instituto de cine nacional-y en Brasil — con la sanción, en 2011, de la nueva legislación sobre TV paga (que estipula cuotas de producción y pantalla destinadas a audiovisuales nacionales, con nuevos tributos a ser manejados por la agencia nacional 
de cine)—. Pero como hasta el momento no pueden vislumbrarse cambios sustantivos en esa potencial convergencia entre cine y televisión debido al poco tiempo transcurrido, se prefirió poner el foco exclusivamente en el cine, ya que existen décadas de experiencia en la materia, y la primera década del siglo XXI muy probablemente será la última en que las políticas públicas de cine latinoamericanas hayan estado enfocadas de manera exclusiva, precisamente, al séptimo arte.

\section{Objetivos}

\section{Objetivo general:}

Analizar comparativamente las políticas públicas cinematográficas en Argentina, Brasil y México en el período 2000-2009 a fin de establecer líneas de continuidad y ruptura en los casos analizados, y producir interpretaciones desde el punto de vista del concepto del neofomentismo, introducido en esta tesis.

\section{Objetivos especificos:}

-Analizar las políticas públicas cinematográficas y los mercados de cada uno de los países estudiados — poniendo especial énfasis en la distribución y la exhibición.

-Examinar comparativamente el comportamiento de las agencias nacionales de cine en Argentina, Brasil y México - tanto a nivel diacrónico (en especial, entre la década de 1990 y la de 2000) como a nivel nacional entre las agencias de los tres países referidos.

-Realizar un estudio comparativo sobre políticas públicas cinematográficas de países referentes en la materia, tales como Francia, el Reino Unido y España.

-Explicar los principales eslabones de la cadena de valor cinematográfica (producción, distribución y exhibición) en los países analizados.

-Trazar las condiciones de producción que se dan en el ámbito cinematográfico de los países analizados a partir de la década de 1990. 


\section{Hipótesis de trabajo}

La hipótesis central es:

El neofomentismo, es decir, las políticas públicas cinematográficas en Argentina, Brasil y México llevadas a cabo durante la primera década del siglo XXI, aplicadas por la presión del sector, no son una continuación del fomentismo -políticas cinematográficas de un Estado activo en la industria-, sino políticas públicas defensivas -medidas que tienden a apoyar especialmente la producción, sin alterar las relaciones de poder en el sector, a diferencia de lo que ocurría durante el Estado fomentista: políticas que promovían por igual a los tres eslabones de la industria (producción, distribución y exhibición), con empresas estatales y normativas decididas (como cuotas de pantalla de cerca del 50\% del tiempo de pantalla).

Las hipótesis secundarias son:

El neofomentismo es una reparación al desmonte del fomentismo —participación activa del Estado en la producción, distribución y exhibición cinematográfica entre las décadas de 1940 y 1970 - de las épocas doradas de los cines latinoamericanos —especialmente, mexicano y brasileño.

El neofomentismo se centra casi exclusivamente en la producción, dejando librados al mercado desregulado y globalizado los eslabones de la distribución y la exhibición.

La producción cinematográfica bajo el neofomentismo aún no es sustentable, a pesar del incremento en las ayudas estatales, del crecimiento en el número de filmes producidos y de la expansión de los mercados cinematográficos nacionales. 
Cuadro 1 - Hipótesis, variables y operacionalización

\begin{tabular}{|c|c|c|}
\hline Hipótesis & Variables & Operacionalización \\
\hline $\begin{array}{l}\text { Hipotesis 1) } \\
\text { Neofomentismo, distinto al fomentismo } \\
\text { (Estado cinematográfico empresario). }\end{array}$ & $\begin{array}{l}\text { 1.1. Políticas de Estado. } \\
\text { 1.2. Marcos jurídicos de cada país. } \\
\text { 1.3. Mercado (actual y anterior a 1990). }\end{array}$ & $\begin{array}{l}\text { 1.1.1. Acciones impulsadas por el } \\
\text { Estado. } \\
\text { 1.2.1. Especificación de la normativa } \\
\text { sobre recursos, incentivos fiscales, } \\
\text { beneficios, protección (cuota de } \\
\text { pantalla), etcétera. } \\
\begin{array}{l}\text { 1.3.1. Cantidad de espectadores, } \\
\text { recaudación, frecuencia de asistencia } \\
\text { habitante/año, precio de la entrada, } \\
\text { porcentaje de mercado de filmes } \\
\text { nacionales y extranjeros, asistencia por } \\
\text { exhibidoras, región, entre otros). }\end{array}\end{array}$ \\
\hline $\begin{array}{l}\text { Hipótesis 2) } \\
\text { Neofomentismo es reparación al } \\
\text { desmonte del fomentismo. }\end{array}$ & $\begin{array}{l}\text { 2.1. Políticas de Estado. } \\
\text { 2.2. Marcos jurídicos de cada país. } \\
\text { 2.3. Mercado. }\end{array}$ & 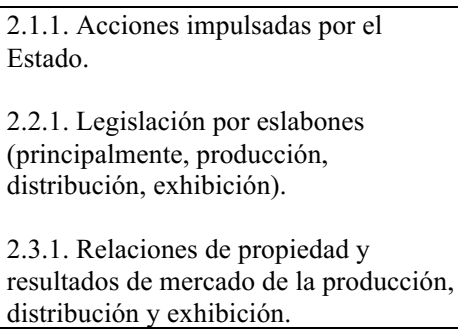 \\
\hline $\begin{array}{l}\text { Hipótesis } 3 \text { ) } \\
\text { Fomento estatal al cine, concentrado en } \\
\text { la producción. }\end{array}$ & $\begin{array}{l}\text { 3.1. Marcos jurídicos de cada país. } \\
\text { 3.2. Producción. }\end{array}$ & $\begin{array}{l}\text { 3.1.1. Legislación por eslabones } \\
\text { (principalmente, producción, } \\
\text { distribución, exhibición). } \\
\text { 3.1.2. Montos de las distintas líneas de } \\
\text { fomento estatal al cine. } \\
\text { 3.2.1. Producción: relaciones de } \\
\text { propiedad, largometrajes producidos, } \\
\text { costo medio de producción, } \\
\text { amortización, etcétera. }\end{array}$ \\
\hline $\begin{array}{l}\text { Hipótesis 4) } \\
\text { La producción cinematográfica en los } \\
\text { tres países analizados no es sustentable, a } \\
\text { pesar de las ayudas estatales y del } \\
\text { mercado en expansión. }\end{array}$ & $\begin{array}{l}\text { 4.1. Marcos jurídicos de cada país. } \\
\text { 4.2. Producción. } \\
\text { 4.3. Mercado. }\end{array}$ & $\begin{array}{l}\text { 4.1.1. Legislación por eslabones } \\
\text { (principalmente, producción, } \\
\text { distribución, exhibición). } \\
\text { 4.2.1. Producción: relaciones de } \\
\text { propiedad, largometrajes producidos, } \\
\text { costo medio de producción, } \\
\text { amortización, etcétera. } \\
\text { 4.3.1. Relaciones de propiedad y } \\
\text { resultados de mercado de la producción, } \\
\text { distribución y exhibición. }\end{array}$ \\
\hline
\end{tabular}

La presente tesis trabajó a partir de este esquema metodológico para comparar, principalmente, las políticas públicas cinematográficas en México, Brasil y Argentina — también se compararon las cadenas de valor y los mercados cinematográficos.

Para una mejor presentación de los casos se agruparon las variables de la siguiente manera:

- aspectos generales: se incluyen datos generales del país tales como superficie, población, Producto Bruto Interno (PBI), Índice de Desarrollo Humano (IDH), forma de gobierno, etcétera;

- antecedentes: reseña histórico-política del sector cinematográfico de cada país analizado; 
- estructura institucional: estructura actual y principales modificaciones acontecidas en la estructura institucional pública destinada al fomento de la cinematografía entre el período 2000-2009 y los años anteriores (especialmente, en las denominadas “épocas de oro” de México y Brasil);

- marco jurídico: presentación y análisis de la legislación sobre cinematografía desde los inicios de la actividad hasta la actualidad (con énfasis en el período 2000-2009);

- cadena de valor: relaciones de propiedad y concentración en los principales eslabones de la cadena de valor cinematográfica (producción, distribución, exhibición), y

- consumo: esta variable tiene en cuenta la relación entre oferta y demanda de las cinematografías de los países analizados, y las características de sus mercados cinematográficos.

\section{Fundamentos teóricos}

Esta tesis aborda la problemática referida a las políticas públicas cinematográficas, teniendo en cuenta las relaciones de poder que se expresan en el sistema de producción y comercialización del sector cinematográfico.

Para ello, la tesis se enmarca en las formulaciones teóricas realizadas por la ya mencionada EPCC.

La EPCC estudia el rol del poder en la producción, en la distribución —especialmente, en este punto (Pendakur, 1990, 2003; Balio, 1993; Curtin, 2011; Wasko, 2011) - y en el intercambio de la comunicación mediada, analizando las relaciones sociales, las estructuras del poder, el proceso por el cual los mensajes se transforman en mercancías y las relaciones entre producción material y producción intelectual. A nivel más básico, la EPCC estudia la manera en que la comunicación y la cultura forman parte del proceso de acumulación de capital, de la estratificación y las desigualdades de clases y de las relaciones entre los centros de poder político y los centros de poder económico (Guback, 1980; Pendakur, 1990; Wasko, 2003; Miller, 2004; Getino, 2005; Sánchez Ruiz, 2006).

Estos procesos afectan no sólo al campo de la comunicación sino de la economía política a nivel global, en vista del incremento en la importación de la comunicación y del crecimiento de los conglomerados multimediáticos transnacionales - que cada vez más poseen mayor control sobre los sistemas de comunicación-(Wasko, 1994, 2003, 
2004; Miller, 2004; Vaughan, 2011). Así, la investigación de este campo atraviesa distintas corporaciones nacionales y multinacionales (empresarias, institucionales, sindicales), organismos gubernamentales y formaciones de clase presentes en los poderes locales y globales.

La economía política debe ser una herramienta que colabore en la praxis de la investigación científica (Mosco, 2009) para, por ejemplo, poner en cuestión la eficiencia de los mercados, la libre competencia, la globalización, entre otras (Guback, 1980; Wasko, 2004), situando - en el caso de esta tesis - al sector del cine como parte de la industria de la comunicación y de las desiguales relaciones sociales y políticas (Wasko, 2004), analizando — por ejemplo- el predominio oligopólico de las majors de Hollywood (Wasko, 2003; McMurria, 2007; Vaughan, 2011), la participación del gobierno estadounidense en la construcción y el sostenimiento de ese oligopolio (Guback, 1980; Wasko, 1994, 2003; Vaughan, 2011), las consecuencias de ese predominio para las cinematografías de otros países, las acciones tomadas por esos países para hacer frente a esa situación (Guback, 1980; Pendakur, 1990; Sánchez Ruiz, 1992, 2000, 2001, 2006; O'Regan, 1996; Curtin, 2011; Trejo, 2009) y las consecuencias políticas, económicas, ideológicas y culturales que de ello se derivan, no sólo describiendo el estado de la industria del cine y de sus políticas públicas, sino también analizando las estructuras de poder en el marco de la sociedad capitalista contemporánea en las que se inserta este sector.

En lo que hace concretamente a la industria internacional del cine, ésta se haya controlada - a excepción de China y la India - por un reducido número de grandes multinacionales, las que, a su vez, son las mismas empresas que actúan en el terreno de la comunicación y los medios, elaborando continuamente sinergias que atraviesan las distintas ventanas de exhibición, los eslabones de la cadena audiovisual — desde la producción hasta el marketing - y sus compañías conglomeradas — de audiovisual, gráfica, merchandising, conciertos y/o presentaciones, etcétera- (Wasko, 1994, 2003, 2004; Pendakur, 2003; Miller, 2004; Getino, 2005; Sánchez Ruiz, 2006; Vaughan, 2011).

En este sentido, observar la expansión del cine a nivel mundial — sobre todo, de Hollywood- ${ }^{4}$ es observar la evolución contemporánea de la globalización (Wasko, 2004).

\footnotetext{
${ }^{4}$ Desde mediados de la década de 1910 ya se vislumbraban técnicas de comercialización globales, con decidido apoyo gubernamental (Guback, 1980).
} 
Según la economía política del cine $-\mathrm{y}$ según postula esta tesis - las películas son mercancías producidas y distribuidas dentro de una estructura industrial capitalista (Guback, 1980; Wasko, 1982, 1994, 2003, 2011), concentrada, con una asimétrica división internacional del trabajo audiovisual (Miller y Yúdice, 2004, se refieren a la "nueva división internacional del trabajo cultural"), en el marco de relaciones de poder dentro del sistema cultural y político, con el agregado de que el cine es a la vez producto y servicio intangible (Pendakur, 1990), importante no sólo por su valor de cambio sino por su valor cultural (Pendakur, 2003; Getino, 1987, 2005) —en cuanto elemento trascendente en la constitución de la identidad y la cultura de los pueblos.

Si bien esta tesis se centra en las políticas públicas, no se basará en teorías como la de la “elección pública” o de las "expectativas racionales" (Mosco, 2009), inmersas en el paradigma neoclásico, comúnmente denominado neoliberal —que tienen como norte al mercado, la elección individual y el interés privado.

Y, a su vez, si bien uno de los abordajes sobre el cine de la presente tesis se basará en la perspectiva económica, ello no se hará a partir de análisis econométricos ni de estudios de organización industrial o institucional - los que, al igual que las teorías de la elección pública, abrevan en el paradigma neoliberal con un tecnicismo descriptivo que no problematiza factores como el poder o la propiedad.

\section{Economía política: aproximación al campo}

La economía política presta especial atención a la descripción y al análisis del capitalismo -es decir, a la cosificación de recursos como los trabajadores, la tierra, las materias primas, la información, en su conversión en mercancías comerciables que producen un beneficio que es apropiado por quienes invierten en el sistema.

La EPCC analiza cómo la comunicación y la cultura participan del proceso de acumulación del capital, abarcando distintas temáticas referidas a las relaciones de poder que atraviesan el sistema cultural, a las condiciones de producción, distribución, intercambio y consumo de las industrias culturales, a la estructura económica de los medios, teniendo como contexto las relaciones entre los centros de poder político y los centros de poder económico y las relaciones entre producción material, producción intelectual y las políticas de comunicación (Herscovici, Bolaño y Mastrini, 1999).

Algunas de las áreas de análisis en las que se especializa la EPCC son la producción de bienes culturales (patrones de propiedad de los medios y sus consecuencias en la 
producción de mensajes, así como las relaciones entre las regulaciones del Estado y los medios), la economía política del contenido de los medios (análisis acerca de cómo los factores económicos condicionan los géneros, las formas y los contenidos de los mensajes) y la economía política del consumo cultural (analizar los factores que determinan los procesos de selección de los mensajes por parte de los consumidores), entre otros (Hinojosa, 2014).

Los primeros aportes de la EPCC al campo de la comunicación fueron realizados, principalmente, a lo largo de las décadas de 1950 y de 1960, por parte de investigadores que podrían agruparse en tres grupos: los estadounidenses — con referentes como Dallas Smythe y Herbert Schiller (que continuaron a Paul Baran y Paul Sweezy)—, los europeos — con los británicos Nicholas Garnham, Graham Murdock y Peter Golding, y los franceses Bernard Miège, Patrice Flichy y Dominique Leroy-y los investigadores de otras regiones del mundo (Mosco, 2010).

Los investigadores estadounidenses se destacaron por estudiar el funcionamiento de los medios en torno a la macroeconomía del sistema capitalista. Sus investigaciones no fueron estrictamente económicas, sino que buscaron establecer relaciones entre las dimensiones económicas e ideológicas de los medios de comunicación, en el contexto de la estructura económica y política internacional.

Dallas Smythe — uno de los pioneros de la economía política de la comunicación — fue funcionario del gobierno estadounidense antes de entrar a la academia, desde donde se dedicó a estudiar principalmente los medios públicos, el control estatal sobre las redes de comunicación satelitales y la desmilitarización de las comunicaciones globales, siendo uno de los impulsores de los estudios y debates sobre el Nuevo Orden Mundial de la Información y la Comunicación (Nomic).

Herbert Schiller — perteneciente a la generación posterior a Smythe- hizo confluir en sus trabajos las definiciones de Althusser — referidas a los aparatos ideológicos del Estado-, la filosofía de Paulo Freire y la postura en contra del conductismo. También apoyó decididamente los estudios sobre el desarrollo de las políticas nacionales de comunicación en América Latina, Asia y África.

Los pioneros Smythe y Schiller — que fueron formadores de varias generaciones de estudiosos del campo de la EPCC - enfocaron sus estudios en el crecimiento del tamaño y el poder de los espacios empresariales multinacionales de medios, tanto en Estados Unidos como en todo el mundo, abordando sus investigaciones a través del concepto de clase social y del imperialismo mediático, produciendo amplia literatura 
sobre las transnacionales de medios y el rol del Estado. También fueron militantes en pos de una comunicación alternativa, que exceda la mera lógica comercial.

La rama europea, a diferencia de la estadounidense, puso mayor énfasis en elaborar aparatos teóricos dentro del ámbito de la EPCC, buscando estudiar la gran expansión e integración de la industria de la comunicación a nivel global, su conexión con los distintos Estados, y las distintas integraciones entre el ámbito público y privado en el contexto capitalista. Sintéticamente, esta rama se caracterizó por su posición acerca de que los medios refuerzan las divisiones de clase y ayudan a construir solidaridad dentro de la clase dominante.

Los investigadores europeos de la EPCC, al igual que en el caso estadounidense, fueron también militantes en pos de una comunicación alternativa, aunque en el caso europeo, estuvieron muy ligados a la defensa de los medios públicos.

Nicholas Garnham — quien trabajó en la industria de los medios (fue director en la BBC) - y Graham Murdock se destacaron en la constitución de la EPCC. Ellos pusieron el énfasis en estudiar el poder de la clase y las inequidades sociales, teniendo influencia tanto de la Escuela de Frankfurt como de Raymond Williams.

En la escuela inglesa de la EPCC también se destacaron Peter Golding y Kevin Robins, entre otros. Golding coescribió con Murdock, el clásico de 1974 For a Political Economy of Mass Communications —allí analizaban las determinaciones mutuas entre las dimensiones ideológica, económica y política-, mientras que Robins coescribió junto a Asu Aksoy otro clásico: el paper de 1992 "Hollywood for the 21st Century: Global Competition for Critical Mass in Image Markets", con el cual protagonizaron el debate acerca del posfordismo en las industrias culturales —especialmente, en el ámbito audiovisual.

En Francia los estudios de la EPCC se conformaron en torno al Groupe de Recherches sur les Enjeux de la Communication (Gresec) fundado en 1978 en Grenoble, en la Universidad Stendhal, por los economistas Bernard Miège e Yves de la Haye. Posteriormente se incorporarían Patrice Flichy y Dominique Leroy.

Este espacio realiza un análisis centrado más en la economía de los medios, sin poner tanto el acento en la ideología o en las instituciones. En el ámbito de influencia de esta escuela francesa de la EPCC puede situarse a los españoles Enrique Bustamante (Universidad Complutense) y Ramón Zallo (Universidad del País Vasco).

Desde una perspectiva clasista, Miège ofrece una valoración de los procesos de trabajo en el marco de las diferentes formas de la producción mediática dentro de la lógica 
capitalista: sugiere que hay una conexión entre el tipo del producto mediático, la estructura del control corporativo y la naturaleza del proceso de trabajo.

Armand Mattelart, sin pertenecer a la EPCC ni al Gresec, también es un prominente investigador francés — contemporáneo de los investigadores del Gresec- de la comunicación y la cultura en el contexto de la lucha de clases, tanto en Europa como en América Latina y África.

Por su parte, la investigación de la EPCC en el llamado "Tercer Mundo" — es decir, regiones y países allende Estados Unidos, Europa Occidental, Japón, Australia y Nueva Zelanda- cubrió un importante arco de intereses, siendo la corriente más extendida la que surgió en respuesta al paradigma desarrollista — surgido en Occidente (también llamado modernizador), que intentaba situar a la comunicación en consonancia con la ideología dominante (básicamente, este paradigma sostenía que los medios eran recursos que, junto a la urbanización, la educación y otras dimensiones sociales, estimulaban la modernización y el progreso económico, social y cultural; de esta manera, este paradigma veía el crecimiento de los medios como una señal de desarrollo).

Los investigadores "tercermundistas" de la EPCC cuestionaron fuertemente la premisa desarrollista, fundamentalmente por su determinismo tecnológico y por la recurrente omisión de todo lo que tuviera que ver con relaciones de clase y de poder imbuidas en los intercambios económicos y sociales entre los países desarrollados y los que están en vías de desarrollo (Mosco, 2010). Desde la década de 1960 los economistas políticos de estas regiones se basaron, fundamentalmente, en las teorías de la dependencia, de los sistemas y, posteriormente, de distintas corrientes neomarxistas — es decir, de teóricos y conceptos que, partiendo de relecturas sobre El Capital y el corpus del pensamiento marxista tradicional, protagonizaron debates menos centrados en la concentración económica y más orientados hacia los modos de regulación, la organización industrial, los mercados mundiales y la reformulación de la tecnología y los procesos de producción y trabajo (flexibilización, posfordismo).

En América Latina distintos economistas políticos de la comunicación, como Enrique Sánchez Ruiz, César Bolaño, Delia Crovi, Guillermo Mastrini, Martín Becerra y Rodrigo Gómez, entre otros, se dedicaron especialmente a estudiar las estructuras y las prácticas de los medios y sus consumos, poniendo especial énfasis en contextualizar las relaciones de poder en el subcontinente más desigual del mundo, las desigualdades de clase y la estratificación social, así como también en analizar las resistencias y 
apropiaciones realizadas por variados actores y colectivos sociales en el ámbito comunicacional y cultural.

En África y en Asia distintos investigadores de la EPCC trabajaron temáticas como la cultura popular, las nuevas tecnologías y las industrias de medios, realizando importantes críticas a las consecuencias del colonialismo, los sistemas de medios neocoloniales y la nueva división internacional del trabajo en el ámbito de la informática, todo ello dependiente del outsorcing realizado por los capitalistas de los países centrales en su búsqueda de "reducción de costos" a partir de bajos salarios y muy escasos derechos laborales, sociales y ambientales —especialmente, en el caso asiático (donde los defensores del modelo desarrollista suelen poner a esta región como un ejemplo de éxito)—. Se destacan autores como S.T. Kwame Boafo, Tessa Morris-Suzuki, F.O. Ugboajah, Jeong-Taik Lee y Luke Uke Uche, entre otros, todos ellos bregando por el desarrollo de formas populares de resistencia e intervención en el ámbito político (Mosco, 2010).

\section{La economía política y otros espacios teóricos}

La EPCC es un campo de reflexiones que construyó su identidad a partir de relaciones controversiales con otras corrientes, escuelas y teorías, especialmente con los estudios culturales.

A partir de la década de 1950 los investigadores que comienzan a abrevar en la EPCC van constituyendo las definiciones fundamentales del campo. A través de su historia, la EPCC se caracterizará fundamentalmente en la oposición al funcionalismo imperante en las ciencias sociales estadounidenses de la época, en el distanciamiento de la Escuela de Frankfurt y —en lo que hace al estudio del Estado - en la crítica a la teoría de la elección pública.

El funcionalismo — con el sociólogo Paul Lazarsfeld como su principal referente — veía a la sociedad como un agregado de intereses y grupos en el que las empresas de medios eran sistemas organizacionales —entidades independientes controladas por una elite-, con grandes márgenes de autonomía con respecto al Estado, a los partidos políticos y a los distintos grupos de presión.

Por el contrario, la economía política de la comunicación pondrá el énfasis en analizar la estructura económica en el campo comunicacional, cuestionando el traslado 
mecanicista - de origen conductista - de los efectos de los medios sobre las audiencias.

En lo que hace a la Escuela de Frankfurt, los investigadores adscriptos a la EPCC fueron alejándose de esa corriente, criticándole una adscripción lineal al modelo basesuperestructura y una falta de atención en las relaciones económicas en el proceso de significación (Mosco, 2009).

Sin embargo, Garnham (1979) señala una contradicción en esta posición, observando que fueron Adorno y Horkheimer los que percibieron en un primer momento las transformaciones ocurridas en el capitalismo monopólico debido a la industrialización de la superestructura y a su invasión por parte de la estructura. El investigador inglés se refiere a "la exactitud de esta intuición original" de los mencionados autores frankfurtianos cuando señalan, por ejemplo, las relaciones de subordinación que se dan en los monopolios de la cultura para con otros monopolios industriales - de mayor peso y poder-, presionando a los primeros a someterse a las lógicas del mercado. Teniendo en cuenta estas salvedades, las críticas de la EPCC a la Escuela de Frankfurt se centraron en la ausencia de un análisis específico de la noción de clase y en la desestimación que operó esta corriente intelectual respecto a la naturaleza económica de las industrias culturales.

Con respecto a los estudios culturales, la EPCC estuvo más relacionada con el grupo de Leicester - enfocado en la preponderancia del Estado y las estructuras de mercadoque con el grupo de Birmingham —dedicado más a la exploración antropológica y discursiva de la cultura y los medios, y criticado por la EPCC por soslayar tópicos como clase y poder (Mosco, 2010).

Los estudios culturales se nutren de distintas disciplinas, en especial de la crítica literaria, la hermenéutica y de ramas del estructuralismo $-\mathrm{y}$ del posestructuralismocentrándose en el análisis textual y del discurso. Los estudios culturales hicieron una crítica importante de la ciencia tradicional —especialmente, de las vertientes conductistas y funcionalistas.

A su vez, los estudios culturales postulan la autonomía de los niveles ideológico y político por sobre el económico en el proceso de producción social de significaciones, algo que la EPCC rechaza. Aunque parten de una matriz marxista, los estudios culturales "entienden a los medios de comunicación como instrumentos del dominio de las clases en el poder" (Garnham, 1979:130), sin problematizar la relación basesuperestructura y abordando el concepto de poder a partir de las subjetividades 
individuales, sus identidades y la acción colectiva, a diferencia de la economía política, que sitúa al poder en el centro del análisis social, estructurado en las instituciones de la sociedad.

En lo que hace a los estudios sobre políticas públicas, éstos se basan en las distintas investigaciones sobre ciencia política, economía y economía política institucional —es decir, liberal-. Un ala principal del enfoque de los estudios sobre políticas públicas es la teoría de la elección pública (public choice), conocida también como el enfoque de las expectativas racionales: esta teoría - que tiene como referentes a Buchanan, Posner y Stigler - se basa en la vertiente conservadora de la teoría económica, buscando crear una ciencia sobre las políticas públicas. A diferencia de los estudios culturales, la teoría de la elección pública utiliza mayormente los modelos de la sociedad basados en el mercado, la elección individual y el auto-interés privado, primando una postura conservadora (Mosco, 2010).

La economía política comparte con la teoría de la elección pública el interés en expandir el análisis sobre la totalidad social, especialmente, sobre la transformación social. Sin embargo, la economía política se despega fundamentalmente de la teoría de la elección pública cuando ésta sostiene un análisis político pluralista que ve al estado como un árbitro independiente envuelto dentro del marco de fuerzas sociales confrontativas, ninguna de las cuales - incluyendo al mercado - tiene la fuerza suficiente para dominar la sociedad (Mosco, 2009).

Por el contrario, la economía política insiste en tener como un punto central del análisis social al poder del mercado y al proceso de mercantilización. Además, la economía política rechaza la postura de la elección pública en construir su análisis de la totalidad social, y de aquellos valores que deberían guiar su transformación -basados en el individualismo y en la "racionalidad" del mercado, según esta corriente.

La economía política trabaja en el análisis de los procesos sociales — con centro en la clase social, el trabajo y el poder-, valorando la comunidad y la vida pública en contraposición a los enfoques en pro del mercado y de la supuesta racionalidad de éste - que, desde una perspectiva de la economía política, en realidad reproduce el poder clasista (Mosco, 2010:20). 


\section{La economía política y el cine}

Georges Sadoul es uno de los máximos exponentes de la historiografía clásica del cine. Él afirmaba que el estudio de este arte es "imposible" sin tener en cuenta el aspecto industrial (Sadoul, 2004:46-49). Sin embargo, durante mucho tiempo estos estudios no se llevaron a la práctica, debido a que los estudios de historia del cine se concentraban mayormente en la conformación del canon del llamado "séptimo arte". Los aspectos económicos, inclusive aquellos más relacionados a la producción, no pasaban de menciones en aquellos estudios que Michèle Lagny llamaba irónicamente la "historia panteón" - es decir, la historia del cine que giraba prioritariamente en torno a la elección de grandes películas y directores (Lagny, 1997: 136).

Jean Mitry, con su Histoire du cinéma, fue de alguna manera una excepción: en este libro, que tenía el subtítulo de Art e industrie, sí prestaba atención a la economía, pero siguiendo el enciclopedismo de la historiografía clásica — por lo que termina cayendo en la práctica de citar largas listas con nombres de empresas y personas de distintos países, pero sin una mayor contextualización sobre los procesos históricos (Autran, 2005: 1).

Recién a partir de la década de 1970 la literatura historiográfica y sociológica sobre la economía cinematográfica se desarrolló, mediante la contribución de autores como Thomas Guback o, más recientemente, David Bordwell, entre otros.

La economía política del cine sigue siendo la cenicienta en los estudios de comunicación - $-\mathrm{y}$, más aún, de cine- - Sin embargo, este campo ya tiene sus "padres fundadores" y sus grandes referentes en Thomas Guback - y su trabajo pionero en este subcampo, La industria internacional del cine-, en Janet Wasko y en el investigador indio Manjunath Pendakur.

Estos autores, básicamente buscaron abordar al gran polo industrial cinematográfico de influencia mundial (Hollywood) en cuanto proceso de producción y distribución de commodities dentro de un sistema capitalista, analizando las implicaciones políticas, sociales y culturales de ese proceso.

La economía política del cine busca estudiar cómo las películas estadounidenses (especialmente, las provenientes de Hollywood) consiguen dominar el mercado cinematográfico internacional desde hace décadas; qué mecanismos se fueron utilizando a lo largo de todo este tiempo para conservar y reforzar este predominio; cómo el Gobierno de Estados Unidos se involucró en esta política desde hace casi un siglo; 
cómo la exportación de películas está relacionada con la comercialización de otros productos mediáticos, y qué consecuencias políticas y culturales se derivan de todo este proceso para los sectores cinematográficos de otros países.

Como señala Janet Wasko sobre la economía política del cine:

La economía política representa una perspectiva diferente y distinta del estudio del cine, aunque no haya recibido el reconocimiento debido en el campo de los estudios fílmicos (...) Es muy importante destacar la relevancia de las implicaciones políticas e ideológicas de las estrategias económicas, pues no en vano el cine debe también enmarcarse dentro del contexto social, económico y político general, y debe ser criticado en la medida en que contribuye a mantener y reproducir las estructuras de poder. (Wasko, 2006:101-202)

El mencionado Thomas Guback fue el investigador que impulsó el desarrollo de la economía política del cine con su investigación publicada en 1969 (la citada La economía internacional del cine), en la que examina la evolución de esta industria desde la década de 1940, estudiando especialmente a los grandes estudios de Hollywood y su íntima relación con el gobierno estadounidense que buscaba (y busca) fomentar la expansión nacional e internacional de este "cartel" — como lo denomina Pendakur $(1990: 88,102)$.

Wasko - quien fuera alumna de Guback en la Universidad de Illinois (UrbanaChampaign) — continuó la tradición de su maestro: en 1982 publicó Movies and Money: Financing the American Film Industry, donde analiza la cambiante relación entre la industria de cine y las instituciones financieras que aportan el capital. Posteriormente, Wasko estudiaría el impacto de las nuevas tecnologías en Hollywood y la creciente integración de la industria audiovisual internacional (1994), a la vez que ahondaría en el análisis de la cadena de valor de la industria del cine en Estados Unidos y de su política de dominación del mercado internacional (2003, 2006, 2011).

Un trabajo referente para la presente tesis es la investigación que el investigador indio Manjunath Pendakur realizara sobre el sector cinematográfico canadiense: Canadian Dreams and American Control. The Political Economy of Canadian Film Industry (1990). 
En esta investigación Pendakur se centra no sólo en las políticas públicas cinematográficas -importantes en ese país estadounidense (se estudian las exenciones fiscales, los subsidios y las coproducciones) - sino que el análisis está claramente enmarcado en las relaciones de poder, atendiendo especialmente a los vínculos entre la producción, la distribución y la exhibición. Como bien señala Mosco (2009) esta relación - principalmente, la que se da entre producción y distribución- es importante en todas las industrias, pero particularmente en las de comunicación —a partir de la fácil reproducción del producto- $-y$, más aún, en la industria cinematográfica, debido a que tanto la producción como la distribución y la exhibición fueron históricamente mercados fuertemente concentrados en una o pocas empresas.

La hipótesis de Canadian Dreams... sostiene que el sector poderoso, monopolístico del cine canadiense - mayormente, compuesto por los estudios de Hollywood (inclusive en los casos de grandes empresas canadienses asociadas a las majors) — está firmemente apoyado por las políticas públicas canadienses, mientras que el sector más pequeño, independiente, competitivo - manejado en su totalidad por canadienses - queda librado a las fuerzas del mercado.

La perspectiva de Pendakur es bastante similar a la de los estudiosos de la industria: se centra fuertemente en lo referido a la estructura del mercado y a su rentabilidad, teniendo como unidad de análisis al filme en cuanto commodity. Pero como investigador de la economía política el investigador indio se sirve de este abordaje para cuestionar mitos como el de la competencia, la independencia o la globalización, contextualizando a la industria del cine como una parte de la industria de los medios y de la comunicación —que la contiene_-, así como de la sociedad en general. Como dice Janet Wasko "el cine es únicamente la punta del iceberg" (Wasko, 2006:102).

Hay otros autores que pueden adscribirse a la economía política del cine como, por ejemplo, uno de los referentes de la economía política de la comunicación, Nicholas Garnham (1990), además de los mencionados Aksoy y Robins (1992): todos ellos estudiaron la industria cinematográfica en Hollywood.

Con respecto a investigaciones de la economía política del cine referidas puntualmente a otras regiones del mundo se pueden nombrar, entre otros, a los mencionados Guback para Europa (1980) y Pendakur — para Canadá (1990) y la India (2003)—, además de Gasher — también para Canadá (1992)—, Curtin (2011) para China, Ryoo (2008) para Corea del Sur, O’Regan (1996) y Bolm y Ethan (2010) para Australia. 
Referentes latinoamericanos en los estudios de la economía política del cine

En lo que respecta específicamente a la economía política del cine en América Latina, se puede ubicar a investigadores que, sin pertenecer a la EPCC, pueden ser considerados como pioneros en el estudio de la economía y las relaciones de poder en las cinematografías de América Latina.

Entre estos investigadores sobre la economía del cine (no adscriptos a la EPCC) encontramos claramente a Octavio Getino y su labor pionera a partir de la década de 1980. También podemos ubicar en la génesis de este tipo de estudios en América Latina al argentino Heriberto Muraro - también pionero en lo que respecta a estudios que podrían encuadrarse como antecesores de la economía política de la comunicación en América Latina, al igual que el venezolano Antonio Pasquali, el chileno Diego Portales, la mexicana Patricia Arriaga y el brasileño Sergio Caparelli-: en 1978 Muraro publicó, junto a José Cantor, el artículo "La influencia transnacional en el cine argentino" en la revista Comunicación y cultura de México.

El mexicano Enrique Sánchez Ruiz puede considerarse, propiamente, el pionero en los estudios latinoamericanos de economía política de cine. Este investigador se enmarca explícitamente en la economía política desde sus primeros estudios en la década de 1980. Durante años fue el único investigador dedicado exclusivamente al estudio del cine adscripto explícitamente en la economía política.

Desde la década del noventa fueron surgiendo en América Latina — y también en países afines a la región, como España - investigadores que comenzaron a estudiar al cine desde su variante económica e industrial, introduciendo en algunos casos variables como las políticas públicas. Así comenzaron a publicar Enrique Guzmán Cárdenas en Venezuela, el uruguayo Gustavo Buquet en España —ambos desde una óptica más virada a la econometría - Anita Simis en Brasil — estudiando las políticas públicas del cine-, la mexicana Ana Rosas Mantecón, el uruguayo Luis Stolovich y el español José María Alvarez Monzoncillo. También a partir de la década de 1990 comenzaron a elaborar algunos análisis sobre la industria del cine reconocidos investigadores del campo de la comunicación como Garcia Canclini, Delia Crovi y Germán Rey. Sin embargo, a excepción de Alvarez Monzoncillo, ninguno de ellos adscribe a la economía política - aunque Buquet saluda la influencia vital de los estudios de Thomas Guback.

A la fecha, en América Latina —a excepción de Sánchez Ruiz- existen pocos investigadores de la industria del cine adscriptos a la economía política: tan sólo es posible encontrar al brasileño César Bolaño —investigador de medios y comunicación, 
pero que ha escrito durante la década de 2000 un par de papers sobre el cine (2006, 2009)_, al chileno Roberto Trejo — quien en 2009 publicó su investigación Crítica de la economía política del cine chileno contemporáneo-, y a los mencionados argentinos Roque González y Santiago Marino.

\section{Abordando el neofomentismo}

A partir de los trabajos de Getino (2005), Harvey (2005), Sánchez Ruiz (2006), Gómez (2006), Chalupe (2010) y Dahl (2010), y de la propia experiencia - trabajando en el Instituto de Cine y Artes Audiovisuales de la Argentina, y en la Reunión Especializada de Autoridades de Cine y Audiovisual del Mercosur-, esta tesis entiende que en América Latina existen tres grandes políticas públicas cinematográficas: Estado empresario (o fomentismo), políticas defensistas (neofomentismo) y Estado ausente (aquel que no apoya al sector cinematográfico).

En efecto, en lo que hace al fomentismo, esta tesis abreva en Getino (2005) cuando llama "política nacionalista de proteccionismo industrial" y "gestión industrial integrada" - especialmente, refiriéndose al caso mexicano de la época de oro-, lo que el mexicano Sánchez Ruiz (2006) y la brasileña Chalupe (2010) entienden como "políticas activas" - Chalupe también se refiere como "Estado empresario" a la actividad de Embrafilme, entre 1969 y 1990, calificativo que también emplea Harvey (2005). Por su parte, en lo que hace al neofomentismo Gómez (2006) habla de "neoregulación" y de "re-regulación", mientras que Chalupe (2010) describe a un Estado "gestor", y ya no activo, como durante el fomentismo. En lo que hace al Estado ausente con respecto a las políticas de fomento cinematográfico, Getino (2005), precisamente, lo denomina así —en el capítulo II ("Políticas públicas cinematográficas") se ahondarán estos conceptos. 


\begin{tabular}{|c|c|c|}
\hline Estado empresario & Políticas públicas defensivas & Estado ausente \\
\hline $\begin{array}{l}\text { Dos únicos casos existentes en la } \\
\text { historia latinoamericana; ejs. } \\
\text { México (1942-1979) y Brasil } \\
\text { (1969-1990). }\end{array}$ & $\begin{array}{l}{ }^{\circ} \text { Estado orientado - recursos del } \\
\text { mercado orientados por el } \\
\text { Estado; ejs. Argentina, } \\
\text { Venezuela, Cuba, Francia. } \\
{ }^{\circ} \text { Mercado orientado - recursos } \\
\text { del Estado orientados por el } \\
\text { mercado; ejs. México (desde } \\
\text { 1997), Chile y Colombia. } \\
{ }^{\circ} \text { Mix entre los dos anteriores; } \\
\text { ejs. Brasil (desde 1991) } \\
{ }^{\circ} \text { Fomento mínimo: } \\
\text { - } \quad \text { sub-producción: apoyo } \\
\text { para una ínfima } \\
\text { cantidad de películas, y } \\
\text { fomento maquila: } \\
\text { estímulos para que } \\
\text { audiovisuales } \\
\text { extranjeros filmen en el } \\
\text { país, sin tener en cuenta } \\
\text { la producción nacional; } \\
\text { ejs. Puerto Rico, } \\
\text { República Dominicana. } \\
\text { ( Regionalismo - intentos de } \\
\text { políticas públicas } \\
\text { cinematográficas regionales } \\
\text { (Caci-Ibermedia, Recam). }\end{array}$ & $\begin{array}{l}\text { No fomentan ni protegen la } \\
\text { actividad cinematográfica y } \\
\text { audiovisual; ejs. Paraguay, } \\
\text { Honduras, El Salvador, } \\
\text { Guatemala, Haití. }\end{array}$ \\
\hline
\end{tabular}

El Estado empresario se refiere a los pocos casos de políticas públicas cinematográficas en América Latina que abarcaron de manera decidida y global todos los eslabones de la cadena de valor, pensando en construir una industria cinematográfica en toda su extensión —desde el desarrollo hasta el consumo.

En este tipo de políticas el Estado tuvo un papel fundamental, con regulaciones y medidas decididas - como cuotas de pantalla del 50\% del tiempo de exhibición, estatizaciones de empresas o creación de compañías vitales para el sector (como productoras, distribuidoras o exhibidoras estatales).

En América Latina este tipo de políticas sólo existieron en México (1942-1979) y en Brasil (1969-1990), constituyendo lo que esta tesis entiende como la esencia del fomentismo. Otro caso en fuerte participación estatal en el cine sería el de Cuba, con un Estado activo y presente desde la Revolución Cubana — vale recordar que la primera medida tomada por el gobierno revolucionario en relación con la cultura fue referida a la cinematografía: la ley $\mathrm{N}^{\circ} 169$, de marzo de 1959 (rubricada tan sólo dos meses después de la toma del poder). 
Sin embargo, la presente tesis se enfocará en México y en Brasil, en términos de fomentismo: en los capítulos siguientes se detallará el sistema de funcionamiento y desarrollo del "Estado empresario" a través de estos dos casos nacionales. También se abordará el caso argentino, que aunque no tuvo políticas públicas cinematográficas abarcando fuertemente todos los eslabones de la cadena productiva, sí posee importantes políticas de fomento al cine desde varias décadas.

El neofomentismo que postula esta tesis entraría en la categoría de políticas públicas defensivas, es decir, medidas que tienden a fomentar uno o varios eslabones de la cadena de valor - aunque se suele preponderar a la producción-, pero que se dan de manera parcial, limitada e inconexa - a diferencia de lo que sucedía en los casos del Estado empresario.

Si bien existen discursos oficiales criticando a Hollywood, en los hechos los Estados latinoamericanos con normativa de fomento al cine avalan la nueva configuración del sector, con Hollywood como actor monopólico: varias de las normativas inclusive invitan, y les dan beneficios, a estas y otras grandes empresas para que incursionen más aún en los distintos eslabones de la cadena productiva - un típico ejemplo en este sentido es el de las exenciones fiscales.

A su vez, el Estado "defensista” en materia cinematográfica tiene distintos niveles, basados no sólo en una mayor o menor intensidad en sus medidas de fomento y apoyo, sino también en el origen y manejo de esas ayudas:

- orientadas por el Estado,

- orientadas por el mercado,

- una combinación de ambas,

- fomento mínimo, y

- regionalismo.

Las medidas de fomento orientadas por el Estado se basan en recursos provenientes principalmente del sector privado: este es el caso argentino. En efecto, el Fondo de Fomento Cinematográfico establecido por la ley de cine argentina prevé, básicamente, impuestos del $10 \%$ por cada boleto cinematográfico vendido, $10 \%$ por cada venta o alquiler de video, y $25 \%$ de la pauta publicitaria televisiva.

Por su parte, las ayudas orientadas por el mercado se basan en recursos estatales. Estas son típicas medidas neofomentistas, adoptadas en varios países desde la década de 
1990, cuya estrella es la exención fiscal: los impuestos que el Estado renuncia a cobrarles a determinadas personas y empresas - por gravámenes a las ganancias y a las remesas enviadas al exterior, entre otros- son transferidos a la producción y comercialización cinematográfica. De esta manera es el mercado, y sus grandes actores —muchos de ellos, multinacionales-, quienes, finalmente, direccionan los recursos de fomento al cine —-son estas empresas las que eligen qué proyectos (qué temáticas y visiones del mundo) apoyarán-. México, Brasil —especialmente, hasta mediados de la década de 2000-, Colombia y Chile basan sus normativas de fomento al cine en este tipo de medidas.

Desde 2007 en Brasil se da un mix, una conjunción entre el fomento "orientado por el mercado" y el "orientado por el Estado". Luego de que en 1990 Collor de Melo extinguiera Embrafilme y las herramientas del Estado empresario, Brasil adoptó medidas de apoyo al cine $-\mathrm{y}$ a la cultura - basadas exclusivamente en la exención fiscal, que dominaron toda la década de 1990, y que continúan hasta la actualidad. Sin embargo, en 2006 se creó el Fondo Sectorial -que entró en vigencia al año siguiente-, nutrido por gravámenes — provenientes mayormente del sector privado, a través del pago al Condecine (en el capítulo nacional de Brasil se ahondará en estos gravámenes y fondos)—, que conforma una importante fuente de recursos manejada directamente por el Estado -Agencia Nacional de Cine (Ancine) - destinada mayormente a la producción, aunque con importantes montos dirigidos a la distribución, a la exhibición y a la promoción nacional e internacional, entre otros rubros.

Por otra parte, existen Estados que fomentan a su cinematografía, pero de manera reducida, principalmente en la producción de un puñado de películas por año —en algunos casos, mediante concursos basados en recursos provenientes del presupuesto nacional, y en otros, basados en mecanismos de exención fiscal-. Muchos países que hasta la década de 2000 no tuvieron ayudas estatales para el cine, y que en esos años se dieron normativas de apoyo al séptimo arte, se encuentran incluidas en esta subcategoría, como Colombia, Chile, Uruguay, Ecuador, Panamá o Nicaragua, entre otros.

Otra característica de este fomento estatal mínimo al cine se basa en medidas que promueven la filmación de películas y audiovisuales extranjeros — principalmente, piezas publicitarias- en el territorio nacional, generalmente como mero escenario exótico — tal son los casos de Puerto Rico, República Dominicana o Nicaragua (antes de la revolución sandinista), sin mayor apoyo a la producción nacional de cine y audiovisual. 
Finalmente, bajo la égida del Estado neofomentista nacieron los intentos de políticas gubernamentales a nivel regional para buscar dinamizar y potenciar realizaciones cinematográficas en coproducción, además de coadyuvar a la creación de un espacio de circulación cinematográfica intra-regional. Constituyeron dichos intentos los casos de Ibermedia - programa bajo el mandato de la Conferencia Iberoamericana de Autoridades Cinematográficas (la Caci) - y de la Reunión Especializada de Autoridades Cinematográficas y Audiovisuales del Mercosur (Recam).

De estos dos intentos, el que más logros ha obtenido ha sido el del Programa Ibermedia de la Caci: en vigor desde 1998, gracias a este programa muchos países con escasa o nula tradición e historia cinematográfica comenzaron -o fortalecieron- su producción de cine desde fines de la década de 1990 y a lo largo de la década de 2000 — tales son los casos de Bolivia, Perú, Uruguay, Ecuador y Panamá, entre otros-. La Recam, por su parte, intentó crear políticas sub-regionales de cine a nivel del Mercosur. Sin embargo, y a pesar de haber firmado un acuerdo de casi dos millones de euros con la Unión Europea en 2009, no ha conseguido mayores logros.

Por último, esta operacionalización se completa con el Estado ausente en materia de fomento cinematográfico. Al no regular el mercado ni fomentar la producción cinematográfica, el Estado deja la mesa servida para que la cinematografía extranjera —especialmente, Hollywood - opere en sus circuitos exhibidores a sus anchas. Hasta la década de 2000 la mayoría de los Estados latinoamericanos operó de esta manera; pero a partir de comienzos de la primera década del siglo XXI varios países comenzaron a darse normativas y legislaciones nacionales de fomento a la cinematografía - tales como los mencionados Chile, Colombia, Uruguay, Ecuador, Nicaragua o Panamá, entre otros.

Sobre la base de lo antedicho, esta tesis operacionaliza sus principales dimensiones (fomentismo y neofomentismo) de la siguiente manera: 
Cuadro 3 - Características de las políticas cinematográficas, de la producción y el mercado durante el fomentismo y del neofomentismo

\begin{tabular}{|l|l|l|}
\hline Rol del Estado & Fomentismo & Neofomentismo \\
\hline Producción cinematográfica & $\begin{array}{l}\text { Estado activo empresario, } \\
\text { ejecutor, proveedor. }\end{array}$ & $\begin{array}{l}\text { Estado pasivo, gestor, mediador, } \\
\text { "autárquico". }\end{array}$ \\
\hline Mercado cinematográfico & $\begin{array}{l}\text { Diversidad en la cartelera } \\
\text { (cinematografías extra } \\
\text { Hollywood poseen un porcentaje } \\
\text { importante del mercado). }\end{array}$ & $\begin{array}{l}\text { Flexible, atomizada, } \\
\text { insustentable. }\end{array}$ \\
\hline Exhibición & $\begin{array}{l}\text { Salas esparcidas por todo el } \\
\text { territorio nacional. }\end{array}$ & $\begin{array}{l}\text { Concentración geográfica y } \\
\text { clasista de las salas. }\end{array}$ \\
\hline Consumo & $\begin{array}{l}\text { Consumo popular (todas las } \\
\text { clases sociales asistían } \\
\text { masivamente a las salas de cine). }\end{array}$ & $\begin{array}{l}\text { Consumo elitista (los asistentes a } \\
\text { las salas de cine pertenecen } \\
\text { mayoritariamente a los sectores } \\
\text { incluidos y a los más pudientes). }\end{array}$ \\
\hline Cine nacional & $\begin{array}{l}\text { Alto porcentaje del total de } \\
\text { espectadores (Arg-Br-Mx en sus } \\
\text { épocas de oro). }\end{array}$ & $\begin{array}{l}\text { Bajo porcentaje del total de } \\
\text { espectadores (Arg-Br-Mx). }\end{array}$ \\
\hline $\begin{array}{l}\text { Circulación internacional de los } \\
\text { filmes nacionales }\end{array}$ & $\begin{array}{l}\text { Fuerte (Arg-Mx en sus épocas de } \\
\text { oro). }\end{array}$ & $\begin{array}{l}\text { Muy reducido número de } \\
\text { estrenos y nula convocatoria (la } \\
\text { poca circulación que existe se da } \\
\text { en nichos: festivales, muestras, } \\
\text { exhibiciones culturales para } \\
\text { elites). }\end{array}$ \\
\hline
\end{tabular}

Fuente: Elaboración propia con base en datos de la presente tesis.

A lo largo de la presente tesis, se ahondará en estas variables para buscar confirmar o refutar la hipótesis de que el neofomentismo intenta — a partir de la década de 1990— retomar el apoyo a la cinematografía, buscando ser una reparación al fomentismo, pero sin alcanzar las "épocas de oro" de los tres países analizados: Argentina, México y Brasil —especialmente, en estos dos últimos casos.

\section{Marco metodológico}

Este trabajo de investigación busca analizar las políticas públicas cinematográficas en América Latina en el marco de los distintos eslabones de la cadena de valor y el mercado: para ello se centrará en los países más desarrollados y con más historia en este sector (México, Argentina y Brasil).

La hipótesis central de esta tesis plantea que el neofomentismo - políticas públicas cinematográficas nacidas en los años noventa para los países analizados - no cambió sustancialmente el mapa de concentración del sector cinematográfico ni incrementó sustancialmente el consumo nacional de los filmes nacionales en estos territorios ni su circulación internacional. 
A partir de este planteo, el presente trabajo analiza las normativas de fomento y regulación implementadas en México, Argentina y Brasil, revisando los resultados más salientes en estos países. Se busca identificar las medidas que obtuvieron mejores resultados y aquellas áreas de la normativa que presentan mayores falencias.

También se analizan los datos del sector — producción, distribución y exhibición-, buscando establecer relaciones entre estas dos dimensiones (la normativa y la sectorial). En virtud de ello, la metodología utilizada en esta investigación se desagrega en cinco partes:

\section{Revisión bibliográfica:}

Se analizan estudios publicados sobre distintos aspectos referidos a las políticas públicas cinematográficas y fuentes secundarias con información estadística. Se abordan tanto investigaciones académicas como informes de organismos nacionales e internacionales, además de bases de datos.

\section{Análisis de legislación cinematográfica:}

Se examinan las legislaciones nacionales de México, Argentina y Brasil. Esta normativa se compara con la de otros países referentes en la materia (por ejemplo, Francia e Inglaterra). Se incluye en el análisis normativa que exceda el ámbito nacional: acuerdos bilaterales y multilaterales, de coproducción, codistribución, cooperación e integración suscriptos por los tres países estudiados. También se explora la presencia de disposiciones relativas al sector cinematográfico en las distintas instituciones estatales —especialmente, cancillerías y ministerios de hacienda - de los países analizados, y el lugar ocupado por el cine en los distintos acuerdos de libre comercio y unión aduanera rubricados por México, Argentina y Brasil.

\section{Creación de una base de datos:}

Esta database analiza la evolución de la producción y del mercado a nivel nacional, así como también su circulación por los mercados latinoamericanos.

La base de datos está divida en las siguientes secciones: 
- filmes producidos en los tres países analizados, para el período 2000-2009;

- coproducciones consideradas como filmes nacionales por Argentina, Brasil y México, para el período 2000-2009;

- $\quad$ estrenos comerciales en Argentina, Brasil y México entre 2000 y 2009;

- distribuidoras que operaron en los tres países analizados en el período estudiado;

- exhibidoras que operaron en los tres países analizados en el período estudiado, y

- datos de mercado de Argentina, Brasil y México (período 2000-2009), basados en indicadores como cantidad de espectadores, recaudación, frecuencia de asistencia habitante/año, precio de la entrada, porcentaje de mercado de filmes nacionales y extranjeros, asistencia por exhibidoras, región, entre otros.

A su vez, la base de datos también contiene abundante información estadística de los tres mercados cinematográficos estudiados a lo largo de su historia, para comparar entre distintos períodos.

\section{Entrevistas en profundidad:}

Se realizaron entrevistas en profundidad a representantes de la industria y de instituciones nacionales y supranacionales de cine. El análisis de los profesionales entrevistados se utiliza para confirmar hipótesis y para apoyar de manera cualitativa algunos de los datos obtenidos.

El proceso de búsqueda de datos de distintas fuentes llevó mucho tiempo y fue bastante trabajoso. América Latina necesita imponer a las empresas relacionadas con el cine a que entreguen información vital sobre este sector al gobierno. ${ }^{5}$

Por su parte, el desarrollo de la investigación se divide en cuatro etapas de recolección y procesamiento de la información:

\footnotetext{
${ }^{5}$ Aunque la normativa argentina obliga al Incaa a fiscalizar el sector, ello no se cumple adecuadamente.
} 
Cuadro 4 - Etapas de investigación y herramientas metodológicas

\begin{tabular}{|c|c|c|}
\hline \multicolumn{2}{|l|}{ Tipo de relación } & Herramientas metodológicas \\
\hline \multicolumn{2}{|c|}{$\begin{array}{l}\text { Etapa } 1 \text { - Legislación y normativa cinematográfica en México, } \\
\text { Argentina y Brasil }\end{array}$} & $\begin{array}{l}\text { Revisión de las legislaciones de fomento a } \\
\text { la cinematografía (principalmente, } \\
\text { nacionales, pero también las regionales a } \\
\text { nivel latinoamericano e iberoamericano), y } \\
\text { de los distintos mecanismos de fomento al } \\
\text { cine. }\end{array}$ \\
\hline \multicolumn{2}{|c|}{ Etapa 2 - Marco institucional del cine en América Latina } & $\begin{array}{l}\text { Análisis de los institutos de nacionales de } \\
\text { cine (así como también de las entidades de } \\
\text { fomento al cine existentes a nivel regional). } \\
\text { Información oficial e institucional, revisión } \\
\text { bibliográfica; entrevistas. }\end{array}$ \\
\hline \multirow{3}{*}{$\begin{array}{l}\text { Etapa } 3 \text { - Relaciones a nivel } \\
\text { intrasectorial }\end{array}$} & Producción/coproducción & $\begin{array}{l}\text { Relaciones de propiedad: base de datos de } \\
\text { productoras de Argentina, Brasil y México } \\
\text { que operaron en el período analizado. } \\
\text { Base de datos de filmes producidos en los } \\
\text { tres países analizados, con énfasis en el } \\
\text { período 2000-2009. } \\
\text { Base de datos de coproducciones } \\
\text { consideradas como filmes nacionales por } \\
\text { Argentina, Brasil y México (con énfasis en } \\
\text { las producidas entre 2000-2009). } \\
\text { Análisis comparativo entre los filmes } \\
\text { producidos en Argentina, Brasil y México } \\
\text { con los realizados en el resto de América } \\
\text { Latina, Estados Unidos, Europa y el resto } \\
\text { del mundo (con énfasis en el período 2000- } \\
\text { 2009). } \\
\text { Información oficial e institucional, del } \\
\text { ámbito privado; revisión bibliográfica; } \\
\text { entrevistas. }\end{array}$ \\
\hline & Comercialización & $\begin{array}{l}\text { Base de datos de los estrenos comerciales en } \\
\text { Argentina, Brasil y México entre } 2000 \text { y } \\
2009 . \\
\text { Base de datos de distribuidoras que } \\
\text { operaron en los tres países analizados en el } \\
\text { período estudiado. } \\
\text { Base de datos de exhibidoras que operaron } \\
\text { en los tres países analizados en el período } \\
\text { estudiado. } \\
\text { Información oficial e institucional, del } \\
\text { ámbito privado; revisión bibliográfica; } \\
\text { entrevistas. }\end{array}$ \\
\hline & Consumo & $\begin{array}{l}\text { Base de datos con los datos de mercado de } \\
\text { Argentina, Brasil y México, con énfasis en } \\
\text { el período 2000-2009, basada en indicadores } \\
\text { como cantidad de espectadores, } \\
\text { recaudación, frecuencia de asistencia } \\
\text { habitante/año, precio de la entrada, } \\
\text { porcentaje de mercado de filmes nacionales } \\
\text { y extranjeros, asistencia por exhibidoras, } \\
\text { región, entre otros). } \\
\text { Información oficial e institucional, del } \\
\text { ámbito privado; revisión bibliográfica; } \\
\text { entrevistas. }\end{array}$ \\
\hline \multicolumn{2}{|c|}{ Etapa 4 - Análisis. Conclusiones } & $\begin{array}{l}\text { Análisis comparativo entre la dimensión } \\
\text { normativa (etapas } 1 \text { y 2) y la sectorial (etapa } \\
\text { 3). }\end{array}$ \\
\hline
\end{tabular}




\section{Etapa 1. Legislación y normativa cinematográfica}

Se recopila información sobre las normativas de regulación y fomento al cine a nivel nacional, poniendo el énfasis en los tres países analizados en esta tesis (México, Argentina y Brasil). También se recopila y analiza la normativa a nivel regional.

1. Se ahonda en las leyes nacionales de cine de México (1998), Argentina (1994) y las leyes "Rouanet" (1991), del audiovisual (1993) y la medida provisoria número 2228 que crea la Agencia Nacional de Cine (Ancine) y la Contribución para el Desarrollo de la Industria Cinematográfica (Condecine) en Brasil. También se hace un racconto de las legislaciones nacionales de cine vigentes en décadas anteriores en estos países.

1.1. También se le presta especial atención a las normativas importantes para el fomento de los cines nacionales de estos países en el período estudiado, tales como el artículo 226 del Impuesto sobre la Renta (estímulo fiscal), el Fondo para la Producción Cinematográfica de Calidad (Foprocine) y el Fondo de Inversión y Estímulos al Cine (Fidecine) en México y la ley 11.437 (2006) que generó el Fondo Sectorial del Audiovisual en Brasil.

1.2. Por otra parte, se analizan decretos y medidas administrativas que abarquen cuotas de pantalla, media de continuidad, incentivos y exenciones fiscales, entre otras disposiciones de importancia para la actividad cinematográfica nacional.

2. Se incluye, además, el análisis de normativas provinciales-estatales de cine y de disposiciones relativas al sector cinematográfico en las distintas instituciones gubernamentales - especialmente, cancillerías y ministerios de hacienda- de los países analizados.

3. Se analizan también iniciativas de cooperación audiovisual, especialmente, el Convenio de Integración Iberoamericana - que diera nacimiento en 1989 a la CACI y, posteriormente, en el año 1997, al Programa Ibermedia - y el Convenio de Integración Cinematográfica Iberoamericana (1989).

\section{Etapa 2. Recolección de información y análisis de las instituciones dedicadas al fomento y la regulación del cine}

Se examina el funcionamiento institucional y el desempeño - especialmente, en el período estudiado por esta tesis - de las agencias nacionales, las instituciones de cooperación cinematográfica a nivel latinoamericano y los acuerdos y convenios (binacionales y multilaterales) referidos, directa o indirectamente, a la cinematografía. 
1. Análisis de las instituciones encargadas de la regulación y fomento de la cinematografía a nivel nacional -especialmente, el Instituto Mexicano de Cinematografía (Imcine), del Instituto Nacional de Cine y Artes Audiovisuales de Argentina (Incaa) y de la Agencia Nacional de Cine de Brasil (Ancine).

2. Análisis de las entidades relacionadas con el fomento de la actividad cinematográfica a nivel internacional, particularmente, la Conferencia de Autoridades Cinematográficas Iberoamericanas (CACI) y de la Reunión Especializada de Cine y Artes Audiovisuales (Recam) -instituciones multilaterales integradas de manera activa por México (excepto la Recam), Argentina y Brasil.

3. Entrevistas y reuniones con personas clave tanto de los sectores cinematográficos, como con funcionarios del sector y estudiosos de esta temática.

\section{Etapa 3. Relaciones a nivel intrasectorial}

Se analizan las relaciones al interior del sector cinematográfico en México, Argentina y Brasil entre 2000 y 2009, a partir de información recolectada.

Estas relaciones se operacionalizan en las dimensiones producción/coproducción, comercialización y consumo.

A partir de la información sobre la legislación y las instituciones relacionadas con el cine (dimensión institucional) se analizan los resultados de producción, de comercialización y de consumo para los cines nacionales de los países analizados (dimensión sectorial).

Se operacionalizaron las relaciones entre ambas dimensiones, para analizar posteriormente el estado de situación de las cinematografías de los países analizados.

Para la recolección y análisis, se utilizaron las siguientes herramientas:

Relaciones de producción:

1. Relaciones de propiedad: creación de una base de datos con el universo de las productoras que trabajen en el campo cinematográfico, ${ }^{6}$ buscando analizar la división del trabajo - a partir de indicadores como tamaño, propiedad (ligazón o no con multinacionales), formas y prácticas de organización, cantidad de largometrajes producidos por períodos de dos años, entre otros.

\footnotetext{
${ }^{6} \mathrm{Se}$ incluirán todas las productoras que tengan actividad en la actividad cinematográfica, aunque no lo hagan exclusivamente en este sector (se incluirá a aquellas que, trabajando en el ámbito cinematográfico, también se dediquen a otras áreas audiovisuales, como la televisión, la publicidad, internet, etcétera).
} 
2. Creación de una base de datos con los filmes de largometraje producidos en cada uno de los tres países analizados, con sus respectivas fichas, con variables tales como financiamiento (estatal, privado, mixto), indicadores como "director debutante", género, etcétera. También se incluyen los datos de las principales empresas de producción, y del costo medio de producción de largometrajes, por país y a nivel regional.

3. Creación de base de datos con las coproducciones realizadas, calificadas como nacionales por México, Argentina y Brasil. Se analiza la información sobre las productoras participantes, los países con los que se coprodujo, la distribución y exhibición de estos filmes, para identificar tendencias y características de la coproducción en los tres países analizados en el presente estudio.

4. Se realiza un análisis comparativo entre el número de filmes producidos en Argentina, México y Brasil, en el resto de América Latina, en Estados Unidos, en Europa, en la India y en el resto del mundo, en el período analizado.

Relaciones de comercialización:

1. Se crea una base de datos con los largometrajes estrenados comercialmente en Argentina, Brasil y México, según principales empresas distribuidoras.

2. Se crea una base de datos con las empresas de distribución, nacionales y extranjeras (y sellos que distribuyen) que operan en cada uno de los tres países analizados.

3. Se crea una base de datos con las salas de cine, pantallas y butacas, a escala nacional y provincial/estatal, atendiendo a análisis de variables como Densidad (porcentaje) de pantallas en las salas — porcentaje de cines con 1, 2 y 3 pantallas, multiplex (4-11 pantallas) y megaplex (12 o más pantallas). ${ }^{7}$

Relaciones de consumo:

Creación de una base de datos con datos de los mercados cinematográficos de Argentina, Brasil y México, enfocado en el período 2000-2009, aunque también se contemplarán otros períodos históricos, para poder analizar comparativamente.

\footnotetext{
${ }^{7}$ Según las exhibidoras multinacionales y los distintos organismos internacionales (institutos nacionales de cine, principalmente europeos, y entidades regionales como el Observatorio Europeo del Audiovisual y el Programa Media, entre otros), además de consultoras y centros de estudio multinacionales (Rentrak, Screen Digest, Deloitte, London Economics, entre otros) que estudian y analizan los mercados exhibidores a nivel mundial, se considera "multiplex" a los complejos que tienen entre 8 y 15 pantallas, y "megaplex" a los que poseen 16 o más pantallas. Pero teniendo en cuenta el mercado latinoamericano más reducido (a excepción de México), en especial el argentino, la presente investigación considera multiplex a los complejos con entre 4 y 11 pantallas (en esta categoría se concentra la mayor cantidad de cines en América Latina), y megaplex a todo aquel cine que posea 12 o más pantallas.
} 
Los principales indicadores son número de entradas vendidas en salas de cine, a escala nacional y provincial/estatal; recaudación de las salas (a nivel nacional y provincial/estatal), frecuencia de asistencia a las salas por habitante/año, precio medio de la entrada de cine (moneda nacional y dólares), porcentajes de entradas vendidas (según país productor de los filmes), densidad (porcentaje) de entradas vendidas en los multicines, porcentajes del mercado según principales empresas de exhibición, comparación entre porcentajes de mercado de los filmes nacionales, latinoamericanos, estadounidenses, europeos y del resto del mundo, ránking de títulos nacionales de mayor número de espectadores y recaudaciones, según director y financiamiento (estatal nacional, privado, fondo regional, coproducción, etc.), en Argentina, Brasil y México entre 2000 y 2009.

\section{Etapa 4. Análisis y conclusiones}

A partir de la información sobre la legislación y las instituciones relacionadas con el cine (dimensión institucional) se analizan los resultados de producción, de mercado, de comercialización y de consumo para los cines nacionales de los países analizados (dimensión sectorial).

Así, se operacionalizan las relaciones entre las dimensiones institucional y sectorial, para analizar el estado de situación de las cinematografías de los países analizados.

\section{Aclaraciones metodológicas}

En todos los casos señalados se privilegió la información de los organismos estatales en toda ocasión que ello fue posible, aunque siempre se cruzaron los datos oficiales con otras fuentes, porque lamentablemente no existe una sólida tradición en la fiscalización $\mathrm{y}$ en el seguimiento estadístico por parte de las agencias nacionales de cine latinoamericanas, aunque son para destacar los esfuerzos realizados durante la última década por parte de la Agencia Nacional del Cine de Brasil (Ancine) — que en 2008 ha creado un Observatorio del Audiovisual Brasileño-, del Instituto Mexicano de Cinematografía (Imcine) — que en 2010 ha comenzado a dar forma a un área de investigación propia - y del Incaa argentino, que desde 2010 viene trabajando en la elaboración de informes anuales.

Por otra parte, fueron importantes los datos obtenidos de consultoras y centros de estudios. Entre las consultoras se trabajó mucho con información de Nielsen (que cambió su denominación a Rentrak en 2010), Ultracine, Filme-B, Screen Digest, 
Dodona Research, Teleco, The Competitive Intelligence Unit, entre otros. De los espacios de investigación se destaca el departamento de estudios del Sindicato de la Industria Cinematográfica Argentina (Deisica) — que lleva 20 años analizando el mercado cinematográfico argentino- y el Sistema de Información Cultural de la Argentina (Sinca). También fueron de gran utilidad los informes periódicos de la Cámara Nacional de la Industria Cinematográfica y Videográfica de México (Canacine).

A su vez, vale aclarar que en lo que respecta a los resultados de mercado, se prepondera al número de espectadores por sobre la recaudación, debido a que América Latina conoció - y conoce - una larga historia de altas de inflación, además de dudosos tipos de cambio - los recientes casos argentino y venezolano así lo muestran—, por lo que la variable "recaudación" puede generar perspectivas distorsionadas y conclusiones erróneas, a diferencia del "número de espectadores" —-más fiable a lo largo de los años y de las décadas.

En lo que hace a la producción cinematográfica en América Latina, para esta investigación se contabilizaron todos los filmes de largometraje producidos en la década del 2000 (sistematizando uno por uno aproximadamente 2000 títulos), ya sean de ficción, documental, animación o cualquier género, más allá de que hayan sido estrenados comercialmente o no.

Por ejemplo: en los últimos años de la década del 2000 se estrenaron, a nivel general, entre 250 y 280 filmes latinoamericanos. La diferencia entre estos números y los 300350 largometrajes producidos radica en que muchas de estas películas fueron documentales —amén de algunas películas de ficción- que no tuvieron estreno comercial pero que sí se exhibieron en festivales, muestras y ciclos, muchos de ellos auspiciados por el Estado nacional. El caso de Venezuela es un caso típico en este sentido: desde 2006 viene incrementándose la producción cinematográfica en ese país, y en 2008 el público venezolano pudo conocer 34 largometrajes nacionales nuevos, aunque sólo 16 de ellos tuvieron estreno comercial; el resto, se exhibió en festivales y muestras apoyadas por el Estado. Los números oficiales argentinos registran la misma tónica: si en 2013 el Incaa acusa 166 estrenos nacionales, en realidad la cifra es de 140 (el instituto argentino de cine cuenta filmes que también listó en 2012, y sobre todo, enumera películas que se exhibieron un solo día en algún Espacio Incaa, generalmente en el marco de una muestra, ciclo o festival). 
Con respecto a la moneda utilizada, tanto los tres países analizados directamente en esta tesis —más los analizados indirectamente, principalmente, los restantes latinoamericanos - manejan distintas monedas, con cotizaciones muy variables a lo largo de los años. A nivel internacional se suele utilizar la moneda local al momento de dar información sobre las políticas públicas y los ingresos de la industria, muchas veces traducidos a dólares estadounidenses. Programas multilaterales como Ibermedia - que se abordan en esta tesis - utilizan también la moneda de Estados Unidos como denominación por defecto.

Por todo ello, la moneda que se utiliza a lo largo de esta tesis es el dólar estadounidense, expresado por defecto en términos corrientes.

La conversión de los valores dinerarios se realiza a partir de las series históricas de la información oficial, empleando como tipo de cambio la cotización media de cada año (utilizando el conversor Oanda). 


\section{CAPÍTULO II}

\section{POLÍTICAS PÚBLICAS CINEMATOGRÁFICAS: INSTITUCIONES Y MECANISMOS DE FOMENTO}

Los bienes culturales, entre ellos, los cinematográficos, son bienes socialmente beneficiosos que deben ser protegidos por los efectos positivos -o "externalidades positivas"- que tienen en la sociedad a partir de su producción y consumo (difusión de valores, reafirmación de identidades, vehículo para la consolidación de la ciudadanía, pluralidad, entre otros).

Dos de las particularidades de los bienes culturales consisten en tener características de bien público y ser producidos en sectores muy concentrados.

Con respecto a este último aspecto, el Estado tiene el poder de intervenir en el ámbito cultural con el objetivo de aumentar la eficiencia en un sector donde existen fallas de mercado, como es el caso del cine en Argentina, Brasil y México - así como en toda América Latina-: falla en la competencia, niveles de comercialización y consumo subóptimos.

En efecto, en el sector cinematográfico contemporáneo de los tres países analizados los distintos eslabones no se entrelazan de manera sustentable: la producción local tiene graves problemas para llegar a comercializarse de manera óptima, por lo que los filmes que llegan a estrenarse lo hacen de manera precaria, reduciéndose las posibilidades de una buena carrera comercial y, por ende, de la recuperación de la inversión - similar situación se da tanto en el resto de América Latina como en la mayor parte del mundo.

Esta falla de mercado se explica, en primera instancia, por la concentración en todos los eslabones de la cadena de valor y por la consecuente falla en la competencia - en los siguientes capítulos (especialmente en el IV y en los casos nacionales) se ahondará más sobre este punto.

A su vez, otra de las razones en la falla de mercado para el cine se debe al requerimiento de grandes inversiones, en cada uno de los eslabones de la cadena de valor.

Es en este contexto que los Estados nacionales intervinieron, e intervienen, en el sector cinematográfico en gran parte del mundo -intervención que, a su vez, es considerada una "falla de mercado" desde el punto de vista económico. 


\section{Neofomentismo, normativas y políticas públicas}

La presente tesis entiende como neofomentismo a las políticas cinematográficas contemporáneas llevadas a cabo desde mediados de la década de 1990 en Argentina, Brasil y México, aplicadas luego del desmantelamiento que —a lo largo de la década de 1990 - hicieran sus respectivos Estados de las distintas ayudas oficiales al fomento productivo — por ejemplo, al cine.

Estas políticas públicas cinematográficas fueron, principalmente, la reforma de la ley de cine en Argentina, que entró en vigencia en 1995; la aprobación del Fondo para la Producción Cinematográfica de Calidad (Foprocine), en México, en 1997 -sumada a la reforma de la ley de cine de este país, realizada en 1998 - y la creación de la Agencia Nacional de Cine en Brasil, en 2001 — amén de la puesta en funcionamiento del Fondo Sectorial, en 2007.

Cabe destacar que en el resto de los países latinoamericanos a lo largo de la década de 2000 se sancionaron legislaciones nacionales de fomento a la actividad cinematográfica que, hasta el momento, no habían existido en ningún período de su historia —Chile, Colombia, Ecuador, Uruguay, Panamá, Nicaragua y República Dominicana son algunos ejemplos.

Esta tesis nombra a este período como neofomentismo en contraposición al fomentismo, que el presente trabajo entiende como el período de las llamadas "épocas de oro" de determinadas cinematografías latinoamericanas (México, Brasil y Argentina), donde las políticas públicas cinematográficas fueron muy activas y tuvieron protagonismo en todos los eslabones de la cadena de valor del sector, y que resultaron fundamentales para coadyuvar a las mejores épocas jamás vividas por sus cines nacionales —en los casos de México y Brasil.

La presente tesis busca marcar la diferencia entre los distintos mecanismos y prácticas de fomento estatal realizados a lo largo del siglo $\mathrm{XX}$ en América Latina —especialmente, en Argentina, Brasil y México— entre las décadas de 1940 y 1970, y las medidas tomadas en estos países entre finales de la década de 1990 y la década de 2000.

México fue el único país latinoamericano donde el Estado tomó una posición firme y determinada a favor del fomento de su cinematografía, llegando a abarcar todos los eslabones de la cadena de valor durante varias décadas —especialmente entre 1942 y 1979-. Brasil también tuvo a su Estado apoyando firmemente al sector 
cinematográfico, involucrándose en todos los eslabones -especialmente, durante la década de 1970- A su vez, Argentina tiene una tradición de apoyo estatal al cine, aunque nunca alcanzó los niveles de los casos mexicano y brasileño, preponderando siempre la producción.

Estas políticas son el germen de lo que esta tesis entiende por fomentismo, y a las que Octavio Getino llama "política nacionalista de proteccionismo industrial" (Getino, 2005:141) y "gestión industrial integrada" —en este último caso, refiriéndose al fomento del Estado mexicano a favor de su cinematografía:

La experiencia desarrollada por el Estado mexicano en materia de gestión industrial integrada de la industria cinematográfica (producción, distribución, exhibición, preservación, capacitación) fue, durante varias décadas, la única de ese carácter en América Latina, y también entre los países de sistema capitalista. (Getino, en Canclini, 2006:180)

En este sentido, Getino agrega:

La gestión estatal en materia de promoción y fomento al sector de la comercialización, allí donde se implementó, tuvo una importancia sustancial para el desarrollo del cine y la cultura —además de la economía- nacional. (Getino, en Canclini, 2006:199)

Enrique Sánchez Ruiz denomina "políticas activas" a este tipo de gestión estatal (2006:21), al igual que la investigadora brasileña Hadija Chalupe, refiriéndose en este último caso a Embrafilme y su papel "empresario" volcado "principalmente a las actividades de coproducción y distribución de las obras cinematográficas brasileñas" (2010:48; traducción propia).

El experto Edwin Harvey -en su investigación sobre distintos regímenes de fomento en América Latina, América del Norte y Europa (2005) - concluye que la principal característica de un "Estado protector" es la instauración de la cuota de pantalla —refiriéndose tanto a los casos latinoamericanos más salientes donde se ha aplicado (Brasil, México y Argentina) como al de países como Francia, Inglaterra, España y Corea del Sur, entre otros. 
Al igual que Chalupe, Harvey también denomina "empresario" al Estado mexicano en las "épocas de oro" de su cine:

El caso de México ha sido único en el sentido de un Estado que durante años ha intervenido directamente como empresario en todas las ramas de la economía del cine, por intermedio del Banco Nacional Cinematográfico y sus filiales. (2005:97)

Para el caso brasileño, Chalupe estructura a través de tres principales variables las características salientes de Embrafilme, el caso más importante de fomento estatal cinematográfico en la historia de ese país:

La primera es la interferencia directa del Estado en la producción, a partir de la elección de los filmes que serían coproducidos por el Estado; la segunda es la verticalización de la cadena económica cinematográfica, actuando como productora, distribuidora y exhibidora; y la tercera (...) es la participación patrimonial en la recaudación de cada filme. (2010:51; traducción propia)

Por su parte, Gustavo Dahl, realizador, periodista, escritor y primer director de la Agencia Nacional de Cine (Ancine), entiende que la "época de oro" de Embrafilme se enmarca en un "desarrollo geiseliano", haciendo referencia al presidente Ernesto Geisel —que gobernó entre 1974 y 1979, en el período dictatorial que se instauró en Brasil entre 1964 y 1985-, período que se caracterizó por reforzar las políticas “desenvolvimentistas" (desarrollistas) impulsadas por la dictadura.

En el plano cinematográfico Dahl define el "desarrollo geiseliano" a partir de tres indicadores: la conformación de la empresa estatal de cine (Embrafilme), la adopción de una función reguladora adoptada por esta empresa desde mediados de la década de 1970 —Embrafilme había sido creada en 1969- y el reforzamiento de la cuota de pantalla (Dahl, 2010:103).

Argentina posee el instituto de cine con un funcionamiento ininterrumpido más antiguo de América Latina, además de una ley de cine con características básicas similares a la legislación francesa de fomento cinematográfico y que, a través de modificaciones, viene fomentando al cine nacional desde hace casi medio siglo. Sin embargo, Argentina 
nunca tuvo experiencias de un Estado interviniendo de manera tan directa $y$ determinante en todos los eslabones del sector cinematográfico como sucedió en México - principalmente-y en Brasil.

En contraposición a estos casos de intervención directa del Estado en las políticas públicas cinematográficas, en las épocas contemporáneas —década de 1990 hasta la actualidad - encontramos lo que esta tesis llama neofomentismo, es decir, políticas públicas cinematográficas surgidas en América Latina a partir de la década de 1990, especialmente en Argentina, México y Brasil - luego del desmonte neoliberal de las políticas públicas cinematográficas fomentistas-, a partir de la presión del sector cinematográfico, pero con escasas normativas de fomento, las que son muy distintas a las que constituyeron aquel fuerte intervencionismo estatal de las "épocas de oro" en los tres países latinoamericanos antedichos.

El investigador mexicano Rodrigo Gómez habla de "re-regulación" y de "neoregulación" en un marco temporal similar al neofomentismo, pero desde una óptica distinta a la de esta tesis: el autor se refiere con estos términos a la apertura privatista que tuvo lugar entre finales de la década del ochenta y comienzos de los noventa de las políticas estatistas de comunicación en Europa y Estados Unidos ("re-regulación") y América Latina y el resto del mundo (“neo-regulación”) (Gómez, 2006:37-38).

Esta tesis inscribe al neofomentismo en la tendencia privatizadora y de apertura de mercado descripta por Gómez, pero también en los intentos estatales para retomar la iniciativa en cuanto apoyo a sectores productivos —en este caso, el cine-, pero con acciones tímidas, que dejan la iniciativa al sector privado.

El investigador Vincent Mosco plantea cuatro instancias en las que actúa la regulación estatal: la comercialización —cuando el Estado establece servicios públicos, tanto en el correo como en los canales de televisión-, la privatización -cuando el Estado comienza a flexibilizar la normativa de la instancia anterior, dando posibilidades a la entrada a agentes privados_, la liberalización — cuando el Estado abre totalmente el mercado a las empresas y a la lógica de la competencia capitalista y el lucro- y la internacionalización —cuando las decisiones estatales comienzan a vincularse en instancias supranacionales de decisión gubernamental (Mosco, 2010:177-178).

De acuerdo a esta clasificación, Gómez enmarca a la "neoregulación" en la etapa de “privatización”, en términos de Mosco —es decir, a la flexibilización que, durante la década de 1980 y 1990, experimentaron las políticas públicas de comunicación (en el 
caso del escrito de Gómez, referidas a las políticas europeas de comunicación de servicio público, que habían sido puestas en pleno funcionamiento a partir de mediados del siglo $\mathrm{XX})$.

A su vez, Gómez habla de "re-regulación" para el caso mexicano, diferenciándolo del caso europeo en el sentido de que en el Viejo Continente la flexibilización de las políticas de comunicación de servicio público acaecida entre las décadas de 1980 y de 1990 no eliminó la normativa, sino que la modificó para dar paso a una incipiente privatización, mientras que en el caso mexicano de la cinematografía directamente se eliminó la ley que rigió al sector durante más de 40 años para, unos pocos años después, instaurar otra - por presión del sector-, aunque mucho más laxa en términos de protección y fomento estatal, totalmente proclive a la libre competencia y favorable a la concentración y a la "liberalización", en términos de Mosco.

El neofomentismo se acerca más a la "re-regulación” de Gómez y, sobre todo, al Estado "gestor", "pasivo" del que habla Hadija Chalupe, refiriéndose a la Agencia Nacional de Cine brasileña (Ancine) nacida en 2001:

[Es un] Estado gestor porque deja de actuar directamente en el mercado cinematográfico brasileño, por medio de su empresa estatal, para asumir la forma de un órgano responsable por la mediación, regulación y fiscalización de los agentes que actúan en el mercado nacional. (2010:21; traducción propia)

Chalupe habla de un Estado que en lugar de ejecutar, intermedia; que en lugar de actuar, intermedia y administra, en una lógica más gerencial que de intervención (2010:47).

\section{Mecanismos de fomento a la cinematografía}

Las distintas medidas de apoyo a la actividad cinematográfica fueron, y son, muy importantes para mantener la producción cinematográfica en América Latina y en los distintos países que realizan cine, en un contexto de creciente e intensa competencia global —con las majors hollywoodenses como protagonistas.

Las medidas más frecuentes de fomento al sector cinematográfico se dan a la producción, aunque también existen — pero en mucha menor medida - apoyos a la 
preproducción, a la posproducción, a la distribución y a la exhibición, ayudas que no son homogéneas y varían entre la regulación, el mecenazgo y la promoción.

Estas ayudas se basan en variados sistemas, principalmente constituidos por operaciones no reintegrables, como subsidios, adelantos sobre ingresos de taquilla y subvenciones de distintos tipos. En América Latina la mayor parte de las ayudas son selectivas, aunque también existen varias de carácter automático.

Por otro lado, también fueron y son muy utilizadas las políticas fiscales de exención impositiva para estimular la inversión de capitales privados, principalmente, en la producción cinematográfica - aunque también se han aplicado líneas basadas en la renuncia fiscal para fomentar la exhibición y otros eslabones de la cadena de valor-. Se destacan los casos de Gran Bretaña, Canadá y, en América Latina, Puerto Rico, Brasil — con la sanción de las leyes "Rouanet" (1991) y del Audiovisual (1993) — y, desde 2003, Colombia — políticas neofomentistas que esta tesis denomina "defensivas" en su variante "mercado orientadas" (ver más en el capítulo I).

Otras medidas no menos importantes son los sistemas basados en el otorgamiento de créditos "blandos" a la actividad cinematográfica —es decir, con tasas de interés preferenciales-, un sector donde el capital y la banca privada son poco propensos a atender las necesidades de la realización cinematográfica - debido al alto riesgo inherente a esta actividad - Este tipo de ayudas se ofrecen en Francia, España, México, Argentina y Brasil, entre otros países.

En este breve compendio sobre ayudas al sector cinematográfico no puede faltar la "banca cinematográfica", es decir, experiencias donde el Estado asume el rol de banquero de la actividad cinematográfica. Se destaca la experiencia francesa, la mexicana (entre 1947 y 1979, con el Banco Cinematográfico), la brasileña (a través de Embrafilme, entre 1969 y 1990) y, en alguna medida, los sistemas español, portorriqueño y colombiano (Getino, 2005) —en estos últimos dos casos, a través de avales dados a los cineastas y productores por parte del Estado-. En Italia sobresale la experiencia de la Banca Nazionale del Lavoro, con su sección cinematográfica (Harvey, 2005). 


\section{Financiamiento público a la cinematografía}

Uno de los aspectos fundamentales de la política cinematográfica de un país es la fuente de recursos de que se dispondrá para hacer frente a los programas de fomento.

Se destacan, como se mencionó, los casos de Francia y Argentina, cuyos recursos se basan en impuestos y distintas contribuciones fiscales, y que provienen principalmente de los ingresos de las salas de cine, de la comercialización del mercado de video hogareño (alquiler y compra) y de los resultados económicos de la televisión - por ejemplo, la publicidad emitida por la pantalla chica—. De esta manera, los ingresos provienen del mercado y no del presupuesto nacional.

Los casos en los que los fondos de fomento al cine sí son alimentados por las arcas estatales — partidas incluidas en los presupuestos públicos del Estado- son los del Instituto Mexicano de Cinematografía, del Fondo de Fomento Audiovisual de Chile, del Consejo Nacional del Cine de Bolivia, de la Dirección de Cinematografía del Perú, del Instituto de Cine y Audiovisual del Uruguay, de los organismos especializados de Costa Rica y de Cuba, del Instituto de la Cinematografía y de las Artes Audiovisuales de España y del National Film Board de Canadá y Telefilm Canada — aunque en el caso canadiense ambas instituciones también disponen de recursos provenientes de la comercialización de producciones y coproducciones.

En otros países se dan situaciones intermedias, como la de la Agencia Nacional de Cine de Brasil, que depende del presupuesto estatal, aunque su principal herramienta de fomento, el Fondo Sectorial del Audiovisual, basa sus ingresos en la Contribución para el Desarrollo de la Industria Cinematográfica Nacional (Condecine), tributos aplicados desde 2002 sobre distintos eslabones del sector audiovisual — principalmente, salas de cine, homevideo, televisión abierta y paga (Ancine, 2012a).

Igual situación se da en Colombia y en Venezuela. La Dirección de Cinematografía de Colombia (que forma parte del organigrama del Ministerio de Cultura) se nutre del presupuesto nacional, no así el Fondo para el Desarrollo Cinematográfico —creado en 2003, como parte fundamental de la nueva ley de cine, y administrado por el Fondo Mixto de Promoción Cinematográfica de Colombia-, cuyos ingresos provienen de la recaudación de la Cuota para el Desarrollo Cinematográfico.

En Venezuela se da similar situación con el Centro Nacional Autónomo de Cinematografía (sus recursos dependen del presupuesto nacional) y con el Fondo de Promoción del Cine (Fonprocine) — que comenzó a funcionar en 2006-, que se nutre 
de una serie de contribuciones parafiscales aportadas por los distintos sectores vinculados a la actividad cinematográfica.

También se puede mencionar a la Corporación para el Desarrollo de las Artes, Ciencias e Industria Cinematográfica de Puerto Rico, que obtiene sus ingresos de la recaudación tanto del impuesto vigente sobre espectáculos públicos como de la licencia pagada por las entidades fílmicas al rodar en el país.

En Gran Bretaña se da una situación particular: las instituciones relacionadas con el cine (hasta 2010, el UK Film Council, y el British Film Institute) reciben importantes recursos tanto del Tesoro nacional como de la Lotería nacional.

\section{Subsidios}

Los sistemas de subsidios a la cinematografía son uno de los recursos fundamentales en las políticas públicas de cine de distintos Estados.

Los subsidios, que generalmente están más volcados hacia la producción que a la distribución o a la exhibición, tienen dos técnicas básicas de asignación: las ayudas automáticas y las ayudas selectivas. Los montos a otorgar por las ayudas automáticas están generalmente determinados por objetivos comerciales, como la recaudación de los filmes -ya sea en salas o en otras ventanas audiovisuales: este estímulo busca estimular a las productoras a alcanzar el mayor número de espectadores posible, o de que sus filmes sobrepasen el límite mínimo de espectadores que dicta la normativa.

Por su parte, las ayudas selectivas suelen ser decididas discrecionalmente por un jurado, a partir de diversos criterios - generalmente, de calidad e "impacto" cultural y social (este último ítem del impacto suele dar lugar a arbitrariedades basadas en el favoritismo político, especialmente, en América Latina, aunque las ayudas selectivas también suelen apoyar trabajos experimentales, y de trabajos con baja perspectiva comercial).

Tanto las ayudas directas como las selectivas son a fondo perdido (no reintegrables), y el requisito sine qua non que se les pide a los destinatarios es que la película sea "nacional" — es decir, se requiere (principalmente) que una parte importante del equipo técnico y artístico sea residente en el país en cuestión.

En América Latina predominan las categorías de ayudas selectivas, especialmente en México, Colombia, Venezuela, Chile, Perú, Uruguay y República Dominicana, aunque en Argentina y en Brasil también existen importantes ayudas que se otorgan a partir de criterios de selección. 
Naciones como Francia, España, Portugal, Argentina y Brasil tienen sistemas de ayuda automática a partir de los ingresos que los filmes obtienen en las salas de cine. Generalmente, el requisito principal es que los recursos otorgados por el Estado al productor beneficiado sean destinados a la financiación de otro filme, o a algún otro gasto relacionado con la actividad — por ejemplo, mejoramiento del equipamiento de la productora-. En algunos casos, como el francés, el argentino o el brasileño, estas ayudas se destinan también a los exhibidores — generalmente, se obtienen si la sala cinematográfica en cuestión exhibió una cantidad importante de películas nacionales-: estos recursos deben destinarse al mejoramiento de la infraestructura - ya sea edilicia o del sistema de proyección.

Son menores las ayudas ofrecidas a la distribución, las que se basan en adelantos sobre futuros ingresos de taquilla - las realiza especialmente Francia, España y Portugal, aunque también lo hacían México y Brasil décadas atrás, en las épocas en que los Estados de estas naciones tenían importantes políticas públicas cinematográficas.

También existen ayudas a la realización de cortometrajes - apuntando a sostener a los estudiantes de cine y a los noveles cineastas - y a la conservación del patrimonio (filmotecas, cinetecas, etc.). En la mayoría de los países latinoamericanos con sistemas de fomento al cine se dan este tipo de ayudas.

\section{Crédito cinematográfico}

El sistema de crédito es otra de las principales formas de financiación de la actividad cinematográfica, y se enfoca principalmente en la producción. Este sistema está atendido tanto por la banca privada como por la pública y es (naturalmente) reintegrable, pero con reducidas tasas de interés.

Son contados los casos de bancas especializadas en el crédito cinematográfico, tal como el caso de la Banca Nazionale del Lavoro, en Italia, que opera desde hace décadas.

En América Latina se destaca el caso de Argentina - cuyos créditos se complementaron, históricamente, con los del Fondo Nacional de las Artes (dependiente del Ministerio de Cultura, o del organismo que funja como tal)_- En el pasado, se destacaron los citados caso mexicano (Banco Nacional Cinematográfico) y brasileño (Embrafilme). El sistema boliviano de fomento al cine también se basa —integralmente - en el crédito, pero el Fondo de Fomento Cinematográfico de Bolivia —instituido junto con la sanción de la ley de cine, en 1991—, en la práctica, hace una 
década que no está operativo por insolvencia - principalmente, por deudas impagas y por la falta de los aportes que debía realizar el Estado (González, 2011b).

En otros casos, la aportación estatal en materia de créditos bancarios se basa en poner a disposición de los actores del sector cinematográfico cauciones y avales en garantía -que, generalmente, no obtendrían en la banca privada, debido al alto riesgo inherente al ámbito cinematográfico- . Tales son los casos de Telefilm Canada, del Instituto de Financiamiento del Cine y las Industrias Culturales (IFCIC) de Francia y del Instituto de la Cinematografía de las Artes Audiovisuales (ICAA) de España.

\section{Beneficios fiscales}

Otro aspecto importante en las políticas públicas de fomento cinematográfico es el de los beneficios fiscales para los interesados en participar en la actividad - generalmente, en la producción.

Estas ayudas varían entre la renuncia fiscal —impuestos que se dejan de cobrar para que, con dichos montos, se incremente la producción de cine-, el mecenazgo y la atracción de recursos provenientes del sector privado (nacional o extranjero) destinados al cine.

Brasil basó su actividad cinematográfica prácticamente en este tipo de ayudas desde comienzos de la década de 1990 hasta $2007,{ }^{8}$ luego de que el presidente Collor de Melo desguazara las instituciones y las herramientas estatales de apoyo al cine que habían funcionado durante más de 20 años — principalmente, la empresa estatal Embrafilme-. La llamada "Ley Rouanet" — aprobada en 1991 — se basó en el mecenazgo, y la "Ley del Audiovisual" - sancionada en 1993 - constituyó uno de los pocos casos en el mundo de un régimen fiscal especial dedicado exclusivamente al fomento para que los capitales nacionales y extranjeros participaran en la actividad cinematográfica (Harvey, 2005).

Similar son los casos mexicano y colombiano - aunque, en este último ejemplo, el sistema busca atraer mayormente capitales del sector privado nacional.

En el Reino Unido y en Canadá (Solot, 2009) los sistemas están ideados no sólo para atraer inversiones nacionales y extranjeras para la producción cinematográfica sino

\footnotetext{
${ }^{8}$ En 2008 se puso en funcionamiento el Fondo Sectorial do Audiovisual, la primera herramienta dirigida por el Estado brasileño para el fomento cinematográfico desde las medidas de Collor de Melo -hasta ese momento, el fomento cinematográfico, prácticamente, había estado sujeto a las decisiones particulares de las empresas, a partir de los proyectos que decidían apoyar para beneficiarse de la renuncia fiscal prevista por el Estado para que el sector privado se involucrara en el fomento al cine nacional.
} 
también para impulsar el mejoramiento de la infraestructura de servicios —aunque en Brasil también existen medidas en este sentido, pero sin ser mayoritarias en su sistema de fomento.

En Puerto Rico, como se mencionó, los beneficios fiscales estuvieron históricamente destinados a atraer inversiones para la realización de películas extranjeras en su territorio - buscando ambientes "exóticos"- y no tanto para fomentar la producción nacional.

De manera similar, pero buscando la contratación de mano de obra nacional y especializada (creadores, actores, técnicos), están enfocados los sistemas de benefício fiscal de Canadá (Solot, 2009) y Australia (Burns-Eltham, 2010) — principalmente, destinados a las producciones de Hollywood.

También se dan casos de fideicomisos y de conformación de sociedades de financiación, tal como sucede en Francia con distintas sociedades, en México, con el Fondo de Inversión y Estímulo al Cine (Fidecine), y en Brasil con los Fondos de Financiamiento para la Industria Cinematográfica Nacional (Funcines).

\section{Medidas de protección al cine nacional}

Existen dos aspectos característicos en lo que hace a la protección del cine nacional: se trata de la cuota de pantalla y de beneficios de fomento aplicados a las películas "nacionales" — definición basada en distintos criterios.

Estas medidas se instauraron tempranamente a finales de la época del cine mundo y principios del sonoro, principalmente en países europeos —como Francia, Gran Bretaña, España, Italia, Alemania, Dinamarca y Portugal (Guback, 1980) - y también en Brasil (Gatti, 2008).

Sin embargo, existieron - $-\mathrm{y}$ existen - otras medidas proteccionistas en el ámbito cinematográfico a lo largo del mundo, tales como restricciones a la importación de filmes extranjeros, a la transferencia de divisas al exterior, limitaciones por exigencias de doblaje, y restricciones a la entrada de capitales extranjeros para constituir empresas relacionadas con la actividad cinematográfica (Harvey, 2005).

Por ejemplo, Gran Bretaña aplicaría — apenas terminada la Segunda Guerra Mundial— restricciones a la transferencia de regalías provenientes de la explotación y exhibición de filmes extranjeros en su territorio; a su vez, en 1949 el Reino Unido pondría en 
práctica la medida Dalton duty, a través de la cual se cobraba un gravamen del $75 \%$ a toda película extranjera — las que eran, en su mayoría, estadounidenses (Guback, 1980). En España, en 1929, se restringió la entrada de filmes extranjeros a través de un porcentaje basado en la cantidad de películas españolas exhibidas. En 1941 el régimen franquista impondría cánones de importación a los filmes extranjeros y doblaje obligatorio a las películas que no estuvieran habladas en castellano. A su vez, en 1946 el Estado español aplicó una normativa por la que todas las empresas de la industria cinematográfica debían constituirse con capital 100\% español, y cuyas acciones eran intransferibles a ciudadanos extranjeros (Harvey, 2005).

\section{"Cuota de pantalla"}

La cuota de pantalla - una de las más antiguas medidas tanto de protección como de promoción de los cines nacionales - básicamente se trata de reservar un tiempo mínimo determinado de programación periódica o anual, para proyectar obligatoriamente películas nacionales en las salas de cine de un país dado.

La cuota de pantalla se viene implementando desde las primeras décadas del siglo XX, cuando en algunos países el sector cinematográfico ya venía alcanzando cierta magnitud - tanto en lo que hace a los empleos generados como a la potencialidad culturalpolítica-, con el fin de proteger a incipientes industrias ante la fuerte competencia del cine extranjero —especialmente, estadounidense (Guback, 1980).

En Francia y en Gran Bretaña se establecieron cuotas de pantalla en 1927. En este último territorio se implantó un régimen de licencias de importación poco tiempo después, por el que cada película importada debía generar la producción de una película nacional — a cargo del importador (un sistema similar adoptaría España en la década de 1940)_- Ya en la década de 1940, Francia reforzaría su cuota de pantalla — cuatro semanas por trimestre en 1946, incrementadas a cinco semanas en 1948- (Harvey, 2005). En España, en 1942 se estableció una cuota de pantalla, en el marco de variadas medidas proteccionistas destinadas a fomentar el cine nacional —anteriormente mencionadas (Getino, 2005).

En el ámbito latinoamericano, en 1932 se estableció en Brasil — durante el gobierno de Getúlio Vargas - una cuota de pantalla — que en 1939 se sancionaría con fuerza de ley: la quota de tela equivalía al $2 \%$ de la programación anual de las salas- La cuota de pantalla brasileña perdura, con cambios, hasta nuestros días — siendo una de las más 
antiguas y sostenidas en el mundo-. En 1944 la dictadura militar argentina también adoptaría una cuota de pantalla. México, por su parte, impondría una cuota de pantalla en 1949, equivalente al 50\% del tiempo anual de proyección de las salas (Gatti, 2008), que por el acuerdo del Tratado de Libre Comercio de América del Norte firmado en 1993 se rebajaría al 10\% que rige actualmente.

Otros países latinoamericanos que poseen cuota de pantalla son México - aunque, en la actualidad, es virtualmente inexistente, como se describirá en el capítulo nacional (entre las décadas de 1950 y 1992 llegó a tener 50\% de cuota de pantalla) - y Argentina —este país posee cuota de pantalla desde mediados de la década de 1940; desde 2004 está ligada a la llamada "media de continuidad" (que asegura la permanencia de un título nacional, si alcanza un número mínimo de espectadores, impidiendo a los exhibidores retirarla de cartel); este aspecto se describirá mejor en el capítulo V.

\section{"Nacionalidad"}

Con respecto a la clasificación de "nacionalidad" para una película - cuyos criterios pueden ser más o menos rígidos - es una de las primeras medidas de fomento que se adoptaron en el mundo (Harvey, 2005), tendiente a alcanzar una más eficiente e intensa utilización de la infraestructura y los recursos nacionales disponibles. Todos los países latinoamericanos con medidas de fomento poseen detalladas disposiciones para determinar los requisitos de nacionalidad de una película. Obtener el certificado de nacionalidad es una condición ineludible a la hora de aspirar a recibir las distintas ayudas, subsidios, exenciones fiscales y créditos estatales destinados al cine.

Son varias las características que definen la "nacionalidad" de una película según la normativa de cada país, destacándose las siguientes: la nacionalidad de los creadores, de los directores, de los actores, de los productores y/o de los técnicos, ya sea de todos o de algunos de ellos; el lugar donde se llevan a cabo las distintas etapas de realización de la película; el idioma original del filme; la nacionalidad de las empresas participantes en el proyecto, y el origen de los capitales destinados a financiar la película.

A su vez, distintas herramientas de cooperación internacional en el ámbito cinematográfico —como, por ejemplo, los acuerdos de integración iberoamericana, o los vigentes en la Unión Europea- proponen una concepción ampliada, y de cierta homogeneización del concepto de "nacionalidad" para un número importante de países. 


\section{América Latina: panorama contemporáneo}

Con excepción de Paraguay y las Guayanas, todos los países de América del Sur y México poseen legislación nacional de fomento a la cinematografía y órgano rector de la actividad —en algunos países, como México, Perú, Bolivia y Venezuela, entre otros, existen debates al interior del sector para reformular sus respectivas leyes de cine.

Las legislaciones nacionales de fomento al cine buscan, primeramente, apoyar la producción cinematográfica con el fin de potenciar el buen uso de la infraestructura disponible dedicada a esta actividad. Por otro lado, buscan aplicar incentivos fiscales para atraer la inversión, tanto del sector privado - como sucede, por ejemplo, en Brasil, Colombia y México- como de los propios contribuyentes del país, a través de impuestos a las taquillas o de partidas provenientes del presupuesto nacional -como ocurre, de distintas maneras, en la Argentina, Uruguay, Venezuela, Perú y Bolivia.

En la letra de las legislaciones latinoamericanas de fomento al cine se incluyen todos los eslabones de la cadena productiva, desde el desarrollo hasta la difusión y la exhibición. A nivel general, las políticas públicas de fomento al cine en América latina se basan en ayudas directas — sobre todo a la producción, aunque en algunos casos, también a la distribución, a la exhibición y a la promoción-, principalmente, a través de subsidios o créditos blandos. En algunos países los incentivos se extienden a otras actividades audiovisuales, como la producción y difusión de contenidos televisivos y audiovisuales - tal como sucede en Chile o en Colombia (hace pocos años, en la Argentina se lanzaron programas específicos para producir contenidos destinados a la futura televisión digital).

Sin embargo, en la práctica, las políticas de fomento en América Latina se concentran mayoritariamente en la producción, siendo la distribución, la exhibición y la comercialización la gran asignatura pendiente. Una de las medidas más antiguas de protección -e, inclusive, de promoción - de la producción cinematográfica a nivel mundial es la cuota de pantalla en las salas de cine —es decir, la reserva de un tiempo mínimo de programación anual o periódica en las salas de cine de un país, destinado a la exhibición obligatoria de filmes nacionales-. A pesar de que las legislaciones de distintos países latinoamericanos contemplan la cuota de pantalla —como México, Chile, Perú-, sólo en Argentina, Brasil y Venezuela el Estado tiene una posición más activa con esta prerrogativa. En algunos casos, como en Chile, la televisión tiene la obligación efectiva de programar en sus pantallas cierta cantidad de películas nacionales —o en Brasil, en el caso de la televisión paga (la Ley de Servicios de Comunicación 
Audiovisual de la Argentina también dispone una cuota de pantalla para la cinematografía nacional, pero no se cumple).

\section{América Latina: estructura institucional}

En el caso de dos de los grandes países latinoamericanos en el ámbito cinematográfico, México y Brasil, no se dio la misma continuidad político-administrativa de Argentina, aunque sí existieron - y existen - importantes instituciones de sus Estados nacionales dedicadas al fomento y a la promoción del cine.

El Instituto Mexicano de Cinematografía (Imcine) cumplió 32 años — fue creado en 1983 - , con una renovada gestión a partir de los programas Foprocine (creado en 1997), Fidecine (2002) y Eficine (2006).

En Brasil, la Agencia Nacional de Cine (Ancine) incorporó herramientas fundamentales como el Fundo Setorial —que comenzó a funcionar en 2007- y las diversas contribuciones normativas, regulatorias y monetarias de la nueva normativa de televisión por cable (2011), que crea cuotas de producción nacional e independiente en los canales internacionales, así como también cuota de canales nacionales en los paquetes de programación.

En lo que respecta a los países andinos (Bolivia, Perú, Ecuador, Colombia y Venezuela), cuentan con estructuras específicas estatales dedicadas al cine. Sin embargo, en países como Bolivia y Perú, sus instituciones nacionales se encuentran crónicamente limitadas por falta de recursos —en el caso de Perú, en 2010 se dio de baja al Consejo Nacional de Cinematografía, creado en 1991, suplantándolo por una más devaluada Dirección de Cinematografía (en el contexto de una arremetida de legisladores fujimoristas por desmontar las medidas de fomento al cine) (González, 2011b).

En el caso de Venezuela, el Centro Nacional Autónomo de Cinematografía (CNAC) está cumpliendo 20 años —fue creado en 1993, heredero del frustrado Fondo de Fomento Cinematográfico (Focine) — . Tanto el CNAC como el sector cinematográfico venezolano tuvieron importantes cambios a partir de la sanción de una nueva ley de cine en 2005: mayor cantidad de líneas de apoyo a la producción, distribución y exhibición, creación de la distribuidora estatal Amazonia Films y de los estudios estatales Villa del Cine (González, 2011b). 
En Colombia la sanción de Ley de Cine de julio de 2003 — que, entre otras medidas, creó el Fondo para el Desarrollo Cinematográfico-, tuvo una fundamental importancia para un lento pero sostenido desarrollo en el sector cinematográfico nacional durante la primera década del siglo XXI (González, 2011b). Hay que remarcar que la sanción de la ley de cine estuvo impulsada por la creación en 1997 de la Ley Nacional de Cultura de 1997, que buscó apoyar fuertemente a la cultura (Harvey, 2005).

En el caso de Chile, fue importante para el sector cinematográfico la promulgación —en noviembre de 2004 - de la Ley del Fomento al Cine y al Audiovisual que, entre otras disposiciones, creó el Consejo del Arte y la Industria Audiovisual — con categoría de ministerio de cultura-. Estas medidas se sumaron a políticas estatales de fomento al cine que venían de décadas anteriores, como las ayudas provistas por organismos como la Corporación de Fomento (Corfo) ${ }^{9}$ y el Fondo de Desarrollo de las Artes y la Cultura (Fondart), este último, creado en 1992 (González, 2011b).

En 1994 se creó en Uruguay el Instituto Nacional del Audiovisual (INA), dependiente del Ministerio de Educación, y en 1995 el Fondo para el Fomento y Desarrollo de la Producción Audiovisual (Fona). Hasta ese momento, el país sudamericano no había tenido instituciones importantes dedicadas a fomentar el cine. Sin embargo, el gran espaldarazo estatal al cine llegó en 2008, con la aprobación de la ley de cine, que crea un fondo de fomento y da nacimiento al Instituto Nacional del Cine y el Audiovisual de Uruguay (el ICAU), reemplazando al INA (González, 2011b).

La política cubana de apoyo al cine no varió mayormente desde 1959, cuando se creó el Instituto Cubano de Arte e Industria Cinematográficos (Icaic), 83 días después de la Revolución Cubana - fue la primera medida del gobierno revolucionario destinada a la cultura (Getino, 2005).

Durante la revolución sandinista que comenzó en 1979, Nicaragua intentó una firme política de fomento al cine — enmarcada en líneas similares a las cubanas - , pero que no sobrevivió a la apertura electoralista de 1990, e inmediata derrota en las urnas del gobierno (Getino, 2005).

Costa Rica posee antecedentes institucionales relacionados con el cine -especialmente, a través de las iniciativas del Ministerio de Cultura, Juventud y Deportes, en 1971, pero que fueron de escasa trascendencia-, basados sobre todo en exenciones y beneficios,

\footnotetext{
${ }^{9}$ La Corfo es una antigua institución estatal creada en 1939, destinada a fomentar la industrialización chilena a nivel general.
} 
que terminaron utilizando mayormente filmaciones extranjeras que buscan paisajes caribeños, sin fomentar mayormente la producción nacional (Getino, 2005).

\section{Normativa de fomento enfocada en esta tesis}

La presente tesis analizará las políticas cinematográficas de Argentina, Brasil y México, principalmente en el período contemporáneo — década de 1990 hasta la actualidad—, que se denomina neofomentismo -es decir aquellas políticas cinematográficas aplicadas luego del desmantelamiento que se hiciera de las distintas ayudas oficiales al fomento cinematográfico en el primer lustro de los años noventa- A su vez, el neofomentismo se comparará con lo realizado durante el período fomentista —es decir, con el comprendido entre las décadas de 1940 y 1980.

En lo que hace al período fomentista, se estudiará lo realizado por los Estados empresarios cinematográficos en México y Brasil —entre 1942-1992, en el caso mexicano, y entre 1969-1990 en el caso brasileño-, principalmente en lo que hace a la creación de empresas estatales de fomento al cine y a la participación activa de los Estados en todos los eslabones de la cadena de valor.

Referido al neofomentismo, la tesis analizará lo relativo a distintos mecanismos de fomento, tales como los subsidios, los créditos y las exenciones fiscales, pero organizados en torno a si están orientados por el Estado — como el Fondo de Fomento argentino y el Fondo Sectorial brasileño- u orientadas por el mercado - como los fideicomisos mexicanos o las normativas de exención fiscal brasileñas.

El Estado, en su capacidad para intervenir en el mercado a favor de un bien socialmente beneficioso como el cine, busca subsanar a través de las políticas cinematográficas las fallas de mercado - concentración, falla en la competencia, requerimiento de grandes inversiones en el sector, bajos niveles de comercialización y consumo de filmes nacionales, entre otros- Para ello se vale de herramientas como las antedichas, junto a la cuota de pantalla — sumada a la media de continuidad, en Argentina-, medida histórica implementada en América Latina por los tres países estudiados por esta tesis. El análisis de estas herramientas de fomento disponibles por el Estado buscará comparar los resultados obtenidos por las políticas cinematográficas en Argentina, Brasil y México desde la segunda parte de la década de 1990 hasta 2009, en comparación con las medidas de fomento tomadas hasta la década de 1980 por los citados países. 


\section{CAPÍTULO III \\ PRODUCCIÓN CINEMATOGRÁFICA}

Entre 2005 y 2011 la producción cinematográfica mundial creció el 39\% —-porcentaje similar al que venía registrándose en años anteriores (Observatorio Europeo del Audiovisual, 2006).

Un centenar de países produjeron de manera profesional largometrajes destinados a la exhibición comercial en salas de cine, dando un promedio de producción de 5987 largometrajes anuales (cuadro 3) entre 2005 y 2011. Las cifras también muestran que en 2008 se dio un estancamiento en la producción cinematográfica a nivel mundial —explicado, principalmente, por los países europeos y latinoamericanos. ${ }^{10}$

Cuadro 5 - Producción mundial de largometrajes* (2005-2011)

\begin{tabular}{|r|r|r|r|r|r|r|r|}
\hline & $\mathbf{2 0 0 5}$ & $\mathbf{2 0 0 6}$ & $\mathbf{2 0 0 7}$ & $\mathbf{2 0 0 8}$ & $\mathbf{2 0 0 9}$ & $\mathbf{2 0 1 0}$ & $\mathbf{2 0 1 1}$ \\
\hline $\begin{array}{r}\text { Número de } \\
\text { largometrajes } \\
\text { producidos }\end{array}$ & 4818 & 5284 & 5760 & 6454 & 6475 & 6548 & \\
\hline $\begin{array}{r}\text { Número de } \\
\text { países }\end{array}$ & 81 & 79 & 85 & 89 & 93 & & \\
\end{tabular}

* Películas realizadas de manera profesional con el fin de ser estrenadas comercialmente (las producciones de Nigeria no se incluyen).

Fuente: Elaboración propia sobre la base de datos del Instituto de Estadísticas de la Unesco y de González (2011b).

Analizando por regiones, se aprecia que América Latina presenta un porcentaje muy reducido del total mundial —entre el $7 \%$ y el $9 \%$ durante la última década一, similar proporción a la que se dio históricamente (Sadoul, 2004).

Vale notar el menor porcentaje que la producción estadounidense representa del total —con una producción estancada entre 700-800 producciones desde hace más de una década-, en contraste con el notable crecimiento chino - con un aumento del $185 \%$ entre 2005 y 2012 (Observatorio Europeo del Audiovisual, 2013)—. Se estima que para finales de esta década el gigante asiático se convertirá en el principal productor y mercado cinematográfico del mundo (González, 2013).

\footnotetext{
${ }^{10}$ Sin embargo, desde 2012 la producción fílmica mundial tuvo un repunte, especialmente en el caso chino. A nivel latinoamericano, también se dio un incremento desde comienzos de la década de 2010 (González, 2013).
} 


\section{Gráfico 1 - Producción cinematográfica a nivel mundial* (2010)}

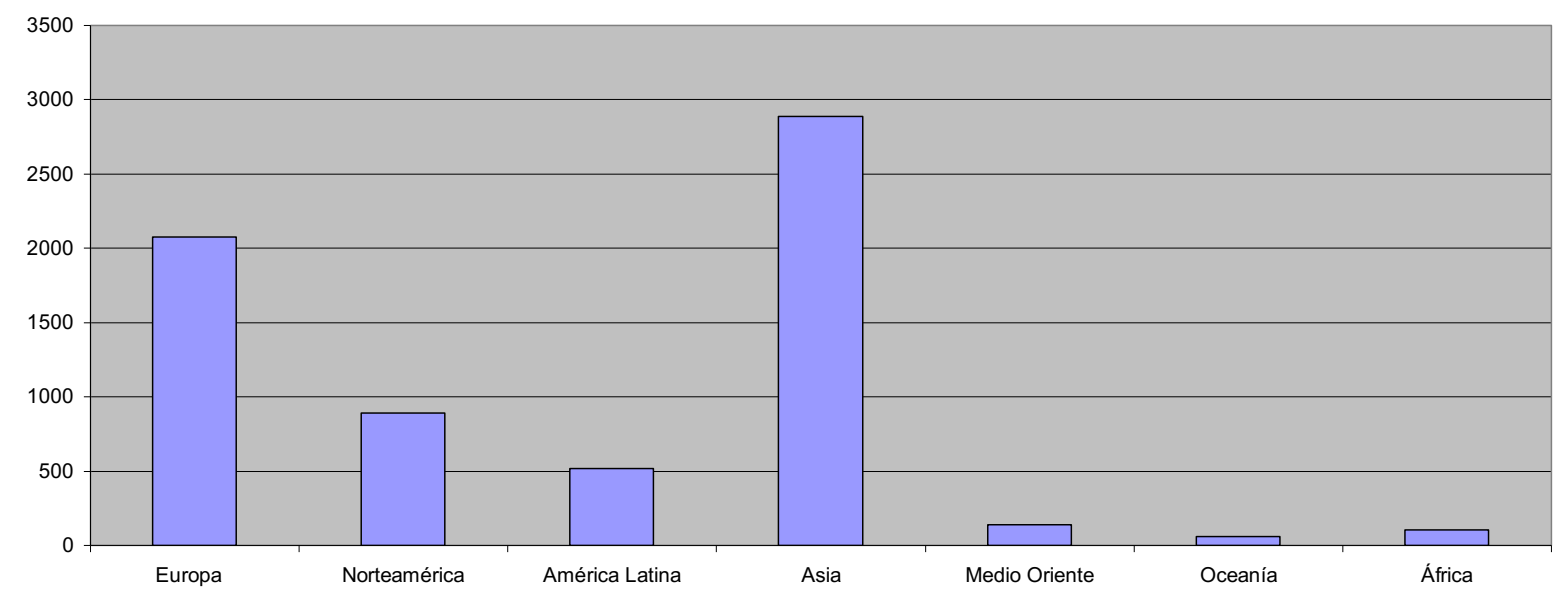

* Norteamérica incluye a Estados Unidos y Canadá

Fuente: Elaboración propia sobre la base de datos del Instituto de Estadísticas de la Unesco y de González (2011b).

Cuando se realiza el análisis por país, se observa que el aumento de la producción cinematográfica a nivel mundial se explica principalmente por los diez mayores productores de cine, quienes representan cerca del $65 \%$ de la producción mundial, como se muestra en el cuadro 6. De estos países, los que tuvieron los mayores crecimientos de su producción cinematográfica entre 2005 y 2011 fueron China —de 260 a 584 largometrajes $(124,6 \%)$ - el Reino Unido — de 106 a 299 (182,1\%) - y Corea del Sur —de 87 a 206 (148,3\%)—. Otros países integrantes del "top 10” que registraron aumentos importantes entre 2005 y 2011 fueron Alemania (45,2\%), España (40,1\%) e Italia $(58,1 \%)$.

Cuadro 6 - Principales productores de largometrajes a nivel mundial (2005-2011)

\begin{tabular}{|l|l|l|l|l|l|l|l|l|}
\hline & $\mathbf{2 0 0 5}$ & $\mathbf{2 0 0 6}$ & $\mathbf{2 0 0 7}$ & $\mathbf{2 0 0 8}$ & $\mathbf{2 0 0 9}$ & $\mathbf{2 0 1 0}$ & $\mathbf{2 0 1 1}$ & $\begin{array}{l}\text { Aumento entre } \\
\mathbf{2 0 0 5} \text { y 2011 }\end{array}$ \\
\hline India & 1041 & 1091 & 1146 & 1325 & 1288 & 1274 & 1255 & $21 \%$ \\
\hline Estados Unidos & 699 & 673 & 789 & 773 & 751 & 792 & 819 & $17 \%$ \\
\hline China & 260 & 330 & 411 & 422 & 475 & 542 & 584 & $125 \%$ \\
\hline Japón & 356 & 417 & 407 & 418 & 448 & 408 & 441 & $24 \%$ \\
\hline Reino Unido & 106 & 107 & 124 & 279 & 313 & 346 & 299 & $182 \%$ \\
\hline Francia & 240 & 203 & 228 & 240 & 230 & 261 & 272 & $13 \%$ \\
\hline Corea del Sur & 87 & 110 & 124 & 113 & 158 & 152 & 216 & $148 \%$ \\
\hline Alemania & 146 & 174 & 174 & 185 & 216 & 189 & 212 & $45 \%$ \\
\hline España & 142 & 150 & 172 & 173 & 186 & 200 & 199 & $40 \%$ \\
\hline Italia & 98 & 116 & 121 & 154 & 131 & 142 & 155 & $58 \%$ \\
\hline $\begin{array}{l}\text { Porcentaje del top } 10 \text { de } \\
\text { países productores en el } \\
\text { total mundial }\end{array}$ & $65,9 \%$ & $63,8 \%$ & $64,2 \%$ & $63,2 \%$ & $64,8 \%$ & $65,8 \%$ & $67,7 \%$ & \\
\hline
\end{tabular}

Fuente: Elaboración propia sobre la base de datos del Instituto de Estadísticas de la Unesco y de González (2011b). 
Es preciso notar la enorme producción cinematográfica de la India: este país representa por sí sólo casi el 20\% de la producción mundial de cine —en el período 2005-2011 realizó un promedio de 1200 largometrajes anuales.

Vale aclarar el caso de Nigeria: allí se realiza una gran cantidad de producciones audiovisuales —un promedio 966 películas anuales entre 2005 y 2011-. Sin embargo, se trata de producciones informales o semiprofesionales, la mayoría de ellas casi artesanales, con escasa exhibición en salas comerciales. Vayan como ejemplo los números de 2010: ese año se produjeron 1074 audiovisuales; sin embargo, en un país de unos 160 millones de habitantes, estas "películas" nacionales sólo vendieron 117 mil entradas. Por esa razón, no se cuenta a los audiovisuales nigerianos en el total de la producción mundial de largometrajes con fines de estreno comercial —estas películas son producciones informales realizadas en su gran mayoría de manera artesanal, que no tienen como objetivo la exhibición comercial, sino una distribución casera y precaria; esto se puede apreciar en los escasos números disponibles: para 2010, se produjeron 1074 "filmes" pero los espectadores de las películas nacionales sumaron nada más que 117.563 personas, en un país con una población de alrededor de 160 millones de habitantes.

Yendo más allá de los diez países con mayor producción cinematográfica, otras naciones que mostraron aumentos significativos fueron Brasil —de 42 a 100 películas (136\%)—, Irán —de 26 a 76 (192\%)—, Turquía —de 28 a 70 (150\%)—, Vietnam —de 12 a 75 (525\%, para el año 2010)—y México —de 71 a 111 (56,3\%) (González, 2013). A su vez, a nivel mundial se da un alto grado de concentración en el ámbito de la producción cinematográfica, como se puede apreciar en el gráfico 2. 


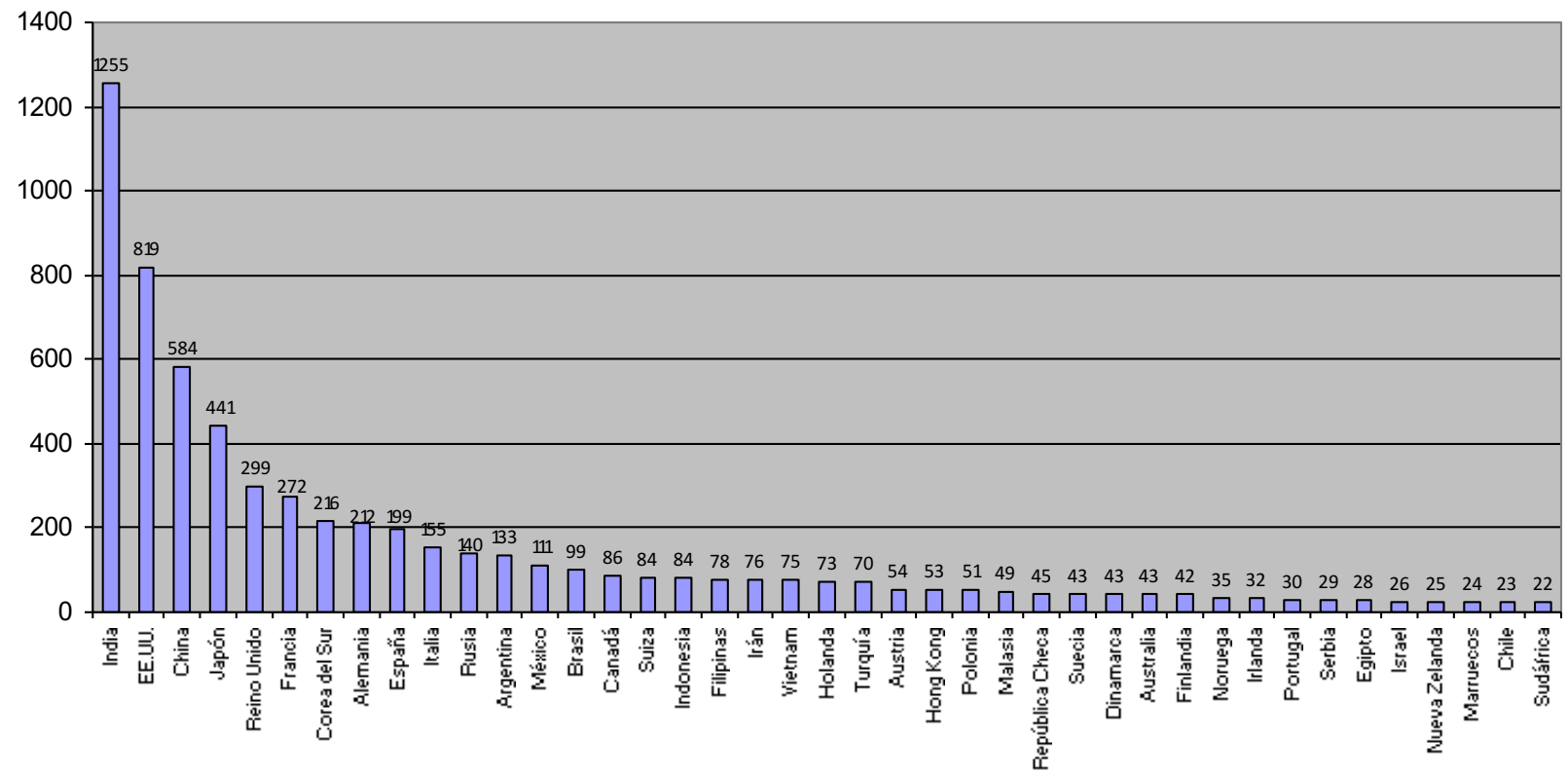

Fuente: Elaboración propia sobre la base de datos del Instituto de Estadísticas de la Unesco y de González (2011b).

Para analizar mejor esta concentración de la producción cinematográfica a nivel mundial, en el cuadro 7 se agrupan — de acuerdo a su nivel de producción- los 90 países que realizaron largometrajes durante al menos tres años entre 2005 y 2011.

Cuadro 7 - Nivel de producción cinematográfica, por número de países* y películas (2005-2011)

\begin{tabular}{|c|c|c|c|c|c|}
\hline \multicolumn{2}{|c|}{ Nivel de producción** } & \multirow{2}{*}{$\begin{array}{c}\text { Número de } \\
\text { países*** } \\
7\end{array}$} & \multirow{2}{*}{$\frac{\%}{7,78}$} & \multirow{2}{*}{$\begin{array}{c}\begin{array}{c}\text { Número de } \\
\text { largometrajes } \\
\text { producidos }\end{array} \\
\text { anualmente } \\
\text { (promedio) }\end{array}$} & \multirow{2}{*}{$\frac{\%}{57,34}$} \\
\hline Muy alto & 200 y más & & & & \\
\hline Alto & 80-199 & 11 & 12,22 & 1258,82 & 20,27 \\
\hline Promedio & $20-79$ & 25 & 27,78 & 981,71 & 15,86 \\
\hline Bajo & 6 a 19 & 33 & 36,67 & 346,85 & 5,60 \\
\hline Muy bajo & hasta 5 & 14 & 15,56 & 39,76 & 0,64 \\
\hline
\end{tabular}

* Películas realizadas de manera profesional con el fin de ser estrenadas comercialmente (las producciones de Nigeria no se incluyen).

** Estas categorías se construyen a partir de la base de datos del Instituto de Estadísticas de la Unesco, y de obtener, a partir de ella, la media de largometrajes realizados en todo el mundo por unos 160 países en los últimos años (González, 2013).

*** Países con al menos un largometraje producido en, al menos, tres años entre 2005 y 2011.

Fuente: Elaboración propia sobre la base de datos del Instituto de Estadísticas de la Unesco y de González (2011b). 
Al analizar los países con una producción cinematográfica "muy alta" —más de 200 largometrajes anuales - los números muestran que entre 2005 y 2011 siete naciones produjeron un promedio de 3561 filmes. Eso significa que el 8\% de los países productores de cine realizaron el 57\% de los largometrajes de todo el mundo.

Los países con producción "alta" —entre 80 y 199 filmes por año— fueron once en el período analizado: todos ellos concluyeron -en promedio- 1259 largometrajes anuales.

Si se suman los países con producción cinematográfica "muy alta" y "alta", se aprecia que el $20 \%$ de los países productores del mundo realizaron el $80 \%$ de las películas de todo el mundo entre 2005-2011 (4820 filmes en total). Los tres países analizados en esta tesis (México, Argentina y Brasil) se ubican en esta categoría.

Con respecto a los países con un nivel de producción "promedio" —entre 20 y 79 largometrajes por año-, se observa que el $28 \%$ de los países productores -25 naciones - realizaron el 16\% de las películas de todo el mundo —un promedio de 982 filmes anuales-. Ningún país latinoamericano se encuentra en esta categoría.

Por último, los países con una menor producción cinematográfica en el período 20052011 sumaron el 52\% de todas las naciones productoras a nivel mundial —es decir, 47 países que produjeron anualmente 19 largometrajes, o menos-, cuya producción cinematográfica sólo representó el 6\% de todas las películas realizadas en el mundo. En esta categoría se ubican nueve países latinoamericanos: Bolivia, Chile, Colombia, Cuba, Perú, Puerto Rico, República Dominicana, Uruguay y Venezuela.

Ajustando el análisis sólo a los países que produjeron - en promedio - hasta cinco largometrajes anuales en el período analizado, se observa que 14 naciones -el 15\% de todos los países productores de cine- produjeron sólo el $0,6 \%$ de los filmes realizados en el mundo -40 filmes en total-. En esta categoría aparecen tres países latinoamericanos: Paraguay, Costa Rica y Guatemala.

\section{Fomento estatal al cine en los principales países productores cinematográficos}

Doce de los quince países con mayor producción cinematográfica del mundo —naciones que también representan una importante porción del mercado mundial de cine- poseen políticas y mecanismos de subsidio por parte del Estado.

En efecto, los principales países productores de películas con un nivel de producción “alto" — de 80 a 199 largometrajes anuales— o "muy alto" —más de 200 películas por año- tienen fomento estatal al cine, además de una tradición en el ámbito de la 
coproducción, como son los casos de Argentina, Francia, España y el Reino Unido, entre otros.

Cuadro 8 - Países con mayor número de largometrajes producidos*, por participación de mercado (cantidad de espectadores) y fomento estatal (promedio 2005-2011)

\begin{tabular}{|c|c|c|c|c|}
\hline & $\begin{array}{c}\text { Producción } \\
\text { promedio } \\
(\mathbf{2 0 0 5 - 1 1 )} \\
\end{array}$ & $\begin{array}{c}\text { Nivel de } \\
\text { producción } * *\end{array}$ & $\begin{array}{c}\% \\
\text { Porcentaje } \\
\text { de mercado } \\
\text { (espectadores } \\
\text { del cine } \\
\text { nacional) } \\
\end{array}$ & $\begin{array}{l}\text { Apoyo } \\
\text { estatal } \\
\text { al cine }\end{array}$ \\
\hline India & 1203 & Muy alto & $90 \% \mathrm{e}$ & No \\
\hline Estados Unidos & 756 & Muy alto & $92 \% \mathrm{e}$ & Indirecto \\
\hline China & 432 & Muy alto & $56 \% \mathrm{e}$ & Sí \\
\hline Japón & 413 & Muy alto & $52 \% \mathrm{e}$ & No \\
\hline Rusia & 292 & Muy alto & $21 \% \mathrm{e}$ & Sí \\
\hline Francia & 239 & Muy alto & $39 \%$ & Sí \\
\hline Reino Unido & 225 & Muy alto & $25 \% \mathrm{e}$ & Sí \\
\hline Alemania & 185 & Alto & $21 \%$ & Sí \\
\hline España & 175 & Alto & $15 \%$ & Sí \\
\hline Corea del Sur & 137 & Alto & $48 \%$ & Sí \\
\hline Italia & 131 & Alto & $29 \%$ & Sí \\
\hline Argentina & 108 & Alto & $11 \%$ & Sí \\
\hline México & 94 & Alto & $7 \%$ & Sí \\
\hline Brasil & 89 & Alto & $13 \%$ & Sí \\
\hline Bangladesh & 88 & Alto & $\mathrm{sd}$ & No*** \\
\hline Filipinas & 87 & Alto & $25 \% \mathrm{e}$ & Sí \\
\hline Suiza & 84 & Alto & $5 \%$ & Sí \\
\hline Canadá & 81 & Alto & $4 \%$ & Sí \\
\hline
\end{tabular}

e (estimado)

sd ( $\sin$ datos)

* Películas realizadas de manera profesional con el fin de ser estrenadas comercialmente (las producciones de Nigeria no se incluyen)

** "Muy alta producción": 200 largometrajes producidos por año. "Alta producción": 80-199 largometrajes producidos al año.

*** Existe un fondo estatal en Bangladesh de fomento al cine, pero apoya sólo unas 5 películas anuales.

Fuente: Elaboración propia sobre la base de datos del Instituto de Estadísticas de la Unesco y de González (2011b).

Sólo tres de los países listados no tienen fomento estatal al cine: India -el mayor productor de cine del mundo-, Japón y Bangladesh. En el caso de Estados Unidos, el sector cinematográfico se beneficia de distintos mecanismos de fomento, como subsidios directos (exenciones de impuestos, pagos diferidos y amortización acelerada) e indirectos (apoyo estatal para "eliminar barreras" al "libre comercio" en la circulación de los filmes estadounidenses en todo el mundo). 


\section{Producción cinematográfica en América Latina}

Durante la primera década del siglo XXI en América Latina se produjeron entre $300 \mathrm{y}$ 400 largometrajes anuales, un número notablemente superior al de las décadas recientes: durante la década de 1980 se produjeron, en promedio, 230 largometrajes anuales, y durante los noventa, ese promedio bajó a 91 producciones al año.

\section{Gráfico 3 - América Latina: producción cinematográfica (1920-2009)}

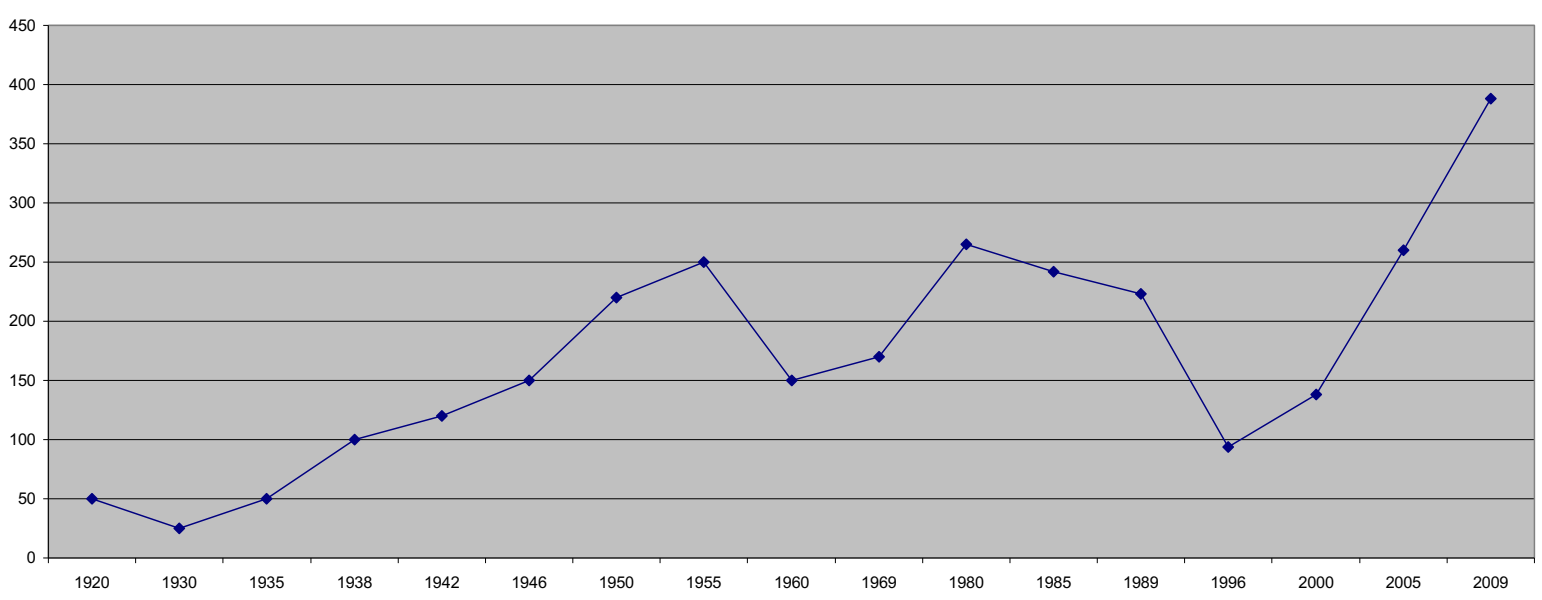

Fuente: Elaboración propia sobre la base de datos de Sadoul (2004), Instituto de Estadísticas de la Unesco, Observatorio Europeo del Audiovisual, González (2011b), Imcine, Ancine, Proimágenes, CNAC, CNCA, Deisica, Nielsen-Rentrak, Ultracine, Cinedística, Filme-B, Box Office Mojo.

A través de la historia, fueron distintos los países que representaron la mayoría de las producciones latinoamericanas —“empujando" los números a nivel regional一: Argentina y México durante la década de 1930, México durante las décadas de 1950 y 1960, Brasil y México durante la década de 1970; Argentina, Brasil y México durante la década de 2000.

Durante el último decenio, la producción cinematográfica en varios países de la región alcanzó picos históricos. El fomento estatal a la producción cinematográfica existente en casi toda América Latina - con excepción de Paraguay y de casi toda América Central-, a través de distintas variantes (subsidios, incentivos fiscales, créditos blandos, premios, entre otros) e intensidad, ha permitido el aumento en la producción de películas como nunca antes en la región; inclusive en países como Argentina y Brasil el número de filmes realizados alcanza valores que sólo se habían conseguido décadas atrás, no así en México, que a pesar de haber experimentado un importante repunte en la actividad cinematográfica durante la última década, la cantidad de realizaciones aztecas no se aproxima a los números que supo tener el cine mexicano en su época de oro, a mediados del siglo XX. 


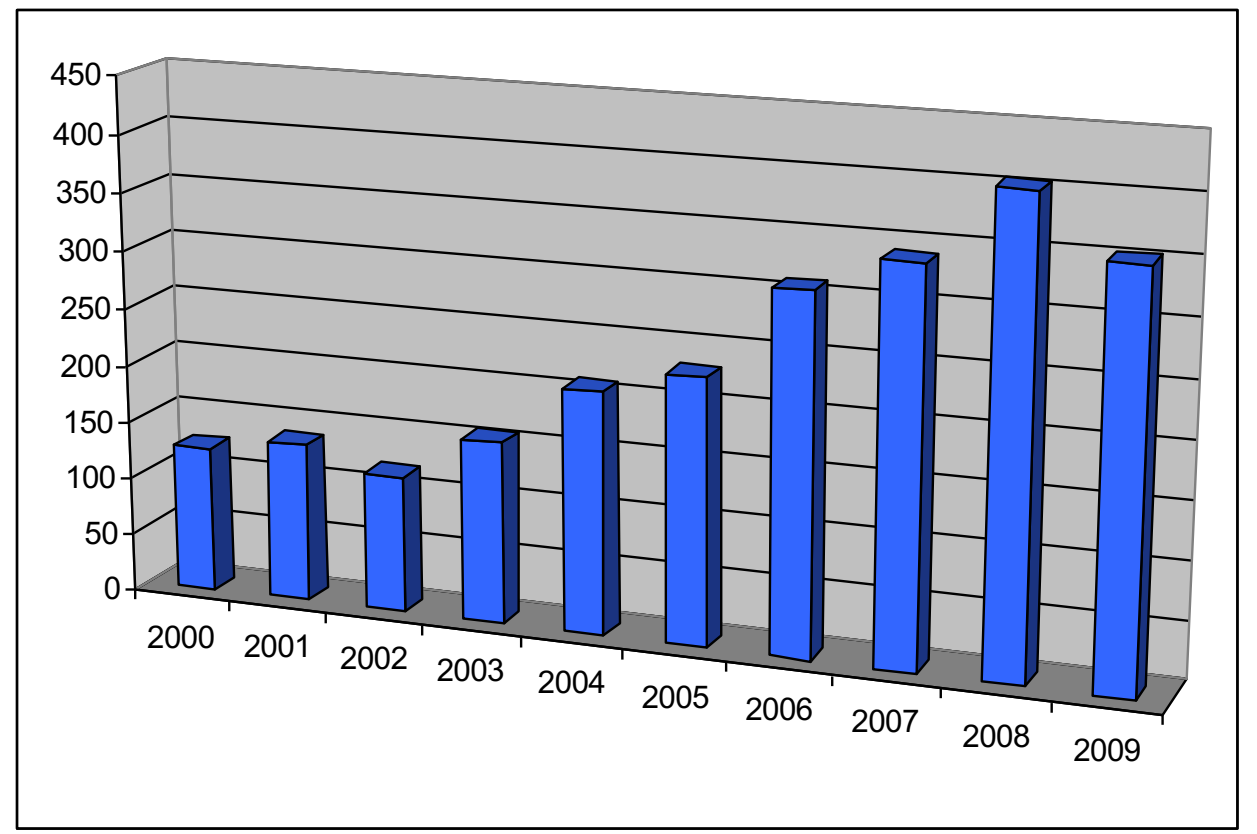

* Argentina, Bolivia, Brasil, Chile, México, Paraguay, Perú, Uruguay y Venezuela.

Fuente: Elaboración propia sobre la base de datos del Incaa, Ancine, Imcine, Ina-Icau, CNAC, CNCA, Conacine (Perú), Conacine (Bolivia), ProImágenes, Villa del Cine, FNCL, Deisica, Nielsen-Rentrak, Ultracine, Cinedística, Filme-B, IMDB, Box Office Mojo, Cinencuentro, Cinestrenos, Cines Argentinos, Cine Nacional, Cines Paraguay, Bolivia Cine, Cine Chile, Onoff, Blogacine, Canacine, Asoprod, Getino (2005b), medios periodísticos.

América Latina produjo, en total, alrededor de 2500 largometrajes durante la última década. La decidida acción del fomento estatal en países como Argentina, Brasil y México se vio reflejada en la cantidad de largometrajes producidos. No es casualidad que estos países hayan sido los únicos que tuvieron industria cinematográfica en algún momento de la historia: en efecto, si bien las diferencias de desarrollo de la actividad fílmica son notorias entre estos países y el resto de América Latina — mayor mercado, mayor desarrollo de políticas públicas de apoyo al cine, mayor desarrollo en los distintos eslabones de la cadena de valor, una importante tradición cinematográfica, entre otros puntos-, ello no termina de configurar una "industria", sino un ecosistema fragmentado en el que conviven algunas pocas empresas profesionales con innumerables microemprendimientos sin sustentabilidad, atomizados e inconexos, con el peso puesto - tanto desde el sector público como en el privado- en la producción mas no en la comercialización y exhibición de los filmes nacionales. Esta situación se repite en los restantes países de la región, en distinta escala. 


\begin{tabular}{|l|r|}
\hline Argentina & 807 \\
\hline Brasil & 602 \\
\hline México & 451 \\
\hline Chile & 181 \\
\hline Colombia & 126 \\
\hline Venezuela & 107 \\
\hline Uruguay & 96 \\
\hline Bolivia* & 60 \\
\hline Perú & 55 \\
\hline Paraguay* & 30 \\
\hline Total & $\mathbf{2 5 1 5}$ \\
\hline
\end{tabular}

*Números aproximados.

Fuente: Elaboración propia sobre la base de datos del Incaa, Ancine, Imcine, Ina-Icau, CNAC, CNCA, Conacine (Perú), Conacine (Bolivia), Dirección de Cinematografía (Colombia), ProImágenes, Villa del Cine, FNCL, Deisica, Nielsen-Rentrak, Ultracine, Cinedística, Filme-B, IMDB, Box Office Mojo, Cinencuentro, Cinestrenos, Cines Argentinos, Cine Nacional, Cines Paraguay, Bolivia Cine, Cine Chile, Onoff, Blogacine, Canacine, Asoprod, Getino (2005b), medios periodísticos.

Argentina es el mayor productor de cine de toda América Latina. A partir de la promulgación de la nueva ley de cine, en 1995, su producción fílmica fue incrementándose hasta duplicarse. En efecto, durante el primer quinquenio la media de producciones anuales en este país era de 60 largometrajes, y durante el segundo fue de 100. ${ }^{11}$ Sin embargo, a partir de la crisis económica internacional, que golpeó duramente a muchos países, entre ellos a España —el principal coproductor de Argentina-, la producción fílmica gaucha cayó de manera importante a partir de 2009 y las condiciones para emprender nuevos proyectos fílmicos se han complicado; prueba de ello es que en 2010 el Incaa ha volcado sus esfuerzos más en el ámbito de la producción y difusión de telefilmes -en virtud del lanzamiento de la televisión digital en ese país- que en el de la industria cinematográfica —-donde la agencia nacional ha acumulado importantes deudas en torno a los subsidios y distintos tipos de ayuda estatal otorgados. Sin embargo, a partir de 2011 el país retomó un ritmo de crecimiento que promedia unos 150 largometrajes anuales - la mayoría, realizaciones audiovisuales realizadas en digital, con escasos recursos (especialmente, documentales, que representan la mitad de los filmes argentinos, dándose en este sentido similar situación que en el resto de América Latina).

\footnotetext{
${ }^{11}$ Los números que aquí se manejan provienen de largometrajes registrados en el organismo nacional de cine. Sin embargo, en el interior del país se realizan desde hace años decenas de películas -especialmente, documentales - de las que el Incaa no tiene registro alguno y que son exhibidas en centros culturales o muestras locales. Si se contaran estas producciones - de las que no se ha realizado un registro fehaciente hasta el momento- el número de largometrajes producidos en la Argentina, desde hace dos décadas, se incrementaría en alrededor de 20 a 30 filmes anuales.
} 
Por otro lado, durante la década del 2000 se destacaron los casos de Brasil y Chile, que en una década multiplicaron por tres su producción fílmica de largometraje: el primero, produjo 31 películas en promedio durante la primera mitad del decenio, número que se incrementó a 90 durante el último lustro. Chile, por su parte, tuvo una media de 10 filmes anuales en el primer lustro de la década del 2000, mientras que en el segundo quinquenio ese número se elevó a 27 , todo un récord para la cinematografía chilena.

La producción mexicana también tuvo un incremento destacado en la última década, multiplicando dos veces y media su producción: si en el primer lustro la media de realizaciones alcanzaba los 26 filmes, en el segundo ese número subió hasta los 65 filmes. En Venezuela, por su parte, el número de largometrajes realizados se duplicó durante la última década, pasando de una media de 8 filmes —durante la primera mitad de la década- a 13 —en el segundo lustro- Colombia presenta similares números —en los primeros cuatro años de la década producía unos 9 largometrajes anuales, número que subió a 19 en 2009.

Gráfico 5 - América Latina: evolución en la cantidad de largometrajes producidos (2000-2009)

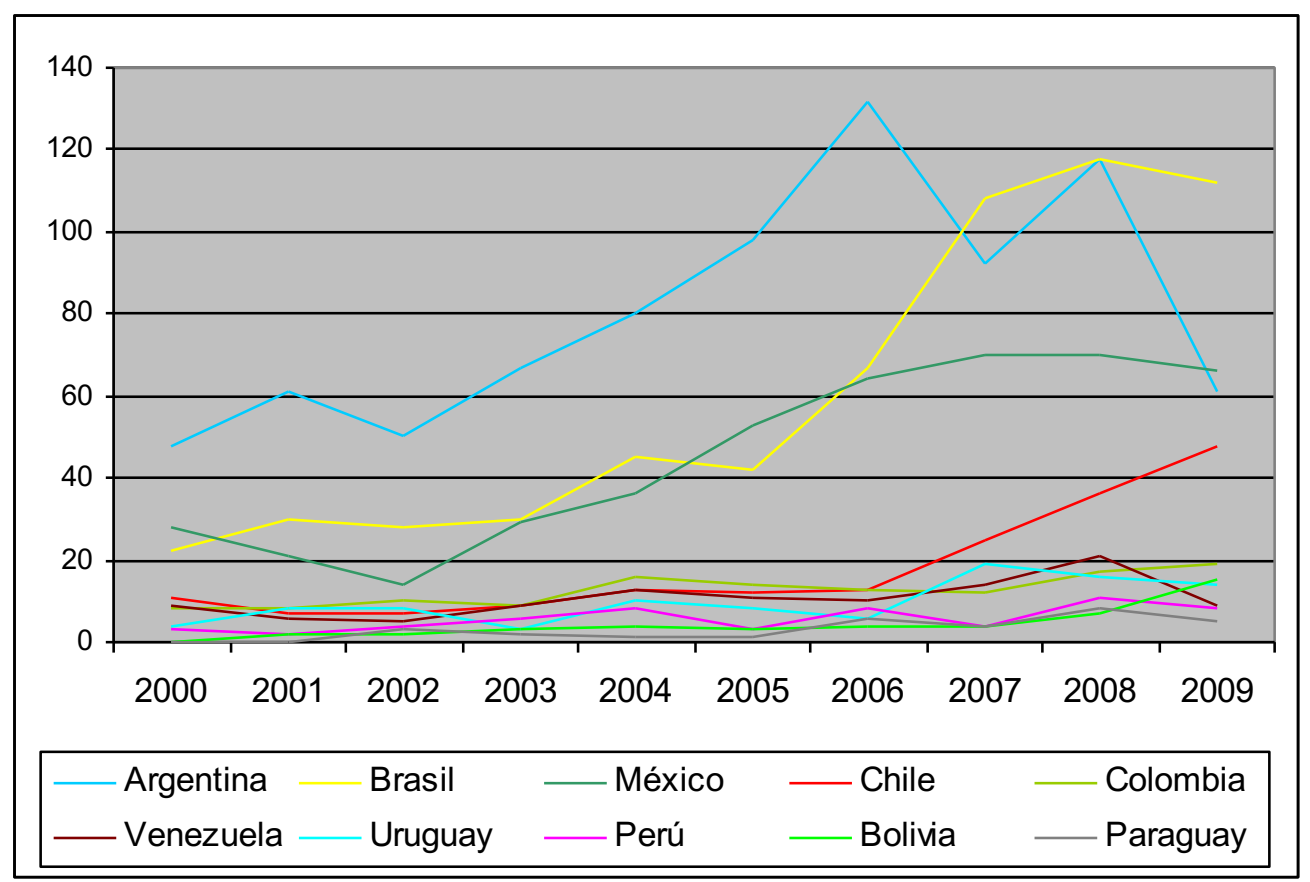

Fuente: Elaboración propia sobre la base de datos del Incaa, Ancine, Imcine, CNCA, CNAC, Dirección de Cinematografía (Colombia), Proimágenes, Conacine, Ina-Icau, Villa del Cine, Canacine, Onoff, Cine Nacional, Filme-B, IMDB, Nielsen-Rentrak, Ultracine, Deisica, Cinedística, Cines Argentinos, Cinestrenos, Cinencuentro, Cine Chile, FNCL, IMDB, Box Office Mojo, Blogacine, Getino (2005b), Stolovich (2004), medios periodísticos.

Los restantes países poseen números más modestos de producción (como Paraguay), aunque también se han incrementado, tal es el caso de Uruguay: de 3 a 6 producciones anuales durante el período 1995 a 2006, a 19 en 2007 y 25 en 2008, aunque cayendo a 9 
en 2009; sin embargo, debido a la reciente promulgación de su ley de cine en 2008, con la incorporación de un fondo nacional de fomento, todo indica que la producción charrúa habrá de crecer en los años venideros.

Bolivia y en Ecuador — país que en 2006 aprobó su ley de cine- vieron incrementarse su producción fílmica, pasando de menos de cinco realizaciones anuales hacia mediados de la década del 2000 a cerca de una docena en el último quinquenio del período analizado.

Perú posee una media de seis producciones anuales, aunque en los últimos años la misma se multiplica por tres si se cuenta la producción semi profesional que se viene realizando en el interior del país desde hace más de diez años.

Con respecto a los costos de realización de un largometraje de ficción, los números varían entre los 350 mil dólares en Perú hasta los 2 millones de dólares en Brasil y México. Entre estos extremos, encontramos que en los países andinos y en Uruguay el costo se sitúa entre los 550 y los 800 mil dólares, mientras que en Argentina (que durante el primer lustro de la década del 2000 vio reducidos sus costos debido a la devaluación operada en 2002, pero que fueron incrementándose conforme finalizaba el decenio) se necesitan más de un millón de dólares para realizar un largometraje de ficción de manera profesional.

En lo que hace a la utilización de cámaras digitales de alta definición (de menor rango que la RED), los costos se reducen sensiblemente, ubicándose entre los 100 y los 200 mil dólares. Asimismo, realizar un documental en la región cuesta entre 50 mil dólares en países de menor desarrollo relativo, como Bolivia, hasta 150 mil dólares en naciones con una cinematografía más desarrollada y un costo de vida más caro, como en México.

Cuadro 10 - América Latina: costo medio de realización de un largometraje de ficción, en miles de dólares (2009)

\begin{tabular}{|c|c|}
\hline País & $\begin{array}{c}\text { Costo medio } \\
\text { largometraje ficción } \\
\text { (millones US\$) }\end{array}$ \\
\hline México & 2 \\
\hline Brasil & $1,8-2$ \\
\hline Argentina & 1,2 \\
\hline Colombia & 1 \\
\hline Bolivia & 0,6 \\
\hline Uruguay & 0,5 \\
\hline Perú & 0,35 \\
\hline Venezuela & 1,5 \\
\hline
\end{tabular}




\section{Coproducción cinematográfica}

En vistas de los altos costos que debe afrontar una producción cinematográfica, la manera de encarar un proyecto de esta naturaleza es mediante el apoyo del Estado o a través de las coproducciones - son pocos los casos, generalmente realizadores reconocidos, que obtienen financiamiento de fondos internacionales, como el World Cinema Fund, el Hubert Bals, por adelantos de distribución, u otros mecanismos.

Otro factor importante de las coproducciones reside en la posibilidad de compartir derechos de explotación en los mercados de los productores involucrados.

Las coproducciones en América latina se orientaron históricamente hacia los países europeos — principalmente, España- o a Estados Unidos —especialmente, aquellos países que se encuentran cerca de su área de influencia, básicamente como reservorio de escenarios "exóticos" para las producciones estadounidenses.

Para algunas naciones, la coproducción fue un instrumento vital para fortalecer y/o revitalizar su cinematografía, como en los casos de Uruguay, Cuba o Bolivia.

En el ámbito latinoamericano de las coproducciones se destaca la fuerte presencia de la Argentina - nación que posee un rol activo y cuyos productores coproducen con prácticamente todos los países de la región-, de España, en menor medida, de Brasil, Chile y México, amén del programa intergubernamental Ibermedia.

La intervención de las productoras latinoamericanas en las coproducciones se encuentra totalmente fragmentada: solamente una decena ha participado en más de cinco coproducciones. No existe un conocimiento óptimo ni un "saber hacer" sobre los requerimientos de la coproducción cinematográfica en las productoras de la región.

Las coproducciones suelen realizarse en el marco de convenios firmados entre los países intervinientes -aunque no es condición sine qua non: los productores igualmente pueden realizar coproducciones con empresas de otros países- que, a su vez, deben respetar convenciones internacionales. Así, a la hora de que la autoridad cinematográfica correspondiente reconozca a una coproducción como película nacional - para obtener los beneficios que otorga la ley- entran a tallar criterios variables: nacionalidad del director, del equipo técnico, artístico, el porcentaje de participación en la coproducción, entre otros. Por ejemplo, Brasil, Colombia, Chile y Bolivia realizan casi todas sus coproducciones como socios mayoritarios, puesto que su legislación así lo indica, mientras que en Colombia y en Chile sus autoridades nacionales no suelen reconocer como película nacional a las coproducciones donde productores locales hayan participado como socios minoritarios, aunque la ley no lo impida. 
Uno de los puntos centrales a la hora de encarar una coproducción es sacar benefício mutuo al compartir los derechos de explotación en los mercados de cada productor vinculado al proyecto.

Sin embargo, así como sucede con las producciones nacionales, las coproducciones suelen tener escasa salida, y en el caso de estrenarse comercialmente, lo hacen solamente en los países participantes de la coproducción, con una convocatoria pobre.

Desde hace décadas los países de la región han intentando encontrar los caminos para integrar sus distintas cinematografías. Los antecedentes cercanos más valiosos son el Convenio de Integración Cinematográfica Iberoamericana, del Acuerdo Latinoamericano de Coproducción Cinematográfica y del Acuerdo para la Creación de un Mercado Común Cinematográfico Latinoamericano — tratados firmados en 1989- y la creación del Programa Ibermedia, un proyecto multilateral de cooperación técnica y financiera, creado para fomentar el desarrollo audiovisual de los países iberoamericanos en los sectores de formación, coproducción, distribución y promoción, así como el desarrollo de proyectos cinematográficos. Fue aprobado en la V Cumbre Iberoamericana de Jefes de Estado y de Gobierno realizada en San Carlos de Bariloche, Argentina, en octubre de 1995. Su puesta en marcha se basa en la decisión de la VII Cumbre Iberoamericana de Presidentes y Jefes de Gobierno llevada a cabo en la isla Margarita, Venezuela, en noviembre de 1997.

La participación española en las coproducciones latinoamericanas es atractiva para los productores de la región porque representa una entrada potencial al mercado europeo. También es atractiva para los productores españoles - la mitad de las coproducciones españolas se realizan con algún país latinoamericano (la gran mayoría, con Argentina)-: el socio español, con una participación que suele ser minoritaria, suele reservarse los derechos sobre el mercado español y europeo, mientras que el/los socio/s latinoamericanos suelen ver muy poco provecho de los dividendos de tal mercado. La misma relación desigual se suele dar entre un país con un sector cinematográfico más importante - como Argentina, Brasil o México- y un país de menor desarrollo relativo -Paraguay, Bolivia o Ecuador.

Otra característica de la participación española es que más del $60 \%$ de esas realizaciones conjuntas contaron en la última década con la participación de un canal de televisión ibérico (De Mora, 2006), debido a que la televisión posee un lugar destacado en el financiamiento cinematográfico en España $-\mathrm{y}$ en Europa, en general-. Por el 
contrario, la participación de las televisoras latinoamericanas en coproducciones es prácticamente nula.

Un caso de estudio: las coproducciones en el Mercosur entre 2000 y 2008

De acuerdo a una muestra obtenida a partir de las coproducciones realizadas entre los países del Mercosur ampliado -incluyendo a Argentina, Brasil, Paraguay, Uruguay, Bolivia, Chile y Venezuela- ${ }^{12}$ más España en el período 2000 y 2008 , se aprecia que Argentina es el país que más coproducciones realiza (en este período, con un $70 \%$ de participación). Le siguen Brasil, Chile, España y Uruguay (con el 42\%, 38\%, 33\% y $31 \%$, respectivamente).

Cuadro 11 - Mercosur* y España: participación en las coproducciones realizadas, en porcentajes** (2000-2008)

\begin{tabular}{|c|c|c|c|c|c|c|c|c|}
\hline & Argentina & Brasil & Uruguay & Paraguay & Bolivia & Chile & Venezuela & España \\
\hline $\begin{array}{l}\% \text { coproducciones } \\
\text { realizadas en el } \\
\text { Mercosur 2000-08 }\end{array}$ & 69,86 & 42,47 & 31,51 & 5,48 & 5,48 & 38,36 & 15,07 & 32,8 \\
\hline $\begin{array}{l}\text { \% coproducciones del } \\
\text { pais que fueron } \\
\text { apoyadas por } \\
\text { Ibermedia }\end{array}$ & 47,06 & 67,74 & 60,87 & 0,00 & 75,00 & 78,57 & 81,82 & 41,67 \\
\hline $\begin{array}{l}\text { \% coproducciones } \\
\text { Ibermedia }\end{array}$ & 54,55 & 47,73 & 31,82 & 0,00 & 6,82 & 50,00 & 20,45 & 40,91 \\
\hline $\begin{array}{l}\text { \% coproducciones del } \\
\text { país que tuvieron } \\
\text { como socio a España }\end{array}$ & 39,22 & 19,35 & 39,13 & 0,00 & 25,00 & 25,00 & 54,55 &....- \\
\hline $\begin{array}{l}\% \text { coproducciones } \\
\text { españolas en } \mathrm{AL}\end{array}$ & 83,33 & 25,00 & 37,50 & 0,00 & 4,17 & 29,17 & 25,00 & \\
\hline
\end{tabular}

* No se incluyeron en esta muestra a Perú, Colombia y Ecuador, Estados asociados al Mercosur, similar status al que poseen Venezuela, Bolivia y Chile.

** Las sumas dan más de 100\% debido a la cantidad variable de países que participan en una coproducción.

Fuente: Elaboración propia sobre la base de datos de Ibermedia, Icaa, Incaa, Ancine, Ina, CNAC, CNCA, FNCL, IMDB, Deisica, Filme-B, Cine Nacional, Cines Argentinos, Cine Bolivia, Cines Paraguay, Cinestrenos.

El país mercosureño con el que España filmó más coproducciones en los últimos años fue con Argentina (en el 83\% de los casos), seguido de Uruguay y Chile (con el 37\% y el 29\%, respectivamente). Es de notar que desde la crisis económica que golpea a gran parte del llamado "Primer Mundo", España ha disminuido considerablemente su participación en coproducciones internacionales, lo que ha repercutido negativamente en las producciones de países como la Argentina.

El Programa Ibermedia, por su parte, apoyó poco más del $60 \%$ de las coproducciones realizadas en el Mercosur entre 2000 y 2008, la mayoría de Argentina, Chile, Brasil;

\footnotetext{
${ }^{12}$ La muestra no incluyó a Colombia, Perú y Ecuador, que también son Estados asociados al Mercosur.
} 
también apoyó el $40 \%$ de las coproducciones que España realizó con países del Mercosur.

En términos relativos, las coproducciones realizadas por los países con un sector cinematográfico menos desarrollado fueron apoyadas en su gran mayoría por Ibermedia —el $81 \%$ en el caso venezolano, y el 75\% en el caso boliviano-, aunque también el $78 \%$ de las coproducciones chilenas y el $68 \%$ de las brasileñas - dos países con cinematografías más sólidas- fueron apoyadas por Ibermedia.

La mayoría de los recursos de este programa se destinan a la coproducción - alrededor de las tres cuartas partes-. Dentro de este rubro, España, Argentina, México y Brasil son los países con mayor cantidad de proyectos que recibieron apoyo monetario. El resto de las áreas del programa (distribución, desarrollo de proyectos y formación) posee una presencia reducida.

Valga un dato al margen, también a manera de muestra: de los 21 proyectos de desarrollo aprobados por Ibermedia en el año 2000, sólo 3 (el 14\%) se convirtieron en películas (con o sin estreno). En cambio, en el rubro de las coproducciones, de los 23 proyectos aprobados por Ibermedia ese año, 19 llegaron a terminarse -y también a estrenarse- De tal manera, 10 años después de aquella convocatoria se observa que en el año 2000 el programa Ibermedia otorgó 668 mil dólares a 22 proyectos que no llegaron a concretarse.

Según el investigador Gustavo Buquet (2011), sólo el 28\% de las coproducciones realizadas con ayuda de Ibermedia tuvieron estreno comercial allende las fronteras de los países productores. 


\section{CAPÍTULO IV \\ MERCADOS CINEMATOGRÁFICOS}

\section{Panorama global de los mercados}

La mayor cantidad de películas que se producen en la actualidad se orientan hacia el mercado de consumo masivo, especialmente al mercado infanto-juvenil. La industria cinematográfica a nivel global se caracteriza, principalmente, por los booms de taquilla —muchos de ellos basados en historietas, secuelas y precuelas, todos ellos respaldados por importantes campañas masivas de marketing-, con el aparato de los grandes estudios de Hollywood taponando los distintos parques exhibidores con copias de sus blockbusters que saturan más de la mitad de las salas, constituyéndose en un perjuicio para los cines nacionales y para toda aquella cinematografía que no siga los parámetros estéticos, narrativos y de negocio de Hollywood.

Como suele ocurrir desde hace un cuarto de siglo, en casi todos los países del mundo los filmes de Estados Unidos -o las coproducciones de Hollywood con otros países, principalmente europeos- dominan la lista de los filmes ubicados en el "top 30". Sumado a la preponderancia de los filmes infanto-juveniles -especialmente, de animación y aventuras- también es notorio el aumento de las películas en 3D entre 2005 y 2013 -desde 2010, un 50\% de los estrenos de las majors se realiza en formato tridimensional-. También resalta en el top 30 global la importante presencia de comedias, especialmente, en los booms no hollywoodenses - pertenecen a este género distintos filmes que quebraron marcas históricas en los últimos años, tanto en Hungría como en México, pasando por China, Perú, la India y Chile.

A su vez, casi todas las películas del top 30 global fueron distribuidas por las majors de Hollywood -incluyendo los escasos sucesos no hollywoodenses.

\section{El dominio de Hollywood}

Estados Unidos, con más de 40 mil pantallas cinematográficas esparcidas en la mayoría de sus ciudades, y un número de espectadores que en 2011 rondó los 1.300 millones —con un índice de concurrencia de 4 veces por persona al año, que pagan, en promedio, 8 dólares la entrada- (MPAA, 2012) explican la recaudación media anual que ronda, en los últimos años, los 10 mil millones de dólares en las salas locales — sin contar las otras ventanas de comercialización y la recaudación mundial de las películas estadounidenses-, lo que convierte a la industria del cine de este país en la más 
poderosa del mundo, la única que efectivamente circula y tiene presencia internacional masiva.

El dominio de las salas de cine a nivel mundial por parte de las películas estadounidenses — que supera, en promedio, el 70\% - no tiene relación con la ínfima presencia de otras cinematografías en los cines del país del Norte, con apenas el $2 \%$ de los títulos exhibidos (Unesco, 2012), situación que no siempre se dio de esta manera: hacia la década de 1950 sólo en la ciudad de Nueva York existían unas 300 salas que proyectaban filmes en castellano (García Canclini, 2004). Este desbalance en la circulación cinematográfica le permitió a la industria hollywoodense incrementar vigorosamente su producción desde los años ochenta.

Aunque el cine estadounidense cuenta con un importante número de empresas volcadas a la producción, distribución y exhibición, sólo un puñado de ellas (las llamadas majors) son las que poseen el control sobre la economía del sector —especialmente, a través de la distribución- $:{ }^{13}$ Columbia, Metro Goldwyn Mayer, Disney, Twentieth Century Fox, Paramount, Warner Bros., Universal y Dreamworks - la major surgida en la década de 1990 - junto a las "mini majors" que, tras un breve período de éxitos a mediados de los años ochenta, fueron absorbidas poco después por las majors -empresas como Miramax, New Line, Lorimar y Orion, entre otras.

Como señala Buquet (2005) Hollywood apuesta desde hace décadas a la integración vertical: todas las majors tienen, sin excepción —en el ámbito cinematográfico-, empresas que producen y distribuyen sus propios productos, siendo el de la distribución el sector más rentable - lo que les permite explotar las economías de escala generadas por las obras audiovisuales-, además de ser el sector que permite crear barreras a la entrada (Sánchez Ruiz, 2012).

Los presupuestos de producción de las majors se fueron elevando a lo largo del tiempo. Un ejemplo de ello se puede apreciar en los llamados "costos del negativo" (negative $\cos t$ ) — que incluyen sólo lo dedicado al rodaje y al primer negativo armado del filme; su costo se multiplicó por 20 entre 1972 y mediados de la década de 2000 (Getino, 2005) - También crecieron mucho en las últimas décadas los costos de la tirada de copias, distribución, publicidad y promoción (print and advertising cost o $P \& A$ ) (Buquet, 2005).

\footnotetext{
${ }^{13}$ No está de más recordar que es muy poco frecuente los distribuidores vendan una copia de una película a los minoristas (exhibidores): desde la década de 1920 la alquilan, dándole a los exhibidores el derecho a mostrar la película en un mercado de espectadores bajo ciertas condiciones específicas como la duración del filme, el número de pantallas, los avances por distribución y los mínimos garantizados.
} 
Si bien desde el último decenio fueron apareciendo en el mercado cámaras digitales cada vez más profesionales, a la vez que las salas de cine van mutando progresivamente hacia el formato digital - lo que reduce el costo de las copias para la exhibición-, igualmente los costos de promoción y marketing siguen representando más de la mitad de los presupuestos de las producciones de las majors —es decir, alrededor de 100 millones de dólares dedicados sólo a este rubro (Wasko, 2011).

La situación que experimentan las cinematografías locales con respecto a Hollywood también se da en los Estados Unidos: cada uno de los grandes estudios de Hollywood produce entre diez y quince títulos por año, mientras que las empresas del sector "independiente" estadounidense — que producen, en conjunto, un mayor volumen anual de producción - apenas realizan como promedio una película cada año, con escasas posibilidades de llegar a las salas comerciales y, en el caso de que lleguen, poseen exiguos presupuestos de marketing y publicidad, lo que —salvo contadas excepciones, como Little Miss Sunshine, Juno, Milk o Transamerica-, y en medio de la competencia feroz de las majors, suelen obtener estrepitosos fracasos comerciales.

Los costos de las películas realizadas por las productoras "independientes" estadounidenses son entre cinco y diez veces menor al que presupuestan las majors. Esto sucede porque se canibalizan entre ellas: decenas de productoras pequeñas y medianas buscan afanosamente un lugar en el mercado. En este contexto, la variable de ajuste es la "flexibilización" de gastos como contribuciones sociales, fondos de jubilación, horas extra, alojamiento y alimento de los equipos técnicos, etcétera (Mosco, 2009).

Estas productoras independientes estadounidenses filman de manera episódica. Muchas de ellas desaparecen prontamente del mercado, para dar lugar a otras tantas que, en su mayoría, seguirán la misma y corta existencia de sus antecesoras.

Por otro lado, muchas producciones realizadas por las majors -entre un $20 \%$ y un $30 \%$ (Getino, 2005) - son filmadas fuera de los Estados Unidos, en países que ofrecen "incentivos" para rodar en su territorio - como exenciones fiscales, laxitud en los derechos laborales, sociales, etc. (Vaughan, 2011) - Los países limítrofes de Estados Unidos acogen una importante cantidad de producciones hollywoodenses (Sánchez Ruiz, 2006); lo mismo sucede en países como Australia e Inglaterra (CEIDR, 2006). Las majors, nacidas como productoras de cine, con el tiempo fueron pasando a formar parte de enormes multinacionales de los más diversos orígenes y procedencias (empresas de televisión, fabricantes de electrónica, bancos, fondos de inversión, grupos 
mediáticos), tras distintas fusiones y enfrentamientos comerciales: desde 1985, la Fox es parte de News Corporation - la empresa del magnate australiano Rupert Murdoch-. Columbia, después de haber sido propiedad de Coca-Cola, pasó a manos de Sony en 1989 —empresa japonesa que en 2005 compraría la Metro (que anteriormente era parte de Crédit Lyonnais)—. También desde 1989, Warner Bros pasó a formar parte de Time Warner. Universal, por su parte, tras la venta de la mayor parte de sus acciones por parte de Matsushita —que había adquirido en 1990-, quedó asociada a la destilería canadiense Seagram, para luego pasar a formar parte de General Electric. Finalmente, Viacom adquirió a Paramount en 1994 y a Dreamworks en 2006.

El desarrollo de las articulaciones empresariales, a nivel vertical y horizontal, permitió a la industria hollywoodense no sólo hacer frente con éxito a los retos de las nuevas tecnologías audiovisuales, sino también aprovecharse de las mismas para multiplicar y consolidar su poder en las distintas clases de pantallas de todo el mundo.

La televisión fue el primer medio que, pese a las resistencias iniciales de Hollywood, sirvió para reforzar el negocio y potenciar la presencia del cine estadounidense en todo el mundo. Luego vendrían otras "amenazas" — como fueron vistas en sus comienzos (Blank, 2012) - que posteriormente se convertirían en baluartes en la comercialización del cine y el audiovisual por parte de las majors, como el homevideo (VHS y, posteriormente, DVD y Blu-ray), las transmisiones satelitales, la TV por cable, el videogame, la TV digital, la interactividad, el cine digital, el 3D, etcétera.

Desde la década de 1980 dos factores fueron primordiales para los negocios de las majors: el video y las ventas internacionales (Buquet, 2005).

El video fue la ventana más importante en el negocio de la comercialización de las majors durante toda la década de 1990 y hasta mediados de la década de 2000 (Blank, 2012), cuando bajó sostenidamente su participación a manos de internet y su consumo predominantemente gratuito, ubicuo y en red - sin que ello produzca, hasta el momento, una monetización significativa para los grandes estudios hollywoodenses.

La hegemonía sobre los mercados mundiales es otro de los factores fundamentales en los ingresos de Hollywood (Guback, 1969): representa desde hace varios años más de la mitad de sus ingresos totales — 58\% a 2010 (Screen Digest, 2011)—. Los países de la Unión Europea constituyeron históricamente el principal mercado exterior para las majors (especialmente, Francia, Alemania, Reino Unido, Italia y España), representando, en promedio, el $70 \%$ de la oferta de filmes en ese continente - mientras que los filmes europeos no llegan a ocupar el $2 \%$ de los estrenos en las salas 
estadounidenses (MPAA, 2012)—. También se destacan en los intereses de las majors los mercados canadiense y australiano (Unesco, 2012). Aunque las pantallas latinoamericanas también están atiborradas de estrenos hollywoodenses (entre el 85\% y el 95\%), nuestro subcontinente representa el 10\%, o menos, de sus ingresos mundiales (Getino, 2005). Sin embargo, hay mercados donde es el cine nacional el que predomina, tales los casos de la India, China, Corea del Sur, Irán y Egipto, entre otros (Unesco, 2012), debido, principalmente, a distintas regulaciones y restricciones estatales a la entrada de filmes extranjeros - por ejemplo, China tiene una cuota que permite estrenar sólo 20 filmes extranjeros por año (Istituto Nazionale per il Commercio Estero, 2011).

Por su parte, las majors, más allá de su poderío en el mercado cinematográfico mundial, tuvieron históricamente una relación sumamente estrecha con el Departamento de Estado estadounidense desde finales de la década de 1910 (Guback, 1980), especialmente, a través de la entidad corporativa que desde 1945 se denomina Motion Picture Association of America (MPAA), gozando de un proteccionismo gubernamental histórico - comparable al que tuvieron las industrias cinematográficas de la Unión Soviética y de sus países satélites hasta la década de 1980 (Getino, 2005).

El proteccionismo del gobierno estadounidense hacia su cinematografía se enmarcó, principalmente, en las relaciones internacionales estadounidenses destinadas, en un comienzo, a abrir mercados, y posteriormente, a fortalecer y consolidar la hegemonía de Hollywood en todo el planeta: son constantes las exigencias del gobierno estadounidense para excluir al cine y al audiovisual de todo tipo de "proteccionismo" (políticas nacionales de fomento) en la negociación de los distintos Tratados de Libre Comercio y en el seno de la Organización Mundial de Comercio (OMC).

Sin embargo, no es este el único apoyo que reciben las majors por parte del Estado norteamericano: también son beneficiarias de diversos subsidios directos - por ejemplo, desgravaciones y exenciones fiscales, pagos diferidos, amortizaciones aceleradas (Rovito, 2004) — e indirectos — la mencionada presión gubernamental a nivel internacional.

En definitiva: las gigantescas fusiones empresariales de las industrias culturales, del sector audiovisual y, particularmente, del cine, se fueron traduciendo en muchos casos en distintos tipos de integración horizontal y vertical, con lo que las grandes multinacionales apuntan cada vez más a conformar economías de escala que les permitan a las majors producir y distribuir más, ahorrando y maximizando recursos. El desarrollo de políticas agresivas de comercialización y distribución en la mayor parte 
del mundo, con recursos técnicos y de mercadotecnia avanzados, sumado al firme apoyo del gobierno estadounidense para proteger y potenciar esta hegemonía, muestra un poder creciente por parte de Hollywood.

Como bien señala el experto mexicano Enrique Sánchez Ruiz:

La primacía mundial del cine estadounidense no es producto de algún destino manifiesto otorgado por alguna deidad, menos de alguna predestinación gratuita venida del cielo. Tampoco es resultado de un juego autónomo y desencadenado de oferta y demanda, es decir, de las fuerzas del mercado dejadas libres de cualquier participación política, estatal. Es un producto histórico multifactorial, en cuya producción han entrado elementos económicos, políticos, culturales y sociales, institucionales, tecnológicos. Pero por omisión o por comisión, los gobiernos estadounidenses de hecho han ejercido políticas públicas activas, que han beneficiado el desarrollo y la expansión internacional de su industria cinematográfica. (Sánchez Ruiz, 2002, en Getino, 2005b:22)

\section{Los mercados mundiales al comienzo del siglo XXI}

Durante los últimos años la recaudación mostró un crecimiento constante e importante a nivel mundial -debido, sobre todo, al aumento del precio de las entradas (especialmente, desde la masificación de las salas con 3D, y de las salas "premium")—. Distinto fue el caso de la cantidad de entradas vendidas, que en algunos países y regiones mostró estancamiento, y en otros, aumento - aunque nunca de manera tan importante como la recaudación.

El incremento del 27,8\% en la recaudación cinematográfica a nivel mundial entre 2006 y 2011 se debió principalmente al crecimiento experimentado en los diez mercados de mayor facturación, los que representan entre el $70 \%$ y el $78 \%$ del total mundial (dependiendo del año).

El crecimiento en la recaudación fue liderado por China - con un extraordinario aumento del $517 \%$ en el período señalado- y Rusia — casi el 172\%—. Otros mercados importantes con un crecimiento destacable en su recaudación fueron Australia (83\%) y Japón (54\%). En cambio, Estados Unidos —todavía el mercado cinematográfico más grande del mundo- presentó una de las tasas de crecimiento más bajas entre los diez mayores mercados cinematográficos del mundo, con un aumento de sólo el 7,36\% entre 
2006 y 2011, una tasa inferior a la de Francia (20,7\%) y del Reino Unido (18,7\%). Corea del Sur fue el único país que tuvo una baja en su recaudación durante el período estudiado $(-3,8 \%)$.

Otros países que mostraron aumentos importantes en su recaudación entre 2006 a 2011 fueron Bielorrusia, Rumania, Ucrania y Venezuela. También varios mercados latinoamericanos, asiáticos y de Europa del Este duplicaron su recaudación durante este período. Sin embargo, la mayor parte de estos países tienen mercados pequeños y, en algunos casos, el aumento se debió a altas tasas de inflación, como es el caso de Bielorrusia, Venezuela y Argentina.

Cuadro 12 - Recaudación total para los 10 mayores mercados, en millones de dólares (2006-2011)

\begin{tabular}{|l|r|r|r|r|r|r|r|}
\hline & \multicolumn{1}{|c|}{$\mathbf{2 0 0 6}$} & $\mathbf{2 0 0 7}$ & $\mathbf{2 0 0 8}$ & $\mathbf{2 0 0 9}$ & \multicolumn{1}{c|}{$\mathbf{2 0 1 0}$} & $\mathbf{2 0 1 1}$ & $\begin{array}{r}\text { Variación } \\
\mathbf{2 0 0 6 / 2 0 1 1}\end{array}$ \\
\hline Estados Unidos & 9488,00 & 9632,49 & 9634,87 & $10.610,18$ & $10.579,66$ & $10.186,11$ & $13,29 \%$ \\
\hline Japón & 1744,92 & 1685,24 & 1885,03 & 2201,93 & 1346,74 & 2765,89 & $53,84 \%$ \\
\hline China & 328,59 & 433,78 & 606,59 & 909,03 & 1502,45 & 2029,72 & $731,61 \%$ \\
\hline Gran Bretaña & 1402,05 & 1878,05 & 1723,26 & 1772,49 & 1526,07 & 1664,52 & $18,89 \%$ \\
\hline Francia & 1474,63 & 1558,85 & 1585,70 & 1788,91 & 1745,22 & 1780,25 & $46,74 \%$ \\
\hline India & 1370,65 & 1729,20 & 1843,45 & 1415,13 & 1355,91 & $1470,00 *$ & $55,97 \%$ \\
\hline Alemania & 1008,25 & 1114,55 & 1103,75 & 1414,63 & 1227,20 & 1244,28 & $35,58 \%$ \\
\hline Corea del Sur & 1036,52 & 1068,85 & 889,71 & 856,96 & 1000,51 & 997,14 & $15,77 \%$ \\
\hline Australia & 615,59 & 749,24 & 793,00 & 848,16 & 1037,56 & 1128,15 & $83,26 \%$ \\
\hline Rusia & 408,54 & 547,40 & 799,42 & 706,54 & 1013,60 & 1109,40 & $239,03 \%$ \\
\hline TOTAL Top 10 & $18.877,74$ & $20.397,65$ & $20.864,78$ & $22.523,96$ & $22.334,92$ & $24.375,46$ & $40,44 \%$ \\
\hline
\end{tabular}

\begin{tabular}{|l|r|r|r|r|r|r|r|}
\hline Mundo* & 25.500 & 26.200 & 27.700 & 29.400 & 31.600 & 32.600 & $27,8 \%$ \\
\hline \% Top 10 & 74,03 & 77,85 & 75,32 & 76,61 & 70,68 & 74,77 & $\begin{array}{c}\text { Promedio: } \\
74,88 \%\end{array}$ \\
\hline
\end{tabular}

* Focus (Observatorio Europeo del Audiovisual).

Fuente: Elaboración propia sobre la base de datos del Instituto de Estadísticas de la Unesco.

Un factor clave en la variación de las recaudaciones a nivel mundial fue el aumento constante del precio promedio de las entradas (46\% a nivel general). Suiza tuvo el precio promedio de entradas más caro del mundo entre 2005 y 2011 (13,55 dólares), seguido por Noruega (12,96 dólares), Suecia (12,07 dólares) y Japón (11,96 dólares). En el top 10 de los países con las entradas más caras del mundo, nueve eran europeos. Por su parte, los países con los precios de entradas más bajos fueron India —el precio más bajo del mundo (48 centavos de dólares)—, Egipto, Níger, Senegal y Etiopía, en África; Filipinas, Indonesia y Laos, en Asia; Bielorrusia en Europa; e Irán, en Medio Oriente. 
Cuadro 13 - Entrada promedio a nivel mundial, en dólares (2005-2011)

\begin{tabular}{|l|r|r|r|r|r|r|r|}
\hline & $\mathbf{2 0 0 5}$ & $\mathbf{2 0 0 6}$ & $\mathbf{2 0 0 7}$ & $\mathbf{2 0 0 8}$ & $\mathbf{2 0 0 9}$ & $\mathbf{2 0 1 0}$ & $\mathbf{2 0 1 1}$ \\
\hline $\begin{array}{l}\text { Precio promedio } \\
\text { del ticket }\end{array}$ & 4,76 & 5,21 & 6,02 & 6,30 & 6,35 & 6,53 & 6,95 \\
\hline Países abarcados & 55 & 55 & 59 & 63 & 60 & 58 & 52 \\
\hline
\end{tabular}

Fuente: Elaboración propia sobre la base de datos del Instituto de Estadísticas de la Unesco.

Si bien los precios de las entradas pueden parecer bajos en los países de menor desarrollo relativo, cuando se los compara con los ingresos medios y el costo de vida, se aprecia que los precios de las entradas de cine en estas naciones son relativamente altos en comparación con los de los países desarrollados: una sola salida al cine con amigos o en familia puede significar alrededor del 10\% de los ingresos mensuales (González, 2012).

La comparación de las entradas y la recaudación muestra claramente esta dinámica diferente: mientras el box office a nivel mundial muestra un incremento global del $27,8 \%$ entre 2005 y 2011 , la cantidad de entradas vendidas en todo el mundo tuvo una disminución del 5,2\%.

Gráfico 6 - Contraste de tendencias entre total de entradas y recaudación a nivel mundial (20052011)

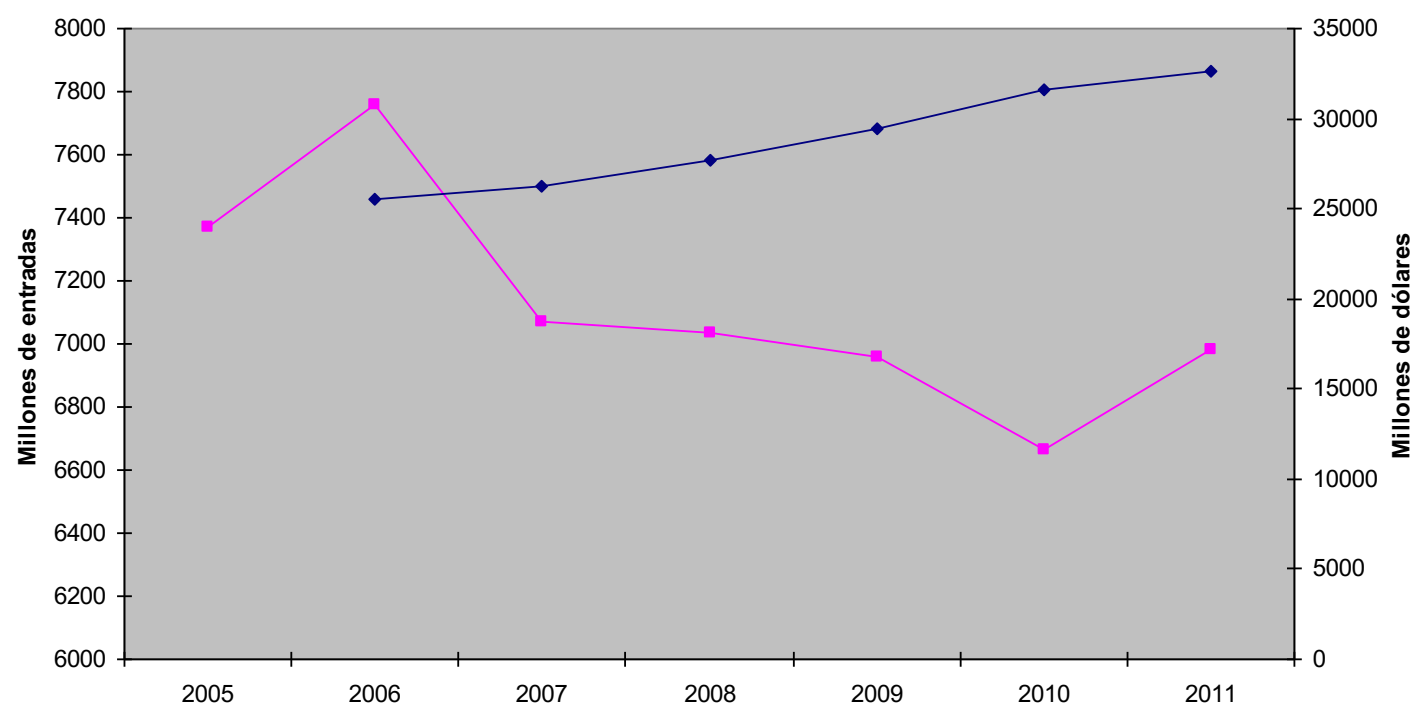

Fuente: Elaboración propia sobre la base de datos del Instituto de Estadísticas de la Unesco. 
Analizando la recaudación se aprecia que en el top 10 aparecen los países más ricos (con un alto precio promedio de las entradas) y los mercados grandes de los países emergentes (como China e India). Pero al examinar los diez principales mercados en términos de entradas vendidas entre 2005 y 2011 (cuadro 3), los mercados de países "emergentes" pasan a ser protagonistas, con aumentos extraordinarios - como fueron los casos de China (135,3\%), Rusia (82,5\%) y Brasil (71,5\%).

Otros países registraron aumentos significativos, como los casos de BosniaHerzegovina, Colombia, Lituania, Malasia y Rumania - con incrementos que van del $138 \%$ al 156\%-. No obstante, estos últimos países — que no se encuentran en el top 10 - tienen mercados pequeños o medianos (de 600.000 a 7 millones de entradas en el año 2011).

Cuadro 14 - Top 10 de los países con mayor cantidad de entradas vendidas (2005-2011)

\begin{tabular}{|l|r|r|r|r|r|r|r|r|}
\hline & $\mathbf{2 0 0 5}$ & $\mathbf{2 0 0 6}$ & $\mathbf{2 0 0 7}$ & $\mathbf{2 0 0 8}$ & $\mathbf{2 0 0 9}$ & $\mathbf{2 0 1 0}$ & $\mathbf{2 0 1 1}$ & Variación \\
\hline India & 3770,00 & 3997,00 & 3290,00 & 3251,00 & 2917,00 & 2706,00 & $2940,00 *$ & $-22,02 \%$ \\
\hline $\begin{array}{l}\text { Estados } \\
\text { Unidos }\end{array}$ & 1403,00 & 1449,00 & 1399,31 & 1341,34 & 1415,23 & 1341,60 & 1283,84 & $-8,49 \%$ \\
\hline China & 157,20 & 176,20 & 195,80 & 209,80 & 263,80 & 290,00 & 370,00 & $135,37 \%$ \\
\hline Francia & 175,52 & 188,77 & 178,17 & 190,08 & 201,14 & 206,95 & 216,63 & $23,42 \%$ \\
\hline México & 153,99 & 154,28 & 175,00 & 182,00 & 178,00 & 189,60 & 204,90 & $33,06 \%$ \\
\hline $\begin{array}{l}\text { Gran } \\
\text { Bretaña }\end{array}$ & 164,70 & 156,56 & 162,40 & 164,20 & 173,50 & 169,20 & 171,60 & $4,19 \%$ \\
\hline Japón & 160,45 & 164,58 & 163,20 & 160,49 & 169,30 & 174,35 & 144,72 & $-9,80 \%$ \\
\hline $\begin{array}{l}\text { Corea } \\
\text { del Sur }\end{array}$ & 145,60 & 153,40 & 158,77 & 150,83 & 156,96 & 149,18 & 159,79 & $9,75 \%$ \\
\hline Rusia & 83,60 & 91,80 & 105,00 & 118,00 & 132,00 & 155,90 & 152,60 & $82,54 \%$ \\
\hline Brasil & 83,90 & 90,20 & 89,31 & 89,11 & 112,67 & 134,83 & 143,89 & $71,50 \%$ \\
\hline $\begin{array}{l}\text { Total } \\
\text { Top 10 }\end{array}$ & 6297,96 & 6621,79 & 5916,96 & 5856,85 & 5719,61 & 5517,61 & 5787,96 & $-8,10$ \\
\hline
\end{tabular}

* Estimación basada en un ticket promedio de 0,5 centavos de dólares.

Fuente: Elaboración propia sobre la base de datos del Instituto de Estadísticas de la Unesco.

La disminución global en la cantidad de entradas vendidas se explica, principalmente, por el descenso en la India y en Japón — teniendo en cuenta que la India es el mercado más grande del mundo en términos de entradas, y Japón, el séptimo. 


\section{La situación en América Latina}

Durante la década analizada, América Latina ha tenido, a nivel general, una buena performance económica. En comparación con los últimos decenios -recordar la "década perdida" de los ochenta, las crisis de la deuda, las hiperinflaciones, las devaluaciones, etc.—, la región ha fortalecido mucho su economía. Vaya como ejemplo el caso argentino, que en el año 2002 —en plena crisis local— tenía un PBI per cápita que apenas superaba los dos mil dólares; hacia 2010 esa cifra trepó a los 14.600 dólares, la más alta de la región. En medio de la peor crisis capitalista de los últimos 80 años, América Latina ha sido una de las regiones que mejor viene capeando el temporal.

En América Latina el mercado cinematográfico muestra situaciones contrastantes entre los diferentes países. Por un lado, hay mercados que en la última década aumentaron al doble o más su cantidad de pantallas, entradas o recaudación (como Brasil, Colombia, México o Perú). Brasil ingresó a la lista del top 10 a nivel mundial en términos de entradas vendidas —durante la última década fue el país latinoamericano que más espectadores convocó-, mientras que México posee el quinto parque exhibidor más grande del mundo. Por otro lado, algunos países presentaron un crecimiento moderado -o incluso un estancamiento- en lo que hace al número de pantallas (por ejemplo, Argentina y Uruguay).

El mercado cinematográfico latinoamericano afrontó cambios drásticos durante las últimas décadas. Hasta hace unos 40 años, las empresas nacionales eran las que dominaban los mercados cinematográficos de América Latina, especialmente en el ámbito de la exhibición. En la actualidad, las majors de Hollywood y las compañías multinacionales asociadas a ellos controlan la distribución y la exhibición cinematográficas (Getino, 1984, 1987; Rey, 2005).

En 2009 América Latina sumó alrededor de 1.600 millones de dólares de recaudación —o 1,6 billones de dólares, según la nomenclatura anglosajona que, en la región, utiliza Brasil- y vendió 417 millones de entradas — que, en promedio, cuestan 4,5 dólares cada una - para asistir a alguna de las 9200 salas - unos dos millones de butacasexistentes en el subcontinente para elegir entre los 210 estrenos que, en promedio, se estrenan anualmente. Brasil y México representaron en conjunto el 65 al 75\% tanto de la recaudación como de las entradas vendidas en toda la región.

Si los latinoamericanos tuvieran una circulación cinematográfica regional óptimamente eficiente, tendrían —en teoría- más de 300 filmes regionales anuales entre los cuales escoger. Sin embargo, ello no ocurre: anualmente se estrenan entre 3 y 20 filmes 
latinoamericanos no nacionales —dependiendo del país-, cuyo público suele ser menor al $1 \%$ del total de los espectadores de cine.

En América Latina se registra una baja frecuencia de asistencia: 0,8 películas promedio por año por persona, excepto en México $(1,7)$, país que tiene el quinto mercado de exhibición más importante del mundo. Sin embargo, la recaudación mostró un aumento del $127 \%$ durante la década de 2000, principalmente debido al aumento constante del precio de las entradas al cine: los precios se duplicaron durante el último decenio (debido mayormente a las proyecciones en $3 \mathrm{D}$, cuyos tickets se venden a un precio superior).

Mientras tanto, la cantidad de entradas vendidas tuvo un aumento promedio del $43 \%$ entre 2005 y 2011 (se vendieron 2,8 mil millones de entradas).

De esta manera, se aprecia que el aumento de la recaudación en América Latina fue 1,6 veces mayor en comparación con el incremento en las entradas vendidas. México y Brasil representaron el $70 \%$ del total latinoamericano, tanto en lo que respecta a la recaudación como a la cantidad de espectadores.

Pero el crecimiento no fue homogéneo en toda la región. Mientras que se observó un crecimiento importante en Brasil, Colombia, México y Perú, Chile y Venezuela solo mostraron aumentos moderados, mientras que Argentina y Uruguay sufrieron un estancamiento relativo durante la primera década del siglo XXI.

Estas cifras están lejos de la cima de la industria cinematográfica en América Latina medio siglo, atrás cuando la frecuencia de asistencia variaba entre cinco y nueve películas promedio por año, de acuerdo al país.

\section{Espectadores}

Durante la primera década del siglo XXI se vendieron en América Latina más de 3400 millones de tickets cinematográficos, creciendo un 70\% entre 2000 y 2009. Sin embargo, la variación en la cantidad de espectadores que tuvieron durante la década los tres mercados más grandes de América Latina - México, Brasil y Argentina, quienes representan el $80 \%$ de la región- no ha sido homogénea: mientras Argentina vendió entre 31 y 35 millones de entradas — salvo algún año excepcional, como el 2004, cuando esa cantidad llegó a los 42 millones-, Brasil contó entre 72 y 90 millones —exceptuando los años de 2003, 2004 (los mejores de la "retomada") y 2009, cuando esa cifra superó los 100 millones de espectadores-. México, durante el primer lustro del siglo XXI, tuvo alrededor de 135 millones de tickets vendidos, y en el segundo, 170 
en promedio. En síntesis: mientras que México en 2009 se vendieron el doble de entradas que en 2000, en Brasil, durante ese mismo lapso de tiempo, concurrieron un 56\% más de espectadores, mientras que en Argentina no varió mucho la cantidad de entradas vendidas durante la década.

Gráfico 7 - América Latina*: cantidad total de espectadores (2000-2009)

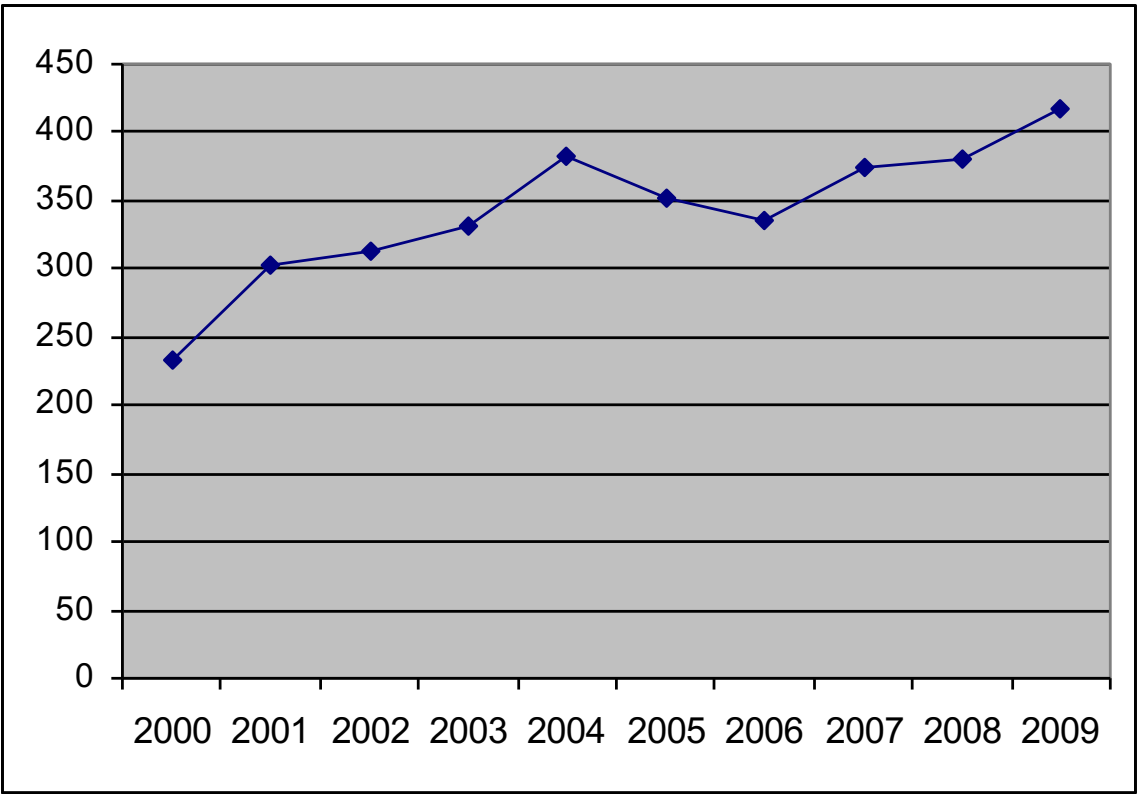

* Argentina, Bolivia, Brasil, Chile, Colombia, México, Paraguay, Perú, Uruguay, Venezuela

Fuente: Elaboración propia sobre la base de datos del Incaa, Ancine, Imcine, CNAC, CNCA, Ina-Icau, Dirección de Cinematografía (Colombia), Conacine (Bolivia), Conacine (Perú), Getino (2005), Stolovich (2004), Guzmán Cárdenas (2005), Cuenca (2007), Rey (2005), ProImágenes, Canacine, Deisica, Nielsen-Rentrak, Ultracine, Cinedística, Filme-B, Otros Cines, medios periodísticos.

Desagregando la cantidad total de espectadores en América latina, se pueden apreciar las diferencias que existen al interior de los mercados analizados, tanto en volumen como en incremento - $\mathrm{o}$ amesetamiento - en la cantidad de espectadores a lo largo de los últimos diez años. 


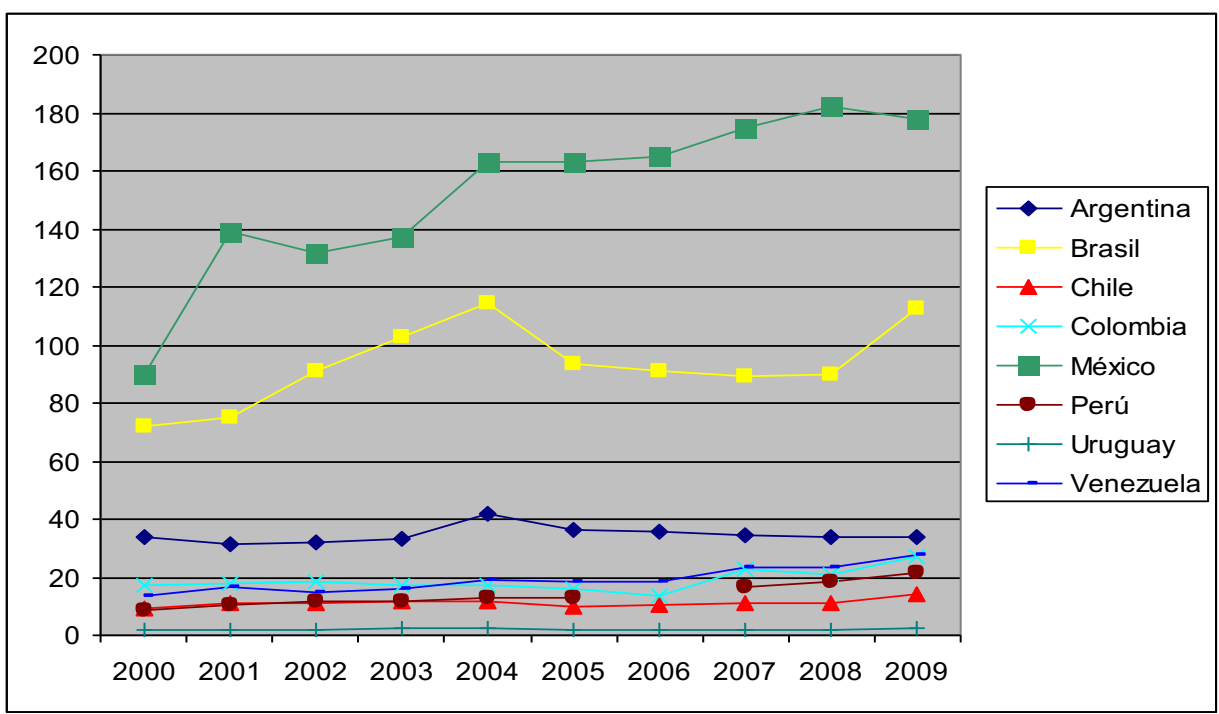

Fuente: Elaboración propia sobre la base de datos del Incaa, Ancine, Imcine, CNAC, CNCA, Ina-Icau, Dirección de Cinematografía (Colombia), Conacine (Perú), ProImágenes, Canacine, Deisica, Nielsen-Rentrak, Ultracine, Cinedística, Filme-B, Otros Cines, Getino (2005), Stolovich (2004), Rey (2005), Guzmán Cárdenas (2005), medios periodísticos.

Se destacan los casos de Perú y de Venezuela, con crecimientos del 161\% y del 108\%, respectivamente, en la cantidad de tickets cinematográficos vendidos a lo largo de la década del 2000. En Chile y en Colombia tal crecimiento fue de alrededor del 55\%, mientras que en Uruguay, al igual que en la Argentina, casi no hubo variación en la cantidad de entradas vendidas durante la década del 2000.

Desde hace casi tres décadas, las estadísticas muestran que los latinoamericanos concurren al cine menos de una vez al año. Durante el último decenio, la excepción fue México. Sin embargo, a pesar de que la nación azteca tiene uno de los parques exhibidores más grandes del mundo, sus habitantes concurren al cine, en promedio, 1,42 veces al año. Estos números están lejos de las épocas de esplendor de concurrencia al cine - mediados del siglo XX hasta comienzos de la década de 1980-, cuando en América latina sus habitantes asistían a las salas, en promedio, entre 2 y 5 veces por año. 
Cuadro 15 - América Latina: índice de concurrencia anual al cine por persona - media- (20002009)

\begin{tabular}{|l|r|}
\hline México & 1,42 \\
\hline Argentina & 0,84 \\
\hline Venezuela & 0,64 \\
\hline Chile & 0,65 \\
\hline Uruguay & 0,58 \\
\hline Brasil & 0,48 \\
\hline Perú & 0,46 \\
\hline Colombia & 0,41 \\
\hline
\end{tabular}

Fuente: Elaboración propia sobre la base de datos del Incaa, Ancine, Imcine, CNAC, CNCA, Ina-Icau, Dirección de Cinematografía (Colombia), Conacine (Perú), ProImágenes, Canacine, Deisica, Nielsen-Rentrak, Ultracine, Cinedística, Filme-B, Otros Cines, Getino (2005), Stolovich (2004), Rey (2005), Guzmán Cárdenas (2005), medios periodísticos.

Existe cierta tendencia en algunos investigadores y analistas a considerar el crecimiento de los mercados latinoamericanos durante la década de 2000 como algo "histórico" —especialmente en lo que respecta a la cantidad de espectadores y número de salascomo si estos números fueran récords nunca antes alcanzados (Oliveros, 2014; Porta Fouz, 2014).

Sin embargo, analizando históricamente se aprecia que los números de los mercados de cine en América Latina durante 2000, si bien han crecido con respecto a la década de 1990, todavía están muy lejanos de los de la década de 1980 (época de decaimiento de los mercados latinoamericanos de cine), y más aún, con respecto a los de las décadas de 1950 у 1960.

Un ejemplo notorio en este sentido se da con la cantidad de espectadores: si en 2009 la cantidad total de entradas vendidas en América Latina era de 417,3 millones -mucho más que los 199,36 millones de 1996-, el número es muy inferior a los 824 millones de 1957, a los 900 millones de 1965, a los 883 millones de 1971, e inclusive a los 594 millones de entradas vendidas en $1980 .{ }^{14}$

\footnotetext{
${ }^{14}$ Elaboración propia sobre la base de datos de Unesco (1955, 1982), Sadoul (2004), González (2011b, 2013).
} 
Gráfico 9 - América Latina: ${ }^{15}$ cantidad de espectadores, en millones (1957-2009)

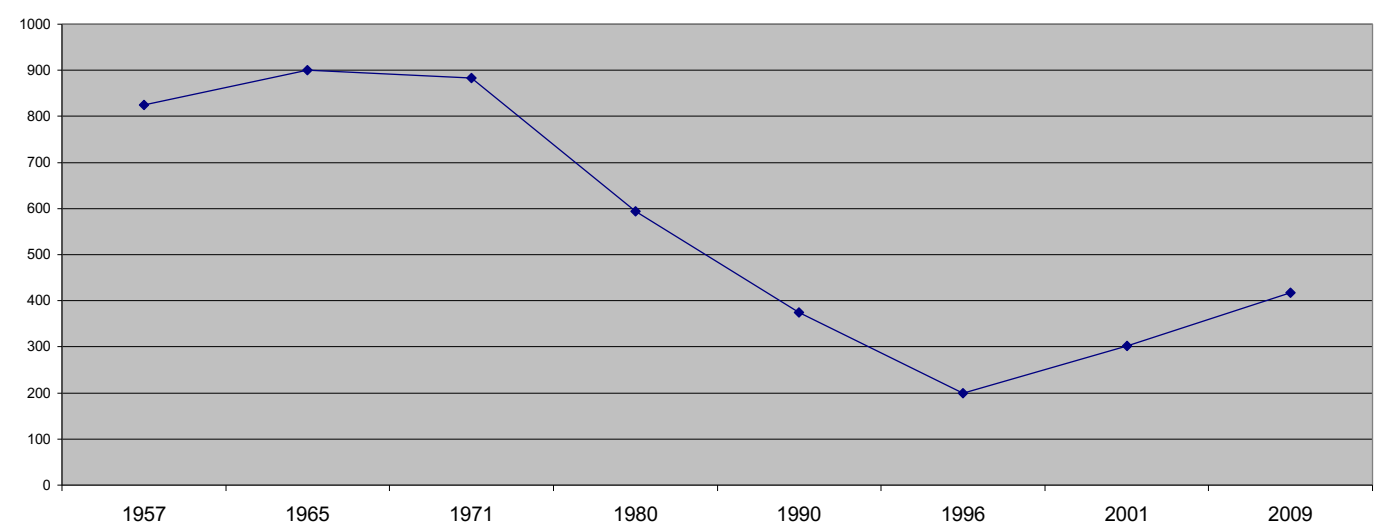

Fuente: Elaboración propia sobre la base de datos de Unesco (1955, 1982), Sadoul (2004), González (2011b, 2013).

\section{Recaudación}

A pesar del bajo nivel de concurrencia al cine en América latina, constante a lo largo de la década de 2000 — como se dijo, 0,8 veces al año, en promedio—, la recaudación cinematográfica creció el 127\%: en efecto, la suba en la taquilla global de la región durante la década del 2000 varió entre el 65\% en Uruguay - a pesar de que en este país casi no hubo variación en el número de espectadores- hasta alrededor del 280\% en Venezuela y en Perú —cuando en estos mercados el incremento en entradas vendidas fue del 108\% y del 161\%, respectivamente.

\section{Gráfico 10 - América Latina*: recaudación total, en dólares corrientes (2000-2009)}

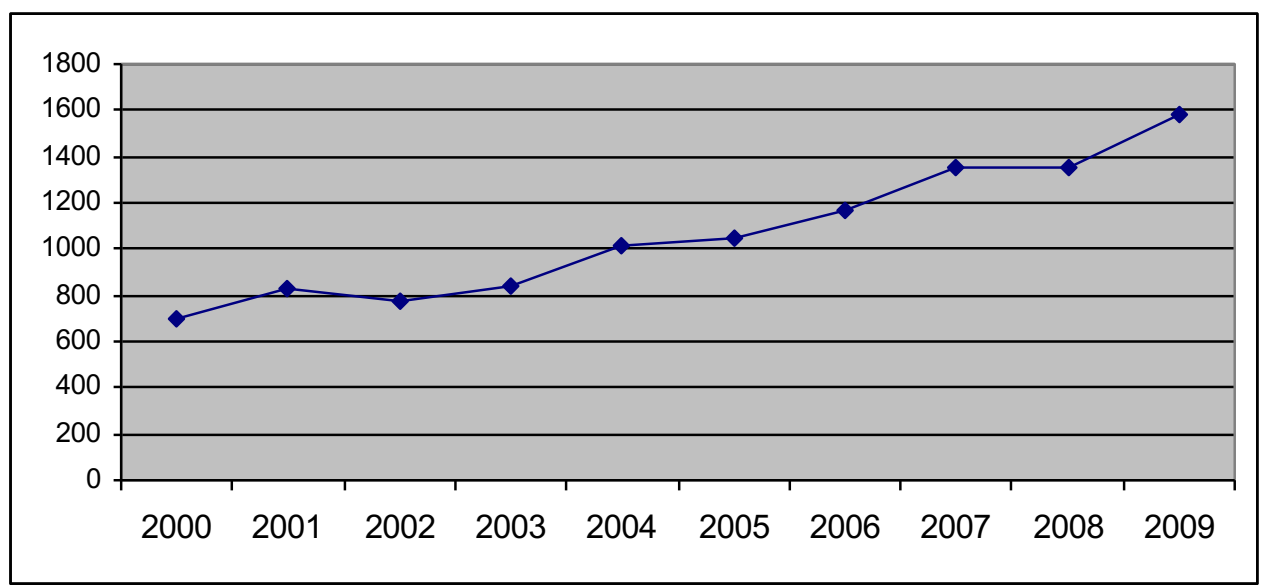

*Argentina, Bolivia, Brasil, Chile, Colombia, México, Paraguay, Perú, Uruguay y Venezuela.

Fuente: Elaboración propia sobre la base de datos del Incaa, Ancine, Imcine, CNAC, CNCA, Ina-Icau, Dirección de Cinematografía (Colombia), Conacine (Bolivia), Conacine (Perú), ProImágenes, Canacine, Deisica, Nielsen-Rentrak, Ultracine, Cinedística, Filme-B, Box Office Mojo, Otros Cines, Canacine, Getino (2005), Cuenca (2007), Rey (2005), Stolovich (2004), Guzmán Cárdenas (2005), medios periodísticos.

\footnotetext{
${ }^{15}$ Se contabilizaron los datos de México, Brasil, Argentina, Colombia, Chile, Venezuela, Perú y Uruguay: el conjunto de estos mercados representa aproximadamente el 90\% del total latinoamericano.
} 
A su vez, en los restantes países analizados, las subas en la taquilla durante el último decenio variaron entre el $83 \%$ en la Argentina, ${ }^{16}$ el $106 \%$ en Chile, el $141 \%$ en Colombia, el 156\% en Brasil y el 173\% en México. Se puede apreciar que la suba en las taquillas es superior entre 1,7 y 4,5 veces en comparación con el incremento en las entradas vendidas.

Gráfico 11 - América Latina: recaudación cinematográfica total, por países, en millones de dólares corrientes (2009)

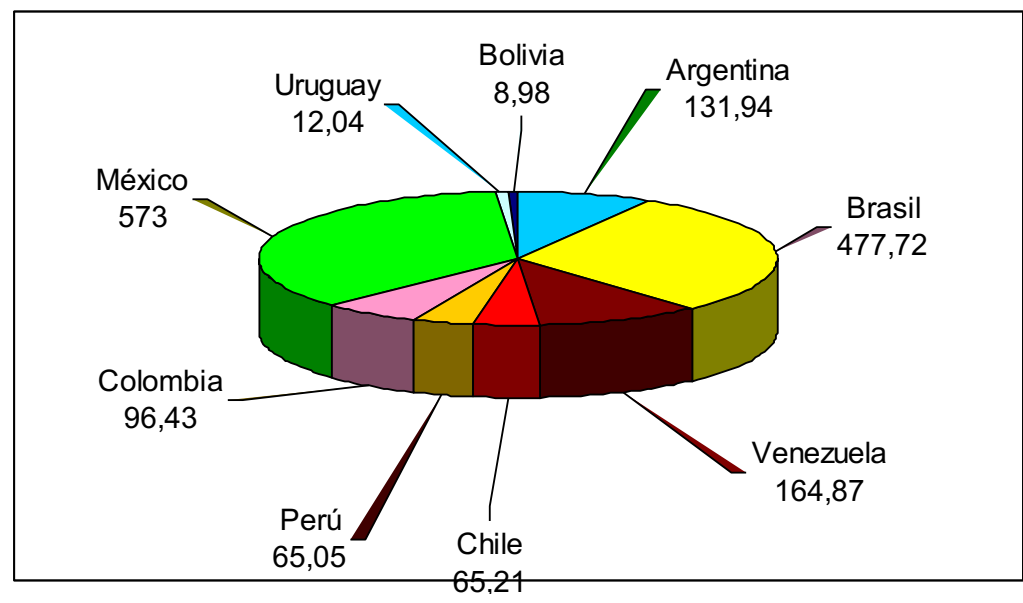

Fuente: Elaboración propia sobre la base de datos del Incaa, Ancine, Imcine, CNAC, CNCA, Icau, Dirección de Cinematografía (Colombia), Conacine (Bolivia), Conacine (Perú), Getino (2005), Rey (2005), Stolovich (2004), ProImágenes, Canacine, Deisica, Nielsen-Rentrak, Ultracine, Cinedística, Filme-B, Box Office Mojo, Otros Cines, Canacine, medios periodísticos.

De los 1600 millones que sumó el mercado cinematográfico en 2009, México —el quinto mayor mercado del mundo en términos de entradas vendidas y de salas de cinerepresenta el 37\% del total. Le sigue Brasil, con el 30\%. Luego, Venezuela participa con el 10\% — aunque esta es una cifra inflada por el alto precio de las entradas de cine en el país caribeño (casi 7 dólares, la más alta de la región); si se analiza la participación de la cantidad venezolana de espectadores en el total regional, el porcentaje no supera el 7\%-. Argentina aporta el 8\% del total recaudado a nivel latinoamericano.

Valor del boleto de cine

El incremento en la recaudación general en América latina tiene su principal origen en la suba del precio del boleto de cine: durante la década de 2000, el ticket cinematográfico duplicó su valor en todos los países analizados. Vale aclarar que en el año 2002 baja el precio promedio a nivel regional debido a la devaluación que sufre la

\footnotetext{
${ }^{16}$ En el caso argentino se tomó como referencia la taquilla de 2002 para comparar con la de 2009, puesto que hasta el año 2001 la moneda de este país estaba sobrevaluada, "inflando" artificialmente los ingresos.
} 
Argentina, país que contaba con unos de los boletos más caros de la región $(4,5$ dólares); a partir del año mencionado, ese valor cae a 1,45 dólares, haciendo bajar el promedio general.

Gráfico 12 - América Latina*: precio promedio del boleto de cine, en dólares (2000-2009)

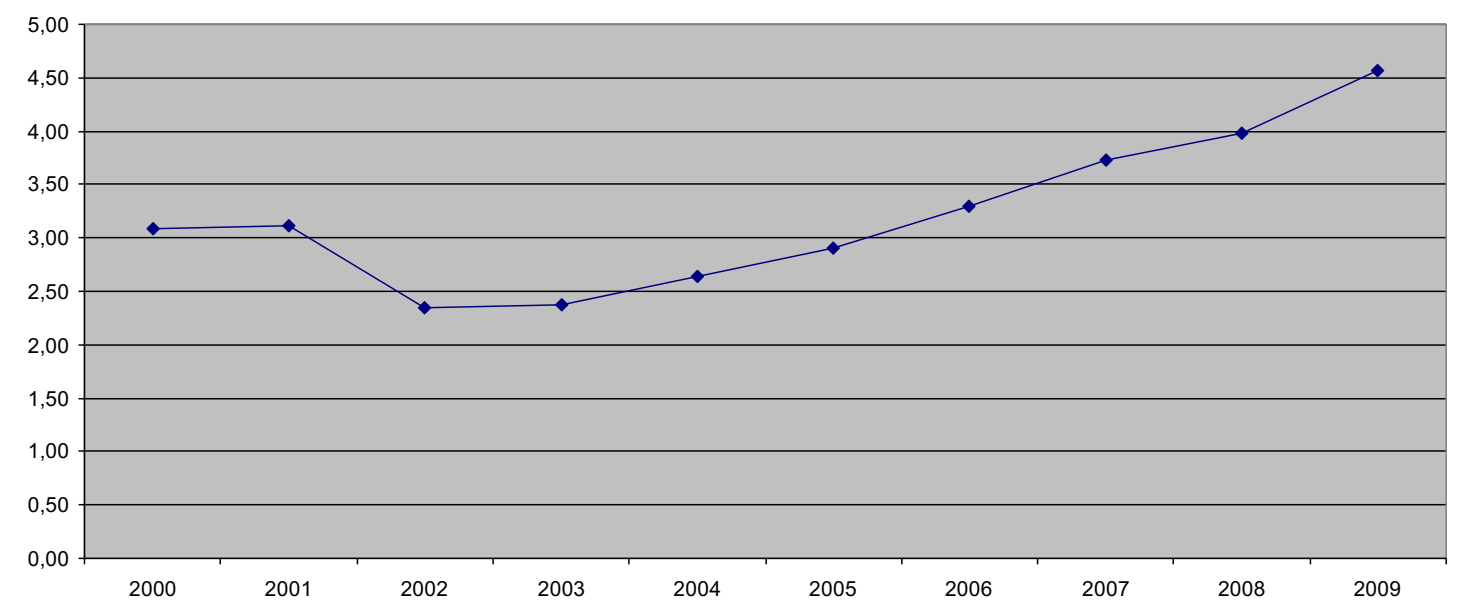

* Argentina, Bolivia, Brasil, Chile, Colombia, México, Paraguay, Perú, Uruguay y Venezuela.

Fuente: Elaboración propia sobre la base de datos del Incaa, Ancine, Imcine, Ina-Icau, CNAC, CNCA, Conacine (Perú), Conacine (Bolivia), Dirección de Cinematografía (Colombia), ProImágenes, Deisica, Nielsen-Rentrak, Ultracine, Cinedística, Filme-B, Onoff, Blogacine, Canacine, Asoprod, Getino (2005), Cuenca (2007), Rey (2005), Stolovich (2004), Guzmán Cárdenas (2005), medios periodísticos.

\section{Exhibición cinematográfica en América latina}

En México y, en menor medida, en Brasil, Perú, Colombia, Venezuela —además de mercados pequeños como Ecuador, Bolivia y Paraguay-, los principales exhibidores son nacionales —notoriamente en México, el quinto parque exhibidor más grande del mundo-. En el resto, dominan las empresas exhibidoras transnacionales, tales como Cinemark y National Amusements (NAI).

Existen empresas que tienen una marcada presencia en el subcontinente, como la estadounidense Cinemark, cuya presencia es la más extendida en la región: se encuentra presente en 13 países de la región (Argentina, Brasil, Colombia, Chile, México, Ecuador, Perú y casi toda América Central). Por su parte, la cadena mexicana Cinépolis tiene presencia en ocho países de América latina (México, Guatemala, El Salvador, Costa Rica, Panamá, Colombia, Perú, y desde 2010, Brasil).

Por su parte, las empresas de exhibición radicadas en América latina que poseen mayor cantidad de salas son las compañías mexicanas Cinépolis - con cerca de 2200 salas en toda la región— y Cinemex — que tras la fusión con la cadena MM Cinemas en 2008, 
suma alrededor de 1800 pantallas en México-. Por su parte, Cinemark posee unas 1100 salas en toda América latina.

Vale destacar el caso de Cinépolis: es la principal cadena exhibidora de México y una de las más grandes del mundo. Durante la década del 2000 se expandió fuertemente tanto al interior de su país como hacia América Latina: está presente en Colombia, Perú, Centroamérica casi en su totalidad, y en 2008 comenzó sus operaciones en Brasil, apostando fuerte en este mercado, donde inauguró sus primeras salas en 2010. También se lanzó al potente mercado indio y hasta hizo pie en el mercado estadounidense.

En lo que hace al número de salas cinematográficas en la región, el mismo se incrementó cerca del 62\% durante la década del 2000, cifra empujada por el notable crecimiento en el parque exhibidor mexicano: pasó de 2100 pantallas en 2000 a más de 4500 en 2009 y 5000 en 2010. Brasil, el otro gran mercado latinoamericano, vio incrementarse el número de sus pantallas un $42 \%$. Colombia - a punto de superar a la Argentina como el tercer parque exhibidor más grande de América Latina- duplicó el número de salas entre 2000 y 2010.

Gráfico 13 - América Latina*: cantidad de salas de cine (2000-2009)

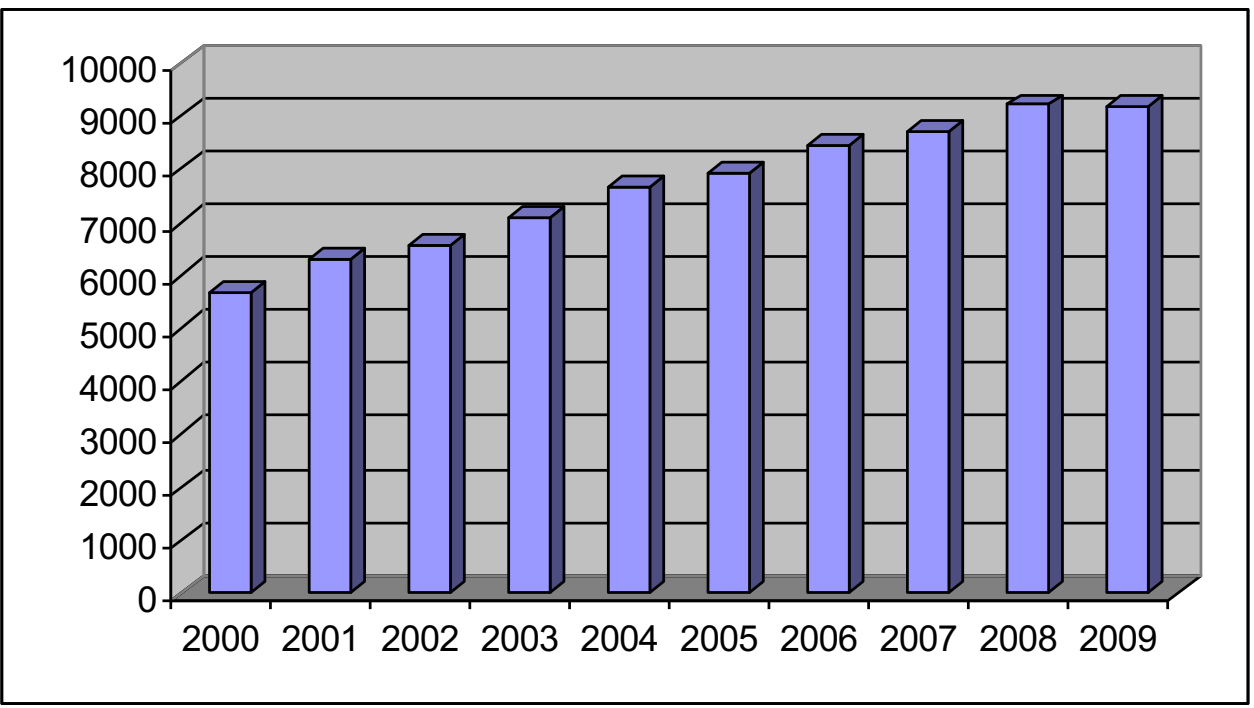

*Argentina, Bolivia, Brasil, Chile, Colombia, México, Paraguay, Perú, Uruguay y Venezuela.

Fuente: Elaboración propia sobre la base de datos del Incaa, Ancine, Imcine, CNAC, CNCA, Ina-Icau, Dirección de Cinematografía (Colombia), Conacine (Bolivia), Conacine (Perú), Otros Cines, Canacine, Ultracine, Proimágenes, Deisica, Filme-B, Cinedística, Nielsen-Rentrak, Getino (2005), Guzmán Cárdenas (2005), Stolovich (2004), Rey (2005), medios periodísticos. 
Los parques exhibidores en los países latinoamericanos son en extremo reducidos —incluyendo al gigante Brasil, que posee unas 2500 salas (2100 en el año 2009) para una población de casi 200 millones de habitantes, lo que representa apenas 1,1 pantallas por cada 100.000 habitantes.

\section{Gráfico 14 - América Latina: evolución en el número de salas de cine (2000-2009)}

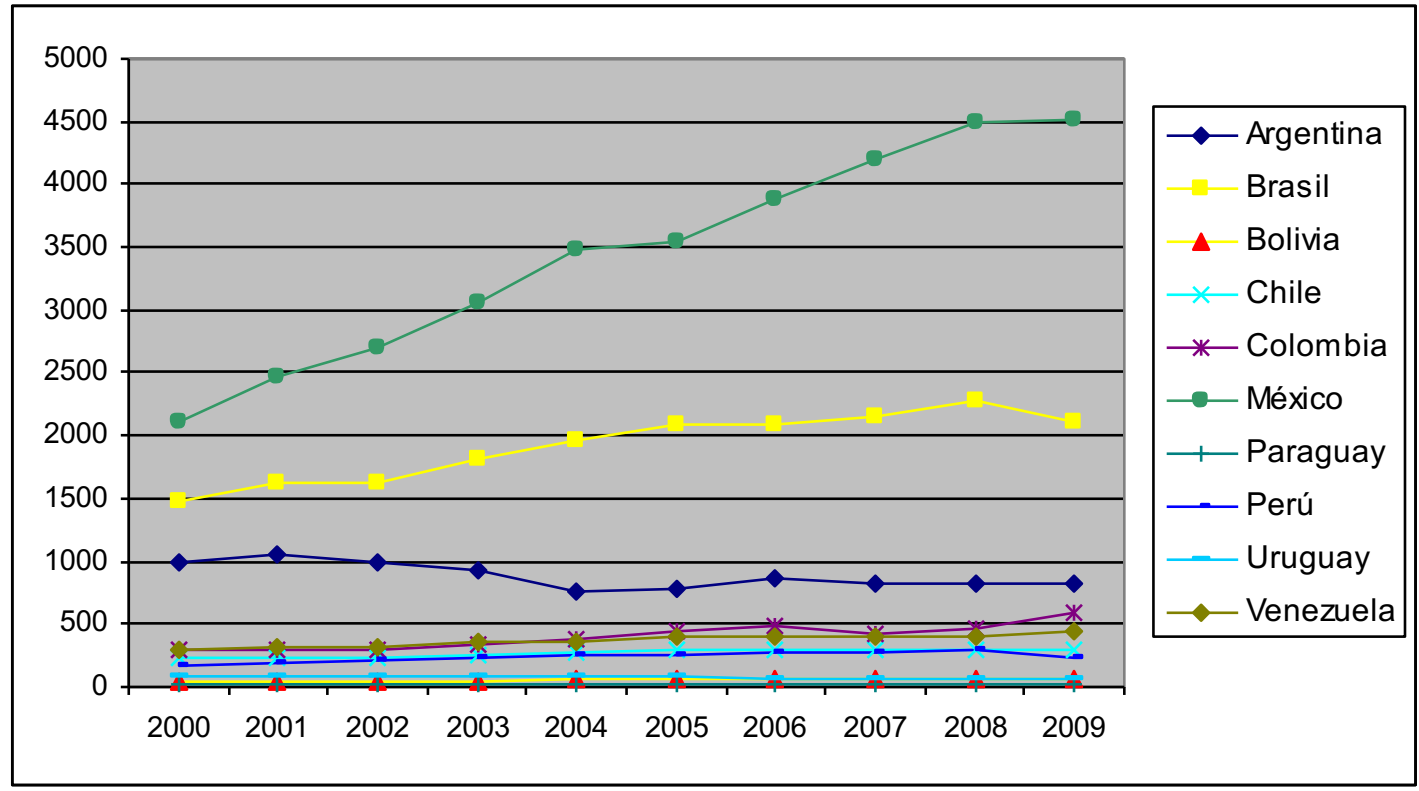

Fuente: Elaboración propia sobre la base de datos del Incaa, Ancine, Imcine, CNAC, CNCA, Ina-Icau, Dirección de Cinematografía (Colombia), Conacine (Bolivia), Conacine (Perú), Otros Cines, Canacine, Ultracine, Proimágenes, Deisica, Filme-B, Cinedística, Nielsen-Rentrak, Getino (2005), Guzmán Cárdenas (2005), Stolovich (2004), Rey (2005), medios periodísticos.

Si se analiza la cantidad de salas por cada millón de habitantes se verá que, efectivamente, la misma es baja en América latina, en comparación con Europa occidental, Estados Unidos o Australia. A nivel regional, el mejor ubicado de acuerdo a este indicador es México. 
Cuadro 16 - América Latina, Estados Unidos, Europa Occidental y Asia: salas, por millón de habitantes (2009)

\begin{tabular}{|c|c|c|c|}
\hline & $\begin{array}{l}\text { Salas } x \\
\text { millón de } \\
\text { habitantes }\end{array}$ & Salas & $\begin{array}{l}\text { Habitantes } \\
\text { (millones) }\end{array}$ \\
\hline EE.UU. & 129 & 40.000 & 310,3 \\
\hline Australia & 93 & 2000 & 21,6 \\
\hline España & 87 & 4000 & 46,1 \\
\hline Francia & 85 & 5500 & 64,7 \\
\hline Reino Unido & 60 & 3700 & 61,2 \\
\hline Alemania & 57 & 4700 & 81,9 \\
\hline Italia & 54 & 3200 & 59,8 \\
\hline México & 40 & 4520 & 112,4 \\
\hline Japón & 27 & 3400 & 127,6 \\
\hline Uruguay & 20 & 70 & 3,5 \\
\hline Argentina & 20 & 800 & 41 \\
\hline Chile & 18 & 300 & 16,7 \\
\hline Venezuela & 15 & 443 & 30 \\
\hline Colombia & 13 & 593 & 45 \\
\hline Brasil & 11 & 2110 & 195 \\
\hline India & 8 & 10.000 & 1207 \\
\hline Perú & 8 & 227 & 30 \\
\hline Bolivia & 7 & 71 & 10,5 \\
\hline Paraguay & 4 & 27 & 7 \\
\hline China & 4 & 4700 & 1334 \\
\hline
\end{tabular}

Fuente: Elaboración propia sobre la base de datos del Observatorio Europeo del Audiovisual, Incaa, Ancine, Imcine, CNAC, CNCA, Ina, Dirección de Cinematografía (Colombia), Conacine (Bolivia), Conacine (Perú), Proimágenes, Filme-B, institutos nacionales de estadísticas, medios periodísticos.

Durante la década del 2000 se consolidó la concentración elitista del mercado cinematográfico latinoamericano, que prepondera las ciudades y las zonas más ricas, a la vez que a las clases más pudientes, para consolidar el incremento sostenido en las taquillas con menos diversidad en las pantallas y de espaldas a las masas que sustentan la base de la pirámide social -el alto costo de las entradas, que representan (considerando una sola salida familiar al cine) alrededor del 10\% del ingreso mensual medio latinoamericano (González, 2012). 
Entre las décadas de 1970 y 1990 se cerró más de la mitad de las salas de cine existentes en todos los países de la región (ver más adelante en el apartado "Comparación histórica"); el cierre de salas fue mayor en los interiores de los países — precisamente, donde históricamente se vio más cine nacional-, en sus pueblos, en sus ciudades pequeñas y en sus barrios humildes, para ser suplantados por templos evangélicos, supermercados o estacionamientos.

Las grandes compañías exhibidoras enfocaron su desarrollo - e incrementaron sus ganancias- a partir de la construcción de multisalas en las principales ciudades y, a su vez, en las zonas de mayor poder adquisitivo, preponderando la exhibición de grandes blockbusters y filmes hollywoodenses y la transformación del hábito de la salida al cine en un factor más de consumo dentro del templo posmoderno de compras por impulso que es el shopping center o mall.

Síntoma de este cambio de hábitos es la creciente importancia en los ingresos de las exhibidoras de la bombonerie —venta de golosinas, gaseosas y demás artículos comestibles, e inclusive, de merchandising del blockbuster en exhibición-, que durante la década pasada ha reforzado la tendencia que comenzó a esbozarse hacia la década de 1970: la participación de los ingresos por alimentos y bebidas en las utilidades de las exhibidoras llegan en muchos casos a más de la mitad de las ganancias obtenidas por sala, especialmente, los fines de semana (Gomezjara, 1973; Britz, 2010; Gonzaga, 2009; Kohan, 2011). En este contexto se entronca la creciente instalación de salas premium -especie de living room con amplio espacio para pocos usuarios, donde (entre otros servicios) se puede ordenar champagne y hasta comida preparada en las inmediaciones por un chef mientras se mira la película.

\section{Los complejos multipantallas}

Sin embargo, de la mano de los complejos multisalas, o multiplex, ${ }^{17}$ que comenzaron a expandirse en la región desde mediados de la década del noventa, el número de pantallas comenzó a incrementarse levemente, mas no el de complejos: si hasta la década del setenta la media de butacas de cada complejo (que, a la vez, poseía una sola

\footnotetext{
${ }^{17}$ A partir de estudios econométricos (Joachim Wolff, Of multiplexes and multiscreens, UNIC, París, 1993; MEDIA Salles, Cinema Exhibition in Europe, White Book of the European Exhibition Industry, Milán, 1994; Dodona Research, Cinemagoing Europe, Leicester, 1994), en regiones como Estados Unidos y Europa occidental se considera "multiplex" a los complejos con ocho o más salas. Sin embargo, en virtud de que en América latina no están extendidos grandes complejos de 8, 10, 12, 16 salas -o, inclusive, con más de 24 pantallas, como en Estados Unidos-, por lo que en este estudio se considera multiplex a los complejos con entre cuatro y once pantallas; y megaplex a los cines con doce o más pantallas.
} 
pantalla) era de 800 - aunque no eran raras las salas que poseían más de mil butacas, habiendo algunas con 1500, 2000 y hasta 3000 asientos-, el promedio se vio reducido en los últimos quince años a unas 200 butacas por cada pequeña sala ubicada en cantidad de cuatro o más en cada complejo.

Cuando comenzó a instalarse el modelo de los multiplex hace quince años, se ponderaba la posibilidad de ofrecer al público una mayor variedad de opciones, en virtud de títulos y horarios. Con el paso del tiempo, esas promesas no se cumplieron: la oferta se contrajo y el mercado se concentró, dando a las exhibidoras mayor poder de presión dentro del negocio cinematográfico, situación que va en detrimento, la mayoría de los casos, de los productores y pequeños distribuidores nacionales — “ninguneando" a las producciones independientes que no tienen un distribuidor importante y/o a las que van con pocas copias, mediante distintos artilugios como la negativa a programar estrenos en buenas fechas, negar buenas salas y buenos horarios, escamotear afiches y material de prensa, entre otros.

Según una investigación de la consultora británica Screen Digest, hacia 2009 los 250 mayores exhibidores del mundo tenían, en promedio, 8,4 pantallas por complejo, mientras que todas las regiones del mundo estaban por debajo de este número, con excepción de Estados Unidos, que tenía 11,6 pantallas por establecimiento cinematográfico. En América latina, según esta investigación, el promedio por complejo es de 8,2 pantallas.

México es el país latinoamericano donde los multiplex poseen mayor cantidad de salas: predominan en la nación azteca los complejos con ocho o más pantallas, mientras que en Brasil —donde aproximadamente el $44 \%$ de sus cines son multipantalla- apenas representan el 10\% de estos complejos y en Argentina -donde el 30\% de los establecimientos cinematográficos son multipantalla-, el $30 \%$ de los multiplex son cines con ocho o más pantallas. El circuito exhibidor de países con un reducido número de salas, como Uruguay y Paraguay, está compuesto entre un 60 y un $80 \%$ por complejos multipantalla.

En lo que hace a concentración de salas por complejo Perú es el país de la región con el número más alto $(9,46$ pantallas por cine), seguido por México $(8,50)$. De los países analizados, Argentina y Uruguay son los que poseen menor concentración: 3 pantallas y 2,2 salas por complejo, respectivamente. 


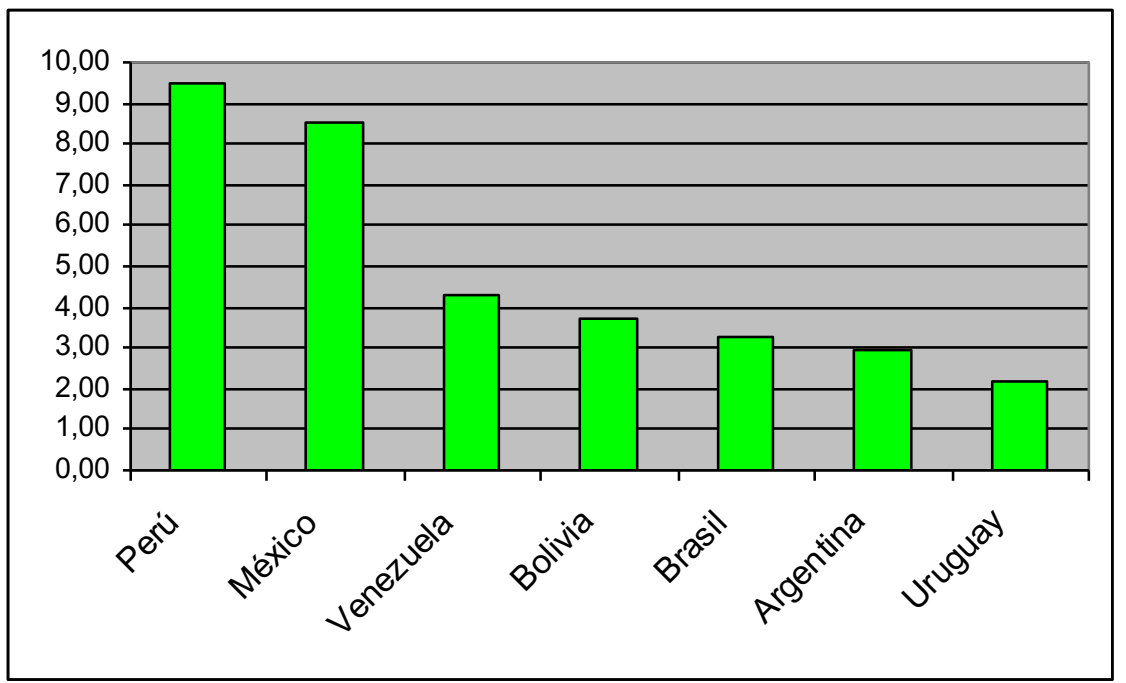

Fuente: Elaboración propia sobre la base de datos del Incaa, Ancine, Imcine, CNAC, Icau, Conacine (Bolivia), Conacine (Perú), Rentrak, Ultracine, Deisica, Canacine, Filme-B, cadenas de cine, medios periodísticos.

\section{Salas digitales}

Desde 2008 se dio en América Latina, como en casi todo el mundo, la explosión de las salas digitales con proyección estereoscópica — popularmente conocida como 3D-, que en un par de años —entre 2007 y 2009- pasaron a representar entre el 30\% y el $40 \%$ de los ingresos globales.

Desde 2007 hasta 2010 el número de salas digitales de alta gama en América Latina pasó de 19 a casi 1100 , más de un $6000 \%$ de aumento, uno de los porcentajes más altos del mundo - el 60\% de las salas digitales latinoamericanas se encuentran en México (42\%) y en Brasil (18\%) (desde que comenzó la digitalización de las salas latinoamericanas, México fue el país líder en la región; en julio del año 2000 se inauguró en la ciudad de México la primera pantalla digital de América Latina: la sala "Mundo E" de Cinemex).

Sin embargo, conforme pasaron los años el ritmo de digitalización en la región se aminoró: en la actualidad (mediados de 2014) sólo cerca de la mitad de los cines de la región son salas digitales, a diferencia de la mayor parte del parque exhibidor mundial, donde entre el $90 \%$ y el $100 \%$ ya son digitales -especialmente en los principales mercados, como Estados Unidos, Europa Occidental y Japón (en América Latina, hacia 2014, México y Colombia tienen digitalizadas entre el $80 \%$ y el $90 \%$ de sus salas).

En América latina las salas digitales se encuentran ubicadas en las ciudades y en los barrios de mayor renta - al igual que la mayoría de los cines con proyección en 35 milímetros-, exhiben los filmes más taquilleros y su entrada es, en promedio, un $30 \%$ 
más cara. Esto explica el incremento en las recaudaciones que experimentaron todos los mercados en 2009: unos quince estrenos tridimensionales (contra 5 en 2008 y 2 en 2007), que significaron menos del $10 \%$ de los lanzamientos de sus respectivas distribuidoras, explicaron alrededor del $40 \%$ de sus ingresos.

\section{Gráfico 16 - América Latina: salas digitales 2K/3D (2007-2010*)}

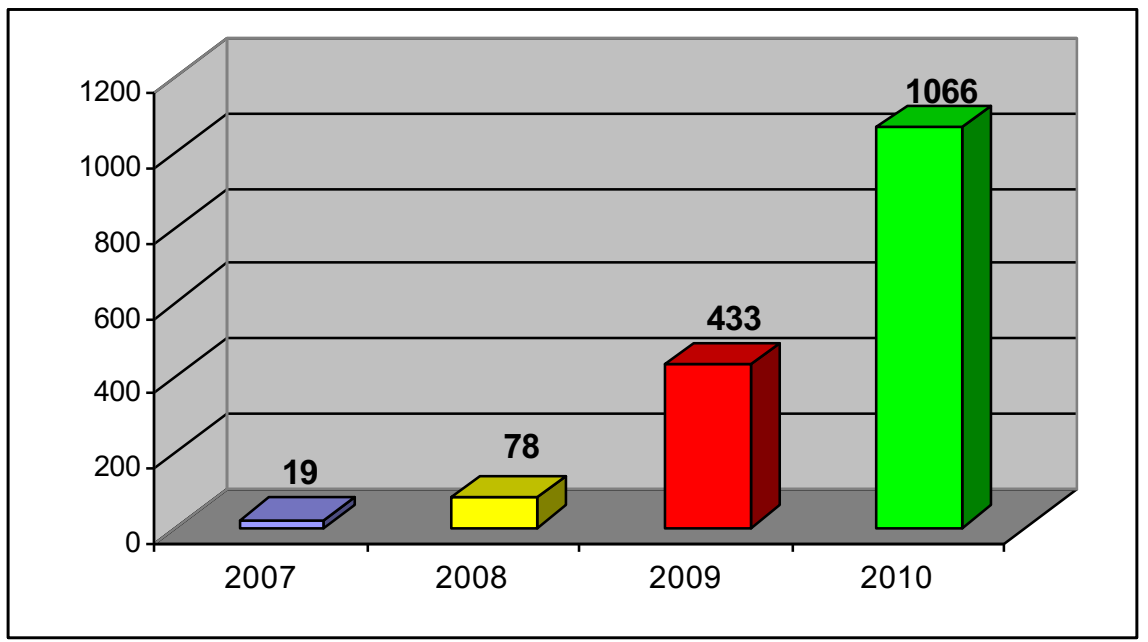

* Se toma 2010, y no 2009, porque el proceso de digitalización en América Latina comenzó muy tarde, en 2008, y hacia 2010 ya estaban consolidadas las tendencias que se fueron dando en los años posteriores.

Fuente: Elaboración propia sobre la base de datos de DCinema Today, Media Salles, Real D, Dolby, X-Pand, Cines Argentinos, Imcine, Filme-B, cadenas de cine, medios periodísticos.

Vale notar que al hablar de "salas digitales" no se está hablando de los proyectores digitales con los que cuentan varias salas, sobre todo, las que proyectan cine arte. La resolución de estos proyectores, si bien es alta, es sumamente inferior a los $2 \mathrm{~K}$ requeridos ${ }^{18}$ para exhibir los filmes $3 \mathrm{D}$-aunque también son mucho más baratos: alrededor de 20 mil dólares-. Esta diferenciación se debe a la norma DCI impuesta por las majors a partir de 2006: si la sala no cuenta con estos requerimientos, las compañías no les facilitan las películas para exhibir -especialmente, los blockbusters que todo exhibidor requiere para hacer rentable su negocio.

\section{Comparación histórica}

Mientras que en 2009 había casi 10.000 salas en toda América Latina —el doble de las cerca de 5000 que tenía toda la región hacia 1995-, esos números se encuentran mucho más lejanos que los de décadas atrás.

\footnotetext{
18 "K" equivale, en este caso, a 2 elevado a 10 (sistema binario), es decir, 1024 píxeles de resolución. Se denominan $2 \mathrm{~K}$ y $4 \mathrm{~K}$ a imágenes de 2048 x 1080 píxeles y 4096 x 2160 píxeles, respectivamente, destinadas a proyectores y archivos de cine digital.
} 
Para realizar una comparación más apropiada entre las distintas épocas, se analizará el número de butacas antes que el de salas. Si se comparara las 10 mil salas existentes al finalizar la década de 2010 se podría asumir erróneamente que la región presenta un número similar al de mediados del siglo XX, cuando la cantidad de cines rondaba ese número (Unesco, 1982). Sin embargo, tal comparación sería incorrecta.

Hasta la década de 1980 la abrumadora mayoría de los cines en todo el mundo eran edificios con una sola y enorme sala, que podía superar fácilmente las mil butacas; el promedio era de 600 butacas por cine. Desde la década de 1990, con el advenimiento de los cines multiplex, comenzó a aumentar exponencialmente el número de complejos con varias salas diminutas, cada una de ellas con una reducida cantidad de localidades. De esta manera, desde hace 20 años el promedio de asientos por sala se redujo drásticamente: sólo 200 butacas por cada sala.

De esta manera, las 10.000 salas latinoamericanas existentes hacia 2010 equivalían a unas dos millones de butacas, menor cantidad que las 2,4 millones de butacas que tenían los 4100 cines existentes en América Latina en 1939, y mucho menor que los 6,2 millones de asientos que sumaban los 10.300 cines que tenía la región en 1951, o las 7,7 millones de butacas que poseían los 12.900 cines existentes en 1960 (Unesco, 1955, 1982).

Gráfico 17 - América Latina: cantidad de butacas de cine (1920-2009)

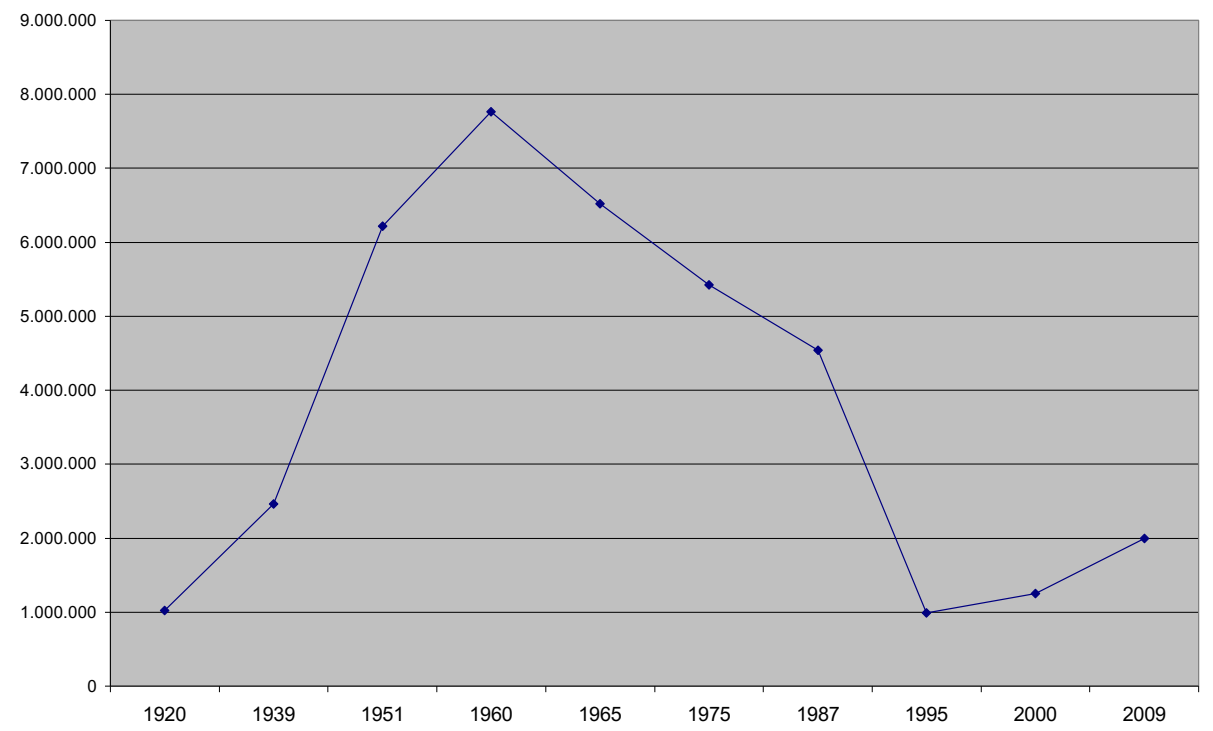

Fuente: Elaboración propia sobre la base de datos de Unesco (1955, 1982), Sadoul (2004), González (2011b, 2013). 
México fue el único país latinoamericano que, durante la década de 2000, recuperó valores importantes, aunque todavía distantes de la "época de oro": si bien en la década de 1990 el número de butacas en las salas aztecas bajó mucho (en 1960 tenía 2 millones de asientos, mientras que en 1995 ese número había descendido a tan sólo 670.000, y en el año 2000, a 423.000), en la actualidad México posee alrededor de 1,1 millones de butacas.

Brasil, por su parte, tenía 1,9 millones de butacas en 1955, mientras que en la actualidad ronda los 530.000 asientos (es decir, la cuarta parte de las localidades que tenía hace poco más de medio siglo). Para tener una idea de este descenso, en 1960 sólo Cuba tenía en su territorio 400 mil butacas de cine.

El caso argentino es más grave: para 1960 el (entonces) importante mercado cinematográfico arañaba el millón de butacas (920.000). Para mediados de la década de 1990 el parque exhibidor de este país había descendido a unas 200.000 butacas. En la actualidad el número ronda las 170.000 (seis veces menos que hace medio siglo; la misma cantidad de asientos que en 1955 sumaban Guatemala, El Salvador y Martinica). Desde hace veinte años, en la Argentina existen entre 700 y 850 salas, variando de acuerdo a los vaivenes de las distintas crisis que atraviesa el país (por el contrario, la mayoría de los parques exhibidores latinoamericanos duplicaron y hasta triplicaron la cantidad de salas en la última década, sobresaliendo los casos de México, Colombia, Brasil y Perú).

Centroamérica y el Caribe, abarcado como un todo, sumaba hacia 1960 unas 800 mil butacas, mientras que en la actualidad ronda las 200.000 —para 1960 sólo Costa Rica, El Salvador y Guatemala poseían esa cantidad de asientos, y (como se mencionó) hace cincuenta años sólo Cuba tenía el doble de la cantidad actual de butacas que posee toda la sub-región.

A su vez, vale recordar que hasta la década de 1980 los cines se encontraban mucho más presentes en los interiores de los países, mucho más cercanos a los sectores de menores ingresos, que lo que sucede en la actualidad, cuando sólo entre el 4\% y el 10\% de los municipios latinoamericanos tienen sala de cine, con un precio de la entrada varias veces más elevado - en términos de poder adquisitivo- que en de décadas anteriores (González, 2011b). 


\section{Distribución cinematográfica en América Latina}

A nivel mundial, existe en la distribución un manejo oligopólico por parte de las majors que resulta decisivo a la hora de la formación de la demanda - beneficiando a sus empresas asociadas-, limitando la competencia en un accionar mancomunado entre ellos y las grandes cadenas de exhibición, realizando colusión, por ejemplo, en torno a los precios y a la programación.

Este control les permite imponer condiciones a los productores, e inclusive a los gobiernos, abordando otras ventanas de comercialización —televisión, video, ${ }^{19} \mathrm{y}$ últimamente, internet y dispositivos móviles-, funcionando en red y a gran escala para poder reducir costos de distribución por unidad - diferenciándose en cuanto producto, costos publicitarios y de negativos.

De esta manera, los riesgos de estas empresas se minimizan y sus tasas de rentabilidad crecen: en América latina los exhibidores —especialmente, las grandes cadenas- se apropian de más de la mitad de la recaudación, mientras que los distribuidores llegan a quedarse con el $35 \%$ de los ingresos netos de boletería -en el caso de que la distribuidora (generalmente, major) haya financiado el largometraje exhibido, ese porcentaje puede trepar hasta el 50\% de los ingresos.

Este accionar resulta en una barrera de entrada a nuevos competidores, convirtiendo al sector de la distribución —en ligazón con la exhibición— en estratégico.

Las majors representan el mayor volumen de espectadores y de recaudaciones, así como de títulos estrenados, los que rondan anualmente los 150 y los 250 , según cada territorio.

La actividad de estas distribuidoras multinacionales acapara en América latina entre el $40 \%$ y el $80 \%$ de la oferta, y ronda entre el $75 \%$ y el $95 \%$ de las cifras de espectadores y recaudaciones.

La presencia oligopólica de las majors, frente a la cual se hace muy difícil competir incluso en aquellos países que disponen de legislaciones de fomento (con cuotas de pantalla, apoyo a la distribución y a la exhibición local, etc.), se ve reforzada con las millonarias inversiones en marketing mundial y local, además de la tirada de numerosas copias que buscan acaparar el tiempo de pantalla de la mayor cantidad posible de salas.

\footnotetext{
${ }^{19}$ A pesar de que el video fue el principal ingreso de las majors de Hollywood durante un cuarto de siglo, hasta mediados de la década de 2000, esta ventana nunca representó un ingreso importante para las películas latinoamericanas -como tampoco lo es la recaudación internacional en salas de cine.
} 
Así, entre el 70\% y el 75\% de copias en los mercados latinoamericanos corresponde a los estrenos estadounidenses, mientras que en los casos de países con un importante número de estrenos nacionales, como Argentina y Brasil, el porcentaje de copias de las películas locales oscila entre el 10\% y el 15\%; en México, este porcentaje es levemente menor. En el resto de los países, el número de copias — con un costo promedio de 1500 dólares cada una- es muy bajo en el caso de los filmes nacionales.

\section{Estrenos}

Analizando la cantidad de estrenos, se aprecia que durante la década hay una tendencia al aumento, en especial en Brasil —donde los estrenos se duplicaron a lo largo de la década-, México y Argentina.

Gráfico 18 - América Latina*: evolución en el número de estrenos comerciales (2000-2009)

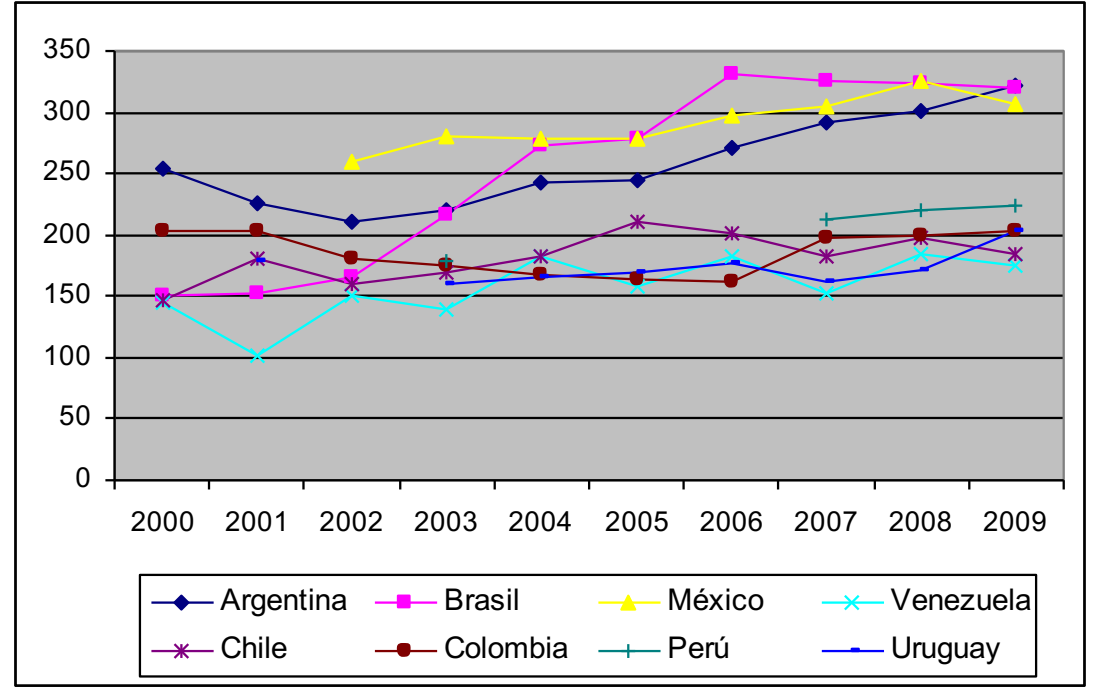

* Argentina, Brasil, Colombia, Chile, México, Paraguay, Perú, Uruguay, Venezuela.

Fuente: Elaboración propia sobre la base de datos del Incaa, Ancine, Imcine, Ina-Icau, CNAC, CNCA, Conacine (Perú), Dirección de Cinematografía (Colombia), ProImágenes, Deisica, Nielsen-Rentrak, Ultracine, Cinedística, Filme-B, IMDB, Box Office Mojo, Cinencuentro, Cinestrenos, Otros Cines, Cines Argentinos, Cine Nacional, Cine Chile, Onoff, Blogacine, Canacine, Asoprod, Getino (2005), Stolovich (2004), Rey (2004), Guzmán Cárdenas (2005), medios periodísticos. 


\section{La presencia del cine nacional en América Latina}

La presencia de los filmes nacionales en las pantallas latinoamericanas varía de acuerdo a la capacidad, la tradición cinematográfica y las políticas de fomento de cada país, aunque - a nivel general - a lo largo de la década de 2000 se incrementó de manera la oferta de películas nacionales en casi toda América Latina. Sin embargo, en conjunto, las películas nacionales alcanzan un recudido market share.

\section{Gráfico 19 - América Latina: evolución en el número de estrenos nacionales (2000-2009)}

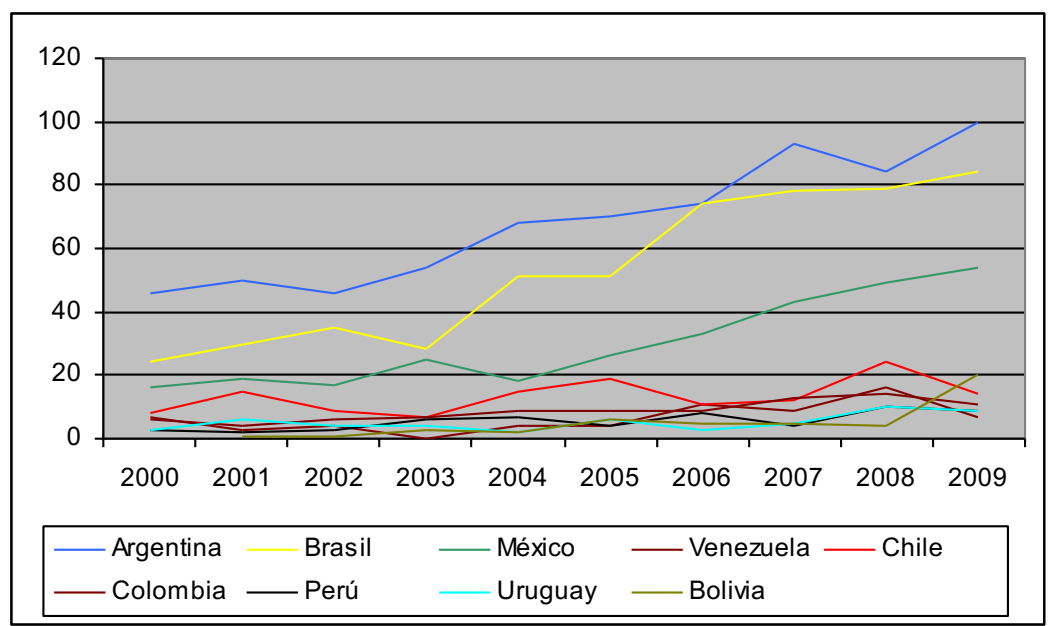

Fuente: Elaboración propia sobre la base de datos del Incaa, Ancine, Imcine, CNAC, CNCA, Ina-Icau, Dirección de Cinematografía (Colombia), Conacine (Perú), Proimágenes, Cine Nacional, Filme-B, IMDB, Nielsen-Rentrak, Ultracine, Deisica, Cinedística, Canacine, Otros Cines, Cines Argentinos, Box Office Mojo, Cinestrenos, Cinencuentro, Cine Chile, Onoff, FNCL, Getino (2005), Stolovich (2004), Rey (2005), Guzmán Cárdenas (2005), Tamayo-Hendrickx (2010), medios periodísticos.

Aunque las políticas públicas de cine hayan incrementado la producción de cine durante la década, las audiencias de los distintos filmes nacionales son muy bajas, no superando, en promedio, el 10\% del market share en los países con una tradición importante de cine nacional, como Argentina, México o Brasil. En el resto de los países - que se encuentran realizado un esfuerzo importante por construir una industria de cine propia, como Chile, Colombia, Venezuela y Uruguay-, el porcentaje de espectadores de cine nacional ronda entre el 1\% y el 5\% — salvo casos excepcionales en que un título local logra captar un porcentaje importante del público, como La teta asustada, Machuca, Whisky o María, llena eres de gracia. 
Cuadro 17 - América Latina: filmes nacionales, market share —media- (2000-2009)

\begin{tabular}{|l|r|}
\hline & $\%$ Market share \\
\hline Argentina & 12,48 \\
\hline Brasil & 12,06 \\
\hline Colombia & 7,67 \\
\hline Chile & 6,55 \\
\hline México & 6,24 \\
\hline Uruguay & 3,07 \\
\hline Venezuela & 2,75 \\
\hline Perú & 2,71 \\
\hline
\end{tabular}

Fuente: Elaboración propia sobre la base de datos del Incaa, Ancine, Imcine, CNAC, CNCA, Ina-Icau, Dirección de Cinematografía (Colombia), Conacine (Perú), Proimágenes, Cine Nacional, Filme-B, IMDB, Nielsen-Rentrak, Ultracine, Deisica, Cinedística, Canacine, Otros Cines, Cines Argentinos, Box Office Mojo, Cinestrenos, Cinencuentro, Cine Chile, Onoff, FNCL, Blogacine, Getino (2005), Stolovich (2004), Rey (2005), Guzmán Cárdenas (2005), Tamayo-Hendrickx (2010), medios periodísticos.

En el caso de los filmes iberoamericanos no nacionales, el panorama es peor: la oferta y el consumo de estas películas se ubican entre el 0,02\% y el 2\% — salvo la presencia de algún éxito excepcional, generalmente distribuido por alguna major estadounidense.

\section{La circulación de las películas iberoamericanas en América Latina}

En lo que respecta a la presencia de los filmes iberoamericanos, la misma es prácticamente nula en los distintos mercados analizados: un porcentaje de oferta y de demanda que ronda el 1\%, siendo usuales porcentajes menores y no mayores (algún éxito inusual puede superarlo).

Cuadro 18 - América Latina*: oferta y demanda de filmes latinoamericanos no nacionales. Cantidad de estrenos y market share - media- (2000-2009)

\begin{tabular}{|l|l|r|}
\hline & $\begin{array}{l}\text { Cantidad de estrenos } \\
\text { anuales de filmes } \\
\text { latinoamericanos no } \\
\text { nacionales (media) }\end{array}$ & Market share (media) \\
\hline Venezuela & 9 & 1,12 \\
\hline Chile & 11 & 1,01 \\
\hline Brasil & 10 & 0,33 \\
\hline Perú & 5 & 0,53 \\
\hline Argentina & 6 & 0,24 \\
\hline
\end{tabular}

* Debido a la escasez de información estadística confiable sobre los mercados latinoamericanos de cine, y en particular sobre este indicador, sólo se pudo trabajar con estos países.

Fuente: Elaboración propia sobre la base de datos del Incaa, Ancine, CNAC, CNCA, Conacine (Perú), Cine Nacional, Filme-B, Nielsen-Rentrak, Ultracine, Deisica, Cinedística, Otros Cines, Cines Argentinos, Box Office Mojo, FNCL, IMDB, Cinestrenos, Cinencuentro, Cine Chile, Onoff, Blogacine, medios periodísticos. 
La circulación de películas iberoamericanas al interior de la región es muy limitada, de tal modo que estos filmes se estrenan en número reducido en los distintos países, variando entre 3 y 20 estrenos anuales, dependiendo del mercado.

Gráfico 20 - América Latina: cantidad de estrenos iberoamericanos no nacionales (2006-2009)

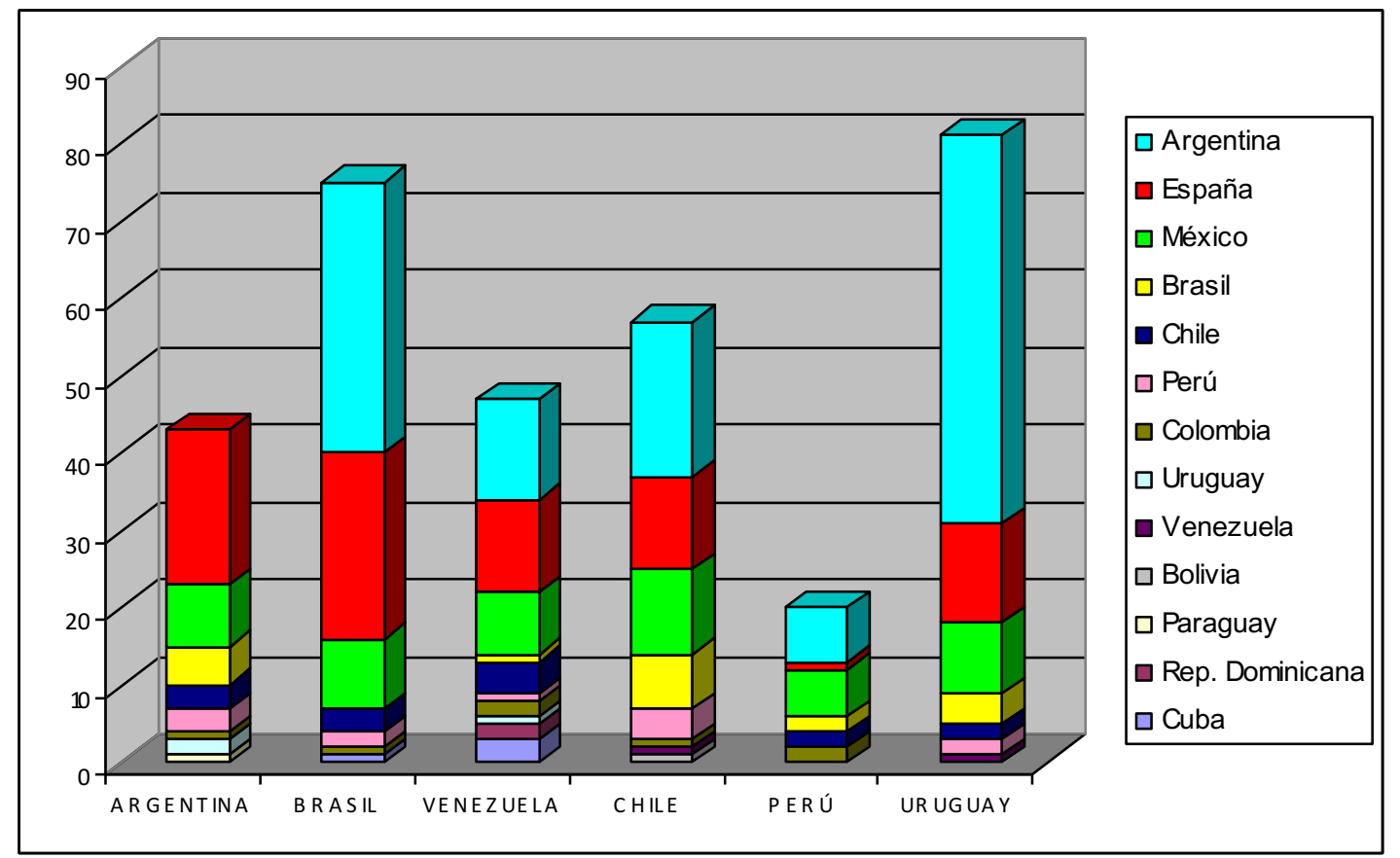

Fuente: Elaboración propia sobre la base de datos del Incaa, Ancine, CNAC, CNCA, Conacine (Perú), Cine Nacional, Filme-B, Nielsen-Rentrak, Ultracine, Deisica, Cinedística, Otros Cines, Cines Argentinos, Box Office Mojo, FNCL, IMDB, Cinestrenos, Cinencuentro, Cine Chile, Onoff, Blogacine, medios periodísticos.

Uruguay tiene una "alta" cantidad de filmes iberoamericanos exhibidos en sus salas comerciales, debido a la tradición cinéfila de su público —si se contaran las exhibiciones en los variados espacios alternativos existentes en el país, sobre todo en Montevideo (destacándose una entidad señera como la Cinemateca Uruguaya), el número de estrenos iberoamericanos registrados en la presente investigación se duplicaría.

En Brasil también existe una destacada red de salas de "cine arte", en especial en Río de Janeiro, San Pablo, Brasilia y Porto Alegre, que es donde se exhiben principalmente los filmes iberoamericanos.

En Argentina existen los Espacios Incaa, una buena idea que comenzó a funcionar en 2004, aunque con una gestión no profesionalizada que no arrojó importantes resultados de mercado. 
Gráfico 21 - América Latina*: cantidad total de estrenos iberoamericanos no nacionales (20062009)

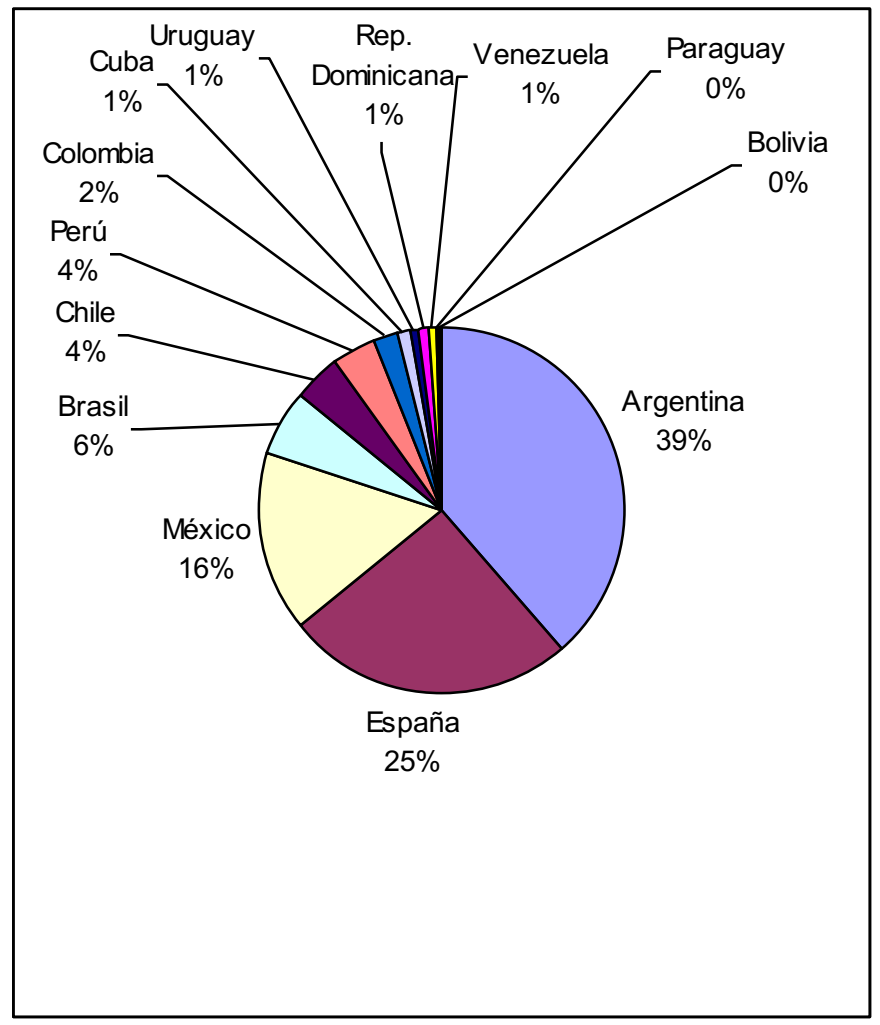

* Argentina, Brasil, Chile, Perú, Uruguay y Venezuela.

Fuente: Elaboración propia sobre la base de datos del Incaa, Ancine, CNAC, CNCA, Conacine, Ina-Icau, NielsenRentrak, Filme-B, Deisica, Box Office Mojo, Cinestrenos, IMDB, Cines Argentinos, Onoff, Blogacine, Getino (2005), Stolovich (2004), Rey (2005), Guzmán Cárdenas (2005), medios periodísticos.

En términos de público el market share de los filmes iberoamericanos rondó entre el $0,02 \%$ y el $2 \%$ anual en los países analizados. Los pocos miles de espectadores que suelen acudir a ver estas películas provienen de los sectores de mayor educación y poder adquisitivo, caracterizados por un mayor nivel de exigencias en materia de originalidad y calidad artística y técnica, puesto que las películas iberoamericanas que alcanzan a salir de sus fronteras son, generalmente, las que han ganado premios en importantes festivales internacionales, las que tienen el favor de la crítica internacional y no los grandes éxitos populares en sus respectivos países.

\section{Mercados y neofomentismo}

Como se vio a lo largo del capítulo, los mercados mundiales de cine muestran un reforzamiento del dominio de Hollywood, la concentración del mercado por parte de multinacionales - extranjeras y locales - y el crecimiento del mismo - frenado momentáneamente hacia 2009-2010 por la crisis sub-prime estadounidense. 
En efecto, las majors de Hollywood vienen realizando campañas cada vez más agresivas, con mayor gasto en publicidad, lanzamientos simultáneos a nivel mundial, mayor cantidad de copias — que taponan las salas, quitando espacio para que los filmes locales realicen lanzamientos competitivos-, en un contexto en que existe una importante reducción en el número de butacas de cine, si se compara con algunas décadas atrás.

A pesar de la notable expansión del parque exhibidor en toda América Latina a lo largo del período 2000-2009 -y posteriormente también-, con México y Colombia duplicando el número de salas, Brasil registrando un aumento de casi un $50 \%$ — con Argentina virtualmente estancada-, en la actualidad toda la región suma unas dos millones de butacas de cine, menos que las que existían en 1939 (2,4 millones) y muchísimo menos que las registradas en 1951 (6,2 millones) y 1960 (7,7 millones).

A su vez, se da una concentración geográfica y clasista: la menor cantidad de salas y butacas se distribuyen de peor manera que hace medio siglo. En efecto, sólo entre el 4\% y el $10 \%$ de los municipios de nuestros países cuentan con cine, y la mayoría se ubica en las ciudades y barrios con población de mayor poder adquisitivo. Los cines que masivamente se cerraron desde fines de la década de 1970 en toda la región se ubicaban en las zonas con población de menores recursos, que era la mayor consumidora de filmes nacionales.

Las multinacionales son las que manejan la exhibición —destacándose Cinemark y National Amusements (a finales de la última década, surgieron exhibidoras latinoamericanas con presencia en varios países de la región, destacándose la mexicana Cinépolis y, en menor medida, empresas como la peruana Cineplanet o la portorriqueña Caribbean Cinemas).

Similar relación entre países y en términos históricos se da con respecto a la cantidad de espectadores y recaudación.

En lo que hace a la distribución las majors son las que dominan el negocio en toda América Latina: en efecto, Hollywood se queda con entre el $70 \%$ y el $90 \%$ de la recaudación y los tickets vendidos en toda América Latina, y es el jugador preponderante en la comercialización cinematográfica de toda la región.

En este contexto, los cines nacionales - especialmente, los de Argentina, Brasil y México- si bien registran mayor cantidad de estrenos con respecto a la década de 1990, su convocatoria es constantemente baja — salvo por blockbusters que surgen 
ocasionalmente-, a diferencia de lo que ocurría décadas atrás con las cinematografías de estos tres países, los de mayor historia y tradición cinematográfica en toda la región. En este contexto, las políticas neofomentistas — reparación a la baja del fomentismo (políticas cinematográficas activas vigentes hasta la década de 1980, en México y Brasil) - buscan hacer frente a las fallas de mercado antedichas mediante cuotas de pantalla (en los casos argentino y brasileño), media de continuidad (en el caso argentino), impuestos a las remesas de las multinacionales (en el caso brasileño) o con impuestos a la cantidad excesiva de copias (en el caso argentino), entre otras medidas.

En los próximos capítulos dedicados a los casos nacionales se analizará el impacto de estas políticas neofomentistas en los aspectos referidos en este capítulo, especialmente en lo que hace a la proporción del fomento estatal a los eslabones de la distribución, de la comercialización y de la exhibición en comparación con el de la producción, a la presencia y a la convocatoria de los filmes nacionales en las salas nacionales y latinoamericanas, a la existencia de empresas nacionales en los ámbitos de la exhibición, la distribución y la comercialización, al consumo cinematográfico y, en definitiva, a la sustentabilidad del sector cinematográfico en Argentina, Brasil y México. 


\section{CAPÍTULO V \\ POLÍTICAS PÚBLICAS CINEMATOGRÁFICAS EN MÉXICO}

\section{Los inicios del cine mexicano}

En plena consolidación de la Revolución Mexicana, con Villa y Zapata todavía levantados en armas, el presidente Carranza (1914-1920) respaldó al cine en cuanto nuevo arte -fomentó el desarrollo de algunos realizadores, y creó una cátedra relacionada con la incipiente cinematografía.

Ya en la década de 1920 el presidente Obregón — que tuvo en su gobierno al intelectual José Vasconcelos, primer rector de la Universidad Nacional Autónoma de México (UNAM) - fomentó un cine con tintes propagandísticos del Estado posrevolucionario recientemente conformado —especialmente, ensalzando a las Fuerzas Armadas (De la Vega Alfaro, 2000).

Para la década de 1930 en México ya existían tres estudios cinematográficos y 17 estudios productoras, a las que luego se sumaría la importante Compañía Nacional Productora -empresa que posteriormente también sería distribuidora y exhibidora-; en 1935 el gobierno del presidente Lázaro Cárdenas —un presidente que, en la actualidad, sigue siendo bien valorado por la sociedad mexicana, quien nacionalizó el petróleo, instauró la reforma agraria impulsada, entre otros, por Emiliano Zapata en la Constitución de 1917 (y nunca cumplida hasta entonces), promovió derechos sociales y laborales, además de la cultura y las artes, fomentando la acogida de importantes contingentes de exiliados de régimenes fascistas de todo el mundo- financió la construcción de los estudios de Cinematográfica Latinoamericana S.A. (Clasa), que contaban con los mejores equipos de toda América Latina (García Riera, 1999). En 1934 se formó el primer sindicato de cine —en Brasil se crearía en 1938 y en Argentina en 1944- Para estos años ya existían cuatro revistas especializadas sobre cine (Gómez, 2006).

La punta de lanza para la "época de oro" del cine mexicano, tanto a nivel nacional como internacional, fue el éxito descomunal de Allá en el Rancho Grande (1936): enseguida todo lo que fueran comedias o dramas rancheros fueron ampliamente demandados en toda América Latina.

King señala que hacia 1938 la industria cinematográfica en México se ubicaba sólo luego de la industria petrolera, agregando: "La comedia ranchera situó a México como 
el mayor exportador de películas entre los países latinoamericanos, y sus cintas también fueron bien recibidas por la España de Franco" (King, 1994:77).

Sin embargo, para finales de la década de 1930 el filón parecía haber cansado a las audiencias latinoamericanas, por lo que el cine mexicano se diversificó, ofreciendo mayor variedad en sus filmes — destacándose los dramas y comedias urbanas, además del melodrama-, retomando su lugar de privilegio en América Latina, consolidándose como la industria cinematográfica más importante de todo el subcontinente, desplazando a sus competidores: los cines argentino y español.

A su vez, a comienzos de la década de 1940 hubo otro factor importante para que el cine mexicano entrara de lleno en su "época de oro" y se convirtiera en la principal cinematografía de América Latina: el apoyo de Hollywood —con la anuencia del gobierno estadounidense- para que México tuviera un acceso abierto a los insumos principales de la industria - principalmente, de película virgen (al contrario de la posición tomada en contra de la Argentina: en 1942 Washington comenzó a cortar la provisión de material fílmico hacia Argentina, siendo una de las represalias tomadas por la posición del gobierno de Buenos Aires en la Conferencia de Río de Janeiro, en enero de 1942)..$^{20}$

Entrada la década de 1940 el cine mexicano se había convertido en una industria triunfante tanto dentro de su territorio como fronteras afuera, representando una auténtica competencia para Hollywood tanto en México como en gran parte de América Latina.

A partir de charros, madres sufrientes y pillos urbanos, con estrellas como Dolores del Río, Cantinflas, María Félix o Jorge Negrete, y con directores como Emilio Fernández, Alejandro Galindo o Roberto Gavaldón, las películas mexicanas penetraron en la mayor parte de América Latina: para mediados de la década de 1940 Venezuela, Colombia y Cuba - sin olvidar Perú y toda América Central y el Caribe- estaban ávidas de todo filme que proviniera de México, cuyos públicos se veían y escuchaban en la pantalla grande, más allá de que las películas fueran inequívocamente mexicanas, por temática e historias: estos públicos latinoamericanos se sentían más cercanos a esta cultura,

\footnotetext{
${ }^{20}$ Esta conferencia continental se realizó pocas semanas después del ataque japonés a Pearl Harbor. En la Conferencia de Río de Janeiro, Washington pretendía que los países latinoamericanos rompieran relaciones con el Eje y que se solidarizaran con Estados Unidos. La posición argentina pedía libertad de acción para los países latinoamericanos. Triunfó la posición argentina, algo que Washington no perdonó, efectuando desde ese momento diversas represalias contra el gobierno de Buenos Aires: discriminaciones comerciales - como el referido al bloqueo de la exportación de película virgen-, la obstrucción de fondos argentinos en Estados Unidos, el no reconocimiento de gobiernos, el retiro de embajadores, etcétera (Rapoport, 1995).
} 
costumbres y tradiciones (muchas, romantizadas) que con los filmes provenientes de Hollywood. Las películas mexicanas conformaban una cinematografía más "nuestra" para el público latino que las provenientes de Estados Unidos.

\section{Políticas públicas cinematográficas en México}

Esta tesis clasifica a las políticas públicas cinematográficas en México en dos etapas fundamentales: la fomentista, la del cine industrial-estatal, en la que el Estado estuvo presente - por períodos - en todos los eslabones de la cadena de valor (1942-1992), y la neofomentista (1992-actualidad), caracterizada por un Estado pasivo, gerenciador de recursos que son orientados por las fuerzas de mercado.

\section{Fomentismo cinematográfico en México}

Entre comienzos de la década de 1940, con la constitución del estatal Banco Cinematográfico - hito único en América Latina, siendo uno de los pocos casos en el mundo-, y hasta comienzos de la década de 1990 — con el proceso privatizador, aperturista y extranjerizante que golpeó al cine, como a otras actividades productivas-, el cine mexicano tuvo un Estado activo, creando empresas públicas tanto en la producción como en la distribución — tanto a nivel nacional como internacional一, en la exhibición y en distintas ramas de la comercialización — como en la venta de golosinas en las salas y en la realización de los afiches y las campañas publicitarias de los filmes. En esa etapa de cine industrial estatal, el Estado mexicano tenía un rol activo, creando empresas públicas de cine, produciendo filmes, distribuyéndolos, comercializándolos, expropiando empresas varias —como las principales cadenas de exhibición, en 1961o vinculándose como socio mayoritario - como en el Banco Cinematográfico o en Cimex-, interviniendo en el mercado para favorecer los estrenos y la circulación del cine nacional, tanto en el propio país como en el mundo. Durante décadas el cine mexicano fue ampliamente popular tanto en su país como en gran parte de América Latina y del mundo: el decidido apoyo estatal en la conformación de esta industria fue fundamental.

Los inicios del decidido fomento estatal mexicano a su cine pueden ubicarse en 1942, con la creación del Banco Cinematográfico, único existente en América Latina hasta la actualidad. 
Este banco se creó como sociedad anónima con participación estatal minoritaria (10\%), bajo la órbita del Banco Nacional de México, en reemplazo de la Financiera de Películas, constituida durante el gobierno de Lázaro Cárdenas (García Riera, 1999).

En 1947 el Banco Cinematográfico se estatizó completamente. La institución fue un pilar fundamental de la cinematografía mexicana tanto en lo que hacía a la producción, como también a la difusión, comercialización y exhibición del cine nacional, dentro y fuera del país. El Banco Cinematográfico se disolvería en 1979.

En 1947 también se creó otro hito en la historia del cine mexicano: los Estudios Churubusco.

Para esta época el Estado mexicano crearía distribuidoras estatales para comercializar filmes mexicanos. Para ello se dio nacimiento a Pelnal — distribuidora destinada a la comercialización en el territorio mexicano-, Pelmex —dedicada a distribuir filmes mexicanos en los países de Iberoamérica — y Cimex — abarcando el resto del mundo.

En diciembre de 1949 el Congreso sanciona la Ley de la Industria Cinematográfica, que regiría los destinos del sector hasta 1992.

Con estas medidas -especialmente, la creación del Banco Cinematográfico y la sanción de la ley de cine- el Estado buscaba no sólo incrementar la producción, sino también evitar los monopolios tanto en la producción como en la distribución y en la exhibición -en estos dos últimos eslabones de la cadena productiva se había generado un fuerte control del sector por parte de la Compañía Operadora de Teatros (más conocida por su sigla, Cotsa), creada en 1943 por un grupo de exhibidores que se fueron organizando en pequeñas cadenas locales y regionales hasta llegar a tener, en 1949, el $80 \%$ del mercado nacional; más de la mitad de Cotsa pertenecía al empresario estadounidense William Jenkins, un peculiar personaje que sería relevante en la época del "cine de oro" del cine mexicano, por métodos comerciales agresivos y non sanctos. En 1952 el Ejecutivo declaró a la industria cinematográfica "de interés público", a la vez que enviaba un proyecto para reformar la ley de cine, con el fin de redoblar esfuerzos en reducir el poder de los monopolios en la distribución y en la exhibición —el mencionado Jenkins no sólo poseía cerca del 80\% de las salas del país, sino que también tenía variadas denuncias en contra sobre la utilización en beneficio propio de recursos estatales provenientes tanto de mecanismos provenientes de la ley del cine como del Banco Nacional Cinematográfico (Contreras Torres, 1960; Heuer, 1964; Lay, 2005). 
A través de estas medidas, se promovían nuevas alianzas entre productores y distribuidores: así, los productores pasaron a constituirse en los accionistas mayoritarios de las distribuidoras estatales, lo que generó varios hechos de corrupción —en la práctica, los productores (a través de las distribuidoras estatales) pasaron a darse créditos a sí mismos (a sus productoras), principalmente, en concepto de adelantos de distribución (basados, en esencia, en los mercados internacionales en los que se iban a comercializar); hasta 1952 esos adelantos no superaban el 10\%, y luego de ese año pasaron a rondar entre el $60 \%$ y el $85 \%$ de los presupuestos de las películas a realizar (presupuestos que, generalmente, se confeccionaban con sumas superiores al costo real)- A su vez, los productores mantenían buenos contactos con la exhibición, es decir, con el estadounidense Jenkins (Heuer, 1964; Martínez, 1977; García Riera, 1999; Harvey, 2005).

A continuación, se detallarán las distintas instituciones y normativas que conformaron el Estado empresario mexicano bajo el fomentismo.

\section{Instituciones del Estado empresario cinematográfico}

\section{Banco Cinematográfico}

El 14 de abril de 1942 se crea el Banco Cinematográfico S.A., por iniciativa del Banco de México, para sustituir a la empresa Financiera de Películas S.A., entidad estatal creada bajo la anterior presidencia del general Lázaro Cárdenas, y que hacia 1942 formaba parte de la cartera del Banco de México. En estos comienzos, el Estado poseía 10\% del Banco Cinematográfico.

Esta entidad constituyó una experiencia única en América Latina: una fuente financiera de crédito exclusiva para la industria del cine.

Sin embargo, esta no sería una acción aislada del Estado mexicano en este sentido: entre 1925 y 1975 se crearon 18 bancos nacionales de desarrollo (Ayala Espino, 2001).

Ante un descenso de la actividad cinematográfica, producto de la recuperación de la presencia de Hollywood en México, a dos años de finalizada la Segunda Guerra Mundial, en 1947 el gobierno mexicano, bajo la presidencia de Miguel Alemán, adquirió la mayoría de las acciones del banco, que desde ese momento pasó a llamarse Banco Nacional Cinematográfico. 
Desde su creación (1942) hasta el control estatal (1947) este banco se concentraba en otorgar créditos para la producción de películas y las actividades relacionadas. Pero luego de este año también comenzó a financiar los otros eslabones de la cadena de valor: distribución, exhibición, difusión, exportación, importación y hasta capacitación. Inclusive, financiaba actividades relacionadas con la comercialización de películas extranjeras (Martínez, 1977).

Los efectos de la estatización del Banco Cinematográfico fueron inmediatas: en sólo tres años se pasó de producir 57 largometrajes a realizar 123 —cifra que recién se alcanzaría más de seis décadas después, en 2013.

La participación estatal que, mediante créditos blandos del nuevo banco, auspiciaba la creación de nuevas productoras y el financiamiento de producciones con menor riesgo - los filmes vendían territorios de exhibición por adelantado- generó una creciente especulación y casos de fraude (García Riera, 1999), pero alcanzó su objetivo principal: el incremento de la producción fílmica nacional, consolidando la "época de oro".

A lo largo de 37 años este banco estatal dedicado al cine fue vital en la consolidación de la que fue la mayor industria del cine en América Latina: casi el 90\% de las distintas actividades del cine mexicano fueron financiadas por el Banco Nacional Cinematográfico (Lay, 2005). Tal era su poder, que el Banco Cinematográfico llegó a ser accionista y a ocupar la presidencia de los consejos de administración de varias empresas — principalmente, productoras y distribuidoras. ${ }^{21}$

\section{Estudios Churubusco Azteca}

En 1945, en plena "época de oro" del cine mexicano, los Estudios Churubusco fueron creados por la familia Azcárraga — posteriores creadores, y dueños, de Televisa—, junto con la major de Hollywood, RKO. Pronto estos estudios llegarían a ser los principales de la industria cinematográfica mexicana, condición que conserva en la actualidad.

En 1950 Estudios Churubusco adquiere los Estudios y Laboratorios Azteca - también privados, creados en 1937-, con lo que la empresa pasaría a denominarse Estudios Churubusco Azteca.

En 1956 estos estudios emblemáticos del cine azteca fueron adquiridos por el Estado, más precisamente por el Banco Nacional Cinematográfico.

\footnotetext{
${ }^{21}$ Eduardo Martínez, La política cultural de México, Unesco, París, 1977, pág. 53.
} 
En 1979 los estudios quedaron bajo la órbita de la Dirección General de Radio, Televisión y Cinematografía de la Secretaría de Gobernación —una especie de Ministerio del Interior del Estado federal mexicano-, debido a que el gobierno del momento (López Portillo) extinguió el Banco Cinematográfico.

En 1983 se crea el Instituto Mexicano de Cinematografía (Imcine): los estudios Churubusco pasaron a formar de este nuevo organismo.

Finalmente, a fines de 1988 se crea el Consejo Nacional para la Cultura y las Artes (Conaculta), en una reestructuración total en el organigrama estatal relativo al área cultural: desde esa fecha y hasta la actualidad, los estudios pasan a formar parte de este virtual ministerio de cultura —así como también lo hicieron los distintos organismos vinculados con el arte y la cultura mexicanos.

Durante más de 70 años de vida, la mayor parte de los filmes mexicanos producidos desde entonces -incluyendo producciones internacionales, como Titanic - han sido rodados o posproducidos en las instalaciones de los Estudios Churubusco.

\section{Ley de la Industria Cinematográfica (1949-1992)}

El 13 de diciembre de 1949 se sancionó la ley de cine — se reglamentaría dos años más tarde, en 1951-, constituyéndose en la primera normativa latinoamericana de este tipo. Esta ley regularía la industria cinematográfica mexicana hasta 1992 —cuando, por presión estadounidense, a partir de la próxima firma del Tratado de Libre Comercio de América del Norte (TLCAN), se darían de baja distintos apoyos estatales a varias industrias (entre ellas, el cine).

Con la Ley de la Industria Cinematográfica de 1949 el Estado comenzó a tener mayor incidencia en este sector, lo que sería vital para explicar el cine mexicano de allí en más. Un aspecto fundamental de esta normativa era la cuota de pantalla anual, que establecía la obligatoriedad de exhibición de filmes nacionales en no menos del 50\% del tiempo total anual de proyección de todas las salas del país.

A su vez, la ley de cine creó la Dirección General de Cinematografía, que se encontraba bajo la órbita de la Secretaría de Gobernación — una especie de Ministerio del Interior en México.

En agosto de 1951 se reglamentó la ley de cine: allí se establecía que los exhibidores no podían tener intereses económicos en las empresas de producción y distribución, y viceversa -aunque este impedimento se fue haciendo más laxo: con las distribuidoras estatales y la posterior estatización de las principales cadenas exhibidoras, los intereses 
de los distintos sectores se fueron mezclando, produciendo anomalías, resultando en varios casos de tráfico de influencias y corrupción (Contrera Torres, 1960; Heuer, 1964; García Riera, 1999).

\section{Comercialización cinematográfica estatal}

En esta época de oro del cine mexicano las distribuidoras estatales jugaron un papel muy importante. Estas empresas fueron creadas con participación del Banco Nacional Cinematográfico, y a lo largo de su existencia dependieron ampliamente de esta institución bancaria.

Las distribuidoras estatales eran: Películas Nacionales (Pelnal), Películas Mexicanas (Pelmex) y Cinematográfica Mexicana (Cimex).

Pelnal, que comercializaba los filmes mexicanos dentro de su país, fue fundada en 1947 como empresa privada por productores cinematográficos que buscaban evitar seguir siendo explotados por el sector de la exhibición, monopolizado por el estadounidense Jenkins, dueño de las dos cadenas más importantes: Cadena de Oro y Cotsa. Pocos años después el Banco Cinematográfico se convirtió en socio de Películas Nacionales, que se convierte en empresa mixta. Hacia 1967 el 90\% de los productores cinematográficos mexicanos estaban relacionados con Pelnal (Gómezjara, 1973).

Películas Mexicanas (Pelmex), fundada en 1945, fue vital en la internacionalización del cine mexicano y en los públicos masivos que formó en varios países latinoamericanos (como Venezuela, Colombia o Perú). Desde 1955 comenzó a operar también en España y Portugal.

Por su parte, Cinematográfica Mexicana (Cimex) fue fundada en 1947. Su operatoria abarcó los restantes territorios del mundo —en un comienzo fue sólo Estados Unidos, pero luego se extendió a Europa- Cimex trabajó siempre con capital del Banco Cinematográfico —a diferencia de Pelmex y Pelnal, que no tenían capital propio (Pelmex trabajó adeudándole cifras millonarias al Banco Cinematográfico, y Pelnal estaba constituida en un $97 \%$ por capitales privados y en un $3 \%$ por dinero del Banco Cinematográfico) (Heuer, 1964).

En 1961 el Estado mexicano compró las salas de las principales exhibidoras de ese momento: Operadora de Teatros (Cotsa) y Cadena de Oro -entre ambas conformaban un duopolio en el mercado exhibidor mexicano-. El gobierno federal también adquirió la distribuidora Continental de Películas — que pasó a ser filial de Cotsa-. En 1968, las 
acciones de las exhibidoras Cotsa y Cadena de Oro fueron transferidas del Banco Nacional Hipotecario de Servicios al Banco Nacional Cinematográfico.

De esta manera, el Estado poseía una presencia importante en los eslabones fundamentales de la cadena de valor: la producción, la distribución y la exhibición.

En 1968 el Estado federal mexicano creó otra nueva empresa relacionada con el audiovisual: Procinemex, destinada a la promoción de los filmes mexicanos en todo el mundo.

\section{Echeverría y el segundo esplendor de la industria cinematográfica (1970-1976)}

En 1970 asume la presidencia Luis Echeverría, quien había sido el secretario de Gobernación (ministro del Interior) durante el gobierno anterior de Díaz Ordaz ${ }^{22}$, y responsable por la matanza de Tlatelolco, de octubre de 1968.

El hermano del presidente, Rodolfo Echeverría, estaba ligado a la industria del cine desde hacía años. En 1970, Rodolfo Echeverría era el presidente del Banco Nacional Cinematográfico.

Durante la presidencia de Echeverría, el Estado mexicano afianzó la presencia en todas las áreas de la industria del cine, produciéndose - a decir del estudioso Emilio García Riera (1999) - el único caso en el mundo de una virtual estatización del cine nacional (producción, distribución, exhibición, comercialización, difusión) en un país no comunista. Sin embargo, las empresas privadas siguieron haciendo negocios, cada vez más lucrativos — con la mayor parte de los riesgos asumidos por el Estado, y con la liberación del precio de las entradas de cine (hasta entonces habían estado congeladas, dentro de la canasta básica, cuyos precios se encontraban regulados por el Estado)-. Sin embargo, el gobierno intentó controlar con mayor ahínco el acceso a los créditos, para que no se generaran los "autocréditos" y el relajamiento de la actividad, como había ocurrido durante la década de 1960.

Es en este período cuando se crea la Corporación Nacional Cinematográfica (Conacine), en 1975, y la Corporación Nacional Cinematográfica de Trabajadores y Estado (Conacite) $\mathrm{I}^{23}$ y II —ambas fundadas en 1976-: el control de la mayor parte de las operaciones de estas productoras estaba bajo la órbita del Banco Nacional Cinematográfico —institución que en 1975 también compró los Estudios América.

\footnotetext{
${ }^{22}$ Según el libro de Philip Agee, CIA Diary: Inside the Company (Penguin, Londres, 1975), tanto Echeverría (pág. 452) como Díaz Ordaz (pág. 428) fueron informantes de la CIA.

${ }^{23}$ Conacite I fue absorbida por Conacine en 1977.
} 
Cabe agregar que en el control de Conacite I y Conacite II también participaban los poderosos sindicatos de trabajadores de cine -mediante el aporte de dinero en producciones fílmicas, con derecho a posteriores utilidades provenientes de la comercialización.

En este período el Estado mexicano también adquirió la distribuidora Pelimex —dedicada a la comercialización de películas nacionales en el extranjero.

En 1975, a partir de recursos aportados por la exhibidora estatal Cotsa -canalizados por un fideicomiso del Banco Nacional Cinematográfico-, se crea el Centro de Capacitación Cinematográfica (CCC), la escuela estatal de cine de México $^{24}$, cuya actividad perdura hasta la actualidad — bajo la órbita de Conaculta—, siendo la principal escuela de cine de América Latina.

Durante el fuerte fomento estatal al cine operado bajo la presidencia de Echeverría, numerosos cineastas - sobre todo, jóvenes- incursionaron en el séptimo arte, directores luego serían renombradas figuras en toda Iberoamérica, como Arturo Ripstein, Jaime Humberto Hermosillo y José Estrada.

En esta época se volvieron a realizar películas de calidad, e inclusive, filmes y documentales con temática social y política - a pesar de la censura que imperaba por esos tiempos-, que ganaron premios en distintos festivales internacionales.

Durante estos años el Banco Cinematográfico había llegado al clímax de su actividad. Como comenta Martínez:

(...) el Banco ha llegado a ser prácticamente la corporación que rige la economía de las empresas cinematográficas, interviniendo como accionista en varias de ellas, u ocupando la presidencia de los consejos de las distribuidoras y estudios y otorgando casi el 90\% de los créditos con los que se ha financiado la cinematografía nacional entre 1970-1976, el Banco financió la producción de 318 -45 películas por año en promedio-, con créditos que ascendieron a 636 millones de pesos (de los que se habían recuperado 401 millones al final de ese lapso). (1977:53)

\footnotetext{
${ }^{24}$ En 1963 se había creado el Centro Universitario de Estudios Cinematográficos (Cuec) en el marco de la Universidad Autónoma de México (Unam). El Cuec continúa su actividad hasta la actualidad, siendo una de las escuelas de cine más importantes de América Latina.
} 
Vale también recuperar las palabras expresadas en 1976 por Rodolfo Echeverría, presidente del Banco Cinematográfico, hermano del presidente de la República, como fresco de cómo la elite dirigente del país de ese momento justificaba su presencia en la industria cinematográfica:

El ausentismo de la producción privada, el deterioro de las instalaciones de los estudios, la reiteración de la temática, la baja calidad de material por la excesiva economía en la filmación y una política de puertas cerradas a las jóvenes generaciones de cineastas eran, entre otras muchas, algunas de las razones del estado crítico de la producción. Ante esto había que desarrollar un plan estructural. (Echeverría, en Getino, 1998a:141)

\section{López Portillo y el comienzo del fin del Estado empresario}

Sin embargo, con la nueva administración del presidente López Portillo (1976-1982) el fomento estatal al cine en México sufrió un duro revés, no sólo con respecto a la administración anterior, sino en lo que hace a décadas de políticas en este sentido: en 1977, se liquidó la productora estatal Conacite I, y en 1979 — tras varios intentos realizados a lo largo de 1978- se liquida el Banco Nacional Cinematográfico.

A su vez, el gobierno creó un nuevo organismo: la Dirección de Radio, Televisión y Cinematografía (RTC), que fue encabezada por la hermana del presidente, Margarita López Portillo —quien no tenía ninguna experiencia en el sector.

Esta funcionaria decía que había que volver a la "época de oro" y a realizar películas de calidad, para lo cual contrató a directores extranjeros mediante contratos ruinosos para el país, que no repercutieron ni en grandes películas ni en éxitos de público.

A su vez, luego de años de fuerte intervencionismo estatal, el sector privado fue generando una mayor participación en la industria cinematográfica, aunque con películas sin vuelo artístico, realizadas rápidamente y con bajo presupuesto.

Como símbolo de este período, en marzo de 1982 se incendia la Cineteca Nacional, perdiéndose para siempre gran parte del acervo de la cinematografía mexicana, incluyendo, películas invaluables de la "época de oro". 


\section{La década de 1980: prolegómenos del desmantelamiento}

Durante toda la década de 1980 la industria cinematográfica estuvo en franca decadencia, tanto en lo que hace el fomento estatal como a la actividad privada: si en 1981 el presupuesto gubernamental para el sector había sido de 325 millones de pesos mexicanos — 9,5 millones de dólares de ese año-, en 1983 la cifra se había reducido a cero.

Al tiempo que el sector privado se dedicó a realizar comedias livianas y "sexicomedias", también surgieron jóvenes cineastas, debutantes, que -mediante cooperativas, con mucho esfuerzo y nulo apoyo estatal- buscaron abrirse camino en el séptimo arte local, aunque la gran mayoría de las veces, sin éxito.

Bajo la administración del presidente Miguel de la Madrid (1982-1988) se reestructuró el sistema gubernamental relacionado con el cine: ${ }^{25}$ en 1983 se crea el Instituto Mexicano de Cinematografía (Imcine) — que perdura hasta la actualidad-, primeramente bajo la órbita de RTC —Secretaría de Gobernación (ministerio del Interior)_, y a partir de 1988, dependiente de la recién creada Conaculta — virtual ministerio de Cultura, enmarcado en la Secretaría de Educación.

\section{Instituto Mexicano de Cinematografía (1983-1989)}

El Imcine fue creado con el objetivo de constituir un organismo que aglutine y organice todas las entidades paraestatales vinculadas con el cine, imbuido con los atributos de un organismo descentralizado con personería jurídica y patrimonio propio.

Las principales funciones asignadas al Imcine en sus comienzos eran promover los distintos eslabones de la industria cinematográfica (producción, distribución, exhibición), así como la capacitación y la formación, coordinando las distintas entidades estatales abocadas a ello; también realizar convenios de coproducción y cooperación con los distintos organismos nacionales y multilaterales.

Las distintas empresas estatales existentes al momento de creación del Imcine, y que esta agencia debía coordinar, eran numerosas:

\footnotetext{
${ }^{25}$ A pesar de que en esta reestructuración también se crearon los institutos nacionales de televisión (Imevisión) y de radio (Imer), no se extinguió la RTC, produciéndose variadas y engorrosas superposiciones burocráticas (Ugalde, 2009:28-29).
} 
- en lo relativo a la producción: Conacine, Conacite I, Conacite II, Centro de Producción de Cortometraje; servicios de producción: Estudios ChurubuscoAzteca y Estudios América;

- distribución: Pelmex y Continental de Películas;

- exhibición: Cotsa;

- promoción y publicidad: Promotora Cinematográfica Mexicana y Publicidad Cuauhtémoc, y

- formación: Centro de Capacitación Cinematográfica (CCC).

En sus primeros tiempos, la dirección del Imcine estaba organizada en torno a un director general designado por el presidente de la República, además de una Junta Directiva presidida por el secretario de Gobernación y conformada por los representantes de nueve ministerios, más el director de Comunicación Social de la Presidencia de la República, el rector de la Universidad Nacional Autónoma de México (Unam), el director general del Instituto Politécnico Nacional y el director general de Radio, Televisión y Cinematografía (RTC) de la Secretaría de Gobernación —éste último actuaba como secretario técnico de la Junta-. A su vez, había un Consejo Consultivo integrado por referentes de la comunicación.

A pesar de la cantidad de objetivos importantes que recayeron sobre el Imcine, lo cierto es que en los primeros años el organismo no tenía un peso relevante en el sector cinematográfico, ni tampoco contaba con mucho apoyo gubernamental (Isaac, 2009:33). En este sentido, la primera acción importante llevada a cabo por el Imcine fue organizar, en 1984, el III Concurso de Cine Experimental, gracias al cual muchos cineastas nóveles pudieron comenzar a insertarse en la industria, a pesar de la histórica cerrazón de los poderosos sindicatos de trabajadores de cine, que continuaban poniendo muchas trabas para el ingreso de nuevos directores al sector.

\section{Políticas cinematográficas neofomentistas}

A partir de comienzos de la década de 1990 la situación cambió radicalmente, comenzando la etapa neoliberal-neofomentista que perdura hasta la actualidad.

Luego del desmantelamiento de las ayudas estatales al cine en México - como ocurrió con otras áreas de la cultura y la comunicación-, especialmente a partir de las negociaciones por el Tratado de Libre Comercio de América del Norte —que entró en vigencia el 1 de enero de 1994-, el rol del Estado pasó a ser pasivo, mero gerenciador 
de los recursos públicos orientados básicamente por el mercado, de acuerdo a los nuevos instrumentos de apoyo al cine que se implementaron a partir de 1997.

En efecto, hacia finales de 1997, luego de la movilización del sector —a partir de la aprobación de la nueva ley de cine de 1992, que sustituía a la de 1949, y abolía el fuerte apoyo estatal al cine-, el gobierno mexicano creó un fideicomiso para apoyar películas "artísticas" (Foprocine). Al año siguiente, la ley de cine tuvo variadas modificaciones, tanto por la presión del sector como por cambio en la relación de fuerzas políticas — por primera vez en décadas, el gobernante Partido Revolucionario Institucional (PRI) perdía la mayoría en el Congreso-, que alumbraron un nuevo fideicomiso (Fidecine), esta vez destinado a la producción "industrial" - la que apuntaba a un público masivo-, y exenciones fiscales — siendo la principal el Eficine.

Sin embargo, todas estas ayudas estimulan a que los cineastas y productores deban acudir a entidades para-estatales ${ }^{26} \mathrm{y}$, principalmente, a grandes empresas privadas para obtener su apoyo - beneficiándose éstas de un menor pago al impuesto a las ganancias-, por lo que los proyectos deben "maquillarse" y restringir lo máximo posible todo posicionamiento crítico, adecuándose a la visión del statu quo.

\section{Neoliberalismo y Tratado de Libre Comercio de América del Norte}

En la década de 1990, tal como sucedió en toda América Latina, las políticas neoliberales — privatizaciones, apertura económica, baja de la participación del Estado en la actividad productiva, desregulación, extranjerización (bajo el impulso del "Consenso de Washington")— pasaron a dominar la escena mexicana. La presidencia de Salinas de Gortari (1988-1994) se caracterizó principalmente por la aplicación de estas políticas, cuyo clímax se alcanzó con la firma del Tratado de Libre Comercio de América del Norte (TLCAN) entre México, Estados Unidos y Canadá.

Las promesas en torno a este acuerdo se centraban en el incremento de las exportaciones, en el aumento del empleo y en la elevación del poder adquisitivo, entre otras.

Para poder firmar el TLCAN el partido gobernante desde hacía décadas -el Partido Revolucionario Institucional (PRI) - , con mayoría absoluta en el parlamento —-también desde hacía varios decenios-, reformó un gran número de importantes leyes y decretos

\footnotetext{
${ }^{26}$ Comités técnicos compuestos por autoridades del instituto de cine, pero también de sindicatos, del Banco de Desarrollo, y del Ministerio de Cultura y de Economía.
} 
—sin consulta alguna con los sectores involucrados-, entre ellos, los relacionados con la cultura y el cine.

Al negociar el TLCAN Canadá hizo uso de la excepción cultural con el fin de proteger las políticas públicas de fomento a la cultura. México no lo hizo, sino que decidió incluir a la cultura como un producto comercial más, con el argumento de que "nos respalda la fortaleza de más de 30 siglos de cultura”, tal como afirmó uno de los principales negociadores, Jaime Serra Puche —en ese momento, secretario de Comercio de México- Vale resaltar que en las negociaciones no hubo ninguna participación de Conaculta (el ministerio de Cultura mexicano).

En este contexto, y refiriéndonos específicamente al cine, entre 1990 y 1993 el Estado mexicano liquidó y disolvió las distintas empresas estatales de cine, destacándose los casos de las productoras Conacine y Conacite II, los Estudios América, las distribuidoras Pelimex ${ }^{27}$ y Continental, la exhibidora Cotsa, la empresa estatal de venta de golosinas Dulcerías de Oro y la empresa estatal de publicidad cinematográfica —en el ámbito televisivo, se privatizaron los canales 7 y 13, que dieron nacimiento al gigante Televisión Azteca- Los estudios Churubusco-Azteca permanecieron en manos del Estado, así como la Cineteca y el Centro de Capacitación Cinematográfica (CCC).

En 1992 se produce la reforma de la ley de cine, vigente desde 1949 - la aprobación de manera urgente de esta reforma le demandó al Senado sólo 20 minutos... (Lay, 2005); Diputados le dio fuerza de ley una semana después, sin mayores trámites-. La nueva normativa desmanteló la cuota de pantalla, que fuera tan importante en la época de oro del cine mexicano.

En efecto, la ley de cine de 1949 disponía una cuota de pantalla del 50\% para producciones nacionales, mientras que en la nueva ley de cine de 1992 el porcentaje comenzó a reducirse de manera gradual para llegar en 1997 al 10\% del tiempo de exhibición destinado a los filmes mexicanos.

De esta manera, muchos inversores que apostaban al cine —en el sentido comercial más estricto- lo hacían, hasta la década de 1980, con cierta seguridad de que la película en que habían invertido se proyectaría. Con la reducción del tiempo de la cuota de pantalla, las inversiones prácticamente desaparecieron, con un notable descenso en la cantidad de producciones nacionales para esa época.

\footnotetext{
27 Para esta época, la distribuidora mixta (estatal-privada) Películas Mexicanas (Pelmex) estaba constituida por mayoría de capital privado. En 1992 el gobierno la dejó entrar en bancarrota. Durante décadas, Pelmex había sido la principal distribuidora de cine mexicano en el ámbito iberoamericano.
} 
Si bien en la actualidad existe formalmente cuota de pantalla en México, en la práctica casi no se aplica. El párrafo segundo del artículo 19 de la Ley Federal de Cinematografía establece que "toda película nacional se estrenará en salas por un período no inferior a una semana, dentro de los seis meses siguientes a la fecha en que sea inscrita en el Registro Público Correspondiente, siempre que esté disponible en los términos que establezca el Reglamento". La Cineteca Nacional asegura la exhibición de toda cinta mexicana dentro de los seis meses que establece la legislación en la materia. Así, cumplida esta disposición formal, los directores y productores pueden esperar años hasta ver estrenado comercialmente su filme.

Por otra parte, la nueva ley de 1992 también liberó el precio del boleto de cine: los precios se dispararon por encima de la inflación, y se volvieron crecientemente onerosos para la mayoría de la población, lo que repercutió inmediatamente en una baja en la cantidad de espectadores a las salas cinematográficas mexicanas — con la mayoría de la población que venía de sufrir la crisis de la deuda, que generó la "década perdida" en los años ochenta, sumado a la fuerte devaluación aplicada en 1994-: se pasó de 450 millones de espectadores en 1985 a 195 millones en 1990 y a 62 millones en 1995 (CACI, 1997).

Todos estos cambios drásticos en el sector del Estado dedicado al fomento cinematográfico se enmarcaban en los acomodamientos que imponía la firma del TLCAN, que se produjo el 1 de enero de 1994 -que entró en vigencia el 1 de enero de 1994 (la misma fecha en que el Ejército Zapatista se lanzó a la lucha).

El sector cinematográfico mexicano colapsó —-de manera similar a lo que ocurrió en otros países de la región para la misma época, como Argentina y Brasil—: en 1997 se produjeron en México tan sólo nueve largometrajes —la cifra más baja desde 1932-. Por otra parte, también cayeron la cantidad de salas y de espectadores -especialmente, los de las películas locales.

Las distintas entidades y trabajadores del sector, además de numerosos intelectuales y ciudadanía en general, se movilizaron para reformar esta ley, lo que se logró en 1998, obteniéndose como principal logro la constitución del fideicomiso Fondo de Inversión y Estímulos al Cine (Fidecine) —este fondo se creó a manera de "trueque" con el sector, que propugnaba un impuesto del 5\% a las entradas de cine para conformar un fondo de fomento dedicado a filmes con una orientación más "industrial”-; el Fidecine comenzó a regir en 2001 -en 1997, se había creado el Fondo para la Producción Cinematográfica de Calidad (Foprocine), destinado a películas de "calidad". 
En 2006 el Estado mexicano sumaría otra herramienta de fomento al cine: el Estímulo Fiscal a Proyectos de Inversión en la Producción y Distribución Cinematográfica Nacional (Eficine), una típica medida de exención fiscal, tal como las que operan en Brasil, Chile y Colombia, entre otros países.

\section{Estructura actual del gobierno federal en materia cinematográfica}

En la actualidad, el fomento estatal al cine en México se centra en las funciones y competencias repartidas entre los organismos dependientes de la Secretaría de Educación - Conaculta (virtual ministro de Cultura) es su institución principal, en lo que referido al cine- y de la Secretaría de Gobernación (Ministerio del Interior mexicano), a través de la Dirección General de Radio, Televisión y Cinematografía (RTC).

Aunque con la reforma de 1988 la Secretaría de Educación —a través de Conacultapasó a marcar el rumbo de la política cinematográfica mexicana, la Secretaría de Gobernación ${ }^{28}$ continuó teniendo atribuciones importantes en el terreno del cine -a través de la Dirección General de Radio, Televisión y Cinematografía (RTC)—, tales como la autorización de lo que respecta a la distribución, exhibición y comercialización de películas en todo el territorio mexicano - tanto en salas como en salas de video o cualquier soporte-, la clasificación de los filmes - tanto nacionales como extranjeros-, la expedición de los certificados de origen para las películas — tanto en lo que hace a la comercialización como a la producción y coproducción con otros paísesy la autorización de doblaje.

\section{Instituto Mexicano de Cinematografía (1989-presente)}

A finales de diciembre de 1988 el gobierno mexicano realizó una profunda transformación de la estructura institucional dedicada a la cultura, con el centro puesto en la Secretaría de Educación Pública —el equivalente a un ministerio de Educación en ese país.

Por esos días se creó el Consejo Nacional para la Cultura y las Artes —en un comienzo abreviado como CNCA, mas luego conocido como Conaculta.

\footnotetext{
${ }^{28}$ Hasta 1988 la Secretaría de Gobernación había monopolizado el accionar del Estado en materia de cine —así había sido desde los tiempos de la "época de oro".
} 
Conaculta continúa siendo un órgano autárquico, con el objetivo principal de coordinar un accionar común entre las distintas entidades relacionadas con la cultura y las artes, incluyendo los medios de comunicación.

Así, el instituto de cine (Imcine) dejó de estar bajo la órbita de la Secretaría de Gobernación (Interior) para pasar al área de Educación. En este cambio, la Junta Directiva pasó a estar presidida por el presidente de Conaculta, y se redujeron los representantes ministeriales —ahora sólo estarían los de Hacienda, Programación y Presupuesto y Comunicaciones-, además de la Dirección General de Comunicación Social de la Presidencia de la República.

A su vez, pasó a estar bajo la órbita del Imcine el Fondo de Fomento a la Calidad Cinematográfica - había sido creado en 1986 con aportes de los exhibidores: a cambio de que el sector cinematográfico avalara un aumento en las entradas (controladas por el gobierno durante años), se constituyó este fondo-: eran créditos blandos, virtualmente a fondo perdido — se pedía la devolución de los mismos sólo si la película obtenía ganancias-, apuntando a producciones de calidad. Más de cincuenta largometrajes recibieron recursos financieros de este fondo, tales como La mujer de Benjamín (1991), Como agua para chocolate (1991) y El callejón de los milagros (1994), lo que permitió a varios cineastas y técnicos ingresar en el sector cinematográfico - generalmente, egresados de las escuelas de cine.

También comenzaron a operar bajo la dirección del Imcine la Academia Mexicana de Artes y Ciencias Cinematográficas y la Cineteca Nacional —creada en 1974 (hasta 1989 también pertenecía a la Secretaría de Gobernación). ${ }^{29}$

En la actualidad, el Imcine controla los principales recursos con que se fomenta al cine mexicano: los fideicomisos del Fondo para la Producción Cinematográfica de Calidad (Foprocine) y del Fondo de Inversión y Estímulos al Cine (Fidecine), más la norma que estimula la inversión privada en producciones de cine a través de exenciones fiscales -Estímulo Fiscal a Proyectos de Inversión en la Producción y Distribución Cinematográfica Nacional (Eficine).

En enero de 2003 el Congreso mexicano aprobó un impuesto de un peso mexicano por cada boleto de cine destinado a engrosar los fondos de fomento manejados por el Imcine: la normativa fue cancelada menos de un año después, a partir de la férrea oposición del sector de la distribución y la exhibición —donde son predominantes las

\footnotetext{
${ }^{29}$ Aunque en el caso de la Cinemateca Nacional, su paso a la órbita del Imcine se hizo efectiva recién en 1997.
} 
majors estadounidenses (la diplomacia estadounidense también formó parte del lobby en contra de esta disposición).

En 2005 el gobierno del presidente Fox quiso eliminar el Imcine. Pero la decidida movilización del sector — tanto cinematográfico, como cultural en general- logró impedir el cierre.

\section{Cineteca Nacional}

Esta institución señera y a la vanguardia en el ámbito latinoamericano en lo que hace a la conservación y cuidado del acervo cinematográfico fue inaugurada en 1974, y hasta 1997 estuvo bajo la órbita de la Secretaría de Gobernación, pasando en ese año a la Secretaría de Educación —en 1984 la Cineteca había sido declarada de utilidad pública. La normativa vigente establece que todos los productores y distribuidores - nacionales y extranjeros- deben aportar a la Cineteca una copia de las películas que realicen o comercialicen.

\section{Instituto Nacional del Derecho de Autor}

La legislación mexicana establece numerosas disposiciones referidas a los derechos intelectuales y patrimoniales de los autores de la obra cinematográfica.

En México existe un Instituto Nacional del Derecho de Autor, órgano de aplicación de la Ley Federal de Derecho de Autor. La legislación vigente sobre cinematografía establece que este instituto debe llevar el registro de las obras cinematográficas, promover la cooperación internacional con instituciones afines, poner en práctica medidas tendientes a prevenir y combatir la violaciones del derecho de autor en lo que hace a las obras cinematográficas, y aplicar las tarifas vigentes por el pago de regalías obtenidas a partir de la explotación de obras cinematográficas.

En junio de 2010 la Corte Suprema de Justicia estableció que Televisa debe pagarle regalías a los directores mexicanos de cine cada vez que emita sus películas - de la misma manera en que lo hacía la Sociedad de Autores y Compositores de Música, a la Sociedad General de Escritores de México, a la Asociación Nacional de Intérpretes y a las distintas sociedades de ejecutantes de música.

Desde noviembre de 2010 el multimedios mexicano tuvo que hacer efectiva esta disposición, a la cual venía oponiéndose desde hacía tiempo. El fallo fue inapelable, inmodificable y retroactivo para todas las películas que hayan sido emitidas por los 
canales de Televisa desde julio de 2003, por lo que debió pagarle un $6 \%$ anual punitorio a los cineastas cuyas películas hayan sido exhibidas por Televisa desde esa fecha.

\section{Mecanismos vigentes de fomento al cine mexicano}

La normativa de fomento al cine mexicano en la actualidad se basa en los mencionados fideicomisos -Foprocine (destinado al cine de "calidad") y Fidecine (destinado al cine “industrial”) - y del mecanismo de exención fiscal Eficine. ${ }^{30}$

Estas ayudas se centran en la producción de largometrajes —de ficción, documentales y de animación (preproducción, producción y posproducción)—, aunque también hay apoyos para la distribución, comercialización, exhibición y para la realización de cortometrajes.

Se lanzan convocatorias y premios tanto para la escritura de guiones como para el desarrollo de proyectos o la realización de talleres. También se apoya la realización de ciclos, muestras y festivales de cine, así como también la presencia de filmes mexicanos en festivales -nacionales e internacionales - como de realizadores y productores, principalmente en espacios internacionales - mercados de cine, clínicas de guión, desarrollo de proyectos, etcétera.

\section{Fondo para la Producción Cinematográfica de Calidad (Foprocine)}

El Fondo para la Producción Cinematográfica de Calidad (Foprocine) comenzó a regir en diciembre de 1997: en medio de los reclamos del sector, luego de que el Estado mexicano desguazara el apoyo público al cine nacional que estuvo vigente durante décadas, y de que el séptimo arte nacional entrara en crisis como consecuencia directa de este retiro estatal, la administración del presidente Zedillo creó el Foprocine, un fideicomiso destinado a apoyar los filmes de "calidad", experimentales o documentales, mediante un financiamiento compartido entre los sectores público y privado a través de

\footnotetext{
${ }^{30}$ Hacia 2010, Conaculta, el virtual ministerio de Cultura mexicano, comenzó a otorgar de manera discrecional ayudas económicas a fondo perdido a algunas películas bajo una figura denominada "Conaculta Cine". Esta no es una línea institucionalizada ni figura en ninguna normativa — no realiza convocatorias ni rinde cuentas—, razón por la cual fue denunciada por los distintos gremios de directores, productores y demás integrantes del sector cinematográfico. Por ejemplo, se denunció que la película "Morelos" recibió de manera discrecional unos seis millones de dólares —cifra que supera todos los recursos destinados a apoyar filmes de autor y experimentales por parte del Foprocine, y excede el límite de 850 mil dólares de ayuda que puede recibir un filme mediante el Foprocine y del Fidecine, y de 1,7 millón de dólares a través del Eficine- También se denunciaron apoyos similares a las películas "Cinco de Mayo" y "Colosio".
} 
un modelo de asociación en participación, cuya aplicación se encuentra bajo la responsabilidad del Imcine, hasta nuestros días.

El Foprocine opera bajo la coordinación de un Comité Técnico conformado por cinco miembros designados por el Imcine, la Secretaría de Hacienda, la Secretaría de Educación y Nacional Financiera —que funge como el banco estatal de desarrollo de México- El presidente de este comité es el presidente de Conaculta, mientras que el secretario ejecutivo es el director del Imcine.

A su vez, el Comité Técnico tiene una Comisión Consultiva, integrada por profesionales con trayectoria en el sector, evaluando y opinando sobre los méritos de los proyectos presentados para buscar el apoyo del Foprocine - los funcionarios del Imcine no tienen participación en este comité.

Los apoyos del Foprocine se centran en capital de riesgo - tanto a través de contratos de coproducción como de compra anticipada de derechos-, créditos y garantías. Cada proyecto puede recibir hasta dos apoyos en cada convocatoria, aunque en total la ayuda no puede superar el $80 \%$ del costo del proyecto -o un millón de dólares en total一. A su vez, no puede ser beneficiario de ningún apoyo del Foprocine si quien se presenta tiene algún incumplimiento con apoyos que haya recibido del Fidecine o del Imcine.

Los recursos financieros del Foprocine se nutren de los aportes del fideicomitente (el Imcine), de los aportes que realice cualquier persona (física o jurídica), por los rendimientos y recuperación de los créditos otorgados anteriormente (comisiones, intereses, derechos de autor, etc.). Los fondos del Foprocine son administrados por la fiduciaria: la Nacional Financiera (banco de desarrollo).

El Foprocine comenzó a operar a finales de 1997 con unos 17,5 millones de dólares aportados por el Estado. Hasta 2012 este fondo ayudó a la concreción de 234 películas nacionales.

\section{Fondo de Inversión y Estímulos al Cine (Fidecine)}

El Fondo de Inversión y Estímulos al Cine (Fidecine) fue creado a partir de la reforma de la ley de cine de 1998.

El Fidecine es un fideicomiso que el gobierno federal estableció formalmente en agosto de 2001, a través de la Secretaría de Hacienda — la reglamentación también se produjo este año-, con una aportación inicial de unos 7,5 millones de dólares.

El principal objetivo del Fidecine - que realiza dos convocatorias por año- es apoyar a los filmes de porte más "industrial" — a diferencia del Foprocine, que contempla la 
ayuda a películas de "calidad"-, tanto en lo que hace a la producción, distribución y exhibición, mediante apoyos financieros, de garantía e inversión. Sin embargo, el grueso de los apoyos se centra en la producción (Imcine, 2011).

Los recursos del Fidecine se destinan, preferentemente, a otorgar capital de riesgo, créditos, garantías, capital de trabajo y distintos estímulos económicos.

La ayuda que reciba cualquier persona física o jurídica no puede exceder el $49 \%$ del costo del proyecto - porcentaje que alcanza el $80 \%$ en el caso de que el beneficiario reciba ayuda tanto del Fidecine como del estímulo fiscal (Eficine)-, no pudiendo superar, a su vez, el 10\% del patrimonio del Fidecine.

El Fidecine se constituye con ingresos provenientes del gobierno federal —la aportación inicial fue hecha por éste-, los recursos anuales que se incluyen en el presupuesto general de la República, los aportes que provengan de los sectores público y privado, las donaciones -deducibles de impuestos - que realicen personas físicas o jurídicas, los rendimientos - utilidades, derechos, etc.- que se hayan generado en las películas que este fideicomiso haya apoyado y las sanciones que se realicen por incumplimientos al reglamento del Fidecine.

\section{Constitución del Fondo de Inversión y Estímulos al Cine (Fidecine)}

El único fideicomitente del Fidecine es la Secretaría de Hacienda, mientras que la fiduciaria es la Nacional Financiera (banco de desarrollo mexicano) —esta entidad financiera estatal también es la fiduciaria del Foprocine.

Los fideicomisarios son los productores, distribuidores, comercializadores y exhibidores de filmes nacionales.

El Fidecine posee un Comité Técnico que está integrado por representantes de la Secretaría de Hacienda, del Imcine, de la Academia Mexicana de Ciencias y Artes Cinematográficas, del histórico Sindicato de Trabajadores de la Producción Cinematográfica de la República Mexicana (STPC), además de representantes de asociaciones de productores, distribuidores y los exhibidores.

El Comité Técnico es la máxima autoridad del Fidecine, y es el encargado de aprobar todas las operaciones, incluyendo la autorización de los proyectos que habrán de apoyar, el otorgamiento de recursos a esos proyectos y la aprobación del presupuesto anual.

Entre 2001 y 2012 el Fidecine — que tuvo un aporte inicial de 7,2 millones de dólaresapoyó la producción de 154 largometrajes mexicanos. 


\section{Estímulo fiscal del Cine (Eficine)}

A través de esta herramienta las empresas pueden destinar el 10\% del pago del Impuesto sobre la Renta a la producción cinematográfica mexicana, tanto de ficción, documental o animación.

El artículo 226 (189 desde 2014) ${ }^{31}$ de la Ley del Impuesto sobre la Renta es un estímulo fiscal que se otorga a los contribuyentes (personas físicas o morales) que aporten dinero de su impuesto a las ganancias para la actividad cinematográfica de una productora $-\mathrm{y}$, desde 2014, empresa distribuidora — que realice $\longrightarrow$ o distribuya - un filme mexicano —el valor del apoyo no puede exceder el 10\% del monto de ganancias que pagó el aportante el año anterior a la ayuda que brindó a un proyecto cinematográfico.

A cambio, el contribuyente recibe un crédito fiscal por parte de la Secretaría de Hacienda -el Ministerio de Economía mexicano- que puede usar en sus declaraciones de ganancias. La persona física o moral puede aplicarlo en el pago de su impuesto hasta agotarlo, o hasta 10 años posteriores al año en que aportó el dinero para el proyecto cinematográfico.

A diferencia del Fidecine y del Foprocine —que no pueden "mezclarse" (un proyecto no puede recibir ayuda de ambos fideicomisos)-, un proyecto beneficiario del Eficine sí puede haber recibido ayuda de Fidecine o de Foprocine.

Los beneficiarios son elegidos por un Comité Interinstitucional, constituido por representantes de la Secretaría de Hacienda, de Conaculta —ministerio de Cultura- y del instituto de cine.

Por disposición del Congreso nacional, la convocatoria del Eficine se abre dos veces al año.

\section{Otros apoyos}

El Imcine también tiene un programa de Estímulo a Creadores, que da apoyos para escritura de guión y desarrollo de proyectos. A su vez, realiza talleres sobre estas temáticas.

\footnotetext{
${ }^{31}$ Desde 2014 el Eficine pasó a denominarse "Eficine 189": los cambios radicaron en que se aumentó la cantidad límite de 500 a 650 millones de pesos mexicanos anuales que esta herramienta puede otorgar por ejercicio a proyectos cinematográficos mexicanos - todos los proyectos beneficiados no pueden superar ese monto en cuanto ayuda recibida- Otra novedad que trajo el cambio de 2014 residió en que el 189 también apoya la distribución, con hasta 50 millones de pesos mexicanos por año para todos los proyectos beneficiados —en 2012 el gobierno mexicano había lanzado el Estímulo a la Promoción del Cine (Eprocine), que duró solo una convocatoria.
} 
El instituto de cine también ofrece una línea de apoyo a los cortometrajes, tanto para su realización como para la posproducción, a través de dos convocatorias públicas anuales: el Concurso Nacional de Proyectos de Cortometraje y el Concurso Nacional de Apoyo a la Postproducción de Cortometrajes. ${ }^{32}$

Si bien la Ley Federal de Cinematografía obliga a todos los estados a impulsar al cine, sólo Nuevo León y el Distrito Federal lo hicieron.

En el caso del Estado de Nuevo León se creó en 2007 un sector Promociones de Nuevo León, organismo estatal que cuenta con una alta participación de los realizadores locales, el cual se creó gracias al primer fideicomiso estatal de apoyo a la producción cinematográfica, dependiente del Consejo para la Cultura y las Artes de Nuevo León.

En el Estado de Sonora en 2010 se creó un fondo estatal de apoyo a la cultura (incluyendo proyectos cinematográficos), y en 2014 se lanzó un fondo de apoyo a la realización de cortometrajes.

Aunque existen distintas iniciativas similares en Jalisco, Michoacán, Aguascalientes, Chihuahua, Durango y Zacatecas hasta 2014 ninguna pudo concretarse, a excepción de la ciudad de México: en efecto, en diciembre de 2008 el Congreso aprobó la Ley de Filmaciones y la Ley de Fomento al Cine. Esta última ley busca apoyar la producción cinematográfica - a través de Procine DF (un fideicomiso a la producción)—, la exhibición sin fines de lucro - mediante la creación de una red de salas (alrededor de 50) a instalarse en los barrios que no posean salas comerciales, y dedicado, principalmente, a la exhibición de cine mexicano (con un mínimo de permanencia de diez semanas) y de cine mundial no hollywoodense-, los festivales y eventos relacionados con el cine, la "investigación en el campo de las nuevas tecnologías de la imagen" y la creación de la filmoteca digital y de una base de datos de cine mexicano.

Por su parte, la Ley de Filmaciones regula todo lo relacionado a las filmaciones realizadas en el Distrito Federal —exime de pagos a las producciones audiovisuales de estudiantes de cine.

\footnotetext{
32 También existe un fideicomiso creado en 2010 llamado Fondo ProAudiovisual, coordinado por ProMéxico - organismo del gobierno federal creado en 2007, dedicado a la internacionalización de bienes y servicios mexicanos-. El Fondo ProAV apoya la producción y posproducción mexicana tanto de películas (largometrajes y cortometrajes), filmes de animación, documentales, como también de series de televisión, telefilmes, obras audiovisuales publicitarias, videojuegos y distintos desarrollos multimedia. La ayuda consiste en una devolución del IVA y del reembolso en efectivo de hasta el 17,5\% de los gastos de producción realizados en la realización del proyecto beneficiado.
} 
Con este repaso, se observa que los organismos estatales mexicanos dedicados al cine se redujeron desde productoras, distribuidoras, exhibidoras, "dulcerías", empresas de marketing, entre otras, de propiedad estatal, al Imcine, a los Estudios Churubusco Azteca — dedicados a la producción y posproducción (aunque en 1994 le redujeron su extensión para ubicar allí al recién creado Centro de las Artes)—, al Centro de Capacitación Cinematográfica (escuela de cine estatal) y a la Cineteca Nacional.

De las viejas épocas del fomentismo, de un Estado muy presente en el fomento de todos los eslabones de la cadena de valor cinematográfica, se pasó a un Estado neofomentista, apenas coproductor —compartiendo riesgos, en contadas ocasiones-, administrando fideicomisos y una normativa de exención fiscal —en todos los casos, enfocados casi exclusivamente en la producción.

\section{Producción y mercados}

En términos de cantidad de espectadores cinematográficos, históricamente México y Brasil fueron los mayores mercados de cine en América Latina.

Ya para la década de 1930, cuando se estaban estableciendo los pilares de la industria mexicana de cine, el promedio de asistencia a las salas decía que cada habitante concurría 7 veces por año al cine, sumando 66 millones de espectadores anuales a finales de esa década (Sadoul, 1979:378) —en la actualidad ese promedio es de 2, y es el más alto de América Latina por lejos-. Por esos años, cerca de un 40\% de todos los espectadores de cine latinoamericanos fueron mexicanos -relación que se fue incrementando durante las décadas: en la actualidad ronda el 55\%-60\% del total latinoamericano (González, 2011b:110).

En lo que hace a la cantidad de filmes producidos, durante la década de 1930 México disputaba con la Argentina el podio de mayor productor cinematográfico de América Latina —aunque en esa década el cine argentino, en plena “época de oro", se imponía en todo el subcontinente- Sin embargo, 1942 marca un año clave en esta "disputa": Estados Unidos toma represalias en contra de la Argentina debido a la postura neutral de este país en la Segunda Guerra Mundial — como ya se explicó al comienzo de este capítulo- Parte de las sanciones incluyeron el corte de película virgen. Por ello, el cine argentino se vio de repente sin insumos para rodar, entrando en una crisis de producción de la que no se recuperaría - si bien pocos años después el gobierno peronista impulsaría medidas para fomentar el cine nacional, éste no pudo retomar la calidad y la popularidad internacional de sus épocas de oro. 
La década de 1940 marca el cénit de la popularidad nacional e internacional del cine mexicano, que perduraría durante varios años de la década siguiente. Si para finales de la década de 1930 el mercado cinematográfico sumaba 66 millones de espectadores, en 1953 esa cifra se había elevado a 162 millones, y a 358,7 millones en 1968 —en la actualidad ese indicador suma 248 millones de espectadores (ubicando al país azteca en el cuarto mayor mercado cinematográfico del mundo, en términos de entradas vendidas).

Durante la década de 1950, en pleno auge del fomentismo, es decir, del fomento activo del Estado mexicano a su cinematografía nacional — con productoras y distribuidoras estatales-, México produjo más de 1000 largometrajes, convirtiéndose en el país de mayor producción cinematográfica de Iberoamérica -en ese mismo lapso España realizó 587 películas, Argentina 352 y Brasil 281 (García Riera, 1999:379).

En esta época, las películas mexicanas tenían una gran circulación internacional. Como afirmaba Georges Sadoul en 1959:

El cine mexicano ocupa en el mundo de habla española un mayor sitio que la producción de Hollywood, ya que las cien películas que produce México anualmente, como promedio, se difunden en las veinte repúblicas hispanoamericanas. (Sadoul, 1959:19)

Debido a la actividad de las distribuidoras estatales - descriptas anteriormente- el cine mexicano no sólo circulaba en toda Iberoamérica, sino que también gozaba de popularidad en países como Yugoslavia y Serbia (Castro Ricalde, 2011) y la comunidad hispana de Estados Unidos —en épocas en que en este país existía una importante cantidad de salas dedicadas a exhibir filmes en castellano: hacia en 1950 sólo en Nueva York existían 300 salas que proyectaban películas en español (García Canclini, 2004:198).

En esos "años de oro" el parque exhibidor azteca también era uno de los más grandes a nivel latinoamericano: entre las décadas de 1950 y 1970 poseía entre 2000 y 2500 salas (que sumaban entre 1,2 y 1,5 millón de butacas); Brasil era el país con el mayor parque exhibidor del subcontinente: tenía entre 3000 y 3300 salas en ese período (Unesco, $1955,1982)$. 
Conforme la época de oro iba consolidándose, se incrementó la afluencia de espectadores a las salas: si para 1938 acudían unos 66 millones de espectadores - lo que daba un promedio de siete veces de concurrencia por habitante-, para 1953 esa cifra había subido a los 162 millones —índice de concurrencia de 7-, y para 1957 el número llegó a los 266,2 millones de espectadores —índice de concurrencia de 9.

Entre la década de 1950 y hasta entrada la década de 1980 la cantidad total de espectadores a las salas mexicanas se ubicaba entre los 260 y los 350 millones de espectadores.

Si bien la "época de oro" clásica se suele ubicar entre la década de 1940 y finales de la de 1950, y a pesar de que la masificación de la televisión supuso un reto para la industria cinematográfica — como sucedió en todo Occidente—, la afluencia a las salas de cine por parte de los mexicanos no se vio reducida durante la década de 1960.

En la década de 1970 el gobierno de Echeverría fomentaría un resurgimiento de la industria nacional de cine, con decididas políticas públicas de fomento al sector, con el público acompañando mayormente.

E inclusive en la década de 1980, cuando en toda América Latina el sector cinematográfico comenzó a debilitarse — tanto en lo que hace a la producción nacional como al sector en general-, en México continuó la afluencia masiva a las salas de cine, empujada mayormente por un cine nacional más popular, aunque de menor "calidad" —según los gustos de la elite intelectual-, con películas que los mexicanos denominan "sexy-comedias" y de "albur" (doble sentido).

Sin embargo, durante la década del ochenta México sufrió - como toda América Latina- el cierre de muchas salas de cine: unos mil establecimientos cinematográficos desaparecieron —pasando de casi 2900 en 1980 a 1900 en el año 1990.

Durante el primer lustro de la década de 1990 se daría el pico más bajo en el parque exhibidor mexicano: 1400 salas en 1993 —el número más bajo desde finales de la década de 1940.

Desde mediados de los noventa, comenzarían a llegar los multicines — de la mano de grandes exhibidoras, como la local Organización Ramírez (Cinépolis) o Cinemark-, que le darían un nuevo impulso al sector azteca de la exhibición, que alcanzaría un incremento constante, siendo en la actualidad el quinto parque exhibidor más grande del mundo. 


\section{Producción nacional}

La baja en la producción nacional fue más acentuada: a pesar de que desde finales de la década de 1970 el Estado rebajó sustancialmente el fomento del cine nacional, la industria continuó gozando de salud — como se mencionó- a partir de la realización de comedias populares -el promedio de largometrajes realizados en México durante la década de 1980 rondó el centenar.

Sin embargo, durante los primeros años de la década de 1990 el Estado mexicano operó un reforzamiento de las políticas "neoliberales": apertura económica, privatizaciones, extranjerización, baja de las ayudas estatales a distintos sectores productivos -entre ellos, el cine, especialmente hacia 1992: en ese año se da de baja la ley de cine de 1949, sancionándose en tiempo récord una nueva ley de cine que no contemplaba empresas estatales, sumado a la liquidación y privatización de las existentes hasta el momento, una cuota de pantalla que bajaba del 50\% al 10\%, apertura a los capitales extranjeros, entre otras características-, en virtud de las exigencias aperturistas que clamaba la firma del Tratado de Libre Comercio de América del Norte, que comenzaría a regir el 1 de enero de 1994.

De esta manera, la producción mexicana de cine pasó de 104 largometrajes en 1989 a 62 en 1991, a 49 en 1993, a 16 en 1995 y a 9 en 1997 —este último fue el número más bajo desde 1932 (Imcine, 2013).

\section{Gráfico 22 - México: filmes producidos (1930-2010)}

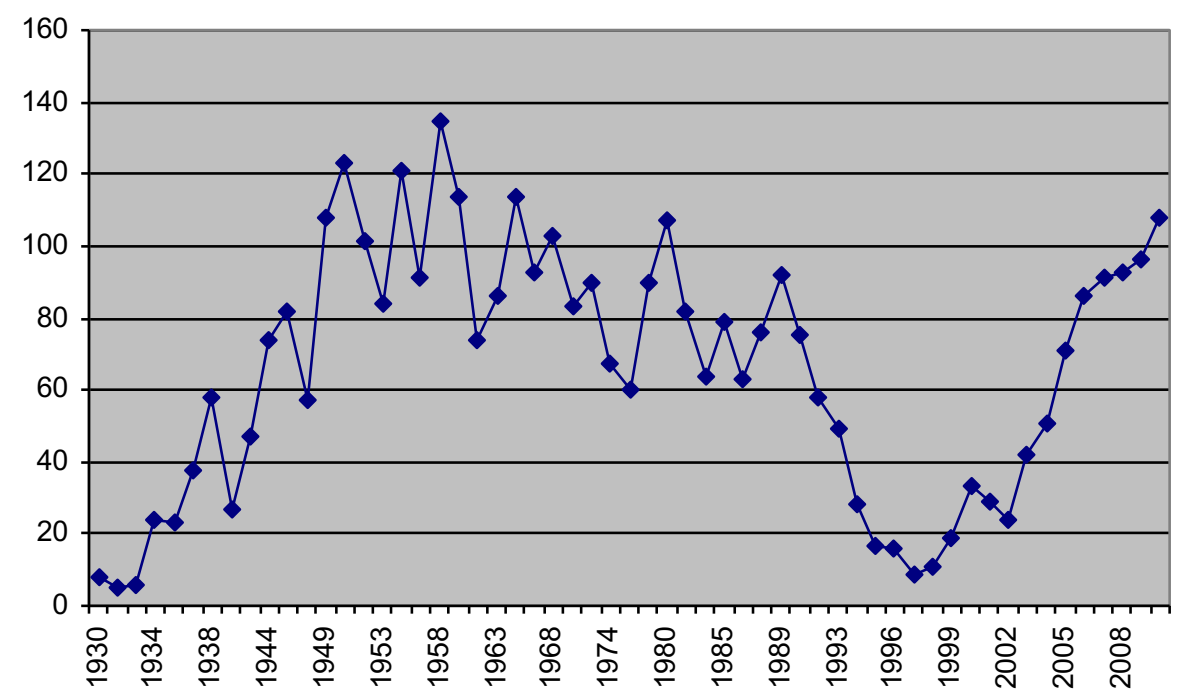

Fuente: Imcine. 
Al dejar de existir las empresas estatales de distribución, exhibición y comercialización —privatizadas o liquidadas entre los años 1990 y 1993-, las majors de Hollywood rápidamente tomaron el control del mercado mexicano.

De esta manera, desde 1992 el número de espectadores bajó entre un $20 \%$ y un $25 \%$ anual durante varios años - aunque desde finales de los ochenta el número venía en bajada, las bajas interanuales no habían sido tan pronunciadas.

Junto con la menor oferta, la baja de la cuota de pantalla, la liquidación de las distribuidoras estatales dedicadas a comercializar las películas locales y la extinción de la cadena estatal de salas, el público del cine mexicano también bajó abruptamente: de convocar a millones de espectadores en su época de oro, durante los últimos años del siglo XX el puñado de películas nacionales estrenadas tenían un porcentaje de mercado que rondaba el 1\% y el 3\% —entre 500 mil y 2 millones de espectadores (lo mismo que convocaba una película con mediano éxito poco tiempo atrás).

A pesar de ello, la década de 1990 sí tuvo algunos blockbusters nacionales, algunos con repercusión internacional: Como agua para chocolate (hasta la actualidad, uno de los filmes latinoamericanos más taquilleros en toda la historia estadounidense), El héroe, El callejón de los milagros, Profundo carmesí y Sexo, pudor y lágrimas.

Sin embargo, a mediados de los noventa el parque exhibidor comenzó a aumentar su número de salas, a través de los nuevos multiplex. También comenzó a incrementarse la cantidad de espectadores, creciendo constantemente hasta nuestros días (2014) —en términos de entradas vendidas, México es el cuarto mercado cinematográfico más grande del mundo.

Hacia finales de la década del noventa también repuntó la cantidad de producciones nacionales $-\mathrm{y}$, por lo tanto, de estrenos locales.

\section{Gráfico 23 - México: estrenos nacionales y extranjeros (1990-2009)}

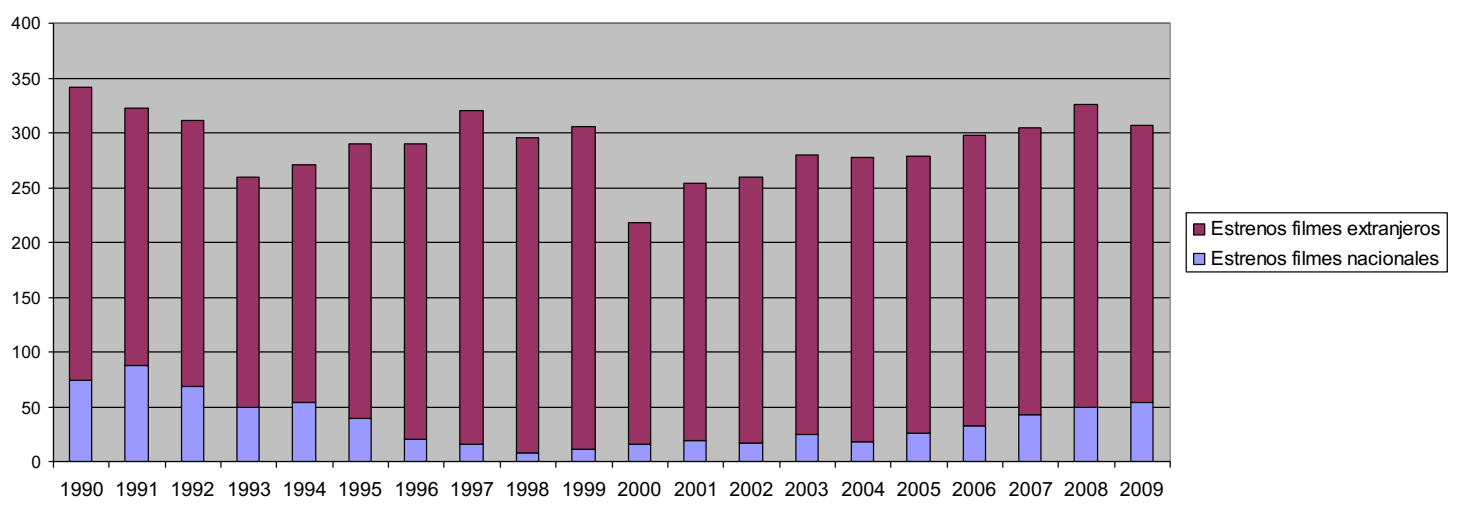

Fuente: Imcine. 
A partir de la implementación del Fondo para la Producción Cinematográfica de Calidad (Foprocine), instrumentado por el gobierno a raíz de la presión del sector que demandaba apoyo del Estado para la cinematografía nacional, comenzó a incrementarse el número de largometrajes, y de estrenos locales.

En efecto, el Foprocine - un fideicomiso administrado por el instituto nacional de cine (Imcine) - constituyó un importante instrumento para la alicaída producción cinematográfica mexicana de mediados de la década de 1990.

A nivel del ecosistema de empresas productoras, a finales del siglo XX cambió el tipo de operatoria. Primeramente, la principal productora de esos años fue la filial del poderoso Grupo Televisa: Televicine. A su vez, surgieron nuevas productoras -como Argos, Altavista, Titán, Bandidos, Coyoacán, ${ }^{33}$ entre otras-, cuya actividad se desenvolvía mayormente en asociaciones con productoras estadounidenses y españolas. A partir de 2001 el cine mexicano sumó otro fideicomiso, en este caso destinado ya no a filmes de "calidad", sino a producciones "industriales": se trataba del Fondo de Inversión y Estímulos al Cine (Fidecine), cuyo fideicomitente es la Secretaría de Hacienda -el Ministerio de Economía azteca-; la operatoria del Fidecine la realiza un Comité Técnico, integrado por representantes del Imcine, de Hacienda, y de distintas asociaciones y agremiaciones de todos los eslabones de la cadena de valor (productores, trabajadores, distribuidores y exhibidores).

En 2006 se aprobó la reforma del artículo 226 de la Ley del Impuesto sobre la Renta denominado formalmente "Estímulo Fiscal a Proyectos de Inversión en la Producción Cinematográfica Nacional" (Eficine), aunque todos en la industria mexicana se refieren a él como el "artículo 226" (189, desde 2014)—, aunque entró en vigencia en 2007. El “226” se constituyó rápidamente en el instrumento que más ayudó al sector cinematográfico para incrementar la producción.

\footnotetext{
33 Inclusive, casos como la productora Coyoacán se trataba de joint ventures entre poderosas multinacionales: en el caso de Coyoacán, era una propiedad en partes iguales de Televisa y Warner.
} 
Gráfico 24 - México: apoyo del Estado a la producción cinematográfica*, en millones de dólares (2001-2007)

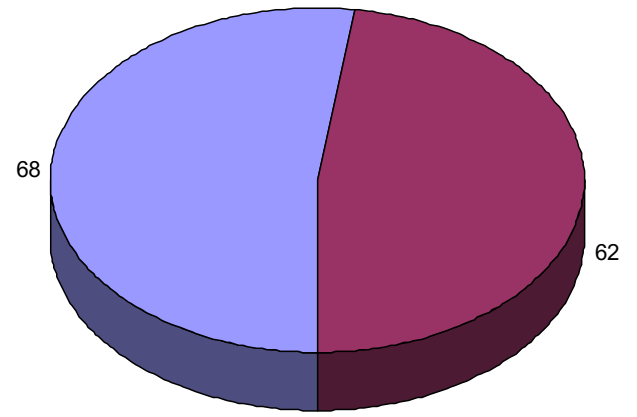

Con la implementación efectiva del Eficine se dio una inyección notable de recursos para la producción cinematográfica en México: para graficar la relevancia de la entrada en vigencia del Eficine valga decir que en el "sexenio" 2001-2006 el Estado mexicano había destinado a la producción cinematográfica — principalmente, a través de los fideicomisos Foprocine y Fidecine- 670 millones de pesos mexicanos —unos 68 millones de dólares-. Sólo en 2007 — primer año de vigencia del Eficine (estímulo fiscal) - el monto fue de 680 millones de pesos mexicanos (unos 62 millones de dólares).

Gráfico 25 - México: presupuesto estatal asignado a la producción fílmica, en millones de dólares (2003-2009)

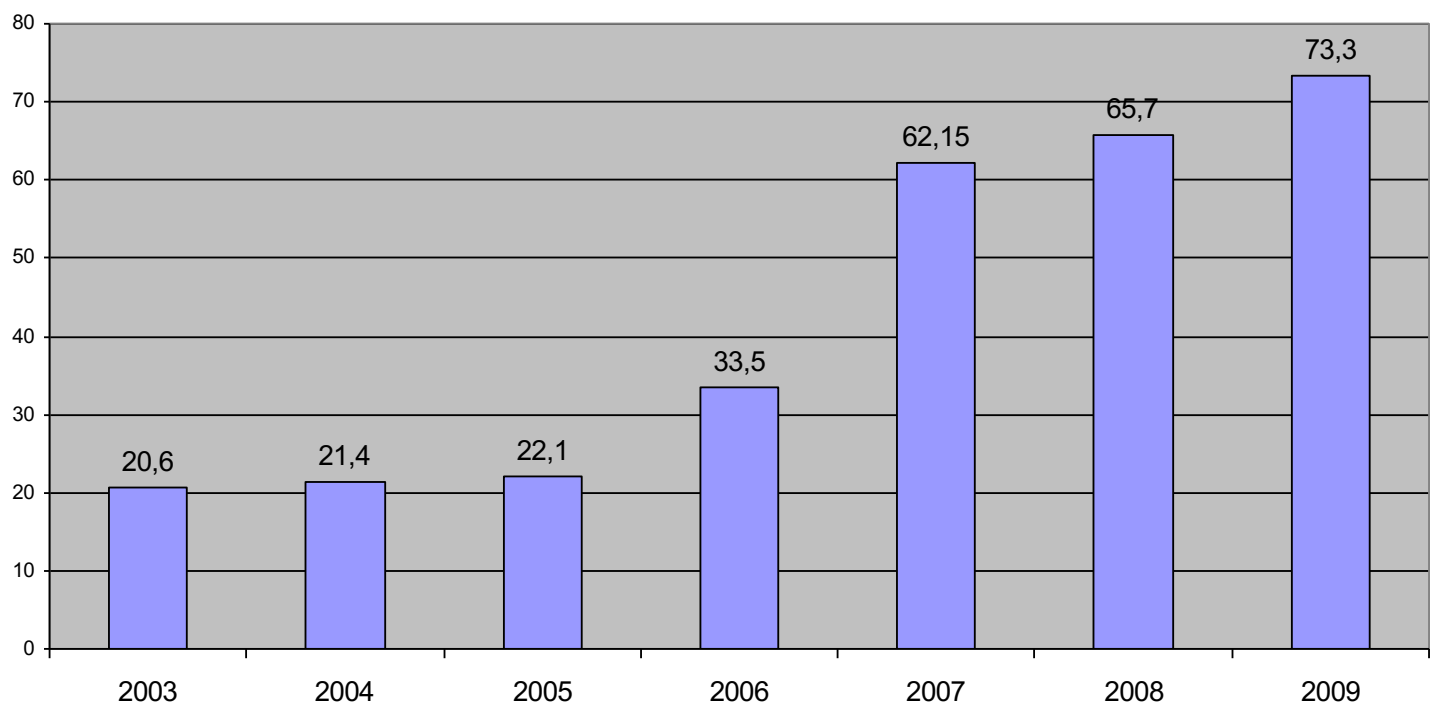

Fuente: Imcine. 
A lo largo de los años, el Eficine (estímulo fiscal) se convirtió en el principal mecanismo de apoyo estatal al cine: para 2009 otorgó tres veces más dinero que los fideicomisos Fidecine y el Foprocine juntos -37 millones de dólares del Eficine, contra 12,4 millones de dólares del Fidecine y 3 millones de dólares del Foprocine (Fuertes, 2014).

Al finalizar la primera década del siglo XXI, el $80 \%$ de los largometrajes mexicanos habían sido apoyados por el Estado (Imcine, 2011).

De esta manera, durante la década de 2000 la producción mexicana se incrementó notablemente, pasando de 9 largometrajes en 1997 a 19 en 1999, de 29 películas en 2001 a 41 en 2003 y 71 en 2005.

A partir de 2007 la producción mexicana arañó el centenar de largometrajes (91), creciendo progresivamente hasta superar el centenar en 2010 (108), cifras que no se daban desde hacía 30 años.

\section{Participación de mercado de los filmes nacionales}

Sin embargo, el aumento en la cantidad de filmes mexicanos producidos no fue acompañado por la respuesta del público.

Aunque la convocatoria de los filmes nacionales creció desde comienzos del siglo XXI, la misma no llegó a niveles importantes: durante toda la década de 2000 varió entre el 4,5\% y el 8\% del público asistente a las salas de cine — salvo 2002, cuando llegó al $11 \%$ (debido al gran éxito de El crimen del padre Amaro). Se pasó de un rango de espectadores de filmes nacionales de entre $600.000 \mathrm{y}$ dos millones de espectadores durante el segundo lustro de la década de 1990, a entre 7 y 14 millones durante la década de 2000 (ningún año de ese período bajó de los 7 millones). ${ }^{34}$

\footnotetext{
${ }^{34}$ En 2013 se produjo un doble récord: en el primer semestre de ese año el filme Nosotros, los Nobles —una adaptación comercial de un filme de Buñuel— rompió el récord de convocatoria para una película nacional en las últimas décadas (7,13 millones de espectadores). Pero en el último trimestre de ese año otro estreno local volvería a romper el récord: No se aceptan devoluciones — protagonizado y dirigido por la estrella televisiva Eugenio Derbez, con el apoyo de Televisa- convocó a 15,2 millones de espectadores. Ambos títulos representaron el $74 \%$ de la convocatoria de todos los filmes nacionales de 2013.
} 
Gráfico 26 - México: estrenos nacionales y porcentaje de mercado por espectadores (1992-2010)

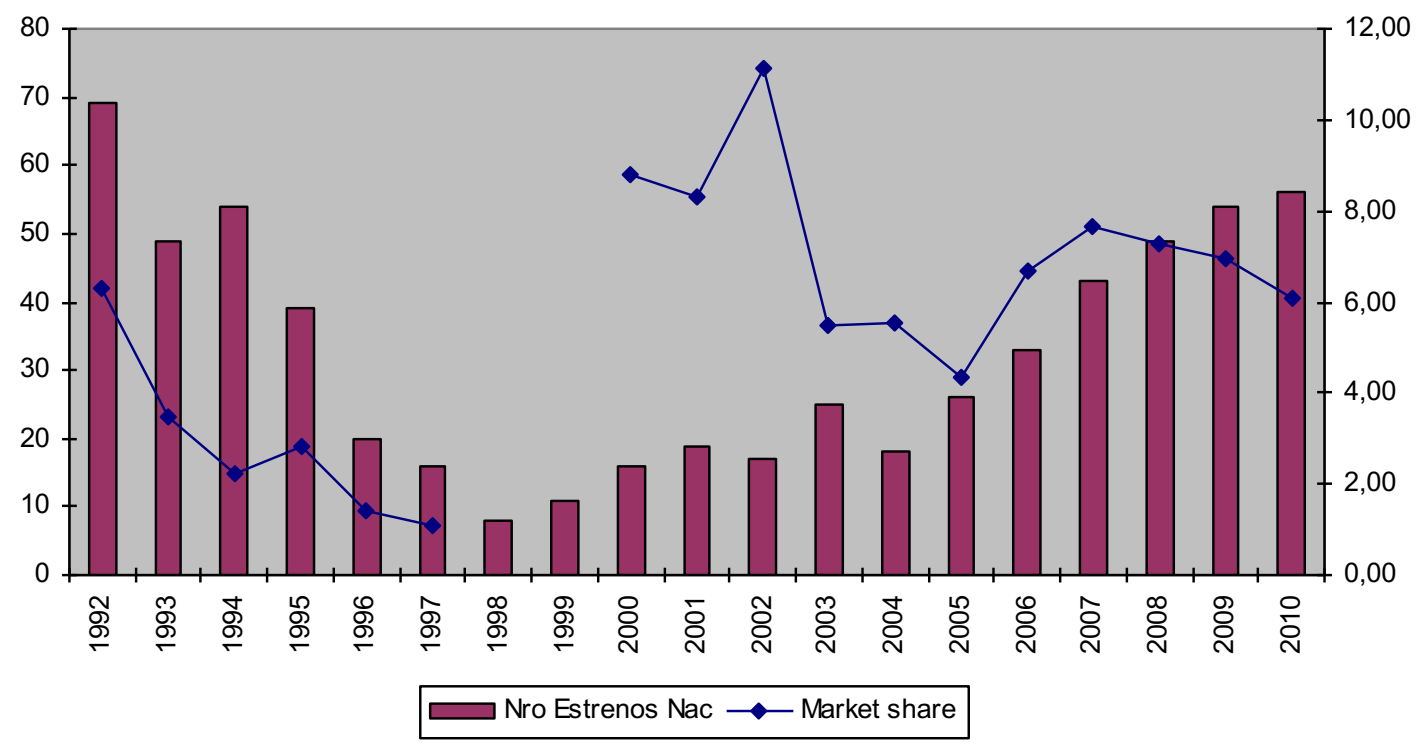

Fuente: Elaboración propia sobre la base de datos de Imcine, Canacine y Nielsen-Rentrak.

Por otra parte, en México también se dio una característica recurrente en toda América Latina desde la década de 1990: la concentración en el consumo de los filmes nacionales. Aunque la porción de mercado de las películas locales sea baja o, en casos excepcionales, un poco más alta, siempre ocurre que dos o tres películas representan entre el $80 \%$ y el $90 \%$ del total de los espectadores que eligieron ver filmes de su país.

En efecto, en todos los años analizados, tanto para el período que abarca esta tesis, como para la década de 1990 (González, 2011b), y hasta la actualidad (González, 2014), el éxito de cada año acapara por sí solo un cuarto del público del cine nacional -en algunos casos, ese porcentaje se eleva al 30\% y 35\%, en casos como Amores perros (30\%), El crimen del padre Amaro (35,3\%) y Una película de huevos $(36,3 \%)$.

Tal como ocurre en América Latina, si a ese blockbuster se le suma lo recaudado por los filmes que ocuparon el segundo y tercer puesto de las películas locales más vistas en un año dado, el porcentaje de esos tres títulos se eleva a cerca del $90 \%$ de todos los espectadores que fueron a ver cine nacional (González, 2011b).

Como se aprecia, la gran mayoría de las películas mexicanas alcanzan cifras muy bajas de convocatoria, lo cual repercute negativamente a la hora de recuperar sus costos. 
Cuadro 19 - México: promedio de concurrencia a las películas nacionales, por espectadores (20002009)

\begin{tabular}{|l|c|c|c|c|c|c|c|c|c|c|}
\hline & $\mathbf{2 0 0 0}$ & $\mathbf{2 0 0 1}$ & $\mathbf{2 0 0 2}$ & $\mathbf{2 0 0 3}$ & $\mathbf{2 0 0 4}$ & $\mathbf{2 0 0 5}$ & $\mathbf{2 0 0 6}$ & $\mathbf{2 0 0 7}$ & $\mathbf{2 0 0 8}$ & $\mathbf{2 0 0 9}$ \\
\hline $\begin{array}{l}\mathrm{N}^{\text {o }} \text { promedio } \\
\text { de } \\
\text { espectadores } \\
\text { por estreno } \\
\text { nacional }\end{array}$ & 715.000 & 626.316 & 864.706 & 300.000 & 500.000 & 273.077 & 333.333 & 311.628 & 269.388 & 229.630 \\
\hline
\end{tabular}

Fuente: Elaboración propia sobre la base de datos de Imcine, Canacine y Nielsen-Rentrak.

\section{Costos de producción}

A pesar de que existen ayudas estatales para la realización cinematográfica, los crecientes costos de producción se tornan impagables sólo con el fomento estatal (fideicomisos y exención fiscal): por ley, las principales líneas que nutren de apoyo financiero al cine mexicano (Fidecine, Foprocine y Eficine) no pueden apoyar más del $80 \%$ del costo del proyecto - porcentaje al que acceden sólo contados casos.

Durante la década de 1990 los costos de producción de un largometraje realizado en México pasaron de unos 220 mil dólares en 1989 a 800 mil dólares en 1996 y a 1,2 millones de dólares en 1999. Durante la década de 2000 el costo llegó al millón y medio de dólares en 2005, situándose en 1,6 millones de dólares en 2009 —en la actualidad (2014) realizar un largometraje en México cuesta unos 1,7 millones de dólares.

Cuadro 20 - México: costo medio de producción de un largometraje, en dólares* (1989-2010)

\begin{tabular}{|l|c|c|c|c|c|}
\hline & $\mathbf{1 9 8 9}$ & $\mathbf{1 9 9 6}$ & $\mathbf{1 9 9 9}$ & $\mathbf{2 0 0 5}$ & $\mathbf{2 0 1 0}$ \\
\hline $\begin{array}{l}\text { Costo medio } \\
\text { de producción }\end{array}$ & 220.000 & 810.000 & 1.200 .000 & 1.500 .000 & 1.600 .000 \\
\hline
\end{tabular}

* Tipo de cambio promedio de cada año.

Fuente: Imcine.

Analizando cómo se reparte la recaudación cinematográfica, se observa que, de manera similar a como ocurre en toda América Latina, el exhibidor - luego de deducir cargas impositivas, incluyendo el IVA y el derecho de autor — se queda con más de la mitad de lo que genera cada boleto de cine vendido —en México, el porcentaje ronda el 60\%-. El distribuidor, luego de haberse cobrado los gastos en copias, publicidad y comercialización general, se queda con el $25 \%$. Finalmente, el productor retiene tan sólo el 15\% de cada entrada vendida en los cines (Getino, 2005b; Ugalde, 2012; Matute, 2014). 
Cuadro 21 - México: estrenos nacionales con más de 2,5 millones de espectadores (2000-2009)

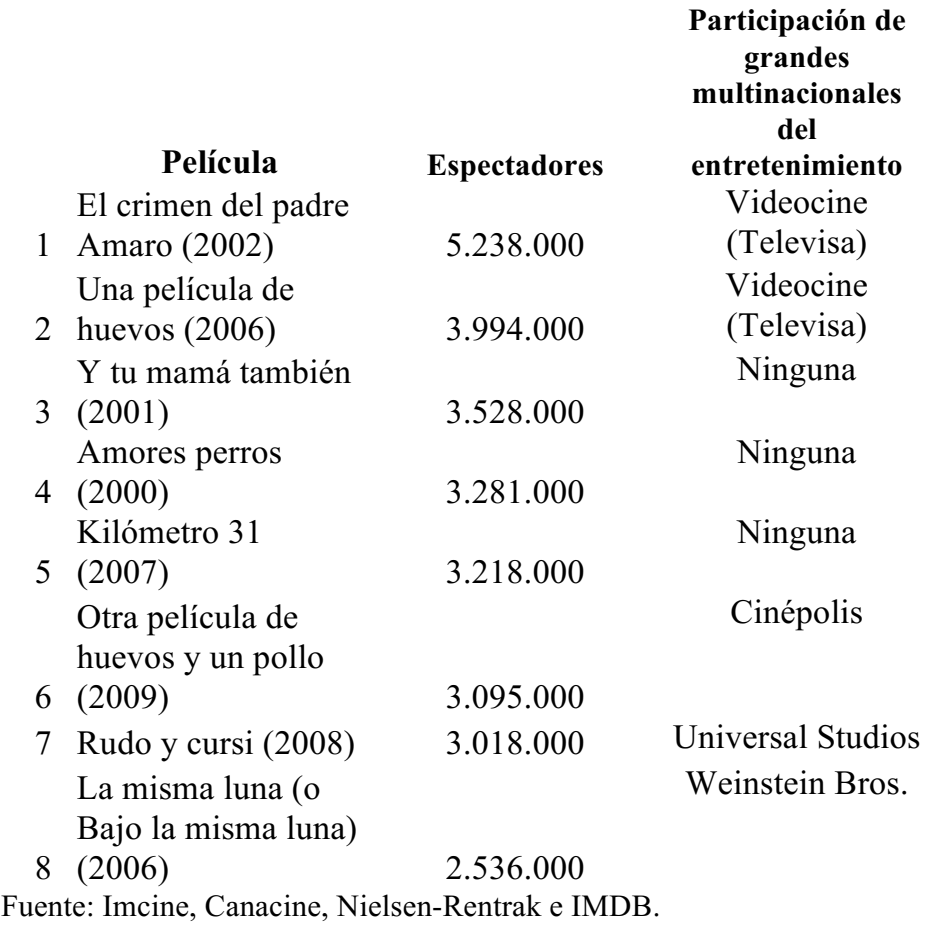

Desde la década de 1990 se necesitan entre 2,5 y 3 millones de espectadores para amortizar un filme —en el caso de que un proyecto no cuente con un importante apoyo estatal-, tomando en cuenta que el productor se queda sólo con el 15\% de cada entrada, y de que el ticket cinematográfico durante la década de 2000 se ubicó en torno a los tres dólares —en el año 2014 el precio promedio del ticket cinematográfico es de 3,7 dólares.

Cuadro 22 - México: cantidad de largometrajes nacionales estrenados y de títulos nacionales que superaron los 2,5 millones de espectadores (1990-2013)

$\begin{array}{lrr} & \begin{array}{r}\mathrm{N}^{\mathrm{o}} \text { de } \\ \text { largometrajes }\end{array} & \begin{array}{r}\mathrm{N}^{\circ} \text { de filmes } \\ \text { mexicanos que } \\ \text { superaron los }\end{array} \\ \text { nacionales } & 2,5 \text { millones de } \\ \text { Período } & \text { estrenados } & \text { espectadores } \\ 1990-99 & 428 & 1 \\ 2000-09 & 300 & 8 \\ 2010-14 & 353 & 7\end{array}$

Fuente: Elaboración propia sobre la base de datos de Imcine, Canacine y Nielsen-Rentrak. 
Sin embargo, de entre los 300 largometrajes mexicanos estrenados entre 2000 y 2009 sólo 8 títulos alcanzaron los 2,5 millones de espectadores -12 películas mexicanas de entre 586 estrenos nacionales, si se toma el período 2000-2014; y si se abarca el período 1990-2014, en el que se estrenaron 1081 películas mexicanas, sólo 16 filmes estrenos nacionales alcanzaron la cantidad necesaria de espectadores que, en promedio, se necesita para amortizar los costos de producción. ${ }^{35}$

\section{Filmes iberoamericanos no nacionales}

Tal como sucede en toda América Latina desde hace muchos años, en México los filmes latinoamericanos apenas se estrenan, salvo en circuitos restringidos a la franja de la población de mayor educación e ingresos más altos — principalmente en festivales, muestras y encuentros, además de las contadas salas de "cine arte".

En efecto, analizando la década abarcada por esta tesis (2000-2009), se observa que tanto el porcentaje de estrenos como el de consumo -medido en términos de recaudación de los filmes latinoamericanos estrenados — son extremadamente bajos.

Durante toda la primera década del siglo XXI se observa que la oferta de estrenos latinoamericanos en México promedia unos ocho largometrajes anuales —similar número se da para los filmes españoles-, es decir, alrededor del $3 \%$ de los títulos estrenados en el mercado azteca cada año.

\footnotetext{
${ }^{35}$ Se trata de los títulos No se aceptan devoluciones, producción de Televisa de 2013 (que convocó 15,20 millones de espectadores, un récord histórico), Nosotros, los Nobles, producción de 2013 (7,13 millones de espectadores), Sexo, pudor y lágrimas (1999: 5,32 millones de espectadores), La dictadura perfecta (sátira política de 2014, que convocó a 4,12 millones de espectadores), Cásese quien pueda (comedia de 2014, con 4,09 millones de tickets vendidos), No eres tú, soy yo (adaptación de la película argentina No sos vos, soy yo; estreno de 2010, con 2,90 millones de espectadores), Cantinflas (biopic de 2014 del gran cómico mexicano, que convocó a 2,82 millones de espectadores) y la animación Don gato (2010: 2,59 millones de espectadores).
} 


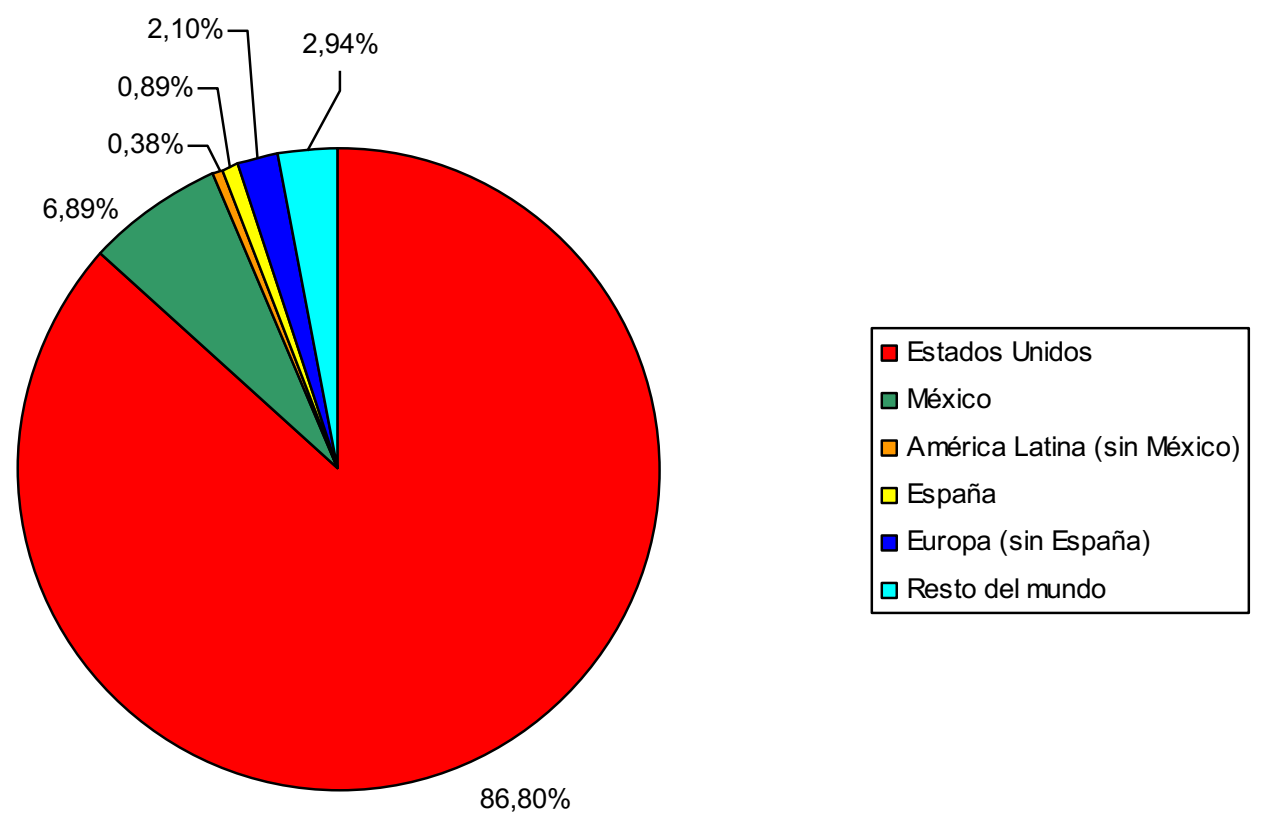

Fuente: Elaboración propia sobre la base de datos de Nielsen-Rentrak, Imcine, Canacine y Box Office Mojo.

Sin embargo, los resultados de mercado son aún menores: el promedio de la década de 2000 para los estrenos latinoamericanos es del $0,38 \%$ — es decir, unos 1,7 millones de dólares anuales, en promedio-, mientras que el porcentaje para los títulos españoles también es ínfimo: 0,89\% — los largometrajes del país ibérico recaudan, en promedio, unos 4 millones de dólares por año.

Los resultados anuales tanto de los filmes latinoamericanos como de los españoles varían entre el $0,02 \%$ y el $1 \%$ al año. Un año excepcional puede arrojar un porcentaje superior al 3\%, pero debido a algún título exitoso que "tracciona" la estadística — por ejemplo, como sucedió en 2008, cuando el porcentaje de mercado de los filmes españoles alcanzó el 3,66\%, explicado básicamente por dos éxitos: las cintas de terror El orfanato (que recaudó 11,5 millones de dólares en México, una cifra inusual para un título iberoamericano en el mercado azteca) y $\operatorname{Rec}$ (con más de 5 millones de dólares recaudados).

Analizando la distribución de filmes iberoamericanos no nacionales en el período 20002009 - unos cuarenta en total-, las empresas mexicanas comercializaron tres cuartas partes de esas películas, y las majors de Hollywood, la cuarta parte restante. 
De las distribuidoras nacionales, se destacan Gussi, Latina, Arthaus y Videocine —entre las cuatro representan el $40 \%$ de lo comercializado por las empresas nacionales en torno al cine iberoamericano no nacional (se destacan Gussi y Latina, con 17 y 15 títulos comercializados).

En lo que hace a las majors se destaca ampliamente Disney (Buena Vista) con 18 títulos comercializados en el período antedicho, seguido por Fox (9), Sony/Columbia (5), Warner (4) y Universal (1).

Cuadro 23 - México: porcentaje de mercado de filmes de estreno, por origen (2000-2009)

\begin{tabular}{|l|c|c|}
\hline & OFERTA & CONSUMO \\
\hline Región & Títulos estrenados & Recaudación \\
\hline Estados Unidos & $58,84 \%$ & $86,80 \%$ \\
\hline México & $10,70 \%$ & $6,89 \%$ \\
\hline $\begin{array}{l}\text { América Latina (sin } \\
\text { México) }\end{array}$ & $3,43 \%$ & $0,38 \%$ \\
\hline España & $3,07 \%$ & $0,89 \%$ \\
\hline Europa (sin España) & $11,73 \%$ & $2,10 \%$ \\
\hline Resto del mundo & $12,23 \%$ & $2,94 \%$ \\
\hline
\end{tabular}

Fuente: Elaboración propia sobre la base de datos de Nielsen-Rentrak, Imcine, Canacine y Box Office Mojo.

La desproporción con respecto a los títulos ofertados (estrenados) y a la convocatoria que éstos generan también se da con los filmes europeos: contando los largometrajes provenientes del Viejo Continente —excluyendo a los españoles — se aprecia que durante el período 2000-2009 representaron el 11,73\% de los estrenos anuales realizados en México —un promedio de unos 40 filmes europeos estrenados al año.

Sin embargo, este $12 \%$ de oferta de los filmes europeos cae a un $2,10 \%$ de convocatoria en el período analizado - lo que representa una recaudación conjunta de unos 10 millones de dólares anuales.

\section{Distribución cinematográfica}

Las distribuidoras cinematográficas más importantes que existieron en México fueron Películas Nacionales (Pelnal) —creada por el Estado en 1947 (posteriormente se convertiría en empresa de capital mixto)—, Películas Mexicanas (Pelmex) —creada por el Estado en 1945- y Cinematográfica Mexicana Exportadora (Cimex) —otra empresa estatal que comenzó a operar en 1947- Estas empresas distribuían el cine mexicano a 
nivel nacional, iberoamericano e internacional —más allá de Iberoamérica-, respectivamente.

Películas Nacionales operó durante casi medio siglo, período durante el cual fue la principal distribuidora de la industria mexicana de cine: llegó a controlar el $80 \%$ del mercado nacional, inclusive hasta la década de 1980. En el interior del país, en las ciudades medias y pequeñas, ${ }^{36}$ la cuota de mercado de Pelnal alcanzaba entre el 90\% y el 100\% de la programación cinematográfica (Ugalde, 1998:49-50). Este dominio del mercado local le daba a la empresa un gran poder para imponer fechas de estreno a los distintos exhibidores del país, en beneficio del cine mexicano.

Por su parte, Pelmex, la distribuidora estatal encargada de comercializar el cine mexicano en el ámbito iberoamericano, compitió fuertemente con las majors de Hollywood a lo largo de varias décadas: llegó a operar en 17 países de la región a través de empresas subsidiarias (España, Argentina, Bolivia, Brasil, Chile, Colombia, Ecuador, Perú, Uruguay, Venezuela, El Salvador, Honduras, Nicaragua, Haití, Panamá, Puerto Rico y República Dominicana). Englobando las sedes centrales y sus sucursales, Pelmex tenía 48 oficinas en América Latina, destacándose en número las que poseía en Venezuela — su principal mercado latinoamericano-, Brasil, Argentina ${ }^{37}$ y Colombia, en ese orden (Heuer, 1964:39). Películas Mexicanas también disponía de una red de salas por toda América Latina, que sumaban 90 cines propios —este fue el único caso que se dio en América Latina de una red regional de salas estatales de cine.

Pelmex fue la "empresa comercial mexicana con mayores ramificaciones y mejor asentada en el extranjero" y la red de distribución más "poderosa y completa" de América Latina — superando en todo el subcontinente a las majors de Hollywood, excepto en Argentina y Brasil (Heuer, 1964:43).

A su vez Cimex - la empresa estatal que comercializaba los filmes mexicanos en Estados Unidos, Europa y el resto del mundo (exceptuando Iberoamérica) - llegó a tener oficinas en Estados Unidos (Nueva York, Los Ángeles, Chicago, Miami, San Antonio), Francia (París), Italia (Roma) y Alemania (Munich) (Getino, 2005b:189; Heuer, 1964:40).

\footnotetext{
${ }^{36}$ Pelnal tenía sucursales en todos los puntos del país: Guadalajara, Monterrey, Veracruz, Torreón, Mazatlán y Mérida (Heuer, 1964:37).

${ }^{37}$ En Argentina, Pelmex tenía su oficina central en Buenos Aires, y sucursales en Rosario, Córdoba, Mendoza y Bahía Blanca.
} 
Sin embargo, hasta la década de 1980 también existían otras distribuidoras de capital privado, y local, que tenían una buena presencia en el mercado azteca, tales como Cooperación Mexicana de Cine, Arte Cinema de México y Producciones Carlos Amador - junto con Películas Nacionales, este puñado de empresas dominaba la distribución del cine mexicano en esos años (Gómez, 2006:255).

A comienzos de la década de 1990, en tiempos de privatizaciones y extranjerización, el gobierno dejó libradas a su suerte a varias empresas estatales, entre ellas, a las distribuidoras cinematográficas: Películas Nacionales quebró en 1991, y Pelmex en 1992.

Ante la desaparición de las principales distribuidoras del cine mexicano — tanto estatales como privadas-, aparecieron nuevas empresas que intentaron ocupar el enorme vacío dejado por las empresas estatales de comercialización cinematográfica. Entre las flamantes distribuidoras se destacaron Videocine - filial de Televisa (empresa que se expandiría enormemente, a medida que el Estado se iba retirando del cine y la televisión)- Zafra, Mercury y Piscis. Videocine se convertiría en la distribuidora mexicana más importante —comercializando tanto filmes extranjeros como nacionales. Por esa época, el instituto de cine comenzaría a encargarse progresivamente de la distribución de filmes nacionales.

Posteriormente aparecerían nuevas empresas locales que, en la actualidad, tienen una importante presencia en la distribución de cine nacional, latinoamericano y mundial (no hollywoodense), tales como Gussi, Corazón y Nuvisión, entre otras.

Desde mediados de la década de 1990, tal como sucedió en toda América Latina, Hollywood pasó a dominar de manera monopólica el mercado cinematográfico local: de tal manera, la mayoría de los filmes que, desde entonces, se proyectan en las pantallas locales son de origen estadounidense —a su vez, estas películas se quedan con la mayor parte de la recaudación (como se vio en el cuadro 23).

En la actualidad, el mercado de la distribución en México se concentra en seis empresas: las majors Universal, Warner, Disney, Fox, Paramount y Sony/Columbia. 


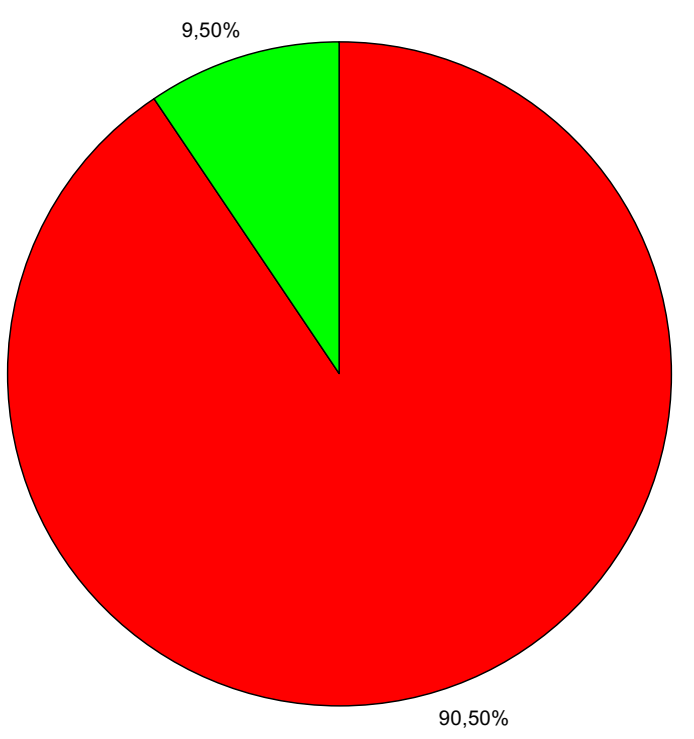

Fuente: Imcine.

\section{Exhibición cinematográfica}

Desde los comienzos del cine en México, a comienzos del siglo XX, el público azteca acogió ampliamente al séptimo arte, convirtiéndose en un importante consumidor de filmes - especialmente, en la capital y en las principales ciudades, como Guadalajara, Monterrey y Puebla—, en salones y "carpas", que devendrían importantes salas (De la Vega Alfaro, 2000).

El parque exhibidor en México creció sostenidamente durante las primeras décadas del siglo XX: para 1933 ya existían 700 cines — casi medio millón de butacas—, ${ }^{38}$ mientras que para 1941 se contabilizaban 1125 cines —unos 675.000 asientos—; en 1953 el número ya había alcanzado los 2500 cines — 1,5 millones de butacas-(Unesco, 1955): en 20 años se cuadruplicó el número de salas en México.

Lo mismo sucedió con la cantidad de espectadores: si para 1938 se habían vendido 66 millones de entradas, para 1953 la cifra trepó a los 162 millones. Estos números, tanto en la década de 1930, como hasta finales de la década de 1960, dan un promedio de asistencia al cine de siete veces por habitante - con picos de 9 y 10 entre 1955 y

\footnotetext{
${ }^{38}$ Para tener una referencia de las casi 500.000 butacas existentes en todos los cines de México a comienzos de la década de 1930, basta señalar que en la actualidad existen en la Argentina unos 170.000 asientos.
} 
1965-, cifras similares a las del consumo cinematográfico en Europa por esos años (Unesco, 1955; Sadoul, 2004 [1967]).

Hacia la década de 1950 se había formado un duopolio entre las cadenas exhibidoras Cadena de Oro y Operadora de Teatros — más conocida por su sigla Cotsa—: ambas eran propiedad del estadounidense William Jenkins, ${ }^{39}$ y representaban el $80 \%$ de los cines de todo el país (Gómez, 2006).

A pesar de que en estos años el Estado mexicano poseía productoras y distribuidoras propias —que fueron fundamentales para construir la "época de oro" del cine azteca—, el duopolio de la exhibición muchas veces retaceaba los estrenos de cine nacional.

En enero de 1961 el gobierno de López Mateos nacionalizó las cadenas exhibidoras Cadena de Oro y Cotsa.

Sin embargo, la incipiente televisión le restaría público a las salas de cine al finalizar la década de 1950 — amén de que la calidad de la producción nacional había decaído—. A su vez, el cine local también debía enfrentar otro fenómeno cultural propiamente mexicano que explotaría en la década de 1960: la lucha libre.

Aunque habían caído, los índices de concurrencia entre la década de 1970 y 1980 seguían siendo altos: en promedio, los mexicanos acudían al cine entre 4 y 5 veces al año.

Pero para la década de 1980, en plena "década perdida" — fundamentalmente, por la crisis de la deuda, desencadenada en 1982-, en México se cerraron unas mil salas, casi todas de pequeños y medianos empresarios - la mayoría, ubicadas en pueblos y ciudades pequeñas - Cierto abandono en el mantenimiento de las salas, sumado al deterioro en el poder adquisitivo de la mayoría de la población y al creciente cambio de consumo audiovisual, a manos del video, terminan de explicar el cierre de salas durante esta década.

Las condiciones antedichas se agravarían en los primeros años de la década de 1990, momento en que se privatizarían distintas empresas estatales —entre ellas, la exhibidora

\footnotetext{
${ }^{39}$ En los papeles, Gabriel Alarcón y Manuel Espinosa eran los dueños de la exhibidora, pero en realidad eran testaferros del estadounidense Jenkins — quien, por problemas legales, no podía fungir como dueño de Operadora de Teatros-; estos tres personajes venían de amasar fortunas a partir de la comercialización de la caña de azúcar — convertida en alcohol, en épocas de la prohibición de las bebidas alcohólicas en los Estados Unidos-. Jenkins fue el "zar" de la exhibición y de la industria cinematográfica en México entre las décadas de 1940 y 1950. Tuvo aceitadas —y conflictivasrelaciones con el poder local — desde las familias Azcárraga y Milmo, a comienzos del siglo XX (de donde nacerían los futuros fundadores y dueños de Televisa), hasta la familia Avila Camacho, de donde saldría un presidente de la República (1940-1946).
} 
Cotsa, que para entonces dominaba el mercado exhibidor azteca—: de 2850 salas existentes en todo el país hacia 1987, el número había caído a la mitad tan sólo seis años después —en 1993 había 1415 salas (la menor cantidad registrada en 40 años).

Sin embargo, hacia mediados de la década de 1990 comenzaron a abrirse complejos multiplex — varias salas de reducido número de butacas (a diferencia de los cines que habían existido hasta ese entonces)-, de la mano de un creciente número de centros comerciales que comenzaron a inaugurarse por todo el país.

Se destacarían en este proceso multinacionales de la exhibición como Cinemark, pero también empresas nacionales, como la Organización Ramírez y su cadena Cinépolis —que, con el tiempo, se convertiría en la exhibidora líder de México, se expandiría a toda América Latina, y sería la quinta cadena cinematográfica más importante del mundo.

A partir de la apertura de complejos multiplex, México cuadruplicaría su número de salas en tan sólo 20 años, figurando en los primeros lugares a nivel mundial: si en el año 2000 se ubicaba en el décimo lugar a nivel mundial en términos de cantidad de salas de cine, a finales de la década ya estaba en el quinto lugar de ese ránking (Gómez, 2006; González, 2014b).

Sin embargo, tal como ocurre en América Latina, tan sólo un ínfimo porcentaje de los municipios mexicanos tienen sala de cine: únicamente el 7\% de los ayuntamientos de este país disponen de un cine - las salas existentes se concentran en unas 50 ciudades (que albergan al $57 \%$ de la población), mientras que un cuarto de las pantallas cinematográficas de todo el país se concentran en el Distrito Federal (porcentaje que crece al $43 \%$ si se considera todo el valle de México, en el centro del país, la zona más rica del país); sólo el 13\% de las salas se ubica en el sur, la región más pobre del país (Imcine, 2011; 2012).

En el caso de la cantidad de espectadores a las salas se dio una evolución similar a la de las salas: luego de los picos de asistencia al cine, hacia las décadas de 1950 y 1960 —cuando las entradas vendidas rondaban entre los 340 y los 375 millones de espectadores anuales_-, durante la década de 1970 el número cayó, pero conservando cifras importantes -220 y 265 millones de espectadores-. Sin embargo, para la década de 1980 comenzó a declinar la convocatoria de las salas, con números que para la década de 1990 tocaron pisos históricos —en 1995 fueron tantos espectadores como en 1933 (alrededor de 62 millones). 
Cuadro 24 - México: número de espectadores e índice de concurrencia por habitante (1938-2010)

\begin{tabular}{|l|l|l|l|l|l|l|}
\hline & $\mathbf{1 9 3 8}$ & $\mathbf{1 9 5 7}$ & $\mathbf{1 9 6 8}$ & $\mathbf{1 9 8 0}$ & $\mathbf{1 9 9 5}$ & $\mathbf{2 0 1 0}$ \\
\hline $\begin{array}{l}\text { Número de } \\
\text { espectadores }\end{array}$ & 66.000 .000 & 266.200 .000 & 358.700 .00 & 264.000 .000 & 62.000 .000 & 189.600 .000 \\
\hline $\begin{array}{l}\text { Índice de } \\
\text { concurrencia } \\
\text { por } \\
\text { habitante* }\end{array}$ & 7 & 9 & 7,5 & 3,7 & 0,6 & 1,7 \\
\hline
\end{tabular}

*Se obtiene dividiendo el número total de espectadores por la cantidad de población del país.

Fuente: Elaboración propia con base en datos de Unesco $(1955,1982)$ e Imcine.

No obstante, hacia finales de la década de 1990, y durante toda la d

e 2000, operó una notable recuperación en la convocatoria de las salas de cine, pasando de 95 millones de espectadores en 1997 a 120 en 1999, 143 en 2001, 163 en 2004, 175 en 2007 y 189,6 en 2010 en 2014 la cifra rondó los 253 millones de entradas vendidas (es decir que en 20 años la cantidad de espectadores a las salas de cine en México se cuadruplicó).

Si bien el índice de concurrencia en México ya no llega a 9 o 10, como hacia a finales de la década de 1950 y comienzos de la de 1960, sino a 2, es el índice más alto de toda América Latina desde mediados de la década de 2000.

\section{Concentración}

Desde que comenzó la expansión de los multiplex en México, hacia mediados de la década de 1990, comenzó a operar una fuerte concentración en el mercado de la exhibición.

A comienzos de la década de 2000, existían en México unas 30 cadenas de cine, pero sólo cuatro empresas controlaban el $85 \%$ del mercado cinematográfico y el $87 \%$ de las pantallas: Cinépolis, Cinemex, Cinemark y la local MM Cinemas.

Cinépolis pertenece a la empresa local Organización Ramírez —en 1972 abrieron su primer complejo multiplex, pero la empresa familiar viene trabajando en la exhibición cinematográfica desde 1946, en Morelos- Cinemex, por su parte, es una empresa mexicana $^{40}$ fundada en 1993, en ocasión de la privatización de las exhibidoras estatales.

\footnotetext{
${ }^{40}$ En 2002 la empresa fue vendida a un conglomerado conformado por la empresa canadiense Onex y la estadounidense Oaktree; en 2004, este grupo lo vendió al estadounidense The Carlyle Group, quien a su vez lo traspasó al consorcio local Empresarios Industriales de México, grupo empresarial dedicado a la metalurgia, a la minería, al transporte ferroviario y a la banca, comandado por Germán Larrea Mota, el segundo hombre más rico de México, aunque también uno de las más desconocidos - la prensa lo llama "el multimillonario sin rostro" - L Larrea también intenta, desde hace años, hacerse con canales de televisión: por lo pronto, hasta septiembre de 2014 fue miembro del Consejo de Administración de Televisa.
} 
Multimedios Cinemas (MM Cinemas) comenzó con una sala en Monterrey, en 1981; con el tiempo fue expandiéndose a todo el país, y durante la década de 1990 y comienzos de la de 2000 fue un actor preponderante en el sector de la exhibición; en 2008 fue comprada por Cinemex.

A comienzos de la década de 2000, las exhibidoras “independientes" representaban aproximadamente el 20\% —destacándose Cinemas Lumière, Econocinemas e Intecine-: todas estas cadenas eran mexicanas, y varias ofrecían precios "populares". La mitad de estos cines tenían una sola sala (Gómez, 2006; Ugalde, 2004).

Cuadro 25 - México: concentración en el sector de la exhibición (2000-2013)

\begin{tabular}{|l|c|c|}
\hline & $\mathbf{2 0 0 0}$ & $\mathbf{2 0 1 3}$ \\
\hline $\begin{array}{l}\text { Número de cadenas de } \\
\text { cine }\end{array}$ & 30 & 10 \\
\hline Principales cadenas & $\begin{array}{c}\text { Cinépolis, Cinemex, } \\
\text { Cinemark, MM } \\
\text { Cinemas }\end{array}$ & Cinépolis, Cinemex \\
\hline $\begin{array}{l}\text { \% del total de las salas } \\
\text { del país (principales } \\
\text { cadenas) }\end{array}$ & $87 \%$ & $77 \%$ \\
\hline $\begin{array}{l}\% \text { del total de la } \\
\text { recaudación } \\
\text { (principales cadenas) }\end{array}$ & $85 \%$ & $90 \%$ \\
\hline
\end{tabular}

Fuente: Elaboración propia con base en información de la tesis.

Para finales de la década de 2000, la concentración se había acentuado en el parque exhibidor mexicano: sólo existían unas 10 cadenas de cine, y sólo tres de estas empresas poseían el $77 \%$ de las salas $-\mathrm{y}$ se quedaban con más del $90 \%$ de los resultados de mercado- Estas exhibidoras eran Cinépolis, Cinemex y Cinemark - MM Cinemas fue adquirido por Cinemex en $2007^{41}$ (Ugalde, 2012; González, 2013).

\section{$\underline{\text { Salas digitales }}$}

México y Brasil fueron pioneros a la hora de instalar salas digitales de alta gama —en ese momento, con una resolución de $1,3 \mathrm{~K}$, la mayor disponible para una sala comercial de cine.

En el país azteca la exhibidora nacional Cinemex inauguró la primera pantalla numérica de todo el subcontinente en julio de 2000 —en el complejo Mundo "E” del Distrito Federal, la cual continúa en funcionamiento-. Al año siguiente, Brasil vio inaugurar

\footnotetext{
${ }^{41}$ En 2013 Cinemex absorbería a Cinemark: de esta manera, en la actualidad (2014) el mercado exhibidor mexicano está dominado por un duopolio compuesto por las empresas nacionales Cinépolis y Cinemex.
} 
otras dos salas digitales por parte de la empresa UCI - entonces perteneciente a una sociedad entre Paramount y Universal- en Río de Janeiro y San Pablo.

A diciembre de 2007 sólo cinco países en toda América Latina y el Caribe poseían salas digitales (21 en total), siendo México uno de ellos, junto con Brasil, Ecuador, Colombia y Chile.

Durante 2008 las principales cadenas de cine instaladas en América Latina - tanto empresas multinacionales como nacionales - comenzaron a adquirir proyectores digitales para equipar algunas de sus salas. A finales de ese año, ya eran nueve los países latinoamericanos que tenían alguna pantalla numérica entre su parque exhibidor, sumando 84 en toda la región — tan sólo el 1,1\% del total mundial que superaba los 7800 proyectores digitales de alta gama (de los cuales el 69\% se hallaban en Estados Unidos y el 16\%, en Europa).

La exhibidora mexicana Cinépolis se convirtió en la impulsora de la digitalización, no sólo en su país, sino en los mercados en los que comenzó a abrir complejos, desde mediados de la década de 2000: Guatemala, El Salvador, Costa Rica, Panamá, Colombia —y desde 2010—, Brasil y Perú —Cinépolis también abrió salas en Estados Unidos y en la India.

\section{La recuperación operada desde finales de la década de 1990}

Lo que parece una notable recuperación durante la década de 2000 con respecto a la de 1990, superando niveles históricos, por ejemplo, 6000 salas contra 3000, es materia cuestionable.

Como se vio en el capítulo IV sobre mercados cinematográficos, la cantidad de espectadores y de salas comenzó a decaer de manera constante en el subcontinente, incrementando su ritmo de decadencia a finales de la década de 1980 y comienzos de la de 1990, y comenzando una lenta pero progresiva recuperación durante la década de 2000 - aunque sin acercarse a los valores que se dieron entre las décadas de 1940 y 1970.

Hasta mediados de la década de 1990 las salas eran los antiguos palacios de cine, es decir, un único y amplio edificio, con una gran cantidad de butacas, que podía superar el millar —en promedio, la cantidad de asientos de los antiguos cines era de 600- A partir de la proliferación de los multiplex durante la década de 1990, el número de butacas por sala se redujo drásticamente: el promedio cayó a 200. 
El número de butacas a mediados del siglo XX rondaba los 2 millones; hacia 2010 sólo rozaba el millón —en la actualidad (2014), siendo el quinto parque exhibidor del mundo, el número de butacas de cine en México apenas supera el millón, una cantidad similar a la que poseían Colombia y Chile hacia 1960 (ambos mercados, en conjunto, siempre representaron un cuarto del mercado mexicano, tanto a mediados del siglo XX como en la actualidad).

Gráfico 29 - México: cantidad de butacas de cine (1933-2010)

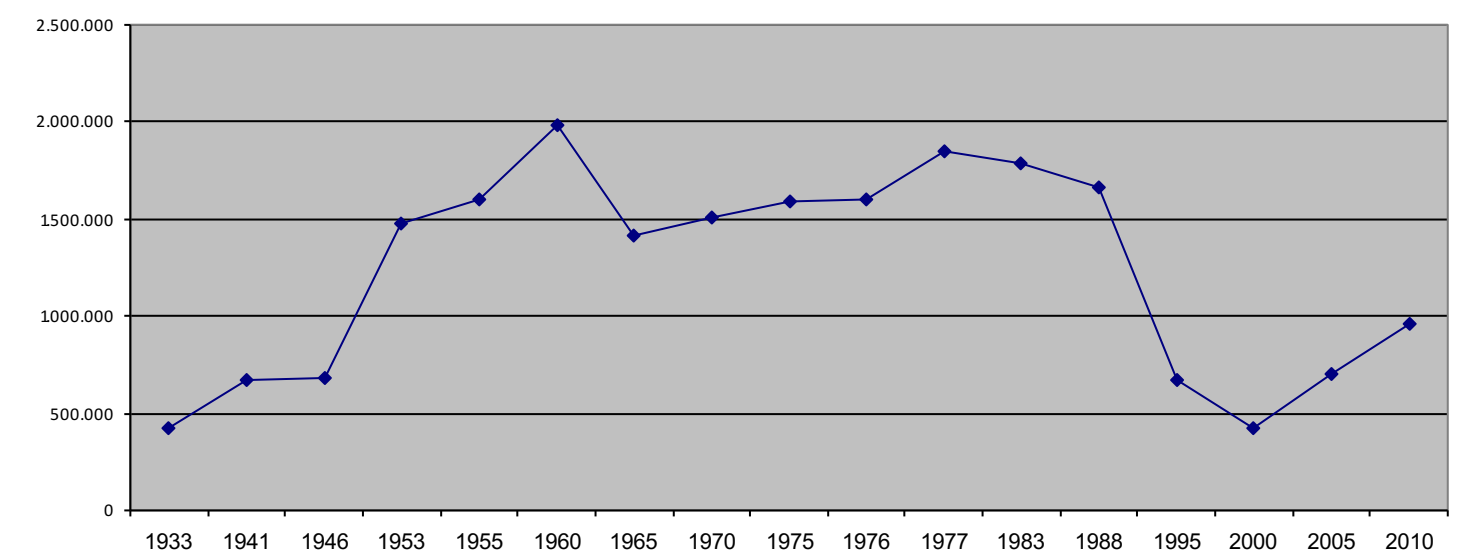

Fuente: Elaboración propia sobre la base de datos de Unesco (1955, 1982), Sadoul (2004), Getino (1987), González (2011b, 2013), Gómez (2006), Imcine, Rentrak.

Sin embargo, en comparación con los otros mercados latinoamericanos de cine, México es el país donde los indicadores de mercado más se "aproximan” a los que tenían a mediados del siglo XX — tal como se apreciará en los casos argentino y brasileño, en sus respectivos capítulos nacionales.

En lo que hace a la cantidad de espectadores, si bien México registró la misma caída abrupta que el resto del mundo desde finales de la década de 1970, la recuperación operada durante la última década lo deja en valores similares a los de finales de la década de 1950 - 250-260 millones de espectadores (que en la actualidad es, lejos, el mayor número de asistentes a las salas de cine en toda América Latina, y el quinto valor a nivel mundial)—, valores que se ubican un $30 \%$ por debajo del pico registrado durante la década de 1960 (340-360 millones de entradas vendidas). 
Gráfico 30 - México: cantidad total de espectadores cinematográficos (1933-2010)

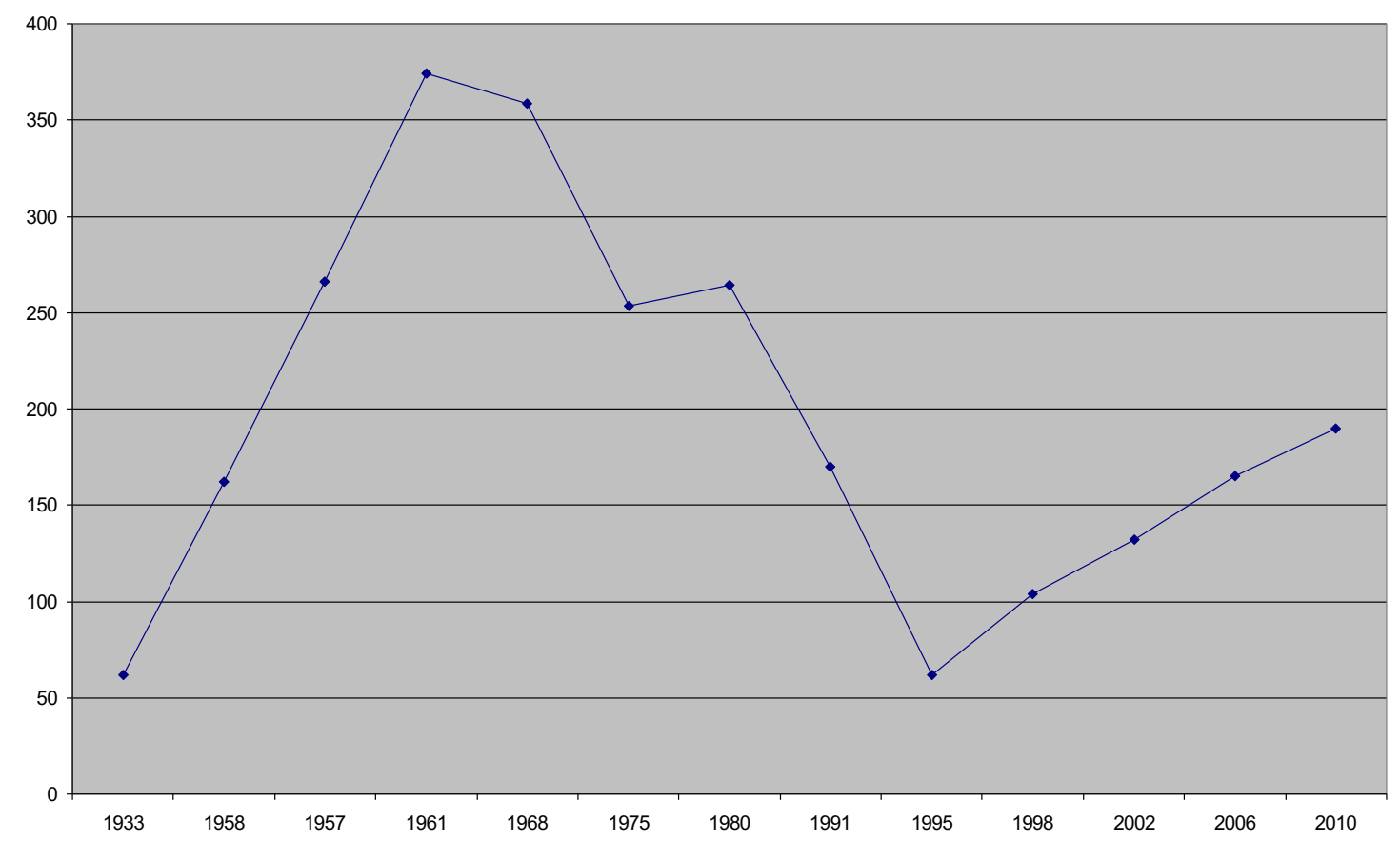

Fuente: Elaboración propia con base en datos de Unesco (1954, 1982), Sadoul (2004), Imcine, Rentrak.

Para comienzos de la década de 2010 México es el quinto mercado más grande del mundo en términos de entradas vendidas —en 2013 alcanzó el cuarto lugar, detrás de Estados Unidos, China, India y Francia (Observatorio Europeo del Audiovisual, 2014)—. A su vez, también ocupa el quinto puesto en el ranking mundial de cantidad de salas de cine.

\section{Conclusiones del capítulo}

Entre las décadas de 1940 y 1980 en México existían importantes políticas de Estado en materia de cine, al crearse distintas herramientas para intervenir en el mercado en favor de las películas nacionales.

Las instituciones públicas mexicanas dedicadas a fomentar el séptimo arte eran instituciones generalistas, con un amplio radio de acción - productoras y estudios estatales (especialmente, Churubusco-Azteca)—, para coadyuvar a generar una industria poderosa, al alcance de una mayoría; distribuidoras estatales (como Pelmex y Pelnal), destinadas a una tarea fundamental como es la de hacer circular las películas, tanto en el propio país como en el extranjero; exhibidoras estatales (Cotsa y Cadena de Oro), para ser un vehículo que priorice la programación de cine nacional, iberoamericano y diverso de todo el mundo. 
En el período fomentista del cine mexicano la producción era industrial: había un sistema de estudios sustentable — que se había iniciado en la década de 1930 (cuyo primer gran éxito fue Allá en el rancho grande, de 1936)—, con miles de trabajadores y profesionales laborando sostenidamente en todos los ámbitos de la cadena de valor cinematográfica, con empresas que eran mayormente nacionales.

En esta etapa, el cine nacional poseía altos porcentajes de consumo (Heuer, 1964:60), que en esos años se encontraban dispersos a lo largo del territorio nacional - como ocurría en América Latina y en la mayor parte del mundo-, en pueblos, ciudades pequeñas y barriadas humildes — público que, históricamente, fue el mayor consumidor de las películas nacionales-, con precios baratos, accesibles para los sectores de menores ingresos -durante muchos años el precio de la entrada al cine estuvo protegido en la canasta básica mexicana.

A su vez, en las carteleras existía diversidad en la oferta: títulos de todo el mundo se estrenaban, muchos de ellos de América Latina —especialmente, de la Argentina-; Hollywood era un actor importante, pero sus películas no se quedaban con el $80 \%-90 \%$ de los resultados de mercado, sino con aproximadamente la mitad.

Desde la década de 1990, bajo el neofomentismo, el apoyo estatal al cine se circunscribe a exenciones fiscales y fideicomisos, donde ya no existe, ni se fomenta, una industria ni una identidad propia y corporativa — que, es necesario decirlo, en la etapa del cine industrial estatal tuvo derivaciones marcadas por vicios de procedimiento $\mathrm{y}$ corrupciones varias ${ }^{42}$-, sino que los destinos del fomento cinematográfico se dejan librados a la tecnocracia "autárquica" y "neutra" de la burocracia profesional del Estado —donde no sólo tiene parte aquella perteneciente al instituto de cine, sino que las decisiones reales terminan recayendo en los representantes del Ministerio de Economía, totalmente desconocedores y ajenos de la realidad del sector cinematográfico.

Desde la década de 1990, bajo el neofomentismo, la institucionalidad del fomento al cine mexicano se circunscribe, principalmente, al instituto de cine (Imcine): un ente que se torna dependiente de la visión acotada y cortoplacista de los funcionarios de Hacienda de la Nación.

\footnotetext{
${ }^{42}$ En la etapa del cine industrial estatal se había vuelto común realizar "churros" — películas filmadas rápidamente, sin mayor rigor ni en la factura técnica o narrativa-, puesto que el riesgo empresarial era casi nulo, debido a que el Estado asumía el costo casi al momento de realizado el guión, mediante pagos adelantados en concepto de derechos anticipados. Además, se había generado un fuerte espíritu corporativo en el peor sentido, donde se habían establecido fuertes barreras de entrada para los jóvenes y principiantes, salvo que tuvieran la bendición de los caciques del sector — tanto en el ámbito de la dirección, como de la producción y la comercialización, así como en los poderosos sindicatos cinematográficos (García Riera, 1999; De la Vega, 2000; Harvey, 2005; Matute, 2014).
} 
A su vez, el Imcine no posee un fondo de fomento de manejo propio, sino que es una parte más en la dirección de un par de fideicomisos, y en la reasignación de millonarios montos destinados por grandes empresas del sector privado al cine, a través de mecanismos de exención fiscal.

Además, el grueso de las ayudas al cine se concentran casi exclusivamente en la producción, a diferencia de lo que pasaba en la etapa del cine industrial estatal (fomentista).

En la actualidad existen contadas entidades estatales de apoyo al cine, como Film Commissions en algunas provincias del país, pocos programas de apoyo a aspectos puntuales -como desarrollo de proyectos, guión, apoyo a la distribución y presencia en festivales- por parte de Conaculta (ministerio de Cultura) o Cancillería, y de algunos estados, como el Distrito Federal o Nuevo León.

En lo que hace a la producción cinematográfica, éste sufrió una fuerte contracción a partir de la década de 1990, registrando niveles de la década de 1930 — tanto en lo que hace a la cantidad de filmes realizados y estrenados, como a la pobrísima cantidad de público que las películas nacionales convocan desde finales del siglo XX, a diferencia de lo que sucedió entre las décadas de 1930 y 1980.

A su vez, durante la etapa del neofomentismo la producción cinematográfica se volvió fragmentada, de nicho, atomizada, insustentable: sólo un puñado de productoras tienen una producción constante, con realizaciones que generen ingresos como para vivir de la actividad cinematográfica. La mayoría de los realizadores trabajan en múltiples actividades, y las productoras que se forman lo hacen para encarar uno o dos proyectos, para inmediatamente disolverse. Ya no existe el sistema de estudios de antaño, con millares de trabajadores dedicados a una actividad específica, trabajando establemente en una industria sustentable.

Por su parte, el mercado bajo el neofomentismo también se fragmentó: dentro del poco margen que dejan los estrenos de Hollywood, el cine mexicano fue lentamente recuperando presencia en las carteleras mexicanas desde finales de la década de 1990, pero con escasa porción de mercado.

Similar situación se da con los estrenos de otras latitudes, como América Latina y Europa: durante la primera década del siglo XXI estas películas se quedaron, en conjunto, con el 5\% de la oferta y demanda del mercado cinematográfico mexicano - la latinoamericana, lamentablemente, sólo representó entre el $0,1 \%$ y el $1 \%$ de los resultados de mercado en el país azteca. 
Con el tiempo, fueron surgiendo algunos blockbusters nacionales, aunque muy escasos en el tiempo - sólo una docena superaron los 2,5 millones de espectadores en el último cuarto de siglo- La mayoría de los estrenos mexicanos tienen destino de nicho — salas alternativas, de "cine arte", cinematecas, centros culturales, además de muestras y festivales varios-, al igual que la europea, latinoamericana y de otros países allende Estados Unidos. Las salas mexicanas perdieron "cine-diversidad", como dice García Canclini (2004), a diferencia de lo que acontecía en el período del cine industrial estatal. En la etapa neofomentista, el cine azteca no circula ni en América Latina ni en el resto del mundo -así como el cine latinoamericano y mundial (no estadounidense) apenas llega a México-, a diferencia de la importante presencia que la filmografía azteca tenía en gran parte del planeta algunas décadas atrás.

A su vez, el parque exhibidor mexicano no sólo se contrajo, sino que se alejó de las zonas populares, concentrándose en las regiones de mayor adquisitivo, con entradas cuyos precios se vuelven prohibitivos para la generalidad de la población mexicana, con precios que oscilan entre los 4 y los 8 dólares por boleto —más de la mitad de los mexicanos son pobres (los grupos familiares ganan menos de 150 dólares mensuales)—, situación muy distinta a la que se daba décadas atrás, cuando el boleto cinematográfico estaba controlado por el Estado, costaba pocos centavos de dólar y el poder adquisitivo de la población era mayor.

Las multinacionales hollywoodenses dominan el mercado mexicano de exhibición cinematográfica, y el oligopolio nacional de la exhibición actúa aliado a las majors - son los representantes locales de varios estudios, y preponderan los estrenos de este origen en detrimento del cine nacional, latinoamericano y del resto del mundo, salvo unos pocos títulos de estas últimas procedencias (que son comercializados por las distribuidoras hollywoodenses).

Se concluye que en lo que hace a las políticas públicas cinematográficas, México pasó de tener un Estado activo, presente, a uno pasivo, neofomentista, mero gerente de intereses — situación en la que, generalmente, termina primando el provecho de las grandes empresas concentradas, pertenezcan o no al sector cinematográfico. 


\section{CAPÍTULO VI \\ POLÍTICAS PÚBLICAS CINEMATOGRÁFICAS EN BRASIL}

\section{Introducción histórica}

Brasil produce filmes desde la década de 1910. Desde la década de 1930 el Estado incentivó la realización de películas —especialmente, educativas-, y fue uno de los primeros países en el mundo en instaurar una cuota de pantalla establecida —es decir, la obligatoriedad de una cantidad mínima de días de exhibición para las películas nacionales-. Brasil fue el primer país de América Latina en hacerlo, y desde esa época la medida proteccionista continuó aplicándose ininterrumpidamente. ${ }^{43}$

Para 1915 en Brasil se habían realizado unas 100 películas de un rollo - lo que era común en la época, así como eran poco comunes los largometrajes en el mundo-, destacándose éxitos de público como Os estranguladores (1906), Nhô Anastácio chegou de viagem (1908) y Viúva alegre (1909).

En lo que podría denominarse la prehistoria del cine brasileño, se pueden encontrar los llamados ciclos regionales — principalmente, originados en Río y San Pablo, pero también en Pelotas, estado de Río Grande del Sur, y en el estado de Bahia-, y nombres como Paulo Benedetti, Humberto Mauro y Roquette Pinto, entre otros.

En las primeras décadas del siglo pasado se fundaron compañías cinematográficas como Leal Filmes, Carioca y Guanabara, constituyendo el principio del cine realmente comercial. Cinédia, fundada por Ademar Gonzaga, fue pionera en la producción de filmes de estudio, y con las chanchadas — nacidas a finales de la década de 1930buscaron conquistar al gran público.

A lo largo de la década de 1930 se formaron varias organizaciones corporativas de distintas actividades —entre ellas, el cine-. En esos años se formaron la primera asociación de productores de cine y el primer sindicato de técnicos de cine.

Durante la década de 1940, y a lo largo de la de 1950, en Brasil se intenta construir un cine de "grandes estudios" — buscando emular, de algún modo, el sistema de Hollywood, un modelo mundial de industrialización cinematográfica-, que ya había sido llevado a cabo en Argentina y en México.

En el caso brasileño, el intento de construir grandes estudios a la manera hollywoodense tuvo lugar con el caso emblemático de Atlântida Cinematográfica, durante las décadas de 1940 y 1950. Atlântida producía "chanchadas" — género cómico popular brasileño

\footnotetext{
${ }^{43}$ Salvo el breve período comprendido entre marzo de 1990 y enero de 1992, durante la presidencia de Collor de Melo. La movilización del sector promovió que se volviera a instaurar la cuota de pantalla.
} 
que perduraría durante décadas- y musicales de carnaval, con un elenco de estrellas ya consagradas en la radio (star system). Este estudio tenía una producción "industrial” en gran escala - aunque en condiciones precarias-, y esbozó una integración vertical por medio de la asociación con Severiano Ribeiro, propietario de uno de los mayores grupos exhibidores de Brasil.

En 1951 un grupo de industriales paulistas asociados a un banco impulsan un ambicioso programa de cine en Brasil. Fundan otro estudio que sería mítico: la Compañía Cinematográfica Vera Cruz. Para esta experiencia se montaron grandes estudios en Sao Bernardo do Campo, encarándose una alta producción anual de filmes, de calidad técnica y artística.

En Vera Cruz todo giraba en torno al prestigioso Alberto Calvacanti —quien, sin embargo, sólo hizo un filme comercial de éxito: Simao, el bizco (1952)—. El proyecto de Vera Cruz, que se caracterizó por sus melodramas, también fracasó: los elevados gastos con los estudios y los altos costos de los filmes acabaron por llevarla a la quiebra. A mediados de la década de 1950 comienza a surgir en Brasil una renovación en el cine brasileño, de la mano del "realismo".

El realismo brasileño en el cine comenzó en 1954 y 1955. Anteriormente, las incursiones consideradas serias y realistas eran melodramas sin mayor vuelo. Se trataba de buscar un lenguaje cultural y artístico adaptado a la realidad brasileña.

El pionero en esta búsqueda de un nuevo lenguaje cultural y artístico adaptado a la realidad brasileña fue Nelson Pereira dos Santos, principalmente con el filme Río, cuarenta grados, una visión de la vida cultural de Río de Janeiro de esa época.

Otro hito en esta línea estética lo constituyó otro filme de Nelson Pereira dos Santos: Vidas secas -un filme realizado con escaso equipamiento técnico y con actores "económicos" (en el sentido del habla y de la gestualidad)—. Pereira dos Santos muestra ahí las condiciones infrahumanas que se viven en el sertão, región nordestina conocida en Brasil como el "polígono de la sequía".

Cineastas relevantes surgieron a lo largo de esa década, como Walter Hugo Khouri, Roberto Farias, Roberto Santos y Carlos Coimbra. Estos realizadores querían llevar a la pantalla la realidad subdesarrollada del hombre común brasileño. Pero en la literatura, en la música y en la pintura esta inquietud ya había sido acometida en 1922, en la famosa Semana de Arte Moderno. 
Posteriormente, en la década de 1960, aparece con todo su vigor el cinema novo. Como decía el director de cine Paulo César Saraceni: "nuevo no es por una cuestión de novedad, sino de verdad" (Keize, 1976b).

El cinema novo comienza en el interior del país - especialmente, en Bahia- Como sucede en el país con otras actividades, los principales cineastas del cinema novo se dirigieron al sur (Río, San Pablo) buscando mejores perspectivas de financiamiento para encarar sus realizaciones.

Un dato importante a tener en cuenta es que este nuevo espacio cinematográfico se montó sobre una estructura industrial importante, aquella que venía de las décadas de 1940 y 1950, y tenía en Atlântida y Vera Cruz sus principales referentes.

Al mismo tiempo, esta corriente intentaba volver a películas más populares, de mayor llegada masiva, con inspiración en temas culturales y urbanos. Glauber Rocha realizó Dios y el diablo en la tierra del sol y toda una producción centrada en el tema del subdesarrollo. Joaquim Pedro de Andrade hizo Macunaíma.

El cinema novo realizó manifiestos estético-políticos bajo el lema "Una cámara en la mano y una idea en la cabeza", pero al momento de plasmar sus películas - tanto en la preproducción, en la producción, como en la comercialización- utilizaban los canales tradicionales de la industria. Los cineastas de este movimiento realizaron algunas buenas y trascendentes películas —además de las mencionadas, se cuentan Ganga zumba, Cinco veces favela o Los fusiles-, filmes que tuvieron algún suceso internacional, pero que finalmente fueron fagocitados por la vieja estructura cinematográfica - de hecho, muchos de los que se iniciaron con el cinema novo en la década de 1960 hicieron posteriormente mucho cine comercial, como las “pornochanchadas", desde la década de 1970 en adelante.

A finales de la década de 1960 surgió el llamado cine marginal —o "udigrudi" (deformación en el habla brasileña de underground)—, un cine "lumpen" — como lo postulaban sus integrantes-, como una especie de crítica a las poses del cinema novo. Filmes de este efímero espacio — cuya posta luego tomarían las pornochanchadas de la década de 1970 - fueron Mató a la familia y se fue al cine o Bandido de luz roja. 


\section{Políticas públicas cinematográficas}

La presente tesis designa "neofomentismo" a las políticas cinematográficas contemporáneas llevadas a cabo desde mediados de la década de 1990 en Argentina, Brasil y México, aplicadas luego del desmantelamiento que —a lo largo de la década de 1990 - se hicieran del fomento estatal al cine.

El neofomentismo se contrapone al fomentismo, que el presente trabajo entiende como el período de las llamadas "épocas de oro" de algunas cinematografías latinoamericanas (México, Brasil y Argentina), donde las políticas públicas cinematográficas fueron muy activas en todos los eslabones de la cadena de valor del sector.

\section{Fomentismo}

Esta tesis entiende como fomentismo a la participación activa del Estado en la industria cinematográfica, tal como ocurrió, por períodos en Brasil (1969-1990) y México (19421992), interviniendo decididamente tanto en la producción, en la comercialización, en la distribución y en la exhibición, a través de la creación de empresas estatales para tal fin (como sucedió en el caso mexicano) o de asociación del Estado con empresas del sector (como ocurrió en el caso brasileño).

\section{Instituciones y normativa}

\section{Getulio Vargas, populismo y cine}

La primera normativa de protección al cine brasileño (ley $\mathrm{N}^{\mathrm{o}} 21.240$ ) data de abril de 1932, siendo una de las primeras en el mundo y la pionera a nivel latinoamericano. Esta ley contenía varias medidas, por ejemplo, nacionalizaba la calificación y censura de filmes a nivel nacional, creaba la primera tasa cinematográfica del país — la "tasa cinematográfica para la educación" (que se percibiría por la nacionalización del cobro de la calificación de películas nacionales y extranjeras)—, reducía tasas aduaneras para la importación de película virgen y, principalmente, obligaba a proyectar cortometrajes nacionales en las funciones comerciales de cine y, principalmente, creaba la cuota de pantalla, medida protagonista de las políticas cinematográficas en todo el mundo desde comienzos del siglo XX, que en el caso brasileño continúa en vigor hasta la actualidad. Esta ley se dio en un contexto de creciente nacionalismo que la dictadura de Getúlio Vargas luego reforzaría. Sin embargo, el nacionalismo en Brasil no se explica sólo por Vargas: éste supo captar lo que las nuevas fuerzas políticas venían bregando desde la década de 1920: por ejemplo, el "tenentismo" —movimiento de jóvenes oficiales con 
simpatías socialistas, surgido durante comienzos de la década de 1920-, la emergente burguesía industrial, los liderazgos obreros, e inclusive, los movimientos artísticos de los años veinte, todos ellos estaban en contra del poder omnímodo que hasta entonces habían tenido las oligarquías en el país. Las nuevas fuerzas políticas identificaban la solución de los problemas de Brasil con soluciones de tipo nacionalista. Vargas imprimió ese tinte a su gobierno.

El populismo se caracteriza principalmente por la emergencia de las clases populares en las luchas políticas y sociales. Según Weffort (1998), el populismo expresa dos cuestiones principales: la debilidad política de los grupos dominantes y la irrupción de las clases populares en el proceso de desarrollo urbano e industrial.

Ianni (1973) considera que los regímenes populistas sucedieron a los movimientos de clase media, como el tenentismo en Brasil o el yrigoyenismo en Argentina -movimientos que, en su momento, fueron la resistencia más fuerte contra el Estado y las elites oligárquicas.

El surgimiento del populismo como respuesta al quiebre de la hegemonía política de las oligarquías y el vacío de poder que fueron dejando frente a distintas crisis —especialmente, la del crack de Wall Street de 1929-, en medio de la crisis del modelo primario-exportador, el caso brasileño se aplica especialmente en este caso de ruptura de la hegemonía oligárquica. En el caso brasileño esto se ve claramente, mientras que en casos como el mexicano (con Lázaro Cárdenas) la emergencia de las clases populares se dio muy anteriormente al fenómeno populista -la Revolución de 1910, fue el quiebre hegemónico de la oligarquía) (Stanley, 2007).

En efecto, la llamada "Revolución del 30" marca un punto de quiebre en la historia brasileña: marca el fin de la Primera República (o "República Vieja"), estableciéndose una nueva forma de organización del Estado.

El nuevo estado dejó de representar los intereses de un sector determinado de la sociedad, en este caso, la burguesía del café, que había sido preponderante durante décadas, y que a partir de distintas crisis, ya no estaba en el centro de la escena, aunque seguía siendo gravitante. A su vez, la clase media no era suficientemente fuerte, y el tenentismo había fracasado en su intento de generar un gran movimiento basado en ella. Frente a este empate de fuerzas, el gobierno de Getulio Vargas se arrogó el papel árbitro y mediador de las disputas al interior de la sociedad brasileña. Se redefine el rol y la función del Estado, enmarcados en la ideología nacionalista y corporativista que atravesará el pensamiento político y económico durante la década de 1930, tanto en 
Brasil como en buena parte del mundo. Las antiguas disputas territoriales que alimentaron el nacionalismo ahora daban paso al desarrollismo (Camargo, 1993).

El Estado Novo - recrudecimiento del régimen totalitario y corporativo impuesto por Vargas en 1937- fue básicamente un estado autoritario que se transformó en el instrumento de acumulación capitalista al servicio de la burguesía industrial brasileña, mediante la "armonía de clases" y el aplacamiento de las demandas sociales y sindicales. Vargas nunca llegó a ser un líder de un movimiento unificado y en gran parte homogéneo, como fue el caso de Perón, pero sí fue un articulador de fuerzas heterogéneas sobre las que impuso su dominio personal mediante difíciles y cambiantes sistemas de alianzas. A su vez, Laclau (1986) afirma que el populismo brasileño nunca pudo construir un lenguaje y un imaginario político de dimensiones nacionales como sí lograron hacerlo Cárdenas y Perón.

Getúlio Vargas decía que las características del nacionalismo del siglo XX eran aquellas que le daban al Estado la responsabilidad de mantener el orden moral, la virtud cívica y la consciencia colectiva de la sociedad. En este contexto, Vargas destacaba el papel pedagógico del cine:

El cine será el libro de imágenes luminosas, en el cual nuestras poblaciones playeras y rurales aprenderán a amar al Brasil, acrecentando la confianza en los destinos de la patria. Para la masa de analfabetos, será esa la disciplina pedagógica más perfecta, más fácil e influyente. Para los letrados, para los responsables por el éxito de nuestra administración, será una admirable escuela. (Vargas, en Simis, 2008:30; traducción propia)

A su vez, debido a los altos índices de analfabetismo en Brasil —en 1900, el 85\% de los brasileños era analfabeto-, el Estado federal vio en el cine ventajas para utilizarlo como herramienta de enseñanza.

En 1927 una reciente comisión de cine educativo organizó una exposición de "aparatos de proyección fija y animada" que se llevaría a cabo en 1929; tenía el objetivo de conocer los últimos avances tecnológicos en la materia, y a partir de ellos evaluar futuros planes de acción. En 1930 el gobierno del Distrito Federal -que en ese entonces se ubicaba en la ciudad de Río de Janeiro- comenzó a instalar proyectores en las aulas (Simis, 2008). 
En 1931 el gobierno del estado de San Pablo también realizó acciones en este sentido: los recursos estatales se destinaron, en primera instancia, para adquirir equipamiento. Los proyectores adquiridos se utilizaron tanto para realizar funciones educativas como de entretenimiento: estas últimas eran pagas. Un par de años después el gobierno impulsó la apertura de filmotecas en todo el estado. Por su parte en el estado de Bahia, en 1935, se estableció el servicio de radio y cine educativo en las escuelas.

Durante el resto de la década, otros estados del país - como Rio Grande do Sul y Minas Gerais-, y diversos tipos de establecimientos —públicos, privados, estatales, municipales- siguieron estos pasos - hacia 1937 existían 542 escuelas con proyectores de cine en todo el país (el 64\% de ellas se encontraban en el Distrito Federal y en San Pablo) (Simis, 2008).

Además de la ley 21.240 de 1932, durante el primer período de Vargas en el poder (1930 a 1945) se ejecutaron varias medidas trascendentes en torno al cine. Una de ellas se inspiró en las experiencias alemana e italiana: la creación, en julio de 1934, del Departamento de Propaganda y Difusión Cultural (DPDC), un organismo dedicado al cine de propaganda política oficial.

En torno al DPDC se suscitó una puja entre el Ministerio de Educación y Salud y el Ministerio de Justicia por ver bajo qué órbita se ubicaría este flamante departamento de propaganda: Vargas, finalmente, se inclinó por el Ministerio de Justicia. El citado decreto también ratificaba la obligación de exhibir cortometrajes en las funciones comerciales de cine.

En enero de 1937 se crea el Instituto Nacional de Cine Educativo (INCE). Esta vez, el Ministerio de Educación tuvo su compensación: el Ince quedó bajo su órbita —así como el también nuevo Servicio de Radiodifusión Educativa.

El Ince quedó bajo la dirección de Edgar Roquette-Pinto, funcionario proveniente del Partido Socialista Brasileño, quien tenía antecedentes en la realización de documentales y en la utilización de la radio con fines educativos - "quiero sacar la ciencia del dominio exclusivista de los sabios para dársela al pueblo" (Roquette-Pinto, en Massarini, 2003; traducción propia).

Durante la gestión de Pinto — que se extendería hasta 1947- el Ince llegó a producir documentales educativos -este organismo estatal tenía instalaciones de revelado, montaje, sonido, copiado y estudios de filmación-, creó una filmoteca y armó una red de circulación de distintos filmes en escuelas, centros culturales, obreros y deportivos 
(Simis, 1996:36). Pinto inclusive invitó a cineastas reconocidos, como Humberto Mauro, ${ }^{44}$ para trabajar en la institución.

Mauro conformó dentro del Ince un equipo que daría al organismo una producción cinematográfica ininterrumpida a lo largo de dos décadas - Humberto Mauro realizaría 357 filmes durante toda su vida (entre cortos y documentales), la mayoría de ellos en el ámbito del Ince (Saraiva, 2004).

En noviembre de 1937 comenzó en Brasil el período denominado Estado Novo (19371945), que se inició a partir de un autogolpe de Vargas que disolvió la Legislatura, creó una nueva constitución que le daba a Getúlio el manejo de los tres poderes del Estado, prohibió los partidos políticos y recortó derechos civiles. Sin embargo, el endurecimiento del régimen de Vargas había comenzado en 1935, luego de un frustrado golpe comunista en noviembre de ese año.

Durante el Estado Novo se implementó una activa política cultural de Estado, conformando las bases de una burocracia profesional dedicada a la temática cultural (Harvey, 2005). En relación con el cine, se destaca la continuación de la labor del Ince —en el marco de la política que promovía la función pedagógica del cine- y la transformación, en 1938, del Departamento de Propaganda y Difusión Cultural en el Departamento de Prensa y Propaganda, cuya área de acción abarcó no sólo al cine sino también a la radio, la prensa y el turismo.

A su vez, en diciembre de 1939 se reestructuró el Departamento de Propaganda y Difusión Cultural (DPDC): por el decreto 1915 pasa a ser el Departamento de Prensa y Propaganda (DIP, por sus siglas en portugués). Este reconstituido órgano de gobierno subía de rango - ahora era un órgano de primer nivel en la burocracia estatal-, y dejaba de estar bajo la órbita del Ministerio de Justicia — como lo estaba el DPDC-, para pasar a depender de la tutela personal de Getúlio Vargas. Se nombró director del DIP a Lourival Fontes, fundador de la revista de tendencia fascista Hierarquia, y "hombre fuerte de la Intelligentzia estadonovista" durante largos años (Simis, 2008).

El DIP no sólo enfatizó el rol del cine al servicio de la propaganda política y de la censura cinematográfica, sino que también promovió la realización de los Cinejornais brasileiros, una serie de cortometrajes documentales que debían ser exhibidos obligatoriamente en las salas comerciales de cine de todo el país.

\footnotetext{
${ }^{44}$ Realizadores de la talla de Nelson Pereira do Santos y Glauber Rocha reconocían en Mauro a un maestro.
} 
Entre 1938 y 1941 se llegaron a realizar 250 cinejornais. Según José Inácio Souza “en la década de 1940 el Estado era el mayor productor y animador cultural del país" (citado en Simis, 2008:64; traducción propia). En 1942, Lourival Fontes crea el Consejo Nacional de Cinematografia dentro del DIP —específicamente, dentro de la División de Cine y Teatro del DIP.

En mayo de 1945 — año de la caída de Getúlio Vargas-, el DIP fue disuelto, casi once años luego de ser creado (como DPDC).

\section{Una etapa intermedia (1946-1965)}

El período que va de 1946 — año posterior a la caída de Getulio Vargas— hasta 1965 se caracterizó por un progresivo aumento de la cuota de pantalla a través de distintas medidas administrativas, ${ }^{45}$ que comenzaron en los 21 días (3 filmes) al año ( $6 \%$ del total anual) —cuantía vigente para el período 1946-1950 - para luego pasar a 31 días por año (5 películas, u 8\% del total anual) entre 1951 y 1958, 42 días anuales (6 filmes o $12 \%$ del total anual), llegando a 56 días por año (7 películas o $15 \%$ del total anual) entre 1963 y 1968 (Autran, 2004:43; Harvey, 2005:46; Johnson, 1987:185). Posteriormente, ya en el período "Embrafilme", del que se hablará más adelante, la cuota de pantalla alcanzaría los 140 días por año para el período 1980-1990 (Amancio, 2000:47). ${ }^{46}$

A la cuota de pantalla se agregaron, en este período 1946-1965, distintas disposiciones sobre exención de derechos aduaneros para la importación de material destinada a la industria cinematográfica nacional.

Por ejemplo, en 1949, el gobierno del presidente Dutra ofreció exención impositiva a la importación de equipamiento de rodaje y exhibición. Esta medida fomentó el nacimiento de grandes estudios.

En 1955, luego del suicidio del presidente Getúlio Vargas -elegido por el voto popular en 1950-, el gobierno de la ciudad de San Pablo aplicó un impuesto del 15\% sobre la recaudación cinematográfica de las salas instaladas en la ciudad, con el fin de fomentar la producción fílmica local. Diez años después, la ciudad de Río de Janeiro adoptaría una medida similar.

\footnotetext{
45 Hasta la creación del Instituto Nacional de Cine, la cuota de pantalla se estipulaba en "portarias" (decretos ministeriales). Posteriormente, a partir de la primera presidencia de Fernando Henrique Cardoso, la cuota de pantalla comenzó a establecerse por decreto presidencial —medida administrativa que continúa hasta la actualidad.

${ }^{46}$ Después de que Collor de Melo eliminara la cuota de pantalla en 1990, el Estado brasileño volvió a instituirla apenas un año y medio después, por presión del sector cinematográfico. Desde fines de la década de 2000 el número anual de exhibición obligatoria de largometrajes brasileños es de 49 . La cantidad de días para el cumplimiento de la cuota son establecidos anualmente por decreto del/a presidente de la República.
} 
En 1956 se conforma una Comisión Federal de Cine, que posteriormente sería sustituida tanto por el Grupo de Estudios de la Industria Cinematográfica (GEIC) —enmarcado en el entonces Ministerio de Educación (1958) - como por distintos organismos de estudios y consultas. En 1961, se crearía el Grupo Ejecutivo de la Industria Cinematográfica (Geicine) — que en 1963 pasaría a depender del Ministerio de Industria y Comercio-. Por su parte, en 1964 el Estado brasileño instrumentó con mayor detalle las características que debía tener una película brasileña para ser considerada "producto nacional", mientras que en 1965 promovió el suministro de material virgen para los cineastas locales (Simis, 1996; Amancio, 2000; Autran, 2004).

\section{Instituto Nacional do Cinema (1966-1975)}

Luego de los organismos nacionales pioneros dedicados al cine - los mencionados Instituto Nacional de Cine Educativo (Ince) y el Grupo Ejecutivo de la Industria Cinematográfica (Geicine)-, la institución relevante en el sector fue el Instituto Nacional de Cine (INC), creado en noviembre de 1966 por la dictadura militar que gobernaba el país desde abril de 1964.

El instituto de cine era un proyecto largamente impulsado por la comunidad cinematográfica brasileña desde fines de la década de 1940.

El INC fue constituido como una entidad autárquica, con autonomía administrativa, técnica y financiera, dependiente del entonces Ministerio de Educación y Cultura. El INC se creó y configuró de manera similar a otras importantes instituciones culturales impulsadas por la dictadura militar — como el Consejo Federal de Cultura, Funarte y Pro-Memoria, entre otros-, en su proyecto "desarrollista", modernizador y crecientemente represivo (Chalupe, 2010).

El instituto de cine -que aglutinó al viejo Instituto de Cine Educativo (el Ince de Humberto Mauro) y al Geicine - tenía distintas actividades y funciones, por ejemplo, diagramar y llevar a cabo la política gubernamental destinada a la producción, distribución e importación de películas; desarrollar la industria de cine, su fomento y promoción en el exterior; regular, junto al Banco Central, la importación de películas extranjeras para ser exhibidas en los cines y en la televisión; regular la producción, distribución y exhibición de filmes brasileños, fijando los precios del alquiler, los plazos de pago y otras condiciones; regular las condiciones de alquiler de películas extranjeras en las salas brasileñas de cine; otorgar financiamiento y premios a las películas nacionales; crear y llevar un registro de productores, distribuidores y exhibidores; 
realizar y comprar filmes educativos y culturales; firmar acuerdos de coproducción cinematográfica con otros países —el primero había sido suscripto en 1963, con España-, y reglamentar la filmación de películas extranjeras en Brasil (Simis, 1996; Amancio, 2000).

A su vez, el instituto de cine estaba compuesto de dos consejos: el Consejo Consultivo y el Consejo Deliberativo. El primero estaba conformado por los representantes de los productores, directores, distribuidores y exhibidores, mientras que el Consejo Deliberativo lo constituían representantes de distintos ministerios: de las actividades de este último - que duraron nueve años- se aprobaron 112 resoluciones, entre las que se destacaban el aumento en la cantidad de días de la cuota de pantalla, la obligatoriedad de que las películas extranjeras realizaran las copias que serían exhibidas en Brasil en laboratorios nacionales, y la implantación del control de recaudación en las boleterías de cine a partir de máquinas registradoras.

Entre los distintos recursos que manejaba el INC se encontraba, principalmente, la Contribución para el Desarrollo de la Industria Cinematográfica Nacional (Condecine) - tributo que todavía existe, y que consiste en el pago obligatorio que deben realizar los productores y distribuidores cinematográficos sobre la base del cálculo por metro lineal de copia positiva de todas las películas que han de exhibirse comercialmente en los cines y en la televisión-. Otro recurso importante del que disponía el Instituto de Cine provenía de las tasas que debían pagar las empresas extranjeras dedicadas a la explotación de películas en el circuito exhibidor brasileño por las remesas que enviaban a sus casas matrices.

El Instituto Nacional de Cine fue disuelto formalmente en diciembre de 1975. Sin embargo, en 1969 sus ingresos y recursos, además de varias de sus atribuciones, habían sido transferidos a la recién creada Empresa Brasileña de Filmes (Embrafilme), que sería la entidad más relevante en la construcción de una industria de cine en Brasil.

\section{Empresa Brasileira de Filmes (Embrafilme) (1969-1990)}

Embrafilme llegaría a incursionar en el fomento a todos los eslabones de la industria cinematográfica, con el explícito apoyo del gobierno militar y su política de industrialización y creación de agencias nacionales productivas.

La experiencia del Instituto Nacional de Cine (INC) en lo que hace a su propuesta de incentivo, fomento y fiscalización de este sector, además de la del Departamento de Cine Educativo (Ince) y la del Grupo Ejecutivo de la Industria Cinematográfica 
(Geicine), fueron los antecedentes que abonaron el terreno para que se creara la Empresa Brasileña de Filmes (Embrafilme).

La Embrafilme fue constituida el 12 de septiembre de 1969 por el decreto-ley 862, con el objetivo de que una empresa estatal actuase en los distintos eslabones de la cadena productiva cinematográfica -coproducción, financiamiento, distribución y regulación- Los recursos de la empresa provenían del impuesto a la renta sobre los giros de remesas de las distribuidoras extranjeras.

Embrafilme, empresa de economía mixta —el Estado era accionista mayoritario, con el $70 \%$ - tenía como objetivo inicial la distribución y promoción de filmes brasileños en el exterior, además de realizar muestras y presentaciones en festivales.

En síntesis, la Empresa Brasileña de Filmes fue creada con el objetivo de consolidar un programa que concentrara en el Estado la posibilidad de desarrollo industrial del cine. Asimismo, buscaba ser un órgano legislador — de fomento e incentivo- y fiscalizador, responsable por el mercado externo y por las actividades culturales.

Al comienzo, el sector cinematográfico reaccionó negativamente por la forma en que la empresa había sido concebida, puesto que las actividades estaban direccionadas solamente hacia la distribución de filmes brasileños en el exterior, lo que "explicitaba también el carácter autoritario de la medida, llevada a cabo sin la necesaria discusión con los distintos sectores de la industria cinematográfica" (Amancio, 2000:24).

Pero esta fueron los comienzos. Se pueden diferenciar tres grandes períodos en la existencia de la Embrafilme:

- de 1969 a 1974 hubo un acercamiento entre el nuevo e importante ente gubernamental y el sector cinematográfico; la dirección de Embrafilme se encontraba todavía delineando el rumbo de la empresa estatal;

- entre 1974 y 1978 se dio la "época de oro" de Embrafilme: el sector cinematográfico asume el mando de las actividades. La dirección general pasa a ser ocupada por uno de los representantes de los gremios: Roberto Farias, un cineasta ligado al cinema novo, en detrimento de otros sectores internos, como los realizadores paulistas de filmes populares conocidos como "boca do lixo". ${ }^{47}$ El estatuto de la Embrafilme es reformado y la empresa, además de distribuir y financiar filmes brasileños, pasa también a coproducir cine nacional, y

47 "Boca de basura." 
- entre 1979 y 1990 se da una paulatina decadencia de Embrafilme, hasta llegar a la extinción de la entidad en marzo de 1990, a partir de la oleada privatizadora y desreguladora del recién asumido presidente Fernando Collor de Melo.

Un instrumento importante de la "época de oro" de Embrafilme fue el Consejo Nacional de Cine (Concine), creado en 1976 y dedicado a la regulación y fiscalización de la actividad cinematográfica $-\mathrm{y}$ del que se hablará con mayor detalle en un apartado posterior.

Vale acotar que Embrafilme, en tanto empresa de economía mixta, operaba en el mercado como una empresa privada, mientras que el Concine poseía autarquía, aunque en la realidad se encontraba muy ligado a los humores gubernamentales.

En la "época de oro" Embrafilme había logrado variadas atribuciones: coproducir con los cineastas locales, financiar, distribuir, exhibir y comercializar filmes brasileños en los mercados nacional e internacional; además llevaba el registro de productores, distribuidores, exhibidores, laboratorios y estudios cinematográficos —según las normas del Concine-, aprobaba los proyectos de instalación, ampliación y renovación de estudios y laboratorios; fiscalizaba la venta de entradas en los cines; y hasta publicaba libros sobre cine brasileño, como el clásico "Revolução do cinema novo" de Glauber Rocha, publicado en 1981 (Chalupe, 2010; Autran, 2004).

Al comenzar la década de 1980 Embrafilme comenzó a enfrentar distintas dificultades administrativas y presupuestarias, momento de "vaciamiento político y económico de la actividad cinematográfica nacional" (Gatti, 1999:9), obteniendo resultados de mercado poco auspiciosos, con una gran crítica en contra, tanto desde el propio sector cinematográfico como desde los principales medios de comunicación.

En esta década la protección del cine nacional se desdobló en diferentes medidas legales, tales como el impedimento de que un filme nacional sea retirado de cartel en el caso de que estuviera teniendo una convocatoria por encima de la media de la sala — "lei da dobra", similar a la media de continuidad argentina impuesta a mediados de la década de 2000—;8 la obligatoriedad de exhibición de cortos nacionales antes de un largo extranjero; y una cuota para el cine brasileño en el entonces incipiente mercado de

\footnotetext{
48 Tanto la "lei de dobra" como la media de continuidad refieren al porcentaje mínimo de público necesario para que una película nacional que fue exhibida gracias a la cuota de pantalla, y que haya obtenido un número mínimo de espectadores, no pueda ser retirada de cartelera, generando la obligatoriedad de exhibición en la misma sala en la semana siguiente.
} 
video. Todas estas medidas tenían la presión en contra tanto de la industria televisiva local como de las majors estadounidenses.

En 1986 se intentó una renovación con el lanzamiento de la "política nacional de cine", en un contexto de crecientes cuestionamientos por parte de la opinión pública y de los medios - principalmente, de la Folha de Sao Paulo - con respecto al apoyo estatal al sector cinematográfico y al cine brasileño en en general - con adjetivaciones como "paternalismo" y "burócratas del cine".

En 1990 la flamante administración de Collor de Melo ordenó la liquidación de la Embrafilme -entre otras entidades estatales de apoyo, fomento y regulación del cine, como el Concine.

\section{Conselho Nacional de Cinema (Concine) (1976-1990)}

La ley 6.281 de diciembre de 1975 extinguió el Instituto Nacional de Cine —creado en 1966, tres años de Embrafilme- y amplió las atribuciones de la Empresa Brasileña de Filmes.

En marzo de 1976 el decreto 77.299 creó el Consejo Nacional de Cine (Concine), en el marco del entonces Ministerio de Educación y Cultura. El Concine quedó directamente ligado al ministro como órgano de orientación normativa y de fiscalización.

Este Consejo Nacional de Cine tuvo un peso importante en el sector. Sus principales actividades se relacionaban con la regulación de la exportación e importación de filmes, las condiciones de comercialización de las películas (nacionales y extranjeras) 一en lo que hace, principalmente, a plazos y precio-, la cuota de pantalla - tanto para largos como para cortometrajes-, la elaboración de normas de coproducción —en relación con la Cancillería-, la regulación de las normas de filmación de películas extranjeras en Brasil y la instrumentación y puesta en marcha del registro de productores, distribuidores, exhibidores, exportadores e importadores, de laboratorios y también de compañías de insumos y equipamiento cinematográficos (Harvey, 2005).

El Concine también regulaba la participación de los productores brasileños en los resultados de mercado de los filmes, así como también en la realización de filmes — de aquellos producidos con recursos provenientes de la comercialización de filmes extranjeros en Brasil-. A su vez, el Consejo Nacional de Cine velaba por la aplicación de la contribución fiscal para el desarrollo de la industria cinematográfica (Condecine) - a pagar, principalmente, por los productores y distribuidores-, y establecía premios e incentivos para filmes nacionales —en conjunto con Embrafilme (Tunico, 2000). 
El Concine estaba compuesto por un presidente, designado directamente por el presidente de la República, a quien acompañaban representantes de distintos ministerios, así como también el director de Embrafilme y tres representantes de los distintos sectores de la actividad (productores, directores, distribuidores y exhibidores) —estos últimos eran designados por dos años (al igual que el presidente del Consejo) (Gatti, 1999).

En 1985, mediante el decreto 91.144, el Concine fue vinculado al recién creado Ministerio de Cultura — bajo el flamante gobierno de José Sarney (el primero ungido en las urnas luego de 30 años de dictadura militar)—. Esta acción buscaba regular las actividades del cine en todo el territorio nacional mediante su normatización, control y fiscalización (Tunico, 2000).

$\underline{\text { La influencia de Embrafilme en el cine brasileño }}$

Embrafilme fue la mayor financiadora del cine brasileño, y su principal distribuidora. A pesar de haber surgido en plena dictadura militar, Embrafilme dio cabida a los intereses de los cineastas — que, desde la década de 1950, ya proponían acciones estatales más enérgicas para el cine.

Sólo para tener una idea del vínculo entre Embrafilme y los cineastas -inclusive los de izquierda-, el realizador Roberto Farias - ligado al grupo del cinema novo- fue funcionario de Embrafilme en uno de sus períodos más productivos, entre 1974 y 1979. Durante más de dos décadas de actuación (1969-1990), Embrafilme fue responsable de la regularidad de la producción de cine en Brasil, por medio del financiamiento de la producción, del apoyo en la exhibición -mediante la cuota de pantalla para los filmes nacionales- y de la comercialización de las películas brasileñas.

Además de eso, en su período más productivo Embrafilme ayudó a conformar la época donde el público consumió más cine nacional, entre mediados de la década de 1970 y comienzos de la de 1980. En estos años el cine brasileño disputaba el mercado local de cine con las majors de Hollywood, batió récords de público que apenas se repitieron en años posteriores.

Entre 1974 y 1978 el número de espectadores del cine brasileño pasó de 30 millones a 60 millones, y la cuota de mercado de los cines nacionales llegó al 36\% en 1982 (Amancio, 2000). Fue en ese período cuando un filme brasileño batió el récord absoluto de convocatoria: Dona Flor e seus dois maridos (Bruno Barreto, 1976), que tuvo más 
de 10 millones de espectadores, marca que recién se superaría 34 años después, en 2010, con el filme Tropa de élite (11 millones de espectadores).

Sin embargo, aunque Embrafilme era la mayor productora y distribuidora del cine brasileño en el período señalado, no era la única - y ni siquiera financiaba la mayoría de los filmes nacionales (Keize, 1976b)—. Paralelamente a Embrafilme había productores independientes que hacían sus filmes sin financiamiento del Estado. Por ejemplo, las "pornochanchadas" de la década de 1970, o los filmes abiertamente más pornográficos de los años ochenta — producidos en Río de Janeiro y principalmente en la "boca do lixo" (boca de basura) de San Pablo_-, con su mezcla de irreverencia y pasatismo, comedia y erotismo simplistas, y cierta crítica social a los valores establecidos. Los directores de esta especie de movimiento sui generis fueron criticados tanto por los referentes del cinema novo como por los funcionarios de Embrafilme y las posturas políticamente correctas del momento.

Estos son ejemplos de esa producción que existió al margen de Embrafilme, y que se desarrollaron merced a un particular mecanismo de producción, distribución y exhibición desarrollado en estos "polos cinematográficos" (Gatti, 2008): los filmes eran producidos utilizando prácticas de producción "industriales" — sin tener grandes estudios-, a la vez que eran distribuidos por pequeñas empresas locales y exhibidos únicamente en los cines de la región en que fueron producidos.

Según José Ortiz Ramos el cine de boca do lixo paulista presentó "algunos esbozos de producción industrializada, y también ensayos de una producción de estudio" (Ortiz, 2004:21). De cierta manera, este cine "basura" consiguió realizar por algunos años la tan soñada integración vertical del cine brasileño, uniendo producción, distribución y exhibición.

Sin embargo, es justo resaltar que aunque la producción del boca do lixo no tenía apoyo gubernamental, indirectamente sí lo tenía al momento de su estreno comercial, a través de la fuerte cuota de pantalla y de la "lei da dobra" - similar a una media de continuidad-, que permitía a una gran cantidad de filmes permanecer en cartelera.

Esta modalidad de producción cinematográfica fue conocida en Brasil como “cineminha", en contraposición al "cinemão" (Izar, 2009), que sería el heredero de la tradición del cinema novo, más "culto" - y que, paradójicamente, fuera financiado por la estatal Embrafilme durante la dictadura militar. 


\section{Neofomentismo}

Esta tesis entiende al neofomentismo como las políticas cinematográficas que tienden a fomentar uno o varios eslabones de la cadena de valor - aunque preponderando a la producción-, que se dan de manera limitada, parcial e inconexa - a diferencia de lo que sucedía en el caso del Estado empresario.

A su vez, las ayudas "mercado orientadas" (una de las categorías del neofomentismo, muy relacionadas con el caso de Brasil) se basan en recursos estatales. Estas son medidas adoptadas en varios países desde la década de 1990, centradas en la exención fiscal, es decir en la renuncia fiscal por parte del Estado para que determinados gravámenes a las ganancias y a las remesas enviadas al exterior, entre otros, se vuelquen a la producción y comercialización cinematográfica.

De esta manera es el mercado, y sus grandes actores - muchos de ellos, multinacionales-, quienes, finalmente, direccionan los recursos de fomento al cine — son estas empresas las que eligen qué proyectos (qué temáticas y visiones del mundo) apoyarán—. Es el caso de Brasil desde comienzos de la década de 1990.

En marzo de 1990 el recién asumido presidente Collor de Melo realizó diversas privatizaciones en áreas productivas apoyadas por el Estado, entre ellas, el cine. Unos de los primeros decretos declarando extintas a empresas y agencias del Estado fueron los dedicados a la liquidación de Embrafilme y de otras entidades estatales de fomento al cine y a la cultura.

Posteriormente, y a partir de la movilización y presión del sector cinematográfico, el Estado brasileño adoptó medidas de apoyo al cine -y a la cultura- basadas con exclusividad en la exención fiscal, situación que continúa hasta la actualidad - aunque en 2008 comenzó a regir una importante herramienta de fomento dirigida por el Estado (el Fondo Sectorial), la preponderancia la sigue teniendo la renuncia fiscal, tal como se verá a continuación.

Por ello esta tesis postula que en Brasil se da, desde finales de la década de 2000, una conjunción entre el fomento "orientado por el mercado" y el "orientado por el Estado".

\section{0: fin de una época}

Fernando Collor de Melo, hijo y nieto de políticos brasileños, ganó las primeras elecciones libres posteriores a la dictadura militar. Asumió con 41 años la presidencia de la República, cubierto por un manto de "outsider" de la política que llegaba a 
combatir la corrupción y los privilegios, en medio de una hiperinflación de 38\% mensual y de un descreimiento generalizado de la clase política.

Los dos años de la administración de Collor (quien renunció el 27 de diciembre 1992, minutos antes de que comenzara su juicio político) estuvieron marcados por la privatización de empresas estatales (con el consiguiente despido de miles de trabajadores estatales), en un marco de programa global de reformas y de revisión cuestionadora del rol del Estado en la economía, por ejemplo, en lo que hace a la protección a la industria (fin de subsidios e incentivos fiscales), a la reformulación integral del comercio exterior (con una fuerte apertura comercial, incentivando las importaciones) y a un fuerte ajuste fiscal (reducción del gasto público) —el primer día de su presidencia Collor anunció la confiscación provisoria por 18 meses de cuentas corrientes, de ahorro y financieras que excedieran los 50 mil cruceiros (unos 1300 dólares de entonces); posteriormente anunciaría el congelamiento de precios y salarios.

Sin embargo, la oleada privatizadora no comenzó en Brasil con Collor, sino con la dictadura militar, diez años antes: en 1981 se creó la Comisión Especial de Desestatización. Entre este año y 1989 el Estado brasileño privatizó 38 empresas estatales -en realidad, muchas fueron reprivatizaciones (compañías que en sus orígenes fueron privadas y posteriormente fueron estatizadas por problemas financieros)—, aunque ninguna era una sociedad importante, como serían las privatizadas durante el gobierno de Collor — vaya como ejemplo: en el período 19811989 se realizaron 17 procesos de privatización, recaudando 549 millones de dólares; en los dos años de Collor se produjeron 16 procesos de privatización, equivaliendo a 3900 millones de dólares (una sola empresa estatal, Usiminas, privatizada en 1991, recaudó el doble de todo lo que el Estado consiguió durante la década de 1980).

La medida provisoria (una especie de decreto de necesidad y urgencia) que sentó las bases de las políticas privatizadoras tomadas por Collor fue dictada el 15 de marzo de 1990.

Ese momento histórico también marcó el fin de un ciclo en la historia del cine brasileño: el día 16 de ese mes Collor de Mello clausuró la política cultural practicada hasta entonces, cuando extinguió la única ley brasileña de incentivo fiscal para inversiones en cultura (ley $N^{0} 7505 / 86$, conocida como Ley Sarney) y — principalmente, en lo que hace al cine- por medio de la medida provisoria 151 (del 15 de marzo de 1990) disolvió y extinguió autarquías, fundaciones y empresas públicas federales, como la Empresa Brasileña de Filmes (Embrafilme), la Fundación del Cine Brasileño (FCB), la 
Fundacion Nacional de las Artes (Funarte) y el Concine -Consejo de Cine, órgano vinculado a Embrafilme, responsable por las normas y por la fiscalización de la industria cinematográfica del mercado de cine en Brasil, controlando la obligatoriedad de la exhibición de filmes nacionales-. El mismo paquete de medidas disolvió el Ministerio de Cultura — transformándolo en una secretaría de gobierno-, y en general, la regulación del mercado, las políticas de apoyo a la producción, la estructura de distribución de filmes nacionales, la fiscalización y la recolección de datos y estadísticas.

El fin de Embrafilme coincide con cuestionamientos sobre la posibilidad de que el cine sea una actividad autosustentable en Brasil y sobre la relación de dependencia del sector con respecto al Estado. El gobierno de Collor, que concibió a la cultura y al cine como "problemas de mercado", provocó reacciones del campo cinematográfico y revisiones dentro del propio Estado, iniciando discusiones que llevarían a la implantación de una política cinematográfica basada en la renuncia fiscal.

El fin de Embrafilme, del Concine y de la Fundación del Cine Brasileño representa el cierre de un ciclo de la historia cinematográfica brasileña. Y no solamente porque desde entonces el cine brasileño perdió a su principal financiador y distribuidor, sino básicamente porque perdió sus mecanismos de protección frente al cine extranjero.

Además de la extinción de estos órganos gubernamentales de apoyo al cine, Collor también promovió la desregulación de la actividad, acabando con la cuota de pantalla y promoviendo la apertura irrestricta de las importaciones. A partir de ello, el cine extranjero -en especial, el hollywoodense- tomó las salas de proyecciones, reforzando su hegemonía. En 1990, el público de cine nacional fue de 10,51\%, mientras que en 1983 había alcanzado el 35,93\% de los espectadores de cine, el período más productivo de Embrafilme; es decir, si a inicios de la década de 1980 se había llegado a un tercio del mercado, en 1990 se había retrocedido a menos de un quinto. 
Gráfico 31 - Brasil: porcentaje de mercado de los filmes nacionales, por espectadores (1971-2009)

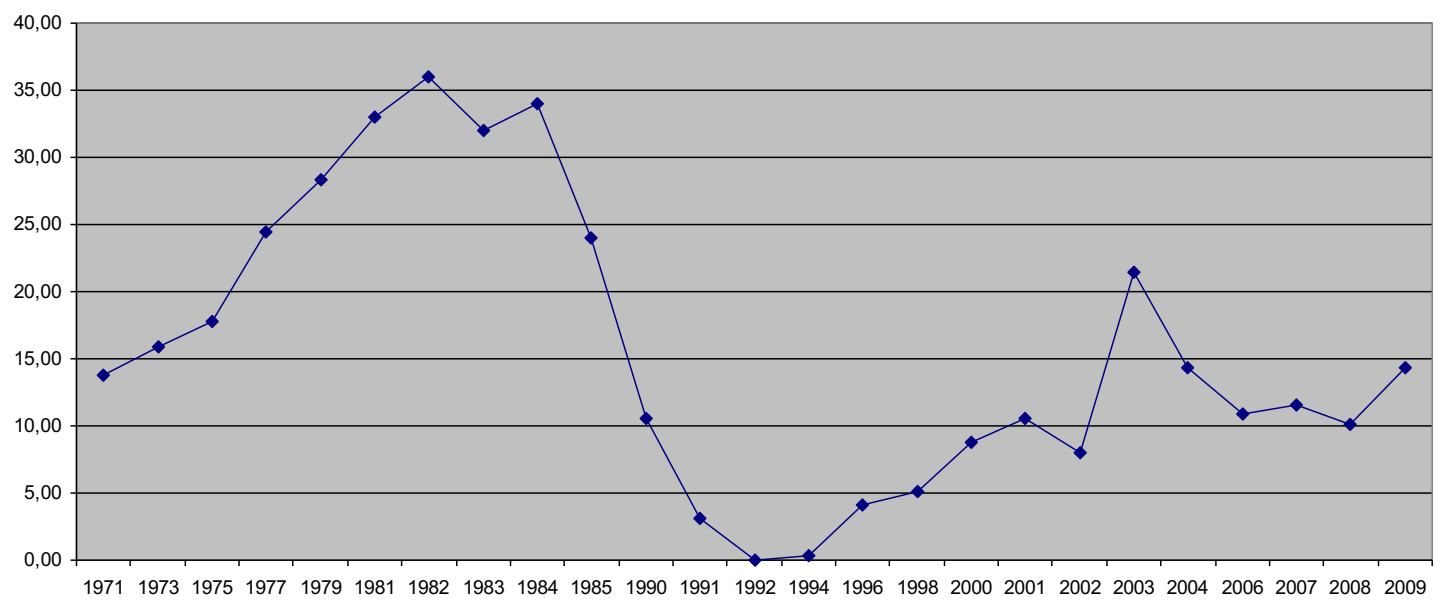

Fuentes: Ancine, Embrafilme, Instituto Nacional de Cinematografía, Filme-B, Johnson (1993), Unesco (1982).

Para empeorar más la situación, el gobierno dejó de cumplir compromisos y contratos asignados en la época de Embrafilme, incluyendo acuerdos internacionales de coproducción, haciendo que varios filmes que estaban siendo producidos quedaran parados.

Es decir, que no sólo se extinguió Embrafilme y otras empresas del Estado para fomentar al cine, sino que en su lugar no se generó ninguna política pública cinematográfica, lo que desestructuró al sector.

Tímidamente fueron surgiendo algunos filmes, realizados por medio de coproducciones internacionales pactadas de manera privada, de la asociación con emisoras de televisión y del apoyo de algunos pocos estados federales y municipales. A diferencia de lo que venía sucediendo en el cine brasileño, con una tradición que buscó construirse en torno al reflejo de una nación y de su pueblo, los filmes de comienzos de la década de 1990 se realizaron con estéticas y contenidos más "internacionales", y con estilos narrativos provenientes de la televisión.

Al interior del sector se impuso la premura de resolver las distintas situaciones personales: los trabajadores cinematográficos migraron, en su mayoría, a la publicidad, la televisión u otras profesiones. A comienzos de la década de 1990 la parálisis se había apoderado del sector como conjunto, y a diferencia de lo sucedido durante las décadas de 1960 y 1970, cuando los grupos se disputaron las riendas de fuertes apoyos y las estéticas y sentidos de un cine con creciente influencia, al comenzar la década de 1990 el sector solamente luchaba por sobrevivir.

De a poco el sector cinematográfico fue saliendo de su apatía, y volvió a movilizarse pidiendo al gobierno medidas de fomento al cine. Así, luego de diálogos entre el 
gobierno y representantes del sector, que culminaron en la conformación de una comisión mixta, se logró la sanción de la ley 8.401 en enero de 1992, cuyos principales logros fueron la vuelta de la cuota de pantalla y la facilitación de las coproducciones internacionales. Esta ley fue el embrión de la futura (y trascendente, para el sector) Ley del Audiovisual, que sería sancionada al año siguiente.

Otro hecho importante ocurrido en estos años — todavía bajo el gobierno de Collor, con Sergio Rouanet como secretario de Cultura - fue la obligatoriedad de la exhibición de cine en televisión, aunque sólo restringida a los canales públicos.

Con Rouanet al frente de la Secretaría de Cultura, se dieron los primeros pasos hacia el llamado "cine de la retomada" —es decir, un período de auge del cine brasileño a mediados de los años noventa-, debido principalmente a la presión del campo cinematográfico que pedía una nueva normativa de fomento hacia el sector.

Al finalizar el gobierno de Collor (diciembre de 2002) (9 $^{49}$ ya se vislumbraba la política cinematográfica que se desarrollaría durante el resto de la década de 1990: un sistema basado en la exención fiscal - concentrado en el sector de la producción (con dineros del Estado que finalmente son orientados por grandes empresas, base de lo que esta tesis llama "neofomentismo-mercado orientado")-, propiciando un sector más concentrado que produce un acotado número de filmes de nicho, de autor, con perspectivas comerciales y estética "televisiva" e internacional.

En definitiva, el sector cinematográfico brasileño sobrevivió durante los primeros años de los años 1990 (gobierno de Collor) a través de una normativa estatal sostenida por la renuncia fiscal - varios estados y municipios crearon concursos, incentivos fiscales locales y patrocinios-, y de algunas coproducciones realizadas en conjunto con otros países -especialmente, España.

Entre 1993 y 1994 - ya en la presidencia de Itamar Franco (vicepresidente del destituido Collor de Melo) — un importante número de filmes se encontraba en fase de producción, merced a la llamada "ley Rouanet" — basada en la renuncia fiscal— y de la Ley del Audiovisual —aprobada en 1993- A mediados de la década la prensa comienza a hablar de "retomada" del cine brasileño.

El período 1995-1998 se da el período propiamente dicho del cine de la "retomada" en Brasil: un resurgimiento del cine nacional, con mayor producción y visibilidad de los

\footnotetext{
49 Collor de Melo dejó de ser presidente en septiembre de 1992, esperando la finalización del juicio político en su contra, que en diciembre de ese año decidió su destitución.
} 
filmes brasileños, con éxitos tanto a nivel local como internacional. Este período coincide con el primer gobierno del presidente Fernando Henrique Cardoso.

La aprobación de las leyes de incentivo fiscal promulgadas algunos años antes (1991 y 1993) abonó el terreno para este resurgimiento, con producciones como Carlota Joaquina (1995), O quatrilho (1996) y Central do Brasil (más conocida en el ámbito latinoamericano como "Estación central", del año 1998), con un cine que tuvo gran éxito local y ganó variados premios internacionales, recobrando legitimidad frente a la sociedad y fuerza dentro del Estado.

Para el segundo mandato de Cardoso (1999-2002) al interior del sector cinematográfíco comienzan a darse cuestionamientos, y se da un retorno del discurso político al cine brasileño: los realizadores, productores y demás actores cuestionaban que las políticas públicas cinematográficas se centraran en la mera renuncia fiscal, en tiempos en que la concentración se reforzaba. El sector exigió al Estado que propiciara las condiciones de posibilidad en pos de la industrialización del cine y el audiovisual.

Esta movilización del sector se reflejó en la realización de los III y IV Congresos Brasileños de Cine (2000 y 2001) — una conjunción del sector que sólo se había dado medio siglo antes, en 1952 y en 1953, con el I y el II Congreso Brasileño de Cine- ${ }^{50}$ La creación de la Agencia Nacional de Cine (Ancine) en 2001 fue un resultado directo de esta articulación y movilización del sector.

A continuación se detallarán las instituciones cinematográficas estatales surgidas en este período.

\section{Instituciones públicas relacionadas con el cine}

\section{Secretaría para el Desarrollo del Audiovisual (1995-2002)}

Durante los dos gobiernos de Fernando Henrique Cardoso (1995-2002) se reestructuraría el Ministerio de Cultura. En lo que hace al cine, al interior de este ministerio se creó la Secretaría para el Desarrollo del Audiovisual (SDAv), la que se dedicó a gestionar y coordinar las actividades del sector en todo el país -especialmente, en lo que hace al cine-, mediante programas y distintas acciones

\footnotetext{
${ }^{50}$ Los "Congressos Brasileiros de Cinema" son hitos en la historia del sector cinematográfico brasileño: ellos fueron excepcionales, y se realizaron con el pleno de los trabajadores, creadores, empresarios y referentes de los distintos eslabones de la cadena de valor, en ocasiones en que el sector se unió como cuerpo para exigir al Estado acciones y/o cambios de rumbo. El IV Congreso Nacional de Cine Brasileño fue el que acá se menciona, realizado en noviembre de 2001.
} 
relacionadas con la producción, difusión, conservación y establecimiento de relaciones con el exterior en torno a las actividades del sector.

A partir de 1999 la SDAv se transformaría en la Secretaría del Audiovisual -que todavía subsiste-, también enmarcada en la estructura administrativa del Ministerio de Cultura: hasta 2002 —todavía bajo la gestión Cardoso- este organismo vería incrementado su presupuesto, consolidaría la aplicación de las leyes de incentivos cultural y audiovisual y se realizarían varios concursos y premios para el sector -aunque, en definitiva, el fomento del cine seguía estando, principalmente, en manos del sector privado, mediante los incentivos fiscales.

En el año 2001 tuvo lugar la trascendente creación de la Agencia Nacional de Cine (Ancine), a partir de la creciente movilización y politización del sector —que fructificaron en la realización de dos Congresos Brasileños de Cine, en 2000 y 2001, medio siglo después de que se realizaran los dos primeros-. El sector demandaba mayor involucramiento del Estado para con el cine. La Ancine se convertiría con el tiempo en el organismo estructurador de las políticas cinematográficas brasileñas.

\section{Ancine}

En 2001 la medida provisoria $2281^{51}$ creó la Agencia Nacional de Cine (Ancine).

La directiva gubernamental también creó el Fondo de Financiamiento de la Industria Cinematográfica Nacional (Funcines) - fondos de financiamiento a proyectos cinematográficos que operan en bolsa-, el Programa de Apoyo al Desarrollo del Cine Nacional (Prodecine) y modificó la legislación sobre la Contribución para el Desarrollo de la Industria Cinematográfica Nacional (Condecine).

La Ancine es un órgano federal autárquico de fomento, regulación y fiscalización del cine y el video en el país — desde 2011, a partir de la ley 12.485, la agencia también

\footnotetext{
${ }^{51}$ En Brasil una "medida provisoria" no es estrictamente provisoria, sino un instrumento del Poder Ejecutivo que no pasó por el Congreso pero que tiene fuerza de ley — similar al decreto de necesidad y urgencia de Argentina-. La normativa establece que las "medidas provisorias" deben ser luego ratificadas o rechazadas por el Congreso, pero ello no siempre ocurre, y la medida "provisoria" funge como una ley en firme del Estado brasileño - como en el caso de esta medida provisoria que creó la Ancine, entre otras medidas importantes para el sector cinematográfico brasileño, y que rige hasta la actualidad (2015).
} 
tiene injerencia en la televisión paga (producción, programación y "empaquetamiento" 52 de contenido audiovisual). ${ }^{53}$

Ancine está compuesta por un directorio integrado por un presidente y tres directores, con mandatos de cuatro años no renovables —aunque esta última disposición se mostró bastante laxa- Es el/la presidente de la República quien los nomina; posteriormente, esta nominación debe pasar por el Senado Federal.

Los recursos con que cuenta esta agencia federal se basan de las asignaciones previstas en cada presupuesto general de la Unión, más un porcentaje de lo recaudado por la Contribución para el Desarrollo de la Industria Cinematográfica (Condecine) — uno de los principales recursos con los que dispone el Estado nacional en relación con el cine. Condecine cuenta básicamente con dos modalidades de tributación: 11\% sobre los lucros que se remesan al exterior — cuando el contribuyente no haya optado por el descuento del $70 \%$ al impuesto a la renta para todo coproductor cinematográfico brasileño-; la otra modalidad es el incentivo que permite a las emisoras de televisión paga invertir en producción audiovisual el 3\% del valor del impuesto a la renta (Harvey, 2005).

Desde 2008, la Ancine comenzó a expandir sus fondos de fomento, quitándole peso a las exenciones fiscales en la producción nacional, destacándose el Fondo Sectorial Audiovisual —aprobado en 2006-, que se nutre de la Condecine y del Fondo de Fiscalización de Telecomunicaciones (Fistel) —éste último, se encuentra enmarcado en la Agencia Nacional de Telecomunicaciones (Anatel).

A su vez, la Ancine opera en conjunto con el Banco Nacional de Desarrollo de Brasil diversos fondos y programas de apoyo al cine -especialmente, en lo que hace al fomento a la exhibición.

Desde 2003 la Ancine está vinculada al Ministerio de Cultura - de manera distinta a lo que reclamaba el sector, que aspiraba que la Ancine estuviera bajo la órbita del Ministerio de Industria-. Desde su creación y hasta este año, la Ancine quedó enmarcada en la Casa Civil de la Presidencia de la República, obteniendo los acervos técnico y patrimonial, y los derechos y obligaciones de la División de Registro de la Secretaría de Desarrollo del Audiovisual —antecesora, durante la década de 1990, de la

\footnotetext{
${ }^{52}$ En Brasil la ley distingue claramente las empresas “empaquetadoras" de señales de televisión paga (por ejemplo, Turner y sus canales CNN, TNT, TCM y Cartoon Network), distintas de las empresas operadoras de televisión paga (en la Argentina, por ejemplo, Cablevisión, Telecentro o Supercanal).

${ }^{53}$ Por su parte, la Agencia Nacional de Telecomunicaciones (Anatel) regula las actividades de distribución (es decir, se concentra más en las redes que en los contenidos).
} 
Secretaría del Audiovisual (Ministerio de Cultura)—, así como también la gestión de los distintos procesos relacionados con aprobación de proyectos varios ligados a exenciones fiscales - generados a partir de las leyes Rouanet (1991) y del Audiovisual (1993) (Harvey, 2005).

Entre los principales objetivos y funciones de la Ancine se destacan la ejecución de proyectos de producción, coproducción, distribución, exhibición e infraestructura técnica -a ser ejecutados con recursos públicos e incentivos fiscales-, cumplimiento de la cuota de pantalla, registro de obras audiovisuales nacionales y extranjeras, y recaudación y control de la contribución Condecine.

A su vez, la Ancine también vela por la integración de las distintas actividades estatales relacionadas con la industria del cine y el audiovisual, y es el organismo estatal encargado de la regulación del derecho de autor de las obras audiovisuales brasileñas.

La Agencia Nacional de Cine también se encarga de otorgar los certificados de "producto brasileño" a las obras cinematográficas y audiovisuales, además de llevar el registro de contratos de producción, coproducción, licencias, distribución, cesión de derechos de comercialización y exhibición.

Por su parte, la Ancine establece vínculos en nombre de Brasil con los distintos países y organismos internacionales en materia cinematográfica.

\section{Consejo Superior de Cine}

Con la aprobación en septiembre de 2001 del programa macro sobre políticas públicas cinematográficas en Brasil se creó, además de la Ancine, el Consejo Superior de Cine, dependiente de la Casa Civil de la Presidencia de la República.

Este Consejo define la política nacional de cine y va evaluando la ejecución de los distintos mandatos mediante reuniones periódicas que se llevan a cabo con la participación de representantes de la Secretaría del Audiovisual y de la Ancine, de los ministros y representantes de Justicia, Relaciones Exteriores, Hacienda, Cultura, Desarrollo, Industria y Comunicaciones; del jefe de la Casa Civil de la Presidencia; y de especialistas y representantes de la industria —estos últimos son designados por el/la Presidente de la República.

Otra función importante del Consejo Superior de Cine —además de proponer cambios en la normativa relacionada con el cine- es establecer la distribución de la Contribución para el Desarrollo de la Industria Cinematográfica (Condecine).

Las decisiones del Consejo se adoptan por mayoría simple. 
Los recursos humanos y presupuestarios para ejecutar los trabajos del Consejo -que también incluyen conformación de comités y grupos temáticos que se van formando para realizar estudios y elaborar propuestas específicas- son sustentados por la Casa Civil de la Presidencia de la República.

\section{Secretaría del Audiovisual}

Las principales funciones de la Secretaría del Audiovisual se centran en ser parte, junto con la Ancine, del diseño de la política nacional de cine y audiovisual - que será sometida a consideración del Consejo Superior de Cine-, crear y ejecutar programas de fomento a las actividades cinematográficas - generalmente, concursos de desarrollo, preproducción y producción de filmes de calidad (documentales, animación, ficción) y cortometrajes-, promover la participación de filmes brasileños en festivales nacionales e internacionales, orientar y controlar las actividades de la Cinemateca Brasileña, promover a través de distintas acciones la difusión, preservación e investigación sobre el cine brasileño, así como la formación y calificación profesional.

Como se comentó más arriba, la Secretaría del Audiovisual se creó en 1999 con el fin de ser la instancia estatal encargada de los asuntos relacionados con el cine y el audiovisual. Pero, en términos concretos, después de la creación de la Ancine en 2001, la Secretaría del Audiovisual funge hasta la actualidad como un órgano de asesoramiento sobre la elaboración y ejecución de políticas públicas cinematográficas.

A partir del espíritu que creó la Ancine en 2001 — que buscaba que la institución estatal dedicada se enmarcara en el área de Industria y no de Cultura (Chalupe, 2010)durante los años 2004 y 2005 el sector promovió la creación de la Agencia Nacional del Cine y el Audiovisual (Ancinav), que buscaba unir en un solo organismo la regulación y el fomento tanto del cine como del audiovisual. Sin embargo, la propuesta fue fuertemente rechazada por el sector de la televisión, especialmente, por los grandes grupos mediáticos — que, en el año 2000, cuando el sector pidió la creación de un organismo estatal de cine, habían estado de acuerdo con esta propuesta.

\section{Conclusiones del apartado}

Desde su creación y hasta la actualidad, la Ancine se ocupa del fomento y la regulación de las actividades relacionadas con la industria del cine (desarrollo, preproducción, producción, distribución y exhibición) - $\mathrm{y}$, desde 2011, también relacionadas con la televisión por cable, a partir de la promulgación de la nueva ley de TV por cable de ese 
año-, mientras que la Secretaría del Audiovisual quedó a cargo de la veta más “cultural" del cine — principalmente, mediante premios y estímulos menores.

El cine en Brasil - y la cultura en general - fue concibiéndose desde comienzos de la década de 1990 como un negocio: debía ser lucrativo y ser producido según la lógica del mercado, tanto a nivel de financiamiento como en términos estéticos —narración según los padrones televisivos, temáticas "universales" y exportables.

En este contexto "neofomentista" cabe subrayar que el dinero utilizado para el resurgimiento del cine brasileño post recortes de Collor sigue proviniendo del Estado, mediante deducción de impuestos — dineros que el Estado dejaba de cobrar para que se vuelquen a la producción cinematográfica-. La única diferencia con respecto al fomentismo (etapa Embracine) reside en que, desde comienzos de la década de 1990 y hasta la actualidad, las decisiones sobre dónde el dinero público será invertido y sobre cuáles proyectos serán privilegiados, caben a la iniciativa privada y al mercado —situación matizada a partir de 2008, cuando entró en vigor el Fondo Sectorial, y en 2011, a partir de los impuestos y obligaciones derivadas de la aprobación de la ley de televisión paga acontecida en ese año.

\section{Mecanismos de fomento al audiovisual}

El fomento al audiovisual en Brasil se divide, básicamente, en tres grupos:

- mecanismos de inversión o coproducción: son aquellos donde el inversor tiene interés en recuperar parte del capital aportado (en algunas situaciones se permite que el inversor sea considerado coproductor);

- mecanismos de patrocinio: son aquellos cuyo mecenas tiene interés, principalmente, en visibilizar su marca (marketing) a partir del aporte que realiza, y

- mecanismos de aporte directo por el Poder Público: son programas considerados prioritarios por el Estado brasileño y que cuentan con recursos estatales para su financiación.

Los distintos mecanismos de fomento estatal al cine y al audiovisual pueden ser utilizados en conjunto o por separado.

Para las dos primeras modalidades arriba mencionadas (mecanismos de inversión y mecanismos de patrocinio) la empresa financiadora puede recibir incentivos fiscales: se 
trata de un mecanismo de fomento del Estado brasileño para estimular la participación privada en una actividad de interés público.

El proceso para la autorización del uso de los mecanismos de incentivo fiscal funciona, básicamente, en dos momentos. Primero, la productora — que debe ser brasileña e independiente - debe presentar a la Ancine una propuesta para la realización de la obra y los beneficios tributarios pretendidos, junto al presupuesto de producción y de documentos que comprueben la adquisición de los derechos del proyecto. La segunda etapa consiste en el análisis que hace el Ancine del proyecto presentado. En el caso de que la Ancine apruebe el proyecto, la productora podrá ofrecer los beneficios tributarios a recibir a los distintos agentes del mercado, con el objetivo de hacerse con los recursos financieros propiamente dichos (Solot, 2014).

Con la aprobación del proyecto, la productora también puede aspirar a recibir subsidios públicos directos - tanto por parte del Gobierno Federal como de los gobiernos estatales y municipales (el municipio de Río de Janeiro se encuentra a la avanzada)—. Los subsidios públicos directos se basan en la inversión del Estado en el proyecto, y son implementados a través del Fondo Sectorial del Audiovisual (FSA) (Solot, 2014).

El FSA requiere la devolución del monto invertido, y lo hace asegurándose una participación porcentual en el ingreso neto del productor, o en el ingreso de distribución, o en una combinación entre ambos ingresos, dependiendo del proyecto y de la línea de fomento en cuestión (Solot, 2014).

\section{Fomento directo e indirecto}

Desde otra perspectiva, se puede catalogar a las medidas de apoyo del Estado brasileño al cine y al audiovisual como de fomento directo e indirecto.

Los apoyos de fomento indirecto se efectivizan a través de las leyes de incentivo fiscal (Ley Rouanet, Ley del Audiovisual, la Medida provisoria 2.228-1/2001, el Funcines y "conversión de deuda"), mientras que los de fomento directo - que pueden ser automáticos o selectivos- se otorgan tanto por el mérito artístico como por el de mercado.

Además de los programas de fomento directo e indirecto, Ancine es responsable por manejar fondos de apoyo de otra naturaleza, como el Fondo Sectorial del Audiovisual (FSA) y el programa Cinema Perto de Você (Cine cerca de usted). En estos programas —que se nutren de recursos presupuestarios del Estado federal- el Estado posee un 
mayor poder de decisión que en las acciones antedichas; fueron creados y puestos en funcionamiento a fines de la década de 2000 y comienzos de la de 2010 , y vinieron a tratar de que el fomento público al cine no fuera totalmente "mercado orientado", tal como postula esta tesis (ver en este capítulo apartados "Fomentismo y neofomentismo a la brasileña" y “Conclusiones").

También existen otros programas de fomento directo ofrecidos a través de concursos convocados por la Secretaría del Audiovisual (Ministerio de Cultura).

A continuación se detallarán los programas hasta acá esbozados.

\section{Fomento directo}

Ancine clasifica como fomento directo el apoyo a proyectos audiovisuales con recursos provenientes de su propio presupuesto. Esos recursos son ofrecidos por medio de una selección cuyo formato es especificado en convocatorias publicadas en el Diario Oficial de la Unión (boletín oficial nacional). Las convocatorias pueden ser de naturaleza selectiva o automática.

a) Fomento directo automático

Las convocatorias de naturaleza automática conceden premiaciones sobre la base de resultados económicos o artísticos de obras cinematográficas. No hay una selección, sino una clasificación de acuerdo a los resultados. Pertenecen a esta categoría el Premio Adicional de Renta (PAR) y el Programa Ancine de Incentivo a la Calidad del Cine Brasileño (PAQ, según sus siglas en portugués).

\section{b) Fomento directo selectivo}

Las convocatorias de naturaleza selectiva determinan los criterios a ser aplicados en el proceso selectivo, realizado por comisiones conformadas por el cuerpo técnico especializado de Ancine y/o por personas de trayectoria reconocida. Entran en esta categoría la Convocatoria de Coproducción Luso-Brasileña, el Programa de Fomento Directo a la Coproducción Cinematografía - programa conjunto entre Ancine y el Consorcio Audiovisual de Galicia-, y el Programa Ibermedia.

\section{Fomento indirecto}

El fomento indirecto está constituido por inversiones y patrocinios realizados en proyectos producidos sobre la base de mecanismos de incentivo fiscal. 


\section{Ley del Audiovisual}

Este mecanismo de inversión es, aunque no lo parezca, temporario — se creó en 1993 y rige hasta 2016-; puede ser utilizado para desarrollo de proyectos y para la producción y coproducción de corto, medio y largometrajes brasileños independientes, documentales telefilmes y miniseries, además de proyectos de infraestructura técnica para la producción y exhibición de obras cinematográficas y audiovisuales, proyectos de reforma de salas de exhibición y proyectos de reforma y adaptación de inmuebles dedicados a servicios audiovisuales (laboratorios, editoras, empresas de posproducción, etcétera).

Los artículos $1^{\circ}$ y $3^{\circ}$ son los principales dentro de esta ley: el primero permite a personas físicas y empresas deducir parte del impuesto a la renta que deben pagar si invierten en la producción de filmes brasileños - aunque con límites, que se detallarán en el párrafo siguiente- El artículo $2^{\circ}$ permite a empresas distribuidoras de cine invertir en filmes brasileños parte del impuesto a pagar sobre el envío de remesas de ganancias al exterior.

En el caso del artículo $1^{\circ}$ de esta ley, empresas e individuos pueden deducir el $100 \%$ del monto invertido en la película como gasto operativo y descontar íntegros estos valores del impuesto de renta adeudado - con un límite del 3\% del impuesto adeudado para las empresas, y del 6\% para las personas físicas-. A su vez, los inversores también se convierten en socios de la película, y son partícipes de los resultados que puedan obtener en su recorrido comercial.

El artículo $3^{\circ}$ de la Ley del Audiovisual se refiere a los beneficios que pueden obtener las empresas extranjeras que deben pagar impuestos sobre las remesas giradas a sus casas matrices a partir de las ganancias obtenidas en Brasil -el artículo $3^{\circ}$ está diseñado especialmente para las distribuidoras majors de Hollywood-: estas empresas pueden beneficiarse con hasta el 70\% del impuesto adeudado si invierten ese valor en el desarrollo y producción de filmes y audiovisuales brasileños; además, este inversor queda exento de abonar el $11 \%$ de impuesto sobre sus remesas -impuesto que se destina a nutrir a la Condecine (contribución que se describe en el apartado "Ancine" de este capítulo)- El inversor también obtiene participación en las potenciales ganancias que obtenga la película en su comercialización.

El artículo $3^{\circ} \mathrm{A}$ es similar al $3^{\circ}$, sólo que está destinado a los canales de televisión abierta y a las programadoras de televisión paga. 
También genera un beneficio parecido el artículo $39 \mathrm{X}$ de la medida provisoria 2228 de 2001 destinado a programadoras extranjeras de televisión paga.

\section{Ley Rouanet}

Esta ley que lleva el número 8313 y es del año 1991, estipula en sus artículos 18, 25 y 26 que las empresas pueden deducir hasta el 4\% del impuesto a la renta adeudado - y los individuos hasta el 6\% - si apoyan producciones de corto y mediometraje, y donan o patrocinan a cinetecas - mediante donaciones, mantenimiento de ese acervo o capacitación de su personal-, festivales de cine y cualquier proyecto que se dedique a la preservación y difusión del acervo audiovisual (brasileño o extranjero).

Fondos de Financiación de la Industria Cinematográfica Nacional (Funcines)

El artículo 41 de la medida provisoria 2228 de 2001 que conformó el Ancine también creó los Funcines, fondos que son administrados por una institución financiera autorizada por el Banco Central de Brasil. Estos fondos están destinados a la inversión mediante bonos de fideicomisos en proyectos audiovisuales.

El patrimonio de los Funcines lo constituyen las cuotas emitidas por la institución administradora del Fondo.

Los Funcines deberán tener, como mínimo, un 10\% de su patrimonio en títulos emitidos por el Tesoro Nacional y/o por el Banco Central de Brasil. La otra parte del patrimonio debe estar destinada a proyectos relacionados con el ámbito cinematográfico, aprobados por Ancine, que pueden ser: proyectos de filmes y audiovisuales - televisión incluida-, inversión en infraestructura —salas, laboratorios, productoras, etc.inversión en reformas de salas, acciones en empresas del sector — tanto del ámbito de la producción, como de la comercialización, distribución o exhibición-, y proyectos de distribución y exhibición de filmes brasileños.

Conversión de deuda externa (ley 10.179/01, art. $1^{\mathbf{0}}$ )

Entre 2001 y 2003 el sector cinematográfico utilizó este instrumento que consiste, básicamente, en convertir títulos de deuda externa adquiridos en el exterior en inversiones dirigidas a la cadena de valor del cine brasileño — se pueden apoyar tanto largos, medios y cortometrajes, así como telefilmes, miniseries e inversiones en infraestructura (por ejemplo, adquisición y renovación de equipos e instalaciones).

Hacia comienzos de la década de 2000 los títulos de deuda brasileña presentaban una gran diferencia entre el valor de mercado y el valor nominal - la presente herramienta 
de fomento permitía contabilizar el valor nominal del título, por lo que se generaba una ganancia importante al haber adquirido el título en el mercado al $40 \%$ o $50 \%$ de su valor, y hacerlo reconocer por el Estado brasileño en un 100\% al momento de deducir impuestos (la producción de Ciudad de Dios utilizó este instrumento).

Hacia 2004 se dejó de utilizar esta herramienta, debido a que la brecha entre el valor de mercado y el valor nominal de los títulos de deuda brasileña comenzó a reducir significativamente.

\section{Otros}

\section{Fondo Sectorial del Audiovisual}

El Fondo Sectorial del Audiovisual (FSA) está destinado al desarrollo articulado de toda la cadena productiva de la actividad audiovisual de Brasil. Creado por la ley 11.437 del 28 de diciembre de 2006, y reglamentada por el decreto 6299 del 12 de diciembre de 2007, el FSA es una categoría de programación específica del Fondo Nacional de Cultura.

Sus recursos se originan en la propia actividad económica, a partir de contribuciones que deben realizar los agentes del mercado — principalmente, la Contribución para el Desarrollo de la Industria Cinematográfica Nacional (Condecine) y el Fondo de Fiscalización de las Telecomunicaciones (Fistel).

Los recursos del Fondo pueden ser utilizados en las siguientes aplicaciones:

- inversiones retornables;

- préstamos reembolsables;

- valores no reembolsables, en casos específicos definidos por un comité gestor;

- participación minoritaria en el capital de empresas, y

- demás aplicaciones dirigidas al desarrollo de actividades audiovisuales.

Por su parte, el Fondo Sectorial Audiovisual posee cuatro líneas de acción. Son inversiones retornables, otorgadas mediante selección y concretadas a través de un contrato de participación financiera del Estado en el resultado de la explotación comercial de la obra audiovisual apoyada. 
Las cuatro líneas son:

- línea de acción A (producción cinematográfica de largometraje);

- línea de acción B (producción independiente de obras audiovisuales para televisión);

- línea de acción C (adquisición de derechos de distribución de largometrajes), y

- línea de acción D (comercialización de largometrajes en salas de exhibición).

\section{Cinema Perto de Você (Cine cerca de usted)}

Este programa fue creado en 2010 para acelerar la implantación de salas comerciales de exhibición en todo el país, especialmente en las poblaciones de menor cantidad de habitantes y en los suburbios de las grandes ciudades. Una línea importante de este programa apunta a la modernización y digitalización de las salas existentes, siendo el primer país latinoamericano en apoyar esta transición digital.

El programa se lleva a cabo en conjunto entre Ancine, el Banco de Desarrollo (BNDES) y el Ministerio de Hacienda.

\section{Programas Especiales de Fomento}

Los programas especiales de fomento son costeados por los patrocinios que realizan las empresas brasileñas a partir de los beneficios fiscales previstos en la Ley del Audiovisual.

Los recursos de los programas especiales de fomento pueden ser aplicados en:

a) concesión de subvención económica y de auxilio —en forma reembolsable o no reembolsable - a instituciones brasileñas para la producción independiente, exhibición, difusión y distribución de obras audiovisuales;

b) ejecución de convenios con otras instituciones públicas, relacionados con el desarrollo del sector audiovisual, y

c) concesión de subvención económica para proyectos de investigación, innovación, preservación, formación profesional y cualificación empresarial. 


\section{Convocatorias de la Secretaría del Audiovisual (Ministerio de Cultura)}

La Secretaría del Audiovisual lanza periódicamente distintas convocatorias para el fomento de la producción audiovisual, tanto para largos como cortometrajes, ya sean de ficción, de animación o documentales, y pueden aplicar tanto directores como productores y guionistas — dependiendo de la convocatoria.

\section{Leyes estaduales y municipales de incentivo al audiovisual}

En casi todos los Estados brasileños, y también en gran número de ciudades, existen leyes estaduales (provinciales) y municipales de incentivo a la producción cultural en general, y al audiovisual en particular.

La mayoría de estas leyes se encuadran bajo el sistema de incentivo fiscal y, a nivel general, otorgan a los inversores créditos tributarios que varían entre el $70 \%$ al $100 \%$ de los valores que destinaron a apoyar proyectos de producción audiovisual.

De la misma manera que sucede con los incentivos federales, en cada estado o municipio donde rigen estas normativas existe un órgano específico para recibir y analizar proyectos y apoyos, y con competencia para aprobarlos y autorizar la renuncia fiscal en beneficio de los inversores de proyectos audiovisuales.

\section{Conclusiones del apartado}

Hasta 2003, el financiamiento público al cine y al audiovisual prácticamente se restringía a tres mecanismos de incentivo fiscal:

- artículo $1^{\mathrm{o}}$ de la Ley del Audiovisual: incentivo a la inversión de empresas y personas físicas como socios de proyectos cinematográficos; los inversores se benefician con la exoneración de un determinado porcentaje del impuesto a la renta;

- artículo $3^{\circ}$ de la Ley del Audiovisual: incentivo a las distribuidoras internacionales para coproducir filmes brasileños, con una reducción del 70\% del impuesto que deben pagar por las remesas giradas al exterior, a partir de las ganancias obtenidas en el país por su actividad; además se les exime del 11\% de esas remesas que deben pagar por el Condecine, y

- Ley Rouanet: incentivo al patrocinio de proyectos audiovisuales, con renuncia fiscal de hasta el $100 \%$ del valor del impuesto de renta que debía pagarse. 
Esos mecanismos surgieron en 1990 como respuesta a la extinción de las estructuras de financiamiento al cine.

Hacia finales de la década de 2000 las fuentes de financiamiento se diversificaron, como se aprecia en el gráfico siguiente. Vale observar que el Fondo Sectorial (FSA) pasó a tener una presencia significativa a finales de la década — recordando que este Fondo es una herramienta manejada por el Estado para retomar la iniciativa en el fomento cinematográfico más allá de los programas de incentivo fiscal (programas que continuaron existiendo y que siguen siendo los instrumentos más utilizados a la hora de financiar las películas en Brasil).

Gráfico 32 - Brasil: composición del financiamiento público al cine y al audiovisual, en \% del total de recursos (2002-2009)

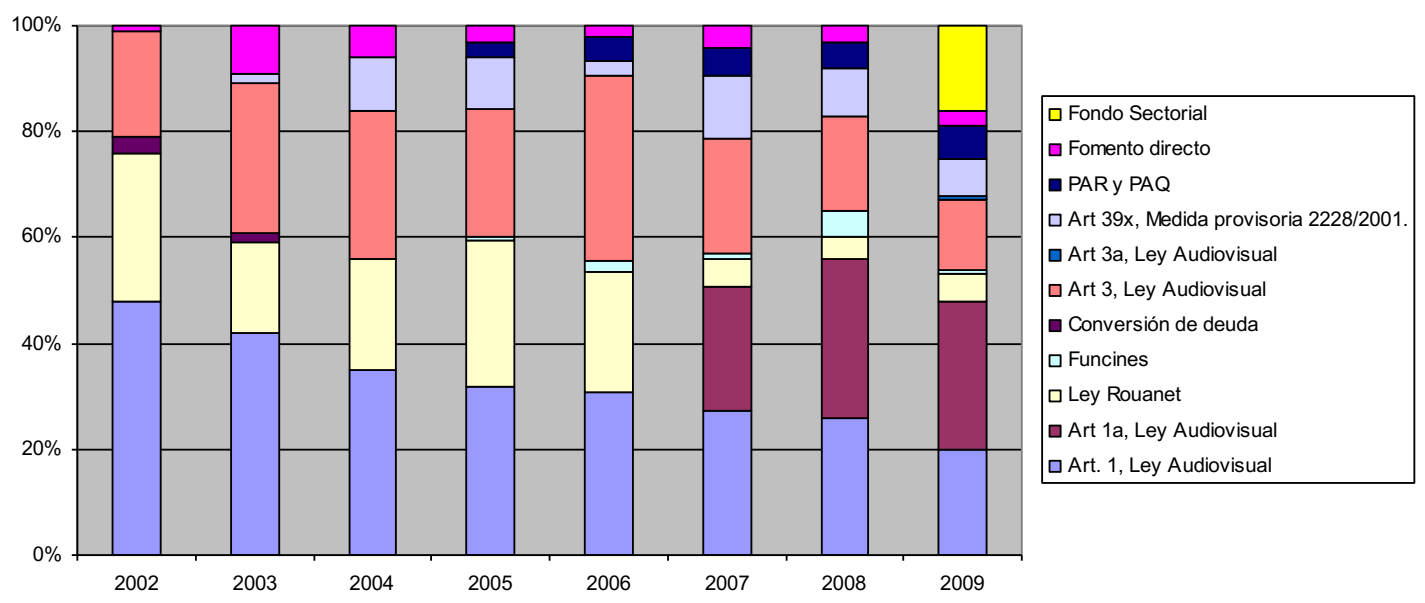

Fuente: Ancine.

En efecto, desde 2005 -y especialmente a partir de 2008- Ancine pasó a trabajar con un modelo de financiamiento más complejo:

- se optó por la ampliación de la política de incentivos, con estímulos a las inversiones de televisoras en la producción independiente;

- la participación directa del presupuesto federal pasó a ser más valorada, reduciendo el peso proporcional de los incentivos fiscales en el financiamiento al audiovisual (aunque siguen siendo los que mayor peso tienen), y

- se abrieron más líneas de apoyo (a la producción para televisión, a la distribución de filmes, a la exhibición de cine); sin embargo, el énfasis de los apoyos continuó siendo para la producción. 
Con estos cambios, las políticas cinematográficas neofomentistas intentaron ir más allá de la producción de largometrajes: la distribución pasó a recibir más atención y recursos —especialmente, a través de recursos provenientes de Funcines, la Ley del Audiovisual y una línea financiera específica del Fondo Sectorial一; a su vez, pasó a apoyarse también la producción independiente de televisión, coexistiendo con el fomento al cine. $^{54}$

Sin embargo, en las políticas cinematográficas neofomentistas el peso de la producción continúa siendo absolutamente dominante, como se detallará en el subcapítulo siguiente (especialmente, en torno al cuadro 25).

\section{Producción y mercados}

Como señala Mastrini (2014:14) la valorización del capital que realizan las industrias culturales se potenció desde la década de 1990 con la desregulación y la privatización.

En efecto, en el caso brasileño, luego de que Collor de Melo liquidara las entidades estatales de fomento al cine, la concentración pasó a ser una característica de toda la cadena de valor (producción, distribución y exhibición).

En la producción, Globo y contadas productoras más son las que dominan el sector: son las que se llevan la mayor parte de los recursos públicos y de los espectadores que acuden a ver cine nacional.

En la distribución, las distribuidoras de Hollywood son las que mandan en el mercado, mientras que las empresas nacionales del rubro apenas tienen incidencia.

En la exhibición, sólo un puñado controla el mercado: si bien hay empresas nacionales entre las principales, éstas se encuentran relacionadas con Hollywood, por lo que su condición de nacionalidad no es una ventaja per se para el cine nacional —es decir: tal como sucede en el mundo (González, 2013) las cadenas brasileñas no son más proclives a exhibir películas nacionales que sus pares extranjeras.

\footnotetext{
${ }^{54}$ A partir de 2011, fecha que excede el período de análisis de esta tesis, se sancionó una trascendencia ley de televisión paga, que establece básicamente un fondo de fomento para el audiovisual brasileño a partir de la recaudación televisiva, y una cuota de pantalla para el audiovisual nacional.
} 


\section{Producción}

En el ámbito de la producción se fue operando una creciente concentración en el sector a partir de finales de la década de 1990, especialmente con la aparición en el sector de la productora de cine Globo Filmes, parte del poderoso multimedios Globo.

Globo Filmes comenzó a operar en 1998 con el lanzamiento del filme "Simão, el fantasma andrajoso" (Simão, o fantasma trapalhão), y comenzó a aprovechar el "espíritu" del sistema de fomento basado en la renuncia fiscal. De tal manera, Globo "invierte" en películas, pero en realidad no aporta dinero sino que brinda espacio en sus medios para las películas "apoyadas" —especialmente en televisión, pero también en sus medios gráficos.

Por otra parte, en las "producciones" de Globo el gigante mediático impone los actores famosos de sus telenovelas y hasta los directores de su staff. La empresa también suele intervenir en los proyectos desde el primer momento, tanto en el desarrollo del proyecto como en el guión, y suele tener injerencia en todo el proceso de producción del filme.

De esta manera, sin aportar recursos monetarios Globo "recupera" con posterioridad su “inversión" quedándose con el 15\% de la recaudación de los filmes — películas de las que es socio, según el artículo $3^{\circ}$ de la Ley del Audiovisual (similar operatoria realizan las majors de Hollywood que invierten en filmes brasileños).

A través de la difusión cross-media realizada por Globo, "sus" filmes suelen ser éxitos de taquilla: de tal manera, de los 50 filmes brasileños más taquilleros para el período 1995-2014, 42 fueron producidos o coproducidos por Globo; si se observa el top 20 de los mayores éxitos de este período se verá que 19 tuvieron participación de Globo. 
Cuadro 26 - Brasil: top 20 filmes brasileños, por cantidad de espectadores (1995-2014)

\begin{tabular}{|c|c|c|c|c|}
\hline \# & $\begin{array}{l}\text { Año de } \\
\text { estreno }\end{array}$ & Título & Espectadores & $\begin{array}{l}\text { Participación } \\
\text { de Globo }\end{array}$ \\
\hline 1 & 2010 & Tropa de elite 2 & 11.000 .000 & Sí \\
\hline 2 & 2009 & Se eu fosse você 2 & 6.119 .000 & Sí \\
\hline 3 & 2005 & Dois filhos de Francisco & 5.319 .677 & Sí \\
\hline 4 & 2003 & Carandirú & 4.693 .853 & Sí \\
\hline 5 & 2013 & Minha mãe é uma peça & 4.600 .145 & Sí \\
\hline 6 & 2010 & Nosso lar & 4.060 .304 & Sí \\
\hline 7 & 2013 & De pernas pro ar 2 & 3.787 .852 & Sí \\
\hline 8 & 2006 & Se eu fosse você & 3.644 .956 & Sí \\
\hline 9 & 2010 & Chico Xavier & 3.412 .969 & Sí \\
\hline 10 & 2002 & Cidade de Deus & 3.370 .870 & Sí \\
\hline 11 & 2012 & Até que a sorte nos separe & 3.322 .561 & Sí \\
\hline 12 & 2003 & Lisbela & 3.152 .713 & Sí \\
\hline 13 & 2013 & Meu passado me condena & 3.137 .795 & Sí \\
\hline 14 & 2002 & Abril despedaçado & 3.117 .220 & No \\
\hline 15 & 2011 & De pernas pro ar & 3.095 .894 & Sí \\
\hline 16 & 2004 & Cazuza & 3.082 .522 & Sí \\
\hline 17 & 2004 & Olga & 3.075 .749 & Sí \\
\hline 18 & 2011 & Cilada.com & 2.998 .560 & Sí \\
\hline 19 & 2003 & Os normais & 2.957 .556 & Sí \\
\hline 20 & 2014 & Até que a sorte nos separe 2 & 2.930 .693 & Sí \\
\hline
\end{tabular}

Fuente: Elaboración propia con base en información de Ancine, Filme-B, Nielsen-Rentrak, IMDB.

La gran mayoría de las películas en las que participó Globo Filmes lo hizo bajo la figura de coproducción. De esta manera, quienes se encargan de asumir el riesgo y hacer el trabajo duro son las productoras que ponen su nombre y responsabilidad civil al momento de aplicar a los recursos estatales de fomento. 
Precisamente, las diez productoras brasileñas de cine y audiovisual que recibieron mayor cantidad de recursos por parte del Estado coprodujeron sus filmes con Globo Filmes.

Cuadro 27 - Brasil: top 10 productoras por monto de apoyo estatal, en dólares (2000-2009)

\begin{tabular}{|c|c|c|c|}
\hline Productora & $\begin{array}{l}\text { Monto total de } \\
\text { recursos } \\
\text { estatales } \\
\text { recibidos } \\
\text { (US\$)* }\end{array}$ & $\begin{array}{l}\text { Cantidad de } \\
\text { filmes } \\
\text { apoyados }\end{array}$ & $\begin{array}{l}\text { Posee } \\
\text { blockbusters } \\
\text { nacionales } \\
\text { coproducidos } \\
\text { con Globo } \\
\end{array}$ \\
\hline $\begin{array}{l}\text { Diler \& } \\
\text { Associados }\end{array}$ & $42.536 .025,34$ & 24 & Sí \\
\hline $\begin{array}{l}\text { Conspiração } \\
\text { Filmes }\end{array}$ & $27.171 .136,53$ & 16 & Sí \\
\hline $\begin{array}{l}\text { Filmes do } \\
\text { Equador }\end{array}$ & $20.651 .290,73$ & 9 & Sí \\
\hline O2 Cinema & $16.001 .890,63$ & 9 & Sí \\
\hline $\begin{array}{l}\text { Total } \\
\text { Entertainment }\end{array}$ & $13.528 .404,79$ & 7 & Sí \\
\hline $\begin{array}{l}\text { Lereby } \\
\text { Produções }\end{array}$ & $12.693 .567,66$ & 6 & Sí \\
\hline $\begin{array}{l}\text { Videofilmes } \\
\text { Produções } \\
\text { Artísticas }\end{array}$ & $12.525 .033,54$ & 18 & Sí \\
\hline $\begin{array}{l}\text { Tambellini } \\
\text { Filmes e } \\
\text { Produções } \\
\text { Audiovisuais }\end{array}$ & $8.265 .215,09$ & 6 & No \\
\hline Gullane Filmes & $8.878 .896,80$ & 6 & No \\
\hline $\begin{array}{l}\text { Natasha } \\
\text { Enterprises }\end{array}$ & $8.573 .223,11$ & 4 & Sí \\
\hline Total & $170.824 .684,19$ & 105 & ::: \\
\hline $\begin{array}{l}\text { \% del total de } \\
\text { productoras y } \\
\text { proyectos } \\
\text { apoyados 2000- } \\
09\end{array}$ & $39,50 \%$ & $20,23 \%$ & $:::$ \\
\hline
\end{tabular}

* El tipo de cambio se calculó sobre la base del valor promedio del dólar de 2009.

Fuente: Elaboración propia con base en datos de Ancine, Filme-B, IMDB.

A nivel general, con el incremento de los recursos destinados a producción que se operó desde la década de 2000 —y que continúa en la actualidad (2015) — creció no sólo la cantidad de filmes producidos - como se aprecia en el gráfico 35- sino el número de productoras cinematográficas. 
Gráfico 33 - Brasil: recursos públicos destinados al cine y al audiovisual, en millones de dólares (2000-2009)

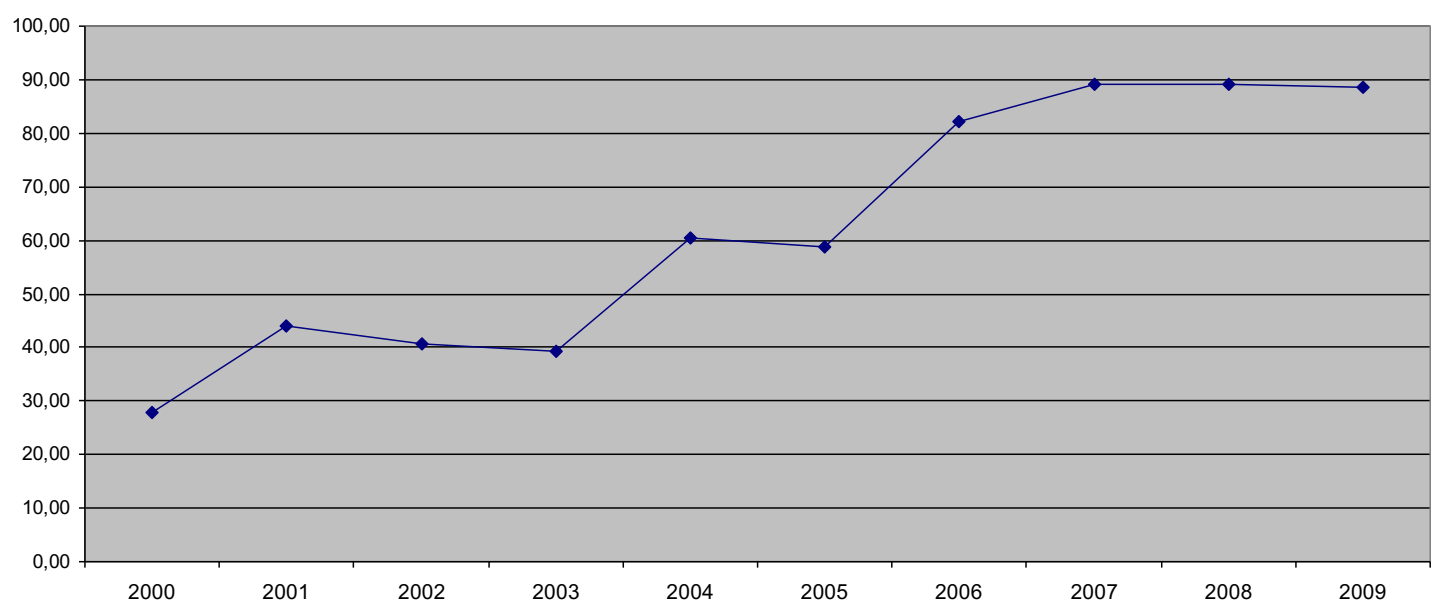

Fuente: Ancine.

Sin embargo, como sucede en toda América Latina, muchas de las productoras son insustentables y tienen una vida efímera, realizando uno o dos largometrajes, como mucho, y teniendo que cerrar posteriormente (González, 2011b).

A su vez, la expansión en la cantidad de productoras no trajo una mayor competencia, sino por el contrario, una mayor concentración: en el período 1995-2004 las películas de sólo 13 productoras de un total de 144 registradas se quedaron con el 43,2\% de los espectadores que acudieron a ver cine nacional.

Acotando el período al estudiado por esta tesis (2000 y 2009) se apreciará que solamente 10 productoras - las que se enumeran en el cuadro 27 - sobre un total de 283 empresas registradas en ese lapso de tiempo acapararon el 61,56\% de las entradas vendidas para ver películas brasileñas.

Gráfico 34 - Brasil: porcentaje de espectadores de cine nacional, por productoras (2000-2009)

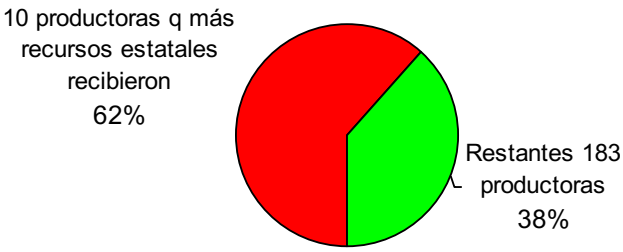


Los recursos estatales privilegiaron al sector de la producción, siendo menores los apoyos a la preproducción, a la distribución, comercialización y exhibición. Hasta la aprobación del Fondo Sectorial —es decir, durante la etapa en que las políticas cinematográficas se basaban exclusivamente en la exención fiscal (1991-2007)—, los recursos de fomento al cine se dedicaban casi exclusivamente a la realización de filmes. A partir de que el Fondo Sectorial comenzó a ejecutarse, en el año 2008, el Estado brasileño comenzó a incorporar otras importantes líneas de apoyo a los otros eslabones de la cadena de valor. Aunque la producción continúa siendo el sector más beneficiado.

Cuadro 28 - Brasil: recursos públicos destinados al cine y al audiovisual, por eslabón de la cadena de valor, en porcentaje (2008-2010)

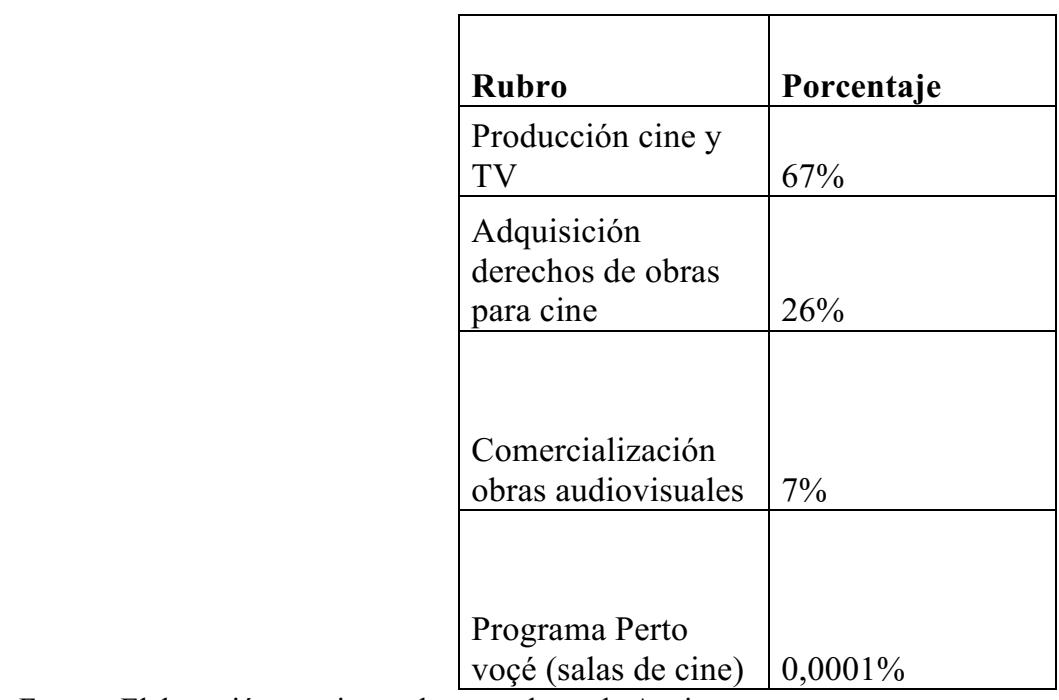

Fuente: Elaboración propia con base en datos de Ancine.

Sin embargo, como se observa, la producción sigue teniendo un peso ampliamente mayoritario entre los recursos asignados por el Estado brasileño para el cine.

Esta preponderancia de los recursos públicos favoreciendo a este sector se vio reflejada en un incremento notable en la cantidad de filmes producidos en los últimos 15 años. 
Gráfico 35 - Brasil: cantidad de largometrajes producidos (1936-2009)

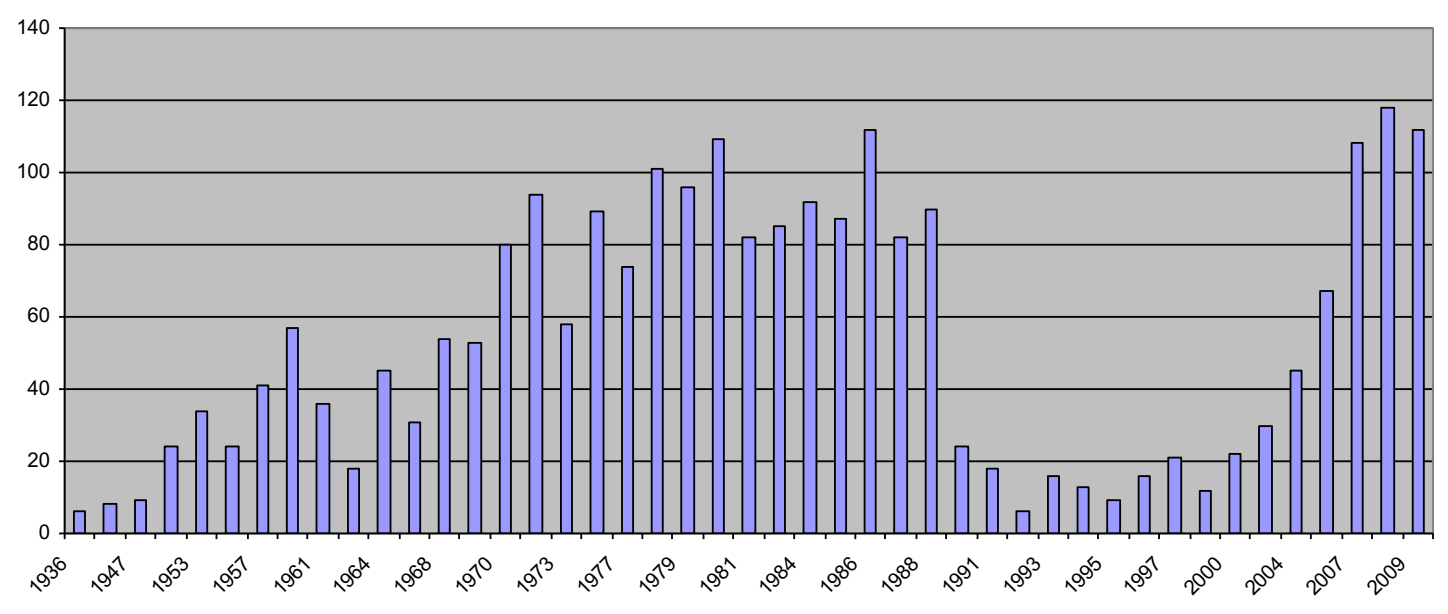

Fuentes: Ancine, Embrafilme, Filme-B, Reis (1998), Unesco (1982).

En efecto: luego de la baja abrupta en la producción cinematográfica brasileña operada a comienzos de la década de 1990 — a partir del recorte que la administración Collor realizara a esta industria-, las normativas de incentivo fiscal permitieron mantener al sector, aunque con números modestos en lo que hace a filmes producidos, en comparación a la "época de oro" de Embrafilme, cuando se producían entre 70 y 110 largometrajes anuales — hasta la década de 1970 Brasil llegó a producir unos 40 filmes por año (pico que se alcanzó hacia finales de la década de 1950); el promedio rondaba los 10 durante las décadas de 1930 y 1940; se ubicaba entre los 15 y 40 durante la década de 1950, y entre 15 y 30 en la de 1960 (Sadoul, 2004; Unesco, 1982).

Con la creación de la Ancine, en 2001, y especialmente, del Fondo Sectorial, la cantidad de filmes se incrementó notablemente durante la década de 2000, llegando hacia el final de la misma a números similares que los de la época de oro.

\section{Dinámica neofomentista}

Si en la época áurea de Embrafilme el $60 \%$ del presupuesto total era sostenido por recursos estatales (Amancio, 2000) bajo el neofomentismo -especialmente, bajo el modelo donde sólo existían las leyes de incentivo (durante la década de 1990 y 2007)— el 95\% del presupuesto podía ser utilizado mediante la captación de recursos originados por la renuncia fiscal; de hecho, todavía se utiliza esta operatoria -además, los proyectos para hacer películas pueden ser considerados para conseguir el otro 5\% de recursos públicos tales como aportes estaduales o municipales (siendo Riofilme el fondo municipal más importante de Brasil). 
En la práctica los elevados presupuestos autorizados para la captación de recursos hacen que, en realidad, las utilidades de los productores y realizadores sea cero o negativa. Sin embargo, como sucede históricamente en América Latina, los presupuestos se "inflan" —es decir, se presupuesta de más- para obtener un margen de ganancia, ante la poca posibilidad de que los filmes resulten un éxito de taquilla.

Desde la década de 1990 hasta la actualidad (2015) se necesitan entre 1,9 y 3 millones de espectadores para amortizar un filme - en el caso de que un proyecto no cuente con un importante apoyo estatal-, tomando en cuenta que el productor se queda sólo con entre el 15-20\% de cada entrada (Britz, 2010; Gonzaga, 2010), y de que el ticket cinematográfico se ubicó, entre 1995 y 2014, entre 2,5 y 5,2 dólares.

Sin embargo, de entre los 534 largometrajes brasileños estrenados entre 2000 y 2009 sólo 21 títulos alcanzaron los 2 millones de espectadores — si se toma el período 20002014, fueron 37 las películas brasileñas que alcanzaron esa cifra de entre 1033 estrenos nacionales; y si se abarca el período 1995-2014, en el que se estrenaron 1147 películas brasileñas, sólo 38 filmes estrenos nacionales alcanzaron los dos millones de espectadores.

Cuadro 29 - Brasil: cantidad de largometrajes nacionales estrenados y de títulos nacionales que superaron los 2 millones de espectadores (1995-2014)

$\begin{array}{lll} & \begin{array}{l}\mathrm{N}^{\mathrm{o}} \text { de } \\ \text { largometrajes } \\ \text { nacionales } \\ \text { estrenados }\end{array} & \begin{array}{l}\mathrm{N}^{\mathrm{o}} \text { de filmes } \\ \text { brasileños que } \\ \text { superaron los 2 } \\ \text { millones de } \\ \text { espectadores }\end{array} \\ \text { Período } & 114 & 1 \\ 1995-99 & 534 & 21 \\ 2000-09 & 499 & 16 \\ 2010-14 & & \end{array}$

Fuente: Elaboración propia sobre la base de datos de Ancine, Filme-B, Nielsen-Rentrak.

Hasta finales de la década de 1990 los productores no tenían ninguna obligación para devolver los recursos que obtuvieron a partir de la renuncia fiscal del Estado: todos esos mecanismos no eran reembolsables, sino que eran a fondo perdido. Es decir, que el modelo de fomento indirecto no era ni una modalidad de financiamiento (préstamo a tasa subsidiada) ni un mecanismo de inversión retornable (con participación en los ingresos provenientes de la explotación comercial de la obra).

A partir de finales de la década de 1990, el Estado comienza a incrementar las condiciones para acceder a los recursos provenientes de los estímulos fiscales, con el fin de evitar abusos. Sin embargo, lo que se consiguió fue fortalecer la posición de las 
empresas ya establecidas en lugar de estimular el desarrollo de un mayor número de productoras.

Como no había límite en el nivel de captación de recursos que, en la práctica, correspondía al costo integral del proyecto, no hubo estímulo para que los productores desarrollasen proyectos que fueran competitivos a la hora de atraer al público. Como los filmes se "pagaban" simplemente en su propio proceso de producción, y no mediante su circulación en el mercado, la orientación primera de los productores fue trabajar la viabilización financiera de los proyectos: es decir, que en lugar de orientarse al mercado —realizar productos destinados a convocar a la mayor cantidad de espectadores-, los proyectos eran esencialmente “orientados a la captación” (Ikeda, 2012). Más aún: tenía más importancia el montar un proyecto que caiga en el gusto de los inversores que uno que remita al gusto del público — críticos del sistema sostienen que esta situación se sigue dando en el país a lo largo de la década de 2000 (Autran, 2004; Izar, 2009; Chalupe, 2010). Este es uno de los factores que explica la existencia, especialmente en el período inicial de la retomada, de un conjunto de filmes históricos (caros) que basaron su existencia en las convocatorias basadas en la exención fiscal, pero que tuvieron, en conjunto, poca convocatoria.

Bajo el modelo de las leyes de incentivo se instaló la percepción de que el apoyo del Estado sería un estímulo para el financiamiento de la producción de obras audiovisuales -mayormente, cinematográficas-, pero sin ofrecer instrumentos legales que favorecieran la inclusión de esas películas en un mercado cuyas perspectivas comerciales eran (y son) cada vez más restringidas. Los productores brasileños —especialmente durante la década de 1990-, atemorizados por el fantasma de los recortes de Collor, solamente lucharon por el aumento de los montos de los recursos públicos para la producción audiovisual; es decir, era una lucha por la autopreservación, pero que profundizaba la dependencia para con el Estado, en lugar de contribuir a superarla, tal cual era el presupuesto original cuando se aprobó la normativa de fomento cinematográfico basado en las leyes de incentivo. 


\section{Distribución}

La notable recuperación en la cantidad de filmes producidos en Brasil no tuvo un acompañamiento similar por parte del público local, situación que sí se daba décadas atrás. Un factor importante para entender esta situación reside en la distribución.

El mercado cinematográfico brasileño - al igual de lo que sucede en toda América Latina y en gran parte del mundo- se encuentra dominado por las majors de Hollywood que controlan la mayor parte del mismo.

Para realizar la distribución tanto de filmes nacionales como extranjeros existen unas 30 empresas, con un puñado muy reducido de distribuidoras que copan el mercado y se imponen por sobre las independientes.

Las principales distribuidoras cinematográficas en Brasil son las majors de Hollywood, que se quedan con las tres cuartas partes del mercado: Fox, Sony (Columbia), Warner, Disney, Paramount y Universal.

Gráfico 36 - Brasil: market share de distribuidoras, por espectadores (2009)

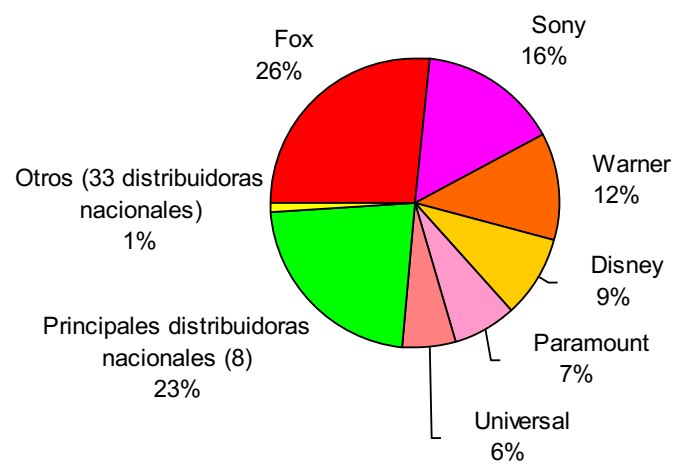

Fuente: Elaboración propia con base en datos de Ancine y Filme-B.

Entre las empresas independientes del rubro —es decir, las que no dominan el mercado (todas nacionales) - se destacaban, hasta $2009,{ }^{55}$ Riofilme - distribuidora estatal creada en noviembre de 1992-, Paris Filmes, Playarte, Imagen, Califórnia, Downtown —que se dedicó más al cine nacional—, ${ }^{56}$ Imovision, Europa y Pandora —estas últimas, dedicadas al circuito de "cine arte".

\footnotetext{
${ }^{55}$ Cinépolis, la poderosa exhibidora mexicana instalada en Brasil en 2010, se convirtió desde ese año en un destacado actor no sólo en la exhibición sino también en la distribución.

${ }^{56}$ En 2010 se creó la distribuidora Tucumán Filmes, que ha tenido en poco tiempo un gran trabajo distribuyendo películas latinoamericanas en Brasil.
} 
Varias de estas distribuidoras son pequeñas exhibidoras - generalmente, instaladas en Río, San Pablo, Belo Horizonte y Porto Alegre- que, ante los escasos recursos para contratar distribuidoras de gran porte, decidieron comercializar filmes por su cuenta.

Sin embargo, al interior de las distribuidoras nacionales también se da una fuerte concentración: dentro de este universo, tan sólo 5 de 41 empresas se quedan con el 90\% de los espectadores, como se aprecia en el gráfico 37.

Gráfico 37 - Brasil: distribuidoras nacionales, market share por espectadores (2009)

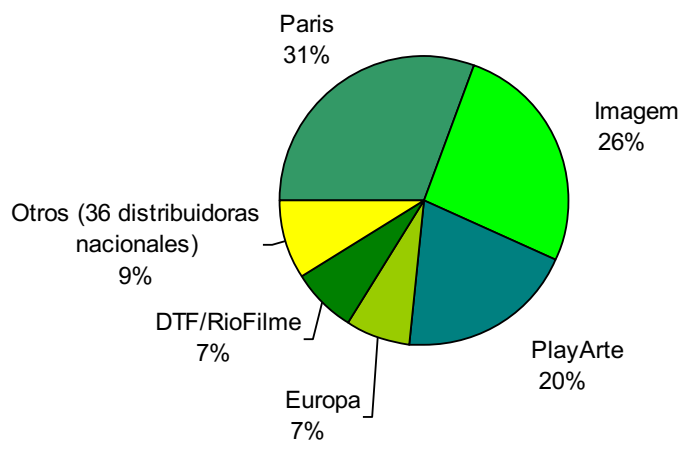

Fuente: Elaboración propia con base en datos de Ancine y Filme-B.

\section{Exhibición}

Durante el siglo XX, primera década del XXI y en la actualidad Brasil posee uno de los principales parques exhibidores a nivel mundial.

El mercado exhibidor brasileño estaba compuesto a 2009 por aproximadamente 2100 salas de exhibición, divididas en poco más de 640 cines - a 2014 se cuentan unas 2700 salas, constituyendo el $12^{\circ}$ parque exhibidor más grande del mundo.

Sin embargo, como ocurre a nivel mundial, existe una diferencia abismal entre la cantidad de cines y de butacas que existían hacia mediados del siglo XX y las que se cuentan en la actualidad.

En 1955 Brasil tenía 1,9 millones de butacas, mientras que en la actualidad ronda las 530.000 - es decir, el décimo parque exhibidor del mundo tiene la cuarta parte de los asientos que tenía hace poco más de medio siglo-. Para tener una idea de este descenso —que es similar a lo que sucedió a nivel mundial- en 1960 sólo Cuba tenía casi la misma cantidad de butacas que las que posee Brasil en la actualidad — la isla caribeña tenía en aquel momento 400 mil butacas de cine. 


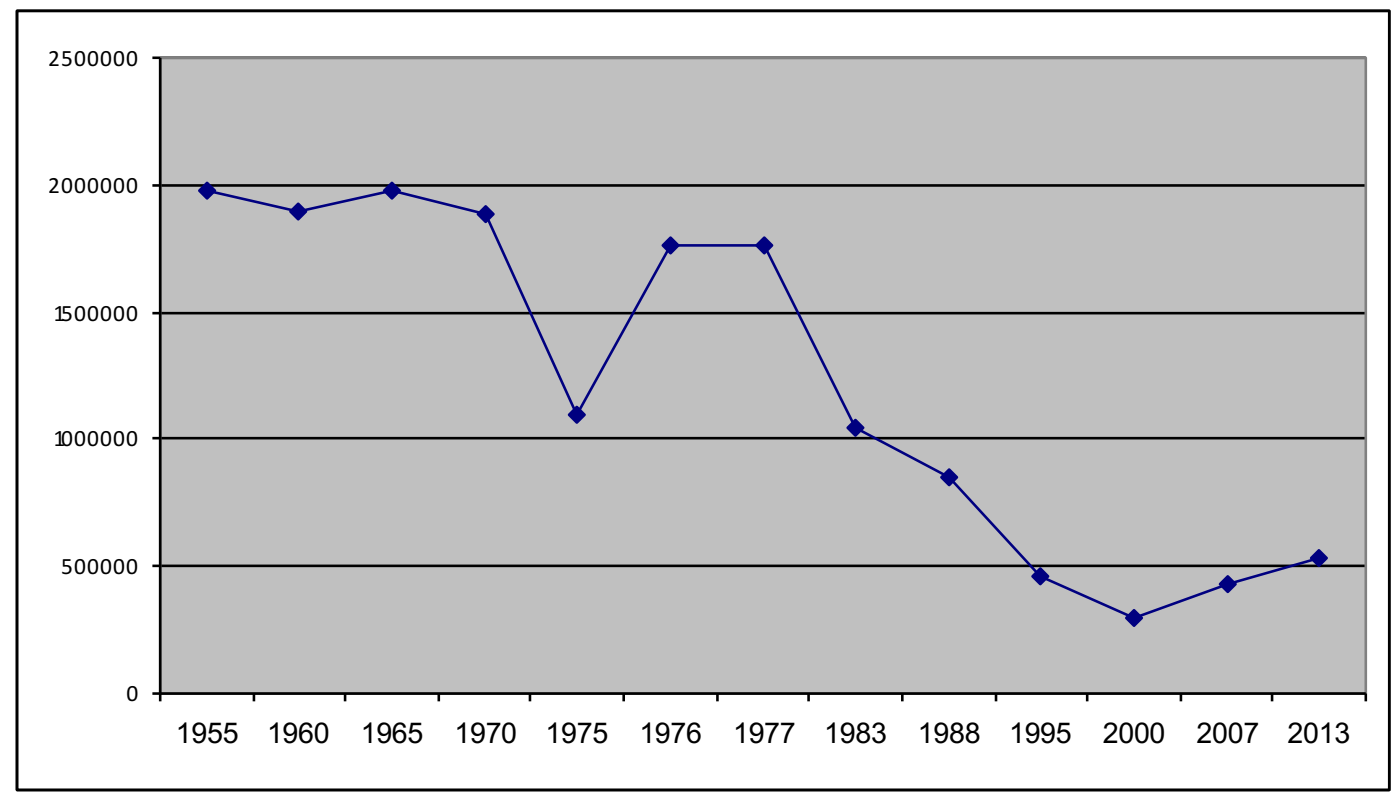

Fuente: Elaboración propia sobre la base de datos de Unesco (1955, 1982), Sadoul (2004), Getino (1987), González (2011b, 2013), Ancine, Rentrak.

El punto más bajo en la caída de la cantidad de butacas se dio durante la década de 1990. Como se explicó en el capítulo 1, esta tesis toma como referencia el número de butacas para hacer una comparación histórica, precisamente por lo sucedido a partir de la década de 1990 tanto en Brasil como en la mayor parte de los mercados cinematográficos del mundo: el ingreso de los multiplex, y su posterior predominio en la exhibición, complejos que - a diferencia de lo que sucedió por décadas hasta ese decenio- poseían un reducido número de butacas. ${ }^{57}$

En efecto, desde la segunda mitad de la década de 1990, con la estabilización monetaria y la apreciación del real, entraron en el mercado brasileño grandes multinacionales del sector, como Cinemark, UCI (National Amusements), Hoyts ${ }^{58}$ y Box (de capitales españoles $)^{59}$ - vale agregar que, posteriormente al período que estudia esta tesis, en 2010, comenzó a operar en Brasil la principal exhibidora latinoamericana: la mexicana Cinépolis, con presencia (a 2015) en México, Brasil, Colombia, Perú, Panamá, Costa Rica, El Salvador, Guatemala, Estados Unidos y la India; en sólo cinco años se convirtió en la segunda principal exhibidora de Brasil.

\footnotetext{
${ }^{57}$ Los multiplex poseen, en promedio, unas 200 butacas, contra 600 que poseían los cines hasta la década de 1990 - no eran raros los casos de cines con 800, 1000 o 1200 butacas, llegando a haber "teatros", como se los denomina en gran parte de América Latina, con 2000 y 3000 asientos.

${ }^{58}$ Comprado por Cinemark en 2009.

${ }^{59}$ En 2011 Box fue comprada por la mexicana Cinépolis.
} 
Además de los grupos extranjeros operando en el mercado exhibidor brasileño también se destacan los grupos nacionales, en su mayoría familiares y tradicionales, como Severiano Ribeiro, Araújo y Arcoiris. El mercado en expansión desde la segunda parte de la década de 1990 también atrajo el surgimiento de otros grupos nacionales (como Cinesystem, GNC, Moviecom), con la presencia de un segmento de "arte" en las principales ciudades del país - este nicho representó el 5\% de las salas de exhibición en 2009 (Ancine, 2012b).

A partir de la década de 1990 el mercado comenzó a concentrarse crecientemente. En efecto, tanto en lo que hace a oferta de salas como al consumo las 10 empresas más importantes concentran tres cuartos del mercado.

Gráfico 39 - Brasil: exhibidoras cinematográficas, porcentaje por público (2009)

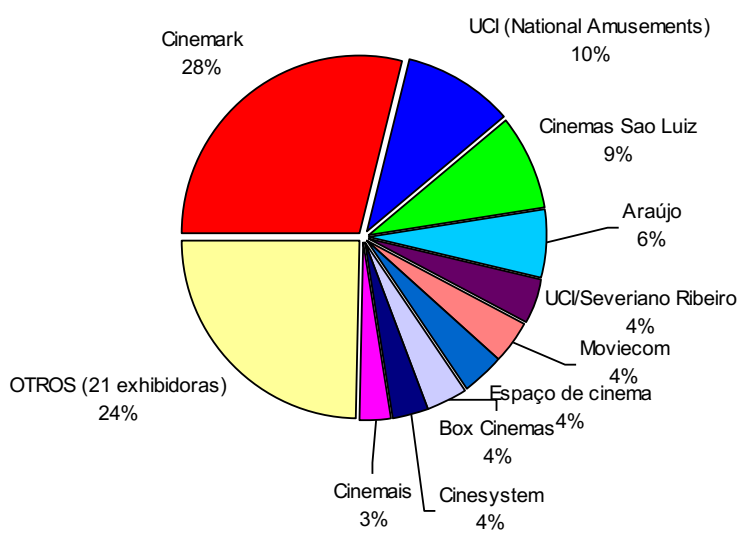

Fuente: Elaboración propia con base en datos de Filme-B.

Por otra parte, la concentración del parque exhibidor brasileño también se da en términos geográficos: en efecto, sólo el 7\% de los municipios brasileños tienen sala de cine —sólo dos ciudades, Río y San Pablo, concentran el 18\% de todas las salas del país, mientras que el Estado de San Pablo, por sí solo, se queda con el 34\% de los cines brasileños; si se le suma el Estado de Río de Janeiro, el 46\% de las salas en Brasil se ubican en estas dos provincias (similar desproporción se repite en toda América Latina). 
Cuadro 30 - Brasil: cantidad de salas por estados (2013)

\begin{tabular}{|l|l|l|}
\hline Estado & Cantidad de salas & Porcentaje \\
\hline San Pablo & 915 & $34,17 \%$ \\
\hline Río de Janeiro & 312 & $11,65 \%$ \\
\hline Resto (25 estados*) & 1451 & $54,18 \%$ \\
\hline Total & $\mathbf{2 6 7 8}$ & $\mathbf{1 0 0 \%}$ \\
\hline
\end{tabular}

*Se incluye el Distrito Federal (todas las “entidades federativas" de Brasil poseen cine).

Fuente: Elaboración propia con base en datos de Ancine.

En lo que hace a cantidad de espectadores, Brasil constituye el $9^{\circ}$ mercado más grande del mundo - tanto en 2009 como en la actualidad-, y de la misma manera que con las salas y butacas, históricamente el mercado brasileño fue siempre uno de los más importantes a nivel latinoamericano.

Hacia el segundo lustro de la década de 1950 Brasil era el principal mercado latinoamericano, en términos de cantidad de entradas vendidas —en 2013 es el segundo, a importante distancia del primero (México).

Desde la segunda mitad de la década de 1970 el gigante sudamericano comenzó un declive en la cantidad de espectadores cinematográficos, cayendo hasta una meseta que duraría unos 20 años (1985-2005) —que tocó un fondo histórico en 1997-, y que comenzaría a recuperarse en 2010.

En efecto, durante la década de 2000, el período que estudia esta tesis, se reflejó una notable recuperación, que luego de 2009 continuó en crecimiento sostenido: en 2013 acudieron a los cines brasileños casi 3 veces más de espectadores que en 1997.

Sin embargo, tal como sucede a nivel mundial, si se comparan los números de consumo cinematográfico, las diferencias entre mediados del siglo XX y la actualidad son muy grandes: en la actualidad, a pesar de la notable recuperación del mercado brasileño, acude a los cines menos de la mitad del público cinematográfico brasileño que existía en 1957. 
Gráfico 40 - Brasil: cantidad total de espectadores cinematográficos (1957-2013)

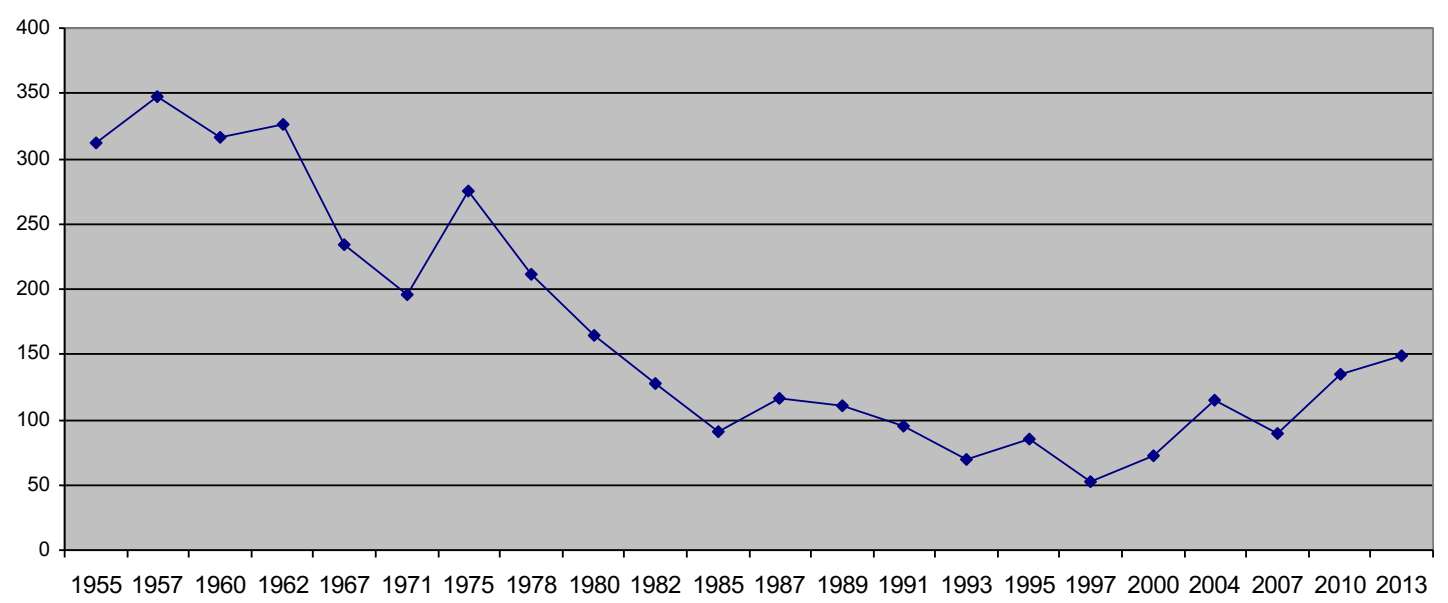

Fuente: Elaboración propia con base en datos de Unesco (1954, 1982), Sadoul (2004), Ancine, Filme-B.

Los filmes estadounidenses —especialmente, de Hollywood- dominan el mercado brasileño — como sucede en los distintos de América Latina-, especialmente a partir de la década de 1990, luego de desmontadas las instituciones de fomento al cine nacional —especialmente, Embrafilme.

Gráfico 41 - Brasil: cantidad de espectadores de estrenos extranjeros y nacionales (1971-2009)

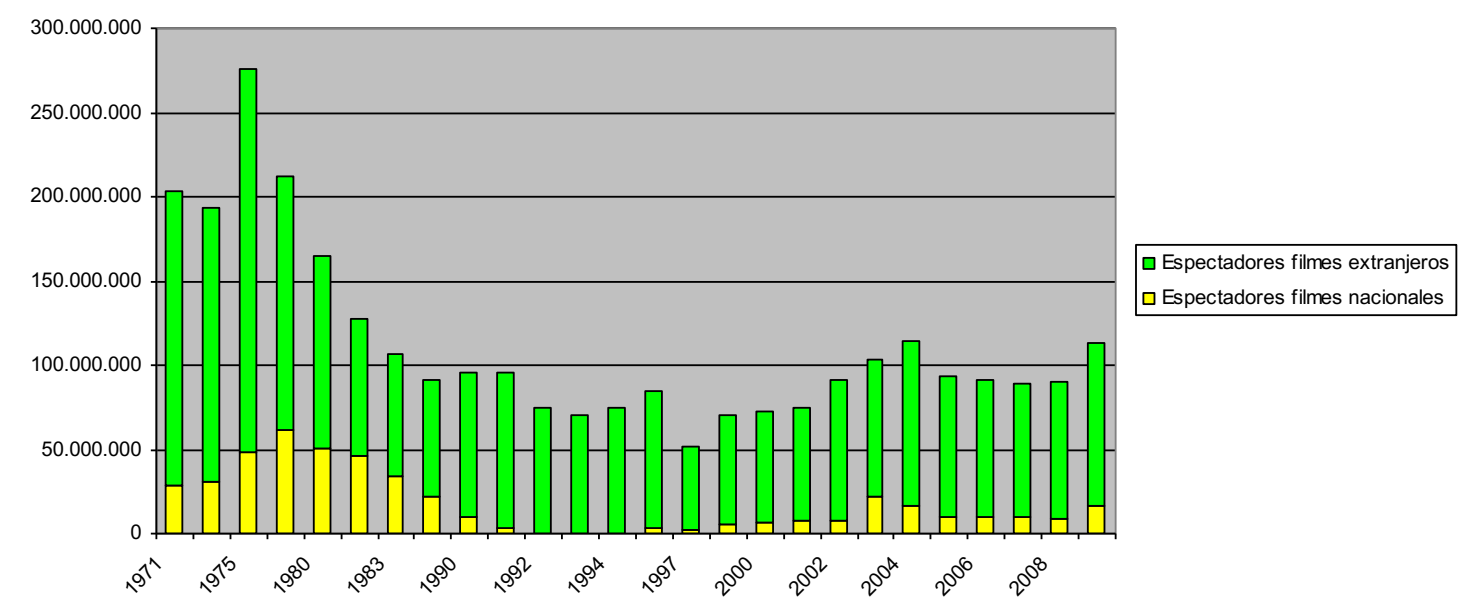

Fuentes: Elaboración propia con base en datos de Ancine, Filme-B, Nielsen-Rentrak, Amancio (2000).

Aunque se observa una "retomada" en la convocatoria de los filmes nacionales a partir de mediados de la década de 2000 - a la par que se incrementan la producción y los estrenos locales-, el market share de las películas brasileñas sigue siendo bajo, rondando el $12 \%$ promedio para la década de 2000 , salvo excepciones acaecidas por algún blockbuster nacional que "empuja" algunos puntos hacia arriba el porcentaje de mercado de estos filmes - similar situación se da en toda América Latina (en los países 
de mayor mercado y tradición cinematográfica, como México y Argentina, el market share es similar al brasileño, siendo mucho más alto décadas atrás, como se aprecia en los respectivos capítulos nacionales presentes en esta tesis).

Cuadro 31 - Brasil: porcentaje de mercado de filmes de estreno, por origen (2000-2009)

\begin{tabular}{|l|l|l|}
\hline & OFERTA & CONSUMO \\
\hline & Títulos estrenados & Recaudación \\
\hline Estados Unidos & $47,77 \%$ & $76,49 \%$ \\
\hline Brasil & $21,05 \%$ & $11,29 \%$ \\
\hline $\begin{array}{l}\text { América Latina (sin } \\
\text { Brasil) }\end{array}$ & $3,45 \%$ & $0,25 \%$ \\
\hline España & $1,66 \%$ & $0,37 \%$ \\
\hline Europa (sin España) & $18,61 \%$ & $2,45 \%$ \\
\hline Resto del mundo & $7,46 \%$ & $9,15 \%$ \\
\hline
\end{tabular}

Fuente: Elaboración propia sobre la base de datos de Nielsen-Rentrak, Ancine, Filme-B y Box Office Mojo.

Así como los filmes nacionales tienen poco market share en Brasil, lo mismo sucede con las cinematografías que no provienen de Estados Unidos — situación que se replica en toda América Latina desde la década de 1990.

Con respecto a la filmografía latinoamericana en Brasil no debe llevar a confusión el tema del idioma: los mismos magros porcentajes se dan en toda América Latina de habla hispana para las películas latinoamericanas no nacionales.

\section{Conclusiones del capítulo}

Brasil es - junto con Argentina y México- uno de los países latinoamericanos con mayor número de películas producidas y que posee una importante tradición cinematográfica. También fue históricamente uno de los principales mercados en el subcontinente - hacia 1969 era el quinto mercado más importante del mundo en términos de entradas vendidas (Keize, 1976c); en la actualidad es el décimo (Focus, 2014).

El gigante sudamericano fue el primer país en imponer cuota de pantalla y medidas estatales para fomentar al sector cinematográfico desde la década de 1930.

Sin embargo, el cine brasileño tuvo auges de producción con alguna repercusión masiva, pero en un siglo de historia no llegó a configurar una industria sustentable (Simis, 1996; Salles, 1996; Autrán, 2005; Gatti, 2008). 
En efecto: el cine de Brasil tuvo períodos y corrientes que trascendieron épocas y fronteras, como las producciones de Atlântida y Vera Cruz, que intentaron emular el sistema de producción de Hollywood, el sistema de grandes estudios —replicado con algún suceso en México y en la Argentina entre las décadas de 1930 y 1950—. No obstante, en Brasil ese intento de cine "industrial" no prosperó, prevaleciendo hasta nuestros días la característica del sector cinematográfico brasileño: una producción atomizada, con pocas productoras que tuvieran una actividad que les permitiera vivir del cine -característica que, por otro lado, es común a todas las cinematografías latinoamericanas desde la década de 1990.

Al finalizar la década de 1960 el cine en Brasil comienza su período más importante en lo que hace a producción y consumo, de la mano de la creación del ente mixto, con control estatal, Embrafilme (Empresa Brasileña de Filmes), que tuvo una activa presencia en todos los eslabones de la cadena productiva.

Brasil y México fueron los únicos países en América Latina que tuvieron un estado empresario cinematográfico, es decir, políticas públicas cinematográficas que abarcaron todos los eslabones de la cadena de valor, con el fin de construir una industria cinematográfica fuerte -desde el desarrollo hasta el consumo-. Con estas políticas el Estado jugó un rol fundamental, con regulaciones tales como altas cuotas de pantalla, intervenciones directas o indirectas en empresas del sector (tales como productoras, distribuidoras o exhibidoras).

En el caso brasileño la implantación de este tipo de política pública cinematográfica fue más tardía que en el mexicano: si en la nación azteca la participación activa y decidida del Estado en todos los eslabones de la industria comenzó a darse en la década de 1940, en Brasil esa acción estatal se dio a partir de 1969, con la creación de Embrafilme.

Las políticas públicas cinematográficas del Estado brasileño a través - principalmente- de Embrafilme es lo que esta tesis entiende como estado empresario, actor preponderante del período fomentista.

Sin embargo, la década de 1980 vio languidecer este período, hasta llegar a comienzos de los noventa, cuando se liquidó repentinamente toda política estatal activa de fomento al cine, pasando de un paradigma de activo fomento estatal a otro dominado por la renuncia fiscal - que, en definitiva, se trata de recursos estatales manejados por las empresas.

A partir de la movilización del sector realizada luego de la liquidación de Embrafilme y de otras entidades estatales de fomento al cine a comienzos de la década de 1990, el 
Estado brasileño creó normativas basadas en incentivos fiscales para apoyar al cine. Sin embargo, el sector deberá sobrevivir durante una década una meseta productiva, en medio de un achicamiento del mercado y con esporádicos auges hasta que en 2001, por una mayor organización y presión del ámbito cinematográfico —especialmente, de la producción - se crea la Agencia Nacional de Cine (Ancine).

Así se termina de conformar la etapa neofomentista que perdura hasta la actualidad: es decir, un fomento estatal al cine con una impronta más "pasiva" que durante el fomentismo.

Ya no existe más el Estado empresario, sino un Estado gestor, que actúa a la defensiva, apenas interviniendo en las relaciones de poder del sector, por lo que terminan imponiéndose los sectores concentrados y relacionados con Hollywood, en un contexto donde predomina la exención fiscal y no las empresas estatales o el fomento directo.

Así se llega a un contexto de mercado fragmentado, donde - a diferencia de lo que ocurría hasta hace 30 años- sólo el 10\% de los municipios del país cuentan con una sala de cine, el porcentaje de mercado de las películas nacionales es constantemente bajo a lo largo del último cuarto de siglo — promedia el 10\% en el período estudiado-, y sólo un reducido número de productoras, distribuidoras y exhibidoras son económicamente sustentables —es decir, tienen una actividad que les permite funcionar como empresa sin tener que recurrir a las ayudas estatales para subsistir.

Desde la década de 1990 en América Latina se dieron distintas variantes del neofomentismo. Según esta tesis, en Brasil predominó la dimensión de las "políticas públicas defensivas”. Entre 1990 y mediados de la década de 2000 en Brasil se impondrá el indicador "mercado orientado": es decir, recursos estatales dirigidos por el mercado - dinero que el Estado deja de cobrar por la renuncia fiscal, que terminan volcados mayormente hacia las principales empresas del medio, especialmente, en aquellas relacionadas con Hollywood y con las multinacionales vinculadas al entretenimiento global.

Sin embargo, hacia 2008 el Estado brasileño comienza a retomar su presencia en el sector cinematográfico, con el Fondo Sectorial, un importante recurso dirigido por las autoridades públicas, que termina siendo una destacada herramienta de fomento cinematográfico hasta nuestros días (2015), aunque la exención fiscal - los recursos “orientados por el mercado"- continúan siendo la principal fuente de recursos del sector. 
En resumen, para esta tesis el fomentismo brasileño en cuanto a políticas públicas cinematográficas se sitúa en el período dominado por la empresa mixta dominada por el Estado, Embrafilme (Empresa Brasileña de Filmes), que operó entre 1969 y 1990, y cuyo período de auge —que fue el mejor período para la cinematografía brasileña (en términos de mercado y aceptación popular)— se situó entre la década de 1970 y comienzos de la de 1980.

Por su parte, el neofomentismo cinematográfico brasileño comienza en la década de 1990, a partir de la movilización del sector, golpeado por la desregulación y la apertura estatal que había desmontado las distintas entidades estatales de fomento al cine: así, el Estado brasileño genera una legislación de fomento al sector, pero mucho más laxa que durante el fomentismo, basada en la renuncia fiscal.

De esta manera, la actual normativa brasileña de fomento al cine se encuentra focalizada en la producción, y basada en la renuncia fiscal, a diferencia de lo que sucedía durante el fomentismo (Embrafilme), donde el Estado intervenía fuertemente tanto en el sector de la producción como en los de la distribución y de la exhibición.

Los recursos terminan timoneados por el sector privado, beneficiando a los sectores más concentrados — generalmente, ligados a Hollywood y a grandes multinacionales. 


\section{CAPÍTULO VII \\ POLÍTICAS PÚBLICAS CINEMATOGRÁFICAS EN ARGENTINA}

\section{Introducción histórica}

En julio de 1896 se realiza la primera proyección de "rollos filmados" en la Argentina —en el Teatro Odeón, de Buenos Aires-. El propulsor de las primeras proyecciones fue el belga Enrique Lepage -el primer importador de productos y máquinas cinematográficas (francesas)—. En su negocio trabajaban también sus socios el austríaco Max Glucksmann y el francés Eugenio Py. Todos ellos serían los pioneros de la realización cinematográfica en la Argentina, aportando las primeras "vistas" del país — precisamente, la primera película registrada y procesada en el país fue La bandera argentina, filmada por Py en 1897.

En 1908 se estrena el primer filme argentino dramatizado, El fusilamiento de Dorrego, del italiano Mario Gallo - un inmigrante recién llegado al país como maestro de coros líricos (Getino, 2005a).

En ese mismo año Glucksmann pasó a manejar la casa Lepage — desde donde Py continuaba con una prolífica labor cinematográfica-. Glucksmann seguía realizando películas, pero también llevaba a cabo una importante actividad de distribución y comercialización de filmes nacionales y extranjeros, sumada al manejo de una importante red de salas tanto en la Argentina como en Uruguay y Chile (Getino, 2005a). En 1912 se funda la Sociedad Cinematográfica Argentina. Para esta época, el país ya contaba con un estudio de filmación (fundado en 1909) y laboratorios (Di Núbila, 1998).

En 1915 se estrenó el primer gran éxito del cine argentino: Nobleza gaucha, un filme que trataba la realidad argentina a partir de cierta mirada crítica - a lo largo de la película se insertaban textos del Martín Fierro- Este filme - cuyo costo fue de 20.000 pesos, mientras que su ganancia fue de 600.000 pesos - llegó a estrenarse en España y en varios países latinoamericanos (Mahieu en Getino, 2005a:14).

Un año antes, en 1914, Glucksmann había realizado un filme también basado en una obra literaria del siglo XIX, Amalia, auspiciado por la alta burguesía (la "Sociedad del rostro divino"). Pero no tuvo la repercusión de Nobleza gaucha -como tampoco lo tendría ninguna película argentina durante mucho tiempo.

Por esta época también se destacaría otro italiano devenido en realizador cinematográfico: Federico Valle, quien se dedicó principalmente a los documentales -especialmente, de la geografía nacional-. Valle, a su vez, había fundado unos 
nuevos estudios de filmación, donde se realizaría buena parte de los filmes nacionales de fines de la década de 1910 y de los años veinte, y fue productor de distintas realizaciones, entre ellas la que es considerada la primera película de animación del mundo: El apóstol, de 1917. Valle también fundó el noticiero cinematográfico Valle Revista Valle, que se exhibiría en los cines argentinos hasta 1930 (Di Núbila, 1998; Getino, 2005a).

A fines de la década de 1910 surge quien sería el principal director del cine argentino durante los años venideros: José Agustín “el Negro" Ferreyra, quien realizaría filmes que plasmaban una "imagen poética de arrabal", como las define Getino (2005a:15), entre las que se destacarían Organito de la tarde (1925), La muchachita de Chiclana (1926) y Perdón, viejita (1927).

Ferreyra, quien lanzaría al estrellato a figuras como Libertad Lamarque, es retratado por José María Couselo:

Ferreyra descubrió cinematográficamente el rostro de Buenos Aires. O uno de los rostros de Buenos Aires, el de su humildad y sufrimiento. El de su pobreza cotidiana. Él nació pobre, y pertinazmente se aferró a esa pobreza como no queriendo evadirla... La ciudad real es el tema. El barrio es el prisma madre de esa ciudad real, su paisaje, su horizonte. El argumento del film es nada o poco. O es el pretexto en el avistar más humano que geográfico del paisaje. (Couselo, en Getino, 2005a:14)

En 1919, en pleno año de la "Semana trágica" - pogrom fascista contra los trabajadores, especialmente los de origen judío, por parte de sectores de la oligarquía porteña-, se estrenó un filme que tuvo una importante repercusión: Juan sin ropa, que trata sobre la explotación de los trabajadores. Domingo Di Núbila lo retrata así:

Buenos Aires y la pampa, como su antecesora, Nobleza gaucha, le dan ambiente; carne y cereales, riqueza del país, están en sus fotogramas, y por último, pero no "lo" último, están en ella conmociones espirituales y el fermento reivindicatorio de una época argentina en que el hombre de trabajo renunciaba a seguir inclinándose sumiso ante el amo omnipotente, $\mathrm{y}$ se lanzaba a luchar por el rescate de su dignidad y de indeclinables aspiraciones humanas. (Di Núbila, en Getino, 2005a:15) 
Mientras tanto, el Estado se encontraba notoriamente ausente en lo que hace al fomento cinematográfico. Así lo grafica Federico Valle:

Hasta ahora no hemos contado los productores nacionales con la ayuda de los poderes públicos. La película virgen paga el mismo derecho aduanero que la película impresa (...) Tenemos las leyes alemanas, francesas e italianas que protegen las industrias autónomas, que limitan la importación, que favorecen la exportación y que también podrían tomarse como patrón y como índice. Aquí no tenemos nada de eso. (Valle, en Getino, 2005a:24)

Precisamente, años después, sería el propio Valle quien debería vender su gran acervo cinematográfico a una fábrica de peines, a quien le interesaba el celuloide de los rollos -luego de intentar infructuosamente, en reiteradas ocasiones, que el Archivo General de la Nación adquiriera estos filmes.

Sin embargo, durante la década de 1930 la cinematografía nacional se consolida y conforma su "edad de oro". En 1932 se fundaron Lumiton y Argentina Sono Film, los dos grandes estudios de la época de oro del cine argentino, que serían referentes de la industria durante décadas. Poco después se abrió el estudio SIDE — no tan relevante como los dos anteriores-: los tres estudios se equiparon con los últimos adelantos tecnológicos de la época y se dedicaron a la experimentación del cine sonoro.

En 1933 Sono Film estrenaba ;Tango! y, pocas semanas después, Lumiton llevaba a las pantallas Los tres berretines, convirtiéndose en las dos primeras películas sonoras y habladas del cine argentino. ${ }^{60}$

Cinco años antes de la fundación de Lumiton y Sono Film se habían abierto los Laboratorios Alex, que llegó a ser el principal de Argentina, y uno de los más importantes a nivel latinoamericano. Durante la década de 1930 y comienzos de la de 1940 se abrirían otros destacados estudios, como el San Miguel, y laboratorios, como el Baires. Para 1942 existían en la Argentina unos 30 estudios cinematográficos y cuatro mil trabajadores en la industria (Getino, 2005a), números sólo equiparados por México, en el ámbito latinoamericano, a lo largo de esa época (García Riera, 1999).

\footnotetext{
${ }^{60}$ Según estudiosos como Di Núbila (1998) y Getino (2005a) el primer filme sonoro argentino fue Muñequitas porteñas, de 1931, que tenía sonido sincronizado Vitaphone, a diferencia de iTango! y Los tres berretines, que habían sido rodadas con el sistema Movietone de sonido óptico.
} 
En esa década se produjeron en la Argentina un promedio de 8 filmes anuales entre 1930 y 1935, creciendo hasta un promedio de 45 entre los años 1936 y 1942 (Getino, 2005a; Unesco, 1955). Muchas de estas películas triunfaron no sólo a nivel local sino en toda América Latina: el star system criollo era reconocido en todo el subcontinente y más allá.

En 1942 finaliza la época de oro, debido principalmente a la escasez repentina de película virgen impuesta por Estados Unidos en represalia, básicamente, por la neutralidad argentina en la Segunda Guerra Mundial. ${ }^{61}$ Comienza así una creciente crisis en el cine argentino.

Durante el peronismo, el cine argentino busca recrear su época de oro, encerrándose en los últimos estudios que van quedando, pero apuntando a adaptaciones de clásicos de la literatura universal y a comedias de "teléfono blanco" sin mayores pretensiones artísticas; la "época de oro" había quedado en los años treinta. Para la década de 1940 y 1950 el cine mexicano ya se había convertido en el gran referente del cine latinoamericano, con proyección no sólo regional sino mundial.

Para fines de la década de 1950 se crea el último gran estudio argentino, Aries, fundado por Fernando Ayala —en una época donde ya estaban en decadencia los antiguos.

La década de 1960 se caracterizó por un "boom" del cine de autor —el llamado "nuevo cine argentino" de entonces-, contemporáneo y deudor de la nouvelle vague, del Free Cinema inglés o incluso del cinema novo brasileño. Este "nuevo cine argentino" tenía como referentes a Manuel Antín, Fernando Ayala, Leopoldo Torre Nilsson, Rodolfo Kuhn, David Kohn, Leonardo Favio o Héctor Olivera.

Para 1968 de la industria existente en la edad de oro sólo quedaban los estudios de Argentina Sono Film y algunas galerías, mientras que un clima de liberación y rebeldía cundía especialmente en las clases medias y en la actualidad, en medio de la dictadura de Onganía, aunque también se había dado un auge del revisionismo histórico y sociológico de la historia y la cultura política, que también se plasmaría en el cine.

\footnotetext{
${ }^{61}$ Una de las medidas que más irritaron a Washington fue la postura argentina en la conferencia continental que se realizó en Río de Janeiro, en enero de 1942, pocas semanas después del ataque japonés a la base estadounidense de Pearl Harbor. En la Conferencia de Río de Janeiro, Washington pretendía que los países latinoamericanos rompieran relaciones con el Eje, y que se aliaran con Estados Unidos. La posición argentina se oponía a esta postura, pidiendo libertad de acción para cada país de la región. Triunfó la posición argentina. Desde ese instante Washington tomó diversas represalias contra el gobierno de Buenos Aires: discriminaciones comerciales - como el referido al bloqueo de la exportación de película virgen-, la obstrucción de fondos argentinos en Estados Unidos, el no reconocimiento de gobiernos, el retiro de embajadores, etcétera (Rapoport, 1995).
} 
A su vez, tanto en Argentina como en la mayoría de América Latina comienzan a surgir —especialmente, desde el segundo lustro de la de la década de 1960 y la primera mitad del decenio siguiente- cineastas y movimientos de cine comprometidos con el cambio social y político, tales como el Grupo de Cine Liberación y el Grupo Cine de la Base, en Argentina -el documental argentino La hora de los hornos, estrenado en 1968, se convertiría un referente latinoamericano de este tipo de cine-; el cinema novo, en Brasil; el Grupo Ukamau, en Bolivia, el "cine imperfecto" postulado por el cubano Julio García Espinosa, entre otros.

Con la llegada de la dictadura militar en la Argentina en 1976 el sector cinematográfico, sus realizadores, sus artistas y técnicos también sufrirían la represión, la persecución, además de la concentración y la extranjerización que atravesarían todo el sector productivo del país, mientras que en la filmografía local de esos años dominarían las comedias pasatistas con cómicos televisivos o cantantes de moda — realizadas casi en su totalidad por Argentina Sono Film y Aries Cinematográfica-. También decaería la cantidad de largometrajes realizados: si en 1974 se produjeron 40 filmes, en 1976 el número había descendido a 16 y a 15 en 1977 (Getino, 2005a).

Con la llegada de la democracia, el cine fue volviendo a incorporar temáticas sociales, de cierto riesgo estético y artístico. El gobierno de Raúl Alfonsín dio impulso a una gestión a favor de la cultura, con Manuel Antín al frente del Instituto de Cine. Se levantó la censura, el Ente de Calificación Cinematográfica dejó de existir, se apoyó el surgimiento de jóvenes realizadores, y las películas más vistas ya no fueron exclusivamente las comedias pasatistas - como había sucedido durante la dictadura militar- sino filmes como Camila, Hombre mirando al sudeste o La historia oficial, título que le daría a la Argentina el primer Oscar a mejor película extranjera en 1986.

La crisis económica y política de fines de la década de 1980 y comienzos de la de 1990 también afectaría al cine: en esos años, el número de filmes producidos caería a pisos que no se veían en décadas, mientras que el Instituto de Cine (hacia 1989 y 1990) estaba al borde de la insolvencia.

En 1994 se sancionaría la reforma de la ley de cine. La producción crece y surge una nueva camada de realizadores que la prensa especializada bautizó como el "nuevo cine argentino", con referentes como Pablo Trapero, Lucrecia Martel, Adrián Caetano, Daniel Burman o Bruno Stagnaro, entre otros, cuyos filmes tuvieron una gran repercusión entre la crítica nacional e internacional y, en algunos casos, también en la convocatoria a las salas. 
Una de las características de esta década fue el abaratamiento de los equipos de producción y posproducción, la masificación de la televisión paga y de distintos canales que emitían películas por ese sistema - aunque no muchas argentinas-, sin olvidar la proliferación de decenas de escuelas de cine y audiovisual en todo el país. ${ }^{62}$

Durante la década de 2000 la producción argentina continuó creciendo hasta situarse en la más prolífica de América Latina - aunque a fines de este decenio ya era seguida a muy poca distancia por Brasil y México, en lo que hace a cantidad de largometrajes realizados-. En 2001 otra película argentina es nominada al Oscar (El hijo de la novia) aunque, como ocurrió con La tregua en 1974, perdió; sin embargo, en 2009 El secreto de sus ojos sí se llevó la estatuilla — filme que sería uno de los títulos más vistos en el país en el último cuarto de siglo.

\section{Políticas públicas cinematográficas en la Argentina}

\section{Neofomentismo}

Como se dijo en capítulos anteriores, esta tesis entiende por neofomentismo a las políticas cinematográficas impulsadas desde mediados de la década de 1990 por Argentina, Brasil y México, luego de un período donde el Estado se desentendió del fomento al cine —entre finales de la década de 1980 y comienzos de la de 1990.

Como también se explicó, el neofomentismo existe luego del fomentismo, políticas cinematográficas que nunca se dieron en la Argentina, pero que sí se produjeron en dos países latinoamericanos (México y Brasil) —entendiendo por fomentismo aquellas políticas cinematográficas en las que el Estado tuvo participación directa en todos los eslabones de la cadena de valor del sector (producción, distribución y exhibición).

De acuerdo a esta operacionalización, las políticas cinematográficas argentinas contemporáneas se ubican dentro de las políticas públicas defensivas (neofomentismo), variante "Estado controlado" —esto es: se trata de recursos dirigidos por el Estado-. En el caso argentino - como en el caso francés- se trata de recursos que no provienen del presupuesto público — como sí sucede en gran parte de América Latina-, sino que provienen del mercado - a través de cargas impositivas a eslabones de la cadena: exhibición, publicidad en televisión y comercialización de video-películas.

A continuación se detallarán las políticas cinematográficas en la Argentina.

\footnotetext{
${ }^{62}$ Unos 43 establecimientos que, a 2005, albergaban a más de 12.000 estudiantes, y se concentraban en un $65,5 \%$ en la Capital Federal y en el Gran Buenos Aires, según datos del Censo Nacional de Educación Cinematográfica realizado por el Incaa entre 2004 y 2005 (Deisica, 2009).
} 


\section{Antecedentes}

Hace 80 años la Argentina dispuso la creación de su primera organización gubernamental de cinematografía, cuando se aprobó la ley 11.723 de propiedad intelectual —normativa promulgada el 28 de septiembre de 1933.

Esa ley disponía en el artículo 69, inciso d, que el 20\% de los ingresos que se recaudaran a partir de la aplicación de esta normativa, fueran a crear el "Instituto Cinematográfico Argentino", "destinado a fomentar el arte y la industria cinematográfica nacional, la educación general y la propaganda del país en el exterior, mediante la producción de películas para el Instituto y terceros".

Esta normativa también enunciaba: "A los efectos artísticos, educativos y de propaganda en el exterior, el Poder Ejecutivo designará una junta de consejeros adhonorem entregada por cinco miembros representantes de la Sociedad Argentina de Exhibidores Cinematográficos, escritores argentinos, Academia de Bellas Artes, Consejo Nacional de Educación y uno de los representantes nombrados por el Congreso de acuerdo al artículo 70 de esta ley. Dicha junta será presidida por el director técnico del Instituto Cinematográfico Argentino". En lo que hace a la parte instrumental, la ley disponía que "los materiales y maquinarias que sean necesarios introducir del extranjero, para la instalación de los talleres y estudios del Instituto, quedan exonerados del pago de derechos de aduana".

De lo anterior se aprecia la intención de quienes aprobaron la normativa de crear un organismo gubernamental dedicado al fomento del cine tanto en su dimensión artística como industrial, a partir de una empresa estatal dedicada a la producción de filmes.

Sin embargo, en la reglamentación de esta ley — realizada medio año después (en mayo de 1934)— ya no se mencionaba ningún instituto de cine.

Dos años luego, una vez que ya estaba constituida la Comisión Nacional de Cultura, el Poder Ejecutivo Nacional designó en agosto de 1936 al presidente de esa Comisión y al director técnico del futuro Instituto Cinematográfico Argentino, para que elaboraran un proyecto con las directivas de organización, funcionamiento y reglamentación, así como también las maneras en que el Estado iba a intervenir en el sector cinematográfico; más las acciones dirigidas a fiscalizar la actividad cinematografía y a proteger la actividad. A partir de esto, el 1 de febrero de 1937 se estableció que "las producciones cinematográficas editadas en el país, que interpreten, total o parcialmente, asuntos relacionados con la historia, las instituciones o la defensa nacional, serán sometidas a la 
aprobación del argumento a desarrollar y de la realización definitiva" por una comisión integrada por funcionarios arriba citados (Campodónico, 2005).

Un par de años después, en septiembre de 1938, el senador nacional Matías Sánchez Sorondo - una destacada figura del conservadurismo argentino ${ }^{63}$ - presentó en el Senado de la Nación un proyecto de ley que promovía la creación de un Instituto Cinematográfico del Estado, que implicaba una importante intervención del Estado. Sánchez Sorondo había realizado un largo viaje por Europa con el fin de estudiar e interiorizarse de las legislaciones estatales de fomento al cine, tanto en países fascistas (Alemania e Italia) como de tradición liberal (Gran Bretaña y Francia). El legislador introducía su proyecto de ley de la siguiente manera:

(...) primero, el cinematógrafo, como industria, como comercio, como expresión artística, debe gozar de toda la libertad que nuestras leyes otorgan al ejercicio de los derechos privados y debe ser especialmente protegido por el Estado; segundo, el cinematógrafo, como factor de difusión de ideas y de cultura, debe estar sometido a la fiscalización del Estado, que ejerce así una función irrenunciable de gobierno. (Campodónico, 2005)

Sin embargo, pasaban los años y el instituto no terminaba de concretarse: para agosto de 1941 se reglamentaron las atribuciones de una futura agencia que pasaría a llamarse Instituto Cinematográfico del Estado. En esta reglamentación se disponía que:

a) tendrá a su cargo la producción de las películas oficiales para los departamentos de Estado o las entidades autárquicas, que efectuará directamente o por intermedio de empresas privadas; b) adoptará los medios conducentes al fomento, estudio y enseñanza del arte y de la industria cinematográfica; estimulará las investigaciones de técnica y de laboratorio que contribuyan al progreso de la producción argentina; organizará exposiciones que revelen el adelanto de la misma y concursos que permitan la incorporación al cinematográfico de nuevos valores; editará publicaciones especializadas; mantendrá una sección de estadística cinematográfica y

\footnotetext{
${ }^{63}$ Sánchez Sorondo fue ministro del Interior de José Félix Uriburu, y estuvo a cargo de la "Sección Especial de Represión de actividades comunistas", encargada de perseguir militantes de izquierda, de clausurar establecimientos y de requisar libros y distintos materiales de inspiración comunista.
} 
creará un archivo de películas y fotografías destinado a funciones de estudio. (Poder Ejecutivo Nacional, 1941)

No obstante, nada de ello se cumplió: la dictadura que tomó el poder el 4 de junio de 1943 creó el área de prensa y difusión, que absorbió las funciones del proyectado Instituto Cinematográfico del Estado, formalmente dado de baja el 1 de febrero de 1944. El gobierno conservador gobernante durante la "década infame" comprendió la importancia de distintas instituciones y juntas impulsadas por el Estado. Así, crea el Instituto Cinematográfico del Estado, ente que buscaba orientar, proteger y tutelar al cine argentino. Por su parte, en 1938 el senador Matías Sánchez Sorondo —destacada figura del conservadurismo argentino- presentó el primer proyecto de ley de protección para el cine argentino, aunque no prosperó, pese a que desde la aparición del cine sonoro en el país, en 1933, el sector cinematográfico reclamaba una normativa que abarcara a esta industria.

La importancia de la protección estatal hacia el cine se vio reflejada - de manera especular- en 1943, cuando el boicot estadounidense contra la Argentina por su neutralidad en la Segunda Guerra Mundial canceló la importación de película virgen, lo que dejó a la industria prácticamente sin su insumo básico, perdiendo su hegemonía en el mercado latinoamericano, y decayendo en el mercado local.

En efecto, para esta época distintos países ya poseían políticas de protección al cine, destacándose Francia, Inglaterra, Alemania, Italia, y en América Latina, Brasil. Estas normativas ponían el énfasis en medidas tanto de fomento a la producción - con beneficios impositivos para el abastecimiento de material y equipamiento cinematográfico- y proteccionistas - barreras arancelarias y para-arancelarias a la importación de películas extranjeras, y cuotas de pantalla, establecimiento la obligatoriedad para los exhibidores de exhibir filmes nacionales por un período mínimo de tiempo estipulado por el Estado, que en casos como el británico fomentó la realización cinematográfica (películas que en esa época se denominaron quota quickies).

En Argentina recién en 1944 se sancionaría el primer decreto relacionado con el sector cinematográfico: la cuota de pantalla para el cine argentino. 


\section{El peronismo y el cine}

En agosto de 1944 se firma el decreto 21.344 estableciendo la cuota de pantalla. La medida establecía la obligación para todos los cines del país de exhibir una cantidad mínima de películas argentinas, de acuerdo a tres categorías relacionadas con el tamaño y localización de las salas (Perelman, 2004).

Luego de que Perón fuera elegido presidente por el voto popular, el Estado argentino comienza a apoyar la producción cinematográfica y a restringir el ingreso de filmes extranjeros. Pero investigadores como Getino (1998) y Fabbro (2014) indican que este período se caracterizó no por una época de esplendor sino por filmes sin riesgo estético ni económico, por lo que los "logreros", como los denomina Getino - directores y productores a los que sólo les interesaba recibir dineros estatales y no realizar un buen producto-, dominaron la realización cinematográfica entre 1946 y 1955 — sin olvidar el control ejercido por el gobierno hacia quienes no eran simpatizantes peronistas (con Raúl Alejandro Apold, subsecretario de Informaciones y Prensa, como personaje central en este aspecto).

Con las medidas gubernamentales de subsidio a la producción cinematográfica lograron incrementar la cantidad de filmes realizados a comienzos de la primera presidencia de Perón —-pasando de 23 películas producidas en 1943 a 56 en 1950.

\section{Área de Informaciones de la Presidencia de la Nación}

Desde el golpe de 1943 hasta la caída de Perón, en septiembre de 1955, el gobierno (más que el Estado) estuvo ligado al sector del cine a través del área de Información y Prensa de la Presidencia de la Nación.

En efecto: el 21 de octubre de 1943 se reorganizó lo que hasta entonces había sido la Subsecretaría de Informaciones y Prensa, para pasar a ser la Subsecretaría de Informaciones, que se encargaría de centralizar todo lo referido a informaciones del Estado y publicidad. Esta Subsecretaría tenía distintas secciones llamadas Direcciones Generales, entre las que figuraba la de Espectáculos Públicos - la que, a su vez, contenía las direcciones de Cinematografía, Control y Teatro-; la Dirección de Cinematografía contenía, por su parte, a las divisiones de abastecimiento, de fomento y de producción (Harvey, 2005).

La Dirección de Cinematografía tenía una función vital para el sector: propender al abastecimiento de película virgen importada - Argentina no la producía, y a partir de 1942 había sufrido una merma muy significativa, debido a la mencionada represalia de 
Estados Unidos, en el contexto de la neutralidad argentina durante casi la totalidad de la Segunda Guerra Mundial.

En 1946 se realizaron elecciones, ganando Perón. El racionamiento de película virgen continuó de manera drástica hasta 1950. El gobierno peronista aprovechó esta escasez para ejercer un estrecho control sobre los distintos integrantes del sector cinematográfico. A su vez, el peronismo otorgó de manera discrecional y poco transparente cuantiosos dineros públicos a los empresarios afines al gobierno (Getino, 2005a), generando millonarios negociados que generaron una mayoría de películas intrascendentes.

En 1954 la Subsecretaría de Informaciones fue elevada al rango de Secretaría de Prensa y Difusión de la Presidencia de la Nación (Harvey, 2005). El nuevo organismo continuó centralizando el fomento al cine argentino y se convirtió en un poderoso medio de difusión y propaganda del gobierno peronista.

Por esta época, México había construido la industria cinematográfica más grande de América Latina, con el Estado apoyando fuertemente, en pleno período fomentista - es decir, con intervención activa y plena del Estado en la cadena productiva-. En Argentina, si bien desde mediados de la década de 1940 el Estado había comenzado a intervenir, lejos estaba de políticas activas —no construía estudios estatales, ni había propiciado una ley de cine con, por ejemplo, el 50\% de cuota de pantalla, como en México-, sino de acciones dispersas, que no construyeron un sector fuerte: muestra de esto es que los estudios iban cerrando uno a uno, y que la otrora importante presencia de la cinematografía argentina en América Latina había languidecido a manos de las películas mexicanas.

\section{“Revolución Libertadora” y Frondizi}

El 16 de septiembre de 1955 se produjo un golpe militar que derrocó a Perón —cuatro meses antes se había producido un intento frustrado, con un bombardeo criminal sobre la Plaza de Mayo, dejando centenares de víctimas civiles.

Al ser derrocado Perón el Estado argentino dejó inmediatamente de lado la cuota de pantalla y los apoyos a la producción, por lo que el número de filmes producidos cayó en picada -12 en 1956, a diferencia de los 44 en 1954 y 43 en 1955 (Getino, 2005a).

Asimismo la dictadura militar disolvió la Secretaría de Prensa y dispuso que la Dirección de Espectáculos Públicos — que contenía la división dedicada al fomento del cine- pasara al Ministerio de Educación. 
Posteriormente, en 1957, la dictadura militar eliminaría esta división de cinematografía para dar paso al Instituto Nacional de Cinematografía (INC). Al año siguiente, el gobierno constitucional de Frondizi avala la creación del INC y además instrumenta un Fondo de Fomento, por el cual ese año se incrementa nuevamente el número de filmes nacionales producidos -39 en ese año de 1958; por casi una década el promedio de películas argentinas producidas rondará la treintena.

El gobierno de Frondizi también fomentó la producción de cortometrajes, en plena época germinal que luego devendría en el "nuevo cine argentino".

\section{Creación del Instituto Nacional de Cinematografía}

En enero de 1957 la dictadura militar que estaba en el poder dispuso una nueva normativa que derogaba todas las disposiciones anteriores que se le opusieran. Se trataba del decreto ley 62/57, que entre las cláusulas salientes se destacaban las relacionadas con las condiciones que debían tener las películas para ser consideradas "nacionales", la libertad de expresión, la libertad sindical del trabajador cinematográfico, normas acerca de la exhibición obligatoria de películas nacionales y distintas medidas de fomento cinematográfico — destacándose el fondo de fomento(Presidencia de la Nación, 1957).

Una medida fundamental de esa nueva normativa fue la constitución del Instituto Nacional de Cinematografía (INC) -en abril de 1957-, que pasaría a ser tanto organismo de aplicación como administrador del fondo de fomento recién creado.

El INC era un ente autárquico del Estado, cuya dirección estaba a cargo de un directorio compuesto por un presidente y cuatro vocales - se pedía que fueran "versados" en el sector-, quienes eran designados por el Poder Ejecutivo Nacional. El fondo de fomento, por su parte, estaba compuesto por el monto equivalente al $10 \%$ del precio de cada entrada de cine, más el importe de las tasas de exhibición de largometrajes extranjeros que establecía el gobierno nacional (Harvey, 2005).

De esta manera, se asentaban las bases -institucionales, administrativas y financieras- del sistema de fomento al cine nacional y del instituto de cine. Esta institución perduraría hasta la actualidad — con algunos posteriores-, siendo al día de hoy la agencia nacional de cine más longeva de América Latina. 


\section{La ley de cine de 1968 y la posterior normativa sobre cine}

En junio de 1966 una nueva dictadura había llegado al poder en la Argentina. Este gobierno de facto dispuso en mayo de 1968 un cambio en la normativa cinematografía vigente desde 1957.

Con el decreto-ley 17.741 el Instituto Nacional de Cinematografía continuó siendo el encargado del fomento y la regulación del sector cinematográfico tanto en la Argentina como en el exterior -en lo que hace a la difusión internacional-, sin perder la percepción y fiscalización del $10 \%$ sobre las entradas de cine. A su vez, se ampliaron las responsabilidad de regulación para el INC: a partir de 1968 también quedaba en su órbita la posibilidad de regular la exhibición de filmes emitidos por televisión (Harvey, 2005).

El principal cambio que generó esta nueva normativa fue que el instituto de cine pasó a depender de la Secretaría de Difusión y Turismo de la Presidencia de la Nación, manteniendo una limitada autarquía. A su vez, también hubo un cambio en la dirección del instituto: ahora estaba al mando el director nacional de Cinematografía de la mencionada Secretaría de Difusión y Turismo, a quien secundaba una Junta Asesora Honoraria, designada por la misma Secretaría. Entre las funciones de este nuevo instituto estaban las de regular las cuotas de ingreso y distribución de filmes extranjeros y de hacer cumplir la obligación de procesar, doblar y subtitular copias de películas extranjeras dentro del país, "en la medida que lo considere necesario en función del mercado nacional" (Harvey, 2005; Poder Ejecutivo Nacional, 1968).

Relacionado con esta prerrogativa de regulación sobre la distribución cinematográfica, en los últimos días de ese mismo año, mediante la ley 18.019 se crea el Ente de Calificación Cinematográfica — dependiente del Poder Ejecutivo-, entidad censora que gozaría de importante poder dentro del sector hasta 1983.

Vale notar que la normativa establecida en 1968 por una dictadura militar es la que se encuentra todavía vigente - la que ha tenidos cambios importantes en 1973, 1994 y 2002.

La primera modificación grande se realizó en febrero de 1973, por parte de otra dictadura militar. Se trata del decreto-ley 20.170 de Fomento y Regulación Cinematográfica que en "uno de sus artículos excluía de la exhibición y subsidios a las películas que atentaran contra el estilo nacional de vida" (Maranghello, 2005:195).

Con esta reforma se fortalecieron las atribuciones del director del INC y se endureció la censura, excluyendo de los beneficios de la normativa (cuota de pantalla, créditos y 
subsidios) a los filmes "que atenten contra el estilo nacional de vida, o las pautas culturales de la comunidad o vayan en detrimento de los intereses de la Nación".

Durante el corto gobierno de Héctor Cámpora, en 1973, la censura se relaja con Octavio Getino como interventor del Ente de Calificación Cinematográfica: bajo su gestión, se aprueba la proyección de decenas de películas que estaban censuradas desde hacía varios años, incluyendo varias nacionales. ${ }^{64}$

Posteriormente, comienza un período de prohibición y persecución —con la organización paramilitar Triple A a la cabeza-, que se incrementaría luego del fallecimiento del presidente Perón, en julio de 1974, persecución que también alcanzaría a los intelectuales y artistas de izquierda pertenecientes al sector cinematográfico. A su vez, el gobierno peronista nombra como interventor a Paulino Tato - cargo que conservaría durante la dictadura, hasta septiembre de 1978-; Tato se convertiría en uno de los censores con más poder dentro del medio - se calcula que en sus cuatro años de “gestión” censuró más de 600 películas (Getino, 2005a).

El golpe militar de marzo de 1976 reforzó el genocidio — que había comenzado un año antes, con el Operativo Independencia-y, a nivel de la cultura, amplió el oscurantismo sobre el cine, el teatro, la literatura, la televisión y la radio: durante la última dictadura cívico-militar numerosos directores, guionistas y actores, entre otros, debieron exiliarse del país, mientras otros desaparecieron y fueron asesinados.

Aunque en 1978 la dictadura instrumenta mecanismos de promoción para el cine nacional, la censura dominaba el ambiente, por lo que sólo se apoyaban filmes apologísticos de la dictadura y/o meramente comerciales, predominando las comedias “picarescas". De esta manera, de los 32 largometrajes producidos en 1975 se bajó a 16 en 1976 y 15 en 1977 - precisamente, en este año cierra el último gran estudio que quedaba de la época de oro: Sono Film deja de funcionar como productora-. A partir de 1978 el cine nacional alcanzaría una media de 30 filmes realizados por año, número que se mantendría hasta entrada la década de 1980 (Getino, 1987).

En diciembre de 1983 asume el nuevo gobierno constitucional presidido por Raúl Alfonsín. Uno de los primeros actos con respecto al cine consistió en derogar la política de censura - la ley 23.052, de febrero de 1984, prohíbe toda forma de censura, a la vez que crea la Comisión Asesora de Exhibiciones-. Por otro lado, se vuelve a disponer

\footnotetext{
${ }^{64}$ Por estas medidas, Getino sufriría juicios posteriores por parte del Estado argentino, uno de los cuales llegó a pedir su extradicción de Perú en 1976, país en el que el cineasta se había exiliado poco tiempo antes.
} 
del 10\% sobre cada entrada vendida, por lo que el INC vuelve a contar con fondos para ayuda y fomento. Además, comienza una política de fomento a la coproducción, especialmente con España e Inglaterra, con el objetivo de internacionalizar el cine argentino -en este sentido, en 1985 se crea en Madrid la agencia estatal Argencine, que operó entre ese año y 1990, fungiendo como una especie de agente de ventas del cine argentino en Europa (Getino, entrevista personal, marzo de 2012; Falicov, 2007).

Manuel Antín fue el director del Instituto Nacional de Cinematografía durante la presidencia de Alfonsín. Durante su gestión se apoyará el surgimiento de nuevas camadas de cineastas, abundando las óperas primas en estos años —aunque, la mayoría, con escasa repercusión de público (Getino, 2005a)—; en este sentido, comenzaron a proliferar las cooperativas, estrategia para que los jóvenes (y no tan jóvenes) cineastas pudieran acometer su proyecto ante la falta de recursos - estrategia que perdura hasta la actualidad, y que se extendió al sector cinematográfica en general, en muchos casos utilizada por experimentados productores con acceso a recursos, con el fin de evadir impuestos y cargas laborales, según denuncia desde hace años el sindicato de trabajadores de cine (Deisica, 2009).

Con el fin de la década viene la crisis política, social y económica —con hiperinflaciones récord-, situación que también sacudirá al cine: la cantidad de filmes producidos comienza a descender drásticamente, así como también todos los indicadores del mercado - principalmente, número de salas, espectadores, recaudación- Para comienzos de la década de 1990 todos estos números tocan su piso histórico —si en 1987 se realizaron 32 filmes en 1989 la cifra bajó a 13, mientras que en 1994 se realizaron sólo 5 largometrajes, la cantidad más baja desde 1932 (Getino, 1987; 2005a).

Precisamente en la reforma de 1994 - ley 24.377 que ordena, mas no suplanta a la 17.741 - se cambió el nombre del organismo, pasando a llamarse Instituto Nacional de Cine y Artes Audiovisuales (Incaa), y aunque conservó su autarquía se lo transfirió a la Secretaría de Cultura, dependiente del Ministerio de Cultura y Educación de la Nación. Esta reforma buscó obtener una mayor independencia productiva, un financiamiento más amplio y otorgar protección para la exhibición de nuestro cine. A partir de esta importante reforma normativa se logró una mayor recaudación para el Fondo de Fomento Cinematográfico, mediante un impuesto a las teleradiodifusoras y un impuesto al video. 
De manera general el Incaa tiene a su cargo fomentar y regular la actividad cinematográfica en todo el país - y en el exterior, a través de su difusión-. A la par del Incaa, en el interior de la Argentina algunos gobiernos provinciales se han dado legislaciones culturales $\mathrm{y}$, específicamente, de fomento al cine -aunque sólo una ha elaborado una ley de cine (San Luis), mientras que otros municipios o provincias han creado film commissions y diversas normativas para atraer filmaciones y fomentar tímidamente el sector.

En esta reforma de la ley se modificó el órgano de gobierno y administración del instituto, transformándolo de individual en colectivo, y pasando a estar integrado por tres instancias administrativas: el director y el subdirector; la Asamblea Federal, y el Consejo Asesor.

Sin embargo, el presidente Carlos Menem dejó sin efecto el apartado de la ley que facultaba al Incaa para "regular las cuotas de ingreso y la distribución de películas extranjeras", así como también la potestad para implementar cuota de pantalla en la televisión.

Aunque en 1994 el instituto de cine pasó a denominarse también de "artes audiovisuales" no sería hasta 2010 que el Incaa se ocuparía explícitamente de los contenidos televisivos.

Uno de los cambios principales de la reforma de 1994 fue la consolidación financiera del instituto al conformarse dos nuevos recursos que alimentarían el Fondo de Fomento Cinematográfico: un impuesto del $10 \%$ sobre el precio de venta o alquiler de videocasetes grabados — pocos meses antes en Francia se había adoptado una medida similar-, y del 25\% sobre lo recaudado por el Comité Federal de Radiodifusión (Comfer) a partir de los gravámenes a la facturación publicitaria televisiva -un impuesto similar había sido implementado en Francia en 1986.

En 1996, una disposición del Ministerio de Economía, entonces comandado por Domingo Cavallo, impuso el manejo ilegal de los fondos del ahora llamado Instituto de Cine y Artes Audiovisuales (Incaa). Desde entonces, y hasta la cancelación de dicha medida en 2002, los envíos de fondos se tornaron irregulares, por lo que el cobro puntual de los subsidios y créditos tuvieron retrasos significativos, alterando toda la cadena de valor del sector entre 1996 y 2003 — año en que, luego de un año de trabajo, comenzó a regularizarse la dinámica de pagos.

En 2002 gobernaba provisionalmente el presidente peronista Eduardo Duhalde. Durante su gobierno el Incaa recuperó la autarquía y cambió su naturaleza jurídica: desde ese 
momento pasó a ser un ente público no estatal, y en sus relaciones con terceros la actividad comercial e industrial del Incaa comenzó a regirse por el derecho privado (Harvey, 2005). También se flexibilizaron los procedimientos del instituto de cine -lo que, posteriormente, sería utilizado de manera discrecional y generaría hechos de corrupción.

A partir de la autarquía del Incaa, y de la libre disponibilidad de los fondos que por ley le corresponde - sin tener que depender de los recursos y de los humores del gobierno central-, comienza a incrementarse significativamente la cantidad de filmes producidos, hasta llegar a valores superiores a los registrados en la época de oro (como se verá en el subcapítulo "Producción y mercados").

En 2004 se crea la media de continuidad. ${ }^{65}$ Sin embargo, ni la cuota de pantalla ni la media de continuidad dieron resultados trascendentes en lo que hace al porcentaje de mercado logrado por las películas argentinas desde esa fecha hasta la actualidad (tal como se verá en el apartado "Producción y mercados").

Otras políticas públicas relevantes durante la década de 2000 fueron la creación de los Espacios Incaa —destinados a fomentar la exhibición de filmes nacionales e iberoamericanos en todo el país-, el reforzamiento de las coproducciones y la apuesta a la conformación de un espacio regional para pensar políticas públicas en el marco del Mercosur - a través de la fallida Reunión Especializada de Autoridades de Cine y Audiovisual del Mercosur (Recam) ${ }^{66}$

En 2009 la presidencia estaba ocupada por Cristina Fernández de Kirchner, quien había sucedido a su marido. En octubre de ese año se promulgó la Ley 26.522 de Servicios de Comunicación Audiovisual (LSCA) —comúnmente llamada "Ley de Medios"—, ${ }^{67}$ que había sido impulsada por el gobierno, tomando viejos reclamos de distintas organizaciones sociales.

\footnotetext{
${ }^{65}$ La media de continuidad refiere al porcentaje mínimo de público necesario para que una película nacional que fue exhibida gracias a la cuota de pantalla, y que haya obtenido un número mínimo de espectadores, no pueda ser retirada de cartelera, generando la obligatoriedad de exhibición en la misma sala durante la semana siguiente.

${ }^{66}$ Queda fuera del análisis de esta tesis - por exceder el espacio temporal analizado- el impacto de la Ley 26.522 de Servicios de Comunicación Audiovisual, la federalización de las ayudas a la realización audiovisual, el apoyo a contenidos televisivos, el impuesto establecido a los lanzamientos de filmes con una cantidad importante de copias que saturen el reducido parque exhibidor nacional, la virtual "obligación" hacia las distribuidoras de Hollywood para distribuir filmes nacionales - lo que, en la práctica, condujo a la virtual desaparición de los distribuidores nacionales como comercializadores de cine argentino-, la creación del canal de televisión Incaa TV y la creación y consolidación del espacio de comercialización regional Ventana Sur (realizado en conjunto con el Festival de Cannes).

${ }^{67}$ En realidad, la "Ley de Medios" no es tal ya que no regula medios gráficos.
} 


\section{Incaa: estructura administrativa}

El gobierno y el entorno administrativo del instituto de cine de Argentina se organiza de la siguiente manera: a) el presidente y el vicepresidente —anteriormente a 1994 se denominaban director y subdirector-, b) la Asamblea Federal y c) el Consejo Asesor.

\section{El presidente del instituto de cine}

El presidente del Incaa representa legalmente al organismo. Posee una categoría similar a la de un subsecretario de Estado. El Poder Ejecutivo Nacional designa al presidente y al vicepresidente del instituto de cine —este último reemplaza al presidente por ausencia o por delegación expresa-; ambos cargos tienen un mandato de cuatro años. Entre las principales atribuciones y deberes del presidente del Incaa se cuentan:

- dar cumplimiento a las medidas de fomento aprobadas por la Asamblea Federal, pudiendo para ello convocar concursos, establecer premios u otras medidas que se consideren convenientes. Vale aclarar que lo que sucede en realidad es que las medidas las promueve el propio presidente del Incaa, más allá de la Asamblea Federal. Con respecto a los concursos, vale notar que el antecedente más antiguo se remonta a 1938, cuando el Concejo Deliberante (legislatura) de la ciudad de Buenos Aires dispuso un premio para las mejores películas argentinas estrenadas en la ciudad: el premio consistía en la devolución de los impuestos municipales a las salas que hubieran estrenado los filmes premiados (Campodónico, 2005);

- administrar el Fondo de Fomento Cinematográfico;

- disponer el cumplimiento de la obligatoriedad de doblar, subtitular, procesar y obtener copias en el país de películas extranjeras;

- impulsar convenios de coproducción, codistribución y de intercambio de películas con otros países, así como el apoyo a muestras y festivales en el país o en el exterior, con el fin de difundir el cine nacional;

- asesorar a otros organismos estatales en temas relacionados con el sector cinematográfico, además de entablar convenios con algunos de estos organismos, y con entidades mixtas o privadas, y

- realizar y aprobar el presupuesto anual de gastos — con el cálculo de recursos e inversión-, redactar la memoria anual y aprobar el balance y estado de cuentas y la ejecución de gastos, información que debe elevarse al Poder Ejecutivo —tanto a la Secretaría de Cultura como a la Jefatura de Gabinete de Ministros. 
En lo que hace a las funciones relacionadas meramente con lo administrativo, el presidente del Incaa puede comprar, vender o gravar bienes, así como también contratar préstamos, celebrar contratos de todo tipo y convenios de reciprocidad o de prestación de servicios con organismos oficiales o privados — vale decir que estos contratos de "prestación de servicios" son los que se utilizan frecuentemente en el Estado argentino desde hace décadas para subcontratar empleados por magros sueldos y sin prestaciones ni beneficios sociales.

En este sentido, el presidente del Incaa también puede designar discrecionalmente al personal del instituto, así como determinar la estructura del personal y sus funciones.

El presidente del instituto también puede designar jurados, comisiones o delegaciones, y aceptar donaciones y legados.

\section{La Asamblea Federal}

Este órgano de co-gobierno del instituto de cine está integrado por su presidente, el titular del Incaa y los secretarios - o subsecretarios- de Cultura de cada provincia del país - incluyendo a la ciudad de Buenos Aires-. Según la ley, este órgano — cuyas decisiones se toman por mayoría- se reúne al menos una vez al año.

Entre las funciones y facultades de la Asamblea Federal se encuentran formular medidas de fomento a la cinematografía en las distintas regiones del país -incluyendo la exhibición y la preservación-; reglamentar la exhibición de los cortos y de las placas publicitarias comerciales exhibidas durante las funciones cinematográficas de todo el país; recibir cada año la rendición de cuentas del presidente del Incaa y del Consejo Asesor, enviando a la Auditoría General de la Nación los distintos estados, balances y documentación que exige la ley —aunque esto casi nunca se cumplió-, designar a los miembros del Consejo Asesor - lo que se realizó recién en 2010-, y aprobar las reglamentaciones pertinentes propuestas por el presidente del Incaa.

\section{El Consejo Asesor}

Según la ley el tercer órgano de co-gobierno del Incaa, el Consejo Asesor, esté presidido por el titular del instituto de cine, e integrado por once miembros honorarios con mandato anual, extensible a un año más. Cinco de estos miembros serán propuestos por la Asamblea Federal - uno por cada región cultural en la que está dividida el país, 
según estos organismos estatales-, ${ }^{68}$ mientras que los seis miembros restantes serán propuestos por las entidades gremiales — dos, por parte de los directores; dos, por productores (uno de los cuales debe ser productor de "telefilmes" o series dirigidas a la televisión); uno, proveniente de los técnicos, y el restante, de actores.

Entre las funciones del Consejo Asesor se destacan la de aprobar o rechazar los actos del presidente del Incaa y la de designar los comités de selección - compuestos por personalidades del cine y la cultura- Estos últimos comités tienen una función clave, puesto que son los que seleccionan los proyectos cinematográficos que buscarán obtener los distintos beneficios de fomento que establece la ley.

Vale aclarar que hasta 2010 el Consejo Asesor nunca había sido convocado y constituido por el Incaa: los comités de selección se designaban discrecionalmente por las autoridades del instituto.

\section{Marco jurídico}

A nivel general, la política cinematográfica argentina, dirigida por el Instituto Nacional de Cine y Artes Audiovisuales, dispone principalmente de un Fondo de Fomento, que se nutre de la taquilla cinematográfica, de la comercialización de video y de la publicidad televisiva.

Los principales subsidios empleados en la Argentina para el fomento al cine son, por un lado, el denominado subsidio de sala —que es un mecanismo de recuperación industrial-: en determinados casos que se verán más adelante, cuando un filme argentino se estrena, el Incaa le devuelve una entrada más por cada entrada que vende.

Por otro lado, también se utiliza mucho el "subsidio por medios electrónicos": de manera muy simplificada, se puede decir que es una devolución para el productor, por parte del Incaa, de un porcentaje importante del costo de producción de la película, una vez que ésta se haya estrenado en cines y en formatos "electrónicos" — por ejemplo, televisión o homevideo)—, independientemente de la cantidad de espectadores que convoque el filme. La creación de este subsidio en 1994 — junto con la ley 24.377- fue un apoyo importante para el sector.

\footnotetext{
${ }^{68}$ Son cinco las regiones culturales: Noroeste (NOA) - integrado por las provincias de Catamarca, Jujuy, Salta, Santiago del Estero y Tucumán-, Noreste (NEA) - integrado por las provincias de Corrientes, Chaco, Entre Ríos, Formosa, Misiones y Santa Fe-, Cuyo - integrado por las provincias de La Rioja, Mendoza, San Juan y San Luis-, Centro - integrado por las provincias de Buenos Aires y Córdoba-, y Patagonia - integrado por las provincias de La Pampa, Neuquén, Río Negro, Chubut, Santa Cruz y Tierra del Fuego.
} 


\section{Fondo de Fomento Cinematográfico}

En la reforma de 1994 se creó el llamado Fondo de Fomento Cinematográfico, que sería administrado por el Incaa.

Este Fondo de Fomento financia distintas acciones, principalmente, el otorgamiento de créditos y subsidios - directos e indirectos - a todas las etapas de la cadena de valor -aunque con una notable preponderancia en la producción (como ocurre en toda América Latina con respecto al fomento cinematográfico).

El Fondo de Fomento apoya la producción de largometrajes y cortometrajes ${ }^{69}$ a través de un sistema de coparticipación entre el instituto y los realizadores, financiando producciones nacionales junto a organismos estatales, mixtos o privados.

En lo que hace a la difusión, el Fondo de Fomento apoya la participación en festivales de cine - tanto argentinos como extranjeros-, contribuye a la realización de festivales - también, tanto en el país como en el exterior-, solventa la promoción —dentro y fuera del país- de actividades de difusión del cine argentino - campañas de publicidad, envío de delegaciones, realización de semanas de cine argentino, etc.- y organiza concursos y, en raras ocasiones, otorga ayuda a la impresión de libros relacionados con el cine argentino.

El fondo también contribuye con los gastos de tiraje de copias y gastos de envío y publicidad, entre otros, para fomentar la comercialización de filmes argentinos, tanto en el país como en el exterior.

La formación también es un aspecto incluido en las funciones del Fondo de Fomento: el Incaa mantiene la Escuela Nacional de Experimentación y Realización Cinematográfica (Enerc) y una biblioteca especializada. La ley también establece la creación de una Cinemateca Nacional, que tendría que estar a cargo del Incaa, pero hasta 2015 la Cinemateca no ha pasado de un proyecto y de declaraciones de intenciones.

El instituto de cine también aporta los beneficios sociales de los distintos trabajadores de la actividad cinematográfica, ya sea mediante mutuales u obras sociales reconocidas oficialmente.

Del Fondo de Fomento también salen los recursos para el mantenimiento del funcionamiento administrativo del instituto de cine: sin embargo, cabe mencionar que la ley pone un tope del $50 \%$ de los recursos del fondo que pueden ser destinados a la administración del instituto. Sin embargo, durante la década de 2000 ese porcentaje se ha superado: si en 2007 el 50\% del presupuesto del Incaa se destinaba a fomento, en

\footnotetext{
${ }^{69}$ Desde 2010 también subsidia la realización de contenidos televisivos.
} 
2008 ese porcentaje había bajado al 42\% y en 2009 al 38,7\% —el instituto de cine es la agencia nacional de cine iberoamericana con mayor cantidad de empleados: cerca de 800, a fines de la década de $2000,{ }^{70}$ a diferencia de, por ejemplo, el Instituto de Cine y Artes Audiovisuales de España, que para fines de la década de 2000 tenía sólo 90 empleados y un presupuesto seis veces mayor (Azar, 2009).

\section{$\underline{\text { Recursos del Fondo de Fomento }}$}

Los tres principales recursos del Fondo de Fomento Cinematográfico de la Argentina son: un impuesto del 10\% a las entradas de cine -lo paga el público, y los exhibidores lo suman al precio básico-, del 10\% sobre la venta y alquiler de videos — que recae sobre los consumidores; los vendedores o locadores son los agentes de recepción del impuesto-, y del 40\% del total de las sumas percibidas por la autoridad nacional de radiodifusión a partir del gravamen a la publicidad comercial de las emisoras de televisión.

En lo que hace a los ingresos provenientes de la publicidad televisiva, cabe aclarar que entre 1995 y 2002 este porcentaje fue del 25\%, mientras que la Ley de Servicios de Comunicación Audiovisual —comúnmente llamada "ley de medios"——1 sancionada en 2009 establece que el 25\% de lo recaudado en su totalidad por la Autoridad Federal de Servicios de Comunicación Audiovisual (Afsca) — que reemplazó al Comité Federal de Radiodifusión (Comfer) - será asignado al Incaa, aclarando que ese monto no podrá ser inferior al $40 \%$ de la publicidad televisiva que venía recaudando el Incaa. Estas sumas provenientes de la radiodifusión son transferidas automática y diariamente al Incaa.

También forman parte de los recursos del Fondo de Fomento los reembolsos por los créditos otorgados por el Incaa, además la amortización e intereses devengados por ellos, legados y donaciones, los fondos no utilizados de ejercicios anteriores, multas, servicios a terceros, etcétera.

A su vez, el Incaa tiene la facultad para destinar fondos con el fin de adquirir títulos de la deuda pública y otras emisiones de valores públicos, en tanto el instituto no haya dado a esos fondos el destino que la ley le exige (fomento cinematográfico).

\footnotetext{
${ }^{70}$ Estos cargos se otorgan discrecionalmente por afinidad política, o por recomendación de empleados del instituto que hacen ingresar a sus familiares; como sucede en el Estado argentino, en el instituto de cine no existe examen de conocimiento alguno para llegar a ser funcionario.

${ }^{71}$ Como se mencionó, la LSCA no es una "ley de medios" debido a que no regula medios gráficos.
} 
Antecedentes del Fondo de Fomento

En 1948 —durante la primera presidencia de Perón- se firmó un acuerdo por dos años entre productores (Asociación de Productores de la Argentina) y exhibidores (Asociación de Empresarios Cinematográficos), mediante el cual se retenía 10 centavos de cada ticket "no inferior a ochenta centavos". De ese dinero retenido, la mitad iba para la Fundación Eva Perón —organismo estatal creado por la esposa de Perón, dedicado a la beneficencia social-; el 40\% iba para un fondo de fomento a la producción y de mejoramiento de salas. Y el 10\% restante se destinaba a la mutual de la asociación de exhibidores (Harvey, 2005).

En 1950 se prorrogó el acuerdo — que continuaría durante todo el primer período peronista (es decir, hasta 1955)—. Este nuevo acuerdo modificó los aportes: el 60\% de lo recaudado por la retención a las entradas de cine iría a la Fundación Eva Perón; el porcentaje destinado al Fondo de Fomento se reducía al 33,5\% — en este porcentaje estaba incluido el porcentaje que iba para el sindicato de trabajadores de cine (Sica) $(3,5 \%$ del total)-; mientras que la asociación de exhibidores recibía $6,5 \%$ (Campodónico, 2005).

La dictadura militar que comenzó a gobernar en septiembre de 1955 continuó con este recargo sobre las entradas de cine, que para 1956 ya alcanzaba los 40 centavos sobre cada ticket. En 1956 se dispuso que el 59\% del total recaudado iría al Instituto de Acción Social —ex Fundación Eva Perón-; el 30\% se destinaría a la producción de largometrajes, y el 5\%, a la producción de cortos; el 4\% iría a la obra social de los exhibidores —entidad que ahora se llamaba Federación Argentina de Exhibidores Cinematográficos (Fadec) - , y el 2\% restante, para el sindicato de trabajadores de cine (Sica). Sin embargo, a partir de ese año se agregaron 20 centavos más al sobreprecio de las entradas de cine, de cuya recaudación se destinaría el 45\% para producir largometrajes, $8 \%$ para realizar cortos, $16 \%$ para financiar festivales, $15 \%$ para premios, $10 \%$ para la obra social de exhibidores y $6 \%$ para crear un Instituto Cinematográfico Argentino (Maranghello, 2005).

En lo que hace a los impuestos sobre las estaciones de radiodifusión —destinados al fomento al cine- también existen antecedentes en la Argentina, aunque dichos gravámenes se relacionaban indirectamente con el cine: en 1958, un año después de la creación del Instituto Nacional de Cinematografía, comenzaron a regir dos impuestos de estas características —uno adicional al otro-: el 5\% de los ingresos brutos de las 
emisoras de radio y televisión de todo el país, y el 5\% sobre el precio de toda publicidad comercial transmitida por radio y televisión.

Ambos impuestos eran recaudados y destinados como recursos dirigidos a fomentar la cultura y las artes en general, en todo el país; los administraba el Fondo Nacional de las Artes - un organismo autónomo, creado en 1958 por el flamante gobierno de Arturo Frondizi-. Entre 1967 y 1968 ambos tributos fueron derogados y sustituidos por un nuevo impuesto, dirigido al Comité Federal de Radiodifusión (Comfer); este nuevo gravamen estaba destinado al fomento del cine, y es el antecedente directo del Fondo de Fomento Cinematográfico vigente en la actualidad — valga señalar que el Fondo Nacional de las Artes, que todavía existe, nunca vio restituir un impuesto destinado a otorgarle recursos, luego de que los gravámenes dirigidos a financiar el apoyo a la cultura y las artes, fuera trocado por uno destinado exclusivamente al cine (Harvey, 2005); desde hace décadas, el Fondo Nacional de las Artes sobrevive con escaso presupuesto asignado por el Poder Ejecutivo Nacional.

\section{Beneficios y prestaciones}

\section{Crédito industrial para la cinematografía argentina}

Una de las dos vías principales para el apoyo a la producción de cine en la Argentina la constituye el otorgamiento de créditos -es decir, operaciones reintegrables a bajo interés - previsto por la ley 17.741 (artículo 9), y solventado por el Fondo de Fomento. Estos créditos tienen una tasa baja - aproximadamente un cuarto de la tasa de mercado- y un plazo de gracia de 9 a 12 meses.

Cada año el Incaa determina los recursos que destinará a los créditos, los que se suman a los ingresos que se obtienen por los pagos de créditos anteriores.

Los créditos se otorgan mediante la aprobación de los proyectos que presentan los interesados, con el fin de producir largometrajes (nacionales o coproducciones), de comercializar dichos filmes, de incorporar equipamiento industrial — tanto para las productoras, como para las exhibidoras o laboratorios-y de renovar las salas de cine.

La línea destinada a la producción es la principal y tiene prioridad sobre las otras dos -incorporación de equipamiento y renovación de salas-. Para acceder a los créditos para la producción se debe haber cancelado el crédito al momento de comercializar el filme en el exterior; a su vez, el monto del crédito no puede superar el $50 \%$ del costo de producción reconocido por el Incaa. En el caso de que el proyecto sea declarado de “interés especial” por el instituto — la máxima calificación prevista-, ese porcentaje 
podrá elevarse hasta el 70\% — sin embargo, en la Argentina (como en otros países de América Latina) se suelen "inflar" los presupuestos, con el fin de obtener mayores recursos por parte del Estado-; en cualquier caso, el monto del crédito no podrá superar el tope previsto para el subsidio por medios electrónicos — ver en el capítulo correspondiente a subsidios-. En el caso de las coproducciones, sólo se tendrá en cuenta el aporte del coproductor argentino que haya sido reconocido por el Incaa.

La normativa establece que los créditos deben devolverse, no importa cuáles hayan sido los resultados económicos de la explotación del filme beneficiado con este apoyo.

Una vez otorgados, los créditos se otorgan en cuotas de acuerdo a los avances de la producción —según resolución 1891 de 2008-: el 20\% al inicio de la preproducción, el $40 \%$ al inicio de la fotografía principal del rodaje (inicio del rodaje), el $30 \%$ al finalizar el rodaje y el $10 \%$ contra entrega de la copia A.

\section{Subsidios a la producción y exhibición}

Los subsidios, junto con los créditos, constituyen uno de los aspectos más importantes del fomento al cine en la Argentina.

Estas prestaciones no reintegrables se encuentran descriptas en el artículo 26 de la ley 17.741 vigente:

El Incaa subsidiará las películas de largometraje cuando contribuyan al desarrollo de la cinematografía nacional en lo cultural, artístico, técnico e industrial, con exclusión, en especial, de aquellas que, apoyándose en temas o situaciones aberrantes o relacionadas con el sexo o las drogas, no atiendan a un objetivo de gravitación positiva para la comunidad.

Para acceder a los subsidios, sobre la base de este criterio cualitativo, el Incaa clasifica a los proyectos de largometrajes presentados como de "interés especial" —se ponderan aquellos que "contengan relevantes valores morales, sociales, educativos o nacionales", junto con los filmes dedicados a la infancia y aquellos que sean de "jerarquía artística" (artículo 37 de la ley de cine)—. Los proyectos también pueden ser declarados de "interés simple" o "sin interés" —estos últimos proyectos son excluidos del régimen de subsidios.

A su vez, dependiendo de los antecedentes de quienes presentan el proyecto de película, recibirán mayores o menores ingresos. En efecto, existen tres "vías": en la primera, se 
requiere un productor con, al menos, cinco largometrajes realizados; en la segunda vía, el productor debe haber trabajado como tal, mínimamente, en un largometraje estrenado comercialmente, $\mathrm{y}$, en la tercera vía se le exige al productor que se presenta una experiencia de, al menos, un largometraje digital (calidad inferior a 35 milímetros y $2 \mathrm{~K}$ DCP) o telefilm, estrenado comercialmente; y en la cuarta vía los requisitos son muy bajos, el productor debe tener al menos un documental registrado en el Incaa. El productor que se presenta a la primera vía debe demostrar que puede solventar el $80 \%$ del presupuesto de su proyecto de filme, mientras que los productores que se presentan a la segunda y tercera vía deben demostrar que pueden hacer frente al 50\% del presupuesto que presentan.

Los subsidios no se otorgan automáticamente, sino que el/a interesado/a debe presentar un proyecto - a través del productor del filme- sobre el que el Incaa debe expedirse dentro de los 30 días, y son confirmados cuando la película se termina, observándose que se haya realizado según el proyecto presentado. Para presentarse, se debe pagar un arancel, que varía de acuerdo a la vía y al tipo de filme presentado - a fines de la década de 2000 iba de 500 a 6000 pesos.

Existen dos grandes tipos de subsidios que otorga el Incaa: el subsidio de "recuperación industrial" — también llamado comúnmente "subsidio de sala"- y el subsidio por "medios electrónicos".

El subsidio de recuperación industrial (de "sala") se basa en los resultados de mercado que logre la película en cuestión. Si el filme es "de interés especial”, el Incaa puede otorgarle el 100\% de lo que haya hecho en taquilla —-deduciendo los impuestos.

Por su parte, el subsidio por medios electrónicos otorga el $70 \%$ del costo del filme en cuestión reconocido por el Incaa. Se accede a este beneficio cuando se alcanzó un mínimo de espectadores en las salas, o cuando se haya emitido en televisión o editado en video.

En lo que hace a los montos de los subsidios, éstos tendrán una proporción variable de acuerdo a los índices que fije el Incaa. Primeramente, se ayudará a la recuperación, con un máximo determinado por el instituto de cine, basado en fórmulas contables.

Para el caso de los subsidios por medios electrónicos, los topes máximos dependen de si el proyecto se enmarca en la primera, segunda, tercera vía o cuarta vía, y de si se trata de una obra de ficción, animación o documental. El Incaa determinará los porcentajes con que ayudará a cada filme, teniendo en cuenta los topes máximos estipulados. 
Para los subsidios por recuperación industrial, el tope actual (2015) es de 5,5 millones de pesos para las películas de interés especial y 4 millones de pesos si es de interés simple; existen otros topes de menores montos, de acuerdo a las características de los filmes — si se encuadra dentro de la primera, segunda, tercera o cuarta vía, y si se trata de una obra de ficción, de animación o de un documental.

En el caso de las coproducciones, se toma en cuenta la inversión del coproductor argentino.

Si se trata de filmes declarados de "interés especial", se les asigna un índice suplementario.

Los subsidios se liquidan por trimestre calendario, durante dos años a partir de la fecha de estreno comercial. Es decir: el productor recibe trimestralmente el 50\% de los montos correspondientes a los coeficientes de cálculo; el 50\% restante se paga al final de los dos años, prorrateando el saldo de los fondos de acuerdo al desempeño del filme en cuestión. Sin embargo, si en ese momento los recursos del Incaa no fueran suficientes para afrontar su deuda, el organismo pagará al productor un monto menor, sin que los responsables de la película beneficiada puedan hacer reclamo alguno al Incaa.

Por otro lado, el Estado obliga a que el productor destine el 5\% del subsidio a producir una nueva película, o para que adquiera equipamiento.

A su vez, también existe un subsidio a la exhibición cinematográfica que será otorgado a aquellas empresas y salas que hayan exhibido más películas nacionales que las que les correspondía de acuerdo a la cuota de pantalla. El subsidio a otorgar es equivalente al porcentaje que fije el Estado sobre la taquilla obtenida (deduciendo impuestos).

Si los beneficiarios de estos subsidios - tanto el productor como el exhibidor- no solicitaran su beneficio dentro de un año desde que les correspondió la liquidación, perderán su derecho al subsidio $-\mathrm{y}$ en el caso de los subsidios de reinversión, los beneficiarios perderán su derecho si no lo utilizan hasta dos años después de que debieron percibir el respectivo subsidio.

\section{Otras ayudas no reintegrables}

El Incaa también convoca a distintos concursos anuales según variadas temáticas, por ejemplo: concurso para óperas primas, para telefilmes, para cortometrajes, etc. Se destaca las ayudas a la realización de telefilmes y seriados para televisión que comenzaron a incrementarse desde 2010 —aunque, como se mencionó al comienzo de 
la tesis, no se analizarán estas ayudas, por excederse del período temporal establecido para esta investigación, y también porque no transcurrió una cantidad considerable de años (como en el caso de las políticas meramente cinematográficas) como para analizar en profundidad estas políticas cinematográficas y audiovisuales del Incaa y el Estado argentino (que se entrecruzan con la televisión digital y diversas medidas de la Subsecretaría de Comunicación, dependiente de Presidencia de la Nación, especialmente, desde 2010).

\section{Protección}

\section{Concepto de "película nacional" en la Argentina}

La legislación argentina considera "películas nacionales" tanto a los largometrajes (60 minutos o más) como a los medio y cortometrajes (menos de 60 minutos) producidos por "personas físicas" domiciliadas en la Argentina o personas jurídicas argentinas.

Las películas deben reunir requisitos tales como estar habladas en castellano, ser realizadas por personal técnico y artístico de nacionalidad argentina -o extranjeros domiciliados en el país-; que el filme haya sido rodado y procesado en el país; hasta 2008, se exigía que la película haya sido rodada, o transferida, a 35 milímetros — desde ese año se fueron incorporando formatos digitales de alta gama, como el DCP.

El Incaa puede establecer excepciones a las exigencias de que la película esté hablada en castellano, de que esté realizada por personal argentino o de que el filme haya sido rodado y procesado en el país.

\section{El concepto de nacionalidad en el caso de las coproducciones}

También se consideran películas nacionales a aquellas que hayan sido realizadas en el marco de un convenio de coproducción.

Si una coproducción nacional se realiza con un país con el que la Argentina no tiene firmado convenio de coproducción, el proyecto debe ser autorizado por el Incaa.

Cuando el proyecto a ser realizado en coproducción obtiene el certificado de película nacional, tiene derecho a los beneficios previstos por la ley argentina de fomento al cine, a los que se suman la exención de los derechos de importación y exportación de negativos, "lavander", “dup negativos”, internegativos -todos estos materiales crecientemente en desuso-, y el tránsito de materiales y equipamiento destinado a la realización del filme. Estos últimos beneficios también se aplican a las importaciones temporarias que se realicen para filmar en la Argentina, o para obtener copias en 
laboratorios nacionales — sin embargo, en este último caso, muchos consideran a estos beneficios ruinosos para el realizador y para el cine argentino, puesto que las majors ingresan al país sin cargo alguno los internegativos, o masters digitales, para realizar las copias de los blockbusters que serán exhibidos en el país, y que inundarán las pocas pantallas existentes en el país, mientras que los cineastas argentinos deben pagar impuesto al valor agregado por el material fílmico, y las producciones deben pagar distintas clases de impuestos, por ejemplo, a las "ganancias" (aunque no las tuvieran) (Rovito y Raffo, 2003).

\section{Cuota de pantalla}

La normativa argentina entiende por "cuota de pantalla" la cantidad mínima de largometrajes nacionales - en la actualidad, uno por trimestre calendario- que debe exhibirse obligatoriamente en cada una de las salas de cine inscriptas en el Incaa.

Según la ley, deben cumplir cuotas de pantalla tanto las salas de cine como otros lugares de exhibición del país — por ejemplo, la televisión abierta y la televisión paga一, tanto para largometrajes como cortometrajes. Sin embargo, la obligación de la cuota de pantalla en televisión fue vetada por el presidente Menem en 1994 —cuando se aprobó la reforma a la ley de cine 17.741 - y la reflotada obligación de emitir películas nacionales por la televisión abierta y paga a partir de la Ley de Medios, de 2009, tampoco se cumple. A su vez, la cuota de pantalla para cortometrajes no está reglamentada, por lo que dicha medida no se lleva a cabo.

La cuota de pantalla se estableció por primera vez en la Argentina en agosto de 1944, mediante el decreto 12.999 del gobierno militar comandado por el Grupo de Oficiales Unidos, donde Juan Perón tenía un peso importante. Esta medida —que supuso la primera medida intervencionista sobre el cine por parte del Estado argentino- obligaba a los cines de estreno y de primera línea de la ciudad de Buenos Aires — con más de 2500 localidades - a exhibir un filme nacional cada dos meses — como mínimo-, durante siete días en total — comprendiendo un sábado y un domingo-; los restantes de primera línea, y todos los que estaban en el radio céntrico de la ciudad, uno por mes. Y con respecto al resto de los cines ubicados en Capital Federal, más los del Interior del país, la disposición los obligaba a exhibir como mínimo dos de cada cinco semanas —abarcando dos sábados y dos domingos (Muraro y Cantor, 1978). 
Por su parte, el artículo 9 de la ley de cine 17.741 (1968) establecía la obligatoriedad de la cuota de pantalla para los filmes nacionales por trimestre calendario — definido por el decreto 1405 de 1973, y modificado por el decreto 2414 de 1985-. Quedaban exceptuadas de esta obligación las salas condicionadas (exhibición de filmes pornográficos), las salas no comerciales, las que funcionaban sólo cuatro días a la semana y las que abrían solamente en temporadas de vacaciones.

En 2004 se desató una polémica a partir de dos películas exitosas: Luna de Avellaneda, de Juan José Campanella, y Los guantes mágicos, de Martín Rejtman —uno de los pioneros del llamado "nuevo cine argentino" de la década de 1990-. Estos filmes venían teniendo muy buena repercusión y haciendo buena taquilla; sin embargo, las empresas exhibidoras las retiraron de cartel para programar blockbusters estadounidenses. A partir de esta acción, y por presión del sector cinematográfico, el Incaa aprobó la resolución 2016 que reglamentaba la media de continuidad —establecida en la ley de cine, pero que no se aplicaba-, es decir, el porcentaje mínimo de público necesario para que una película argentina que fue exhibida gracias a la cuota de pantalla, y que haya obtenido un número mínimo de espectadores, no pueda ser retirada de cartelera, generando la obligatoriedad de exhibición en la misma sala en la semana siguiente.

Para el cumplimiento de la cuota de pantalla y de la media de continuidad, el Incaa clasifica a los largometrajes en tres categorías de acuerdo a las copias que tendrá cada título: hasta 5 copias —antes de 2006 (resolución 1.582) esta categoría era hasta 10 copias-; entre 6 a 34 copias (anteriormente, entre 10 y 19 copias); 35 copias o más (antes, 20 o más copias).

A su vez, el Incaa ofrece un circuito alternativo de exhibición a los filmes con lanzamientos con menor cantidad de copias - hasta cinco-, mediante acuerdos entre el instituto y algunas empresas exhibidoras. En este circuito alternativo esta clase de películas tienen garantizada una permanencia mínima de dos semanas —en la práctica, y con el tiempo, este circuito quedó reducido a los Espacios Incaa.

A los efectos de aplicación de la media de continuidad se clasifica a los cines de acuerdo al tamaño de las salas, generando tres categorías: hasta 250 butacas; de 250 a 500 butacas; y más de 500 butacas.

De esta manera, por ejemplo, en temporada alta — del 1 de abril al 30 de septiembre (sumado el período comprendido entre el 25 de diciembre y el 1 de enero, y el fin de semana de la Semana Santa)—, la media de continuidad obligatoria en salas de hasta 
250 localidades es del 18\%. Para la misma temporada, la media de continuidad para salas de más de 500 localidades es del 10\%.

En el caso de haber películas argentinas que no hayan conseguido sala de estreno, deberán notificar su situación al Incaa, que pondrá estas películas a disposición de las empresas exhibidoras que hasta el momento no hubieran cumplido con la cuota de pantalla para filmes argentinos.

La ley también estipula que si no hubiera películas nacionales disponibles hasta 30 días corridos antes de que finalice el trimestre, las salas que no hubieran cumplido la cuota de pantalla quedarán exceptuadas para ese trimestre, debido a la falta de material.

\section{Producción y mercados}

\section{Producción}

Argentina es el mayor productor de cine de toda América Latina - aunque desde fines de la década de 2000 Brasil y México poseen números muy cercanos en lo que hace a este indicador.

Desde hace 15 años en la Argentina se producen entre 30 y 150 largometrajes anuales, deteniendo la caída en la producción fílmica que se venía registrando desde los años ochenta: en las décadas de 1940 y 1950 se realizaron, en promedio, 40 largometrajes anuales, mientras que en las décadas de 1960 y 1970 ese número se redujo a 30, para decrecer aún más, pasando a 25 en la década de 1980 y a 12 en el período 1989-1994 ${ }^{72}$ (Unesco, 1982; Getino, 2005a; González, 2011b).

\footnotetext{
${ }^{72}$ Este período está delimitado por dos años hito: 1989 fue el año de una de las peores crisis económicas, políticas y sociales del país — con índices récord de hiperinflación-, mientras que 1994 fue el año en que se aprobó la ley de cine número 24.377 .
} 
Gráfico 42 - Argentina: número de largometrajes realizados (1971-2010)

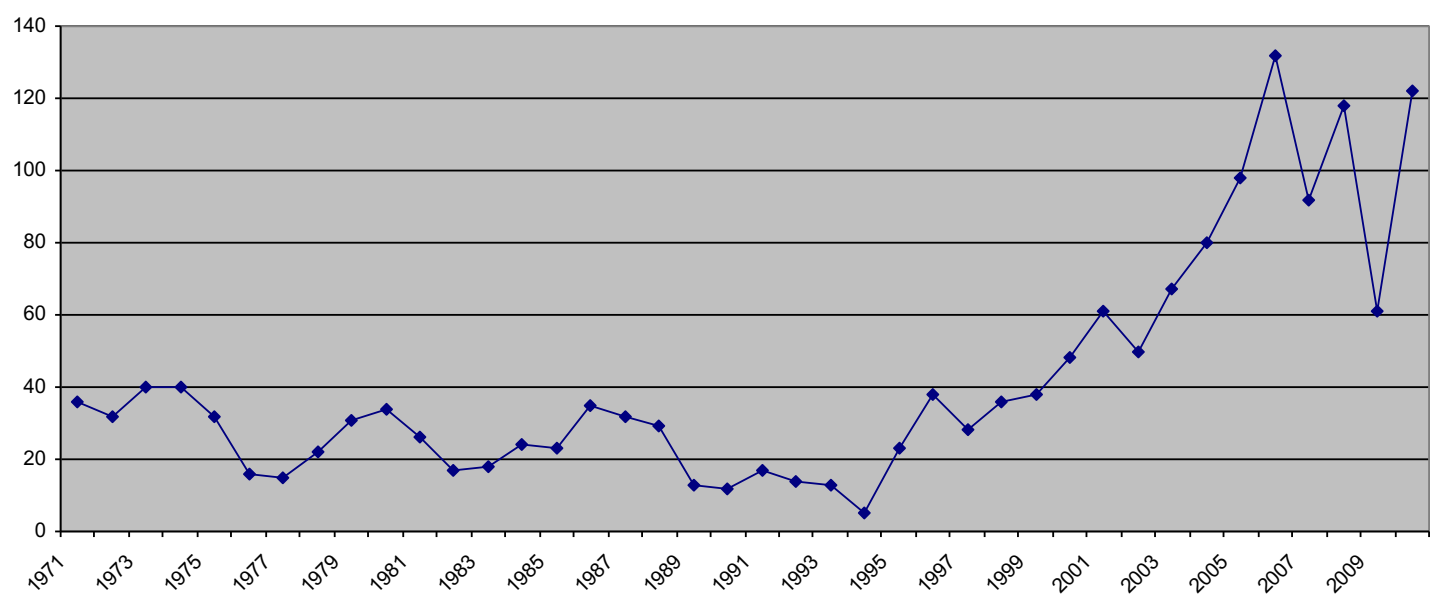

Fuente: Elaboración propia con base en datos de Getino (1987, 2005a), Incaa, Nielsen-Rentrak, Deisica, Ultracine.

A partir de la promulgación de la nueva ley de cine, en 1995, la producción fílmica argentina fue incrementándose hasta duplicarse. En efecto: en el período 1995-1999 la producción media subió a 33 largometrajes anuales realizados, mientras que durante el primer quinquenio del siglo XXI la media de producciones anuales fue de 60 largometrajes, y durante el segundo alcanzó los 100 largos, ${ }^{73}$ superando los números de su "época de oro".

Sin embargo, el sector de la producción sufre una marcada concentración desde la década de 1990 — tal como sucede en los otros eslabones (distribución y exhibición).

Por ejemplo, en el año 2010 fueron 77 los productores y compañías productoras que estrenaron títulos argentinos. Sin embargo, sólo 4 de esos productores - con 8 de los 128 títulos argentinos estrenados en 2010 - concentraron el 71,19\% de los espectadores convocados por el cine (Incaa, 2011). Precisamente, esas 4 productoras fueron también las que mayores aportes recibieron por parte del Incaa hacia finales de la década de 2000 y comienzos de la siguiente.

\footnotetext{
${ }^{73}$ Los números que aquí se manejan provienen de largometrajes registrados en el organismo nacional de cine. Sin embargo, en el interior del país se realizan desde hace años decenas de películas -especialmente, documentales- de las que el Incaa no tiene registro alguno y que son exhibidas en centros culturales o muestras locales. Si se contaran estas producciones - de las que no se ha realizado un registro fehaciente hasta el momento- el número de largometrajes producidos en la Argentina, desde hace dos décadas, se incrementaría en alrededor de 20 a 30 filmes anuales.
} 
Cuadro 32 - Argentina: productoras con mayores aportes del Incaa (2008-2011)

\begin{tabular}{|l|c|}
\hline Productora & Monto recibido (\$arg) \\
\hline Aleph Media & 12.000 .000 \\
\hline Patagonik & 11.000 .000 \\
\hline BD Cine & 7.500 .000 \\
\hline Haddock & 7.000 .000 \\
\hline
\end{tabular}

Fuente: Grillo Trubba (2011), con información del Incaa.

Entre ese "top 5" de 2010 se encuentra a la cabeza Patagonik —empresa ligada a Disney, Canal 13, Polka y el laboratorio Cinecolor desde la década de 1990-. Precisamente, esta productora figura al tope de las que mayores montos recibieron por parte del Incaa a finales del período en estudio por esta tesis.

Cuadro 33 - Argentina: top 10 películas argentinas, según espectadores (2001-2009)

\begin{tabular}{|c|c|c|c|c|}
\hline $\begin{array}{c}\text { Nro en el } \\
\text { ranking de } \\
\text { los filmes } \\
\text { nacionales }\end{array}$ & Año & Título & $\begin{array}{l}\text { Productora } \\
\text { participante }\end{array}$ & Espectadores \\
\hline $\begin{array}{l}1^{\circ} \text { (ranking } \\
\text { general y de } \\
\text { filmes } \\
\text { nacionales) }\end{array}$ & 2009 & $\begin{array}{l}\text { El secreto de } \\
\text { sus ojos }\end{array}$ & Telefé & 2.400 .000 \\
\hline $1^{\mathrm{o}}$ & 2004 & Patoruzito & Patagonik/Artear & 1.951 .447 \\
\hline $1^{o}$ & 2005 & $\begin{array}{l}\text { Papá se volvió } \\
\text { loco }\end{array}$ & Telefé & 1.486 .490 \\
\hline $1^{\mathrm{o}}$ & 2008 & $\begin{array}{l}\text { Un novio para } \\
\text { mi mujer }\end{array}$ & Artear/Polka & 1.293 .263 \\
\hline $\begin{array}{l}1^{\circ} \text { (ranking } \\
\text { general y de } \\
\text { filmes } \\
\text { nacionales) }\end{array}$ & 2001 & $\begin{array}{l}\text { El hijo de la } \\
\text { novia }\end{array}$ & Patagonik/Artear & 1.267 .163 \\
\hline $2^{\circ}$ & 2004 & $\begin{array}{l}\text { Luna de } \\
\text { Avellaneda }\end{array}$ & Artear/Polka & 1.093 .356 \\
\hline $1^{o}$ & 2006 & $\begin{array}{l}\text { Bañeros } 3 . \\
\text { Todopoderosos } \\
\end{array}$ & $\begin{array}{l}\text { Telefé/Argentina } \\
\text { Sono Film }\end{array}$ & 1.072 .659 \\
\hline $1^{\mathrm{o}}$ & 2002 & Apasionados & $\begin{array}{l}\text { Telefé/Argentina } \\
\text { Sono Film } \\
\end{array}$ & 1.052 .047 \\
\hline $1^{\mathrm{o}}$ & 2003 & $\begin{array}{l}\text { Vivir } \\
\text { intentando }\end{array}$ & Patagonik/Artear & 945.103 \\
\hline $3^{\circ}$ & 2004 & $\begin{array}{l}\text { Peligrosa } \\
\text { obsesión }\end{array}$ & $\begin{array}{l}\text { Telefé/Argentina } \\
\text { Sono Film }\end{array}$ & 921.024 \\
\hline
\end{tabular}

Fuente: Elaboración propia con base en datos de Incaa, Nielsen-Rentrak, Deisica, Ultracine, Patagonik, Telefé. 
Tanto Patagonik como Telefé Cine concentran la mayor cantidad de blockbusters nacionales de los últimos años. En efecto, los 10 filmes argentinos más taquilleros entre 2001 y 2009 fueron realizados en su totalidad o por Patagonik (Disney-Grupo Clarín), Canal 13 (Artear-Grupo Clarín) o Telefé (Telefónica de España).

\section{Gráfico 43 - Argentina: presupuesto del Incaa, en millones de pesos (2002-2008)}

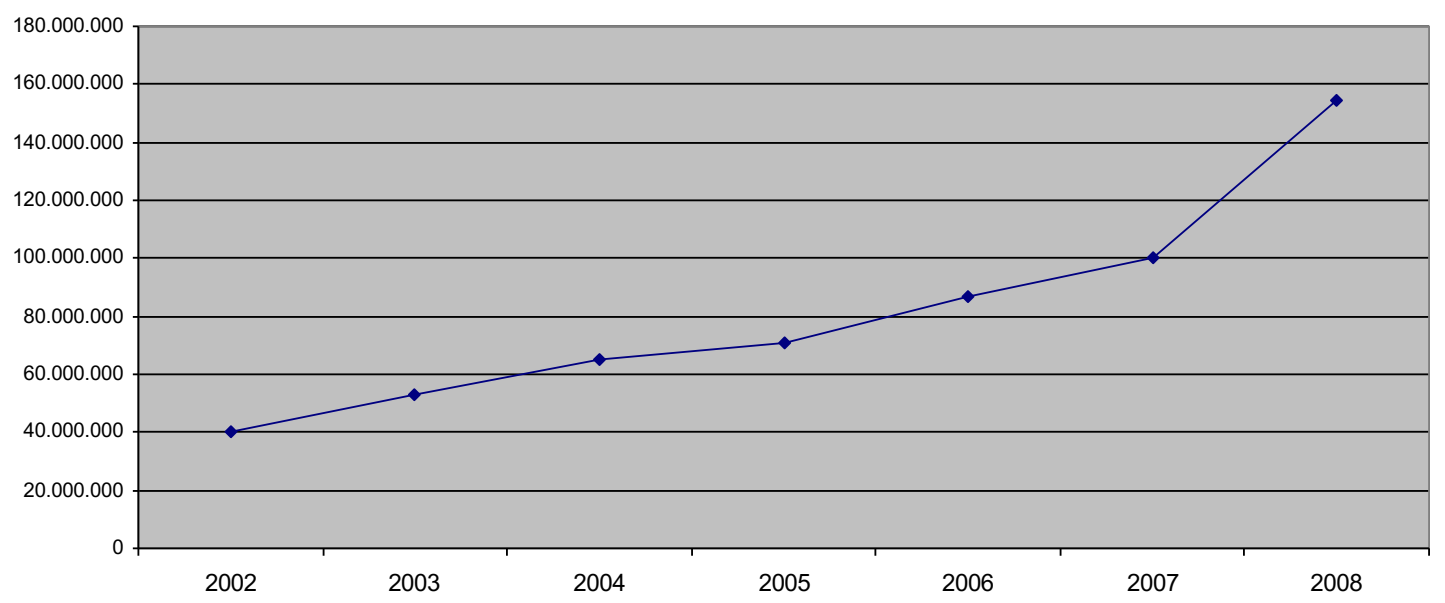

Fuente: Incaa, Azar (2009), Calvo (2007).

Este apoyo a productoras relacionadas con multinacionales del entretenimiento se da en un contexto donde la proporción del presupuesto del Incaa destinada a fomento se ha ido reduciendo -2007, 50\%; 2008, 42\%; 38,7\% en 2009-, a la vez que fueron subiendo los gastos administrativos y de personal - 1270\% en el período 2002-2009, mientras que el aumento del presupuesto del Incaa para el mismo período fue menor: 599\% (Azar, 2009).

A su vez, como sucede en toda América Latina, la mayor parte del fomento cinematográfico manejado por el Incaa está destinado a la producción —entre subsidios y créditos-: por ejemplo, en 2008 sólo el 5,1\% se destinó al fomento a la difusión y exhibición $-10,2 \%$ si se cuentan los apoyos a festivales (Batlle, 2009). ${ }^{74}$

\footnotetext{
74 Lamentablemente, no se puede ofrecer mayor información sobre montos de fomento y su desagregación por rubros, productoras y demás categorías debido a la dificultad para obtener información por parte del Incaa.
} 


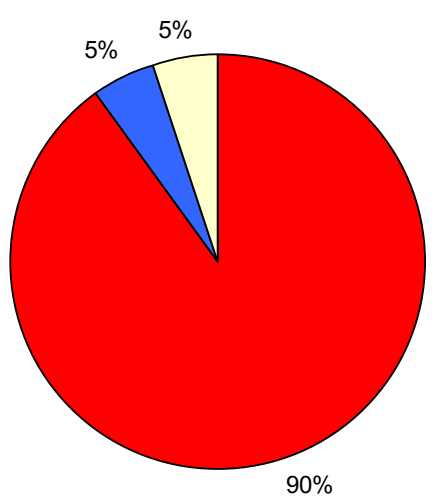

Fuente: Elaboración propia con base en datos del Incaa.

Como sucede en la mayoría de los países que producen cine, la ayuda del Estado es vital: sin ella, la actividad cinematográfica sería inviable. De acuerdo a estimaciones de expertos del sector, menos del $30 \%$ de los ingresos obtenidos por una película luego de su recorrido comercial proviene del mercado: cerca de las tres cuartas partes son recursos estatales.

Gráfico 45 - Argentina: película argentina media (50.000 espectadores), contribución por medio* (2007)

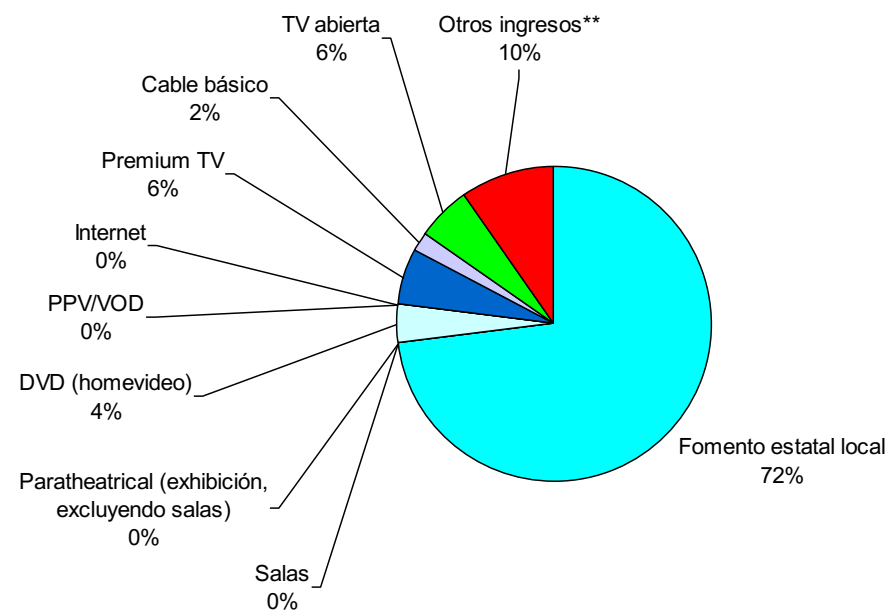

* Costo de lanzamiento: 50.000 dólares.

** Otros ingresos: apoyos de empresas, fondos internacionales de apoyo al cine —Programa Ibermedia, World Cinema Fund (Berlinale), Fonds Sud (gobierno francés), Huber Bals (Festival Internacional de Cine de Rotterdam), etcétera.

Fuente: Nadal (2007). 
Son precisamente los filmes que no son blockbusters, que no son éxitos, los que constituyen la mayoría de las películas argentinas. Para amortizar estas realizaciones, si no existiera el fomento estatal al cine se necesitarían unos 1,1 millones de espectadores para amortizar un filme -el costo promedio de un filme argentino se estima en 500.000 dólares durante la década de 2000-, considerando que el productor se queda sólo con entre el $12-15 \%$ de cada entrada -descontando impuestos y comisiones de comercialización (copias, carteles, publicidad, etc.), y de que el ticket cinematográfico se ubicó, en la década de 2000, en un promedio de 3 dólares.

Gráfico 46 - Argentina: cantidad de largometrajes nacionales estrenados y de títulos nacionales que alcanzaron los 1,1 millones de espectadores (2000-2009)

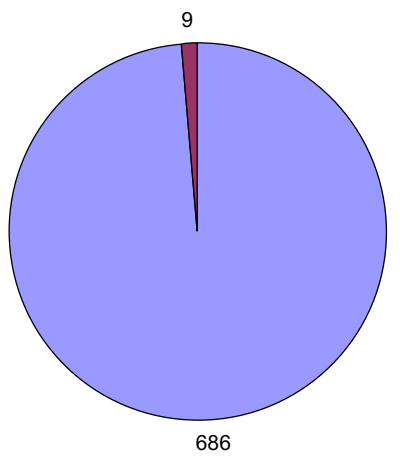

Fuente: Elaboración propia sobre la base de datos de Incaa, Nielsen-Rentrak, Deisica, Ultracine.

Teniendo en cuenta estos parámetros, se aprecia que de entre los 686 largometrajes nacionales estrenados entre 2000 y 2009 sólo 9 películas alcanzaron, o superaron, los 1,1 millones de espectadores — si se toma el período 2000-2014, fueron 12 los filmes argentinos que alcanzaron la cifra necesaria para lograr la amortización, teniendo en cuenta que en este período se estrenaron 1394 películas nacionales; y si se abarca el período 1990-2014, en el que se estrenaron 1620 filmes argentinos, sólo 16 de esas películas alcanzaron, o superaron, los 1,1 millones de espectadores. 
Cuadro 34 - Argentina: filmes argentinos que superaron los 1,1 millones de espectadores (19902014)

\begin{tabular}{|l|c|c|c|}
\hline Título & Espectadores & Productora participante & Año de estreno \\
\hline Relatos salvajes & 3.403 .000 & Telefé & 2014 \\
\hline $\begin{array}{l}\text { El secreto de sus } \\
\text { ojos }\end{array}$ & 2.400 .000 & Telefé & 2009 \\
\hline Manuelita & 2.320 .000 & Telefé & 1999 \\
\hline Metegol & 2.113 .566 & Telefé & 2013 \\
\hline Patoruzito & 1.951 .447 & Patagonik/Artear & 2004 \\
\hline Corazón de león & 1.704 .511 & Telefé & 2013 \\
\hline Tango Feroz & 1.600 .000 & Mandala (Arg)-Kuranda (Esp) & 1993 \\
\hline $\begin{array}{l}\text { Papá se volvió } \\
\text { loco }\end{array}$ & 1.486 .490 & Telefé & 2005 \\
\hline Comodines & 1.390 .000 & Artear/Polka & 1997 \\
\hline Papá es un ídolo & 1.370 .000 & Telefé & 2000 \\
\hline $\begin{array}{l}\text { Un novio para } \\
\text { mi mujer }\end{array}$ & 1.293 .263 & & 2004 \\
\hline $\begin{array}{l}\text { El hijo de la } \\
\text { novia }\end{array}$ & 1.267 .163 & Artear/Polka & 2008 \\
\hline Nueve reinas & 1.260 .000 & Patagonik/Artear & 2000 \\
\hline Dibu & 1.163 .000 & Patagonik & 1997 \\
\hline $\begin{array}{l}\text { Luna de } \\
\text { Avellaneda }\end{array}$ & 1.093 .356 & Telefé & \\
\hline $\begin{array}{l}\text { Bañeros 3. } \\
\text { Todopoderosos }\end{array}$ & 1.072 .659 & Telefé/Argentina Sono Film & \\
\hline Folka & \\
\hline
\end{tabular}

Fuente: Elaboración propia sobre la base de datos de Incaa, Nielsen-Rentrak, Deisica, Ultracine.

\section{Mercado cinematográfico}

En 2009 Argentina sumó alrededor de 132 millones de dólares de recaudación y vendió 33,6 millones de entradas - que, en promedio, costaban 3,7 dólares cada una- para asistir a alguna de las 800 salas existentes en el país para elegir entre los 320 estrenos que se estrenaron — de los cuales unos pocos concentraron el $80 \%$ de la cantidad de espectadores y de recaudación, tal como sucede en todo el mundo.

Si en América Latina existiera una circulación cinematográfica regional óptimamente eficiente, los argentinos — que, en promedio, concurren 1 vez por año al cine- tendrían —en teoría- más de 300 filmes regionales anuales entre los cuales escoger. Sin embargo, ello no ocurre: anualmente se estrenan entre 3 y 10 filmes latinoamericanos no nacionales - cifra similar a la que se da los otros países de la región-, cuyo público representa, en promedio, el $0,2 \%$ del total de los espectadores de cine. 
Cuadro 35 - Argentina: mercado cinematográfico (2009)

\begin{tabular}{|l|r|}
\hline Salas & 832 \\
\hline Salas digitales (2K-3D) & 35 \\
\hline Largometrajes producidos & 61 \\
\hline Espectadores (millones) & 33,6 \\
\hline $\begin{array}{l}\text { Recaudación (millones } \\
\text { US } \$ \text { ) }\end{array}$ & 131,9 \\
\hline Estrenos & 322 \\
\hline Estrenos nacionales & 100 \\
\hline Estrenos latinoamericanos & 5 \\
\hline Estrenos españoles & 3 \\
\hline Market share cine nacional & $15,8 \%$ \\
\hline $\begin{array}{l}\text { Market share cine } \\
\text { latinoamericano }\end{array}$ & $0,1 \%$ \\
\hline $\begin{array}{l}\text { Índice de concurrencia } \\
\text { anual al cine }\end{array}$ & 0,8 \\
\hline $\begin{array}{l}\text { Ticket (precio promedio, en } \\
\text { US\$) }\end{array}$ \\
\hline
\end{tabular}

Fuente: Elaboración propia con base en datos del Incaa, Rentrak, Ultracine, Deisica, Otros Cines, Cines Argentinos y medios periodísticos.

Analizando la cantidad total de estrenos desde 2004 hubo una tendencia al aumento, situación que se viene dando paulatinamente desde fines de la década del noventa —con un ligero retraimiento entre el año 2001 y el 2003 (en plena crisis económica, social y política)—: sin embargo, los números siguen siendo bajos en comparación con décadas pasadas —con promedios de entre 310 y 350 estrenos anuales (registrados en las décadas de 1980 y 1970, respectivamente), en comparación con los 260 estrenos promedio de la década de 2000; estos últimos, sin embargo, son mejores que los 217 estrenos promedio registrados durante la década de 1990.

\section{Gráfico 47 - Argentina: cantidad de estrenos comerciales (1971-2009)}

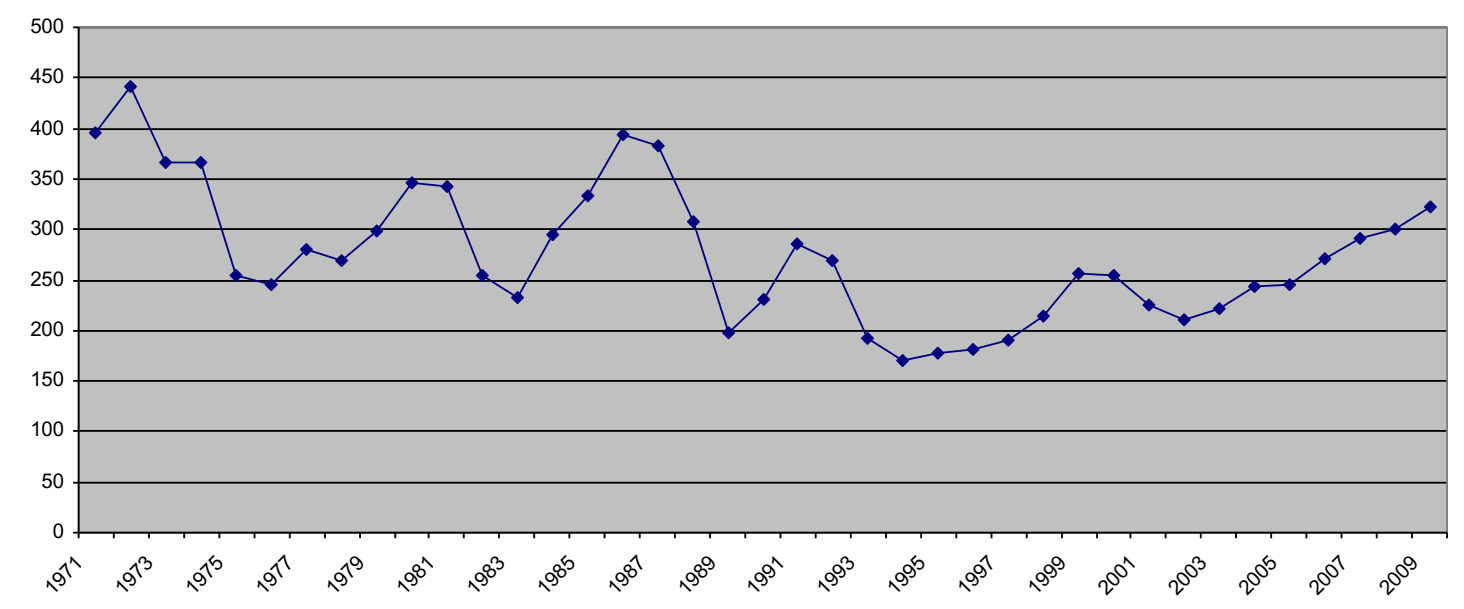

Fuente: Elaboración propia con base en datos del Incaa, Nielsen-Rentrak, Ultracine, Deisica, Otros Cines, Cines Argentinos y medios periodísticos. 
Estos números están lejos de las épocas de esplendor de concurrencia al cine - desde mediados del siglo XX hasta comienzos de la década de 1980-, cuando en Argentina —así como sucedía en América Latina- sus habitantes asistían a las salas entre 4 y 7 veces por año. Desde hace casi tres décadas, las estadísticas muestran que los argentinos —como muchos latinoamericanos- concurren al cine, en promedio, sólo una vez al año.

En efecto: hacia mediados del siglo XX concurrían a las salas argentinas de cine entre 77 y 145 millones de espectadores por año (Unesco, 1982). En la década de 2000 promediaron 34,5 millones de espectadores anuales.

Hasta mediados de la década del ochenta, el piso de espectadores cinematográficos era de 45 millones en un mal año, como 1982 — año de la guerra de Malvinas y de una incipiente crisis económica en medio de la llamada "crisis de la deuda" que acababa de desatarse en América Latina-. La cantidad usual de espectadores en Argentina, hasta la década de 1980, rondaba los 60 millones de espectadores por año (Unesco, 1982).

La cantidad de espectadores de cine nacional siguió un derrotero similar: durante la década de 1980 — década de decadencia para el mercado cinematográfico argentino, en términos de reducción en la cantidad de espectadores en general, de recaudación y en el número de salas- el market share de los filmes argentinos se ubicaba entre el 15\% y el $22 \%$ - no existen números fiables para las décadas anteriores, pero se presupone un elevado market share para el cine nacional (especialmente, entre las décadas de $1930 \mathrm{y}$ 1950), debido a la mayor popularidad de los filmes argentinos, a la mayor permanencia de los títulos en cartel (no era inusual que una película permaneciera en las carteleras durante un año, o más), a la mayor afluencia a las salas y a la mayor cantidad de éstas (especialmente, en el Interior del país, donde el cine nacional era particularmente popular, al igual de lo que sucedía en toda América Latina). 
Gráfico 48 - Argentina: número de estrenos nacionales, cantidad de espectadores de filmes extranjeros y nacionales (1980-2010)

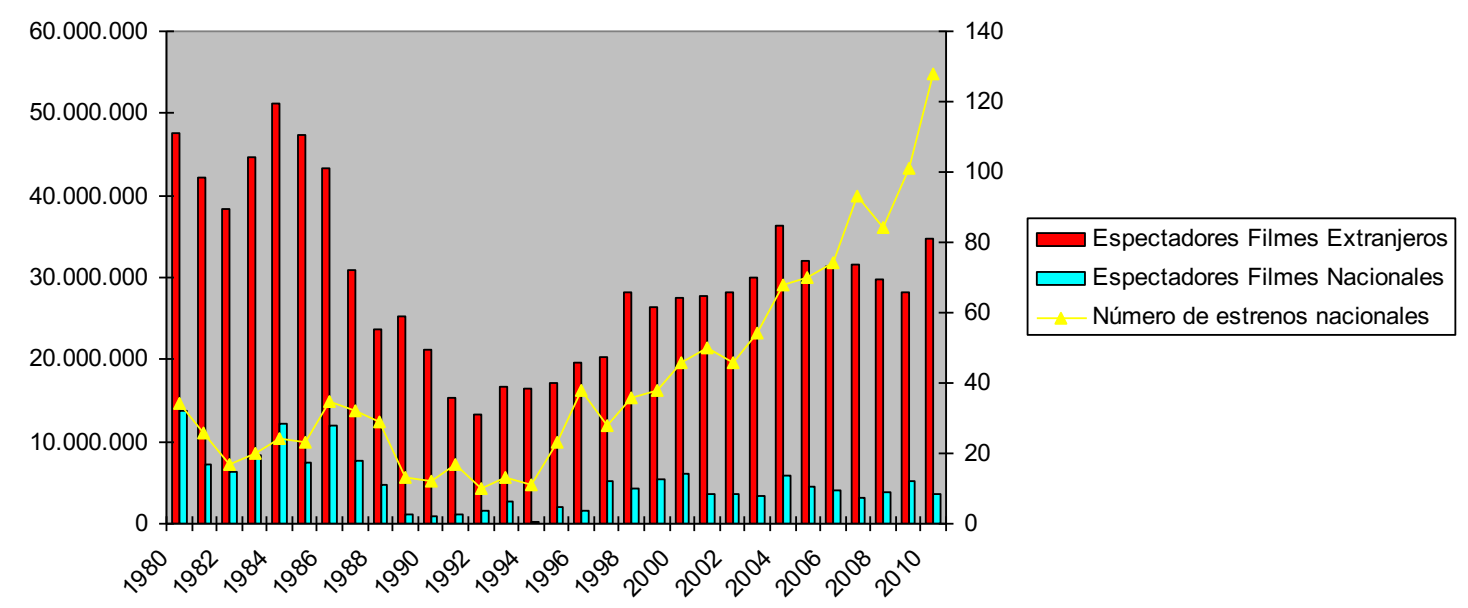

Fuente: Elaboración propia con base en datos de Unesco (1982), Getino (1987), Incaa, Nielsen-Rentrak, Ultracine, Deisica.

Desde 1989 se observa un marcado retroceso en la convocatoria de los filmes nacionales que, si bien tuvo un ligero repunte a partir de 1997, el número de espectadores que concurrieron a ver cine argentino entre fines de los noventa y durante los 2000 se mantuvo estable entre los 3 y los 5 millones —en 25 años sólo en seis ocasiones la cantidad de espectadores de filmes nacionales superó los 5 millones (1997, 1999, 2000, 2004, 2009 y 2013), recordando que hasta la década de 1980 un número malo para el cine argentino lo constituía la convocatoria de 6,4 millones de tickets vendidos.

Este pobre market share de los filmes nacionales se da a pesar de que el número de filmes locales estrenados creció constante y exponencialmente desde mediados de la década de 1990 — cuando se produjo la sanción de la reforma de la ley de cine-: entre 1994 y 2010 el número de estrenos nacionales creció 11 veces; sin embargo, como se observó, la convocatoria de los mismos no varió significativamente.

Durante la década de 2000 hubo años excepcionales -dentro del contexto de pauperización del mercado-, como fue el caso de 2004: este año también fue una buena y atípica temporada en todo el mundo, especialmente, en el mercado estadounidense, con tres enormes sucesos como Shrek II, Spiderman II y La pasión de Cristo.

Como no había pasado en el mercado argentino de cine desde hacía muchos años, en 2004 doce filmes (extranjeros y nacionales) superaron el millón de espectadores —a manera de comparación, en 2009 sólo tres filmes superaron el millón de espectadores 
(uno de ellos, fue El secreto de sus ojos, con casi 2,5 millones de entradas vendidas)—; hasta la actualidad (2015) esa marca no fue superada. ${ }^{75}$ En efecto, en 2004 dos filmes superaron los 2,5 millones de espectadores: Shrek II fue vista por tres millones de personas —ninguna película alcanzó esa cifra en toda la década-, mientras que $L a$ pasión de Cristo vendió 2,6 millones de tickets. A su vez, el cine argentino alcanzó en ese año el $14 \%$ del market share, porcentaje impulsado por dos filmes nacionales que superaron el millón de entradas vendidas - hecho que tampoco ocurrió en otro año de la década-: Patoruzito, con casi 2 millones de espectadores, y Luna de Avellaneda, con cerca de 1,1 millones de tickets vendidos.

Sin embargo, al año siguiente la cantidad total de espectadores bajó a 36,5 millones; en 2006 fueron 35,4 millones de espectadores al cine, en 2007, 34,7 y en los dos últimos años analizados la cifra siguió reduciéndose a 33,7 y a 33,5, al mismo tiempo que la recaudación aumentaba sostenidamente, debido al incremento del boleto de cine.

Con respecto a la distribución cinematográfica, en la Argentina, como en la mayor parte del mundo, las majors -es decir, las principales empresas de Hollywood (principalmente, Buena Vista, UIP, Warner, Fox y Sony)—, se quedaban con la mayor parte del mercado nacional, con ligeras variaciones anuales y con distinto "campeón" anual de acuerdo al/los blockbuster/s más taquillero/s que cada uno haya comercializado.

En 2010 alrededor del 70\% de las películas estrenadas en el país (extranjeras y nacionales) fue comercializado por distribuidoras argentinas - en el caso del cine nacional, suele ocurrir que sean los mismos productores nacionales quienes fungen como "distribuidores" ( $\sin$ tener la expertise en la materia, lo que conlleva un menor margen para alcanzar una buena performance del filme)- - Sin embargo, la mayoría de estos estrenos realizados por distribuidoras argentinas son lanzamientos con muy escasa cantidad de copias, y por ende, con una muy reducida presencia en las salas.

\footnotetext{
${ }^{75}$ Aunque en 2013 once filmes ( 9 extranjeros y 2 argentinos) superaron el millón de espectadores y, a su vez, en 2014 el filme Relatos salvajes batió el récord de convocatoria para un filme nacional en, al menos, 45 años - a nivel oficial, de consultoras y de los distintos investigadores del área no existen datos confiables y sistematizados anteriores a 1970 .
} 
Gráfico 49 - Argentina: porcentaje de mercado de las distribuidoras según origen, por títulos, copias y espectadores (2010)

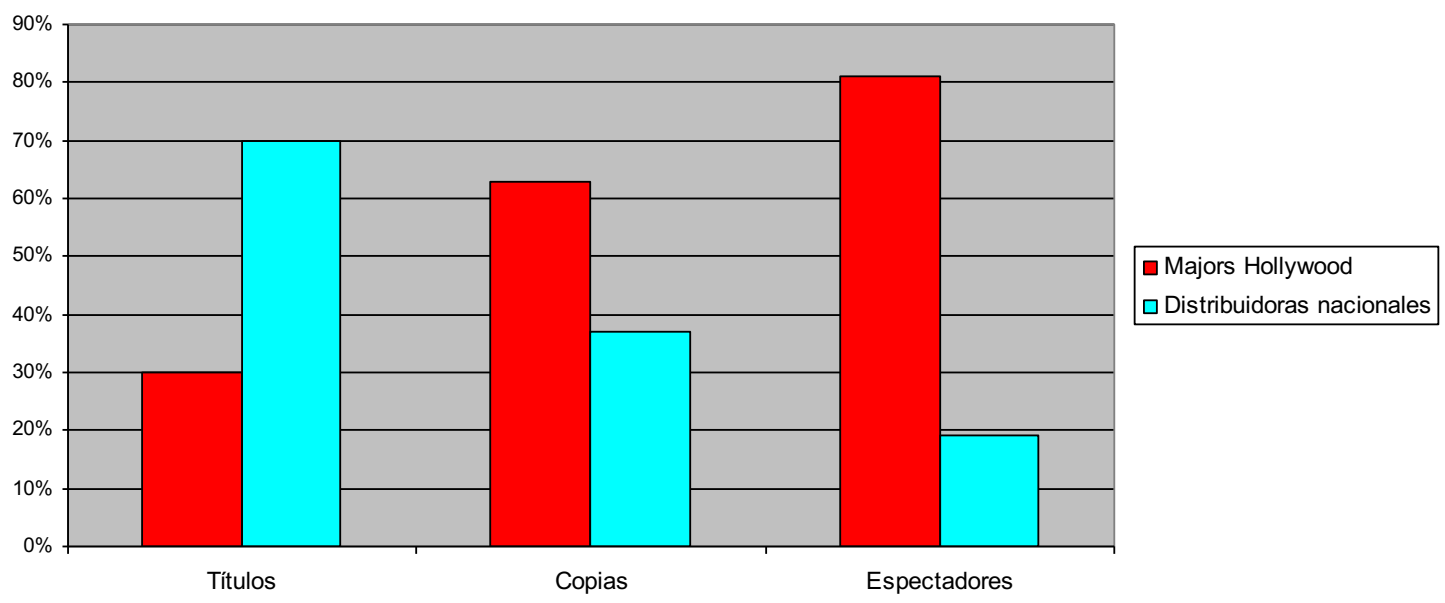

Fuente: Deisica (2011).

De tal manera, en 2010 las majors estrenaron el 28,4\% de los títulos, pero si se analiza el número de copias, las distribuidoras de Hollywood representaron el 63\% (lo que significa mayor presencia en salas), y si se compara con los resultados de mercado, el $81 \%$ de los espectadores argentinos acudieron a ver filmes comercializados por las majors de Hollywood.

Esta (des)proporción se repite de manera constante en el mercado cinematográfico argentino desde la década de 1990.

En lo que respecta a las distribuidoras nacionales, sólo tres se destacan —Distribution Company, Primer Plano ${ }^{76}$ y Alfa-, dedicándose tanto a la comercialización tanto de cine nacional como europeo, asiático y, en general, de "cine de autor" —es decir, filmes que no provienen de Hollywood.

\footnotetext{
${ }^{76}$ En abril de 2013 Pascual Condito, el fundador y alma pater de Primer Plano, anunció que desde agosto de ese año la empresa dejaba de distribuir en la Argentina. La principal causa fue el incremento de la porción de mercado tomada por las majors de Hollywood, especialmente, a partir de la virtual obligación de la Secretaría de Comercio hacia las distribuidoras extranjeras de que "por cada dólar que importen, deben exportar otro", realizada a fines de 2011. De ese momento, los filmes argentinos más taquilleros fueron distribuidos por Fox y Disney. De esta manera, Hollywood terminó distribuyendo contados estrenos nacionales, los más taquilleros, hiriendo gravemente al reducido puñado de distribuidoras argentinas dedicadas al cine local.
} 
Gráfico 50 - Argentina: porcentaje de mercado de las salas según origen, por espectadores (20002010)

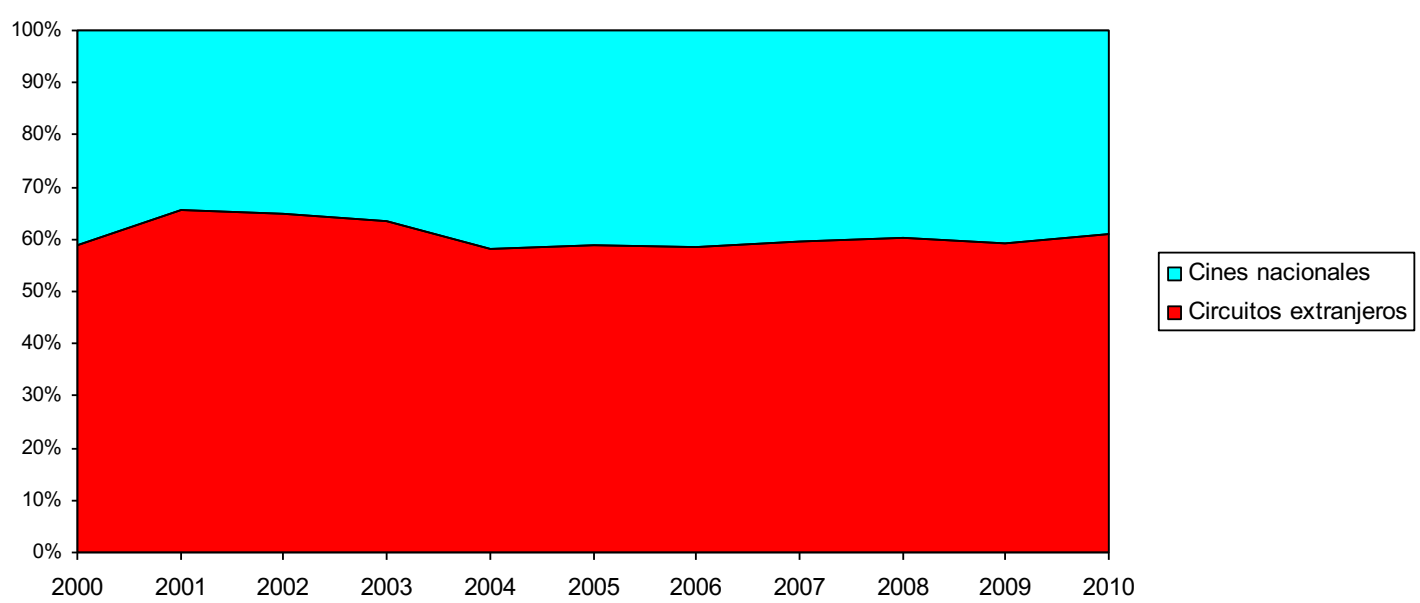

Fuente: Deisica (2011).

Analizando el sector de la exhibición, la desproporción es similar: las salas comerciales en manos de empresas extranjeras representaron entre el $40 \%$ y el $45 \%$ de las aproximadamente 800 salas existentes en el país entre 2000 y 2009 (González, 2011b). La totalidad de los cines en manos de multinacionales extranjeras son complejos cinematográficos —es decir, establecimientos con cuatro o más pantallas — propiedad de sólo cuatro empresas: Hoyts, ${ }^{77}$ Cinemark, Village y National Amusements. Estos complejos se quedaron con entre el $58 \%$ y el $66 \%$ del mercado en el período analizado — cada una de estas empresas acapara entre el 12\% y el 23\% del mercado total一, mientras que el 55\%-60\% de las salas, que son propiedad de empresas nacionales, representaron entre el $35 \%$ y el $40 \%$ del mercado.

\footnotetext{
${ }^{77}$ La empresa de exhibición Hoyts fue propiedad, hasta 2007, de capitales australianos y estadounidenses. Desde ese año está en manos de un fondo de inversión argentino, chileno y venezolano manejado por brokers relacionados con el JP Morgan.
} 
Gráfico 51 - Argentina: porcentaje de mercado de las salas según nacionalidad, por cantidad de pantallas, espectadores y recaudación (2006-2008)

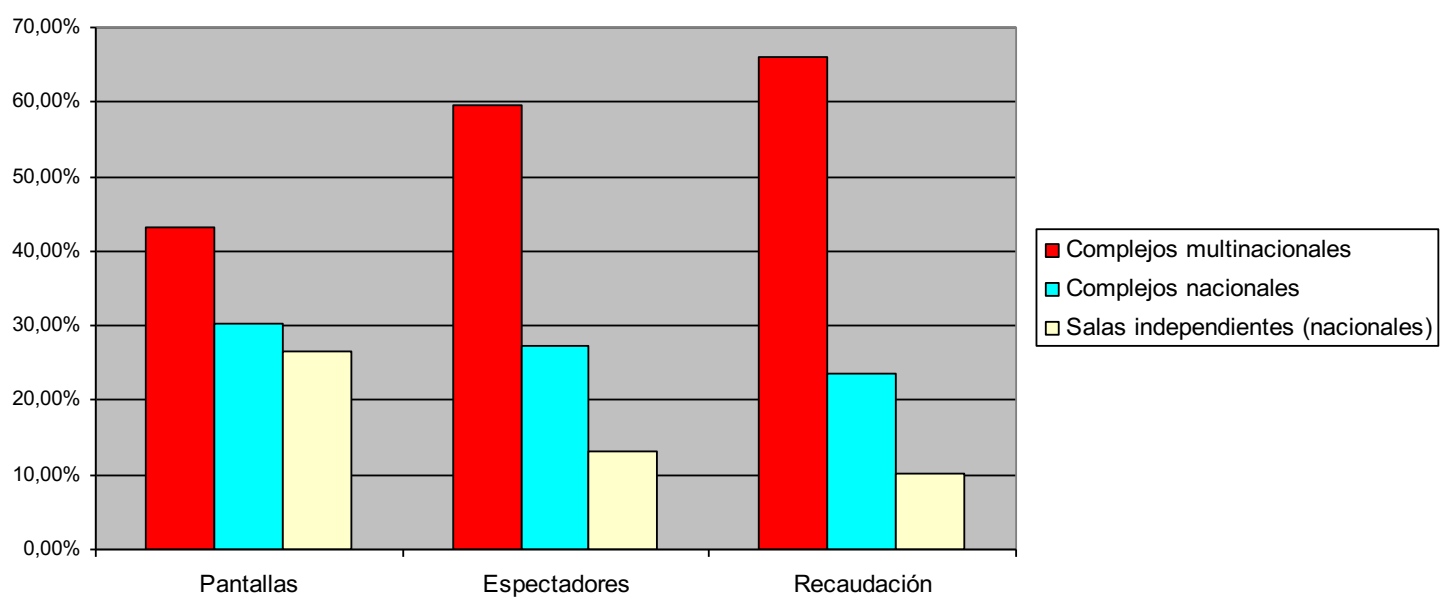

Fuente: Elaboración propia con base en datos del Observatorio de Industrias Culturales de la Ciudad de Buenos Aires.

Cabe destacar que los Espacios Incaa ${ }^{78}$ están incluidos entre las salas nacionales, pero -lamentablemente - no tienen ninguna gravitación en el mercado cinematográfico nacional: en 2010 sólo el 0,85\% de los espectadores argentinos eligió un Espacio Incaa para ver alguna película - a su vez, el número de espectadores de los Espacios Incaa (325.000 en todo el país, según el Incaa) se concentra en el cine Gaumont ("Kilómetro Cero"), de la ciudad de Buenos Aires, en el barrio de Congreso.

Por otra parte, existe en la Argentina una fuerte concentración de las salas de cine en la Capital Federal y en las zonas más ricas del país, como así también en las ciudades más prósperas de las provincias de Buenos Aires, Santa Fe y Córdoba. Esta región representa el 80\% de las salas de cine existentes en el país (González, 2011b). A su vez, sólo el 6\% de los municipios de la Argentina poseían sala de cine a 2013 (Deisica, 2014).

A diferencia de lo que ocurrió en prácticamente toda América Latina durante la década de 2000, donde los parques exhibidores se duplicaron, triplicaron y hasta cuadruplicaron en una sola década, en la Argentina la cantidad de salas se encuentra estancada desde 1998 en un número que fluctúa entre 800 y 1000 pantallas — desde 2004 hasta la actualidad (2015) el estancamiento es más pronunciado: entre 800 y 850.

\footnotetext{
${ }^{78}$ Los Espacios Incaa constituyen una política del instituto de cine puesta en funcionamiento en 2004, consistente en auspiciar salas en todo el país dedicadas exclusivamente a la exhibición de filmes nacionales e iberoamericanos. En la actualidad (2015) los Espacios Incaa están constituidos por más de 40 salas distribuidas a lo largo del país.
} 
Vaya un ejemplo comparativo: en 1998 Argentina poseía el doble de pantallas de países como Colombia. En la actualidad (2015) el país caribeño ha alcanzado a la Argentina en este indicador.

Si se extiende el análisis a varias décadas atrás, los números son peores: siguiendo la comparación con Colombia, para fines de la década de 1940 Argentina poseía más 5 veces más cantidad de cines (Comisión Nacional de Cinematografía, 1949).

Cuadro 36 - Mundo, países elegidos: cantidad de cines (1948)

País

Estados

Unidos

Inglaterra

Francia

España

Brasil

México

Argentina

Cuba

Colombia

Venezuela

\section{Cantidad de cines}

16.880
5100
4650
3500
1769
1726
$\mathbf{1 6 9 0}$
442
400
279

726

690

400

279

Fuente: Comisión Nacional de Cinematografía de México, 1949.

En esa época nuestro país se ubicaba a muy poca distancia de países como México y Brasil, que históricamente tuvieron los parques exhibidores más grandes de América Latina —en la actualidad, el país azteca tiene 7 veces más salas que nuestro país, mientras que en el caso brasileño la distancia es de 3,5 veces a favor del gigante sudamericano.

\section{Gráfico 52 - Argentina: cantidad de butacas de cine (1955-2013)}

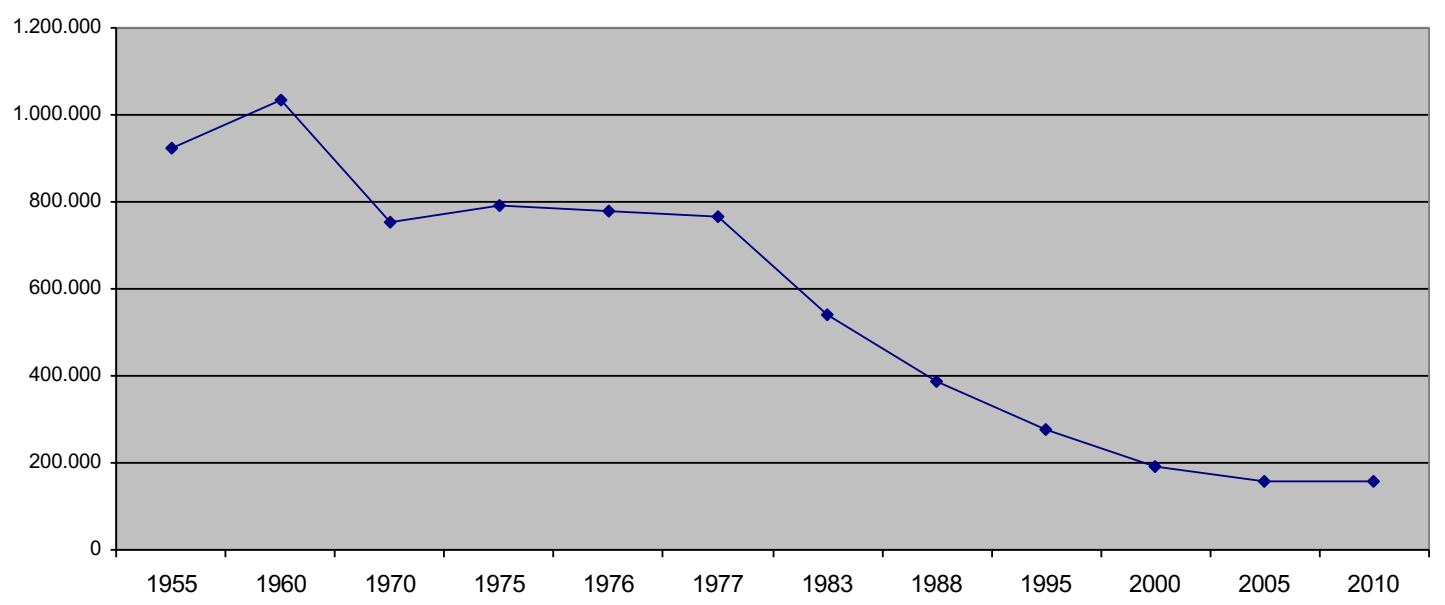

Fuente: Elaboración propia sobre la base de datos de Unesco (1955, 1982), Sadoul (2004), Getino (1987), González (2011b, 2013), Incaa, Deisica, Ultracine, Rentrak. 
Para mediados del siglo $\mathrm{XX}$ el (entonces) importante mercado cinematográfico argentino rondaba el millón de butacas. A mediados de la década de 1990 ese indicador había descendido a unas 200.000 butacas. En la actualidad el número ronda las 170.000 — seis veces menos que hace medio siglo (la misma cantidad de asientos que en 1955 sumaban Guatemala, El Salvador y Martinica).

\section{Conclusiones del capítulo}

Argentina nunca tuvo etapa fomentista - Estado activo interviniendo en todos los eslabones de la cadena productiva-, aunque sí tuvo políticas cinematográficas importantes, especialmente desde mediados de la década de 1940.

Sin embargo, a pesar de no haber tenido fomentismo, Argentina sí tuvo época de oro —durante la década de 1930, incluyendo los primeros años de la de 1940- y tuvo industria —entre las décadas de 1930 y comienzos de la de 1950—, caracterizada por una etapa de producción "fordista" realizada por la iniciativa privada, basada en la producción en serie de filmes en grandes estudios, con un importante número de trabajadores formales, con un star system reconocido, con un sólido aparato de difusión y con proyección internacional — sistema que, hacia la década de 1930, no tenía parangón en América Latina.

Aunque el Estado argentino intentó regular y fomentar la actividad - a finales de la década de 1930 se establecen las primeras normativas regulatorias de calificación-, no fue hasta mediados de la década de 1940, durante el gobierno militar del GOU ${ }^{79}$ —donde descollaba Juan Perón-, que se aplicaron las primeras disposiciones con respecto al cine, primeramente referidas a una cuota de pantalla para los filmes nacionales, y posteriormente —durante las dos primeras presidencias de Perónmediante apoyos a la producción cinematográfica.

Posteriormente tendrán lugar otros hitos de las políticas cinematográficas argentinas: en 1957 se crea el Instituto Nacional de Cinematografía - la entidad de este tipo más antigua en América Latina- y en 1968 se sanciona el decreto-ley de cine 17.741 que, con cambios, continúa vigente hasta la actualidad.

Una de las medidas trascendentes que tomó el Estado argentino fue la reforma, en 1994, de la ley de cine, que creó - entre otras medidas - el Fondo de Fomento, vigente en la actualidad. Este Fondo constituye una herramienta fundamental para el cine argentino,

\footnotetext{
${ }^{79}$ Grupo de Oficiales Unidos, cofradía de militares que propició y ejecutó el golpe militar de junio de 1943.
} 
que tiene puntos en común con legislaciones cinematográficas de avanzada a nivel mundial, como la francesa - principalmente, porque el Fondo de Fomento, tanto argentino como francés, se nutre de los recursos del mercado, sin tener que recurrir al presupuesto nacional (como sucede en la mayoría de los países con normativas de fomento al cine), siendo el Estado quien direcciona los fondos.

Sin embargo, a pesar de que el Estado tiene un rol importante en las políticas cinematográficas argentinas los filmes argentinos no tienen ni los altos porcentajes de mercado que sus pares franceses — que rondan entre el $40 \%$ y el $50 \%$ del mercado-, ni diversidad en su cartelera, ni un extendido parque exhibidor -el argentino se encuentra estancado entre 800 y 1000 pantallas desde hace casi dos décadas-, sino que se da una creciente concentración, extranjerización.

De esta manera, como se vio a lo largo de este capítulo, las políticas cinematográficas argentinas, a pesar de que se encuadran en la categoría "Estado orientado", no son fomentistas sino neofomentistas.

Aunque el Estado argentino tenga un rol importante en el sector cinematográfico, ello no repercute en un sector productivo sustentable y robusto. 


\section{CAPÍTULO VIII \\ CONCLUSIONES}

La hipótesis principal que buscaba comprobar esta tesis era que "el neofomentismo, es decir, las políticas públicas cinematográficas en Argentina, Brasil y México llevadas a cabo durante la primera década del siglo XXI, surgidas a partir de la presión del sector, no son una continuación del fomentismo - políticas cinematográficas de un Estado activo en la industria-, sino políticas públicas defensivas - medidas que tienden a apoyar especialmente la producción, sin alterar las relaciones de poder en el sector, a diferencia de lo que ocurría durante el Estado fomentista: políticas que promovían por igual a los tres eslabones de la industria (producción, distribución y exhibición), con empresas estatales y normativas decididas (como cuotas de pantalla de cerca del 50\% del tiempo de pantalla)".

A lo largo de los distintos tipos de políticas públicas cinematográficas adoptadas desde la década de 1990 se aprecia una voluntad por superar el desmantelamiento del fomento estatal al cine acaecido en el primer lustro de ese decenio. Sin embargo, los resultados de mercado, las características de los distintos eslabones - la fragmentación de la producción, la concentración y la extranjerización en la distribución y la exhibiciónmuestran que la actividad cinematográfica, aunque creció en términos de producción desde finales de la década de 1990, tanto para Argentina, Brasil y México, como para casi la totalidad de los países latinoamericanos, no lograron consolidar una industria sustentable, sino filmes nacionales que no registran importantes niveles de convocatoria, que apenas circulan y casi no se ven a lo largo de la región.

La India es el mayor productor de películas en el mundo, seguido por China, Estados Unidos y Francia. Argentina, Brasil y México — desde finales de la década de 2000también forman parte de este club selecto, con entre 100 y 160 largometrajes anuales.

Sin embargo, en Argentina, Brasil y México no se da un alto market share - porcentaje de los espectadores de cine que concurren a ver filmes nacionales-, como sí sucede en Francia o Japón — con porcentajes que rondan entre el 30\% y el 45\%—, Estados Unidos o la India -mercados donde el consumo local de filmes nacionales se ubica en torno al 95\% (González, 2013)—. Los filmes de Argentina, Brasil y México convocan —desde el año 2000- el 10\% del público, en promedio — sólo años con estrenos con un éxito excepcional, como El secreto de sus ojos, Tropa de elite o El infierno, se logran market shares de entre el 14\% y el 16\% (como una excepción que se da cada década, en 2003, 
en Brasil, los filmes nacionales se quedaron con una porción de mercado del $21 \%$, a partir del gran éxito de Carandirú) ${ }^{80}$

\section{Gráfico 53 - Argentina, Brasil y México: porción de mercado de los filmes nacionales, en} porcentaje (2001-2009)

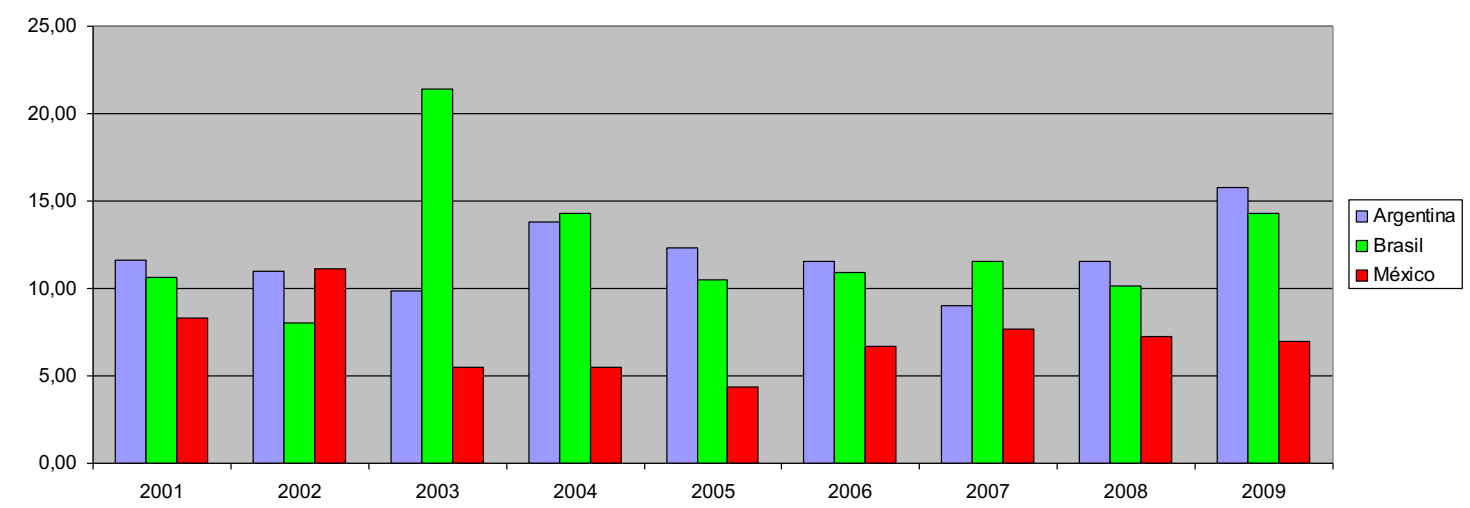

Fuente: Elaboración propia con base en datos de Incaa, Ancine, Imcine, Canacine, Deisica, Rentrak, Ultracine, FilmeB.

Tal como sucede en todo el mundo, la diferencia entre los últimos 25 años y lo que sucedía a mediados del siglo XX es abismal: para la década de 1950 un índice de concurrencia bajo en América Latina era de 3 -resultante de dividir la cantidad de espectadores por la población del país-. Lo habitual en los principales países de la región era un valor de entre 6 y 9. El promedio regional se ubicaba en 5.

En la actualidad -y desde hace un cuarto de siglo - un índice de 2 es un valor muy alto en la región. En efecto, desde hace muchos años en América Latina los índices de concurrencia al cine varían entre 0,2 y poco más de 1 (en Argentina y en Brasil este índice se ubica en alrededor de 1; mientras que México es el único país latinoamericano donde la cifra llega a 2). ${ }^{81}$

\footnotetext{
${ }^{80}$ En 2013 cuatro blockbusters de Globo convocaron, cada uno, entre 2,7 y 4,6 millones de espectadores.

${ }^{81}$ A partir de 2012 el mercado cinematográfico azteca alcanzó, y superó levemente este índice de 2.
} 
Cuadro 37 - Argentina, Brasil, México: índice de concurrencia* a los cines (1960-2010)

\begin{tabular}{|l|r|r|r|r|r|r|r|r|}
\hline & $\mathbf{1 9 6 0}$ & $\mathbf{1 9 7 5}$ & $\mathbf{1 9 8 5}$ & $\mathbf{1 9 9 0}$ & $\mathbf{1 9 9 5}$ & $\mathbf{2 0 0 0}$ & $\mathbf{2 0 0 5}$ & $\mathbf{2 0 1 0}$ \\
\hline Argentina & 7 & 3,2 & 1,81 & 0,68 & 0,55 & 0,91 & 0,94 & 0,9 \\
\hline Brasil & 5 & 2,6 & 0,67 & 0,64 & 0,53 & 0,41 & 0,5 & 0,69 \\
\hline México & 10 & 4,2 & 5,78 & 6,48 & 0,65 & 0,87 & 1,47 & 1,69 \\
\hline $\begin{array}{l}\text { Promedio } \\
\text { América }\end{array}$ & & & & & & & & \\
Latina & 5,75 & 2,96 & 2,15 & 1,5 & 0,43 & 0,59 & 0,7 & 0,93 \\
\hline
\end{tabular}

* Este índice se obtiene de dividir la cantidad total anual de espectadores cinematográficos por la población del país en cuestión.

Fuente: Elaboración propia con base en datos de Unesco (1982), Incaa, Ancine, Imcine, CNAC, CNCA, Ina-Icau, Dirección de Cinematografía (Colombia), ProImágenes (Colombia), Conacine (Perú), Getino (1987, 2005a, 2005b), Stolovich (2004), Guzmán Cárdenas (2004), Rey (2005), Canacine, Deisica, Nielsen-Rentrak, Ultracine, Cinedística, Filme-B, Otros Cines, Cinencuentro, Cinestrenos, medios periodísticos.

A pesar del importante incremento registrado en distintos indicadores de mercado entre la década de 1990 y fines de la década de 2000, la cantidad de entradas vendidas representa la mitad de los espectadores convocados medio siglo atrás —cuando la población de los países era sustancialmente menor.

\section{Gráfico 54 - Argentina, Brasil y México: cantidad total de espectadores (1957-2009)}

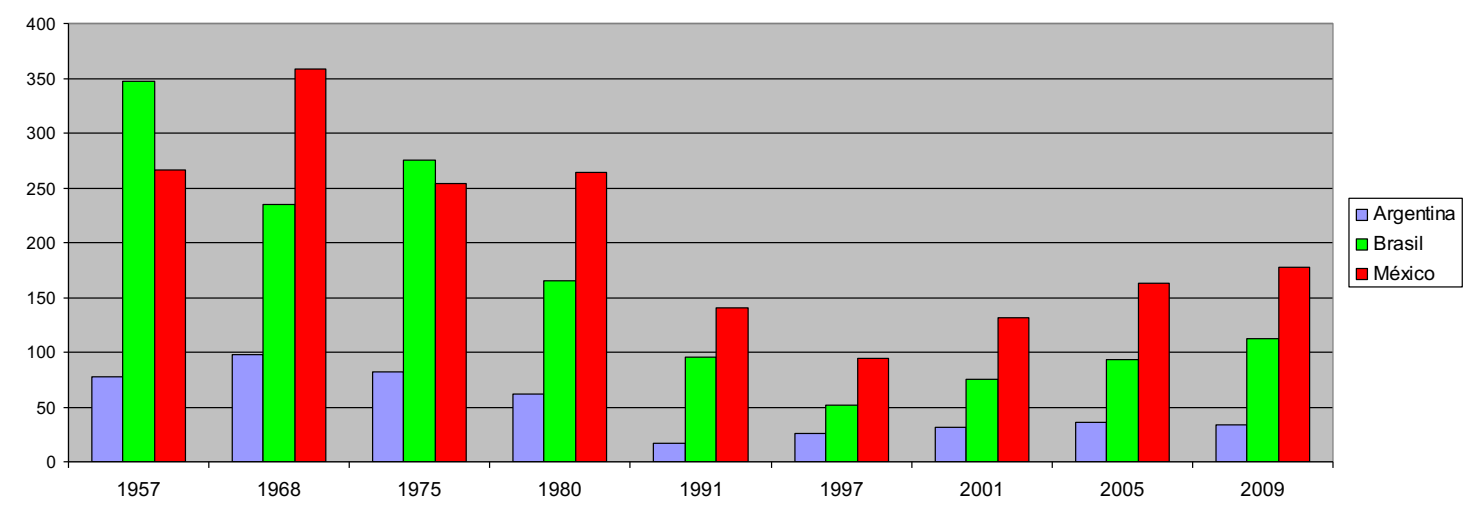

Fuente: Elaboración propia con base en datos de Unesco (1982), Incaa, Ancine, Imcine, Getino (2005b), Canacine, Deisica, Nielsen-Rentrak, Ultracine, Cinedística, Filme-B.

Otro tanto ocurre con las butacas -indicador más preciso que el número de salas para comparar el parque exhibidor (los cines de antaño poseían 600 butacas en promedio hasta la década de 1980, mientras que los multiplex que predominan desde la década de 1990 tienen sólo 200 asientos en promedio)—: si para mediados del siglo XX los tres países estudiados en esta tesis tenían entre 1 millón (Argentina) y 2 millones de butacas (Brasil y México) desde la década de 1990 esos números se redujeron drásticamente —en 2009 las salas argentinas contaban con 166.000 asientos, las brasileñas con 
420.000 y México tenía cerca de 1 millón (siendo el quinto parque exhibidor más grande del mundo).

\section{Gráfico 55 - Argentina, Brasil y México: número de butacas (1947-2009)}

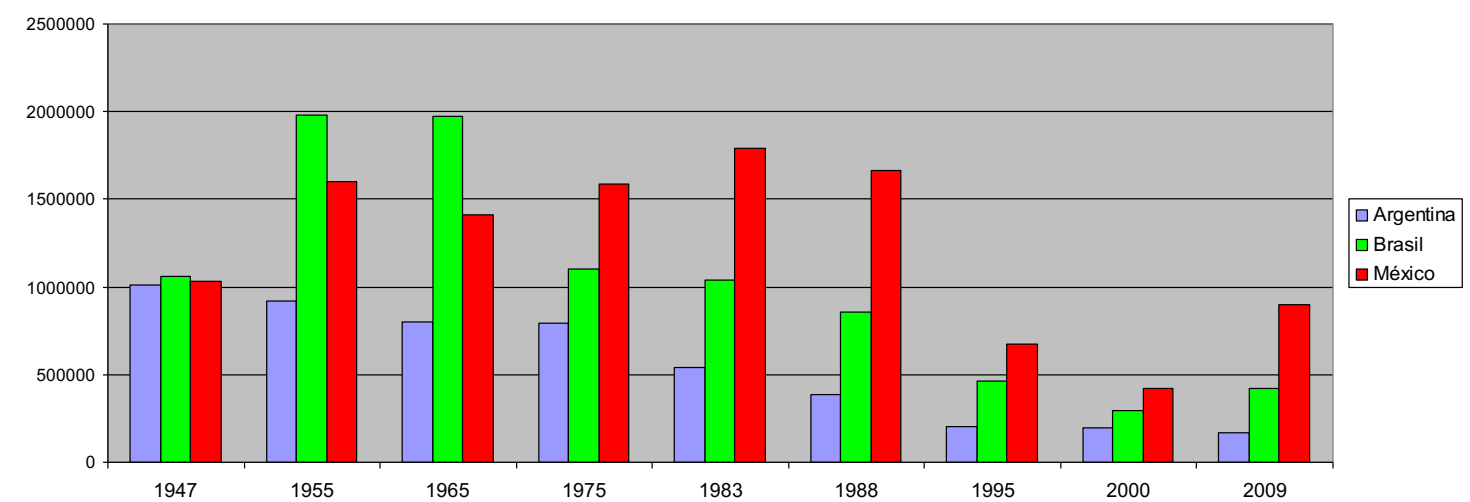

Fuente: Elaboración propia con base en datos de Unesco (1982), Incaa, Ancine, Imcine, Getino (2005b), Canacine, Deisica, Nielsen-Rentrak, Ultracine, Cinedística, Filme-B, Otros Cines, medios periodísticos.

A su vez, la concentración geográfica de las pantallas es muy alta en todos los países latinoamericanos. En México sólo el 7\% de las ciudades tiene una pantalla de cine; en Brasil —el segundo mercado de exhibición más importante de América Latina— sólo el $10 \%$ de las ciudades cuenta con una sala de cine, mientras que en Argentina el porcentaje es del 6\% (González, 2011).

Haciendo una visión de conjunto, si se agregan los datos de producción y mercados de Argentina, Brasil y México se aprecia que estos tres países representan entre el 55\% y el $65 \%$ de los diversos indicadores de mercado de toda América Latina (salas, cantidad de espectadores, recaudación total, filmes nacionales).

Cuadro 38 - Argentina, Brasil, México: porcentaje del mercado cinematográfico latinoamericano (2010)

\begin{tabular}{|l|r|r|r|}
\hline & Arg, Br, Mx & $\begin{array}{l}\text { \% del total } \\
\text { latinoamericano }\end{array}$ & $\begin{array}{l}\text { Resto América } \\
\text { Latina }\end{array}$ \\
\hline Espectadores & 362,24 & $57 \%$ & 274,76 \\
\hline $\begin{array}{l}\text { Recaudación } \\
\text { (millones de } \\
\text { dólares) }\end{array}$ & 1681,04 & $57 \%$ & 1274,96 \\
\hline Salas & 7830 & $65 \%$ & 4241 \\
\hline $\begin{array}{l}\text { Cantidad de } \\
\text { largometrajes } \\
\text { producidos }\end{array}$ & 340 & & \\
\hline
\end{tabular}

Fuente: Elaboración propia con base en datos de Incaa, Ancine, Imcine, CNAC, CNCA, Icau, Dirección de Cinematografía (Colombia), ProImágenes (Colombia), Conacine (Perú), Canacine, Deisica, Rentrak, Ultracine, Filme-B, Otros Cines, Cinencuentro, Cinestrenos, medios periodísticos. 
México destaca su supremacía en los números de mercado. El país azteca posee la mitad del total de las salas latinoamericanas, mientras que durante la década de 2000 convocó al $41 \%$ del total de espectadores que fueron al cine en América Latina, recaudando por sí solo el $35 \%$ de la taquilla latinoamericana global en ese mismo decenio. ${ }^{82}$

Brasil también posee una presencia importante en el mercado latinoamericano: el 23\% de las pantallas del subcontinente están instaladas en su territorio, mientras que el 29\% de los espectadores latinoamericanos son brasileños y el 35\% de la taquilla de la región se recaudó en Brasil. ${ }^{83}$

Distinta es la presencia de Argentina en el mercado latinoamericano global ( $8 \%$ de las salas latinoamericanas, $8 \%$ de los espectadores y $8,5 \%$ de la recaudación) ${ }^{84}$

En lo que hace a la producción fílmica, hasta 2006 Argentina se destacaba ampliamente del resto de América Latina, alcanzando el centenar de largometrajes producidos desde 2005. Sin embargo, desde 2007 Brasil y México también comenzaron a rondar el centenar de largometrajes realizados (Brasil superó ese número en ese año de 2007, mientras que México lo hizo en 2010). ${ }^{85}$

\section{Gráfico 56 - Argentina, Brasil y México: cantidad de largometrajes producidos (2000-2010)}

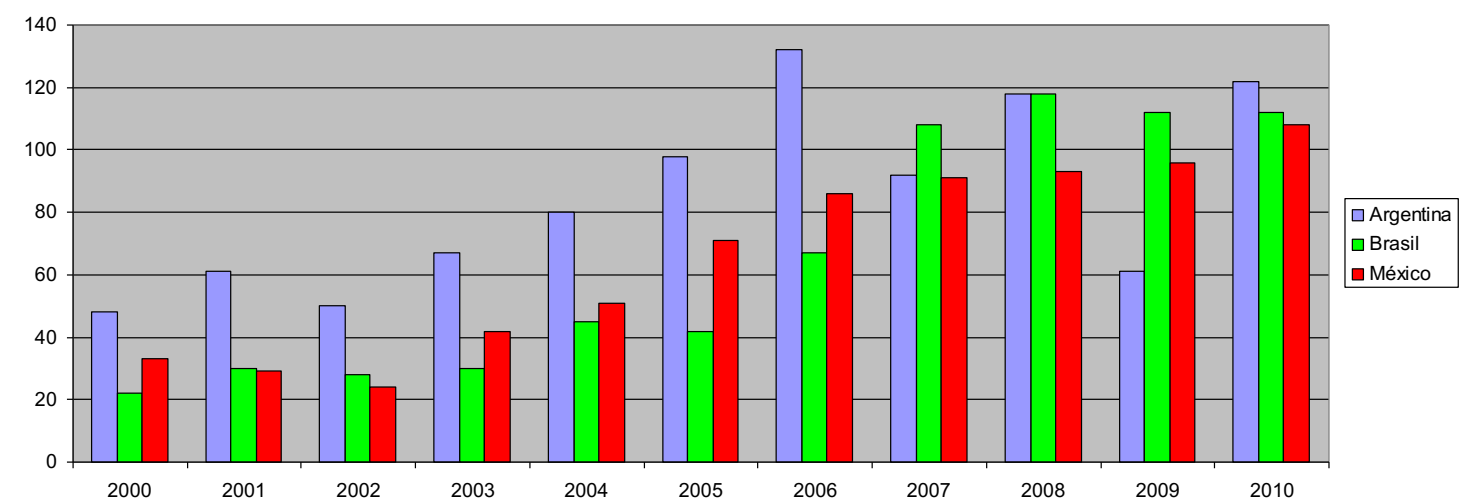

Fuente: Elaboración propia con base en datos de Incaa, Ancine, Imcine, Canacine, Deisica, Rentrak, Ultracine, FilmeB.

A pesar de producirse mayor cantidad de largometrajes en los países analizados, no se registra una importante convocatoria de estos filmes, ni dentro ni fuera de sus fronteras.

\footnotetext{
${ }^{82}$ Información propia elaborada a partir de los números del Imcine, Nielsen-Rentrak y Canacine.

${ }^{83}$ Información propia elaborada a partir de los números de Ancine, Filme-B y Nielsen-Rentrak.

${ }^{84}$ Información propia elaborada a partir de los números del Incaa, Deisica, Nielsen-Rentrak y Ultracine.

${ }^{85}$ Información propia elaborada a partir de los números del Incaa, Imcine, Ancine, Deisica, Filme-B, Nielsen-Rentrak, Ultracine y Canacine.
} 
A pesar del poco espacio en la cartelera que dejan los estrenos de Hollywood desde la década de 1990, y debido a que la oferta de cine nacional se ha incrementado notablemente en los casos de Argentina, México y Brasil gracias al neofomentismo estatal —duplicando en el primer caso, y triplicando en los dos restantes el número de películas nacionales estrenadas entre 1990 y 2009-, los filmes nacionales de los países analizados fueron lentamente recuperando presencia en las carteleras locales desde finales de la década de 1990, pero con escaso market share (porción de mercado).

En efecto, la mayoría de los filmes argentinos, brasileños y mexicanos no llega ni siquiera a los diez mil espectadores - la mitad de los estrenos nacionales apenas alcanza los mil espectadores (entre 20 y 30 filmes [lo que representa la producción total de países como Ecuador, Uruguay y Bolivia, juntos] no llegan a convocar, cada uno, 200 espectadores).

La mayoría de las veces los exhibidores mantienen las películas nacionales apenas una semana en cartelera. A esto se suma la escasa promoción y marketing —ausentes en la mayoría de los proyectos fílmicos latinoamericanos, y deficientes en las estrategias de las distribuidoras locales que comercializan la mayoría de los filmes nacionales en América Latina.

De entre los 1000 y 1600 estrenos nacionales registrados en Argentina, Brasil y México (por separado) entre 1990 y 2014, sólo entre 16 y 38 títulos (entre el 1\% y el 3\%) convocaron entre 1 a 2,5 millones de espectadores (o más), la cantidad necesaria para amortizar el costo promedio de producción si no se contara con la ayuda estatal —ayuda que, en muchos proyectos, no llega a cubrir la totalidad de los costos.

Con el tiempo fueron surgiendo algunos títulos nacionales muy exitosos, aunque muy escasos en los últimos 25 años - sólo una treintena de estrenos locales de Argentina, Brasil y México superaron los 2,5 millones de espectadores en el último cuarto de siglo (mientras que los tres países estrenaron en ese lapso de tiempo 3800 títulos nacionales)—, tal como se pudo apreciar en las estadísticas ofrecidos en los respectivos capítulos nacionales.

A esta baja convocatoria de los filmes nacionales hay que sumar otro factor: el porcentaje ínfimo que reciben los productores cinematográficos de los países analizados - y de toda América Latina- de cada entrada vendida: del valor neto de la recaudación hecha por sus películas, los productores sólo reciben entre un $10 \%$ y un $20 \%$ - hecho que sucede en los escasos casos en que se registran ganancias, lo que suele ocurrir 
cuando una major de Hollywood comercializa el filme (en este caso, esta empresa se queda con entre el $25 \%$ y el $35 \%$ de los ingresos del filme).

La mayoría de las películas locales en los distintos países latinoamericanos se estrenan al margen de los grandes circuitos de exhibición, y cuando lo hacen -debido a la existencia de una cuota de pantalla (Argentina y Brasil) - se exhiben en horarios y salas marginales, con muy escasa promoción —insistimos: salvo que sean comercializadas por las majors.

Cuando existe algún intento de realizar un buen estreno comercial de un filme nacional - con todo el esfuerzo y el gasto que ello representa, frente a los tanques hollywoodenses-, las majors bloquean las salas con una inmensa cantidad de copias y, a su vez, refuerzan la práctica anticompetitiva del block booking, llevada a cabo en todo el mundo -inclusive en Estados Unidos- desde hace casi un siglo —en el sentido de negociar con los exhibidores locales paquetes de películas que incluyen los "tanques" que las cadenas quieren, pero también películas hollywoodenses de menor calidad y convocatoria, que el exhibidor se ve obligado a programar.

A su vez, las cinematografías latinoamericanas no nacionales representan porcentajes ínfimos, tanto en los tres países analizados como en el resto de América Latina - situación que contrasta con la importante presencia que las filmografías mexicana y argentina tenían en las salas comerciales de América Latina y el mundo algunas décadas atrás.

Cuadro 39 - Argentina, Brasil y México: estrenos comerciales latinoamericanos no nacionales, porcentaje a partir de la cantidad de estrenos (2000-2009)

\begin{tabular}{|c|c|c|c|c|c|c|c|c|c|}
\hline \multirow{3}{*}{ Argentina } & & 2002 & 2003 & 2004 & 2005 & 2006 & 2007 & 2008 & 2009 \\
\hline & \begin{tabular}{|l|} 
Filmes \\
latinoamericanos \\
no nacionales
\end{tabular} & 4 & 6 & 10 & 7 & 10 & 6 & 3 & 5 \\
\hline & $\begin{array}{l}\text { Filmes de otras } \\
\text { procedencias }\end{array}$ & 207 & 215 & 233 & 238 & 261 & 286 & 298 & 317 \\
\hline \multirow[t]{2}{*}{ Brasil } & \begin{tabular}{|l|} 
Filmes \\
latinoamericanos \\
no nacionales \\
\end{tabular} & 5 & 3 & 11 & 11 & 16 & 7 & 13 & 11 \\
\hline & $\begin{array}{l}\text { Filmes de otras } \\
\text { procedencias }\end{array}$ & 160 & 214 & 262 & 267 & 316 & 319 & 310 & 308 \\
\hline \multirow[t]{2}{*}{ México } & \begin{tabular}{|l|} 
Filmes \\
latinoamericanos \\
no nacionales \\
\end{tabular} & 12 & 10 & 15 & 11 & 8 & 10 & 8 & 10 \\
\hline & $\begin{array}{l}\text { Filmes de otras } \\
\text { procedencias }\end{array}$ & 248 & 270 & 263 & 268 & 290 & 295 & 318 & 297 \\
\hline
\end{tabular}

Fuente: Elaboración propia con base en datos del Incaa, Ancine, Imcine, Canacine, Deisica, Nielsen-Rentrak, Ultracine, Cinedística, Filme-B. 
Durante la primera década del siglo XXI las películas extranjeras no hollywoodenses (latinoamericanas no nacionales, europeas y de otras nacionalidades) se quedaron, en conjunto, con alrededor del $5 \%$ de la oferta y demanda de los resultados de mercado en los tres países analizados - la cinematografía latinoamericana no nacional rasguña cifras paupérrimas (que muchas veces se cuentan de a decenas o de a pocas centenas de entradas vendidas), representando sólo el 2,5\% promedio de los estrenos y el 0,3\% promedio de los resultados de mercado tanto en Argentina, Brasil y México como en toda América Latina, desde hace un cuarto de siglo.

Gráfico 57 - Argentina, Brasil y México: estrenos comerciales latinoamericanos no nacionales, porcentaje a partir de la cantidad de espectadores (2000-2009)

\begin{tabular}{|l|l|r|r|r|r|r|r|r|r|}
\hline \multicolumn{1}{|c|}{ Argentina } & $\begin{array}{l}\text { Filmes } \\
\text { latinoamericanos } \\
\text { no nacionales }\end{array}$ & $0,11 \%$ & $0,38 \%$ & $0,30 \%$ & $0,13 \%$ & $0,09 \%$ & $0,12 \%$ & $0,13 \%$ & $0,36 \%$ \\
\cline { 2 - 9 } & $\begin{array}{l}\text { Filmes de otras } \\
\text { procedencias }\end{array}$ & $99,89 \%$ & $99,62 \%$ & $99,70 \%$ & $99,87 \%$ & $99,91 \%$ & $99,88 \%$ & $99,87 \%$ & $99,64 \%$ \\
\hline \multirow{2}{*}{ Brasil } & $\begin{array}{l}\text { Filmes } \\
\text { latinoamericanos } \\
\text { no nacionales }\end{array}$ & $0,61 \%$ & $0,11 \%$ & $0,26 \%$ & $0,31 \%$ & $0,36 \%$ & $0,06 \%$ & $0,66 \%$ & $0,15 \%$ \\
\cline { 2 - 9 } & $\begin{array}{l}\text { Filmes de otras } \\
\text { procedencias }\end{array}$ & $99,39 \%$ & $99,89 \%$ & $99,74 \%$ & $99,69 \%$ & $99,64 \%$ & $99,94 \%$ & $99,34 \%$ & $99,85 \%$ \\
\hline \multirow{2}{*}{ México } & $\begin{array}{l}\text { Filmes } \\
\text { latinoamericanos } \\
\text { no nacionales }\end{array}$ & $0,16 \%$ & $0,40 \%$ & $0,25 \%$ & $1,11 \%$ & sd & $0,10 \%$ & $0,36 \%$ & $0,55 \%$ \\
\cline { 2 - 9 } & $\begin{array}{l}\text { Filmes de otras } \\
\text { procedencias }\end{array}$ & $99,84 \%$ & $99,60 \%$ & $99,75 \%$ & $98,89 \%$ & sd & $99,90 \%$ & $99,64 \%$ & $99,45 \%$ \\
\hline
\end{tabular}

Fuente: Elaboración propia con base en datos del Incaa, Ancine, Imcine, Canacine, Deisica, Nielsen-Rentrak, Ultracine, Cinedística, Filme-B.

A partir de este contexto, a continuación se detallarán las distintas hipótesis que la presente tesis fue contrastando a lo largo de sus páginas:

\section{Hipótesis 1:}

El neofomentismo es una reparación al desmonte del fomentismo — participación activa del Estado en la producción, distribución y exhibición cinematográfica entre las décadas de 1940 y 1970. 
Al analizar las políticas públicas cinematográficas en México, Brasil y Argentina, se pueden apreciar dos etapas:

- la del cine industrial estatal, en la que los Estados mexicano y brasileño estuvieron presentes — por períodos- en todos los eslabones de la cadena de valor (1942-1992) -Argentina también tuvo cine industrial (especialmente, en la época de oro, en la década de 1930), pero sin ninguna clase de apoyo estatal en ese momento; el Estado nacional comenzó a dictar normativas de fomento a la cinematografía desde mediados de la década de 1940, y

- la neofomentista (1992-actualidad) donde el Estado se tornó gerenciador de recursos bajo la lógica del mercado, enfocándose casi exclusivamente en la producción, descuidando la distribución, la comercialización y la exhibición.

Luego de décadas de políticas cinematográficas activas, a comienzos de la década de 1990 la situación cambió radicalmente, comenzando la etapa neofomentista que perdura hasta la actualidad.

Los años noventa vieron brillar en América Latina el llamado "Consenso de Washington" - lo que en Argentina se sintetizó bien como "relaciones carnales" con Estados Unidos y el llamado "Primer mundo"-: privatizaciones de empresas públicas, bajas de distintas ayudas sociales, extranjerización, creciente concentración en las distintas ramas productivas, financierización de la economía, con las consecuencias de desempleo, precarización laboral, empobrecimiento de la población y exclusión social a niveles nunca vistos.

En el sector cinematográfico el comienzo de este decenio vio dar de baja políticas de apoyo, con la consiguiente contracción tanto en la producción como en el mercado: ambas dimensiones se redujeron en esa época a niveles históricos.

Sin embargo, a lo largo de la década del noventa, y especialmente en su segundo quinquenio, los Estados comenzaron tímidamente a implementar mecanismos de apoyo al cine -aunque con una mínima intervención estatal, dejando la iniciativa al sector privado-, debido a la creciente presión de trabajadores, técnicos y profesionales del sector, que de la noche a la mañana habían visto que los distintos eslabones de las cinematografías locales se desplomaron. La mayoría de estos profesionales emigraron laboralmente a la televisión y a la publicidad para sobrevivir, pero nunca cejaron en sus luchas para reconstruir sus cines nacionales. 
A diferencia de la situación contemporánea de los sectores cinematográficos que se describió en la primera parte de estas conclusiones - en cuanto mercados concentrados, consumos elitistas, sector de la producción fragmentado y sin sustentabilidad-, entre la década de 1930 y 1980 Argentina, Brasil y México vivieron —en algún momento de ese período de medio siglo - una producción industrial: es decir, contaron con un sistema de estudios, con miles de trabajadores y profesionales laborando sostenidamente en todos los ámbitos de la cadena de valor cinematográfica, con empresas que eran mayormente nacionales.

Por otra parte, antes de la década de 1990 las cinematografías nacionales de Argentina, Brasil y México convocaban a un importante número de espectadores, que en esos años se encontraban dispersos a lo largo del territorio nacional, merced a la existencia de cines en pueblos, ciudades pequeñas y barrios humildes — público que, históricamente, fue el mayor consumidor de los filmes locales-, con precios baratos, accesibles para la población de menor poder adquisitivo.

A su vez, las carteleras argentina, brasileña y mexicana - como la del resto de América Latina y del mundo- exhibían diversidad: se estrenaban títulos de todo el mundo, muchos de ellos de América Latina; Hollywood era un actor de peso, pero sus filmes no representaban el 75\%-90\% de los resultados de mercado - como sucede desde la década de 1990—, sino aproximadamente la mitad (Getino, 1987).

Por su parte, vale realizar la comparación entre los tres países analizados en esta tesis a partir de las políticas cinematográficas que tuvieron un rol activo del Estado interviniendo fuertemente tanto en la producción, en la comercialización, en la distribución y en la exhibición, ya sea mediante asociación o, directamente, mediante la creación de empresas estatales para tal fin -como se dio especialmente en el caso mexicano. 
Cuadro 40 - México (1942-1992), Brasil (1969-1990) y Argentina: características del Estado empresario cinematográfico

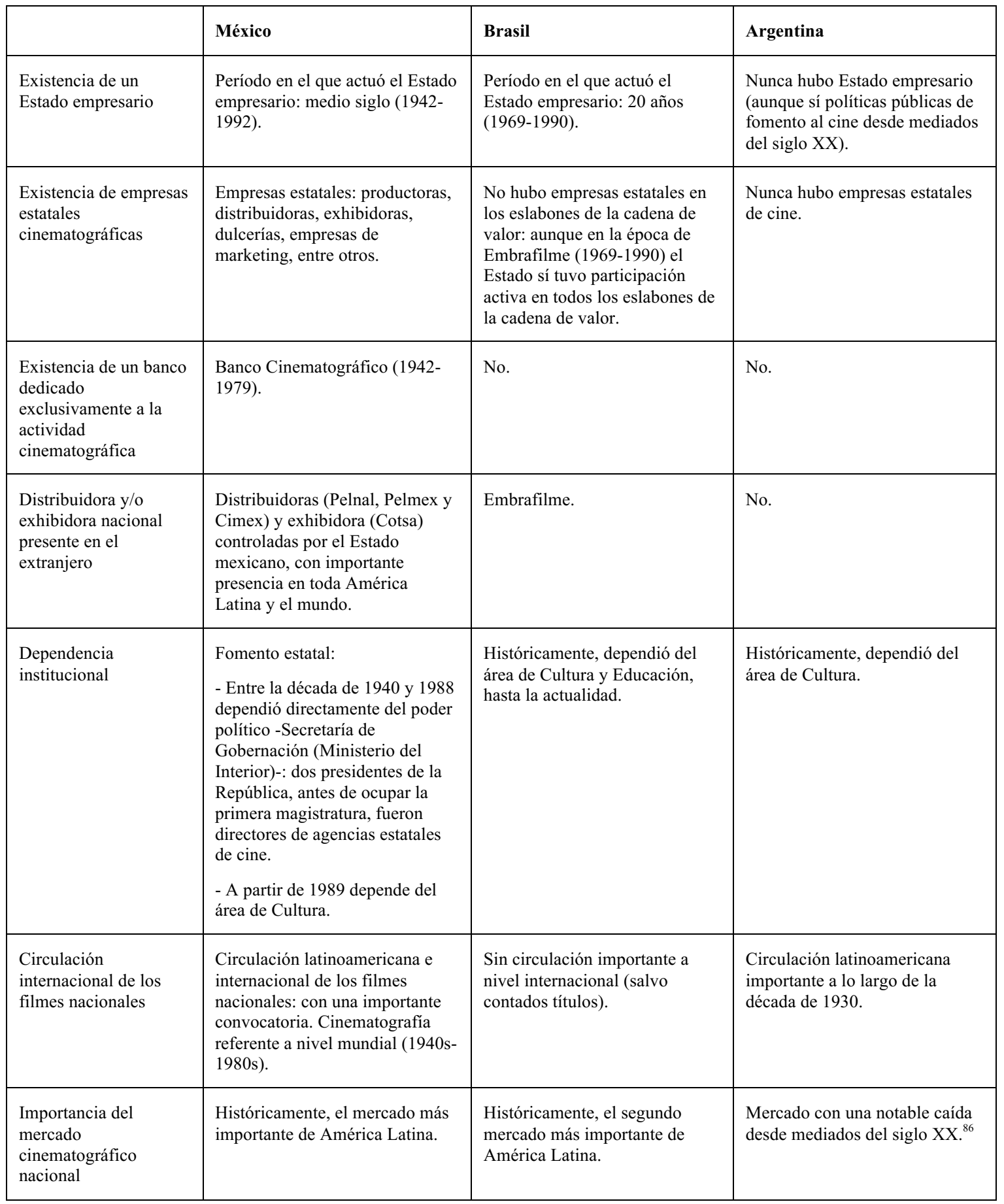

Fuente: Elaboración propia con base en datos de la presente tesis.

${ }^{86}$ Valga un ejemplo: hacia 1950 Colombia tenía un mercado cuatro veces más pequeño que el argentino: actualmente es similar al argentino, estando muy cerca de superarlo como el tercer mercado más grande latinoamericano —estadísticas elaboradas a partir de Unesco (1955), Canacine (1949) y González (2011b). 
Entre las décadas de 1940 y 1992 existían en México políticas cinematográficas de Estado activas, habiéndose creado distintas herramientas para intervenir en el mercado en favor de las películas nacionales.

Durante esta etapa — que la presente tesis califica como fomentista (Estado activo) las instituciones públicas mexicanas dedicadas a fomentar la cinematografía nacional eran instituciones generalistas, con un amplio radio de acción (productoras y estudios estatales), para coadyuvar a generar una industria fuerte, al alcance de una mayoría: la creación de un Banco Cinematográfico — que fue herramienta fundamental para el cine mexicano durante más de 35 años-, de distribuidoras estatales —destinadas a una tarea fundamental como es la de hacer circular las películas, tanto en el propio país como en el extranjero-, exhibidoras estatales — para ser un vehículo que priorice la programación de cine nacional, iberoamericano y diverso de todo el mundo (sin olvidar que, en este período, México contó con la cuota de pantalla más alta que tuvo un país latinoamericano: 50\%)—; hasta hubieron dulceras estatales —destinadas a proveer a las salas- y empresas de realización de afiches cinematográficos.

Por su parte, en Brasil la intervención activa del Estado se dio desde 1969 — con la creación de la empresa Embrafilme, comandada por el Estado- hasta 1990. Sin embargo, no se llegaron a crear productoras, distribuidoras o exhibidoras estatales, como en México, aunque el Estado sí tuvo una determinante acción en estos distintos eslabones, ya sea mediante créditos blandos destinados a la producción, o derivando recursos propios a la realización de películas a través de la figura de coproducción; en lo que hace a la distribución, el primer objetivo importante de Embrafilme fue la comercialización y difusión internacional de los filmes brasileños por parte del Estado, política que luego se extendió al mercado interno.

Por su parte, Argentina nunca tuvo un Estado empresario - ni empresas estatales de cine, ni injerencia en los eslabones de la cadena de valor (la distribución y la exhibición siempre estuvieron bajo la égida de las principales empresas de estos eslabones, a pesar de existir cuota de pantalla desde hace 70 años y media de continuidad desde hace una década)- Sin embargo, es un país que tuvo políticas de fomento al cine —especialmente, en el ámbito de la producción - desde mediados del siglo XX, comenzando en la primera presidencia de Perón con cuotas de pantalla e incentivos a la realización, posteriormente con la creación del instituto de cine más longevo de América Latina todavía en funcionamiento (1957), con la sanción de la ley de cine (1968) y su actualización (1994). 


\section{Hipótesis 2:}

El neofomentismo se centra casi exclusivamente en la producción, descuidando mayormente los eslabones de la distribución y la exhibición (a pesar de existir normativas dedicadas a ellos)

Tanto en México, Brasil y la Argentina, las entidades estatales dedicadas a apoyar las cinematografías locales destinan la mayor parte de sus recursos a la producción cinematográfica, lo que produjo un notable crecimiento en el número de largometrajes realizados en los últimos 15 años, y a la vez un descuido de los eslabones fundamentales de la cadena de valor (la distribución y la exhibición).

En México, tanto el Foprocine como el Eficine están dedicados expresamente a apoyar la producción de largometrajes. El Fidecine, si bien enuncia apoyar tanto a la producción, como a la distribución y a la exhibición, en la práctica se vuelca casi exclusivamente a la realización de filmes.

En el caso brasileño, el fomento estatal al cine también privilegia la producción fílmica y audiovisual, especialmente hasta 2008, año en que comenzó a funcionar el Fondo Sectorial. En efecto, desde que este fondo está en ejecución, Brasil comenzó a fomentar la distribución y la exhibición; sin embargo, la producción sigue siendo el sector más apoyado (en el período 2008-2010, el 67\% de los recursos estatales destinados al cine se volcaron sólo a la producción).

Por su parte, en la Argentina la proporción de los recursos destinados al fomento de cine en beneficio de la producción es aún mayor: según los últimos datos disponibles -el Incaa, como el Estado argentino, es reacio a brindar información-, en 2008 el eslabón de la producción cinematográfica se llevó el $90 \%$ de los recursos, contra 5\% que correspondió a exhibición y difusión, con igual porcentaje para el apoyo a festivales.

Sin embargo, sí existen medidas de los Estados analizados dedicadas a la exhibición (principalmente) y a la distribución, como son principalmente la cuota de pantalla —aplicadas, mas no sumamente eficaces, en Argentina y Brasil (vigente, según la ley, en México, mas no llevada a cabo)—, la media de continuidad en la Argentina y el plan brasileño "Cinema perto de você" ("cine cerca suyo") de créditos y beneficios para construir salas de cine en urbes medianas y pequeñas, y para digitalizar el parque exhibidor. ${ }^{87}$

\footnotetext{
${ }^{87}$ El Incaa dispuso en 2011 un plan de fomento a la digitalización de las salas de cine; sin embargo, recién en 2014 digitalizó un puñado de salas. A finales de ese año Argentina poseía uno de los índices de digitalización de salas más bajos de América Latina y del mundo.
} 


\section{Hipótesis 3:}

La producción cinematográfica bajo el neofomentismo aún no es sustentable, a pesar del incremento en las ayudas estatales, del crecimiento en el número de filmes producidos y de la expansión de los mercados cinematográficos nacionales.

Los mercados cinematográficos latinoamericanos son pequeños —excepto en México y, de alguna manera, en Brasil-, insuficientes como espacio de comercialización del cine en su formato original -es decir, el estreno en salas (que, en América Latina, sigue siendo el mayor, y virtualmente el único ingreso proveniente del mercado para la enorme mayoría de los filmes locales comercializados)—. E inclusive en estos dos grandes mercados - México y Brasil, ubicados en el top 10 mundial, en términos de espectadores - la cuota de mercado de los cines nacionales es muy baja — al igual de lo que sucede en toda América Latina.

Se dieron cortos períodos de apogeo de los "nuevos cines" surgidos en América Latina desde la segunda mitad de la década de 1990 —especialmente, en los tres países analizados en esta tesis-, muchas veces más parecidos a modas que a movimientos estéticos fuertes o a síntomas de una conformación de una industria sustentable, sin un incremento sustancial en los espectadores de cine nacional (salvo en el caso de algunos pocos títulos).

A su vez, desde la década de 1990 se aprecia tanto en Argentina, Brasil y México un importante número de pequeñas productoras fragmentadas, descapitalizadas, atomizadas, que — con baja intensidad de capital - compiten en el mercado, debiendo sortear su falta de espalda financiera para acceder a economías de escala, además de encontrarse con altas barreras de entrada -debido, especialmente, a los altos y crecientes costos de la producción cinematográfica y a la incertidumbre sobre la recuperación de la inversión.

El financiamiento de las películas latinoamericanas proviene mayormente de subsidios —dinero estatal a fondo perdido-, de créditos blandos —que, en porcentaje importante, tampoco se devuelven-, y en algunos casos, de acuerdos de coproducción. En casos muy excepcionales, se generan ingresos de la comercialización en otras ventanas - como, por ejemplo, el alquiler de video o la exhibición en televisión (sin embargo, las televisoras virtualmente no compran películas nacionales ni aportan a su comercialización, salvo cuando están involucradas en un proyecto cinematográfico propio, y los mercados del homevideo, por su parte, virtualmente no existen en la 
recuperación económica de las producciones fílmicas de nuestra región, así como tampoco las ventas internacionales, salvo para los casos de contados blockbusters locales)- Algunos proyectos reciben apoyos de festivales internacionales, en la figura de sus "mercados" — por ejemplo, en la Berlinale, en Cannes, los fondos Hubert Bals, Cine en construcción, Fonds Sud, entre otros-, y de acuerdos regionales, como Ibermedia.

La mayoría de las productoras en América Latina combina la producción de películas de ficción con otros productos audiovisuales, como programas de televisión y filmes publicitarios, con el fin de generar ingresos, ante la inestabilidad en el ámbito cinematográfico para la mayoría de sus emprendedores y trabajadores —empleos súper especializados en el sector conviven con el canje laboral, la multitarea y el financiamiento personal y familiar.

Los débiles sectores de la producción en toda América Latina se encuentran en círculos viciosos que les impide salir de una situación de debilidad estructural: no pueden invertir las sumas necesarias para generar una cantidad razonable de películas nacionales de alto presupuesto que genere una masa crítica; tampoco tienen la capacidad financiera ni de estructura para realizar anualmente al menos dos largometrajes de presupuesto mediano; como tampoco reúnen los montos que se necesitan para realizar buenas campañas de promoción y publicidad, o para encarar buenos trabajos de investigación y desarrollo con el fin de preparar adecuada y profesionalmente los distintos proyectos - ocurre sólo en contadas ocasiones-. Tampoco se reúne el dinero suficiente ni la expertise necesaria para contratar distribuidores capaces de situar y comercializar correctamente el producto en el mercado.

Por otra parte, en Argentina, Brasil y México, así como en toda América Latina, los productores suelen negociar directamente con los exhibidores - cumpliendo el doble rol de productores y distribuidores-, a diferencia de los estrenos de Hollywood, que son comercializados por empresas distribuidoras con amplios recursos y desde una posición de fuerza.

En este contexto, la enorme mayoría de los estrenos argentinos, brasileños y mexicanos tiene destino de nicho -salas alternativas, de "cine arte", cinematecas, centros culturales, además de muestras y festivales varios-, al igual de lo que sucede en nuestros países con las cinematografías latinoamericanas no nacionales, europeas y de países allende Estados Unidos. Las salas latinoamericanas perdieron “cine-diversidad", 
como dice García Canclini (2004), a diferencia de lo que acontecía en nuestra región hasta la década de 1980.

A su vez, los filmes latinoamericanos no circulan: si las películas latinoamericanas no pueden competir con el cine estadounidense en sus mercados locales, mayor dificultad encuentran aquellas pocas que traspasan sus fronteras para estrenarse comercialmente en algún país latinoamericano o en el resto del mundo.

Esta situación se presenta inalterada desde hace un cuarto de siglo. En el plano internacional lo único relevante para la enorme mayoría de los filmes latinoamericanos es la difusión y el prestigio obtenido en los festivales internacionales de cine $-\mathrm{y}$, para unos pocos, el financiamiento y los acuerdos de coproducción (con empresas cinematográficas, televisivas, distribuidoras, etc.) alcanzados en esos espacios.

Aunque desde finales de la década de 1990 y comienzos de la del 2000, tanto en Argentina, México y Brasil, como en toda América Latina, hubieron una o dos películas nacionales por año que tuvieron una aceptable $-y$, en algunos casos, una extraordinaria - aceptación por parte del público — algunas de ellas, rompiendo récords históricos-, ello no representa una regla para las cinematografías analizadas: los booms esporádicos no llenan salas, y los contados casos de éxito - recuperación de la inversión- son excepciones -entre el 1\% y el 3\% de los estrenos argentinos, brasileños y mexicano de los últimos 25 años.

Por todo ello, se torna necesario relativizar expresiones como "récords históricos" o booms del cine en América Latina durante los últimos años, tal como manifiesta el "entusiasmo discursivo" de investigadores, periodistas y funcionarios: las estadísticas muestran una importante recuperación en comparación con la década de 1990, pero se ubican muy lejos de los valores registrados durante el siglo XX.

\section{Políticas, producción y mercados cinematográficos contemporáneos en Argentina, Brasil y México}

Durante la década de 1990 los Estados latinoamericanos daban de baja fomentos estatales a distintas actividades productivas —entre ellas, el cine. En este contexto, la sobrevivencia de la actividad cinematográfica tanto en Argentina, México y Brasil, como en los distintos países de la región, se volvió dura, debido principalmente a la disminución del apoyo a la producción y a la contracción del mercado, tanto en lo que hace a públicos, recaudación y número de salas. 
Cuadro 41 - Argentina, Brasil y México: dimensiones históricas y contemporáneas de las políticas públicas y el mercado cinematográficos

\begin{tabular}{|c|c|c|c|}
\hline & Argentina & Brasil & México \\
\hline Antecedentes & $\begin{array}{l}\text {-País latinoamericano con el instituto } \\
\text { de cine más antiguo en } \\
\text { funcionamiento (1958-actualidad). } \\
\text {-Época de oro, con su filmografía y } \\
\text { star system presente en toda América } \\
\text { Latina (década de 1930). }\end{array}$ & $\begin{array}{l}\text {-Estado presente en todos los } \\
\text { eslabones de la cadena de valor } \\
(1969-1990) \text {. } \\
\text {-Primer país latinoamericano en } \\
\text { adoptar una cuota de pantalla } \\
\text { (1933). }\end{array}$ & $\begin{array}{l}\text {-Estado presente en todos los } \\
\text { eslabones de la cadena de valor } \\
\text { (1947-1992). } \\
\text {-Único país latinoamericano (y } \\
\text { uno de los pocos a nivel } \\
\text { mundial) en tener un Banco } \\
\text { Cinematográfico. } \\
\text {-Época de oro, con su } \\
\text { filmografía y star system } \\
\text { presente en toda América } \\
\text { Latina (décadas de 1940-1970). }\end{array}$ \\
\hline $\begin{array}{l}\text { Medidas de fomento } \\
\text { preponderantes }\end{array}$ & $\begin{array}{l}\text { Subsidios (fondo perdido) y créditos. } \\
\text { Cuota de pantalla (vigente desde hace } \\
70 \text { años) y media de continuidad. }\end{array}$ & $\begin{array}{l}\text { Subsidios (fondo perdido), } \\
\text { créditos y exención fiscal. } \\
\text { Cuota de pantalla (vigente } \\
\text { desde hace } 80 \text { años). }\end{array}$ & $\begin{array}{l}\text { Exención fiscal y créditos (entre } \\
1949 \text { y } 1992 \text { tuvo una cuota de } \\
\text { pantalla del } 50 \% \text { para los filmes } \\
\text { nacionales; en la actualidad, el } \\
\text { porcentaje es del } 10 \% \text {, pero en } \\
\text { la práctica no se cumple). }\end{array}$ \\
\hline Dependencia institucional & $\begin{array}{l}\text { Ministerio de Cultura (Presidencia de } \\
\text { la Nación). Históricamente, las } \\
\text { políticas públicas cinematográficas } \\
\text { estuvieron enmarcadas en el área de } \\
\text { Cultura. }\end{array}$ & $\begin{array}{l}\text { Secretaría de Cultura. } \\
\text { Históricamente, las políticas } \\
\text { públicas cinematográficas } \\
\text { estuvieron enmarcadas en el } \\
\text { área de Cultura. }\end{array}$ & $\begin{array}{l}\text { Conaculta (ministerio de } \\
\text { Cultura). Hasta } 1988 \text { las } \\
\text { políticas públicas } \\
\text { cinematográficas en México se } \\
\text { encuadraron bajo la Secretaría } \\
\text { de Gobernación (ministerio del } \\
\text { Interior). }\end{array}$ \\
\hline $\begin{array}{l}\text { Eslabón de la cadena de } \\
\text { valor predominante en el } \\
\text { fomento estatal }\end{array}$ & Producción. & Producción. & Producción. \\
\hline $\begin{array}{l}\text { Origen de la mayoría de } \\
\text { los filmes estrenados en } \\
\text { las salas locales, y de los } \\
\text { que generan mayor } \\
\text { convocatoria }\end{array}$ & Hollywood. & Hollywood. & Hollywood. \\
\hline $\begin{array}{l}\text { Situación de la } \\
\text { producción } \\
\text { cinematográfica }\end{array}$ & $\begin{array}{l}\text { Fragmentada, con un puñado de } \\
\text { productoras fuertes y un gran número } \\
\text { de productoras independientes, sin } \\
\text { sustentabilidad, de corta duración. }\end{array}$ & $\begin{array}{l}\text { Fragmentada, con un puñado de } \\
\text { productoras fuertes y un gran } \\
\text { número de productoras } \\
\text { independientes, sin } \\
\text { sustentabilidad, de corta } \\
\text { duración. }\end{array}$ & $\begin{array}{l}\text { Fragmentada, con un puñado de } \\
\text { productoras fuertes y un gran } \\
\text { número de productoras } \\
\text { independientes, sin } \\
\text { sustentabilidad, de corta } \\
\text { duración. }\end{array}$ \\
\hline $\begin{array}{l}\text { Situación de la } \\
\text { comercialización y } \\
\text { consumo } \\
\text { cinematográficos }\end{array}$ & $\begin{array}{l}\text { - Distribución: concentrada en } \\
\text { multinacionales extranjeras } \\
\text { (Hollywood). } \\
\text { - Parque exhibidor reducido, } \\
\text { estancado desde fines de la década de } \\
\text { 1990, con escasa presencia a lo largo } \\
\text { del territorio (6\%), dominado por } \\
\text { empresas extranjeras. }\end{array}$ & $\begin{array}{l}\text { - Distribución: concentrada en } \\
\text { multinacionales extranjeras } \\
\text { (Hollywood). } \\
\text { - Parque exhibidor creciente, } \\
\text { pero con escasa presencia a lo } \\
\text { largo del territorio ( } 10 \%) \text {; } \\
\text { importante presencia tanto de } \\
\text { empresas nacionales como } \\
\text { multinacionales. }\end{array}$ & $\begin{array}{l}\text { - Distribución: concentrada en } \\
\text { multinacionales extranjeras } \\
\text { (Hollywood). } \\
\text { - Parque exhibidor creciente, } \\
\text { pero con escasa presencia a lo } \\
\text { largo del territorio ( } 7 \%) \text {; } \\
\text { duopolio de empresas } \\
\text { nacionales. }\end{array}$ \\
\hline $\begin{array}{l}\text { Situación del cine } \\
\text { nacional }\end{array}$ & $\begin{array}{l}\text { - Baja convocatoria en los últimos } 25 \\
\text { años ( } 10 \% \text { market share, promedio). } \\
\text { - Concentración en } 1-3 \text { títulos locales } \\
\text { del } 70 \%-90 \% \text { de los espectadores del } \\
\text { cine nacional. } \\
\text { - Muy reducida circulación } \\
\text { latinoamericana (con una } \\
\text { convocatoria del } 0,02 \% \text {, promedio). } \\
\text { Allende las fronteras } \\
\text { latinoamericanas la situación es peor. }\end{array}$ & $\begin{array}{l}\text { - Baja convocatoria en los } \\
\text { últimos } 25 \text { años ( } 10 \% \text { market } \\
\text { share, promedio). } \\
\text { - Concentración en } 1-3 \text { títulos } \\
\text { locales del } 70 \%-90 \% \text { de los } \\
\text { espectadores del cine nacional. } \\
\text { - Muy reducida circulación } \\
\text { latinoamericana (con una } \\
\text { convocatoria del } 0,02 \% \text {, } \\
\text { promedio). Allende las } \\
\text { fronteras latinoamericanas la } \\
\text { situación es peor. }\end{array}$ & $\begin{array}{l}\text { - Baja convocatoria en los } \\
\text { últimos } 25 \text { años ( } 10 \% \text { market } \\
\text { share, promedio). } \\
\text { - Concentración en } 1-3 \text { títulos } \\
\text { locales del } 70 \%-90 \% \text { de los } \\
\text { espectadores del cine nacional. } \\
\text { - Muy reducida circulación } \\
\text { latinoamericana (con una } \\
\text { convocatoria del } 0,02 \% \text {, } \\
\text { promedio). Allende las } \\
\text { fronteras latinoamericanas la } \\
\text { situación es peor. }\end{array}$ \\
\hline
\end{tabular}

Fuente: Elaboración propia con base en datos de esta tesis. 
En la región se ha demostrado que la intervención del Estado es fundamental para el (re)surgimiento y el fortalecimiento del sector productivo dedicado a la cinematografía: ante las fallas de mercado - falla en la competencia, niveles de comercialización y consumo sub-óptimos o necesidad de grandes inversiones- las políticas públicas intervienen legítimamente en beneficio de un bien socialmente valioso como el cine —bien relevante tanto por su veta cultural como ecónomica, así como por ser difusor de normas, valores e identidades.

Sin embargo, el neofomentismo de las políticas públicas cinematográficas en América Latina llevado a cabo desde la década de 1990 —es decir, los intentos de los Estados latinoamericanos para volver a fomentar al cine, luego del desmonte de las ayudas públicas y del Estado empresario (en los casos mexicano y brasileño)-, mantuvo inalterada la concentración que se da en todos los eslabones de la cadena de valor del sector cinematográfico; ayudó a incrementar notablemente la producción cinematográfica local, pero registrándose una constante de exiguos niveles de convocatoria y de muy escasa circulación y nula convocatoria a nivel intraregional y mundial por parte de los filmes latinoamericanos — salvo contadas excepciones (se estrenan comercialmente allende sus fronteras el 3\% promedio de las producciones argentinas, brasileñas y mexicanas, con resultados de mercado que promedian el 0,3\%). A partir de la liberalización, concentración y extranjerización fomentadas como políticas de Estado en Argentina, Brasil y México desde la década de 1990, las distintas entidades estatales vinculadas al cine no fueron ajenas a este influjo.

Por ello, las empresas nacionales de distribución y exhibición cinematográficas que existían en México y Brasil hasta la década de 1990 cedieron completamente su lugar —debido a que fueron desmanteladas - en favor de las majors de Hollywood, en el sector de la distribución, y de las grandes cadenas de multiplex — todas ligadas a Hollywood-, en el ámbito de la exhibición. Y en Argentina las antiguas cadenas en manos de nacionales fueron siendo relegadas por exhibidoras multinacionales.

Las agencias nacionales de cine, en plena conformación del neofomentismo - con apoyos estatales centrados en la producción cinematográfica (a partir de la presión del sector, luego del desmonte de las políticas cinematográficas activas)—, dejaron libradas a las fuerzas del mercado tanto a la distribución como a la exhibición cinematográficas. Un gran problema del cine latinoamericano fue, históricamente, el control de la distribución y de la exhibición por parte de las compañías oligopólicas estadounidenses a través de la integración vertical que comenzó, con distintos matices, en la década de 
1920. En la región hubo interregnos a este dominio hollywoodense, como sucedió en México entre las décadas de 1940 y 1980, con el Estado cumpliendo un rol activo en los distintos eslabones de la cadena productiva del cine. Algo similar ocurrió en Brasil, con la empresa estatal Embrafilme hacia las décadas de 1970 y 1980. Pero, además de esas dos excepciones, Hollywood dominó los distintos mercados latinoamericanos, en mayor o menor medida, desde la década de 1920 hasta la actualidad.

Los distribuidores de cine estadounidense en América Latina invierten en copias y publicidad cifras muy superiores a las que destinan sus pares latinoamericanos. A su vez, debido a su control del mercado, los filmes hollywoodenses -o los comercializados por las majors - consiguen más pantallas y mejores fechas de estreno - los estrenos de las majors se encuentran planificados de manera centralizada para varios países, mientras que las películas latinoamericanas se estrenan de manera aleatoria (comercializadas mayormente por distribuidoras locales sin mayor poder de negociación ni recursos importantes).

En todo el mundo el distribuidor se queda con entre el $25 \%$ y el $35 \%$ de los ingresos netos de taquilla —incluyendo los gastos de comercialización (afiches, publicidad, marketing, etc.)- $-\mathrm{Y}$ en caso de que la distribuidora financie la producción del largometraje a una productora independiente, la major se queda con hasta el 50\% de los ingresos obtenidos en las salas. Por su parte, las empresas exhibidoras oligopólicas de Argentina, Brasil y México actúan aliadas a las majors —-suelen ser los representantes locales de varios estudios, y preponderan los estrenos de este origen en detrimento del cine nacional, latinoamericano y del resto del mundo.

Así, las majors son las distribuidoras con mayor presencia entre los top 10 nacionales -y, por lo tanto, son las empresas que se llevan la mayor parte de la torta en las recaudaciones de toda América Latina (González, 2013).

De esta manera, no es la competencia lo que prima, sino una política de creciente hostigamiento hacia todas aquellas películas que no formen parte de la cartera de estas grandes empresas: se pautan lanzamientos simultáneos —estrenos realizados al mismo tiempo en gran parte de los mercados mundiales, con agresivas campañas globales y una cantidad muy alta de copias, en perjuicio de las cinematografías locales-, con el fin de maximizar las ganancias en las dos primeras semanas de exhibición -que, en la actualidad, son clave. 
Estados Unidos exporta anualmente unos 200 filmes a todo el mundo - los 50 títulos más taquilleros, más películas sin mayor atractivo, todos agrupados en el paquete del block booking que las majors imponen a los exhibidores de todo el planeta.

Los 200 filmes exportados por Hollywood llegan ya amortizados a los mercados de los países estudiados en esta tesis $-\mathrm{y}$, en la mayoría de los casos, ni siquiera pagan impuestos relevantes (a veces, tan sólo pagan tasas al soporte en que ingresan), representando un auténtico dumping en contra de los filmes latinoamericanos (Raffo, 2003).

En este contexto, las agencias nacionales de cine de Argentina, Brasil y México poco han hecho para cambiar este ecosistema. Por el contrario, lo han reforzado, por acción u omisión: en el caso brasileño, por las leyes de incentivo fiscal, que invitan a las multinacionales (nacionales e internacionales) a producir en la producción de filmes locales, a cambio de reducir varios millonarios impuestos, lo que generó un dominio absoluto de un puñado de productoras — muchas ligadas a poderosas compañías locales, como Globo, o internacionales, como las majors de Hollywood-. En el caso mexicano, sucedió otro tanto, con los fideicomisos Fidecine y Foprocine, y especialmente, con el Eficine -que consistió en la reforma del artículo 226 (posteriormente, 189) del impuesto a la renta-. En Argentina, se procedió a un laissez faire por el que las grandes cadenas internacionales de cine se llevan la mayor parte de la recaudación cinematográfica, ${ }^{88}$ mientras que la distribución se encuentra fuertemente concentrada por parte de las filiales hollywoodenses ${ }^{89}$ sin olvidar que buena parte de los recursos del fondo de fomento cinematográfico terminan, desde hace años, en manos de productoras que tienen detrás a grandes multinacionales, como Telefé (Telefónica) y Patagonik (Artear).

\footnotetext{
${ }^{88}$ El Instituto Nacional de Cine y Artes Audiovisual (Incaa) creó en 2004 los llamados Espacios Incaa, una red de unas 40 salas -el número baja, o sube, dependiendo del año estudiado- distribuidas por todo el país, aunque con muy modestos resultados: hasta el momento (2015) sólo el 1\% de los espectadores que concurren al cine en la Argentina eligen un Espacio Incaa.

${ }^{89}$ En el caso argentino, merece destacarse un reforzamiento en el apoyo estatal a favor de las multinacionales, aunque con un caso que excede el período estudiado en esta tesis: se trata de la imposición realizada en 2011 por el entonces secretario de Comercio Interior, Guillermo Moreno, a los distribuidores extranjeros (Hollywood) de que "por cada dólar que importen, deben exportar otro", lo que dio por resultado que las majors, históricamente ajenas a la comercialización de cine argentino - excepto en el caso de Disney, con algunos filmes comercializados desde fines de la década de 1990- se dedicaran a distribuir un puñado de películas locales con mayor potencial comercial, lo que generó una mayor concentración al interior de la cinematografía nacional —una, dos o tres películas representan por sí solas entre el $70 \%$ y el $90 \%$ de toda la recaudación alcanzada por todos los estrenos locales-. Por otro lado, esta medida terminó desplazando del mercado de la distribución de cine argentino a históricas distribuidoras nacionales, como Distribution Company y Primer Plano.
} 
De esta manera, gran parte de los recursos estatales destinados a fomentar la cinematografía local terminan volcados a enormes conglomerados nacionales e internacionales.

Por otra parte, durante el neofomentismo se consolidó una producción cinematográfica fragmentada, de nicho, atomizada, insustentable: sólo un número muy reducido de productoras tienen una producción constante, con realizaciones que generan ingresos como para vivir de la actividad cinematográfica. La mayoría de los realizadores trabajan en múltiples actividades, y las productoras que se forman lo hacen para encarar uno o dos proyectos, para inmediatamente disolverse. Ya no existe el sistema de estudios de antaño, con millares de trabajadores dedicados a una actividad específica, trabajando establemente en una industria sustentable.

En Argentina, Brasil y México - y en la mayor parte del planeta- a los realizadores y productores se les hace muy difícil filmar un largometraje con fines de estreno comercial - un proyecto que contrate a profesionales rentados en todas las áreas de preproducción, producción, posproducción y comercialización-; en nuestra región, la mayoría se ve en esa situación. Las dificultades son mayores a la hora de distribuir profesionalmente y con un mínimo de oportunidad para que el filme rinda en taquilla y pueda recuperar aunque sea parte de lo invertido -y, en el caso de que este emprendimiento tenga éxito, el reparto de la taquilla es altamente desigual en perjuicio de los productores y realizadores.

Son muchos los factores que distinguen una industria consolidada de una mera política de fomento e incentivos: principalmente, para que haya una industria es necesario fortalecer la cadena de valor como un todo, y no solamente fomentar una pléyade de producciones sin expectativas de retorno comercial.

Las políticas cinematográficas neofomentistas aceptaron este dominio del sector privado concentrado, dedicándose a actuar meramente como intermediarias y gerenciadoras entre los grandes agentes privados — distribuidoras y exhibidoras ligadas a Hollywood, más productoras ligadas a las principales cadenas televisivas locales- y los sectores independientes -generalmente, cooperativas-, favoreciendo la posición de Hollywood y de distintas grandes empresas del sector, con cines locales que crecen en producción gracias a incentivos y dineros públicos nacionales pero que tienen un escasa repercusión en los públicos locales — salvo contadas excepciones- y una muy reducida circulación allende sus fronteras, con una convocatoria estadísticamente inexistente. 
De esta manera, las normativas y las políticas latinoamericanas referidas al cine mantienen de facto el statu quo de las multinacionales comunicacionales y sus aliados operando la producción, la distribución y la exhibición local — como se vio en la tesis, varias de las normativas y las políticas invitan, y les dan beneficios, a las empresas oligopólicas (extranjeras y nacionales) para que incursionen más aún en los distintos eslabones de la cadena productiva-, mientras que en la región los distintos eslabones de la cadena de valor cinematográfica se encuentran inconexos. Conforme esto siga ocurriendo, los sectores cinematográficos en América Latina continuarán siendo débiles.

El fomentismo — que en América Latina tuvo lugar sólo en México y en Brasil— supo aprovechar condiciones de posibilidad - mercados cinematográficos importantes y en expansión, altos niveles de asistencia a las salas y penetración popular de los filmes nacionales- para crear "épocas de oro" de sus cinematografías. Merced a Estados que decidieron actuar activamente en el fomento de toda la cadena de valor de la industria cinematográfica (producción, distribución y exhibición) los cines locales gozaron como nunca de una gran popularidad en sus respectivos países - y, en el caso mexicano, con éxito más allá de sus fronteras (el cine argentino también tuvo su época de oro tanto en su territorio como en toda América Latina, sin fomentismo, debido a las condiciones de posibilidad antedichas, potenciadas por la pujanza que tenía el país durante el primer cuarto de siglo; pero ante un solo obstáculo [el corte de provisión de película virgen por parte de Estados Unidos, iniciado desde 1942, y que duró varios años] se demostró que el desamparo estatal sobre esta industria eventualmente presenta consecuencias altamente negativas [en el mencionado caso argentino, la industria cinematográfica no volvió a dominar los mercados latinoamericanos, y el pujante sistema de estudios decaería pocos años después]).

Debido al cambio de paradigma acaecido desde comienzos de la década de 1990, dominado por el "Consenso de Washington" y el economicismo neoclásico —denominado popularmente como "neoliberalismo" (propendiendo básicamente a la desregulación estatal, a la apertura económica, a la concentración y a la extranjerización)-, el fomentismo cinematográfico en México y Brasil se dio rápidamente de baja al comenzar este decenio, casi al unísono (en 1990 y en 1992, respectivamente). La movilización del sector, perjudicado por estas medidas, empujó a los Estados a reparar el daño realizado o, al menos, a reducirlo — tanto en México como en Brasil como en la Argentina, país donde el apoyo estatal al cine había colapsado 
desde fines de la década de 1980. Así nace el neofomentismo, políticas cinematográficas que, en medio de la peor situación de los cines locales en décadas, esgrime normativas y acciones tendientes a morigerar la situación. Lo logra, pero los Estados no superan la dinámica de los comienzos de implementación del neofomentismo: los apoyos se destinan mayormente al primer eslabón de la cadena de valor (producción), los sectores vitales de la distribución y la exhibición se dejan librados al mercado, el rol estatal se queda en mero actor que intermedia entre intereses, a diferencia del fomentismo, donde el Estado intervenía fuertemente en toda la cadena — creando, en el caso mexicano, empresas estatales de cine-, siendo un actor principal en la industria: no era el mercado sino el Estado el que ordenaba las fechas de estrenos, altos tiempos de pantalla para el cine nacional o la retribución para los productores a partir de los resultados de taquilla, entre otros factores relevantes para el funcionamiento, la sustentabilidad y el beneficio tanto de la industria como de sus integrantes —en especial, los realizadores y los trabajadores.

Esta tesis comprobó que la presencia del Estado en el sector cinematográfico es relevante y decisiva. También se mostró que el fomentismo generó las mejores épocas de las cinematografías locales (México y Brasil), no sólo por capacidad productiva, sino por masividad, alta convocatoria de los filmes nacionales y buenas condiciones generales en toda la cadena de valor -inclusive en Argentina, que no tuvo fomentismo, se vio especularmente que un Estado activo es vital: su ausencia llevó a que una industria pujante, de la noche a la mañana, por un solo obstáculo, viera extinguirse su supremacía en los mercados latinoamericanos y dañarse su capacidad productiva y de convocatoria a nivel interno.

Finalmente, la presente tesis demostró que si bien el neofomentismo recuperó presencia estatal en el sector, engrosando el número de largometrajes producidos, no llegó a ser una continuación, ni a esgrimir inspiración alguna en el fomentismo - en el sentido de poseer un rol activo y ejecutor-, generando filmes nacionales con baja convocatoria, de muy reducida circulación y casi nulo visionado allende sus fronteras, con la mayoría de las productoras dispersas en microemprendimientos, descapitalizadas y $\sin$ sustentabilidad.

El neofomentismo en Argentina, Brasil y México pone al sector cinematográfico en una mejor posición en comparación con los peores momentos de las cinematografías locales — primer lustro de la década de 1990_, pero no es una continuación del fomentismo, sino una reparación todavía superficial al daño que generó el desmonte de este último. 


\section{BIBLIOGRAFÍA}

AA.VV. (2005), Gestión estatal e industria cinematográfica, Incaa, Buenos Aires.

Acland, Charles (2012), “Analysis of the 2010 UIS Survey on Feature Film Statistics", Unesco, Instituto de Estadísticas, Montreal.

Agência Nacional do Cinema (2012a), “A Ancine e a lei 12.485/2011”, informe de prensa, Ancine, Río de Janeiro.

Agência Nacional do Cinema (2012b), "Informe de acompanhamento do mercado. Exibição", informe de prensa, Ancine, Río de Janeiro.

Agee, Philip (1975), CIA Diary: Inside the Company, Penguin, Londres.

Aguiar Almeida, Cláudio (1999), "O cinema brasileiro no Estado Novo. O diálogo com a Itália, Alemanha e URSS" en Revista de sociología e política, № 12, junio, págs. 121129.

Aksoy, Asu y Kevin Robins (1992), "Hollywood for the 21st Century: Global Competition for Critical Mass in Image Markets" en Cambridge Journal of Economics, vol. $16, \mathrm{~N}^{\mathrm{o}} 1,11-22$.

Albarran, Alan (2004), "Media economics" en John Downing (ed.), The Sage Handbook of Media Studies, Sage Publications, Thousand Oaks, California.

Alvarez Monzoncillo, José María (2003), "La industria cinematográfica: enfermedades crónicas e incertidumbres ante el mercado digital", en Enrique Bustamente (coord.), Comunicación y cultura en la era digital. Industrias, mercados y diversidad en España. Gedisa, Madrid.

Amancio, Tunico (2000), Artes e manhas de Embrafilme, Editora da Universidade Federal Fluminense, Niterói, Río de Janeiro.

Aprea, Gustavo (2008), Cine y políticas en Argentina. Continuidades y discontinuidades en 25 años de democracia, Universidad de General Sarmiento, Los Polvorines, provincia de Buenos Aires.

Augros, Joël (2000), Dinero de Hollywood. Financiación, producción, distribución y nuevos mercados, Paidós, Barcelona.

Autran, Arthur (2004), O pensamento industrial cinematográfico brasileiro, tesis de doctorado, Universidade Estadual de Campinas, San Pablo.

Ayala Espino, José (2001), Economía del sector público mexicano, Unam, México.

Azar, Oscar (2009), "Producción cinematográfica 2008/2009: Estudio de la situación" en site OtrosCines.com, 16 de julio. Disponible en:

http://www.otroscines.com/debates detalle.php?idnota=3016\&idsubseccion=42 (último acceso: 3 de junio de 2012).

Balio, Tino (1993), Hollywood as a Modern Business Enterprise, 1930-1939, Scribners, Nueva York.

Bastos, Mônica Rugai (2001), Tristezas não pagam dívidas: cinema e política nos anos da Atlântida, Olho d'Água, San Pablo.

Batlle, Diego (2009), “El Incaa informó los ingresos y egresos del presupuesto 08” en el site OtrosCines.com, 7 de julio. Disponible en: 
http://www.otroscines.com/noticias_detalle.php?idnota=2978 (último acceso: $11 \mathrm{de}$ noviembre de 2013).

Becerra Artieda y Aníbal Fernando (2002) "Movimientos estratégicos de la investigación social desde una lógica dialéctico/construccionista". Disponible en: http://www.nombrefalso.com.ar/hacepdf.php?pag=12\&pdf=si.

Bedoya, Ricardo (1995), 100 años de cine en el Perú: una historia crítica, Universidad de Lima.Fondo de Desarrollo Editorial, Lima.

Blank, Steve (2012), "Why The Movie Industry Can't Innovate and the Result is SOPA". Disponible en: http://steveblank.com/2012/01/04/why-the-movie-industry-cantinnovate-and-the-result-is-sopa/ (último acceso: 5 de enero de 2012).

Bolaño, César, Cristina Andrade dos Santos y José Manuel Moreno Domínguez (2006), "A indústria cinematográfica no Mercosul: economia cultura e integraçao", en EPTIC Online, dossier especial "Cultura e pensamiento: Economia da cultura, cinema e sociedade”, vol. I Espaço e identidades, noviembre. Disponible en: http://www.eptic.com.br/arquivos/Dossieespecial/espacoeidentidades/Revista\%20EPTI C_CulturaePensamento_vol\%201.pdf (último acceso: 5 de agosto de 2011).

Bolaño, César y Anna Carolina Manso (2009), "Para uma economia politica do audiovisual brasileiro. Cinema, televisão e o novo modelo de regulação da produção cultural", en Alessandra Meleiro (comp.), Cinema e Economia Política, Escrituras Editora, San Pablo.

Bourdieu, Pierre (1995), Las reglas del arte. Génesis y estructura del campo literario, Anagrama, Barcelona.

British Council, "Mapping the Creative Industries: the UK Context" (2005), octubre, 15 págs. Disponible en:

www.britishcouncil.org/mapping the creative industries a toolkit 2-2.pdf (último acceso en: 7 de junio de 2012).

Britz, Iafa; Rodrigo Saturnino Braga; Luiz Gonzaga Assis de Luca (2010), Film business. O negócio do cinema, Elsevier, Río de Janeiro.

Buquet, Gustavo (2005), El poder de Hollywood. Un análisis económico del mercado audiovisual en Europa y Estados Unidos, Fundación Autor, Madrid.

(2011) "Inserción internacional del cine latinoamericano en mercados de la Unión Europea", en Octavio Getino, Producción y mercados del cine latinoamericano en la primera década del siglo XXI, FNCL-CNAC, Caracas.

Burns, Alex y Ben Eltham (2010), "Boom and Bust in Australian Screen Policy: 10BA, The Film Finance Corporation and Hollywood's Race to the Bottom", en Media International Australia, $\mathrm{N}^{\circ}$ 136, agosto, págs. 103 a 118.

Bustamante, Emilio (2004), "Retratos de familia. El cine en los países andinos" en Hueso húmero. Revista de artes y letras, Lima, mayo, $\mathrm{N}^{\circ} 44$.

Bustamante, Enrique (2009), "Industrias culturales y cooperación iberoamericana en la era digital”, en Néstor García Canclini y Alfons Martinell (comp.), El poder de la diversidad cultural, AECID-Fundación Carolina, Madrid, No 4, $2^{\circ}$ época, págs. 75-102.

(2008) "La televisión en Iberoamérica: El nudo central de la cooperación cultural”, en Enrique Bustamante (comp.), La cooperación cultura-comunicación en Iberoamérica, AECID, Madrid.

Butcher, Pedro (2005), Cinema brasileiro hoje, Publifolha, San Pablo. 
Cain, Robert (2013), “The Increasingly Astonishing Rise of China's Film Business", 6 de abril. Disponible en: http://chinafilmbiz.com/2013/04/06/the-increasinglyastonishing-rise-of-chinas-film-business/ (último acceso: 22 de abril de 2013).

Calvo, Javier (2007), "El gran nivel de vida del funcionario que manejó los fondos del cine argentino", diario Perfil, 13 de marzo. Disponible en:

http://www.perfil.com/contenidos/2007/03/13/noticia 0019.html (último acceso: 14 de agosto de 2012).

Camargo, Aspacia (1993), "La Federación sometida. Nacionalismo desarrollista e inestabilidad democrática", en Marcello Carmagnani (coord.), Federalismos latinoamericanos: México, Brasil, Argentina, Fondo de Cultura Económica, México.

Cammaerts, Bart y Bingchun Meng (2011), Creative Destruction and Copyright Protection, London School of Economics, Londres.

Campodónico, Raúl (2005), Trincheras de celuloide. Bases para una historia políticoeconómica del cine argentino, Fundación Autor, Madrid.

Castro Ricalde, Maricruz; Robert McKee Irwin (2011), El cine mexicano "se impone”. Mercados cinematográficos y penetración cultural en la época dorada, Unam, México.

Center for Entertainment Industry Data and Research (CEIDR) (2006), "The Global Success of Production Tax Incentives and the Migration of Feature Film Production From The U.S. to the World" en: http://www.ceidr.org/2005CEIDRReport.pdf (último acceso: 17 de septiembre de 2008).

Chalupe da Silva, Hadija (2010), O filme nas telas. A distribuição do cinema nacional, Terceiro Nome, San Pablo.

Christoperson, Susan y Michael Storper (1989), "The Effects of Flexible Specialisation on Industrial Politics and the Labour Market: The Motion Picture Industry" en

Industrial and Labour Relations Review, vol. 42, № 3, págs. 331-347.

Comisión Nacional de Cinematografía (1949), El cine mexicano, mimeo, México DF.

Conferencia de Autoridades Cinematográficas de Iberoamérica (1997), La realidad audiovisual iberoamericana, CNAC, Caracas.

Contreras Torres, Miguel (1960), El libro negro del cine mexicano, México DF.

Convenio Andrés Bello (1999), Un estudio sobre el aporte de las industrias culturales y del entretenimiento al desempeño económico de los países de la Comunidad Andina, Ministerio de Cultura de Colombia, Bogotá.

Cortés, María Lourdes (2007), La pantalla rota. Cien años de cine en Centroamérica, Fondo Editorial Casa de las Américas, La Habana.

Crovi Druetta, Delia (coord.) (1996), Desarrollo de las industrias audiovisuales en México y Canadá, Proyecto Monarca, Facultad de Ciencias Políticas y Sociales, UNAM, México.

Crusafón, Carmina (2009), "La política audiovisual del Mercosur y la influencia del modelo europeo", en Cuadernos de Información, No 25, julio-diciembre, págs. 93-104.

Curtin, Michael (2011) “Global Media Capital and Local Media Policy”, en Janet Wasko, Graham Murdock y Helena Sousa (eds.), The Handbook of Political Economy of Communications, Blackwell, Londres.

Dahl, Gustavo (2010), “Questoes de base” en Revista Observatorio Cultural, Itaú Cultural, San Pablo, septiembre-diciembre, págs. 103-112. 
De la Vega Alfaro, Eduardo (1995), "La política cinematográfica del régimen salinista", en Signos, No 11, enero.

De la Vega Alfaro, Eduardo (coord.) (2000), Microhistorias del cine en México, Universidad de Guadalajara, Guadalajara.

De Luca, Luiz Gonzaga Assis (2009), A hora do cinema digital. Democratização e globalização do audiovisual, Imprensa oficial do Estado de São Paulo, San Pablo.

(2004) Cinema digital: um novo cinema?, Imprensa oficial do Estado de São Paulo, San Pablo.

De Mora, Raúl (2009), Cooperación e integración audiovisual en Iberoamérica, tesis de doctorado, Universidad Complutense de Madrid, Madrid.

Deisica (2014), Deisica 2013, Sindicato de la Industria Cinematográfica Argentina, Buenos Aires.

(2011) Informe sobre los aspectos económicos y culturales de la industria cinematográfica argentina, Sindicato de la Industria Cinematográfica Argentina, Buenos Aires.

(2012) Informe sobre los aspectos económicos y culturales de la industria cinematográfica argentina, Sindicato de la Industria Cinematográfica Argentina, Buenos Aires.

(2009) Trabajamos por el cine. Informe sobre el trabajo generado por la industria cinematográfica en la Argentina en 2008, Sindicato de la Industria Cinematográfica Argentina, Buenos Aires.

Di Núbila, Domingo (1998), Historia del cine argentino, Ediciones del Jilguero, Buenos Aires.

Dos Santos Alcântara, Rosana (2013), Avaliação do Marco Regulatório da TV por Assinatura, Ancine, Río de Janeiro.

Fabbro, Gabriela (2014), "El cine argentino, una industria que fue", en Ana Sedeño, Pedro Matute y María Ruiz Muñoz (coords.), Panorama del cine iberoamericano en un contexto global. Historias comunes, propuestas, futuro, Dykinson, Madrid.

Falicov, Tamara (2007), The Cinematic Tango: Contemporary Argentine Film, Wellflower Press, Londres.

Fuertes, Marta; Guillermo Mastrini -editores- (2014), Industria cinematográfica latinoamericana, La Crujía, Buenos Aires.

Galperin, Hernán (1999), "Cultural Industries Policy in Regional Trade Agreements: the Case of Nafta, the European Union and Mercosur", en Media, Culture \& Society, vol. 21, № 5, págs. 627-648.

García, Enrique, Antonio López Ortega y Francisco Piñón (2005), Ensayos sobre políticas públicas culturales para la región andina, Corporación Andina de FomentoFundación Bigott, Caracas.

García Canclini, Néstor (1998), Breve historia del cine mexicano. Primer siglo $1897-$ 1997, Mapa-Conaculta-Universidad de Guadalajara.

(2005) "Cultura y comercio: desafíos de la globalización para el espacio audiovisual latinoamericano": conferencia inaugural del encuentro "El espacio audiovisual latinoamericano", organizado por la Unesco y la Universidad de Guadalajara, 14 de junio. 
(2004) Diferentes, desiguales y desconectados. Mapas de la interculturalidad, Gedisa, Barcelona.

(1994) Los nuevos espectadores: cine, video y televisión en México, ImcineConaculta, México.

(1999) "Políticas culturales: de las identidades nacionales al espacio latinoamericano", en Néstor García Canclini y Carlos Moneta (coord.), Las industrias culturales en la integración latinoamericana, Eudeba, Buenos Aires.

(1987) "Políticas culturales y crisis de desarrollo: un balance latinoamericano", en Néstor García Canclini (edit.), Políticas culturales en América Latina, Grijalbo, México.

García Canclini, Néstor; Ana Rosas Mantecón y Enrique Sánchez Ruiz (comps.) (2006), Situación actual y perspectivas de la industria cinematográfica en México y en el extranjero, Universidad de Guadalajara-Imcine, Guadalajara.

García Riera, Emilio (1999), Breve historia del cine mexicano (primer siglo 18971997), Conaculta, México DF.

Garnham, Nicholas (1990), Capitalism and Communication: Global Culture and the Economics of Information, Sage Publications, Londres, 1990.

(1979) "Contribution to a political economy of mass-communication" en Media, Culture \& Society, № 1, págs. 123-146.

Gasher, Mike (1992), "The Myth of Meritocracy: Ignoring the Political Economy of the Canadian Film Industry”, en Canadian Journal of Communication, vol. 17, No 3.

Disponible en: http://www.cjc-online.ca/index.php/journal/article/view/681/587 (último acceso: 16 de agosto de 2011).

Gatti, André (2008), A exhibição cinematográfica: ontem, hoje e amanhã, Centro Cultural São Paulo, San Pablo.

(1999) Cinema brasileiro em ritmo de indústria (1969-1990), San Pablo, Secretaría Municipal de Cultura.

Getino, Octavio (2005a), Cine argentino: entre lo posible y lo deseable, Ciccus, Buenos Aires.

(2005b) Cine iberoamericano: los desafios del nuevo siglo, editorial Veritas, San José de Costa Rica.

(1987) Cine latinoamericano: economía y nuevas tecnologías, Universidad de los Andes, Mérida.

(1990) Cine y dependencia. El cine en la Argentina, Punto Sur, Buenos Aires.

(1998a) Cine y televisión en América Latina. Producción y mercados, LOMCiccus, Buenos Aires.

(1995) Las industrias culturales en la Argentina, Colihue, Buenos Aires.

(2003) "Las industrias culturales: entre el proteccionismo y la autosuficiencia", en Pensar Iberoamérica, № 4, junio-septiembre. Disponible en:

http://www.oei.es/pensariberoamerica/ric04a05.htm (último acceso: 20 de septiembre de 2011).

(1998b) "Las industrias culturales y el Mercosur", en Gregorio Recondo (comp.), Mercosur: la dimensión cultural de la integración, Ciccus, Buenos Aires.

(1984) Notas sobre cine argentino y latinoamericano, Edimedios, México. 
(2000) "Sin imágenes dónde mirarse", en Le Monde Diplomatique, edición Cono Sur, $\mathrm{N}^{\mathrm{o}} 16$, octubre.

Getino, Octavio (coord.) (2002), Industrias culturales. Mercosur cultural, Secretaría de Cultura de la Nación, Buenos Aires.

(2011) Producción y mercados del cine latinoamericano en la primera década del siglo XXI, FNCL-CNAC, Caracas.

Gómez García, Rodrigo (2006), "El impacto del Tratado de Libre Comercio de América del Norte (TLCAN) en la industria audiovisual mexicana (1994-2002)", tesis de doctorado, Universidad Autónoma de Barcelona, Barcelona.

Gomezjara, Francisco; Delia de Dios (1973), Sociología del cine, Secretaría de Educación Pública, México DF.

González, Roque (2011a), Cine latinoamericano y nuevas tecnologías audiovisuales, FNCL, La Habana.

(2011b) "Cine latinoamericano: entre la pantalla de plata y las pantallas digitales (2000-2009)", en Octavio Getino (comp.) Producción y mercados del cine latinoamericano en la primera década del siglo XXI, FNCL-CNAC, Caracas.

(2015a) "En perjuicio de las distribuidoras nacionales. Las normativas argentinas del canon a la copia extranjera y un dólar importado por dólar exportado", en revista Toma, año 7, Nº 40, México DF, mayo-junio.

(2013) "Emerging Markets and the Digitalization of the Film Industry", Instituto de Estadísticas, UNESCO, Montreal, agosto.

(2012a) "Espacio cinematográfico latinoamericano" en Eptic. Revista Electrónica Internacional de Economía Política de las Tecnologías de la Información y la Comunicación, Universidade Federal de Sergipe, Brasil, vol. 14, № 3.

(2009) "Feeling the heat: Latin America sees rapid growth of digital screens", en Film Journal, edición especial para el ShowEast 2009, Nueva York, octubre.

(2014a) "La digitalización en América Latina, en tiempo de descuento" en revista Caimán. Cuadernos de Cine, Madrid, marzo, No 25 (76).

(2015b) "Neofomentismo: a mitad de camino", en revista Toma, año 7, No 38, México DF, enero-febrero.

(2012b) "Progressione lenta: la digitalizzazione in America Latina procede con ritmi assai diversi nei vari paesi", en DGT Online Informer, MEDIA Salles, No 89, 24 de diciembre.

(2014b) "Prólogo", en Ana Sedeño, Pedro Matute y María Ruiz Muñoz (coords.), Panorama del cine iberoamericano en un contexto global. Historias comunes, propuestas, futuro, Dykinson, Madrid.

Grillo Trubba, Diego (2011), "Cómo se subsidia el cine nacional desde el Estado", diario Perfil, 4 de septiembre.

Grupo Mercado Común del Mercosur (2003). Resolución No 49: Reunión Especializada de Autoridades Cinematográficas y Audiovisuales del Mercosur. Reunión LII. Montevideo, 10 de diciembre.

Guback, Thomas (1980), La industria internacional del cine, Fundamentos, Madrid, volúmenes 1 y 2 . 
Guzmán Cárdenas, Carlos (2004), La industria cinematográfica y su consumo en los países de Iberoamérica, Innovarium-Caci, Caracas.

Hancock, David (2011), "International box office increasing in importance", Screen Digest, informe de prensa, Londres.

Harvey, Edwin (2005), Política y financiación pública de la cinematografía. Países iberoamericanos en el contexto internacional, Fundación Autor, Madrid.

Herscovici, Alain, César Bolaño y Guillermo Mastrini (1999), "Economía política de la comunicación y la cultura: una presentación", en Guillermo Mastrini y César Bolaño (eds.) Globalización y monopolios en la comunicación en América Latina. Hacia una economía política de la comunicación, Biblos, Buenos Aires, págs. 9 a 25.

Heuer, Federico (1964), La industria cinematográfica mexicana, Policromía, México.

Hinojosa, Lucila (2014), "El cine mexicano post TLCAN: 20 años de crisis y transformaciones", ponencia presentada en el XXXII Congreso del Latin American Studies Association realizada en Chicago, entre el 21 y el 24 de mayo.

Ianni, Octavio (1973), "Populismo y relaciones de clases" en Gino Germani, Torcuato Di Tella y Octavio Ianni, Populismo y contradicciones de clase en Latinoamérica, Era, México.

Ikeda, Marcelo (2012), "Uma análise das leis de incentivo fiscal para o cinema brasileiro sob a ótica da captação de recursos incentivados”, en Anais do III Seminário Internacional de Políticas Culturais, Casa Rui Barbosa, Río de Janeiro, septiembre.

Instituto Mexicano de Cinematografía (2011), Anuario estadístico 2010, México DF.

(2012) Anuario estadístico 2011, México DF.

(2011) "Panorama de la industria cinematográfica en México", documento presentado en el Seminario internacional sobre políticas de financiamiento audiovisual", 28 de noviembre, Río de Janeiro.

Instituto Nacional de Cine y Artes Audiovisuales de la Argentina (2011), Anuario de la industria de cine, Incaa, Buenos Aires.

Isaac, Claudio (2009), “Alberto Isaac y el parto del Imcine” en Víctor Ugalde (coord.), Múltiples rostros, múltiples miradas. Un imaginario filmico: 25 años del Instituto Mexicano de Cinematografia, Conaculta-Imcine, México DF.

Istituto Nazionale per il Commercio Estero (2011), Overview of China Film Market, informe, Delegación Shangai, 14 de junio.

Izar Marson, Melina (2009), Cinema e políticas de Estado da Embrafilme à Ancine, Escrituras Editora, San Pablo.

Izcué, Nora (2009), Producción, coproducción, distribución y exhibición del cine latinoamericano en América Latina y otras regiones, Fundación del Nuevo Cine Latinoamericano, La Habana.

Johnson, Randal (1993), "Ascensão e queda do cinema brasileiro (1960-1990)", en revista USP, San Pablo, No 19, septiembre-noviembre.

(1987) The film industry in Brazil - Culture and the State. Pittsburgh: University of Pittsburgh Press.

Keize, Minami (1976a), “A fascinante aventura do cinema brasileiro" en revista Cinema em close-up, San Pablo, anuario, pág. 5.

(1976b) "Os pontos básicos de nossa cinematografia" en revista Cinema em close-up, San Pablo, año 2, Nº 11, pág. 10. 
(1976c) "Pequena analise da historia do cinema brasileiro" en revista Cinema em close-up, San Pablo, año 2, Nº 3a, pág. 12.

King, John (1994), El carrete mágico, una historia del cine latinoamericano, Tercer Mundo Editores, Bogotá.

La Ferla, Jorge (2009), Cine (y) digital, Manantial, Buenos Aires.

Laclau, Ernesto (1986) "Hacia una teoría del populismo" en Política e ideología en la teoría marxista, Siglo XXI, México.

Lagny, Michèle (1997), Cine e historia: problemas y métodos en la investigación cinematográfica, Bosch, Barcelona.

Lay, Tonatiuh (2005), Análisis del proceso de la iniciativa de Ley de la Industria Cinematográfica de 1998, Universidad de Guadalajara, Guadalajara.

Luzardo, Julio (2011), "Balance 'im-parcial' de la Ley de Cine", junio. Disponible en: http://enrodaje.net/4balance_imparcial_leydecine.htm (último acceso: 9 de julio de 2012).

Maranghello, César (2005), Breve historia del cine argentino, Editorial Laertes, Buenos Aires.

Marino, Santiago (2014), "La cinematografía argentina" en Marta Fuertes y Guillermo Mastrini (editores) (2014), Industria cinematográfica latinoamericana, La Crujía, Buenos Aires.

(2012) "Virtudes y dilemas de las políticas de comunicación del sector audiovisual (TV y cine) en la Argentina de la LSCA" en Eptic. Revista Electrónica Internacional de Economía Política de las Tecnologías de la Información y la Comunicación. Universidade Federal de Sergipe, Brasil, vol. 14, No 3.

Martín Barbero, Jesús y Ana María Ochoa Gautier (2005), "Políticas de multiculturalidad y desubicaciones de lo popular", en Daniel Mato (comp.), Cultura, politica y sociedad. Perspectivas latinoamericanas, Clacso, Buenos Aires.

Martínez, Eduardo (1977), La política cultural de México, Unesco, París.

Matute, Pedro (2014), “¿Para qué invertir en cine mexicano?”, en Ana Sedeño, Pedro Matute y María Ruiz Muñoz (coords.), Panorama del cine iberoamericano en un contexto global. Historias comunes, propuestas, futuro, Dykinson, Madrid.

McAnany, Emile y Kenton Wilkinson (1996), Nafta and the Cultural Studies, University of Texas Press, Austin.

McGahan, Anita (2004), How Industries Evolve, Harvard Business School Press, Boston.

McMurria, John (2007), "Co-producing Hollywood”, en Alessandra Meleiro, Cinema no mundo: Hollywood, vol. 4, Editorial Escrituras, San Pablo.

Media Research \& Consultancy (1998), La industria audiovisual iberoamericano, AeciFapae, Madrid.

Meleiro, Alessandra (comp.) (2007), Cinema no mundo: América Latina, vol. 2, Editorial Escrituras, San Pablo.

(2009) Cinema e economia politica, Editorial Escrituras, San Pablo.

Miller, Toby y George Yúdice (2004), Política cultural, Gedisa, Barcelona.

Moguillansky, Marina (2011), "Pantallas del Sur. Integración cinematográfica en el Mercosur", tesis de doctorado, Universidad de Buenos Aires, Buenos Aires. 
Moneta, Carlos (coord.) (2006), El jardín de los senderos que se encuentran: políticas públicas y diversidad cultural en el Mercosur, Unesco, Montevideo.

Montero Sánchez, David y José Manuel Moreno Domínguez (2007), "La industria audiovisual. Retos y propuestas para la construcción de un espacio eurolatinoamericano", en Telos, № 72, julio-septiembre. Disponible en:

http://sociedadinformacion.fundacion.telefonica.com/telos/articuloperspectiva.asp@idar ticulo=2\&rev=72.htm (último acceso: 23 de octubre de 2007).

Mosco, Vincent (2009), La economía política de la comunicación. Reformulación y renovación, Editorial Bosch, Barcelona.

(2010) The political economy of communication, 2nd edition, Sage, Londres.

Motion Picture Association of America (2012), "2011 Theatrical Market Statistics", disponible en: http://www.mpaa.org/Resources/5bec4ac9-a95e-443b-987bbff6fb5455a9.pdf (último acceso: 3 de abril de 2012).

Motion Picture Producers Association of Japan (2012), "Statistics of Film Industry in Japan" en: http://www.eiren.org/statistics e/index.html (último acceso, 4 de junio de 2012).

Motta da Silva, Denise (2003), Vizinhos distantes. Circulação cinematográfica no Mercosul, tesis de maestría, Unicamp, Campinas.

Muraro, Heriberto y José Cantor (1978), "La influencia transnacional en el cine argentino" en Comunicación y cultura, No 5, págs. 19 a 69.

Musaluppi, Hernán (2012), El cine y lo que queda de mí, Capital Intelectual, Buenos Aires.

Nadal, Octavio (2007), "Industria cinematográfica: comercialización, mercados internacionales", power point presentado en el seminario de Comercialización Internacional, realizado en Buenos Aires entre el 23 y el 27 de abril.

National Library of Australia (1994), Creative nation: Commonwealth cultural policy, Canberra, octubre. Disponible en: http://pandora.nla.gov.au/pan/21336/200310110000/www.nla.gov.au/creative.nation/contents.html (último acceso: 6 de junio de 2012).

Negri, Antonio y Giuseppe Cuoco (2006), "O monstro e o poeta" en Folha de Sao Paulo, San Pablo, 3 de marzo.

O’Regan, Tom (1996), Australian National Cinema, Routledge, Nueva York.

Observatorio Europeo del Audiovisual (2012), "EU box office inches to record high in 2011 as European comedies provide welcome relief and 3D matures", gacetilla de prensa, Estrasburgo, 14 de mayo.

(2013) Focus 2012. World Film Market Trends, Estrasburgo.

(2014) Focus 2013. World Film Market Trends, Estrasburgo.

Ochoa, Cuauhtémoc (1998), "Las salas cinematográficas en la ciudad de México en tiempos de cambio. 1982-1997”, tesis de maestría, Unam-Azcapotzalco, México.

Organización Mundial del Comercio (2010), International Trade Statistics 2010, Génova.

Ortiz Ramos, José Mário (2004), Cinema, Estado e lutas culturais: años 50/60/70, Paz e Terra, Río de Janeiro.

Paranaguá, Paulo (1996) “América Latina busca su imagen”, en Carlos Heredero (coord.), Historia general de cine, vol. X, Cátedra, Madrid, págs. 207-381. 
Pendakur, Manjunath (1990), Canadian Dreams and American Control. The Political Economy of Canadian Film Industry, Wayne State University Press, Detroit.

(2003) Indian Popular Cinema: Industry, Ideology, and Consciousness, Hampton Press, Cresskill, Nueva Jersey.

Perelman, Pablo y Paulina Seivach (2004), La industria cinematográfica en la Argentina, Cedem-GCBA, Buenos Aires.

PNUD (2004), Human Development Report 2004. Cultural Liberty in Today's Diverse World, PNUD, Nueva York.

Poder Ejecutivo Nacional (1968), Ley número 17.741 de fomento de la actividad cinematográfica nacional, Buenos Aires, 14 de mayo.

Porter, Michael (1998), "Clusters and the New Economics of Competition" en Harvard Business Review, noviembre, págs. 77 a 90.

Proimágenes Colombia (2012), "Evolución del mercado cinematográfico en Colombia". Disponible en:

http://www.proimagenescolombia.com/secciones/cine_colombiano/cine_en_cifras/evol ucion.php (último acceso: 20 de marzo de 2012).

Puttnam, David (1998), Movies and Money, Alfred Knopf, Nueva York.

Ramos, Araceli, Carmen Ojeda y Marco Tulio Méndez (2003), "Distribución y exhibición cinematográfica en el continente americano" en Hiper-textos, $\mathrm{N}^{\circ} 6$, enerojunio. Disponible en: http://hiper-textos.mty.itesm.mx/mainframe 1.htm (último acceso: 3 de abril de 2003).

Rapoport, Mario (1995), “Argentina y la Segunda Guerra Mundial: mitos y realidades” en Estudios Interdisciplinarios de América Latina y el Caribe (EIAL), Vol 6, No 1, enero-junio, págs. 5-21.

Reis, Eustáquio (1998), Economia do cinema brasileiro, Ministerio de Cultura, Brasilia.

Rey, Germán (2002), Modos de ser, maneras de soñar. Retos para una agenda de políticas públicas de las Américas en Cultura, Ministerio de Cultura de Colombia, Cartagena.

(2005) "Tendencias y perspectivas del mercado audiovisual de tres países de América Latina", informe para Unesco, mimeo, octubre.

Rodríguez López, José (coord.) (2012), Cine México 1970-2011, Gran Numeronce Producciones, México DF.

Roncagliolo, Rafael (2003), "La integración audiovisual en América Latina”, en Rafael Roncagliolo, Problemas de la integración cultural: América Latina, Norma, Buenos Aires.

Rovito, Pablo y Julio Raffo (2003), "El mercado y la política cinematográfica”, en AA.VV., Industrias culturales: mercado y políticas públicas en Argentina, Ediciones Ciccus, Secretaría de Cultura de la Nación, Buenos Aires.

Ryoo, Woongjae (2008), “The Political Economy of the Global Mediascape: The Case of the South Korean Film Industry”, en Media, Culture \& Society, № 30, págs. 873 a 889.

Sadoul, Georges (1959), "El cine ya no es arte exclusivo de pocos países" en revista $E l$ Correo, Unesco, pg. 10-19.

(2004) Historia del cine mundial: desde los orígenes, Siglo XXI, México. 
Salles, Paulo Emilio (1996), Cinema: trajetória no subdesenvolvimento, Editora Paz e Terra, San Pablo.

Sánchez Ruiz, Enrique (1998), "El cine mexicano y la globalización: contracción, concentración e intercambio desigual", en Julianne Burton-Carvajal, Patricia Torres y Angel Miquel (coords.), Horizontes del segundo ciclo. Investigación y pedagogía del cine mexicano, latinoamericano y chicano, Universidad de Guadalajara-Imcine, México.

(2005) "El empequeñecido cine latinoamericano y la integración audiovisual ¿panamericana?; ¿fatalidad de mercado o alternativa política?”, en César Bolaño, Guillermo Mastrini y Francisco Sierra (eds.) Economía política, comunicación y conocimiento. Una perspectiva latinoamericana, Ediciones La Crujía, Buenos Aires.

(1992) "El espacio audiovisual mexicano ante el Acuerdo de Libre Comercio Canada-Estados Unidos-México”, en Comunicación y Sociedad, № 14-15, eneroagosto, págs. 177 a 197.

(2012) "El Tratado de Libre Comercio y la casi desaparición del cine mexicano" en AA.VV., El Estado y la imagen en movimiento, Imcine, México.

(2001) "Globalization, Cultural Industries and Free Trade. The Mexican Audiovisual Sector in the Nafta Age", en Vincent Mosco y Dan Schiller, Continental Order? Integrating North America for Cybercapitalism, Rowman and Littlefield, Lanham.

(2011) "Hacia un espacio audiovisual latinoamericano", en Néstor García Canclini (coord.), Conflictos interculturales, Gedisa, Barcelona.

(2000) "Industrias culturales y libre comercio. México, Canadá y la Unión Europea: hacia un análisis comparativo de políticas de comunicación”, en Razón y palabra, $\mathrm{N}^{\circ} 19$. Disponible en: http://www.razonypalabra.org.mx/anteriores/n19/19_eruiz.html (último acceso: 6 de junio de 2002).

(2006) "La industria audiovisual en América del Norte: entre el mercado (oligopólico) y las políticas públicas”, en Néstor García Canclini, Ana Rosas Mantecón y Enrique Sánchez Ruiz (comps.), Situación actual y perspectivas de la industria cinematográfica en México y en el extranjero, Universidad de Guadalajara-Imcine, Guadalajara.

(2002) "Una aproximación histórico-estructural a la hegemonía planetaria de la industria cinematográfica hollywoodense" en Anuario Ininco, Investigaciones de la Comunicación, Caracas, vol. 2, No 14, diciembre.

Sandoval Peña, Natalia (2003), "Las industrias culturales en América latina en el marco de las negociaciones de la OMC y del ALCA" en Pensar Iberoamérica, Organización de Estados Iberoamericanos, junio-septiembre. Disponible en: www.oei.es/pensariberoamerica/colaboraciones04.htm (último acceso: 2 de diciembre de 2010).

Schargorodsky, Héctor (2003), Industrias culturales: mercado y políticas públicas en Argentina, Ciccus-Secretaría de Cultura de la Nación, Buenos Aires.

Simis, Anita (1996), Estado e cinema no Brasil, Annablume-Fapesp, San Pablo, 1996.

Sistema de Información Cultural del Mercosur-Sicsur (2011), "Identidad, cultura y desarrollo, un camino para la integración regional", 1 de noviembre. Disponible en: 
http://www.cultura.gov.ar/prensa/index.php?info=noticia\&id=1442 (último acceso: 8 de diciembre de 2011).

Sistema Económico Latinoamericano y del Caribe-SELA (2011), "Incentivo a las industrias culturales y creativas en América Latina y el Caribe”, Caracas, junio, 89 págs.

Sobrosa, Carla (2014), "Industria cinematográfica brasileña” en Marta Fuertes y

Guillermo Mastrini -editores-, Industria cinematográfica latinoamericana, La Crujía, Buenos Aires.

Solórzano, Javier (1978) "El nuevo cine en México", en Comunicación y Cultura, № 5, México.

Solot, Steve (2009) Incentivos fiscales para la producción y coproducción Audiovisual en Iberoamérica, Canadá y Estados Unidos, Latin America Training Center, Río de Janeiro.

(2014) Mecanismos actuales de financiación de contenidos audiovisuales en Latinoamérica II, Latin America Training Center, Río de Janeiro.

Sorlin, Pierre (1977), Sociología del cine, Fondo de Cultura Económica, México DF.

Souza da Silva, Norlan (2013), "Contra Hollywood: a cota de tela como princípio norteador no cinema brasileiro", en el blog Quem viver verá (1 de octubre de 2013) http://revistaquemviververa.blogspot.com.br/2013/10/contra-hollywood-cota-de-telacomo.html (último acceso: 5 de octubre de 2013).

Stolovich, Luis, Sylvia Barreiro y Valeria Stolovich (2004), La industria audiovisual uruguaya. ¿Realidad o ficción?, Ediciones Ideas, Montevideo.

Stanley, Myriam (2007), "El populismo en América Latina” en Anuario de historia latinoamericana, pgs. 347-359.

Tavares Bastos Gama, Rume Hämäläinen (1999), Industria de cinema no Brasil. Arranjos institucionais e abordajem comparativa, Universidad de San Pablo, Facultad de Economía.

Trejo, Roberto (2009), Crítica de la economía política del cine chileno contemporáneo, Lom-Arcis, Santiago de Chile.

Tremblay, Gaëtan (2011), "Desde la teoría de las industrias culturales. Evaluación crítica de la economía de la creatividad" en Enrique Bustamante, Las industrias creativas, Gedisa, Barcelona.

Tuñón, Julia (1986), Historia de un sueño: el Hollywood tapatío, Universidad de Guadalajara, Guadalajara.

Ugalde, Víctor (2004), "Cine mexicano, uno de los perdedores con el TLC" en Etcétera, enero. Disponible en: http://www.etcetera.com.mx/pag27ne40.asp (último acceso: 23 de marzo de 2008).

(2012) "Luces y sombras en un sexenio de cine (los sub-ejercicios en la cultura" en Proceso, N 1877, Ciudad de México, 21 de octubre, págs. 90 y 91./

(1998) "Panorama del cine en México: cifras y propuestas", en Estudios cinematográficos-UNAM, $\mathrm{N}^{\mathrm{o}} 14$, pgs. 45-59.

Ugalde, Víctor -coordinador- (2009), Múltiples rostros, múltiples miradas. Un imaginario filmico: 25 años del Instituto Mexicano de Cinematografía, ConacultaImcine, México DF. 
UNCTAD (2008), Creative Economy. The Challenge of Assessing the Creative Economy: towards Informed Policy-making, Report 2008, Naciones Unidas, Nueva York.

Unesco (1955), Film and cinema statistics. A preliminary report on methodology with tables giving current statistics, Unesco, París.

(1982) Statistics on film and cinema (1955-1977), Unesco, París.

Unión Internacional de Telecomunicaciones (2010), World Telecommunications Indicators Database 2010, Génova.

Vaughan, Nathan (2011) "MaximizingValue: Economic and Cultural Synergies", en Janet Wasko, Graham Murdock y Helena Sousa (eds.), The handbook of political economy of communications, Blackwell, Londres.

Vidal Bonifaz, Rosario (2010), Surgimiento de la industria cinematográfica y el papel del Estado en México, Porrúa-Cámara de Diputados de la República, México DF.

Wasko, Janet (2005), "Industrias culturales globales: nuevas estrategias, viejas motivaciones", en Anuario Ininco, vol. 17, № 2, Caracas, julio, págs. 88 a 113.

(1994) Hollywood in the Information Age: Beyond the Silver Screen, Polity Press, Cambridge.

(2003) How Hollywood Works, Sage, Londres.

(1982) Movies and Money: Financing the American Film Industry, Ablex Publishing, Norwood, Nueva Jersey.

(2011) “The Dead of Hollywood: Exaggeration or Reality?”, en Janet Wasko, Graham Murdock y Helena Sousa (eds.), The Handbook of Political Economy of Communications, Blackwell, Londres.

(2006) "La economía política del cine", en Cuadernos de Información y Comunicación, vol. 11, págs. 95-110.

Wayne, Michael (2003), "Post-Fordism, monopoly capitalism, and Hollywood`s media industrial complex" en Current Sociology, 6 (1), pgs. 82-103.

Weffort, Francisco (1998), "El populismo en la política brasileña” en Moira Mackinnon y Mario Petrone (coords.), Populismo y neopopulismo, Eudeba, Buenos Aires.

Wildman, Steven y Stephen Siwek (1988), International Trade in Films and Television Programs, Ballinger, Cambridge.

Yúdice, George, El recurso de la cultura, Gedisa, Barcelona, 2002.

\section{Publicaciones periódicas}

Film Journal

Haciendo Cine

Observatorio. Industrias culturales de la ciudad de Buenos Aires

Pensar Iberoamérica

Screen 
Telos

Toma

Variety

Entidades, asociaciones y organismos

Cámara Nacional de la Industria Cinematográfica y Videográfica de México (Canacine)

Motion Picture Associacion of America (MPAA)

ProMéxico

Consultoras, espacios y centros de investigación

Data Nexis

Deisica

Dodona Research

Filme-B

Nielsen-Rentrak

Proimágenes

Observatorio del Cine y el Audiovisual Latinoamericano (FNCL)

Observatorio Europeo del Audiovisual

Screen Digest

Sistema de Información Cultural de la Argentina

Teleco

Ultracine

Institutos y centros de estadísticas

Argentina

Instituto Nacional de Estadística y Censos (INDEC)

Brasil 
Fundacao Instituto Brasileiro de Geografía e Estadística (IBGE)

Chile

Instituto Nacional de Estadísticas (INE)

Colombia

Departamento Administrativo Nacional de Estadística (DANE)

México

Instituto Nacional de Estadística, Geografía e Informática (INEGI)

Perú

Instituto Nacional de Estadística e Informática (INEI)

Uruguay

Instituto Nacional de Estadística (INE)

Venezuela

Oficina Central de Estadística e Informática (OCEI)

Portales y blogs especializados

Blogacine

Cena Cine

Cines Argentinos

Cinencuentro

Corre Cámara

Cultura e mercado

Onoff

Bases de datos

Box Office Mojo

Cine Nacional

Cinestrenos

Cofetel

Chile Cine 
Globalcomms

Icaa

Internet Movie Data Base (IMDB)

Programa Ibermedia

\section{Glosario utilizado}

ANCINE - Agencia Nacional de Cine (Brasil).

ASOPROD - Asociación de Productores y Realizadores de Cine y Video (Uruguay).

CACI - Conferencia de Autoridades Cinematográficas de Iberoamérica.

CANACINE - Cámara Nacional de la Industria Cinematográfica y del Videograma (México).

CEDEM - Centro de Estudios para el Desarrollo Económico Metropolitano (Argentina).

CNAC - Centro Nacional Autónomo de Cinematografía (Venezuela).

CNCA - Consejo Nacional de la Cultura y las Artes (Chile).

CNTV - Consejo Nacional de Televisión (Chile).

CONAC - Consejo Nacional de la Cultura (Venezuela).

CONACINE - Consejo Nacional de Cinematografía (Perú).

CONACINE- Consejo Nacional del Cine (Bolivia).

CORFO - Corporación de Fomento de la Producción (Chile).

DEISICA - Departamento de Estudios e Investigación del Sindicato de la Industria Cinematográfica Argentina.

EMBRAFILME - Empresa Brasileña de Filmes.

FNCL - Fundación del Nuevo Cine Latinoamericano (Cuba).

FOCINE - Fondo de Promoción Cinematográfica (Colombia).

FONA - Fondo Nacional del Audiovisual (Uruguay).

FONCINE - Fondo de Fomento a la Calidad Cinematográfica (México).

FONCINE - Fondo de Fomento Cinematográfico (Venezuela).

FONDART - Fondo Nacional de las Artes y la Cultura (Chile).

FONPROCINE - Fondo de Promoción y Financiamiento del Cine (Venezuela).

FOPROCINE - Fondo de Apoyo a la Producción Cinematográfica (México).

GCBA - Gobierno de la Ciudad de Buenos Aires

ICAA - Instituto de Cinematografía y de las Artes Audiovisuales (España).

ICAU - Instituto del Cine y el Audiovisual Uruguayo.

IMCINE - Instituto Mexicano del Cine.

IMDB - Internet Movie Data Base

INA - Instituto Nacional del Audiovisual (Uruguay).

INCAA - Instituto Nacional de Cine y Artes Audiovisuales (Argentina). 


\section{Argentina}

Instituto Nacional de Cine y Artes Audiovisuales (Incaa).

\section{Bolivia}

Consejo Nacional de Cine (Conacine).

\section{Brasil}

Secretaria do Audiovisual, Ministerio da Cultura.

Agencia Nacional de Cinema (Ancine).

\section{Canadá}

National Film Board de Canadá.

Telefilm Canadá.

\section{Colombia}

Dirección de Cinematografía, Ministerio de Cultura.

Fondo Mixto de Promoción Cinematográfica de Colombia.

\section{Costa Rica}

Centro Costarricense de Producción Cinematográfica.

\section{Cuba}

Instituto Cubano del Arte e Industria Cinematográficos (Icaic).

\section{Chile}

Consejo Nacional de la Cultura y las Artes. Area de Cine y Artes Audiovisuales.

\section{Ecuador}

Consejo Nacional de Cinematografía (CNCine).

\section{España}

Instituto de Cinematografía y de las Artes Audiovisuales (Icaa).

\section{Gran Bretaña}

British Film Institute.

\section{México}

Instituto Mexicano de Cinematografía (Imcine). 
Perú

Dirección de Cinematografía (Dicine).

\section{Puerto Rico}

Puerto Rico Film.

\section{Uruguay}

Instituto del Cine y el Audiovisual Uruguayo (Icau).

\section{Venezuela}

Centro Nacional Autónomo de Cinematografía (CNAC).

\section{Organismos regionales de integración cinematográfica}

Conferencia de Autoridades Cinematográficas de Iberoamérica (Caci).

Secretaría Ejecutiva de la Cinematografía Iberoamericana (Seci), ejercida en Caracas, a través del CNAC.

Reunión Especializada de Autoridades Cinematográficas y del Audiovisual del Mercosur (Recam). Secretaría Técnica en Montevideo. 